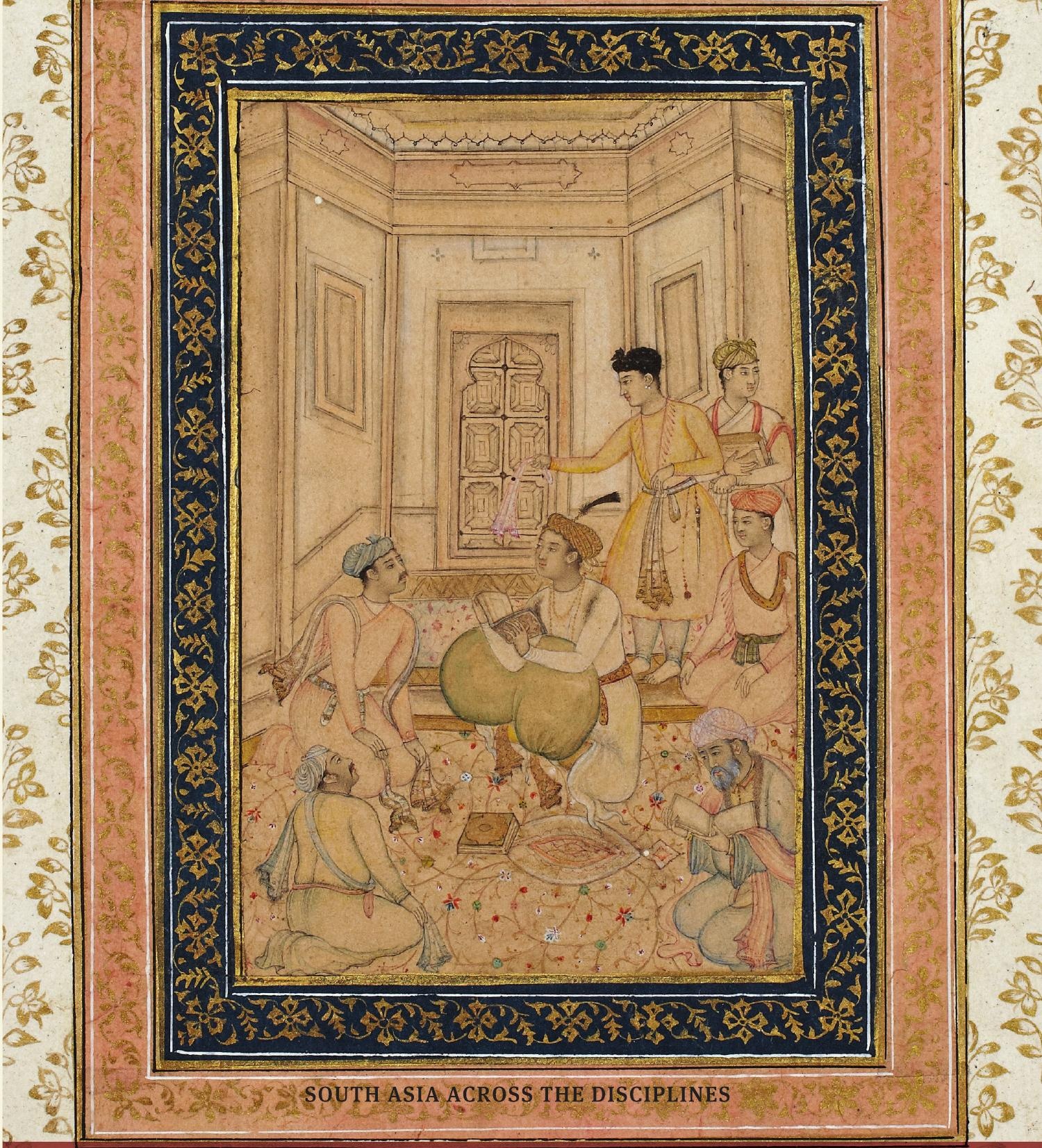

\title{
Writing Self, Writing Empire
}

Chandar Bhan Brahman and the Cultural World of the Indo-Persian State Secretary

RAJEEV KINRA 
Luminos is the open access monograph publishing program from UC Press. Luminos provides a framework for preserving and reinvigorating monograph publishing for the future and increases the reach and visibility of important scholarly work. Titles published in the UC Press Luminos model are published with the same high standards for selection, peer review, production, and marketing as those in our traditional program. www.luminosoa.org 



\section{Writing Self, \\ Writing Empire}


SOUTH ASIA ACROSS THE DISCIPLINES

Edited by Muzaffar Alam, Robert Goldman, and Gauri Viswanathan

Dipesh Chakrabarty, Sheldon Pollock, and Sanjay Subrahmanyam, Founding Editors

Funded by a grant from the Andrew W. Mellon Foundation and jointly published by the University of California Press, the University of Chicago Press, and Columbia University Press

For a list of books in the series, see page 353. 


\title{
Writing Self, Writing Empire
}

Chandar Bhan Brahman and the Cultural World of the Indo-Persian State Secretary

\author{
Rajeev Kinra
}

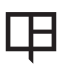

UNIVERSITY OF CALIFORNIA PRESS 
University of California Press, one of the most distinguished university presses in the United States, enriches lives around the world by advancing scholarship in the humanities, social sciences, and natural sciences. Its activities are supported by the UC Press Foundation and by philanthropic contributions from individuals and institutions. For more information, visit www.ucpress.edu.

University of California Press

Oakland, California

(C) 2015 by The Regents of the University of California

This work is licensed under a Creative Commons CC-BY-NC-ND license. To view a copy of the license, visit http://creativecommons.org/licenses.

Suggested citation: Kinra, Rajeev. Writing Self, Writing Empire: Chandar Bhan Brahman and the Cultural World of the Indo-Persian State Secretary. Oakland: University of California Press, 2015. doi: http://dx.doi.org/ 10.1525/luminos.3

Library of Congress Cataloging-in-Publication Data

Kinra, Rajeev, author.

Writing self, writing empire : Chandar Bhan Brahman and the cultural world of the Indo-Persian state secretary / Rajeev Kinra.

p. cm.-(South Asia across the disciplines)

Includes bibliographical references and index.

ISBN 978-0-520-28646-7 (pbk. : alk. paper)

ISBN 978-0-520-96168-5 (ebook)

1. Brahman, Candar Bhan, 1614-1663-Criticism and interpretation.

2. Authors, Indic-Mogul Empire-Biography. 3. Secretaries-

Mogul Empire-Biography. 4. Persian literature-India-

History and criticism. 5. Mogul Empire-History-17th century.

I. Title. II. Series: South Asia across the disciplines.

PK6451.B73Z75 2015

$891^{1} .5512-\mathrm{dc} 23$

2015002789

Manufactured in the United States of America

$\begin{array}{llllllllll}24 & 23 & 22 & 21 & 20 & 19 & 18 & 17 & 16 & 15\end{array}$

$\begin{array}{llllllllll}10 & 9 & 8 & 7 & 6 & 5 & 4 & 3 & 2 & 1\end{array}$

The paper used in this publication meets the minimum requirements of ANSI/NISO Z39.48-1992 (R 2002) (Permanence of Paper). 
For Muzaffar Alam,

a different kind of world conqueror 

Before him stretch

the unsolved algorithms of arcades

drained of people...

- Ranjit Hoskoté 



\section{CONTENTS}

Introduction: A Hindu Secretary in King Shah Jahan's Court 1

1. Chandar Bhan's Intellectual World: A Revisionist Perspective 16

2. A Mirror for Munshīs: Secretarial Arts and Mughal Governance 60

3. King of Delhi, King of the World: Chandar Bhan's Perspective on Shah Jahan, the Mughal Court, and the Realm 95

4. Writing the Mughal Self: Chandar Bhan's Life and Letters 159

5. Making Indo-Persian Literature Fresh:

Chandar Bhan's Poetic World

6. The Persistence of Gossip: Chandar Bhan and the Cultural Memory of Mughal Decline 

When you add it all up, I have been working on this book off and on for nearly fifteen years. As one can imagine, in that time I have accumulated more debts, large and small, than even I can really comprehend, much less tally here with any degree of justice to those who have helped make this work possible. I have benefited immensely from the guidance of some of the greatest scholars in the world; the support of numerous institutions, foundations, colleagues, friends, and family members; and even the help of any number of shopkeepers and innkeepers in dusty towns of the North Indian plains where I did some of my early archival research, baristas and chai-wallas in places like Chicago, New York, London, Berlin, Cairo, Beirut, and just about everywhere else I've traveled; support staff in all the various universities where I have studied, taught, done research, and given talks over the years; and of course the many, many librarians and archivists who make our research possible, yet rarely get the credit they deserve. I remember them all with gratitude, even if, I'm embarrassed to admit, I do not remember all of their names, or have space to thank them all individually even if I could.

First books like this one are somewhat unique, too, in that they usually have their origins in unexpected moments or turns in one's life, in most cases long before one could have even properly conceived of oneself as a professional scholar, much less an "author." In that sense, they often come about almost accidentally, and in my case Writing Self, Writing Empire began as a simple term paper in $\mathrm{Mu}$ zaffar Alam's first graduate seminar on Mughal history after he joined the faculty at the University of Chicago in 2001, a class in which I was lucky to have participated and in which I first became curious about this "Persian-knowing Hindu" named Chandar Bhan Brahman. At the time, of course, I had no clue that I would 
spend much of the next decade and a half thinking and writing about Chandar Bhan's cultural world, or that there would be so many ups and downs, not to mention three children, along the way.

From that early seminar paper, my interest in Chandar Bhan developed into a tentative dissertation proposal, followed by a successful application for a Fulbright-Hayes Doctoral Dissertation Research Abroad (DDRA) fellowship from the US Department of Education, which generously supported my wife and me through a year of archival work in India and London in 2004. Much of that year was spent shuttling back and forth between New Delhi, where my wife and I were based, and Aligarh, where I did much of my research. We enjoyed the hospitality of many in India, but I owe special thanks to my cousin Sunil Kalra, who throughout my adult life has always opened his home to me and my family graciously and generously for weeks and months at a time whenever we came to Delhi, as he did for much of 2004 (and several subsequent trips to India). I owe him, and all of our extended family of Kinras, Kalras, Kakkars, Khannas, Sharmas, Bahls, Vaids, Vermas, and Vijs in Delhi and elsewhere in India, in the United States, and around the world, a continuing debt of gratitude.

In Delhi I also benefited from the guidance of Shahid Amin, Sunil Kumar, and S. H. Qasemi, who were all gracious with their time and generous with their insights. My work in Aligarh, meanwhile, could not have been possible without the extraordinary kindness and assistance of Ishtiyaq Ahmad Zilli, who arranged for my affiliation with Aligarh Muslim University and gave me steady mentorship during my entire time there, and A. S. Jeelani, whom I hired as a Persian tutor, but whose contribution to my development as a scholar goes far beyond mere language instruction. I also owe great thanks to the entire manuscript department at the Azad Library in Aligarh, who took me under their wing and facilitated my work there in countless ways, especially at a time when the idea of digitizing manuscripts was still actually something of a novelty. I should also like to thank the directors and staff of several of the other archives where some of the research for this book was done, including the Gujarat Vidya Sabha in Ahmedabad, the Oriental Manuscript Library and Research Institute in Hyderabad, and the National Museum in Delhi. Dr. Nasim Akhtar, the curator of manuscripts at the National Museum was especially generous with his time and assistance. I am also most grateful to the entire staff at the British Library, where I spent nearly four months reading manuscripts and rare printed books in late 2004, as well as during several subsequent shorter visits to London.

After coming back from India and the United Kingdom, I was fortunate to receive a Whiting Dissertation Fellowship, which gave me a year of support, and a residency at the University of Chicago's Franke Institute for Humanities. I thank all of the other Franke fellows that year for their conversation, camaraderie, and intellectual stimulation, as well as Jim Chandler, the longtime director of the 
Franke Institute, his entire staff, and of course the Institute's generous benefactors, Barbara E. and Richard J. Franke, for their financial and institutional support. That year at the Franke Institute was transformative for me in many ways, and even today there are times when I come up against some intellectual problem or conundrum and my mind wanders back to some illuminating discussion we had that year.

In September-October 2006 I was lucky enough to travel to Beirut as a participant in a workshop organized by Berlin's Forum Transregionale Studien, "Travelling Traditions: Comparative Perspectives on Near Eastern Literatures" (part of the larger initiative "Europe in the Middle East, The Middle East in Europe" [EUME]). There I presented some of the research that is now in this book for the first time in front of an international group of scholars, artists, and graduate students, and I remain grateful for their feedback and friendship, which left a lasting impression on me, expanded my intellectual horizons for the better, and opened my eyes to a new world of comparative possibilities in the study of the global humanities. Since then, I have also been fortunate to participate in two other FTS "Academies" in connection with the Zukunftsphilologie ("Future Philology") project, one in Cairo (December 2010) and the other in New Delhi (December 2012). Together, these three workshops have been among the most rewarding intellectual experiences of my life, and, needless to say, I am extremely grateful to the FTS for creating these opportunities for international humanists to come together, exchange research, and learn from one another. This book would not be what it is without those conversations, all of them made possible by generous funding from the European Union and the municipal government of Berlin. I also want to express my personal thanks to Islam Dayeh, the director of the Zukunftsphilologie program, and Georges Khalil, the academic coordinator of the Forum Transregionale Studien, not only for setting such an exemplary standard of intellectual and administrative excellence, but for doing so with inimitable style, wit, and panache.

My greatest debt from that entire period, however, is to the friends and faculty at the University of Chicago who taught me so much and continue to do so. To all of my teachers and advisers, and to the entire department of South Asian Languages and Civilizations, you have my unending gratitude for making my time at Chicago the engrossing and rigorous experience that it was. They say in jest that Chicago is "where fun goes to die," but that was certainly not my experience. I especially want to thank Professor C. M. Naim for teaching me that I didn't know my "mother tongue" of Urdu nearly as well as I thought I did (and still don't), making me understand that when it comes to language and literature there is always another level of mastery to be sought after, and inspiring me to always stay thirsty in my pursuit of knowledge. Thanks also to Dipesh Chakrabarty, Steve Collins, Wendy Doniger, and Clint Seely for their consistently genial guidance 
and support, even though I wasn't technically their student. Further, I would like to thank my Persian teachers in the Department of Near Eastern Languages and Civilizations, John Perry, Heshmat Moayyad, and Franklin Lewis. Finally, my deepest gratitude to James Nye, the seemingly indefatigable South Asia librarian at the University of Chicago's Regenstein Library. A good percentage of what is contained in the pages to follow would not be there at all if not for my ability to access the extraordinary collections in the "Reg," and James Nye deserves as much credit for acquiring and maintaining those collections as anyone else in my lifetime.

For the last eight years I have been a member of the History Department at Northwestern University, which has been as collegial a place to work, study, and do research as anywhere I've ever been. My great thanks to the entire department, just about every member of which has helped me at some point with advice, encouragement, or even just a kind word on a cold snowy day. I can't list you all by name, but I am grateful to each and every one of you. I do, however, especially want to thank Peter Carroll, whose support, friendship, and mentorship have been a crutch that I have leaned on more times than I can count; Michael Allen, for being there whenever I needed to sound off about the contradictions of liberalism and empire, or just talk movies, catch a ballgame, and hang out; and Amy Stanley, for always being a source of steady wisdom when I needed it. I'd also like to thank John R. ("Jock") McLane, who started teaching at Northwestern in 1961 and spent nearly five decades as the only South Asia historian on campus before I arrived. Your continuing support even in retirement has meant the world to me. A special thanks, too, to the department's entire support staff, without whom none of our teaching, meetings, or writing would ever actually get done.

There are many others in the Northwestern community to whom I, and this book, are greatly indebted. I want to especially thank Laura Brueck not only for her many years of friendship, since long before she joined us here in Evanston, but for being an even better colleague than I could have ever possibly imagined once she got here. Ann Gunther, Holly Clayson, Jessica Winegar, J. Michelle Molina, Claudia Swan, and Brian Edwards have all helped me in ways both big and small over the years, and I thank them all. I also must thank Harriet Lightman, who has never once hesitated in acquiring books for the NU library collections, many of them obscure and expensive, whenever I've asked. We are only as good as our librarians, and you are one of the best.

During my time at Northwestern I have enjoyed the great benefit of a National Endowment for the Humanities research fellowship for the 2010-11 academic year. My thanks to the director and staff of the Endowment, as well as the reviewers who took the time to read my proposal and endorsed the project. Though I missed my students while on leave that year, the financial support of the NEH was pivotal in allowing me the time to reflect and to do further research on a great 
many of the themes discussed in the pages that follow. It would have been a much different, and certainly less ambitious, work without that support.

But speaking of students, I would like to thank the many who have taken my classes since I arrived at Northwestern in 2007. Teaching can be exasperating and exhausting at times, but there is a reason it is integral to the scholarly profession: it has a way of helping clarify what's important and essential, of forcing us to see the big picture and think about the basic elements of the historical narratives that constitute the received wisdom in our fields. I can honestly say that the experience of teaching global history and the history of early modern and modern South Asia at Northwestern for the better part of the last decade has made a crucial difference in my thinking about what is at stake for twenty-first-century Mughal historiography and has fundamentally changed (hopefully for the better) my view of the kind of historical intervention this book could, and should, try to make. A number of my students have been asking me for years when they'd be able to finally read this book; I do hope that they and other students of Mughal history will find it useful and, at least in the case of my own students, that they will recognize within its covers something of the conversations we've had over the years. I have also had the good fortune to work with a number of outstanding graduate students in my time here, conversations with many of whom have directly affected my thinking about some of the themes explored in this book. In particular, I'd like to thank Zirwat Chowdhury, Liza Oliver, Nathaniel Mathews, and Marlous van Waijenburg for their help, questions, and enthusiastic interest in my work these last few years.

I owe another kind of debt entirely to the University of British ColumbiaVancouver for inviting me in 2009 to serve as one of their spring Virani Lecturers in Islamic Studies. Working with the UBC students and Asian studies faculty during my time there was a fantastic experience that I still cherish, and I am especially thankful to Anne Murphy for the invitation and her generous hospitality. It was Anne, in fact, who first convinced me to write something about the "freshspeaking" movement discussed in chapter 5 below, so I have her to thank for that as well.

I have presented material related to this book in many, many conferences and seminars over the years, and I am grateful for the hospitality and useful feedback I have received from audiences at Oxford, Cambridge, Berkeley, Yale, Columbia, George Mason University, Frei University in Berlin, the University of Washington, Cornell, Southern Methodist University, the Library of Congress, the University of Maryland's Roshan Institute for Persian Studies, the Center for the Study of Developing Societies in Delhi, and even my alma mater the University of Chicago. I must also thank the organizers of the Annual Conference on South Asia at the University of Wisconsin-Madison for always doing a splendid job creating a congenial atmosphere for South Asia scholars of all stripes to meet with colleagues and present their work. And I have benefited tremendously from several oppor- 
tunities to present aspects of my research and learn from colleagues at the annual meetings of the American Historical Association, the Association for Asian Studies, and the International Society for Iranian Studies.

There are many friends, colleagues, and other interlocutors who over the years have given me helpful advice and feedback on specific aspects of this book or have simply enriched my intellectual life with their collegiality and support. Some have been friends for years, while others I have met on only one or two consequential occasions. Some might be surprised to find themselves on this list, while others surely deserve more elaborate and affectionate expressions of gratitude than I'm able to give here. But at the risk of offending with a mere alphabetical list (that is in any case almost assuredly incomplete), I thank Sunil Agnani, Jameel Ahmad, Daud Ali, Bernard Bate, the late C. A. Bayly, Eric Beverley, Rajeev Bhargava, Bronwen Bledsoe, Kristin Bloomer, Yigal Bronner, Allison Busch, Dr. Chander Shekhar (Head of the Department of Persian, Delhi University), Indrani Chatterjee, Kavita Datla, Prachi Deshpande, Purnima Dhavan, Thibaut d'Hubert, Jennifer Dubrow, Arthur Dudney, Richard Eaton, Will Ellison, Thomas Ertl, Shamsur Rahman Faruqi, Munis D. Faruqui, Arnika Fuhrmann, Supriya Gandhi, David Gilmartin, Nile Green, Sumit Guha, Jack Hawley, Brannon Ingram, Sonam Kachru, Abhishek Kaicker, Ahmet Karamustafa, Sudipta Kaviraj, Atiya Khan, Mana Kia, Ebba Koch, Hajnalka Kovacs, Sunil Kumar, Corinne Lefèvre, David Lelyveld, Paul Losensky, David Ludden, Rochona Majumdar, Karuna Mantena, Rama Mantena, Justin Marx, Anubhuti Maurya, Lawrence McCrea, Barbara Metcalf, Jane Mikkelson, Christopher Minkowski, A. Azfar Moin, Harbans Mukhia, Sarah Neilson, Christian Novetske, Luther Obrock, Rosalind O’Hanlon, Francesca Orsini, Heidi Pauwels, Stefano Pello, Frances Pritchett, A. Sean Pue, Teena Purohit, Kapil Raj, Ajay Rao, Nikhil Rao, Kristen Rudisill, Guriqbal Sahota, Adheesh Sathaye, Katherine Schofield, Kevin Schwartz, Sunil Sharma, Dan Sheffield, Prithvi Datta Chandra Shobhi, David Shulman, Hasan Siddiqui, Sunit Singh, Travis Smith, Rupert Snell, Fabrizio Speziale, Ramya Sreenivasan, Adam Talib, Robert Travers, Audrey Truschke, Ananya Vajpeyi, Andre Wink, Ed Yazijian, and Karin Zitzewitz.

I would also be remiss if I did not thank the David Collection, Copenhagen, for permission to use a Mughal miniature from their holdings (\#3/2012) on the cover of this volume, and to Pernille Klemp for making the digital image of it. Thanks, too, to Mr. Edward Weech of the Royal Asiatic Society of Great Britain and Ireland for his most generous assistance in locating and digitizing several crucial folios from an unpublished (and, as it happened, uncatalogued) manuscript of the A $\underline{k} b \bar{b}$ rāt-i Darbār-i Mu'allá, the official Mughal court records of the seventeenth century. I should note that an earlier version of portions of chapter 2 appeared in a special issue of the Indian Economic and Social History Review (2010) devoted to secretaries and other service elites in early modern India, and edited by Rosalind O'Hanlon and Christopher Minkowski; parts of chapter 5 first appeared in a 
special issue of Sikh Formations (2007) dealing with time, memory, and historiography, and edited by Anne Murphy, as well as a follow-up volume entitled Time, History, and the Religious Imaginary in South Asia, also edited by Anne Murphy and published by Routledge (2011); and parts of an earlier incarnation of chapter 6 appeared in the Journal of Persianate Studies (2009). I am grateful to all the editors of those journals, and to the journals themselves for permission to reprint revised portions of those essays.

For all its perks, the academic life can be far more hectic and grueling than most nonacademics realize, especially for those whose research takes them to faraway places for conferences, research, and the like. Even when we are at home, though, there are seemingly endless meetings, conferences, events, associated dinners, and other functions to attend, often in the evenings, and sometimes running late into the night. On the one hand, these are among the most lively and invigorating features of the academic life; but on the other, for those with families and especially those with small children, they come at a price-a price often borne by one's partner, who must tend to things at home while we are off conferencing, or researching in some dusty archive, or drinking wine with the latest star writer or scholar who happens to be passing through town. My ability to do these things with any degree of success has been largely due to the unstinting support of my wife Sonia, whom I married barely one month before beginning my PhD at Chicago in 1999, and with whom I have had three children in the intervening years. Mere thanks are not enough to express what I, and this book, owe her. She has been there every step of the way, supporting me even when the work, and doubts about the work, and outright doubts about the career, made me irritable or otherwise difficult (and surely at times downright exasperating) to live with. If this book is worth anything, then a good deal of the credit goes to her.

Some of the credit also goes to our larger extended families for their unwavering encouragement and support, going all the way back to when I first embarked on this eclectic career, destined for years of the sort of job and financial insecurity that usually make Indian parents squirm. But my parents, Kavita Kinra and Lalit Bahl, and my in-laws, Satish and Uma Sharma, have always been behind me and have helped us immensely over the years in ways too numerous to reckon. If this were a film, they would all get executive producer credits. As it is, all I can offer here is my deepest gratitude and affection.

I'd also like to add a special word of thanks to Ms. Akua Mansah, who has spent the better part of eight years as our children's caregiver during the days (and sometimes nights), while my wife and I pursued our respective careers. Raising three small children while trying to write, teach, and manage all the other obligations of an academic in today's university is a challenge even with help, but 
without Akua's steadfast and dependable partnership the task would have been nigh impossible.

Indeed, not all academic debts are purely academic, and I must also acknowledge the personal one I owe to my dear old friends Timothy Beynart, Kevin Fitchard, Eric Gorman, Philip Higgs, Seth McClure, and Colin Murphy, as well as all of their respective families. None of you are academics, but you're still the smartest, funniest guys I know, and your friendship has sustained me through many a period of academic doldrums. Your influence, too, is lurking in the pages that follow, even if you may not recognize yourselves.

Finally, to return to the world of my academic colleagues, I have saved my utmost thanks for two groups of people without whom this book, and indeed whatever success I may have had over the last fifteen years, are simply unimaginable. Manan Ahmed Asif, Whitney M. Cox, and Blake T. Wentworth have been my scholarly soul brothers going back to my first years as a graduate student in Chicago, challenging me, teaching me, teasing me, inspiring me, and entertaining me both intellectually and otherwise, in every conceivable way, and at every conceivable hour, ever since. I don't know what stars aligned to put us all in Hyde Park together at that particular moment, but they definitely were lucky ones, and I will thank them to the end of my days for giving me the chance to call you my friends.

Astrological explanations aside, however, none of us would be where we are without our teachers, and I have been fortunate to have three of the best this world has on offer. Sheldon Pollock took a chance on admitting me to the $\mathrm{PhD}$ program at Chicago despite my lack of what most would consider the conventional training for this line of work. It is therefore no exaggeration to say that I owe my entire academic career to him. But more than that, Shelly taught me almost entirely anew how to read, how to think, and how to ask big, tough questions. To his credit, he also had no objection when I began veering away from Sanskrit and focusing instead on Indo-Persian literary culture and Mughal history, a transition that began with Muzaffar Alam's arrival in Chicago in 2001. This was yet another transformative moment for me. As I mentioned above, the seeds of this book were first sown in a paper for one of Alam Sahib's classes, and he has been there to guide, instruct, challenge, and encourage me ever since. Nearly every conversation I've ever had with him, even those that began with mundane topics like, say, the cost of train tickets in Italy, or the best way to translate the word sulh, has ended up being so illuminating that I later regretted not having recorded it for posterity. I can never even partially repay the massive intellectual debt that I owe him, but, as a small token in that direction, it is to him that this book is dedicated with love, respect, and affection.

It was also through Muzaffar Alam that I first met Sanjay Subrahmanyam, who graciously agreed way back in 2003 to serve as an external member on my 
dissertation committee and who ever since has pushed me to expand my intellectual horizons even further, in ways that I could never have conceived before. All three have taught me so much, not only through their direct instruction and (sometimes) tough love, but also through the example they've set by continuing to produce bold, innovative, and rigorous scholarship long after they've earned the right to rest on their laurels. They have already achieved so much, yet all three remain among the hardest-working people I know-which may well be the biggest lesson of all.

Despite learning so much from so many, and accruing so many incalculable debts along the way, at the risk of stating the obvious I should close by emphasizing that I alone bear responsibility for any errors, gaps, or lapses of judgment in the pages that follow. I have also made a conscious effort to try to write this book in a way that is, as the old Persian adage has it, "both interesting to specialists and intelligible to a general audience" (k $\underline{h} \bar{a} s \underline{s}$-pasand wa 'ām-fahm). Only the reader can judge whether I have succeeded on that score, but whatever the verdict, I thank you too for the opportunity to occupy your thoughts for a little while with these dispatches from the cultural world of a Mughal state secretary. 



\section{A Hindu Secretary in King Shah Jahan's Court}

To gaze upon the Taj Mahal in Agra remains, even today, nearly four hundred years after its construction, an exhilarating experience. One of the most recognizable structures in all of South Asia, and arguably in the entire world, it has become a visual icon not just of the Mughal dynasty that built it but of the entire subcontinent's rich courtly, artistic, and architectural history. Something about the Taj just says India to most observers, almost as a floating visual signifier. And as a result, its iconic image has come to grace countless travel brochures, movie posters, advertisements, coffee-table books, and the like, instantly drawing the beholder's mind to a certain aura of exotic Indo-Muslim mystique, even if the consumers of such images are not always aware that the monument is specifically "Mughal," or that it was built in the 163 os by the bereaved Mughal emperor Shah Jahan (r. 1628-58) as a monument to his beloved late wife, Arjomand Banu Begum, aka Mumtaz Mahal ("the palace favorite"). In a sign of the times, Google even announced recently that in 2014 the Taj Mahal was the most visited destination in Asia for "virtual travelers" using Google Street View to explore historical monuments and other tourist sites from the comfort of their own homes.1

But what of the emperor who built it? What of the court culture that produced it? Many will know the story behind the Taj's construction as a mausoleum for the emperor's wife, and some will surely have heard the popular legends of Shah Jahan's draconian treatment of the builders and craftsmen who designed the exquisite monument (all of which are baseless, as far as any serious scholars have been able to detect). ${ }^{2}$ For some, the Taj is a luminous monument to sublime romantic love-a "solitary tear [that] would hang on the cheek of time," as the Bengali Nobel laureate Rabindranath Tagore once famously called it. ${ }^{3}$ For others, 
it is the embodiment of exotic Oriental romance's evil cousins, decadence, despotism, and intrigue. For still others, somewhat paradoxically, it is both. "Its beauty," as the title to an article accompanying a 1967 photo spread in Life magazine succinctly put it, "veils a Mogul's ruthless whim." ${ }^{4}$ And yet, for all the relative fame or infamy that attaches to it in the modern cultural imagination, when it comes to the general cultural history of the decades just before and after the Taj Mahal was built, or for that matter the entire Mughal seventeenth century, I'd wager that most people would be surprised to learn that there is actually a dearth of original scholarship on the period. Indeed, particularly for the English reading public (which includes a lot of South Asians as well), there is far less new, primary source-based research on the Mughal cultural world generally than most visitors to the Taj-whether real or virtual-probably realize.

This book seeks to help address this considerable gap in our knowledge of the period by examining the life, career, and cultural milieu of a prominent court insider, the Mughal poet and state secretary (munshī) Chandar Bhan Brahman ( $\mathrm{d}$. ca. 1666-70). Chandar Bhan was one of the great Persian prose stylists and poets of his era, and, while we do not know exactly when he was born, we do know that it was almost certainly sometime toward the end of the reign of Jalal al-Din $\mathrm{Mu}$ hammad Akbar (r. 1556-1605), widely considered to have been the greatest, and most transformative, emperor of the Mughal dynasty in India. Indeed, part of the reason there is such a lack of cultural historical scholarship on the later Mughals is that for generations such research has focused largely on Akbar's reign, to the almost total exclusion of the literary and political culture of the ensuing decades.

An intellectual like Chandar Bhan thus provides us an excellent window onto a surprisingly neglected period in Mughal culture and politics. Though he was born during Akbar's reign, he came of age and spent the bulk of his career during the reigns of Akbar's successors Jahangir (r. 1605-28) and Shah Jahan (r. 1628-58) and even continued serving for a time under the last of the so-called "great" Mughals, Aurangzeb 'Alamgir (r. 1658-1707). It was a few years into Aurangzeb's reign that, citing old age, Chandar Bhan withdrew from official imperial service. But he continued to correspond with the emperor, and new evidence (discussed below in chapter 1) suggests that he also served the court in a less official capacity for nearly a decade even after that. This Hindu from Punjab thus lived, worked, and thrived through part or all of the reigns of four different Muslim monarchs, at the peak of the Mughal Empire's power and global influence.

To be sure, it was an age of terrific splendor, and thus it is perhaps not so surprising that the popular memory of the Mughal world in Chandar Bhan's lifetime tends overwhelmingly to fixate on extravagant monuments like the Taj, or on royal intrigue, or on the Mughals' lavish patronage for exquisite miniature painting and other arts. Indeed, to most people, even to many professional scholars who are not specialists of the Mughal era or the Indo-Persian cultural world, they 
remain, simply, in the words of Bamber Gascoigne, "India's most flamboyant rulers." 5

But Chandar Bhan's era was also defined by key cultural and political transitions, both in India and in the wider geographical zones of Eurasia and the Indian Ocean world. It was a time when everyday bureaucratic and administrative policies in northern India were streamlined and rationalized to levels unprecedented in the history of the subcontinent and unsurpassed in all but a handful of states elsewhere in the world for some time to come. As a state secretary who spent most of his career working primarily out of the fiscal office (dīwān $\bar{\imath})$ of the various prime ministers who served Shah Jahan, Chandar Bhan had an insider's view of this administrative culture, and his observations thus provide us with unique insights into how certain classes of Mughal government officials thought about their professional duties and their obligations to the public at large.

The seventeenth century was also a time when the Indian subcontinent bolstered its claim as the critical hub in a vast network of global trade routes that connected China and the rest of East and Southeast Asia, via India, to the Safavid and Ottoman domains, the wider Middle East, the city-states of the East African Swahili Coast, the Mediterranean, and beyond to Europe and even the Americas. In military and political terms, the Mughals were thus engaged on the global stage in what has been described as a "tight grid of interimperial rivalry" with competitors like the Ottomans, the Habsburgs, and the Safavids. ${ }^{6}$

But culturally speaking it was also a time when the Mughals were among the greatest patrons in the world for an Indo-Persian literary and scholarly tradition whose area of influence extended across South, Central, and West Asia, and that, we should not fail to note, ultimately had a pronounced-though routinely unacknowledged-influence even on modern European and American notions of literary romanticism. ${ }^{7}$ Mughal patronage lured an extraordinary number of intellectuals from all over this cosmopolitan ecumene to Delhi, Agra, Lahore, and other major cultural centers in northern India, and all of them continued, along with their native Indian counterparts like Chandar Bhan, to participate in a vast transregional conversation whose voices could also be heard in Bengal, Arakan, the Deccan, Iran, Turkey, Afghanistan, the rest of central and inner Asia, and indeed the entire eastern Muslim world.

For centuries, Indo-Persian literary culture had also been a prime vehicle for the spread of Sufi idioms expressing mystical and existential angst, as well as bacchic rejoinders to the social and religious conservativism of orthodox Muslim clerics. Celebrations of earthly and divine L/love, of worldly and spiritual intoxication, and of devotion to the ostensibly heretical "idols" of T/truth and B/beauty emerged over the years as some of the most common themes in Indo-Persian literary life. And thus, in turn, throughout the seventeenth and eighteenth centuries such antinomian views also became critical components of the wider Mughal 
perspective not just on literature but also on larger societal matters like civility, religious tolerance, the role of the state, and the meaning of what is often referred to nowadays as "political Islam."

This openness to complex and unorthodox views on the basic questions of human existence had a correlate, too, in the flourishing respect during this period for multiple classical religious and intellectual traditions-Indic, Islamicate, Persian, Turko-Mongol, Greco-Hellenic-even while there was also a powerful sense of epochal newness in the air, as the heirs to these various knowledge systems and linguistic traditions sought to recalibrate their literary, philosophical, philological, and scientific bearings in response to the new social, cultural, and political realities of global early modernity. Thus the intellectual foundations of Mughal culture and politics rested precisely on a dual sense of both continuity with the great classical traditions of the old world and the equally strong belief that by integrating these cultural streams into a composite worldview, safeguarded by Mughal power, they were crafting an empire of unprecedented dynamism, social harmony, and "universal civility" (șulh-i kull).

As a native of Lahore and an elite member of the Mughal corps of state secretaries, or munshis, Chandar Bhan Brahman was both an eyewitness to these developments and a prominent participant. But Mughal tolerance and civility, as such, are not really the main concern of what follows so much as they constitute the backdrop against which the administrative and literary career of a figure like Chandar Bhan was even thinkable. They created the conditions of possibility for cultural networks that cut across a wide variety of social, political, and intellectual contexts that were rarely, if ever, constrained solely by ethnic or sectarian affiliation, allowing many Mughal intellectuals to inhabit multiple subject positions and thereby to engage in multiple techniques of self-fashioning depending on the situation in which they found themselves operating. In the chapters that follow, then, we will explore some of the multiple perspectives from which a figure like Chandar Bhan Brahman engaged Mughal life, or, put another way, the multiple Mughal worlds that he was able simultaneously to inhabit.

To begin with, there is the world of Chandar Bhan's family, his social networks, his access to various forms of Mughal patronage early in his career, and the wider context of Mughal attitudes toward diversity and multiplicity in his lifetime, topics that we will take up in chapter 1 . As his name suggests, Chandar Bhan came from the sort of high-caste Brahman family, educated primarily in Sanskrit, that might traditionally have engaged in Hindu scholarly and priestly activities. This "traditional" social location, however, does not seem to have presented many obstacles to his family's employment in the Mughals' nominally Muslim state, an affiliation that began in his father's generation. Nor, for that matter, did it preclude families like his, and entire classes of early modern Hindu literati, from continuing to pursue classical Indic traditions even as many entered into a seri- 
ous engagement with the Perso-Islamic literary and political idioms that were the staple of Mughal high culture.

Too often, modern scholarship has treated premodern social, religious, and even linguistic identities in South Asia as though they were zero-sum phenomena-as though a Muslim ruler had to become "less Muslim," as it were, in order to exhibit genuine tolerance and respect toward the non-Muslims in his realm, or as though a Hindu who learned Persian, for instance, somehow became "less Hindu" as a result. This is certainly the logic, albeit perhaps unintended, of the great Mughal scholar John Richards's praise for the "chameleon-like attributes" of the "caste" of Hindu munshis like Chandar Bhan who came to dominate the Mughal secretariat in the seventeenth century ${ }^{8}$ - the implication being that such non-Muslim service elites had to stage some sort of elaborate performance of collective self-abnegation or dissimulation in order to function in a Muslim state.

But we see nothing in Chandar Bhan's oeuvre to corroborate this notion. Quite the contrary, throughout his writings he evinces consistent pride in his Brahmanical lineage-why else, after all, would he choose "Brahman" as his literary nom de plume? - at one point even boasting that it was precisely their Brahmanical background that made him, his father, and his brothers so well attuned to the PersoIslamicate Sufi ideals of worldly detachment. Perhaps even more significantly-at the risk of stating what ought to be obvious but unfortunately, in a good deal of modern scholarship and commentary, is not-Chandar Bhan's Muslim patrons, colleagues, and interlocutors routinely showed themselves to be perfectly conscious of the fact that he was a Hindu and tended simply to accept him as such. We know of no effort to convert him, nor do we have any evidence that he felt any pressure, at any point in his life, to downplay or otherwise camouflage his religious identity in order to advance his career.

And what a career it was. From relatively modest beginnings as a provincial clerk in his native Punjab, Chandar Bhan rose over the course of his life in Mughal service to occupy some of the most elite secretarial appointments in Shah Jahan's government. Through his employment by various powerful officials along the way, and in his later capacity as the emperor's personal secretary and diarist (wāqi'a-nawīs), Chandar Bhan gained privileged access to the royal household, the courtly society, and the administrative apparatus of the Mughal Empire at the peak of its power and influence. He shares this perspective with us in many of his writings, especially in his celebrated memoir of life at the Mughal court, Chahār Chaman (The four gardens), as well as his separate collection of personal letters, known under various names but most often given the title Munsha'ät-i Brahman.

Chahār Chaman and Munsha'ät-i Brahman were two of the most widely circulated-and emulated-Persian prose texts in seventeenth- and eighteenth-century South Asia, as evidenced by the numerous manuscripts of each that are still housed in archives all over India, Pakistan, Bangladesh, and indeed the rest of the 
world. Both texts were taken as models of exemplary stylistic prose (insh $\bar{a}$ ) for subsequent generations of Indo-Persian secretaries and other literati, and Chandar Bhan's style was still considered so worthy of emulation at the end of the eighteenth century that excerpts of Chahär Chaman were even featured prominently in The Persian Moonshee (1795), a widely used Persian textbook for East India Company officials compiled by Francis Gladwin, a celebrated British Orientalist and member of the Asiatick Society of Calcutta from its founding in 1784 .

What we find in a close examination of Chahār Chaman and Munsha'āt-i Brahman is that Chandar Bhan was a subtle and astute commentator, not only on the ideals of Indo-Persian secretarial conduct, which were his primary area of professional expertise, but also on broader issues like the nature of political leadership, the social value of civility and gentlemanly conduct, the role of literature and mysticism in public life, and the importance of refining the mechanisms of Mughal administration in order to better serve the public good. Our munshiss attitude toward such themes will be the focus of chapter 2, which centers mainly on an analysis of the first of Chahär Chaman's "four gardens" of Mughal self-fashioning. I argue that this long understudied essay on the cultural role and ethical responsibilities of Mughal secretaries, ministers (wazirrs), and other administrators was very likely intended to be read in the rich tradition of Indo-Persian wisdom and advice literature, or nașinhat-nāmas, as a kind of "mirror for munshīs."

Indeed, Chandar Bhan's reflections on his experience of various types of courtly assemblies, his relationships with notable Mughal officials, and his participation in several important military campaigns and diplomatic missions were intended not simply to offer the reader a randomly dazzling display of Persian prose stylewhich is how Chahär Chaman has typically been read by generations of dismissive modern scholars-but also, crucially, to provide once and future Mughal munshīs and other officials with practical models of exemplary conduct and approaches to good administration. By using his own career to showcase the complex package of cultural and administrative skills expected of the elite munshī, Chandar Bhan offered a firsthand illustration of successful career mobility for later generations of Indo-Persian secretaries. Equally important, as we will see, in describing the excellent qualities of the great Mughal wazirs of his era such as Raja Todar Mal (d. 1589), Afzal Khan Shirazi (d. 1639), Sa'd Allah Khan (d. 1656), and Raja Raghunath (d. 1664), Chandar Bhan also showed that successful governance was not simply about military authority (imārat) but also a matter of balanced temperament, managerial skill (wizärat), a keen mystical and literary sensibility (ma'rifat), and a deep concern for the public welfare above one's own.

These themes will continue to resonate in chapter 3 , as we examine Chandar Bhan's views on Mughal kingship itself, beginning with his attempt to locate Shah Jahan within a deeper genealogy of Indic kingship going back to mythical times and to cast the emperor as an ideally just, tolerant, and generous mon- 
arch. One important source for Chandar Bhan's perspective on such topics is his short treatise "History of the Kings of Delhi" (Tārīkh-i Rajahāa $y i$ Dihlī), which traces the rulership of northern India from the mythic heroes of the Sanskrit epic Mahäbhärata forward, all the way up to Shah Jahan himself. This will set the stage for an extended discussion of Chahār Chaman's second "garden," in which Chandar Bhan dilates at length on the emperor, his daily routine, and the general atmosphere at court and in the mobile imperial camp.

This portion of Chahär Chaman takes on added significance when we realize that it was also excerpted and widely circulated as a separate work in early modern India, usually under the title of either Guldasta (a "flower bouquet" plucked from the "four gardens" of Chahār Chaman) or sometimes Qawā'id al-Saltanat (Principles of governance). This was almost surely the means by which this exact passage found its way into the hands of Francis Gladwin, as mentioned above, who used it in his Persian Moonshee (1795) to exemplify what he considered to be the typical "Rules Observed during the Reign of Shahjehan."

Chandar Bhan's work thus had a significant role to play in shaping the early British colonial understanding of what had constituted the norms and practices of Mughal governance, at a crucial historical moment when East India Company officials were still in the incipient stages of studying the Mughal example in order to learn how to manage their own territorial holdings in the subcontinent. ${ }^{9}$ And yet, as was so often the case, the British colonial gaze seems clearly to have missed the mark, for if understanding the actual "rules," principles, and practices of governance in Shah Jahan's reign had truly been Gladwin's intention, then he would have done much better to consult any number of other technical manuals on Mughal administration from the genre known as dastūr al-wizārat (norms of ministerial conduct), including, ironically enough, the earlier sections of Chahār Chaman itself that deal so explicitly with such matters. ${ }^{10}$

At this point in Chahār Chaman the author's attention suddenly radiates outward, from his tight focus on the beating heart of the empire in the form of the emperor's body, person, and routine to a broad geographical survey of the major cities and provinces that constituted the backbone of the Mughals' imperial dominions. This outward spatial movement is suggested even by the order of Chandar Bhan's descriptions, beginning as he does with the newly built capital city of Shahjahanabad (i.e., the part of the city nowadays referred to as "Old Delhi") and moving outward from there to what he calls "Old Delhi" (dihlì-yi kuhna, by which he means the part of Delhi nowadays referred to as "Nizamuddin"), and thence to Agra, Lahore, Multan, Kashmir, Kabul, Thatta, Ahmadabad, the Deccan, Malwa, Ajmer, Awadh, Allahabad, Bihar, Bengal, Orissa, Qandahar, and finally the Central Asian provinces of Balkh and Badakhshan. Chandar Bhan's accounts of these places vary in length, with some running to several pages, while others are only a paragraph or even just a few lines. Mixed in are a handful of anecdotes, for instance 
a particularly interesting account of Shah Jahan's meeting with the Sufi shaikh Miyan Mir while the imperial camp was en route from Kashmir to the Punjab.

But perhaps the most important feature of this section of Chahär Chaman is Chandar Bhan's extraordinary descriptions of the bustle of daily life in urban centers like Shahjahanabad, Old Delhi, and Lahore. These are some of the most vivid firsthand descriptions we have of the everyday atmosphere of seventeenth-century urban public spaces such as the bazaars, gardens, shrines, and grand Mughal boulevards like Chandni Chowk. Chandar Bhan's account of such places may reflect a growing concern in early modern Indo-Persian literary culture with what Sunil Sharma has characterized as a new style of "urban ethnography" and may well be one of the earlier examples of the phenomenon, anticipating by nearly a century some of the more flamboyant and well-known accounts contained, for instance, in sources like Dargah Quli Khan's Muraqqa'-i Dihli (Delhi scrapbook). ${ }^{11}$ Besides adding to our general store of knowledge about the emergent urban public sphere in early modern Indian cities like Delhi, Lahore, and Agra, Chandar Bhan's observations provide a refreshing firsthand look at some of the various types of social and cultural intercourse that were possible in such spaces.

In chapter 4 the perspective shifts once again, from public, to semiprivate, to deeply personal, as Chandar Bhan uses the third of his "four gardens" to explore two important forms of Mughal prose composition, or insh $\bar{a}$, that have been almost entirely neglected by modern scholarship but that were nevertheless critical vehicles of life writing and self-fashioning among Mughal intellectuals: the memoir and the personal letter. Both autobiography and epistolography have long been seen as crucial genres in the cultivation of the early modern self, a historical development that is often assumed to have its exclusive origin in seventeenthcentury Europe. ${ }^{12}$ What most people don't realize is that the seventeenth and eighteenth centuries also saw a boom in such forms of letter and life writing across the Indo-Persian world, a fact that is no less significant for being hitherto all but unexamined.

We don't have many good answers for why Indo-Persian literati, too, became so enamored of epistolary self-expression during this period, largely because very few of the scores of personalized letter collections and prose miscellanies that were produced during this period have received any critical scrutiny. But we do know that Chandar Bhan was widely considered by contemporary and later critics as one of the foremost practitioners of the epistolary arts and thus his particular approach to self-fashioning through memoir and letter writing can be a useful window onto the general cultural practices of the era.

As we examine Chandar Bhan's juxtaposition of his autobiography with various modes of letter writing we will see that he too, like many of his European contemporaries, was capable of crafting a complex, context-specific "epistolary self." 13 And as we read the autobiographical episodes in his memoir, we will see that he 
too, like his contemporary and fellow state secretary Samuel Pepys (1633-1703), was conscious of using diverse modes of life writing to craft a public version of his private persona. ${ }^{14}$ Admittedly, Chandar Bhan was not so obsessed with chronological delineation of daily minutiae in his self-presentation as Pepys was, but his approach was no less "individual" as a result. Moreover, given that Pepys's diary wasn't actually published until nearly a century after his death, one can say with some confidence that even without the benefit of print capitalism Chandar Bhan probably had a much broader imagined community of readers than his English counterpart's "secret masterpiece" ${ }^{15}$ - a great many of them hoping to emulate the Brahman's literary style, his career trajectory, and his confident sense of Mughal gentlemanly identity in order to advance their own careers.

At this point, we might feel confident enough that Chandar Bhan's life and writings have already provided us ample material for an investigation of the seventeenth-century Mughal political and cultural world. Yet we have barely even touched on two of the most compelling features of his oeuvre, namely the mystical and literary sensibilities that are on virtually constant display throughout. These will be a focus of chapters 4 and 5. Like so many intellectuals of his era, Chandar Bhan took a pluralistic and ecumenical approach to religion, drawing heavily on the mystical dimensions of both Islam and Hinduism, weaving the idioms of both Sufism and Vedanta into the fabric of his prose with such deftness and consistency that one would actually be hard pressed to find a single passage in any of his surviving works that does not bear evidence of their powerful effect upon his personality and worldview. Whether he is discussing political matters such as the duties and responsibilities of the prime minister of the empire or personal matters such as his anguish at the death of his father, there is no mistaking the pervasiveness of these mystical idioms in Chandar Bhan's world, not only in his own dayto-day life but also in that of almost everyone around him, from his own family members right up to Emperor Shah Jahan himself.

For our munshi, then, the incorporation of mystical ideals and idioms into his discursive repertoire was not some superficial add-on or ancillary diversion (the camouflage of which we spoke above); nor was it an elusive normative ideal, to be read about in books but never explored in practice; rather, it was constitutive of his very intellectual being and informed his entire approach to the basic matters of daily human existence. One simply can't understand his intellectual landscape without it. Nor, significantly, did Chandar Bhan view his deep personal investment in Sufi modes of mystical awareness as any threat whatsoever to his confident sense of identity as a Brahman. Indeed, as I noted above, he boasts from time to time that being a Brahman made him even more attuned to the esoteric intellectualism and spirituality of Sufism (tașawwuf) - somewhat paradoxically turning the ugly logic of caste pride on its head in order to validate a profoundly radical cultural pluralism. 
We will encounter Chandar Bhan's mystical attitude periodically throughout the early chapters of Writing Self, Writing Empire, and these intermittent forays will culminate with our discussion at the end of chapter 4 of the fourth and final "garden" of Chahār Chaman, a somewhat cryptic miscellany of the munsh $\vec{\imath}$ s most esoteric thoughts on various topics, from the cosmic nature of linguistic expression (sukhan), to meditations on philosophical and mystical subjects such as the desire for spiritual detachment (lazzat-i tark-i ta'alluq), the patient acceptance of divine fate (tawakkul), or simply, the nature of Truth (kaifiyat-i așl-i haqiquat), among other matters. A running theme throughout this series of esoteric reflections is the tension between the individual's experience of the material world of phenomena perceptible through the physical and rational senses and the deeper experience of existential, mystical, and cosmic meaning.

This dynamic interplay between the dueling human experiences of surface reality (șurat) and a yearning for access to the deeper spiritual meaning ( $\left.m a^{\prime} n \bar{\imath}\right)$ behind brute phenomenological existence is, in turn, one of the dominant themes of Chandar Bhan's ghazals, or lyric poems, an examination of which we will take up in chapter 5. Of course, in many ways Chandar Bhan's poetic interest in such philosophical themes simply reflects the larger influence of the Sufi mystical idiom on Indo-Persian literary culture more broadly. But this is precisely why it is so important for any historical analysis of Chandar Bhan's era to take into account both the mystical and the literary sensibilities that shaped the worldview of so many of his contemporaries in the Mughal political and intellectual establishment, from the emperors on down to the administrative clerks.

Indeed, in seventeenth-century Mughal India the ability to produce and appreciate good poetry was not some sort of auxiliary skill cultivated only by a virtuoso cadre of professional, elite practitioners; rather it was an integral feature of daily life, both public and private, not just in the courtly milieu, but also in the bustling world of the bazaars, in the offices of administrators and other minor officials, in the madrasas and other schools, in everyday epistolary correspondence, and throughout many other sites of public and private sociability. Chandar Bhan's letters, for instance, even his "official" correspondence with members of the royal family or other Mughal officials, are full of poetry-making it quite difficult at times to distinguish his "administrative self" from his "poetic self."

Far too often these literary aspects of everyday life in Mughal India go virtually unnoticed in political and administrative histories of the period, and often they are even excised from printed editions of Mughal inshä' collections. But as we will see, given the degree to which Mughal literary tastes informed political, religious, and social policies, one simply cannot dissociate the literary material of these letters and other forms of inshä' from that which is "properly historical." Indeed, for most men of the pen like Chandar Bhan, to be a Mughal state secretary was to be a poet as well, while for the Mughal state more broadly in many cases the language 
of poetry was the language of politics, and the patronage of various types of literary production -in multiple languages, not just in Persian-was a prime vehicle for communicating key aspects of Mughal social and religious policy. ${ }^{16}$

Like so many of his intellectual contemporaries, Chandar Bhan displayed a pronounced veneration for the past masters of classical Indo-Persian literature. But poets of his era also evinced a keen literary historical consciousness, combining their respect for the achievements of "ancients" (mutaqaddimin) like Firdausi, Rudaki, Anwari, Khaqani, Sa'di, Rumi, Hafiz, Amir Khusrau, and Jami (to name a few) with a notable effort to distinguish themselves as the voice of a new age in human history, and their poetry, in turn, as suitably innovative and "fresh" $(t \bar{a} z a)$ to capture the spirit of the new era. Across the seventeenth-century Persianate world, in fact, "speaking the fresh" ( $t \bar{a} z a-g \bar{u}$ ' $)$ emerged as a conscious aesthetic goal, while the poets themselves were typically referred to as "the latest" (muta'äkhkhirin) or sometimes "the contemporary" (mu'āșirin) to distinguish them from the earlier masters.

One cannot help but see interesting parallels between this movement and other types of "new intellectualism" in early modern India, whether among intellectuals of classical traditions like Sanskrit or vernacular literati who leveraged new forms of Mughal and regional patronage to advance their own claims to cultural novelty and authority. ${ }^{17}$ The comparative questions raised by the virtual simultaneity of these intellectual historical developments in multiple knowledge systems across South Asia have barely even begun to be raised, much less pursued with any serious attention. And this is to say nothing of trying to place such developments in a comparative perspective even further afield, for instance, say, with the muchdiscussed "quarrel between ancients and moderns" taking place in almost exactly contemporaneous Europe.

Locating an intellectual like Chandar Bhan's literary cultural persona amid these broader global trends, as we hope to do in chapter 5, will thus be something quite new to the field of Indo-Persian intellectual history. Meanwhile, any analysis of Chandar Bhan's poetry only prompts further questions regarding his ultimate cultural legacy, which we will take up in chapter 6. Though he was widely respected by critics in his own day, it took only a few decades after Chandar Bhan's death (ca. 1670) for the memory of his literary and political career to become the stuff of vivid anecdotes and urban legends. These memorable stories about Chandar Bhan's activities at the Mughal court and his interactions with important patrons appeared largely in the many biographical compendia (tazkiras) and other seventeenth- and eighteenth-century texts that narrated the lives and exploits of prominent Indo-Persian poets-yet another part of the Mughal archive that has received far too little critical attention in modern scholarship. As specialists of Indo-Persian literature and Sufism will of course know, by the seventeenth century the tazkira genre was far from new; but the early modern period 
saw a boom in the production of such compendia that has yet to be historicized in any serious way. Indeed many, many questions remain to be answered regarding why the cultural dynamics of this particular era produced such a sense of urgency among Indo-Persian literati and other intellectuals to recover and preserve collective knowledge about their literary past and to juxtapose that archival knowledge with more ephemeral oral histories, anecdotes, and gossip about more recent and contemporary poets like Chandar Bhan.

We will try to pose and address some of these larger historical questions in Chapter Six, but one thing that we do know and that is worth noting here in the Introduction is that this explosion in early modern tazkira writing had firmly established the genre as a worthwhile venture for a broad range of Indo-Persian intellectuals already by the middle of the eighteenth century, when their distant cousin Samuel Johnson began in the 1740 s to compile his own seminal Lives of the Poets. The latter-not published in its entirety until the $178 \mathrm{os}-$ has of course been hailed for generations as a crucial transitional text, one that helped inaugurate an entirely new form of anglophone literary and critical modernity. Like Johnson's Lives, many texts in the seventeenth- and eighteenth-century Indo-Persian tazkira archive also served as important vehicles for negotiating not only the authority of the classical literary canon but also a whole host of intellectual concerns regarding "the relationship between authorship, experience, and history." ${ }^{18}$ But unlike Johnson's work, which has been exhaustively scrutinized by modern critics and intellectual historians-both for its actual content and as the embodiment of a new type of scholarly sensibility that was recognizably "modern"-the vast corpus of Indo-Persian texts written in an analogous vein have received comparatively scant attention. We don't even know enough about them to say one way or the other whether such tazkira production might represent a kind of "modern" impulse or not, or what the larger significance of the answer would be for the conventional wisdom and familiar narratives of South Asian and global intellectual history.

Indeed, so far as I can tell, not one of these seventeenth- and eighteenth-century tazkiras - not the relevant portions of Muhammad Salih Kambuh's 'Amal-i Ṣālih (ca. 1660), not Muhammad Tahir Nasrabadi’s Tazkkira-yi Naṣrābādī (167273), not Muhammad Afzal Sarkhwush's Kalimāt al-Shu'arā (1682), not Sher Khan Lodi's Mir'āt al-Khayāl (1690-91), not Kishan Chand Ikhlas's Hamesha Bahār (1723-24), not Brindaban Das Khwushgu's Safīna-yi Khhwushgū (ca. 1730?), not 'Ali Quli Khan Walih Daghistani’s Riyāz al-Shu'arā (ca. 1747-49), not Siraj al-Din 'Ali Khan Arzu's Majma' al-Nafä'is (1750-51), not Shaikh 'Ali Hazin's Tazkirat al-Mu'āṣirīn (1752), not Mir Husain Dost Sanbhali's Tazkira-yi Husainī (1759-60), not Lachmi Narayan Shafiq's Gul-i Ra'nā (1767-68) and Shām-i Gharībān (176869), not Shaikh Ahmad 'Ali Hashimi Sandelvi's Maknhzan al-Gharā'ib (1803-4), not Husain Quli Khan 'Ashiqi 'Azimabadi's Nishtar-i 'Ishq (1817-18), or any other comparable contemporary work - has ever even been fully translated into English. 
This is not just a loss for Western scholarship; many of these texts have faded into obscurity even in India, where the percentage of readers and scholars who actually know Persian and/or Urdu has dwindled considerably in modern times. Primary source-based scholarship on the Mughal period has suffered accordingly, and if that weren't bad enough, many of the relevant tazkiras, insh $\bar{a}^{\prime}$ collections, and the like are often difficult to locate even in Persian printed editions. Imagine trying to write on the Italian Renaissance and not having access to the works of Dante, Petrarch, Boccaccio, and Machiavelli, and you'll have some idea of the challenges that scholars of Indo-Persian cultural history sometimes face, even when they do have the requisite skills and interests.

Such tazkiras thus represent yet another chronically neglected chunk of the archive aptly described by the Iranian scholar Mohamad Tavakoli-Targhi as the "homeless texts" of Indo-Persian cultural early modernity. ${ }^{19}$ And even though we cannot hope to provide an exhaustive catalog and analysis of the literary tazkiras of the era in one short chapter, by using chapter 6 to track some of the stories about Chandar Bhan that appear in such texts we will hopefully gain some insight into the mechanics of the genre, as well as the ways in which these tazkiras served as informal, but nonetheless very significant, sites for the production and contestation of certain kinds of cultural historical memory in the shifting contexts of India's late Mughal, and in turn colonial, nationalist, and even postcolonial worlds. As we will see, the production, dissemination, and persistence of an almost entirely fanciful set of memories about Chandar Bhan's experiences at court not only came to shape the modern view of the significance our munsh $\vec{\imath}$ s own life and career but also played an important role in the ongoing negotiation over how the Mughal political legacy itself was to be narrated and remembered by subsequent generations.

As this overview should indicate, it is not as though Chandar Bhan Brahman was some completely obscure or forgotten figure whom I am rescuing from total oblivion. He was one of the most well-known intellectuals of his era, and he continued to be remembered-albeit in the somewhat peculiar fashion that we will examine in chapter 6-in later centuries. Nevertheless, Chandar Bhan's career and oeuvre have never really received a sustained analysis or critique in modern scholarship, and in this he is far from alone. In fact, apart from a handful of isolated case studies or the occasional article in a specialist journal, it is difficult to think of a single Indo-Persian intellectual from the entire seventeenth century, whether Hindu or Muslim, whose work has received sustained critical attention in the last several decades, much less become a household name. Manuscript copies of Chandar Bhan's works abound in archives around the world, but it is only in the last ten years that his two most celebrated prose works-Munsha'ät-i Brah- 
man (2005) and Chahär Chaman (2007)-have even become available in printed editions. Meanwhile none of his works has ever been fully translated into English, except for the brief section of Chahär Chaman excerpted by Gladwin in 1795 .

The two most substantial existing studies of Chandar Bhan's life and career, in fact, are two unpublished $\mathrm{PhD}$ theses that appeared barely two years apart in the 1970s: Narindar Nath's "Chandar Bhan Brahman: A Critical Edition of His Unknown Chahar Chaman" (Delhi University, 1974) and Jagdish Narayan Kulshreshta's "Critical Study of Chandra Bhan Brahman and His Works" (Aligarh, 1976). These two works are both very informative, but they are also both products of their time, and they did not have the benefit of the substantial new scholarly insights and advances of the last forty years. An updated approach is thus surely necessary.

The same could be said for most of the shorter notices of Chandar Bhan in other secondary scholarship-much of it informative but none of it comprehensive. Generally speaking, literary scholars have been the most interested in Chandar Bhan, and indeed the modern editors of his two most important "historical" works are all specialists of Indo-Persian literary culture, not Mughal history. Other literary scholars have also taken notice of Chandar Bhan from time to time. For instance, readers of Urdu can consult the literary critic S. M. 'Abdullah's brief article on Chandar Bhan in the Oriental College Magazine, published all the way back in 1928. Much of the same material was also included in 'Abdullah's later work, Adabiyāt-i Färsī men Hindu'on kā Hișsa (The contribution of Hindus to Persian literature).$^{20}$ Also in Urdu, one could consult a thirteen-page article on Chandar Bhan by Syed Suleiman Nadvi (1947) or the relevant sections of Muhammad Sa id Ahmad Marahravi's Umarā'-yi Hunūd (1910). ${ }^{21}$ And there have been a handful of articles in English over the years as well, such as Iqbal Husain's seven-page article in Islamic Culture, "Chandar Bhan Brahman (A Hindu Writer of Persian Prose and Verse)" (1945), and Hira Lall Chopra's brief pamphlet Chandra Bhan Brahmin (1956). But probably the most informative work in English until now, apart from Nath's and Kulshreshta's $\mathrm{PhD}$ theses, is M. A. H. Farooqui's introduction to his edition of Chandar Bhan's poetic dìwān, Aḥwāl-o-Āṣār-i Chandra Bhān Brahman wa Dìwān-i Pārsī (1967).

Historians, by and large, have been even less interested in the cultural historical significance of Chandar Bhan's oeuvre, even if they have sometimes mined the munsh $\vec{\imath}$ s works for tidbits of empirical data over the years. Thus, while one will often find Chandar Bhan or one or the other of his works referenced as a "useful" source in a fair amount of modern Mughal historiography, there has been very little historical analysis of the munshi himself, his cultural networks, his views of the empire and Mughal governance, his literary and mystical sensibility, and so on-precisely the themes that will interest us in the chapters that follow. With reference to the specific context of Indo-Persian stylized prose, or insh $\bar{a}$, the modern 
scholar Momin Mohiuddin has briefly discussed Chandar Bhan in his work on the technical aspects of Mughal secretarial administration, The Chancellery and Persian Epistolography under the Mughals (1971). A few years earlier, the historian Ibn Hasan made excellent use of parts of Chahär Chaman in his Central Structure of the Mughal Empire (1967), one of the best available modern works on Mughal administration. But after that, the pickings get slimmer and slimmer.

One will note, moreover, that the vast majority of the scholarship mentioned in the previous two paragraphs dates from the 1970s and earlier, meaning that for all intents and purposes, apart from the editors' introductions (in Persian) to the recent editions of Chahär Chaman and Munsha'ät-i Brahman, there has been barely any work at all on this major Mughal intellectual in nearly two generations, and almost none of it in English (or even Urdu, for that matter). Some aspects of Chandar Bhan's urban subjectivity have been analyzed in Taymiya Zaman's $\mathrm{PhD}$ thesis, "Inscribing Empire: Sovereignty and Subjectivity in Mughal Memoirs," ${ }^{22}$ and some of his views on the high level of education required of a successful munshī have been briefly examined by Muzaffar Alam and Sanjay Subrahmanyam ${ }^{23}$ - but that's about it.

I will refer to some of these articles and other secondary sources throughout this book, whenever it is necessary and appropriate. But I also maintain that in the continuing absence of any substantial biographies, scholarly monographs, or comprehensive analyses of Chandar Bhan's life, career, and cultural-historical milieu, the munsh $\vec{\imath}$ s own writings remain the best sources for information about his life and career. Trying to understand these difficult and neglected texts as best I can, and to convey something of their significance to the reader, has been my main focus. And as I hope to show, they have great potential relevance, not only for a revised Mughal historiography, but also for some important debates in postcolonial South Asian historiography more generally, and even for conversations about the global nature of early modernity writ large. 


\title{
Chandar Bhan's Intellectual World
}

\author{
A Revisionist Perspective
}

The typical modern narrative of Mughal history still goes something like this. After its establishment in 1526 by the dynamic Turko-Mongol conqueror Zahir al-Din Muhammad Babur (1483-1530), the Mughal Empire soon passed into the hands of Babur's less effective son, Humayun (r. 1530-40, 1555-56). Within a mere ten years, Humayun had lost the dynasty's Indian territories to an upstart Indo-Afghan rival named Sher Shah Suri (1486-1545), who then established his own imperial order in northern India. The resulting "Afghan interregnum" nearly smothered Mughal imperial ambitions in their infancy, and in fact most historians agree that Sher Shah and his successors deserve considerable credit for actually initiating some of the early modern political, economic, and even cultural reforms that would later be made famous by the resurgent Mughals. ${ }^{1}$ But Humayun did manage to return in 1555, after a fifteen-year exile at the Safavid court in Iran, to defeat the Surs and reestablish the Mughal dynasty's preeminence in northern India, only to die unceremoniously in a fall from the steps of his royal library barely a year later. As the noted British historian Stanley Lane-Poole famously, and derisively, quipped: "He tumbled through life, and he tumbled out of it."'

It is perhaps because of Babur's early death and this air of haplessness surrounding Humayun that most people consider the latter's son and successor, Jalal al-Din Muhammad Akbar "the Great" (r. 1556-1605), to be the Mughal Empire's "real" founder. Besides the mere fact that he ruled for an impressive stretch of roughly five decades, Akbar is credited with numerous successes in terms of consolidating and expanding Mughal territories, rationalizing the Mughal bureaucracy and administrative system, and especially promoting certain policies of cultural pluralism that allowed him and his advisers to integrate all of India's 
multiple linguistic, ethnic, religious, and cultural communities into a unified imperial polity.

These efforts were perhaps best encapsulated by the Mughals' famed ideology of sulh-i kull, a term often translated as "peace with all" and usually associated with Akbar and his celebrated courtier, adviser, biographer, and ideologue Abu al-Fazl ibn Mubarak (1551-1602). ${ }^{3}$ But the term sulh in this context did not simply mean "peace" in the strictly military sense, for the Mughals remained an expansionary conquest state throughout Akbar's reign and for the entire century after his death. Rather, rooted in the deeper Islamic legal traditions regulating negotiations and compromise between states, as well as the wider canon of Indo-Persian treatises on ethics and political wisdom known as $\bar{a} d \bar{a} b$ and $a k h l a \bar{q}$, the term șulh in Mughal parlance also connoted a sense of "hospitality" or "civility" toward allwhether Sunni or Shi'a, Turk or Afghan, Muslim or non-Muslim, Indian or European-as long as they lived amicably within the Mughal imperial dominions and didn't stir up trouble. Thus, for instance, sulh in the sense of "hospitality" played an important part in the ways that Mughal rulers extended courtesy to defeated political rivals, usually preferring to honor and integrate such conquered enemies into the imperial project rather than to punish them out of spite. But the notion of sulh-i kull as a kind of absolute or "universal civility" also had broad implications for the promotion of certain general norms of social comportment, manners, ethical behavior, and cultural etiquette at court and in the society more generally.

This included, of course, the Mughals' famous efforts to accommodate India's multiple religious communities within a conception of "political Islam" far more expansive and tolerant than that term usually connotes today. And it is almost exclusively in this latter, quite narrow, sense of șulh-i kull as an ethos of religious tolerance that the term is usually thought of in modern historiography, and that too almost entirely as a shorthand for Akbar's policies of outreach toward Hindus in particular-establishing marital alliances with Rajputs, translating Sanskrit texts into Persian, patronizing Hindu literary and religious traditions, and so on. The tolerant atmosphere cultivated at Akbar's court, in turn, is typically incorporated into the broader narrative of his military and political success, and thus in modern historiography and South Asian cultural memory alike Akbar's reign is typically viewed as the apex of Mughal imperial statesmanship, civility, tolerance, and success.

Akbar and the concept of șulh-i kull are so conjoined in the modern historical narrative and cultural memory of early modern South Asia, in fact, that most people, scholars and general readers alike, simply assume that values like pluralism and civility went into a steady state of decline after Akbar's death in 1605. His successor Jahangir (r. 1605-27) is typically treated rather like his and Akbar's predecessor Humayun, as an ineffectual but mostly harmless bon vivant who coasted along on the wave of his father's triumphs but failed to make any notable 
contributions of his own. This view is summed up pretty well by the modern historian John F. Richards, whose seminal history The Mughal Empire (1993) remains the standard English-language textbook on the dynasty, and who states plainly: "Unlike his father, Jahangir was not a great general, a great organizer, or a great builder." Jahangir's court, Richards adds, was plagued by "ossifying ceremonial" and a sense of "lost dynamism," all of it exacerbated by the "indolence" brought on by the emperor's taste for alcohol and opium. ${ }^{4}$ There is a subtle hint of emasculation in a lot of modern writing about Jahangir, too, as historians consistently draw attention to his growing dependence later in life on his wife, Queen Nur Jahan (1577-1645), and her family's “junta” of Persian expatriates to actually run the empire. The continuing purchase of this view in the popular imagination is reflected quite pithily in the preface to Tanushree Podder's salaciously titled recent historical romance Escape from Harem [sic] (2013), in which she states flatly: "Jahangir, the next Mughal ruler, inherited a rich empire that needed no great efforts to sustain. He went down in history as one who allowed his wife Nurjahan to hold the reins of the empire while he drowned himself in wine and opium."

Jahangir's successor Shah Jahan (r. 1628-58), although celebrated for building the Taj Mahal and several other notable landmarks of Mughal architecture, is also treated with a marked ambivalence in modern historiography. On the one hand, his brilliant successes as a military commander and as the greatest patron of Mughal architecture at its high-water mark-arguably the high-water mark of Indo-Islamicate architecture generally-are simply undeniable. And yet, for many modern historians and other commentators, Shah Jahan's reign, despite representing virtually the peak of Mughal power, territorial reach, and global influence, also represents a kind of tipping point toward the dynasty's ultimate decline. His military campaigns and all those grand monuments, it is said, simply cost way too much money, draining the Mughal treasury and helping to initiate-or at least exacerbate-a series of damaging economic crises that would eventually prove fatal to Mughal power. The precise nature and effects of these crises has been vigorously debated by modern scholars of Mughal political economy. ${ }^{6}$ However, despite widespread agreement among specialists that a combination of socioeconomic factors-some structural, some contingent, and some the result of specific policies and initiatives-is largely to blame for loosening the central Mughal administration's grip on power by the beginning of the eighteenth century, this is not the most prevalent explanation for the empire's "decline" in most general historiography, and certainly not in the modern popular imagination. Instead, we are too often told, the problem really boils down to religion-specifically, to Islam.

Thus we are told by a recent biographer of Akbar that "in the century after Akbar's death, the Mughal court went through something like an Islamic revival."7 Jahangir is sometimes implicated in this "revival," but, as often happens with Jahangir, he is blamed more for indolence and apathy than for any actual orthodox 
inclinations. Yet the teleological force of this narrative of a post-Akbar fall from grace is so powerful, it would appear, that although Jahangir himself was one of the least dogmatic and most intellectually curious rulers of the entire early modern world-the great Mughal art and architecture historian Ebba Koch recently argued that he was among the world's most powerful exemplars of "Francis Bacon's ideal of the king as an observer and investigator of Nature" - he is implicated nonetheless. How else to explain the modern historian I. H. Qureshi beginning his chapter on the Mughal "revival of orthodoxy" already with Jahangir's accession in 1605 ? This chapter is followed by two more dealing with the reigns of Jahangir's successors Shah Jahan and Aurangzeb, chapters whose titles- "The Decline of Political Power" and "A Diagnosis of the Disease" - pretty much speak for themselves. ${ }^{9}$

If Jahangir has earned a measure of passive blame for these developments, in most historiography it is really with Shah Jahan's reign that a conscious and ominous "return to Islamic political culture" is said to have commenced, fueled by what John Richards specifically describes as "an orthodox reaction to the policies of Akbar and Jahangir." ${ }^{\prime 10}$ This supposed demise of the politics of pluralism and sulh-i kull under Shah Jahan is itself almost always framed, however, as a mere prelude to the supposedly full-blown return to orthodoxy of his successor Aurangzeb 'Alamgir (r. 1658-1707), whose infamous bigotry is held liable for the Mughals' eventual decline and has made him into arguably the single greatest villain of modern Indian historiography. Indeed, Aurangzeb's piety has been magnified in many narratives into a force so militant, so malevolent, and so sweeping that it can be held responsible for initiating virtually the entire chain reaction of India's modern woes. His "implacable orthodoxy" is routinely singled out as the primary cause for any and all resistance to Mughal power during his tenurealienating Hindus, Sikhs, and other non-Muslims generally (all of them!) until the delicate balance of Mughal political coalitions was irreversibly fractured and the treasury irrecoverably drained by his zeal for "extending Islamic dominion." So nefariously omnipotent was this zeal, in many people's minds, that it is even commonly blamed for the fractious nature of South Asian politics after Aurangzeb's death. Thus it is not at all uncommon to find this last of the "great Mughals" being indicted not only for the "perverted genius" of his own career but also for the bungling of those who came after him, stalling India's potential for modernity in its tracks and creating the opening for the British conquest, which in turn set the subcontinent on its inexorable path, with the aid of British colonial mischief, to its traumatic partition in $1947 .^{12}$

This conventional wisdom is not just a common thread in modern Mughal and South Asian historiography; it has also, by virtue of being the narrative most commonly available in English-language sources, become a staple of works on global and world history, even in the present era of otherwise widespread postcolonial 
skepticism of such simplistic explanatory frameworks. Thus, while it is true that a number of specialists in Mughal social, cultural, and economic history have made important interventions in recent years that shed new light on the period and make possible a more nuanced view of its culture and politics, the old teleologies somehow manage to persist and gain wide currency. To take just one of many potential examples, consider this passage from Charles H. Parker's recent survey Global Interactions in the Early Modern Age, 1400-180o (2010): "After Akbar, conservative clerics gained more influence at court, and emperors adopted a much more orthodox Muslim stance. Consequently, Mughal society during the seventeenth and eighteenth centuries became re-Islamized, as jurists applied shari'a $[s i c]$ law, emperors patronized clerics and theologians, and clerics pushed non-Muslims to convert. This trend intensified under Aurangzeb. ... The social division and cultural insularity created by the revival of a strident and uncompromising Islam contributed to the weakening of the empire in the early $1700{ }^{{ }^{13}}{ }^{{ }_{13}}$ The question of Mughal religious tolerance and cultural civility is thus inextricably bound up with the question of the success of the empire as a whole and has powerful implications for how we think, not just about early modern South Asia, but about the early modern world writ large.

For one thing, the idea that Akbar's successors oversaw an Islamic "revival" or a "return" to orthodoxy has a way of also reinforcing the inaccurate and oversimplified notion that "orthodoxy" was somehow the default position of India's pre-Mughal Muslim rulers, too-and in fact of "political Islam" generally. Absent the heroic intervention of a figure like Akbar, the thinking seems to be, the natural inclination of Muslims is to revert-or "re-Islamize," as Parker put it-to an orthodox stance that is intrinsically hostile to other religions and cultures. This fundamental postulate contributes, in turn, to a whole host of other inferences about the nature of the Mughal state, the nature of Islam in South Asia, the status of Indic religious and cultural traditions under Muslim rule, and even the very capacity of South Asian people and polities to participate in modernity. For it was this very "return to orthodoxy" and the attendant Mughal "decline" that is often said to have prevented India from keeping pace with Europe in the seventeenth and eighteenth centuries, in turn helping to produce the great macrohistorical divergence that allowed Europe ultimately to colonize and dominate the subcontinent. The supposed Mughal failure to take full advantage of Akbar's enlightened reforms, in other words, is almost inevitably joined in a good deal of historiography-sometimes only implicitly, but often quite explicitly—to the parallel narrative of triumphal European enlightenment and modernity, as a key explanatory bullet point in the larger story of "the rise of the West." The Mughals may well have had their early modern moment in the sun under Akbar, such narratives will acknowledge, but the poisoned pill of Islamic orthodoxy made it impossible for them to truly modernize, making European colonialism inevitable. 
Perhaps there is some kernel of truth to all this conventional wisdom. But if post-Akbar Mughal society really did witness such a "revival of a strident and uncompromising Islam," then wouldn't we expect to see at least some evidence of it in the testimony of a prominent Hindu who lived through this period? Would we not expect a Brahman like Chandar Bhan, who spent the better part of five decades interacting daily with Muslims in Mughal politics, administration, and society, to show at least some indication that he felt threatened by the "much more orthodox Muslim stance" of Akbar's successors, harried at every turn by the growing influence of "conservative clerics ... pushing non-Muslims [like him] to convert"? Wouldn't the "social division and cultural insularity" of such a "reIslamized Mughal society" make it impossible for a high-caste Hindu to move up the social ladder and forge such amicable professional relationships with so many Muslim denizens of the court, much less earn considerable literary fame among those very same networks?

To the contrary, Chandar Bhan's experience of the Mughal seventeenth century suggests a rather different interpretation of the post-Akbar period. It may be just one voice, but it is a powerful one, and while Chandar Bhan's life and experience by themselves may not be enough to undo generations of scholarly conventional wisdom, they will definitely force us to ask some hard questions concerning what we really know about the period. Before examining some of his works in greater detail in subsequent chapters, then, let us begin with a survey of his life, drawn largely from his own writings and those of his contemporaries, and set against the backdrop of the larger historical context and the various sorts of cultural networks in which he operated.

\section{CHANDAR BHAN'S FAMILY, EARLY LIFE, AND EARLY CAREER}

"I am a Brahman," Chandar Bhan tells us about midway through his magnum opus Chahär Chaman (The four gardens), "who was born in the country [mulk] of the Punjab, and has achieved distinction and esteem among the eminent wearers of the sacred thread of the Brahmans." ${ }^{14}$ Unfortunately, the munshi does not tell us the actual date of his birth, but on the basis of internal evidence within his various writings it would appear that it was sometime toward the end of the reign of Jalal al-Din Muhammad Akbar (r. 1556-1605), who, as we have seen above, was the third and most widely celebrated emperor of the Mughal dynasty. By the reign of Akbar's grandson Shah Jahan (r. 1628-58), the titular "King of the World" and famed builder of the Taj Mahal, Chandar Bhan would emerge as one of the most eminent litterateurs and state secretaries (munshiss) of the early modern Indo-Persian world.

Even though the actual date of his birth remains a mystery, Chandar Bhan does tell us a number of things about his background and early life that show clearly 
that his affiliation with the Mughal state and his abilities as a Hindu savant of Persian were not unique even in his own family, much less in Mughal society generally. The same passage quoted above goes on to explain that Chandar Bhan's father, Dharam Das, was actually the first in his family to learn Persian and enter Mughal service: “This supplicant's birthplace and early education occurred in the city of Lahore, the Abode of the Sultanate. The ancestors of this rightly faithful Brahman had remained engaged in our ancient ways up until the time of this faqi $r$ 's father, Dharam Das. He was a scribe of considerable skill [nawisanda-i kārdānī bū d] and after a time managed to earn an official status as a rankholder [manșabdār] in the imperial government. Later, with an eye toward the fickleness of unpredictable fate, he resigned from his government appointment and retired to a quiet corner" $(C C, 145-46)$. Chandar Bhan's connection with the Mughal court thus begins, in a sense, before he was even born. Alas, there does not appear to be any surviving record to confirm exactly what capacity Dharam Das served in, but presumably it was as some sort of secretary or minor official in Akbar's provincial Punjabi government. ${ }^{15}$ It is important, then, to remember that when it comes to the Mughals the surviving records and statistics do not always tell the whole story. That we know of Dharam Das's connection to the Mughal state at all is thanks only to this fortuitous mention by his much more famous son. But it suggests that probably a far greater number of Hindus and other non-Muslims served medieval and early modern Indo-Muslim states than is often assumed, even if we don't always have the archival traces to prove it.

We also do not know what, if any, social consequences there might have been for Dharam Das's decision in terms of caste. We are so prone in modern times to project strict caste taboos back into the past as "traditional" ways of doing things that it would strike at least some readers, one suspects, as surprising for a sixteenth-century Brahman to risk the loss of his caste purity by learning Persian and working on behalf of a "Muslim" state (even one as ecumenical as Akbar's). But Chandar Bhan, for his part, seems to have had no such reservations, showing no signs of anxiety or conflict between pride in his Brahmanical heritage and his family's affinity for either the Indo-Persian ecumene or Mughal administrative service.

To the contrary, Chandar Bhan seems to have viewed his caste status less in terms of ritual purity than in terms of a general commitment to intellectual excellence. He notes that even though Brahmans as a class (t $\left.\bar{a}^{\prime} \mathrm{ifa}\right)$ "engage in various worldly professions," what sets them apart is that they have "retained the ability to discern the nuances of visible and hidden meanings" ( $p \bar{a} s-i$ marātib- $i$ șuwari wa ma'nawi dāshta) and that they continue to live "in conformity with the ways prescribed for them in reliable ancient books" (ba wajhi ki dar kutub-i mu'tabar-i qadìm dar bāra-yi in guroh șabt shuda). His understanding of Brahman-ness thus definitely had a "traditional" component, but it was not so restrictive that a mere interest in Persian literature, expertise in Sufi mystical idioms, or employment by 
the Mughal state could threaten it. Indeed, he reinforced this expansive understanding of his caste identity through his selection of "Brahman" as his literary pen name (takhalluş) —a decision that meant, of course, that every Persian ghazal he ever composed would include at least one couplet in which he could meditate playfully on the meaning and nature of Brahman-ness. ${ }^{16} \mathrm{He}$ does so, for instance, in this couplet:

It is incumbent upon us to serve the idol, Brahman;

How can any image that resides in the heart be erased?

[lāzim āmad bar sar-i mā khidmat-i but barhaman mahw kai gardad har ān naqshī ki dar dil-hā nishast] $(D B, 73.5)$

Here Chandar Bhan plays with the cliché of the Hindu as idol worshipper to assert that the true "idol" that the Brahman serves is actually the abstract universal truth that one cannot access visually but only through the heart's or mind's eye. He is drawing, in other words, on the idioms of both Hinduism and Islam to express a quintessential mystical theme. There are over three hundred ghazals in Chandar Bhan's printed dìwān of poetry, nearly all of which end on couplets that deploy the term Brahman in similarly playful, unusual, clever, or unexpected ways.

Chandar Bhan had two brothers, too, who were both Persian savants. Indeed, his numerous extant letters to them suggest that they both had not only a high degree of Persian literacy but also considerable secretarial training and familiarity with mystical and literary idioms. ${ }^{17}$ One brother, Ray Bhan, appears to have taken a spiritual path in life and become something of a hermit, for Chandar Bhan explains rather enigmatically that "the passion for self-liberation fell into Ray Bhan's head and he developed an antipathy toward earthly attachments" $(C C, 146)$. But the third brother, Uday Bhan, like Chandar Bhan himself, was at least for a time engaged in more worldly pursuits, including a connection to the Mughal bureaucracy. "On account of his ability and talents," Chandar Bhan explains, "Uday Bhan warmed to the potentials of the age [sar-garm-i nashä'-yi rozgār shud] and received training through his association with that pillar of great nobles, 'Aqil Khan" $(C C, 146)$. (Here Chandar Bhan refers to "Aqil Khan Shirazi, a minor official with whom our munshi was also quite well acquainted, and whom we will discuss in greater detail below.)

Chandar Bhan trained his son Tej Bhan in classical Persian literature and the secretarial arts as well, for the young man clearly knew enough Persian to read his father's many elegant letters to him $(M B, 93-104,106-7) .{ }^{18}$ Unfortunately, we know very little about Tej Bhan's exact career trajectory, but we do know from a reference to him in the official court records of Aurangzeb's reign (discussed in greater detail below) that by the mid-166os Tej Bhan was employed by the state as some sort of revenue official. After that, he seems to disappear from the historical record. 
Be that as it may, it is important to note that a willingness to engage with $\mathrm{Mu}$ ghal forms of civility and Persianate cosmopolitanism wasn't just a family affair in Chandar Bhan's early life. He tells us in a passage from Chahār Chaman that "this faqìr first studied the ta'ì $q$ script with one Banarasi Das, the son of Pratap Ray Kayastha," who appears to have been some sort of provincial treasury officer (mushrif) and who was, according to Chandar Bhan, "endowed with great intellect and understanding" (ba kamāl-i ma'qūliyat wa fahmìdagī ārāsta ast). ${ }^{19}$ Chandar Bhan adds that the latter's brother, a certain Sundar Das, was also a scribe who "writes the broken script [ khatt..t-i shikasta] in the manner of [the renowned Mughal calligrapher] Mirza Muhammad Husain.”

Elsewhere, Chandar Bhan also mentions a number of "shüdra" (i.e., lowercaste) acquaintances who were part of the network of scribes and revenue officials in Punjab at the time, for instance in this passage from another letter to one of his brothers, in which he informs the latter of the death of one of his old teachers:

During the bloom of youth, this faithful supplicant took lessons in the broken script [khatt-i shikasta] from Jatmal Shudra, who, having left the bodily cage, has sauntered off to the world of the spirit [az qafas-i jismānì bar āmada ba 'älam-i rūhānn̄ khirāmida]. Now the only living reminder of that voyager to the eternal world is his brother, Nisbat Ra'o, who was known among his contemporaries for originality, balanced temperament, and the power of his words [matānat-i kalām]. There was also Gopi Chand Shudra, who has a great flair for writing ta'li $q$ and shikasta scripts. In fact, among the community [qaum] of shüdras [there are also] Bhagawant Ray and Narayan Das, and their other brothers, [who] have all become quite famous for draftsmanship, and this faqīr is an avowed disciple of this community [shägirdī-yi in qaum ishtihār dārad]. ${ }^{20}$

Again, to modern ears accustomed to hearing about the inflexibility of "traditional" premodern caste strictures, Chandar Bhan's relaxed attitude here is a refreshing corrective. But more importantly for present purposes, his remarks clearly indicate that the spread of Persian literacy in late sixteenth- and early seventeenth-century Punjab went well beyond the imperial bureaucracy and was by no means exclusive to a few token Hindus, or to specific communities like khattrīs and kāyasthas, as has sometimes been suggested.

Indeed, if one examines Chandar Bhan's collected correspondence, one finds dozens of Persian letters addressed to other Hindu elites of the time like Raja Muhkam Singh, Raja Dhokal Singh, Raja Najab Singh, Ray Mohan La'l, Ray Thakur Das, and Ray Gobind Das. There are also numerous letters of "recommendation" (sifärish) in which Chandar Bhan attests to the Persian literacy and scribal talents of many more friends, family members, and disciples of varying social and caste backgrounds. ${ }^{21}$ Most of these are addressed to various Mughal officials, both Hindu and Muslim, but at least one is addressed to one of his brothers-probably Uday Bhan; in it Chandar Bhan praises the abilities of a certain 
Bihari Das, describing him as "the faujdār of Bareli," whose outstanding penmanship Chandar Bhan has seen with his own eyes while reviewing petitions submitted to the office of the wazir Islam Khan. Chandar Bhan explains that Bihari Das "is a man who understands literature, avoids verbosity, and is an agreeable social companion" (mard-i sukhan-fahm [wa] mudda'ä-nawīs [wa] khhwush-șhbat ast) -one who is also "possessed of an even temperament [tab'-i mauzūnī]" and, for good measure, has authored a good deal of poetry in both the ghazal and mașnawi forms. ${ }^{22}$

Most of the people in this extended network have left little trace in the historical record beyond their names - the aforementioned Bihari Das, as well as others named Shankar Das, Surat Singh, Pran Nath, Khwaja Sagar Mal, and so on-as they appear in Chandar Bhan's letters; and probably very few were all-around litterateurs even approaching Chandar Bhan's caliber. But the echo of their voices in his correspondence speaks volumes about the wide pool of talented Hindu intellectuals and service professionals among whom Persian was viewed as a relatively unproblematic, neutral language of everyday correspondence, literary expression, and social mobility in seventeenth-century North India.

\section{EVERYDAY PLURALISM IN PRACTICE}

The traces of such networks are also a potent reminder that everyday social, cultural, and political life in Mughal North India, even among relative elites, did not begin and end with whatever was going on in the imperial court. The peccadilloes of emperors and the royal family notwithstanding, there was still an empire to be run, and the bulk of that administrative work was performed by career ministers (wazīrs), agents (wakils), provincial notables, magistrates, secretaries, and other officials whose everyday habitus and working relationships tended to be marked by a confident pluralism and the widespread accommodation of cultural diversity in the areas they administered.

Like Chandar Bhan, many, if not most, of these nobles and career civil servants had careers that spanned the reigns of multiple emperors, lending a measure of continuity to Mughal governance even through periods of crisis and transition at the top. Indeed, without the acceptance of such values among a broad swath of nobles and other subimperial officials out in the provinces, the ideology of sulh $-i$ kull propagated from the rarefied atmosphere of the imperial court would likely have amounted to little more than an idealistic desideratum, even in the halcyon days of Akbar's reign.

In Chandar Bhan's case, we see that his whole family was connected quite amicably to a cluster of Mughal nobles, minor officials, and intellectuals in and around Lahore during the reign of Akbar's successor, Jahangir (r. 1605-27). In the passage cited above he does not specify who his father Dharam Das's specific 
patrons were, but he does tell us about some of his brothers' associates, usually with profound respect and even, at times, with a pronounced tone of mystical longing. Note, for instance, the language that he uses to describe his brother Uday Bhan's affection for his friend and employer 'Aqil Khan (d. 1649), who died suddenly while on imperial business in Afghanistan in 1649: "When that Khan, still in the prime of youth and success, hastened from this impermanent world and transient way station to the eternal province [i.e., died], within days [my brother] Uday Bhan lifted a goblet of love from the tavern of truth and turned to the bliss of eternal intoxication. At present he is a complete stranger to the ways of worldly people" $(C C, 146)$. Chandar Bhan, too, had a friendly epistolary correspondence with 'Aqil Khan, who had a long career in Mughal service dating back to the beginning of Jahangir's reign. ${ }^{23}$ According to the eighteenth-century biographical compendium Ma'äsir al-Umarā, he was said to have been "accomplished in both poetry and accounts" (az nazm wa siyāq bahra-war büd) and to have served for a time in the position of 'arz-mukarrar, or editor of royal petitions-precisely the sort of appointment that would earn the appreciation of an elite munshi like Chandar Bhan. ${ }^{24}$

Though he was never one of the elite grandees of the court, 'Aqil Khan did hail from a notable family of Persian émigrés to the Mughal court. He himself was married to the adopted daughter of Sati al-Nisa Khanum (d. 1647), the erudite "seal-bearer" (muhr-dār) of the royal harem, tutor of Princess Jahan Ara, and sister of Jahangir's onetime poet laureate Talib Amuli (d. 1626-27). ${ }^{25}$ His father, 'Abd al-Haqq Shirazi (d. 1644-45; later known by the title Amanat Khan), had come to India and become involved with Mughal politics as early as the 1610s and had left quite an artistic and architectural legacy. ${ }^{26}$ An extremely learned man, Amanat Khan spent some time as the royal librarian and also seems to have been tasked occasionally with certain administrative and diplomatic assignments. But he is best known to posterity as an accomplished calligrapher. Early in his career he designed the decorative inscriptions (and possibly authored some of the poetic eulogies) for Akbar's tomb at Sikandra (Agra), completed in 1613, as well as for the Madrasa Shahi ("King's College") mosque, also in Agra. More famously, however, it was he who crafted the exquisite Qur'anic and literary inscriptions inlaid on the Taj Mahal and its surrounding complex, arguably this legendary monument's "single most important decorative feature." ${ }^{27}$ As we've noted more than once, it is difficult to think of a more iconic symbol of the grandeur of Indo-Islamic imperial architecture-not to mention the visual iconography of modern South Asia generally-than the Taj, and 'Aqil Khan's father was, quite literally, the man who put the writing on the walls.

Arguably, though, the most famous person in the family was not Amanat Khan but rather his brother (and 'Aqil Khan's uncle), Mirza Shukr Allah Shirazi (d. 1639), who is better known to posterity by his Mughal title of "Afzal Khan." Afzal 
Khan had come to India from Persia in 1608 and, after a brief stint in the service of the Mughal grandee 'Abd al-Rahim Khan-i Khanan in Burhanpur, had joined the retinue of Shah Jahan while the latter was still a prince serving in the Deccan. ${ }^{28}$ Renowned as one of the most learned men of the times, Afzal Khan was often hailed in contemporary sources as a second Plato or Aristotle and was saluted, like Akbar's great minister Abu al-Fazl, with the epithet 'Allāmī, or "the learned one." He quickly made a name for himself in Mughal political circles as a keen administrator and an especially astute diplomatic fixer and had already emerged by the 1620 s as one of Shah Jahan's key advisers. But although he spent his career in Mughal service primarily as a political and administrative officer, it would appear from a number of contemporary sources that what those who interacted with him most remembered about Afzal Khan was his profound humility, civility, and mystical orientation. 'Abd al-Baqi Nahawandi's Ma'ạsir-i Rahīmī (1616), for instance, actually lists Afzal Khan under the category of prominent 'ulamā and fuzalā ("learned and eloquent men") of the times, while another contemporary source, Muhammad Sadiq Hamadani's Ṭabaqāt-i Shāhjahānī, similarly lists him first among the era's most "learned, wise, and eloquent men" ("ulamā wa hukamā wa fuzalā). ${ }^{29}$

As we will see below, Afzal Khan was also a crucial mentor to our own Chandar Bhan early in his career, and arguably the single most influential person in the munsh $\vec{\imath}$ s professional life. But even before he became associated with Afzal Khan Shirazi, Chandar Bhan had other early patrons who connected him to the court and probably deserve the credit for giving him his start in Mughal bureaucratic service. We know, for instance, that Chandar Bhan had a profound respect and admiration for the man who appears to have been his first employer, 'Abd alKarim "Ma'muri" ("the builder"), who was at one time the chief architect (mìr-i 'imārat) of Lahore but later went on to even greater renown as one of the superintendents of financing and construction for the Taj Mahal..$^{\circ}$ While his brother was working for 'Aqil Khan, Chandar Bhan tells us, he himself "benefited from worldly training in the service of Mulla 'Abd al-Karim, a master among principled

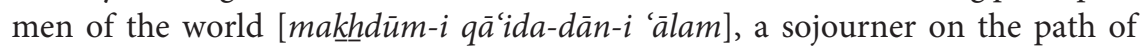
asceticism, renunciation, equanimity, and resolve ['äbir bar jäda-yi faqr wa ghinà' wa qiyām wa mustaqīm]; my apprenticeship to that master has proved to be like a

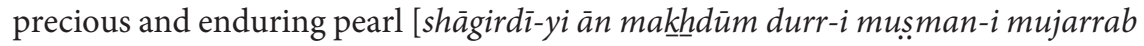
ast]" (CC, 146).

Dating Chandar Bhan's time in 'Abd al-Karim's employ is difficult, but we do know that the latter was already in Jahangir's service as early as March of 1615 , when the emperor dispatched the architect to the summer retreat of Mandu to "build from scratch a palace there for the royal retinue and to repair the buildings of former rulers." ${ }^{11}$ Two years later, on March 18, 1617, Jahangir promoted 'Abd al-Karim to the manșab rank of 80o/40o and "gave him the title Ma'mur 
Khan as a reward for the reconstruction of Mandu, which was carried out under his supervision." "32 Just one month later the newly dubbed Ma'mur Khan "was dispatched to Lahore for construction of imperial buildings," and it is possible, even likely, that it was around this time that Chandar Bhan entered his service..$^{33}$ Thus Chandar Bhan might have been working for 'Abd al-Karim when the latter finished some of his renovations to Lahore Fort in 1617-18, a project that is commemorated by an inscription affixed to the citadel's makätib-khāna, or "secretary's quarters," which names "the servant [ $f i d w \bar{i}]$ Ma'mur Khan" as the chief architect. ${ }^{34}$ If so, then Chandar Bhan was probably also with "Abd al-Karim when the latter was promoted to the mansab of 900/450 in March of 1619 and when Jahangir toured some of the architect's new Lahore buildings in November $1621^{35}$ but unfortunately, we cannot say for sure.

Precise dating aside, the main point here is that, while 'Aqil Khan and Mir 'Abd al-Karim were both well-respected and well-connected figures, in the grand scheme of things they were also, ultimately, relatively minor officials-nowhere near the power and influence of truly elite grandees of the court and the select group of others on whom most modern Mughal historiography has focused. Yet it was precisely such people from this middling to lower tier of Mughal officialdom, almost completely unknown today, that not only provided a level of administrative continuity from one reign to the next but also set a tolerant example and dispensed the kind of local, everyday patronage that made the broader ideology of sulh-i kull actually work in practice. Without figures like 'Aqil Khan and Mir 'Abd al-Karim to recognize their talent and facilitate their careers early on, a great many Hindus like Chandar Bhan and his family would very likely never have even entered Mughal service in the first place, much less had such success once they did so.

It is important to note, too, that Chandar Bhan's family was hardly alone in following this pattern. One of the best-known Hindu munshiss of the seventeenth century besides Chandar Bhan was Harkaran Das Kambuh of Multan, who worked as a secretary for I'tibar Khan (aka "Mumtaz Khan," d. 1623), an important noble and ally of Jahangir's court who served for a time as governor of Agra and helped to defend it during Shah Jahan's rebellion as a prince. ${ }^{36}$ Like Chandar Bhan, Harkaran came from a family in which multiple members were literate in Persian and held administrative jobs. His father, Mathura Das, seems also to have gained some distinction as a poet, while Harkaran himself penned one of the most widely circulated Persian model letter collections of early modern South Asia. Originally titled Irshād al- Tălibìn (A student's primer; 1622), the collection later came to be commonly referred to simply as Insha $\bar{a}^{\prime}$ yi Harkaran (The prose stylings of Harkaran). It was under this latter title that the East India Company doctor Francis Balfour translated it in 1781 (dedicating it to none other than Governor-General Warren Hastings), making it perhaps the first didactic treatise on 
Indo-Persian letter writing produced by the British colonial administration, and among the first printed books ever produced in India. The text contains numerous examples of the appropriate prose style for different types of epistolary correspondence, as well as samples of various official government orders (farmāns) and other types of administrative documents. But the important point here is that Harkaran did not work for Jahangir or one of jewels of the court; he worked for I'tibar Khan, a man who is virtually unknown today. ${ }^{37}$ This fade into relative obscurity notwithstanding, Harkaran nevertheless saw fit to praise I'tibar Khan as "the benevolent Nawab of exalted title, the refuge of the meek, whose workshop is paradise, the Hatim of the times, the Anushirwan of the age." ${ }^{8}$

We have already seen that Chandar Bhan had a similar relationship with 'Abd al-Karim Ma'muri, and another provincial officer who made a big impression on Chandar Bhan early in his career was 'Inayat Khan 'Inayat-Allah (d. 1618), the onetime governor of Lahore province. Chandar Bhan mentions 'Inayat Khan kindly in a brief (though unfortunately undated) letter addressed to "Maulana 'Abd al-Karim," who was apparently a friend of 'Inayat Khan and might well have been the person to have introduced Chandar Bhan to the governor. Be that as it may, after expressing his regrets for not having met his "true teacher" (ustād-i haqi $q \bar{\imath}$ ) in person for some time, Chandar Bhan explains to 'Abd al-Karim that he has enclosed a freshly composed lyric poem (ghazal) for his perusal and then closes the letter by hoping that the recipient will also convey his good wishes "for the descendant[s] of 'Inayat Khan's illustrious family, may they reach a ripe old age under the shadow of kindness from on high" $(M B, 25)$. The context is not entirely clear, but we may surmise that this letter was written soon after 'Inayat Khan's untimely death from alcohol and drug addiction in 1618, which would further corroborate our suspicion that it was sometime in the mid- to late 1610 s that Chandar Bhan entered Mughal service. ${ }^{39}$

But however murky the exact details of Chandar Bhan's acquaintance with 'Inayat Khan, we know for sure that it also gave him a connection to at least one hugely influential member of the extended royal family, the "Right Hand of the Empire" (yamin al-daula) Abu al-Hasan Asaf Khan (1569-1641). We know this from a letter that Chandar Bhan wrote directly to Asaf Khan later in life, in which he recounts having had the opportunity to witness firsthand 'Inayat Khan's elegant comportment, adding that the latter "had neither peer nor equal in terms of honesty and integrity" (dar rāstī wa durustī 'adīl wa nazìir nadāsht) (CC, 151; $M B, 15-16)$. 'Inayat Khan had at some point intimated, apparently, that he would introduce Chandar Bhan to Asaf Khan, of whom he was a protégé of sorts, perhaps with the ultimate goal of securing a more prestigious secretarial post at court for the ambitious munshī. But, as Chandar Bhan laments, "The vicissitudes of fate had kept this from coming to pass" (az ittifāqāt-i rozgār ìn ma'nì dast ba-ham $n a d \bar{a} d$ ) — again, probably a polite way of referring to 'Inayat Khan's problems with 
substance abuse and untimely death. Now, years later, Chandar Bhan explained that since he had nevertheless managed to enter the royal service through the auspices of Afzal Khan Shirazi, he considered himself a servant of Asaf Khan as well, looked forward to learning from him, and wished him a long life and good fortune.

Of course Asaf Khan himself-who is known primarily for having been the elder brother of Empress Nur Jahan (and thus the brother-in-law of Emperor Jahangir), as well as the father of Arjomand Banu Begum, aka Mumtaz Mahal, for whom the Taj Mahal was built (and thus too the father-in-law of Emperor Shah Jahan) - is yet another noble, patron, and contemporary of Chandar Bhan who exemplified the type of multireign cultural continuity that I have discussed above. His life spanned the better part of three reigns and included an illustrious, if complicated, political and military career. ${ }^{40}$ When Shah Jahan came to power in 1628, Asaf Khan was one of the new emperor's most stalwart allies, despite lingering friction between Shah Jahan and Asaf Khan's own sister, the influential Empress Nur Jahan. In return, he was part of the team entrusted by Shah Jahan with taking over the chief administrative responsibilities of the empire, which were initially split between Asaf Khan himself, who served as the wakil (chief adviser), and another noble named Iradat Khan, who had the title of wazir (chief minister).

It is often forgotten, however, that Asaf Khan also had a Hindu assistant by the name of Ray Mukund Das, a kāyastha who, at least according to Chandar Bhan, "was always at Asaf Khan's side" (wa Rāy Mukund Dās Kāyastha ham-dast wa ham-zamān [zabān?]-i Āṣaf Khān būd) (CC, 52). Another source, Shaikh Farid Bhakkari's Zakhīirat al-Kh hawānin, gives the impression that Mukund Das earned great wealth and prestige in Asaf Khan's employ and notes too that after the latter's death in 1641 Mukund Das continued to work in Shah Jahan's governmentfirst as supervisor of royal factories and stores (dīwān-i buyūtāt), then as auditor of crown lands ( $\underline{k} \underline{h} \bar{a} l i s ̣ a-y i$ sharifa), and then as chief payroll officer (șāhib-i tan)adding that "even today he continues to be honored, respected, and held in great esteem." 41

Asaf Khan did more than just hire secretaries, though. He was also one of the most important and influential scientific and intellectual patrons of the era. By the time of his death, he had amassed an enormous fortune valued at over twenty-five million rupees, not only through his imperial salary but also through his enterprising commercial trading ventures, including partnerships with European concerns. ${ }^{42}$ And it was by tapping into such wealth, for instance, that he was in a position to commission the erstwhile 'Adil Shahi astronomer Farid al-Din Mas'ud ibn Ibrahim Dihlawi (d. 1629) to develop a new calendar commemorating the start of Shah Jahan's reign. The Zīj-i Shāh Jahānī, as it came to be known, was grounded in the traditional astronomical computations of the celebrated Timurid ruler and 
scientist Ulugh Beg (d. 1449), but Asaf Khan clearly had an eye toward updating Ulugh Beg's "Modern Calendar" (Zīj-i Jadìd) for the Indian context. Presented to the new emperor soon after he took the throne, the Zīj-i Shāh Jahānī was also, at Asaf Khan's request and expense, immediately translated into Sanskrit by a Delhi Brahman named Nityananda. The latter version, known as the Siddhäntasindhu, circulated widely in the courts of nobles and kings throughout India, both Muslim and Hindu. ${ }^{43}$ And both the Persian original and the Sanskrit translation would, in turn, become key sources a century later for the great Rajput ruler and astronomical savant Sawai Jai Singh II (1688-1743), who wrote his own updated Zijj dedicated to the reigning Mughal emperor Muhammad Shah (r. 1719-48), in which he claimed to outdo even the most up-to-date European astronomical calculations (with which he was more than familiar). ${ }^{44}$

Asaf Khan patronized not only Sanskrit science but also Sanskrit literature. For this he was eulogized by one of the giants of seventeenth-century Sanskrit literary culture, Jagannatha Panditaraja, in an eloquent ode (praśasti) called Āsafa-vilāsa (The elegance of Asaf). ${ }^{45}$ Details of Jagannatha's exact biography are sketchy, but he very likely came to Delhi from Telingana in southern India during the reign of Jahangir, whom he mentions approvingly in his monumental treatise on the poetic arts, the Rasagangādhara (The Ganga-bearer [i.e., Shiva] of aesthetic moods). When power changed hands, he continued to enjoy the patronage of Shah Jahan, who was responsible for giving him the title of Panditaräja (King of Pandits), and whom Jagannatha also praises extensively in Âsafa-vilāsa, calling him the "Lord of All the World" (sarva-bhauma, i.e., an almost exact translation of the Persian "shāh-i jahān").

We do not know if Chandar Bhan himself was personally acquainted with Jagannatha or any of the numerous other Sanskrit and Hindi intellectuals that continued to be patronized by the Mughal court during this period. He does refer quite regularly to "Hindi" musicians and dancers in his descriptions of various court festivals, but unfortunately he does not give us any detailed information on their identities or on the exact nature of their relationship with the court and the many nobles like Asaf Khan who patronized them. Still, as Allison Busch and Katherine Butler Schofield (née Brown) have recently shown, there were clearly plenty of such intellectuals around, even if the sources-including Chandar Bhan's own writings-do not always give us the full picture of their involvement in Mughal court life in the seventeenth century. ${ }^{46}$

Meanwhile, after his stint in the employ of Mir 'Abd al-Karim, Chandar Bhan himself had begun to work for the aforementioned Afzal Khan Shirazi, and was still with him when the latter became prime minister in early 1629 , barely a year into Shah Jahan's reign. Thus began a remarkable stretch in which, over a period of roughly three decades, our munshi worked in some capacity either directly for the emperor himself or for every subsequent prime minister of Shah Jahan's reign. 
Some of this time was spent as Shah Jahan's personal secretary and diarist (wäqi'anawis), a post that required Chandar Bhan to draft papers related to the emperor's

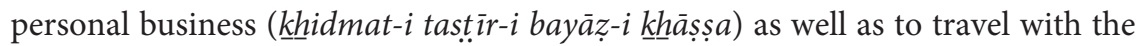
royal retinue and to record his daily impressions of the landscape and particulars of the climate, flora, and fauna of various locales for the imperial diary $(C C, 150)$. But in terms of his official duties, Chandar Bhan spent the bulk of this period working in the imperial fiscal office $\left(\operatorname{di}_{\bar{\imath}} w \bar{a} n \bar{\imath}\right)$, where he worked with a succession of Mughal wazirs like Afzal Khan (d. 1639), and then later Islam Khan Mashhadi (d. 1647), Sa'd Allah Khan (d. 1656), Mir Muhammad Sa'id Ardastani "Mu'azzam Khan," better known simply as "Mir Jumla” (1591-1663), and Ja'far Khan (d. 1670).

Among these, as we will see in the next chapter, Afzal Khan and Sa'd Allah Khan clearly impressed our munshi the most, both for their learning and for their gentlemanly ways. In general, Chandar Bhan's reflections on this part of his life and career provide a fascinating window onto the ideals of ministerial and secretarial conduct as they related to Mughal governance. But the important point to reiterate here is that we get no indication whatsoever from Chandar Bhan's descriptions of the convivial atmosphere cultivated in such Mughal administrative circles of the kind of "social division and cultural insularity created by the revival of a strident and uncompromising Islam" which this period is so often said to have witnessed, as referenced above. Nor, for that matter, do we find any hint or suggestion that any of these Muslim nobles had the slightest problem with Chandar Bhan's religious background, much less pressured him to convert. On the contrary, at least insofar as we can glean from Chandar Bhan's testimony, a general attitude of courtesy and civility remained the dominant mode of professional interaction throughout Shah Jahan's reign, and even, as we shall see below, well into Aurangzeb's.

\section{A GLIMPSE OF MEDICAL SCIENCE AT THE MUGHAL COURT}

Chandar Bhan also gives us occasional, yet tantalizing, glimpses of other aspects Mughal intellectual culture. One such passage, which appears early in most manuscripts of Chahār Chaman, hints for instance at the sophisticated culture of medicine and medical professionals at court, and relates to a well-known incident that happened roughly midway through Shah Jahan's thirty-year reign. In March 1644, to be exact, there was a horrible accident in which the emperor's eldest daughter, Princess Jahan Ara Begum (aka "Begum Sahib”), was severely burned when her dress brushed against one of the lamps in the palace and went up in flames. Jahan Ara was, it should be noted, no ordinary princess. She was by far one of the most beloved figures at court, widely admired not only for her graceful demeanor but also for her learning and patronage, particularly of various prominent Qadiri and Chishti Sufis and their institutions. Her prominence 
in this regard was only enhanced by the fact that Jahan Ara had in many ways taken on the persona and palace responsibilities usually reserved for the Mughal queen following the death in 1631 of her mother, Mumtaz Mahal. Thus Jahan Ara's accident came as a particular shock to the entire court community, and her extensive injuries caused many, including the emperor, to fear for the princess's life. ${ }^{47}$

Chandar Bhan, in his typically florid prose, uses the opening of his version of the episode as an opportunity not only to eulogize the princess herself but also to make a philosophical point about the mysteries of fate and the fragility of human existence, even for the rich and powerful:

In those days when the victorious flags and triumphal standards and conquering imperial banners as high as the sky were majestically encamped in the seat of the caliphate Akbarabad [i.e., Agra], by the force of fate and destiny-the mysteries of which are concealed and veiled even from the eyes of men of vision-on one of the nights in the month of Farwardin a stray spark from a lamp ignited the hallowed skirt of that nawāb of blessed title, the empress of the age, a Rabi'a in character and a Maryam in manner, the Zubaida of contemporary women, the grand dame of the times renowned throughout the world, [Princess Jahan Ara] Begum Sahib, whose dress was so like an ornament in paradise that it pulled a veil over the face of heavenly nymphs [hürān-i bihishtī], and whose veil of honor and curtain of dignity [muhajjaba-i 'izzat wa haudaj-i rif'at] cast a shadow even over the world-illumining sun. $(C C, 33-34)$

From here, in one of the longest extended passages of the entire text, Chandar Bhan goes on to narrate details of the princess's lengthy period of recovery, including her bravery and humble piety in the face of what he describes as "an agony so severe that merely describing it makes my pen tremble like a willow tree [bid]." He also draws our attention to the emperor's own personal involvement in overseeing her medical care. "His Majesty's mind was so distracted by care and concern for that blessed one's condition that these folios don't have space [to describe it]," the munshi tells us, adding that "from the time of the accident's occurrence right up to the day her infirmity receded, throughout the day and night he would give only one general audience in order to assuage the concerns of his subjects before again returning to attend to the treatment of that light in the eye of the sultanate" $(C C, 34)$.

Here we see, if nothing else, Chandar Bhan's first mention of an emotionally sensitive side to Shah Jahan's personality that is rarely acknowledged in modern accounts of the emperor, yet will remain an intermittent theme throughout Chahär Chaman. The emperor also issued an open call for the best doctors and healers in the Mughal dominions to come to court, where he assembled a team of physicians to treat the princess. Chandar Bhan specifically mentions one Hakim Momina, "famous for his medical ingenuity [hikmat wa hazāqat]," as one of the doctors already in residence at the court, along with several others 
named Hakim Fath-Allah, Hakim Salih, and Hakim 'Abd al-Rahim. Two other noted physicians of the time were summoned, Hakim Masih al-Zaman and Muqarrab Khan, the author of a pharmacological treatise known as 'Ain al-Shifā (The fount of healing), which was itself partly based on an earlier sixteenthcentury work on Indian medicine by a certain Miyan Bhuwa (d. 1519), known as Ma'dan al-Shifā-yi Sikandar Shāhì (Sikandar Shah's mine of remedies; 1512), and dedicated to Sultan Sikander Lodi (r. 1489-1517).48 "From every place that had a doctor, physician, healer, or scientist," Chandar Bhan reports, "they arrived at the august court and made themselves available for these efforts” (CC, 34-35).

There was, in other words, clearly a sophisticated network of medical professionals in Mughal India, many of whom were well known by name, and all of whom were understood to fit into certain disciplinary categories based on their degree of scientific professionalization, with the most common such term being Hakim. Most of these masters of the healing arts would have been experts in the Greco-Hellenic tradition known generally in Indo-Persian circles as yūnānī (lit., "Ionian") medicine, much of which can be traced back to the pioneering ancient works of Aristotle and Galen (d. ca. 200-216 CE), which had been continually refined in the Muslim world over a period of centuries by major innovators like Abu Bakr Muhammad ibn Zakariyya al-Razi (ca. 854-925), Abu al-Qasim al-Zahrawi (aka "Abulcasis"; ca. 936-1013), and the massively influential Abu 'Ali al-Hussein ibn Sina (aka "Avicenna”; d. 1037). ${ }^{49}$ The Galenic tradition also had a distinct trajectory in India, where Indo-Persian scientists had the additional resource of being able to compare the Greco-Hellenic and Islamicate medical theories firsthand with Indian traditions like Ayurveda, a comparative project that began already under the early Sultans of Delhi in the thirteenth century. ${ }^{50}$ It is no coincidence, then, that when Chandar Bhan informs us that the eventual credit for curing Jahan Ara went primarily to a recent Iranian émigré to the Mughal court named Hakim Muhammad Da'ud, he hails the Persian doctor specifically as "the Galen of the times" (Jālīnūs al-zamān) (CC, 35).

This fleeting moment in Chahār Chaman gives us a glimpse, albeit in passing, of the larger culture of science in and around the Mughal court and the value placed on expertise and ingenuity in disciplines like medicine. True, early modern Indo-Persian medical practitioners were still steeped in the classical Greek, Indic, and other "ancient" scientific traditions, but this does not mean that they approached such traditions uncritically, or without efforts to improve upon the knowledge of the ancients.

One good example is Chandar Bhan's contemporary Nur al-Din Muhammad 'Abd Allah Shirazi, who held notable administrative positions under both Shah Jahan and Aurangzeb but also came from a major intellectual family-he was the nephew of the celebrated brothers of Akbar's court, Abu al-Fazl and Abu 
al-Faiz Faizi-and made an important contribution to the history of medical science. ${ }^{51} \mathrm{He}$ wrote numerous treatises on the theory and practice of the healing arts, including the 'Ilājāt-i Dārā Shukohī (aka Tỉbb-i Dārā Shukohī) (1646), a major encyclopedic compendium that incorporated both $y \bar{u} n \bar{a} n \bar{\imath}$ and Indic medical knowledge into a comprehensive account of the state of the science. As its name suggests, 'Ilājāt-i Dārā Shukohī, which was composed just two years after Jahan Ara's accident, was dedicated to her brother Prince Dara Shukoh (1615-59). But Nur al-Din had other patrons as well. His dictionary of Arabic and Persian medical terminology, Qisțās al-Ațibbā' (The scales of the physicians; comp. 1630-31) had been dedicated to the Mughal noble Aman Allah Khan (d. 1637), who was himself also a practicing physician and the author of at least one work on pharmacology, as well as a Persian translation of a fourteenth-century Sanskrit medical treatise called Madanavinoda.52 Nur al-Din also wrote a compendium of pathology and treatment called Anìs al Mu'àlijīn (The healers' companion) and a study of the benefits of hygiene called Sabab-i Sitta-yi Rashìdì (Six essentials of hygiene). But perhaps his most well known work, according to the historian of Indian science Fabrizio Speziale, was a pharmaceutical dictionary known as Alfaz al-Adwiya (Technical terms for medicines; 1628-29), which was dedicated to Shah Jahan and contained some 1,441 entries on various drugs from India and elsewhere. As Speziale points out, this work was later translated as a materia medica by the noted British Orientalist Francis Gladwin in 1793, "at the recommendation of the hospital board of Fort William," while at least seven editions of the text appeared in print over the course of the nineteenth century.53

Advancing medical knowledge was thus an important part of the Mughal intellectual landscape, a culture in which elite practitioners like Muhammad Da'ud could quickly make a name for themselves. Indeed, Chandar Bhan doesn't label him "the Galen of the times" because he was old-fashioned but rather because he had "access to novel remedies and wondrous therapies that finally cured that light in the eye of the sultanate and empire" (CC, 35). For this, Muhammad Da'ud was rewarded handsomely, as was an Indian peon who went by the name of 'Arif Chela, who had designed special bandages for the princess, and who was, Chandar Bhan tells us, honored with the lavish gift of an elephant from the royal stables and a promotion in mansab ranking. Meanwhile, according to Chandar Bhan, exorbitant amounts of charity were doled out in honor of the princess to the poor, the needy, and the infirm, while the imperial kitchens were also directed to cook meals for the hungry. Prisoners were released, and the emperor also intervened to approve and disburse the stipends associated with certain tax-free charitable land grants that, as Chandar Bhan explains, "had been delayed due to various bureaucratic entanglements" $(C C, 35)$. In a typical rhetorical flourish, he goes on to lament the inadequacy of language itself to capture the moment, gushing that "such a degree of wealth was spent in charity and alms that it would require another entire book to describe it in detail" $(C C, 35)$. 


\section{LITERARY CIVILITY AND THE MUGHAL COURT}

We should note that Chandar Bhan does not begin his magnum opus with the story of Jahan Ara's accident and recovery entirely for its own sake. In fact, upon closer examination of the context in which it appears, the details of the anecdote seem quite incidental to what appears to be the true aim of the opening sequence of anecdotes in the first "garden" of Chahär Chaman, namely to narrate particular moments in the munsh $\vec{\imath}$ s life when he was able to advance his career by publicly deploying his literary talents, and in so doing to highlight the social, and even moral, benefits of cultivating literary expertise.

One clue as to the author's larger purpose comes in the somewhat long-winded heading that Chandar Bhan uses to introduce the story of Jahan Ara's accident: "Melody making by the nightingale of language [tarāna-pardāzi-yi 'andalīb-i $z a b \bar{a} n]$; and a description of the particulars of the celebrations and thanksgiving following the recovery of that world-famous soul of blessed title, the empress of the world, Begum Sahib (May she forever be shown divine kindness and forgiveness!) [dāma mahfüfan wa 'afūwan]" (CC, 33). Here the "nightingale of language" ('andalīb-i zabān) is of course Chandar Bhan himself, who will proceed to display two types of literary "melody making" (tarāna-pardāzī) in what follows. First, his prose generally will be so melodic that it will be worthy of emulation by others who aspire to master the art of insha' composition. And second, the anecdote will also illustrate a specific occasion on which this "nightingale" was able, as it were, to sing for his supper by reciting one of his poems at a major public event-namely, the festival organized to celebrate the princess's full recovery, for which the munshi was present, and which he proceeds to describe in considerable detail. I quote it at length, if for no other reason than to give the reader a nice sample of the rhythm of Chandar Bhan's ornate (and rarely translated) style of Mughal prose:

Grief was transformed to jubilation, sadness to joy, anguish to exultation, distress to delight, and anxiety to amusement. On the day of the bazaar, singers, musicians, and master entertainers assembled for merrymaking and celebration. The strings of the tambür plucked at hearts, while the sound of melodies and the trill of flutes warmed up the lively throng. And since [under such circumstances] an expression of thanks for the munificence of the True Benefactor [mun'im-i haqiqii, i.e., God] is both necessary and proper, it occurred to the bountifully efficacious mind of His Majesty the Emperor-whose hand as bounteous as the sea is more jewel-scattering than a raincloud, and whose soaring intellect is more illuminating than the sun-that in thanks for this profound joy and boundless delight he would organize a grand festival and lavish party, the spectacle of which would dazzle the eyes of the world, and the likes of which even the eyes of heaven had never seen.

Accordingly, on the fifth day in the month of Shawwal, may God end it happily and with good fortune [ $\underline{k}$ hatam allāh b'il-khair wa'l-iqbäl], a festive and bountiful celebration was organized in the seat of the caliphate, Akbarabad. Eight magnificent 
parties [majlis], corresponding to the eight paradises [hasht bihisht], were superbly and beautifully arranged. [The parties went on] continuously from the fifth to the twelfth, and nourished the fresh fields of the hopes and dreams and desires of the people of the world like jewel-bearing clouds arriving with the monsoon.

In the first party's garden of delights, [it was like] the onset of successful spring; in the second party, the lushness of a succulent garden; in the third party, luxuriant flowers of joy and pleasure; in the fourth party, the jewel-scattering liberality and beneficence; in the fifth party, a garden decked with pleasure and delight; in the sixth party, the flower beds in the garden of dominion and power; in the seventh party, the verdure and lushness of the garden of munificence and graciousness; and in the eighth party, the arrangement of a bouquet of plenty-[each of these events] caused hearts to blossom and bloom, minds to revel and flower.

All the servants of the great court-renowned nobles, mighty chieftains, powerful elites, and the entourages of various imperial servants-were elevated, according to their level of rank and status, by the gift of imperial presents such as elephants, horses, precious robes, manșab promotions, and cash rewards. Men of merit and genius, and those in need from among the [community of] darwishes, hermits, religious divines, state pensioners, and the destitute [umì $w$ warān, lit. "the hopeful"] received the treasure of long lives by way of charity and good works. Masters of language and literature from among the most eloquent poets of the age, such as Muhammad Jan Qudsi, [Abu] Talib Kalim, Mir Ilahi, Mulla Muhammad Amin, Mir Bakhshi, [Mir] Yahyá [Kashani?], and others besides, after reciting panegyrics and narrative poems and quatrains celebrating this grand festival, were enriched with cash gifts and robes of honor. ${ }^{54}$

Audience members of sweet expression, Brahmans reciting in hind $\bar{\imath}$ language, [Zoroastrian] priests [gabrān], astrologers, and the like were similarly ennobled by gifts and robes. Masters of melody and good cheer, performers and entertainers-among them singers and musicians from Iraq and Khurasan, melodists and crooners from Kabul and Kashmir, kalāwants and dancing girls from India-all displayed their skills and in exchange received various luxurious clothes and generous amounts of gold so beyond measure that even the folds in the skirt of anticipation brimmed over.

Finally, everyone who had showed sincere effort in rehabilitating that Rabi'a of the times was promoted with an increase in manșab and favored with cash, elephants, robes, and other varieties of gifts. $(C C, 36-37)$

One gets the flavor of a lavish Mughal festival here, and certainly there are plenty of interesting details in this passage that could be discussed at length among specialists of the social history of the period-the details of the planning, the coordination of the various parties around the theme of the "eight paradises" (hasht bihisht), the theme of giving charity to hermits and mystics as part of the celebration, the naming of specific poets who participated in the proceedings like Abu Talib Kalim and the poet laureate Muhammad Jan Qudsi, the mention of Brahmans reciting in "Hindi," and of course the various other details on the performers and performances. 
But in terms of the larger message of Chahär Chaman, all this extended description is really just window dressing for what seems be the central point of the anecdote, namely, highlighting the connection between literary civility and social mobility. Thus Chandar Bhan closes this opening section, one of the lengthiest in all of Chahār Chaman, as follows:

Since this faithful Brahman is tied to the court of celestial stature among the order of munshīs, and my quatrains are recited before the emperor's luminous gaze on great festival days-such as the world-dazzling New Year's Day [nau-roz], the auspicious [royal] birthday, and the solar and lunar weighing ceremonies-on this bounteous occasion too, having recited a $r u b \bar{a}^{c} \hat{\imath}$, I was granted a promotion and robe of honor [hil' $\left.{ }^{\prime} a t\right]$ :

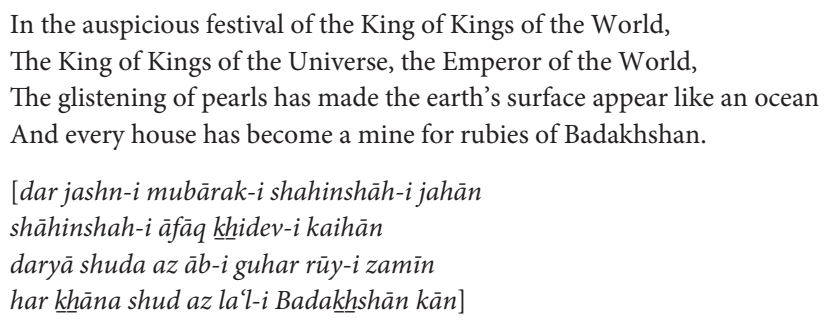

Let us hope that God on high [allāh ta'ālá] stretches the long and continuous shadow of this eternal empire's favor and beneficence upon the world and all its inhabitants. $(C C, 37-38)$

In other words, notwithstanding all the vivid details of Jahan Ara's accident and the sumptuous description of the celebrations that followed her recovery, the real story here is about Chandar Bhan himself, about what it means to be an elite munsh $\bar{\imath}$ at the court, and the role of literary expertise in that occupation. It is a didactic message, an insistence that the job of a true munsh $\bar{\imath}$ is not just to take dictation or to sit in a corner office somewhere scribbling accounts but also to participate in the cultural life of the court, to be one of the elite literati who composed and recited poetry for special occasions and important public functions. This is the implicit theme, in fact, of this entire section of Chahär Chaman, and it will be repeatedly highlighted in the set of anecdotes that follow this one.

One obvious subtext in these anecdotes is of course that if you yourself, as a reader, aspire to a successful career as a Mughal munshi then you would be well advised to learn from Chandar Bhan's example and master the art of poetry-advice that Chandar Bhan makes much more explicit, for instance, in his letters to his son Tej Bhan. But aside from the specific message of literature's utility as a means to career mobility, these anecdotes illustrate the importance of the literary sensibility to the overall atmosphere of civility at the court. Indeed, the denizens of the Mughal court and its main urban centers were engaged in an almost constant exchange of literature, especially poetry, not only on public occasions but also in various other types of private and informal settings. A mastery of the 
Persian literary canon and a facility with extemporaneous composition were thus essential components of a well-rounded gentleman's intellectual tool kit. For the aspiring imperial munshi $\bar{i}$, talent for literary style and wit could also be a crucial ticket to new forms of social intimacy and professional mobility.

This didactic message is reinforced with the very next anecdote of the first chaman, the "joy-increasing story" (afsāna-yi nishāt-afrozī) of how Chandar Bhan originally came into Shah Jahan's direct employ. Chandar Bhan does not give the date of this encounter-unfortunately, Chahār Chaman is a text that spurns chronological specificity throughout-but we do know from the context that it took place in early 1639, some five years before the events surrounding Jahan Ara's accident. Afzal Khan, the Mughal prime minister with whom Chandar Bhan had worked closely for roughly a decade, had just died, and the emperor and many of the notables of the court had assembled in Lahore for his funeral. Among those present, Chandar Bhan specifically mentions Asaf Khan (d. 1641) and Musá (or Musawi) Khan (d. 1644), a jurist (șadr) who had served in the Mughal administration since Jahangir's reign and served in Shah Jahan's government as the Șadr-i Kull, or chief judge (for civil affairs). ${ }^{55}$ After the funeral, Chandar Bhan explains:

The blessed noble royal command was issued that the associates and attendants of the lately deceased Afzal Khan should present themselves before the auspicious [imperial] gaze. When this supplicant's turn arrived, his penmanship in the broken script - which is not devoid of correctness-entered into [the emperor's] alchemical gaze and found favor with his difficult-to-please nature. The lines of this faqi $r$ 's lowly quatrain [also] reached his auspicious ears and earned a measure of appreciation:

[For] A king to whom both worlds submit,

Everywhere that there is a head, it bows at his threshold;

So much is a man ennobled in his era

That even angels would prefer to become men!

[shāhī ki muțī'-yi ù do 'älam gardad

har jā ki sarī-st bar dar-ash kham gardad

az bas ki ba daur-ash ādamī yäft sharaf

khwāhad ki firishta nīz ādam gardad]

$(C C, 38)$

Here again, the purpose of the anecdote is less to convey specific information than it is to stage a particular type of mise-en-scène in which the relationship between a munsh $\vec{\imath}$ s literary talent and his prospects for career mobility is performed. This was one of the most consequential moments in Chandar Bhan's entire life, as a direct result of which he entered Shah Jahan's inner circle. And yet, oddly enough, the salience of the encounter as a turning point in Chandar Bhan's larger autobiography goes completely unmentioned in this version of the anecdote, only to be made clear much later in the text (in the properly "autobiographical" section of the third chaman, which we will discuss in chapter 4 below). 
This omission, and the resulting need to tell the same story all over again later on in the text, might understandably seem puzzling - indeed, I puzzled over it for quite some time myself-until we recognize that Chandar Bhan's purpose here in the opening part of Chahär Chaman is didactic/performative rather than narrative. He wants to illustrate through examples from his own life that literary expertise is a critical tool in the munsh $\vec{\imath}$ s kit and that to be successful one must be equipped to deploy it at a moment's notice, in a whole range of possible settings.

This basic point is only amplified in the next few anecdotes, nearly all of which follow roughly the same pattern, involving some occasion on which either Chandar Bhan himself recited his verse before the emperor or it was relayed to Shah Jahan by some powerful intermediary. For us modern readers, these anecdotes also serve as a powerful reminder that literary connoisseurship in Mughal India was an integral feature of daily life for virtually all the denizens of the court, not just for professional poets and their better-known patrons. Indeed, while literary entertainment was perhaps most prominently on display during major festivals and other conspicuous public events, it was also woven into the fabric of more mundane occasions simply as part of the daily routine, livening up military campaigns, hunting expeditions, and other circumstances that we typically don't associate with the arts.

Thus Chandar Bhan relates the "reputation-polishing incident" (afsāna-yi ashraf-perā) in which, while the imperial camp was on the march to Kabul, "along the way a ghazal from among those sired by this poor soul reached the blessed royal ear through the intercession of the bakhshi al-mulk, Mu'tamad Khan ... and earned a measure of distinction" (CC, 38-39)..$^{56} \mathrm{We}$ are also told of a "delightful occasion" (afsāna-yi farhat- $\bar{a}$ '̄n $)$ not long after Jahan Ara's recovery when a group of courtiers, awaiting the arrival of the emperor, passed the time with a kind of impromptu literary gathering:

On one side the most dignified of illustrious nobles, 'Abd Allah Khan Bahadur Firuz Jang, along with the pillar of state A'zam Khan, the mainstay of the sultanate Islam Khan, and the paymaster in chief Asalat Khan had formed a circle and were livening up the room with poetry; on another side were Rustam Khan and Mir Safdar Jahan, with the high-ranking Sayyids; and in another part [of the room] Raja Bithal Das was sitting with various other Rajputs and chatting.

Later, once the throne of kingship and governance had been decorated by [His Majesty's] power and glory, a quatrain by this faqir entered the royal gaze and earned a measure of appreciation.

So long as the resplendent sun continues to shine,

So long as the moon stays high in the sky,

So long as the cycles of time continue to spin,

So long as there is a world, Shah Jahan will be its king. 
[tā mihr-i munìr rā nishān kh hwwāhad büd

tā māh bar auj-i äsmān kh

tā daur-i zamāna dar miyān kh hwāhad būd

tā hast jahān shäh jahān khwwāhad büd]

Some musicians [qawwālān] have made a song out of this quatrain, which they now perform regularly in the emperor's celestial mehfil. (CC, 39-40)

As in so much of Chahār Chaman, there are tantalizing details here about the quotidian lives of Mughal courtiers. The image we typically have of Shah Jahan's court is one of impeccable discipline and 'ossifying ceremonial,' as the historian John Richards once characterized it ${ }^{57}$-everyone in their correct place, as if frozen in time, as we see them arranged in so many exquisite miniature paintings. But here one gets, as it were, the moments before the painting freezes them in time. One pictures the nobles and other members of the courtly milieu in all their finery, including Chandar Bhan himself, milling around in their various cliques, socializing, probably snacking, and so on, as they wait for the imperial audience to get going. Perhaps one group is discussing politics, but another group starts reciting poetry to pass the time, while in another corner a group of musicians is warming up. The musicians are still there when the emperor arrives, and when they hear Chandar Bhan's panegyric rub $\bar{a}^{-} \hat{\imath}$-which is itself quite musical and rhythmic - they are impressed enough that they set it to music, after which it becomes one of the staples of their repertoire.

This is a different side to the Mughal nobility than we are used to seeing. Indeed, everyone mentioned in this passage is known today almost exclusively for his military exploits, with virtually no mention of their participation in cultivating the cultural sensibilities of the age, much less their individual talents. Islam Khan Mashhadi, for instance, who is noted here as one of the group who had "formed a circle and was livening up the room with poetry" (halqa zada garm-i sukhan budand), is mentioned only once in all of John Richards's The Mughal Empire, and that too merely in passing as one of "the four highest ranking nobles in the empire" under Shah Jahan..$^{8}$ Even in a more recent account that deals only with Shah Jahan's reign, Islam Khan appears only briefly as "a distinguished diplomat of Persian origin" who draws our interest solely for his time as "the man in charge of military logistics," as an envoy to Bijapur, and as the governor of the Deccan. ${ }^{59}$ In Annemarie Schimmel's Empire of the Great Mughals (2004), there is not a single mention of him.

But we see Islam Khan's literary side once again in Chandar Bhan's very next anecdote, a description of the New Year's party held in the imperial camp while it was passing through Sirhind. ${ }^{\circ}$ After dilating over the lovely local weather and the decorations, charitable donations, and other typical trappings of the royal party, Chandar Bhan adds the by now familiar mention of his own poetic contribution to the proceedings. Note, however, that it was only thanks to Islam Khan's initial 
appreciation of Chandar Bhan's verse that it was then conveyed to the emperor himself.

This humblest of servants, being recognized as a "son of the house" [ $k \underline{h} \bar{a} n a z \bar{a} d]$ of this illustrious family, conveyed a quatrain to the auspicious imperial gaze through the intercession of the Pillar of State, Islam Khan. Since great care for his servants and kindness even toward specks of dust [like me] are both integral to [His Majesty's] angelic nature, he took it in his own hands and, with his voice of miraculous expression [zabān-i mu'jiz-bayān], recited it beautifully:

A new day, a new year, may they be blessed.

A new realm, and new wealth, may they be blessed.

O you who have dreams of [new] conquests,

May all your strategies be blessed!

[roz-i nau wa sāl-i nau mubārak bādā

mulk-i nau wa māl-i nau mubārak bādā

ai ān ki khayāl-i mulkgìrì dàrī

tamhīd-i khayāl-i tu mubārak bādā]

By the grace of God and His Majesty the King of Kings's good fortune, this [prediction] became manifest a short time thereafter as the friends [auliy $\bar{a}$ '] of this eternal empire were destined to victory in the territories of Balkh and Badakhshan. $(C C, 41)$

The euphemism at the end of this passage, of conquered territories having the good fortune to become "friends" of the Mughal Empire, is of course a clear indication of Chandar Bhan's politics. But also significant is his specific use of the term khānazād (son of the house) to describe his relationship to the imperial court. This would have had a very specific connotation for a Mughal readership, immediately signaling that as one of the elite munshis of the court, despite being a Hindu, Chandar Bhan could confidently lay claim to the privileges and prerogatives of being associated directly with the royal household, as well as all the responsibilities that such an association entailed in terms of adhering to established norms of ethical behavior and gentlemanly comportment. ${ }^{61}$ Like so many things about Mughal life, the notion of "being a son of the house" ( $\underline{k} \underline{h} \bar{a} n a z \bar{a} d a g \bar{\imath})$ has often been viewed mainly through the lens of categories like martial and aristocratic honor. ${ }^{62}$ But here we see that the term had a much broader applicability beyond the narrow issue of martial valor. Being an agent of the empire had a cultural component, too.

Islam Khan is also a presence, along with a number of other members of the nobility, in Chandar Bhan's next anecdote, a description of an assembly-held "in the village [mauza] of Talwandi, which is in the jurisdiction of the pargana of Amanabad" - while the imperial camp was again in transit, this time from Lahore to Kashmir. Among the nobles whom Chandar Bhan names as having been present were various "elite nobles and high-ranking khāns like the Pillar of State Khan Dauran Bahadur Nusrat Jang, the Great Scholar of the Age Sa'd Allah Khan, the 
Pillar of the Government Islam Khan, the paymaster of the empire Asalat Khan, Khalil Khan, 'Aqil Khan, and other servants of the Solomonic court" (CC, 41).

Note the description of the court as "Solomonic," a common feature of the Mughal court's self-image generally, but especially under Shah Jahan. ${ }^{63}$ Note too the ease with which the rest of the anecdote intermixes the court's "official" business with more literary activities:

On that same auspicious day, the Arm of the Caliphate Islam Khan received the order that, having gone to the Abode of the Sultanate Lahore for a few days to attend to some important business regarding the crown lands [khhālisa-yi shariffa] in the territory of Punjab, he should return to the imperial court. Meanwhile, Asalat Khan was given leave to depart for the șüba of Kabul. And in that very majlis, one of this faqir's quatrains chanced across [His Majesty's] alchemical gaze. As a result of his affection even for specks of dust, he took it in his own blessed hands, and examined it with his precious soul. $R u b \bar{a}^{\top} \bar{\imath}$ :

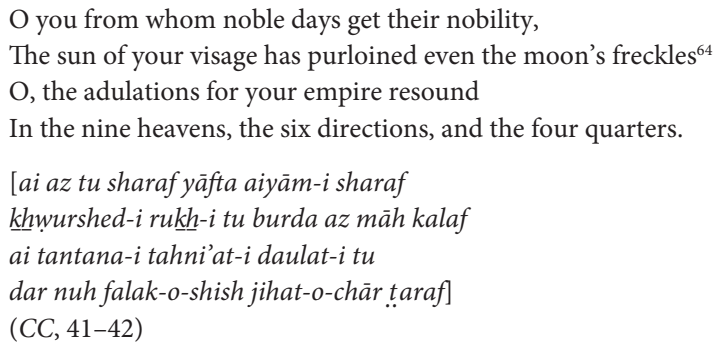

In subsequent anecdotes, other supportive nobles like Sa'd Allah Khan similarly appreciate and convey Chandar Bhan's poetry to the emperor, for instance this panegyric quatrain that our munshi composed upon the imperial camp's return from Kashmir to Punjab:

The days of joy and hunting fun have arrived;

A hundred types of delight have come to this aged world.

From all four directions glad tidings resound;

The King of Kings of the World has, from Kashmir, returned.

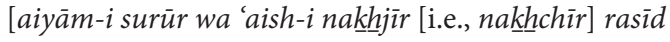

sad gūna tarab ba 'ālam-i pìr rasìd

az chār sū nawed-i shādī bar kh $\underline{\text { ăst }}$

shāhinshah-i äfāq zi kashmīr rasīd]

$(C C, 42)$

The next entry is another in which political business and literary pleasure coexist quite comfortably. The occasion was a party in honor of Shah Jahan's birthday, and Chandar Bhan notes that it was "on that very same auspicious day that greatest of nobles of high station, the amīr al-umarā 'Ali Mardan Khan, arrived 
from Kabul and gained the honor of servitude." Readers familiar with Mughal history will recall that this was no small matter, as 'Ali Mardan Khan was a Persian general of considerable power and prestige, whose defection to the Mughal cause effectively delivered control of the vital frontier outpost of Qandahar right into the Shah Jahan's lap (albeit only temporarily). The occasion was also marked by a moment of high-profile diplomacy when "the Turanian ambassador, too, had the honor of saluting [His Majesty] with a bow [kornish] and was ennobled with cash gifts and the favor of a robe of honor." And yet, as throughout this portion of the text, the anecdote culminates with yet another "one of this faqi r's quatrains [which], as is customary, reached the blessed ear" (CC, 42-43).

In the following anecdote, too, Chandar Bhan has the opportunity to present a quatrain during an intimate party held in the emperor's privy chamber (ghuslkhāna). But it is perhaps more interesting for being the only passage in this section of the text where Chandar Bhan actually quotes someone else's verse. His comments are revealing:

Hakim 'Abd al-Khaliq, famous in his time for literary genius and composition, presented a ghazal in commemoration [dar tahniat] of this joyous occasion before the luminous and blessed gaze, which achieved a high level of appreciation and great praise. The words and meanings were crafted together with such subtlety and elegance that His Highness the Emperor, whose blessed soul is unrivaled in the assessment of literature, was thoroughly delighted. From the entire poem, everyone was lost in thought pondering these two lines for at least a week [ az än jumla bar sar-i ìn do mișra' tā yak hafta muțāli'a dar miyān būd]:

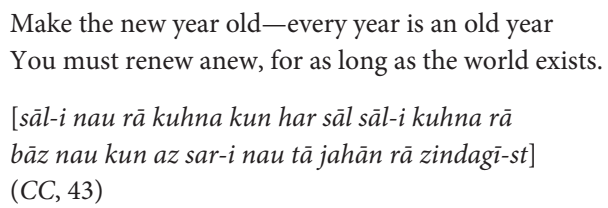

I'll confess, I too have spent more time than I'd care to admit puzzling over the somewhat baffling meaning of this verse, and while I have translated it as best I can, even now I'm not entirely sure I've got it right. But this, in some ways, gives us an opportunity to note another important feature of the literary culture of Chandar Bhan's day. The fact that he and some of the other connoisseurs at court were able to take such delight in puzzling over the meaning of a single peculiar verse may strike some modern readers as somewhat odd, even decadent. Whatever its precise meaning, the verse is clearly concerned with themes like seasonal renewal, putting the past behind one, seizing the moment, living in the present, and so on. But beyond its literal content, it also speaks to a larger thematic shift during Chandar Bhan's era, toward a self-consciously modern sensibility and an awareness of the newness of the historical moment. As we will discuss much more 
extensively in chapter 5 , this was a period of tremendous literary experimentation, as poets placed a high premium on the search for novel themes and, in the parlance of the day, "fresh" ( $t \bar{a} z a)$ new modes of expression. Of course, as in most periods of literary ingenuity, some poets went too far in their quest for "meaning

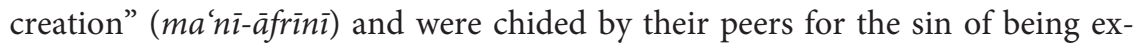
cessively abstruse or using "inaccessible language" ( $n \bar{a}$-rasā' $\bar{\imath}-y i$ lafz $)$-something that Hakim 'Abd al-Khaliq appears to be verging on here. But the overall effect, in terms of both the thematic content of the verse itself and the way in which it provoked a highly self-conscious collective literary critical conversation among the connoisseurs at court, captures something of the nascent culture of literary modernism that was then brewing in the Indo-Persian world.

This important passage is followed by the only entry-out of sixteen such anecdotes in this portion of the text-in which Chandar Bhan doesn't explicitly refer to his own poetry, though one wonders if this was simply an oversight. The occasion was the grand festival held to celebrate the completion of the new palace in the newly built capital of Shahjahanabad (in Delhi) - a party so lavish that, in Chandar Bhan's colorful description, "even the countless celestial eyes of the heavens were staggered by the sight of it all," and gifts and alms were doled out "in such quantities that the scribbling of the accountants was helpless to note it all down [ki muhāsibān dar tahrīr-i ān khațt-i 'ajz kashīdand]” (CC, 44).

The text continues with two more very brief anecdotes that return us to the previously established pattern of culminating with Chandar Bhan presenting poetry before the emperor. After that, the next two passages both involve hunting expeditions, a favorite form of recreation for the Mughal court, and one that also allowed Mughal emperors to tour certain areas informally and keep abreast of the mood in localities outside their typically urbane courtly milieus. In one, Chandar Bhan describes an assembly during which the emperor's solar and lunar birthdays were commemorated together as the imperial camp returned from a hunting expedition "in the picturesque environs" (mauza'-i nūr-nigar) of the Doab, an audience during which not only Muslim nobles like 'Ali Mardan Khan, Rustam Khan, Ja'far Khan, and others were present but also elite Rajputs like Maharaja Jaswant Singh and Raja Jai Singh, all of whom Chandar Bhan mentions by name, and all of whom, presumably, observed the munshi being "singled out for a reward of cash and precious jewels [perāya-yi tahsinn]" when his quatrain was well received $(C C, 45-46)$.

In the next, Chandar Bhan briefly describes a hunting excursion to Mukhlispur, noting that "once the travelers and hunters broke their journey and that delightful place had been ennobled by the splendor of the august imperial footfall, they changed its name to "Faizabad' [i.e., the City of Plenty]." ${ }^{65}$ When the royal retinue returned to Shahjahanabad from this expedition in April 1657, a number of poets composed works in various genres praising Faizabad's beauty, and Chandar Bhan 
explains that "this humblest of servants, too, according to established custom [ $b a$ rasm-i ma'hu$d]$, after reciting a panegyric ghazal sired by my defective character, received the honor and favor of a promotion."

The poem in question is quite long and basically follows the typical conventions of such works. But is nevertheless noteworthy, particularly for the way in which Chandar Bhan compares Shah Jahan explicitly and favorably to great pre-Muslim conquerors of antiquity, going so far as to claim that Fereydun and Alexander would have been mere pensioners of his own emperor (zi shaukat az Faraydūn-oSikandar bāj bastānad), that he is even more just than the celebrated ancient Persian king Khusrau Anushirwan (ba 'adl-o-dād șad tarjīh bar nūshīrwān dārad), and that the intellectuals of the Mughal "house of wisdom" (dār al-hikmat) would put even Plato to shame $(C C, 46-47)$.

\section{POETRY AND THE ART OF THE MUGHAL EPISTLE}

Such literary civility was an important part of epistolary culture, too, as literati and other intellectuals routinely circulated poetry among fellow connoisseurs via the extensive Mughal postal service. Correspondents regularly included explicit requests for literary suggestions and "corrections" (iṣlāh) in such letters, or in some cases simply appended poetry as a courtesy or to punctuate a thought. Chandar Bhan's extant correspondence is full of such letters, most of them addressed to various nobles, minor officials in Shah Jahan's government, and fellow literati-some well known, and some barely identifiable today, but all of them clearly fluent in the sometimes esoteric and often outright antinomian ethos of Indo-Persian literary symbology.

One of Chandar Bhan's epistolary correspondents, for instance, was a minor official named Shaikh Ilahdiya, whose official title was Ikhlas Khan, and who came from a family of noted military commanders and provincial Mughal governors. ${ }^{66}$ Ikhlas Khan was especially close to Aurangzeb, with whom he had been friends since their youth, and whom he had accompanied on numerous military campaigns early in Shah Jahan's reign. By the 1640 s he had made enough of a name for himself that he was appointed governor of Kalinjar, and he was subsequently involved in several of the most prominent military campaigns of the 1640 s and '5os-including the massive campaign in Balkh and Badakhshan under the command of Prince Murad Bakhsh in 1646, the campaign to retake Qandahar under Prince Dara Shukoh in 1653, and the siege of Chittor Fort under the command of the wazir Sa'd Allah Khan in 1654. After that, he rejoined Aurangzeb's retinue when the latter was redeployed to serve as viceroy of the Deccan in the late 1650 .

We are not talking, in other words, about some effete professional poet or artist, but about a man who, particularly when one considers his close ties to Aurang- 
zeb, could easily be thought to embody the cliché of martial and sectarian severity so often attributed to this period in Mughal culture and politics. And yet here he is popping up in the personal letters of our Brahman munshī, addressed as a dear friend and convivial social companion. Chandar Bhan includes only one letter to Ikhlas Khan in the standard collection of his correspondence, the Munsha'ät-i Brahman, but it specifically references the two men spending time together in Daulatabad and the context suggests that they were regular correspondents, even if Chandar Bhan playfully chides his friend for not having written to him in some time: "Greetings, O Khan of utter humanity and liberality! It is true what they say, that 'whoever is out of sight is also out of mind.' But it is nevertheless strange that it has been so long since [the recipient of this letter] has recalled his sincere and true friend by sending me a letter or message. Perhaps the memory of the delightful conversations and lively stories that we shared, especially during the wonderful trip to Daulatabad, has been erased from his heart as deep as the sea. I append here a freshly composed ghazal" $(M B, 17-18)$. Here the lyric that Chandar Bhan includes is especially telling, as the first couplet punctuates the entire point of the letter by playing on the common literary theme of the poet longing for an absent beloved:

I've had no news of my dear friend today;

Yesterday's promise is gone, and I am empty inside today.

[ kLhabar nadāram az ān yār-i mihrbān imroz

guzasht wa'da-yi dī chī-st dar miyān imroz]

Meanwhile, in the ghazal's final couplet, Chandar Bhan as usual offers a nice interplay between his Brahman identity and the stock themes of the Indo-Persian literary canon - in this case, claiming for himself (and for Brahmans) the legacy of Majnun, the quintessential mystical lover of Persian epic poetry:

Majnun's turn in the factory of love is over;

A Brahman has taken up this ancient legacy today.

[guzasht naubat-i majnūn zi kār-ḳhāna-yi 'ishq

barahman ast dar ìn kuhna dūdmān imroz] ${ }^{67}$

Strictly in human terms, the sharing of one's poetry privately is a gesture of considerable intimacy, arguably regardless of the historical context; but how much more so in a case like this, when the verses in question are being used specifically to express such powerful sentiments of friendship and emotional, even mystical, longing. As we will see in greater detail in chapter 4 , the practice of circulating poetry in this way served an important function in Mughal social life, over and above its more obvious value as a literary diversion. Such poetry, and the culture of Mughal letter-writing generally, could also function as a kind of social bridge, 
connecting people of diverse classes, backgrounds, and occupations through the common literary and mystical idiom of Persian verse. Addressing the recipient of the letter as the idealized beloved of the lyrical ghazal universe, as Chandar Bhan does here, was, in other words, a way to harness the power of a poetic medium that has often been accused in modern times of being hopelessly hyperbolic and overwrought and to deploy it for a much more quotidian, even relatable, expression of simple friendship.

The symbiosis between Mughal literary and epistolary cultures reflected in Chandar Bhan's letters is revealing in other ways, too. For instance, another of Chandar Bhan's correspondents during this period was a certain 'Abd al-Nabi Khan (d. 1669), an official in both Shah Jahan's and Aurangzeb's governments who served at one point as the judicial magistrate ( $q \bar{a} z \bar{i})$ of Wazirabad and eventually as the army commander (faujdār) of Mathura district from 1668 until he was shot and killed while attempting to put down a rebellion of Jat peasants less than a year later. ${ }^{68}$ These tussles between the imperial government and the Jat peasantry began roughly a decade into Aurangzeb's reign, and, though there were many factors involved, they have routinely been oversimplified in modern historiography as a straightforward example of Hindu-Muslim antagonism. Thus, as a result of his role as an agent of imperial power vis-à-vis the Jats of the region, 'Abd al-Nabi Khan has been vehemently criticized in modern historiography-when he is mentioned at all-as an exponent of growing orthodoxy under Aurangzeb.

This image is only exacerbated by the fact that 'Abd al-Nabi Khan was one of the chief provincial officials during the run-up to the infamous destruction of the Keshav Rai temple in Mathura in 1670. Though the actual destruction of the temple took place after 'Abd al-Nabi Khan's death, he is nevertheless implicated because it is said that a few years earlier he had personally overseen the dismantling of a decorative devotional railing that had apparently been donated to the temple by none other than prince Dara Shukoh, Aurangzeb's famously liberal older brother and erstwhile rival for the throne. Sources also indicate that 'Abd al-Nabi had patronized the building of a mosque in the area, an act that, though quite unrelated to anything to do with the destruction of the Mathura temple, nevertheless usually gets coded in modern writings as an expression of Muslim piety and thus is lumped in with other examples of his alleged hostility toward non-Muslims into a seamless narrative of a man "more fanatic," as one historian has suggested, "than even his royal master." 69

And yet it is difficult to reconcile this image of 'Abd al-Nabi Khan's character with Chandar Bhan's attitude toward him, which, at least in their extant correspondence, shows no hint whatsoever of any such sectarian animosity. There are two letters to 'Abd al-Nabi Khan included in the standard edition of Munsha' àt-i Brahman, although, as with many of Chandar Bhan's correspondents, these are very likely only a selection of many more that the two probably exchanged during 
their lifetimes. In the first, Chandar Bhan cordially expounds upon the values of tolerance and levelheadedness, noting that "an appreciation for the good in every community and group" (qadar-dān-i har qaum wa har t. $\bar{a}$ 'ifa) is the epitome of 'Abd al-Nabi Khan's "nobility of spirit and gentility of character" (zzät-i sharîf wa 'unșur-i lațîf) $(M B, 21)$.

The second letter, meanwhile, appears to be a letter of introduction, in which Chandar Bhan informs 'Abd al-Nabi Khan that a certain Kunji Das will soon be passing through the khan's jurisdiction and suggests that the latter make an effort to meet the Hindu traveler because they might have productive discussions about spiritual matters. Chandar Bhan notes that Kunji Das had spent much of his life working "in the employ of that illustrious noble I'tiqad Khan" (Asaf Khan's brother; d. 1650). But, Chandar Bhan explains, Kunji Das was nevertheless "a man of few material attachments, who is forever seeking the company of faqi rs" $(M B, 21-22)$ - a generic category of holy men into which, presumably, he is placing 'Abd al-Nabi himself. The letter concludes with a "freshly composed ghazal," demonstrating once again that a certain poetic flair was a crucial ingredient of Mughal epistolary etiquette, even among men like 'Abd al-Nabi Khan who are not typically known for their literary pursuits.

Similarly, a letter to one Qazi Nizama Karhardu'i, also known by his official title of "Mukhlis Khan," who served in various military-administrative capacities during Shah Jahan's reign and the early part of Aurangzeb's, deals almost exclusively with literary matters $(M B, 18-19)$. There are also letters of similar tone and content addressed to figures like Wazir Khan, the noted governor of Punjab who is perhaps best remembered, incidentally, for patronizing the construction of one of the most famous mosque complexes in the city of Lahore (see below, chapter 3, for a brief discussion of the lively commercial and literary culture of the Wazir Khan mosque complex in Chandar Bhan's day). Chandar Bhan does not include any poems in the letter to Wazir Khan that he includes in Munsha'ät-i Brahman, but he does express regret that his occupations at court had kept him from having the chance to meet the khan personally for some time, and he refers to the governor at one point as his friend of thirty years. There are also two letters to a nobleman known as Fida'i Khan, the second of which extols the secretarial skills, comportment, and literary talent of a certain Muni Ram Sahu, whom Chandar Bhan hopes Fida'i Khan will help to find a job $(M B, 19-20)$.

Elsewhere, in a letter to the relatively obscure official Ra'd Andaz Khan, who had served as faujdàr of an area called Bainswara in Aurangzeb's administration, and who, like 'Abd al-Nabi Khan, would also eventually become involved in the campaign against the Jat peasants, Chandar Bhan fondly recalls having met the khan at a literary soiree hosted by another Mughal nobleman, and he punctuates his desire to have another opportunity to converse with Ra'd Andaz Khan with a couplet: "A perpetual longing for [your] company remains in my heart / 
An unending knot in my chest, and a desire in my breast" (dar dil-i man ārzū-yi șuhbat derīna mānd / in girih dar khhäțir-o-īn ārzū dar sina mānd) (MB, 22-23). Ra'd Andaz Khan was also, it's worth noting, the main patron for another notable Hindu munshi of the period, Bhupat Rai, who was himself the author of an important model letter collection known as the Inshä'-yi Raushan Kalām, as well as an anthology of poetry called Mahīsin al-Kalam and a treatise on prosody and rhetoric called Dastūr-i Shigarf. ${ }^{\circ}$

There are also two letters in Munsha'āt-i Brahman addressed to Mir Sayyid Jalal Bukhari (1595-1647), the onetime "judge of judges" (ṣadr al-ṣudūr) under Shah Jahan, and thus exactly the type of person who would superficially corroborate the stereotype of growing clerical influence at court. Sayyid Jalal came from an extremely prominent family of Muslim 'ulamā, whose service as religious officials at court dated back to Akbar's time..$^{71}$ This relationship with the court continued even after Jalal's death, when his son Sayyid 'Ali (aka "Rizwi Khan"; d. 1680) served as a minor official in Aurangzeb's court. ${ }^{72}$ Yet perhaps the most striking thing about Chandar Bhan's extant correspondence with the cleric is just how genial it is, not to mention literary. The first letter concludes, for instance, with a moving mystical quatrain, while the second letter includes an entire ghazal that ends with the following bold couplet: "The Brahman has a way to catch the ear of the literati / My verse has snatched a gem from the necklace of the Pleiades" (dārad ba gosh-i ahl-i sukhan rāh barhaman / naz. girifta ast) $(M B, 42-43) .^{73}$

These are just a handful of the letters to such minor and middling Mughal officials preserved in Munsha'ät-i Brahman, which are themselves, as Chandar Bhan himself tells us in the preface, only a tiny selection of the countless letters he wrote over the course of his lifetime. Most of this extant correspondence has almost nothing to do with official business, consisting instead largely of the exchange of courteous pleasantries, mystical thoughts, the circulation of poetry, and, as Chandar Bhan put it in the letter to Mukhlis Khan mentioned above, "conversations about literary matters" (suhbat-i shi'r wa sukhan) $(M B, 18) .{ }^{74}$ Ironically, this is precisely what has made such epistolary archives seem rather uninteresting to many modern historians, who have tended to see in them nothing but superfluous stylized vanity. But when one actually traces the overlapping networks of the personalities involved and takes the content seriously as an expression of how typical Mughal elites behaved toward one another, a picture of everyday civility and pluralism emerges that is completely at odds with the modern image of this period in Mughal politics and society as one of intense-and intensifying - sectarian hostility.

One also sees clearly, as I have tried to suggest, the importance of a keen literary sensibility to the Mughal ideal of good manners, even among those who were not necessarily professional versifiers. But, having made this point, we should also hasten to add that Chandar Bhan did have a prominent place among the professional 
poets of the day, with a number of whom he exchanged letters and formed intimate personal friendships.

He corresponded, for instance, with Muhammad Jan Qudsi (d. 1646), the famed émigré from Mashhad whose verse once so impressed Shah Jahan that he was rewarded with his weight in gold, and whom Chandar Bhan addresses fondly in one letter as the "nightingale of a thousand tales" (bulbul-i hazār dāstān) (CC, 155-56). ${ }^{75}$ Another friend and correspondent was Abu al-Barakat Munir Lahori (1609-45), whom Chandar Bhan saw as his fellow traveler "across the country of glowing expressions and through the garden of jewel-scattering meanings" (bar kishwar-i sukhan-i tābān wa dar gulshan-i ma'nī-yi gauhar-afshān) (CC, 156-57). ${ }^{76}$ Munir, who was known before his untimely death as a sharp critic unafraid of heated rivalries with fellow poets, nevertheless thought highly of Chandar Bhan, lauding the munsh $\bar{i}$ in one of his own letters as "the eye and lamp of invention, the frontispiece in the book of learning and insight, the pride and joy of the courageous and fortunate imperial house, the opening verse in the preface of wealth and glory, the [auspicious] lines on the forehead of elegant language, the imprint on the seal ring of eloquence, the Sahban of the age, the most elegant man of the times, the lord of poets [malik al-shu'arā] Chandar Bhan." 77 Chandar Bhan's poetry was also appreciated by other luminaries of the period, including the celebrated poet Sa'ib Tabrizi (ca. 1592-1676), who spent several years in India and included at least one of Chandar Bhan's compositions in his own personal anthology (bayāz) of great poets. ${ }^{78}$ Likewise, a number of Chandar Bhan's ghazals were included a generation later in the personal bayāz of Mirza 'Abd al-Qadir Bedil (1644-1721), one of the most renowned metaphysical poets of early modern IndoPersian literature. ${ }^{79}$

Chandar Bhan was also a noticeable presence in some of the literary salons of his day. He himself has noted participating in such events in a number of places throughout his oeuvre, and we also have the testimony of a certain Surat Singh, a contemporary Brahman intellectual from Punjab, who boasts in one of his works of having had the opportunity to meet celebrated poets like Chandar Bhan, Mulla Shaida, and the like at a literary gathering while he was traveling through Agra. ${ }^{80}$

None of this is meant to suggest that everyone always got along, or that there was never any religious controversy in seventeenth-century Mughal culture and politics. But if Chandar Bhan's experience is any indication, we are nevertheless clearly talking about a cultural world that was far less sectarian and "socially insular" than it has too often been made out to be. Literature, far from being a pointless or decadent courtly diversion-as early modern Indo-Persian literature has also often been made out to be-was actually a key vehicle for reducing social distances and promoting a robust form of everyday civility across communal lines. And one of the key media for the exchange of literature, outside the oral transmission of poetry in courtly gatherings and other salons, was the 
lively letter-writing culture of the period. Indeed, however "ossifying" the official court ceremonial may have become under Jahangir and Shah Jahan, such rigid social and political hierarchies were far less in evidence in Mughal epistolary practices, which, as Chandar Bhan's letters suggest, created a space for the regular exchange of witty banter, mystical musings, friendly intimacy, and a whole range of human emotional registers rarely associated with the Mughal court in modern historiography.

\section{THE BRAHMAN AND THE BIGOT?}

Chandar Bhan was among only four intellectuals of Shah Jahan's reign whom his contemporary the historian Muhammad Salih Kambuh considered noteworthy as both a master prose stylist and an elite poet. ${ }^{81}$ Salih, too, was one of Chandar Bhan's epistolary correspondents, and at least one letter from the former to the latter has survived in Salih's (unpublished) collected letters, the Bahär-i Sukhan (Springtime of expression). There he addresses Chandar Bhan as "the cream of discerning intellects of the times, the secretary of the age" (zubda-yi nukta-tarāzān-i daurān munshī-yi al-zamānì Chandar Bhān), and colorfully adds that he hopes an eternally felicitous breeze carrying God's kindness will waft upon "the garden of hopes of that expert of literary eloquence and master of this [epistolary] art" (nasim- $i$ bahjat-i abad-maqrūn az muhibb-i 'ināyat-i ìzad-i ta'ālá wa muwāhab-i 'ālam-i bālā bar gulshan-i umīd-i ān adīb-i sukhan wa ūstād-i in fann). ${ }^{82}$ In his historical chronicle of Shah Jahan's reign, Salih also notes that Chandar Bhan was very

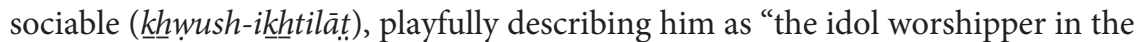
temple of poetic expression” (șanam-parast-i but-khāna-yi sukhan) before adding:

In the norms [ $\left.\bar{a}^{\prime} \hat{\imath} n\right]$ of prose and inshä' he follows [Akbar's legendary courtier] Abu al-Fazl. When he recites his fluid verse, water flows from his eyes; and since he is always pouring out poetry his tear-filled eyes forever have moist lashes. He draws breath from the pain of [mystical] searching, and even though in appearance he is a wearer of sacred thread, his intellect transcends infidelity [sar az kufr bar mìtäbad]. Although his form [șu $r a t]$ is Hindu, in essence [ma'nī] he [breathes] Islam. Like his poetry, he lives in perfect simplicity and without ostentation. The tongue of his pen is exceptionally eloquent, and his talents are the summit of skill in this art. ${ }^{83}$

There is a great pun at the beginning of this passage, as Salih compares Chandar Bhan's expertise in the "norms" ( $\left.\bar{a}^{\prime} \bar{i} n\right)$ of Indo-Persian prose style to that of the great administrator, intellectual, and ideologue of Akbar's reign Abu al-Fazl ibn Mubarak, whose most famous work was itself called $\bar{A}$ '̀̄n-i Akbarì. To an early modern Indo-Persian audience, being mentioned in the same breath as Abu alFazl would be considered extremely high praise indeed, and to have one's prose style compared so favorably, not to mention cleverly, with such a canonical text as $\bar{A}$ '̀n-i Akbarī would only heighten the effect. 
Salih's point, of course, is to insert Chandar Bhan into the canon of great $\mathrm{Mu}-$ ghal secretaries and administrators, and in this capacity our munshi demonstrated considerable range over the course of his career. But he was far from the only one. A number of other prominent Hindu munshis worked in the Mughal administration during this period, some of whom Chandar Bhan mentions in his various works, and others whom we know about from other sources. A handful of these secretaries even rose to positions of great responsibility in Shah Jahan's and Aurangzeb's administrations. One of these, a certain Diyanat Ray, was so accomplished an administrator that he went on to serve as interim chief of the entire

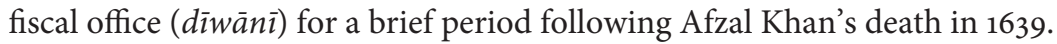

Some years later another celebrated Hindu administrator who has all but vanished from most history books, Raghunath Ray Kayastha (d. 1664), also stepped in and actually ran much of the government for nearly a year after the death of the esteemed wazìr Sa'd Allah Khan (d. 1656). Raghunath Ray was himself a protégé of Sa'd Allah Khan who had spent years working in the dìwān's office and was thus well regarded as a competent administrator. ${ }^{84}$ Chandar Bhan describes him as the "frontispiece in the book of the men of the pen of Hindustan" (sar-daftar-i arbāb- $i$ qalam-i Hindūstān) (CC, 65), and, like Diyanat Ray before him, Raghunath worked during this period as the "acting wazīr" (wizārat-intimā') until the position was taken over by the military commander Mir Jumla. But even after Mir Jumla became wazìr, according to our munshī it was actually Raghunath Ray who continued to manage most of the day-to-day affairs of the dīwānì, with Chandar Bhan and various other career civil servants there to assist him. Meanwhile, as we will discuss in greater detail in the next chapter, Mir Jumla was replaced just a few years later by another nobleman named Ja'far Khan, one of Chandar Bhan's own regular epistolary correspondents who continued on as wazir once Aurangzeb came to power in 1658. Soon thereafter, however, Ja'far Khan was reassigned to serve as governor of Malwa, leaving Raghunath Ray once again in charge of the central dìwānì.

Indeed, for those who might assume that a Hindu like Raghunath Ray would fare poorly in Mughal politics once Aurangzeb the "zealot" came to power, in fact the opposite is true. It was Aurangzeb who gave him the highest promotion of all, appointing him, as Chandar Bhan tells us, to replace Ja'far Khan as the sole and official (rather than merely interim) prime minister not long after the new emperor's accession, and elevating his title to "Raja" Raghunath (CC, 67-68). Significantly, Raghunath Ray not only had supported Aurangzeb's effort to win the throne during the war of succession but also had participated in the later battles against princes Dara Shukoh and Shah Shuja'. And once Aurangzeb's power was secure, Raja Raghunath continued as chief of the dìwān $\bar{\imath}$ for over half a decade, right up to his death in the sixth year of Aurangzeb's reign..$^{85}$ Later in life, Aurangzeb fondly remembered Raja Raghunath in letters to others, noting that he was one of the greatest administrators he had ever known. ${ }^{86}$ 
By this time Chandar Bhan, too was nearing the end of his life and career in Mughal service. There has been much confusion about Chandar Bhan's retirement in modern scholarship and commentary, which we will examine in greater detail in chapter 6 below. Some have suggested that as a devout Hindu Chandar Bhan was so upset by Aurangzeb's accession to the throne that he immediately quit Mughal service altogether and went off to Banaras, spending his final days in that most sacred of Hindu holy cities. But this is little more than a fanciful legend, for we know from Chandar Bhan's own writings that he continued to serve the court even after Aurangzeb became emperor. Indeed, he even wrote an exceedingly courteous letter congratulating Aurangzeb on his accession and included it in Munsha'āt-i Brahman:

Conveying congratulations [tahni-at] on the glad tidings of the accession to the throne of the World-Protecting Emperor Shāh 'Ālamgīr the Conqueror of the Universe

After completing the necessary acknowledgments of servitude and presenting the customary well wishes that are the appropriate, necessary, and incumbent duty of all subjects; having rubbed the forehead of fidelity on the ground of supplication and the brow of devotion on the threshold of [your] angelic footfall, this speck of dust conveys the following message to the place of the court's hearing at the foot of the celestial throne.

May your felicitous and propitious accession, which is like the onset of springtime in a garden of wealth and fortune, and likewise the cause of the opening of the gates of the hopes and desires of the world and its inhabitants, bring happiness and blessings: upon the throne of khiläfat and governance and the seat of kingship and universal rule that is the asylum [maljä'] of kings of the seven climes and the refuge [marja] of rulers on the face of the earth; upon Your Royal Majesty the sovereign emperor of the universe, the qibla of the world and its people, the clarion blast of whose conquest and governance has been broadcast to all four quadrants of the world, and the seed of whose justice and beneficence has been planted in all six directions of the universe; and to all of your sympathizers, well-wishers, relations, and those who pray for the good of your daily increasing empire.

May the True Guardian [hāfiz-i haqīqì, i.e., God], having safeguarded Your Exalted Majesty's spirit-which is itself the evidence of God's grace and the sign of divine mercy-under the shadow of his protection, keep the sun of your eternal empire ablaze and permanent upon the diverse people and places of the world [bar mafāriq-i jahān wa jahāniyān].

O King, may the world bow to your command;

May lips drip with expressions of thanks and salutations;

Since it is your spirit that watches over the people,

Wherever you are, may God watch over you!

[shāhā 'ālam muțīi-yi farmān-i tu bād lab-rez-i adā-yi shukr-o-ihsān-i tu bād chūn żāt-i tu khhalq rā nigahbān bāshad har jā bāshī khudā nigahbān-i tu bād]

$(M B, 11-12)$ 
One may debate the sincerity of these warm congratulations, of course; but absent some concrete evidence indicating that Chandar Bhan was secretly aghast at the prospect of a "bigot" like Aurangzeb becoming emperor, perhaps we should simply take him at his word and conclude that Chandar Bhan saw no reason to fear for his-or his coreligionists'-well-being under the new ruler and really did just want to congratulate him.

We know, moreover, that Chandar Bhan continued to correspond with Aurangzeb even after this. And while it is true that this correspondence included a letter officially requesting permission to retire, in the letter itself the munshi makes clear that he is withdrawing from regular service not as some form of sectarian dissent but rather, simply, on account of his advancing age. The letter adds, moreover, that despite his official retirement Chandar Bhan wished to continue serving Aurangzeb's court, albeit in a less demanding capacity:

To the Emperor: Greetings to the kind, merciful, just, and loving emperor:

We have grown old with [worldly] sins, but now we desire

To leave these transgressions to the unadulterated youths

[shudìm pìr ba 'iṣyān-o-chashm ān dārìm

ki jurm-i mā ba jawānān-i pārsā bakhshshand]

The intention of this feeble ant had been that, having fastened the belt of service to this Solomonic court that is the refuge of kings of the seven continents, a boundless good fortune would allow him to maintain a permanently graceful presence there. But, whereas I have spent all the days of my youth, that is, the best parts of my life, in service to this caliphal lineage, and now the promise of youth has given way to gray hair, and the mind and five senses are no longer sound, the energy and will to exert myself in the celestial court have waned.

I therefore ask to be excused from attending on the luminous Royal Presence so that I may engage myself as the caretaker [ $k \underline{h} \bar{a} k$-rob, lit. "sweeper"] of the sacred illuminated tomb [rauza-i munawwara] that is situated between this world and the hereafter, and thereby gain favor in the present and next life.

At present I am still engaged in the duties to which I am currently assigned, providing the same dedication, humility, and knowledge of essential administrative affairs that I have displayed in all my years of experience in the imperial fiscal offices. And I remain busy in steadfast commitment, purity of motive, and sincere amity with the prayers for your long life and continued prosperity that are the appropriate, necessary, and incumbent duty of noble and ordinary people alike. Of course, even if the reality of everyone's situation is already clear and evident to your enlightened mind, which is like the proverbial mirror onto the whole world, nevertheless, if any proof is needed, many servants of this bounteous government can bear witness to this old retiring Brahman's sincere devotion. $(M B, 12-13)$

In other words, even in his retirement Chandar Bhan planned to continue his connection to the Mughal court and apparently saw no moral conflict in doing so even under Aurangzeb. On the contrary, he expressed his desire to 
continue serving the court in a less formal capacity with considerable affection and respect.

There is still some question, however, about which city he in fact retired to. Some modern commentators have suggested that since Chandar Bhan was from Lahore, the tomb in question was that of Jahangir, which was also in the munshīs hometown. But Chandar Bhan himself does not specify, and while the term he uses- "the illumined tomb" (rauza-yi munawwara)-is one that in Mughal-era Persian could in theory refer to any royal mausoleum, it was almost always used to refer specifically to the Taj Mahal, which is of course located in Agra.

It would appear, then, that Chandar Bhan did not in fact retire to his hometown of Lahore, but rather to Agra, where he spent his twilight years in some sort of caretaker capacity at the Taj Mahal complex. This would certainly explain why some later early modern sources, such as Sher Khan Lodi's Mir'āt al-Khayāl (The mirror of thought; 1690-91), described Chandar Bhan as having been a "resident of Akbarabad"-something that always seemed like a strange mistake, given that anyone who has read even a sampling of Chandar Bhan's own works could have no doubt that he was originally from Lahore.

There is, moreover, yet another suggestive piece of evidence to this effect in the official court records of Aurangzeb's reign, the Aknhbārāt-i Darbār-i Mu'allá, which contain an entry from October 1666 documenting the emperor's instructions that honors be bestowed on "the officials at the tomb of Firdaus Āshiyānī [i.e., Shah Jahan]," who had died earlier that year and been interred next to his beloved Mumtaz (who was also Aurangzeb's mother) in the Taj Mahal itself. Among those who were given robes of honor was none other than Chandar Bhan Brahman, who is described as the "chief executive of the tomb" (dīwān-i maqbara), along with "Tej Bhan, son of Chandar Bhan, the tomb's accounts manager" (Tej Bhān pisar-i Chandar Bhān mustaufi-yi maqbara). ${ }^{87}$

Besides being pretty clear evidence that Chandar Bhan was living in Agra and continuing to serve the court nearly a decade into Aurangzeb's reign, this little archival tidbit suggests that the commonly accepted date of Chandar Bhan's death (1073 AH / 1662-63 CE) is off by at least several years. The earliest source to list the incorrect date, and the one to which most subsequent works refer, is Shir Khan Lodi's aforementioned Mir'āt al-Kh hayāl, a well-known compilation of literary biographies and essays on other miscellaneous topics such as prosody and dream interpretation. Lodi compiled Mir'ät al-Khayāl in the latter part of the seventeenth century - that is, not long after the events themselves. But clearly he got bad information from one of his own sources or simply made a mistake, or perhaps there was a scribal error somewhere along the way that somehow eventually became the accepted date. Whatever the reason, all we can say now with 
any confidence is that Lodi's date has to be wrong and that Chandar Bhan died sometime after October 1666.

This may seem like pedantic quibbling, particularly from the vantage point of some three and a half centuries later. How can it really matter much whether Chandar Bhan died in 1662, or 1666, or sometime soon thereafter, as long as we know approximately when he died? But it does matter. For one thing, it means that even after Aurangzeb's accession Chandar Bhan continued to serve the court, not for a couple of token years, but for nearly a decade, possibly even longer. It also shows clearly that Chandar Bhan not only continued to serve Aurangzeb's court himself but also guided his son to do so-something he surely would not have done if he thought Aurangzeb and his advisers were the agents of a tyrannical Muslim orthodoxy so "strident and uncompromising" that it was determined to root out Hindus and Hinduism from Mughal life, which is how this period has been ubiquitously portrayed in modern historiography.

Moreover, if we have been wrong all this time about something so simple as this, then how much more have we been missing? To the best of my knowledge, I am the first historian even to refer to this entry about Chandar Bhan and Tej Bhan in the $A \underline{k} \underline{h} b \bar{a} r a \bar{t}$ from Aurangzeb's reign, which really is quite extraordinary when you consider that we are talking about the official record of daily business at the Mughal court-records that were not only kept in the central court itself but also regularly circulated as a newsletter to the various Mughal capitals, satellite courts, and other locales. The Ak $\underline{h} b \bar{a} r \bar{t} t$ are not-or at least, were not- exactly an obscure source, in other words. Yet to this day they are not even available in a printed edition, much less a translation, or better yet a searchable digital format. Clearly, then, we still have much to learn about everyday social and political life at the seventeenth-century Mughal court.

This record of Chandar Bhan's position as dìwān of the Taj Mahal complex also puts into better perspective two other surviving letters from the munshi to Aurangzeb. The first, listed in Munsha'āt-i Brahman as "An Official Report from the Humblest of Servants to That Court Which Is the Refuge of Sultans," details the planning and events surrounding a festival commemorating the Prophet Muhammad's birth (majlis-i maulüd) held at the "illumined tomb" in the second year of Aurangzeb's reign, "with all the amenities proper to your heavenly dynasty" $(M B$, 13-14). Chandar Bhan notes that the "Pillar of the Sultanate Wazir Khan"-whom we have encountered above as one of Chandar Bhan's own epistolary correspondents-was among the many notable servants of the court who attended the party and "adorned the assembly throughout the night, right through to the afternoon of the following blessed day." But perhaps more interesting is the vivid description of the types of entertainment that Chandar Bhan organized for the festival, in particular the specific emphasis on doling out charity as an expression of imperial piety, and the fact that at least a certain number of eccentric hermits and other 
heterodox mystical figures (majżūbān) were not only welcome at the proceedings but given a share of the royal largesse:

Group after group and troupe after troupe of masters of knowledge and practice, men of piety and rectitude, and memorizers of the Qur'an and chanters of com-

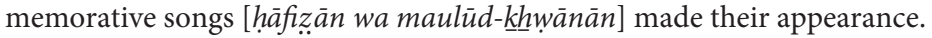

Some six thousand rupees were set aside to spend on charity and the rest of the festival expenditures-there were snack trays [qanqalāt], entrées [ta'àm], perfume [argaja], betel leaf [pān], and various other necessities for brightening up a colorful majlis.

During the majlis-i maulüd itself donations were given to the learned, the eloquent, the pious, the ascetics, the memorizers of the Qur'an, and the penitent, while off to another side the eccentric mystics [majz̄ūbān] and hermits [gosha-nishinnān] [received a share], and at the gate of the blessed illumined tomb the needy, the poor, the widows, and the sick each received a share suitable to their condition and need.

Having received such bounty, the assembled crowds busied themselves with prayers for the continued success of this eternal empire.

The letter closes on a relatively quotidian note, explaining that "after the majlis the necessary equipment that had been brought from the fort was taken back to the fort." As a mundane matter, this suggests that even in his "retirement" Chandar Bhan retained the authority to requisition men and equipment from the main imperial citadel, famously situated around the bend in the Jumna River from the Taj, at his own discretion and with Aurangzeb's tacit approval. But the letter also offers a hint as to the nature of monuments like the Taj as sites for public gathering, and the ways in which royal festivals also functioned as occasions for interaction with the local population-whether purely as entertaining spectacle or as opportunities for the people to avail themselves of Mughal officials' generosity.

We will see several other examples of this public function of Mughal parades and festivals in chapter 3 below, but for now let us stick with Chandar Bhan's final years. There is one more letter to Aurangzeb preserved in Munsha'ät-i Brahman, and it shows that, in addition to arranging public events and managing the Taj complex, Chandar Bhan continued to have a hand in matters pertaining to Aurangzeb's official imperial treasury, even into his retirement. The letter is undated but seems clearly to refer to a period around March 1666, just a few months before Aurangzeb rewarded Chandar Bhan and Tej Bhan with robes of honor. "At this time," according to another contemporary source known as Ma'așir-i 'Ālamgìīi, "the imperial treasury, which the officers had in the fifth year of the reign removed from Agra Fort to Delhi Fort, was again transferred to Agra." ${ }^{88}$ Chandar Bhan's letter to Aurangzeb, in turn, seems to involve working out the logistics of this transfer and the organization of the Taj complex's treasury in coordination with the larger transfer of funds from Delhi back to Agra. ${ }^{89}$

The letter begins with a simple "Greetings, O qibla of the world and its inhabitants!" and proceeds to explain that "previously the illumined tomb's treasury 
was housed in [Agra] Fort," but that ever since the main imperial treasury had been relocated to Delhi, in order to keep a proper account of the Taj's operating expenses Chandar Bhan and his team had kept the funds collected from gifts and rents from the surrounding villages in a treasury at the "blessed shrine" (rauza-yi muqaddasa) itself, not at the fort. Now, with the general treasury being moved back to Agra, he wanted some guidance from Aurangzeb on whether to go on maintaining this pool of money separately or to resume the older practice of calculating the Taj complex's overhead as part of the larger expenditure of Agra Fort. "Whatever exalted command may be issued with regard to this matter," he closes, "may the sun of your day-lengthening empire be forever luminous and resplendent with newly rising grandeur and magnificence" (âftāb-i daulat-i roz-afzūn hamwāra az mațla'yi jāh-o-jalāl sāți 'wa lāmi' bād) $(M B, 14)$.

Needless to say, the evidence about Chandar Bhan's life and experience at court that we have adduced above is probably not, by itself, sufficient to undo generations of conventional wisdom about the growing orthodoxy at Shah Jahan's and Aurangzeb's courts. But hopefully it will provide enough food for thought to prompt serious questions about what we actually know about everyday life at the seventeenth-century Mughal court. For too long, Mughal historiography has focused almost entirely on military, political, and institutional histories without really taking much account of the everyday experience and cultural networks of those who actually lived and worked at the court.

For now, let us simply reiterate that for all the talk in modern historiography about this period as a time of growing intolerance and sectarian hostility, and thus, in turn, as a tipping point toward Mughal cultural decline generally, we see very little evidence of it either in Chandar Bhan's own writings or in those of his contemporaries. On the contrary, over the course of the seventeenth century Chandar Bhan Brahman worked extremely closely with, and formed powerful bonds of friendship and intimacy with, a range of Mughal officials and other members of the seventeenth-century Indo-Muslim cultural elite, nearly all of whom at least appear to have reciprocated his civility and good manners.

Much of that etiquette was bound up in what I have described above as a form of "literary civility" that practically coursed through the entire world of Mughal courtly and urban society. But there were other forms of civility that were equally important to the intellectual world of the Mughal secretaries and other administrators. Two in particular, the discourse on political ethics ( $a \underline{k} \underline{h} l \bar{a} q)$ and a powerful discourse of humility born from what might be called "mystical civility," were especially important in Chandar Bhan's understanding of Mughal governance. Now that we have a better sense of Chandar Bhan's overall cultural world, it is to these more specific notions, and their role in the secretary's understanding of his profession, that we turn in the next chapter. 


\title{
A Mirror for Munshīs
}

\author{
Secretarial Arts and Mughal Governance
}

As an heir to the rich tradition of great secretaries of the Indo-Persian cultural world, Chandar Bhan was expected to embody the high standard of erudition, professional training, administrative ability, political discretion, diplomatic panache, ethical behavior, mystical sensibility, literary flair, and general interdisciplinary excellence that had been cultivated for centuries by notable earlier "masters of the pen" (așhāb-i qalam). "The need for a successful Mughal state secretary to embody these qualities is a regular theme of much of his most famous prose work, "The Four Gardens" (Chahär Chaman), and we will spend much of this chapter examining precisely what that meant in practical terms. But let us begin by looking briefly at Chandar Bhan's general sense of what made a good munshi tick.

\section{THE MIND OF A MUNSHI}

It becomes quickly evident upon any perusal of Chandar Bhan's works that in his view merely being literate in the Persian language and mastering a certain set of scribal techniques might get you a job but was not nearly enough to vault one into the ranks of the elite munshis of the Indo-Persian secretarial world. Perhaps the most explicit formulation of this view on Chandar Bhan's part comes to us from a letter that he wrote to his son Tej Bhan, which is included in both of his major prose works, Chahär Chaman and Munsha'ät-i Brahman. ${ }^{2}$ In it, Chandar Bhan makes clear to Tej Bhan that to be a successful munshī one had to have what we would nowadays call a well-rounded liberal arts education and that to truly excel one had to have, among other kinds of training, the early modern equivalent of 
graduate degrees in disciplines as various as history, literature, philosophy, and political science. He advises Tej Bhan, for instance, to begin his studies of prose composition by emulating the collected letters (ruq'ät) of 'Abd al-Rahman Jami (1414-92), the celebrated poet of Timurid Herat, and by studying Sa'di's Gulistān and Büstān, two cornerstones of Persianate literary culture that have been used to teach the art of prose and inculcate moral wisdom in young and old alike for centuries. The well-educated Mughal gentleman should also have a strong background, Chandar Bhan felt, in the canonical treatises on statecraft, civility, and

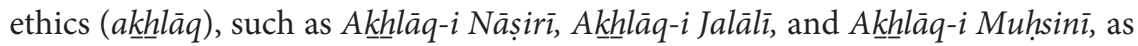

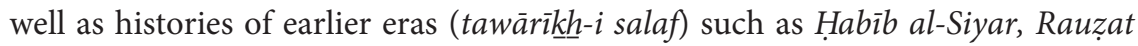

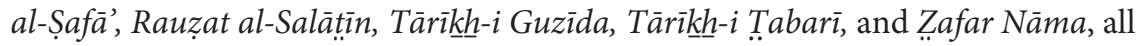
of which he specifically names $(C C, 176)$.

In the same letter, Chandar Bhan also shows his stripes as a professional poet, a vocation that, as we saw in the previous chapter, he saw not just as an entertaining diversion but as a craft that was inextricably tied to his success as a state secretary. To be a great poet, though, one first had to master the canon of literary greats. Thus he provides Tej Bhan with a lengthy syllabus of scores of "some of the great masters [ustādān] whose collections of ghazals and mașnawis this supplicant [i.e., Chandar Bhan himself] studied as a youth"-both ancients and moderns, some of them well known, and some barely traceable today-whose works Tej Bhan ought to study and emulate until, in time, "his own talent has been honed and he has a grasp of the art of expression" (CC, 176-77). ${ }^{3}$

As highbrow as all this sounds, however, Chandar Bhan also placed a high value on expert training in certain more mundane skills, like accounting (siyāq), as eminently necessary for the well-rounded munshi . Indeed, sounding like many parents today who want their children to pursue "practical" undergraduate majors like business, economics, engineering, and so on, Chandar Bhan specifically counsels his son to study accounting because it would greatly improve his job prospects. "It would be best," he tells Tej Bhan, "if you were to master not only literacy but also accounting, because very few munshis also know accounts, meaning such men are scarce; indeed, the person who is able to combine mastery of both crafts is a prized commodity, a "light upon light"' (CC, 175).

The wording here is revealing, in that the phrase "light upon light" (nūr 'alá $n \bar{u} r$ ) is a direct allusion to the Qur'an's so-called Āyat al-Nūr (24:35), a famously esoteric passage that became a favorite among medieval and early modern Sufis, philosophers, and literati who made the chapter's potential for mystical interpretations "the subject of constant meditation and commentary," as one noted modern scholar put it. ${ }^{4}$ Besides showing off Chandar Bhan's erudition-and, for that matter, the level of erudition he expected of his son Tej Bhan-it points to the important overlap between Mughal ideas about good governance and the role of what might be called "mystical civility" in the cultivation of the well-mannered Mughal 
gentleman. In Chandar Bhan's view it was essential that those who made their living through worldly pursuits, from run-of-the-mill clerks and accountants right up to the most powerful men-indeed, especially the most powerful men-should cultivate a refined habitus of mystical disinterestedness amid the bustle of worldly activity. That is, even if professional obligations made it impossible for them to completely embrace the mystical path of the great Sufis and yogis by renouncing material attachments altogether and focusing exclusively on spiritual pursuits, they should nevertheless strive to emulate the humility of such "great men" (buzurgān). Doing so not only would improve one's moral character but also, perhaps counterintuitively, would make one an even more effective administrator, because it would reduce one's susceptibility to the lure of greed and corruption.

Thus in the same letter to his son Chandar Bhan expounds at length upon the moral necessity of treating the material world with an air of detachment ( $b \bar{i}$ ta'alluqī), explaining to Tej Bhan that in his own youth whenever he had troubles he would seek counsel from "recluses, hermits, and mystics" (munzawiyān wa gosha-nashinān wa darweshān) wherever he could find them. "Though there are many varieties of hostility and contentiousness in the actions and ways of the people of this world," he adds, "by maintaining my connection to the sacred thread, my words, and my conduct I have been able to work to set aside ego in all circumstances" $(C C, 173)$. In other words, however involved one might get in the vicissitudes of human power and commerce, in Chandar Bhan's view one should not become "polluted by attachments" (ālüda-yi ta'alluq), and he reinforces the point by invoking the family tradition: “This faqïr's father, your grandfather, even though he was clothed in the visible semblance of those who are attached to the material world [agar chi dar libās-i zāhir mushābahat ba ahl-i ta'alluq dāsht], nevertheless considered himself second to none when it came to [his understanding of the mystical] interior world ['älam-i bātin] and always had the verse 'To remain pure is far better than to be polluted' on the tip of his tongue" $(C C, 174)$.

Of course, given Chandar Bhan's pedigree as a Brahman it is perhaps tempting to read a certain caste inflection into all this discussion of the dangers of worldly "pollution," particularly for someone who spent his entire career working withand usually for-Muslim employers. But we should be very careful about reading such mystical metaphors out of context, for nowhere else in his entire oeuvre does Chandar Bhan even hint at this sort of anxiety about caste purity. To the contrary, though he makes plain on numerous occasions that he is proud of his Brahman heritage, all of his professional pursuits and intellectual interests are ecumenical in the extreme, suggesting that we should read these passages as reflecting more of a generic mystical attitude toward the dangers of worldly attachments, one that could comfortably be read from a Suf, Vedantic, or other spiritual perspective, than as a trace of narrowly sectarian or caste-anxious Brahmanism. Such notions even pop up regularly in his poetry, as in the following verse: 
A liberated man ensnared by the abandonment of desire

Does not let either of the two worlds into the sanctum of his heart.

[kaunain rä ba khalwat-i dil rah namīdihad

$\bar{a} z \bar{a} d a ' i$ ki tark-i tamannā girifta ast]

$(D B, 35.2)$

Also important for the munshī, in both practical and ethical terms, was a commitment to a code of gentlemanly discretion. "The keeping of secrets," he tells Tej Bhan, is a defining feature of a successful state secretary (munshī ham àn ast ki rāzdār bāshad), punctuating the thought with a tidbit of personal experience:

Although in this humble servant's capacity as a munshi at the court of the imperial caliphate there is plenty of opportunity to give in to human nature and indiscretion [basharīyat wa ghaflat], nevertheless when it comes to keeping secrets I have been like the proverbial flower bud, which, though it has a hundred tongues [i.e., the petals], keeps its mouth shut tight. I have never conveyed even a single word from one situation to another, and under no circumstances have I discussed one person's secret with anyone else. Rather, whatever I have heard, and wherever I heard it, I have forgotten it right then and there. $(C C, 175)$

All of this was clearly intended to provide Tej Bhan not only with practical career advice but also with lasting moral guidance. Chandar Bhan makes this aim quite explicit in a kind of paean to the virtues of self-reliance and good character:

Among the ranks of scribes and amid the appeals of mankind, keeping my desired goals in view, I have made sure never to abandon my civility and good character [husn-i sulūk wa nek-żātī], always acting in accordance with my father's admonitions. Hence I also trust that my fortunate son will maintain these good manners and distinguished comportment [auzā'-yi pasandīda wa ațwār-i guzìda] at the forefront of his attention. Whatever employment comes his way will do so without the necessity of another's recommendation. He will find self-satisfaction and will value

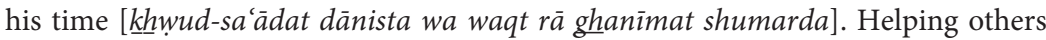
achieve their goals will become central to his own purpose, and he will understand that [even] in this debased material world there is no task that can't be accomplished and no goal that can't be reached. (CC, 175)

One can easily understand why any father, of any era, would want to inculcate such wisdom in the mind of his son. But what was Chandar Bhan's purpose in including such a lengthy didactic epistle in a work intended for wider circulation among the Mughal reading public? In the version of the letter that appears in Chahār Chaman, Chandar Bhan specifically describes the letter as a nașihatnàma (lit., "advice book"), which would have immediately connected it in the minds of discerning contemporary readers with the larger medieval and early modern corpus of Indo-Persian akhlāqī texts on moral and political wisdom. Such texts often fell under the rubric of "advice for kings" (nașinat al-mulūk) 
and thus served a function in the Persianate world similar to that of the genre of "mirrors for princes" in Europe. Classic examples of the genre include works like Nizam al-Mulk's Siyāsat Nāma (Treatise on government; 11th cent.), Ghazali's Nașihat al-Mulūk (Advice for kings; 12th cent.), Kai Ka'us ibn Iskandar's Qābūs Nāma (The book of Qabus; 1082), and Nizami 'Aruzi's Chahār Maqāla (The four discourses; ca. 1155-57), and the celebrated polymath Nasir al-Din Tusi's Aḳhlāq-i Nāṣirī (Nasir's advice on good conduct; 1235), a text that was read especially widely in Mughal India, and was among those which Chandar Bhan specifically recommended Tej Bhan study carefully. ${ }^{5}$ But in this case Chandar Bhan's own letter was not aimed at kings; rather, it was intended as a more general set of norms and advice for the aspiring gentleman and especially the aspiring secretary-a "mirror for munshīs," if you will.

For those of us reading it today, this seemingly minor detail raises a whole host of larger questions about what kind of text Chahär Chaman actually is and how we are meant to read it. It has often been described simply as an "account of Shah Jahan's court," which is of course true up to a certain point. But it is also quite consciously constructed as a memoir of sorts, and a didactic one at that. Chandar Bhan inherited and saw himself as embodying a particular strand of the Indo-Persian cultural tradition where a certain cluster of the secretarial arts was normalized and idealized as applicable-in fact, as necessary-not just for the professional training of munshis but also for the politico-moral regulation of royalty, ministers, nobles, literati, and elites generally. Just as Machiavelli had done, the authors of normative texts on moral and political wisdom in the Indo-Persian $\bar{a} d \bar{a} b$ and $a \underline{k} \underline{h} l \bar{a} q$ traditions had always placed a heavy emphasis on the importance of the state secretary-usually known in Persian texts variously as a dabìr, kātib, or munshī - to the proper functioning of government and society. Certain skills, like penmanship ( $\underline{k} \underline{h} w u s h-n a w \bar{i} s \bar{l})$, accounting (siyāq), the ability to write stylized prose (insh $\bar{a}^{\prime}$-pardāzi $)$, and the ability to traffic in what

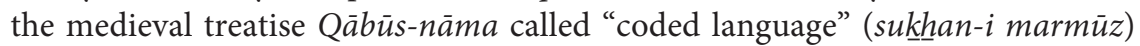
were obviously critical components of any imperial munsh $\vec{\imath}$ s basic professional tool kit. ${ }^{6}$ But even in medieval royal advice books like Qābūs-nāma and Chahār Maqāla a much broader spectrum of qualities came to be associated with truly great munshīs and dabìrs as well: refined etiquette, diplomatic savvy, political discretion, literary flair, scholarly erudition, and even mystical sensibility, to name a few.

Few were considered capable of fully mastering this comprehensive cultural package, which is part of what made becoming truly adept munshi, or "munshiyi haqīq $\bar{\imath}$ in Mughal parlance, so rare. Nevertheless, for aspiring civil servants a talent for the secretarial arts (funūn-i dabīrì or munshīgìrī) was seen as a critical pathway to upward social mobility. Meanwhile, for princes and the nobility, an education in the funūn-i dabīrì was likewise considered essential, at least in theory 
allowing those in positions of authority to understand and practice the norms of good prose composition and epistolary etiquette, to comprehend what was going on in the administrative apparatus around them, and thus, too, to maintain power and govern more effectively. This instrumental view of the secretarial arts as keys to power meant, by extension, that a much broader spectrum of less tangible secretarial qualities also came to be seen as critical components of gentlemanly conduct, moral sentiment, social civility, and ethical politics.

These intellectual historical trends were well established in Indo-Persian literary and political culture long before the consolidation of the Mughal Empire, and thus it is not surprising to see them so clearly reflected in Chandar Bhan's oeuvre. On the one hand, as we will see, he viewed the Mughal state as one in which meritocracy mattered and in which social mobility was possible if one had talent and was willing to work hard. But perhaps more significantly he also considered it perfectly appropriate to judge the competence of various nobles and wazir rs, not necessarily on their military and political capabilities, but rather on the basis of criteria specific to the realm of the secretarial arts. In his view attributes like high birth and martial valor, while certainly important, were not nearly enough to make someone a great leader, much less a great wazir. Rather, having a knack for skills like calligraphy, managing accounts, and drafting elegant letters augmented one's competence as a manager, and possessing the correct balance of diplomacy, discretion, religious tolerance, mystical sensibility, and $a \underline{k} \underline{h} \bar{l} \bar{q} \bar{\imath}$ civility was what separated the truly great Mughal ministers from others whom he saw, as it were, "merely" as great military commanders.

\section{WIZĀRAT, MA'RIFAT, AND MUNSHĪGIRİ: \\ MYSTICAL CIVILITY AND THE ART OF MUGHAL ADMINISTRATION}

These themes are on clear display in the first section, or "garden," of Chandar Bhan's most celebrated work of expressive prose, Chahär Chaman (The four gardens). We saw in the previous chapter that one important message of the opening sequence of Chahär Chaman is that a certain flair for the opportune deployment of literary style and wit could, in Chandar Bhan's estimation, be an important pathway to social and professional mobility. In public settings, the ability to craft a memorable poem in praise of the emperor or some other patron could earn the professional secretary a handsome reward, raise, or promotion. But we saw too that there was a pronounced literary pulse beating through the heart of Mughal letter-writing practices, one that allowed for the circulation of all manner of mystical and heterodox views, even among figures not usually associated with literary and mystical cultures. A keen literary sensibility was a staple of virtually all levels of Mughal social interaction, and this, no doubt, was why Chandar Bhan was so 
insistent that his son Tej Bhan master the canon of medieval and early modern Persian literature as part of his basic education.

Overall, Chahär Chaman is a text that is episodic and fragmentary in the extreme, with a heavy emphasis on the sort of stylistic artistry that was the professional munshīs stock-in-trade. Yet while Chahār Chaman may lack a certain continuity it does not lack coherence. Each of the four main chapters, or "gardens," showcases a different facet of the munsh $\vec{\imath}$ 's self, and thus, however fragmentary, episodic, and lacking in linear narrative it may be, Chahār Chaman unfolds with clear autobiographical and didactic intent. The first "garden," for instance, explores three core components of the munsh $\vec{\imath}$ s profession: the literary (which we have discussed already above), the administrative, and the political/ diplomatic. Moreover, each of these three subsections functions on a more macro level as well, mapping Chandar Bhan's personal experiences as a munshi onto a broader set of reflections on three of the core functions of the Mughal state as a whole: (1) cultural patronage; (2) effective administration in the public interest; and (3) war, politics, and diplomacy. There is an interplay between these two modes-the micro/personal and macro/imperial-throughout the first chaman, and indeed throughout the text as a whole, as Chandar Bhan uses his own experience at court to explore the larger contours of Mughal imperial culture more generally.

While there is some variation in the ordering of contents, most manuscripts of Chahär Chaman begin (as does the 2007 printed edition used here) with a brief prefatory apologia of sorts. After explaining that the first of the text's "four gardens" will provide a description of various public assemblies and festivals "containing all the freshness and succulence of the roses of eternal spring in this everlasting empire," Chandar Bhan notes, however, that the sequence of anecdotes to follow is merely a personalized sampling because it would be impossible to provide a comprehensive account of all the many grand festivals and public occasions held at Shah Jahan's court over the course of his thirty-year reign:

Even though in this age adorned by the felicity and prosperity of His Most Exalted Majesty-the Sovereign of the Times, World Conqueror, and Treasure-Bestowing Emperor, who is bounteous as the sea, and the earthly shadow of the divine splendorous presence-a new social occasion takes place every day, and fabulous assemblies and festivals are arranged every month and every year; and from the six directions an amber-sweetened zephyr of victory and conquest wafts into nostrils eager for a whiff of its grace; and there is no way to measure or count the trappings of the court and the imperial apparatus of this eternal caliphate; and if from the very beginning of this spring of empire and fortune the pen of narration were to commit to writing the details of the day-increasing festivities and freshness and verdancy of the garden of eternal spring in this stalwart empire-the space of many volumes would be necessary. 
The flowing garden imagery that pervades this passage is a sign of things to come in the remainder of Chahär Chaman and echoes a good deal of Mughal writing generally in using the imperial garden as a metaphor for paradise on earth. But we should also note Chandar Bhan's admission, right up front, that this is not a comprehensive account of the history of Shah Jahan's reign, nor is it intended to be. The episodes described are offered, rather, merely as a representative "token" (yumn) of the larger court culture as Chandar Bhan experienced it. This sort of personalized expression would perhaps have struck many readers as unseemly in a straightforward historical chronicle but is perfectly at home in a work of inshä', which was considered to be an extremely flexible genre. Thus, Chandar Bhan explains, for reasons of space he has included only events that were personally witnessed by his own "spectating eye" (ki ba chashm-i tamāshā mushāhada uftāda).

If the purpose of the prologue is to insist that Chahär Chaman is a text founded on personal memories and eyewitness testimony, and if the opening sequence of literary anecdotes is designed to highlight the benefit of literary skill for social and professional mobility generally, then the next section of the opening "garden" takes us in another direction entirely. The overall underlying theme of showcasing the various skills and values necessary and relevant to the secretarial domain remains, but here Chandar Bhan's "mirror for munshīs" is positioned to reflect a different aspect of the court secretary's world-that of governance, administration, and the ideal conduct of ministers, secretaries, and the like. This new section, Chandar Bhan explains, will recount the "efficacious and knot-unraveling" accomplishments (kār-farmā'i wa girih-gusha $\bar{a} \bar{\imath}$ ) of various wazìrs of Hindustan, and it is clearly designed to evoke a specific subgenre of the medieval and early modern akhlāqi texts mentioned above, one that dealt with ministerial theory and practice and was generally referred to as "manuals for wazīrs" (dastūr al-wizārat).

At first glance, then, this section is not about munshis at all, focusing instead mainly on Chandar Bhan's impressions of the various prime ministers and other administrators with whom he worked over the course of the middle decades of the seventeenth century. But Chandar Bhan's idiosyncratic secretarial perspective nevertheless remains a crucial subtext throughout. For, it turns out, in Chandar Bhan's view the ideal Mughal minister was not just an excellent military commander but also a man of deep learning and civility. Specifically, he was a man of secretarial learning, one who had mastered the very same secretarial arts and values that Chandar Bhan himself tried to emulate and promote in his works; and he was, moreover, a man of mystical civility, one whose attunement to esoteric spiritual gnosis (known as ma'rifat in Sufi parlance) gave him the sort of humility that allowed him to do his job with the very sense of detachment (bī-ta'alluqī) from material gain that Chandar Bhan advocated to his own son Tej Bhan. These spiritual and secretarial qualities enhanced a leader's ability to handle affairs of state, over and above the mere brute demands of conquest. And these were pre- 
cisely the kinds of qualities, Chandar Bhan seems to be suggesting, that his readers should seek to emulate too. Indeed, the notion that all gentlemen and good imperial servants should cultivate this trivium of ideal qualities-selfless ministerial leadership (wizärat), spiritual gnosis (ma'rifat), and mastery of the secretarial arts (munshigìi $\bar{l}$ )-is reiterated throughout.

As with the matter of tolerance and cultural pluralism discussed in the previous chapter, such values as the bureaucratic work ethic and the importance of mystical spirituality for everyday civility in Mughal life have not received much if any attention for the post-Akbar period. With regard to administration, for instance, most modern commentators have been inclined to agree with M. Athar Ali's assessment that "the Mughal polity, so long as it functioned with any effectiveness, say, until the early years of the eighteenth century, continued basically with the organizational forms that Akbar instituted." 7 Meanwhile, with the exception of studies of the activities of Shah Jahan's eldest son, Prince Dara Shukoh (1615-59), everyday mystical cultures during this period haven't received much systematic attention either, thanks largely, as we noted in the previous chapter, to the perception that apart from Dara's heroic example Shah Jahan's reign was characterized by "an orthodox reaction to the policies of Akbar and Jahangir." And needless to say, there are few if any studies that treat these two domains of Mughal life-the bureaucratic and the mystical-together as part of the same cultural dynamic. Chandar Bhan's reflections on such matters show, however, that whatever might have been going on with the most conservative clerics during Shah Jahan's period, their influence appears to have been far more limited than has previously been supposed. For a great many Mughal observers, the era of Akbar was still one to be admired, emulated, and built upon.

Indeed, our munshi begins his section on wizärat with an overview of great ministers from earlier reigns, starting with a brief survey of notable wazirs under Akbar such as Bairam Khan, Mun'im Khan, and various others. Among these, Chandar Bhan singles out Akbar's celebrated finance minister Raja Todar Mal for especially high praise. ${ }^{9}$ Chandar Bhan notes that not only Todar Mal's military accomplishments but also his financial and administrative expertise had earned him the title "Master of the Sword and the Pen" (șāhib al-saif wa al-qalam), adding that many of the regulatory principles established by Todar Mal, aimed at improving agricultural productive capacity (ma'mūrì-yi mulk) and ensuring the well-being of the people (rifāhìyat-i ra'ìyat-parwarì), remained, even decades later, "the textbook for expert administrators of the world" (imroz nazm wa nasaq-i $\bar{a}$ dastūr al-'amal-i arbāb-i rozgār ast)..$^{10}$

Here Chandar Bhan relates two anecdotes that highlight key principles of good wizärat, in particular "the raja's integrity, virtue, trustworthiness, expertise, political acumen, and erudition" (rāstī wa diyānat wa amānat wa kār-dānī wa mu'àmala-fahmi wa dāna' $\bar{\imath})$-in other words, precisely the sort of characteristics 
that any good wazir or imperial secretary ought to emulate. He then concludes: "Indeed, the proof of the raja's true wisdom is that the great intellectual of the times, Shaikh Abu al-Fazl, whose attributes and qualities are famous the world over, said of him that whatever [knotty problems] he was able to unravel, no one else could have unraveled, and has said with utmost praise that, like [the great Qadiri Sufi] Miyan Shah Mir [d. 1635]'s understanding of spiritual truths and advanced esoteric knowledge, the expertise displayed by the raja in the fields of agrarian and administrative science [had made him] a khalif $f a$ of the times" (CC, 49). The message is clear: a great leader's true power stems not merely from the sword but also, even especially, from the intellect, and from the sort of humility, self-discipline, and spiritual detachment exemplified by great Sufi shaikhs like Miyan Mir. The power of wizärat, in other words, is nothing without the wisdom of ma'rifat. For munshīs, too, the message is clear: just as a mastery of the secretarial arts enhances a wazìr's abilities, so too the ethos of mystical civility must be a prominent component of the secretary's intellectual repertoire, enhancing his ability to contribute to imperial governance in a way that is ethical and selfless.

A good work ethic is another quality that Chandar Bhan emphasizes repeatedly. Following the discussion of Raja Todar Mal, he moves on to a brief account of some of Jahangir's more prominent wakìls and wazìrs, such as I'timad al-Daula (d. 1622), Asaf Khan (d. 1641), and Khwaja Abu al-Hasan Turbati (d. 1633). The latter was the scion of an important family of patrons, many of whom were notable literati in their own right, and whose court in Kashmir became a prime destination for a number of prominent poets and other intellectuals from the period. ${ }^{11}$ For instance, when the great Iranian poet Sa'ib Tabrizi made his way to the subcontinent in 1624-25, his first Indian patron was actually not the Mughal emperor but rather Abu al-Hasan Turbati's son Mirza Ahsan Allah Zafar Khan (d. 1663), who was then serving as the governor of Kabul and who was himself an accomplished poet who wrote under the pen name "Ahsan." ${ }^{12}$ Zafar Khan was also the primary patron for another great Indian Persian poet of the period, Muhammad Tahir Ghani Kashmiri (d. 1669), while his son 'Inayat Khan (d. 1670-71) became a well-known literary figure in his own right, composing poetry under the pen name "Ashna" and even more famously writing one of the major prose chronicles of Shah Jahan's reign, the Shāh Jahān Nāma.

Chandar Bhan, however, does not mention any of this, finding Abu al-Hasan notable mainly for the dedication he displayed as a Mughal officer and the amiable atmosphere he cultivated in the dīwānì: "The khwaja never abandoned his post and almost never left [the dīwān's office]; he was renowned for his energetic style [tarz-i nishast wa bar- $\underline{k} \underline{h} \bar{a} s t]$, for he used to arrive at the dīwān-khanana even before dawn and managed to handle his administrative duties in just a quarter of the day. During the period of Khwaja Abu al-Hasan's tenure as wazìr, Sadiq Khan was the paymaster [mīr bakhshī], and Mir Jumla (Shahristani; d. 1637) was the 
quartermaster [mīr sāmānì]; all three of these men had the utmost affection and amicability toward one another" $(C C, 50)$. Others come in for praise as well, including 'Abd al-Rahim Khan-i Khanan for the "bravery, courage, fortitude, poise, virtue, and composure" (shujā'at wa shahāmat wa himmat wa hālat wa fażilat wa jāmi'ìat) that he displayed "right up to the end of his life," and especially for his intellect and patronage, thanks to which "the convivial atmosphere and collection of literati, eloquent writers, and intellectuals that assembled in his majlis shone even brighter than the sun" $(C C, 50)$. Chandar Bhan also includes here a letter from the Safavid monarch Shah 'Abbas, in which the erstwhile Mughal envoy Khan-i 'Alam is praised especially for his "excellent manners, expertise in negotiation, epistolary eloquence, and diplomatic grace" (țarz-dānī wa $\bar{a} d \bar{a} b-i$ safärat wa tablīgh-i risālat wa lutf-i mu'àwadat) $(C C, 51)$-in other words, skills squarely within the domain of the secretarial arts.

At this point Chandar Bhan turns to those wazirs whom he knew and had worked with personally. As we noted in the previous chapter, when Shah Jahan came to power, the chief administrative responsibilities were initially split between the current wazi $r$, Iradat Khan, and the wakìl, Asaf Khan, who was himself aided by a trusted Hindu munshī named Mukund Das Kayastha, as Chandar Bhan reminds us. Within a year, however, Iradat Khan was replaced by Afzal Khan Shirazi, who initially continued to split duties with Asaf Khan but was eventually "appointed wazìr in his own right, on account of his intellect of Aristotelian genius [fahhāma-yi Arasțo-manish]" $(C C, 51)$. Other sources record that the occasion was marked by a revealing chronogram that exalted both the king himself and his trusted adviser in grand historical terms: "Plato has become the minister of Alexander" (shud Falātūn wazìr-i Iskandar $=1038 \mathrm{AH}=1629 \mathrm{CE}) .^{13}$ Chandar Bhan was already serving in Afzal Khan's employ when all this happened, and he continued to do so throughout the khan's entire tenure as wazi $r$. Our munshī was thus in an excellent position to observe Afzal Khan's character and demeanor.

We do not know exactly when or how Chandar Bhan entered Afzal Khan's service, but it was certainly one of the biggest turning points in the munsh $\vec{\imath}$ s career. After coming to India early in the seventeenth century, Afzal Khan had spent time in Shah Jahan's retinue while the latter was still a prince; later he served in the important post of imperial procurement officer ( $m \bar{i} r-i s \bar{a} m \bar{a} n)$ toward the end of Jahangir's reign, and he continued in that post in the early part of Shah Jahan's. For some of that time he was based in Chandar Bhan's hometown of Lahore, which is probably how the munshi managed to enter his employment.

However it happened, there is no doubt that Chandar Bhan had great admiration for his new patron, a respect that, at least as far as Chandar Bhan could tell, was mutual. In the autobiographical section later in Chahār Chaman, for instance, he insists that Afzal Khan was fastidious about not showing favoritism among 
his employees, yet he can't help adding a telling boast: "Although many munshīs of excellent penmanship and knowledge of the rules of writing from Iran, Turan [i.e., Central Asia], and Hindustan had all worked closely over the years with that eminent scholar, and although the grace of the great man's alchemical gaze was consistently impartial in both appearance and reality, nevertheless, because of my knack for being an agreeable companion and with help from my lucky stars, he promoted this feeble ant ahead of all others" (CC, 146-47). One proof of his patron's sincerity in this regard, according to Chandar Bhan, was that when Shah Jahan had come to tour Afzal Khan's newly built Lahore estate the khan honored Chandar Bhan by personally introducing him to the emperor. Afzal Khan also gave Chandar Bhan an elephant, "so that," he tells us, "I could always travel alongside that illustrious khan" to keep him company while on official business $(C C, 147) .^{14}$ Meanwhile, Chandar Bhan was a fixture at the khan's literary salons, both as an audience member and as a participant, and the two also carried on a regular epistolary correspondence. ${ }^{15}$

Chandar Bhan consistently praises not only Afzal Khan's intellect and administrative abilities but also, especially, "the inner purity and compassionate heart of that knower of spiritual and universal mysteries" (CC, 53). He was, in Chandar Bhan's estimation, "singular among the literati of the world, the title page in the book of 'ulama' of the times, the cream of renowned wazirs, the acme of elite amirs, the epitome of mastery over manifest and hidden meanings, the knower of spiritual and worldly subtleties, the grand wazir of Hindustan, the great scholar of the age and times ['allāmat al-'așr wa'l-daurān], Afzal Khan, who achieved universal fame for his virtue, learning, civility [husn-i k $\underline{k} u l q]$, gentility, and kindly nature" $(C C, 52)$. This string of glowing epithets might seem like flowery and pointless hyperbole to some modern readers, but from the pen of a writer as careful as Chandar Bhan they were definitely not random; rather, such compliments were carefully calibrated to point to certain qualities in the wazir rather than others. In this case, Afzal Khan's fame as a man of great political clout and acumen notwithstanding, Chandar Bhan wants his readers to focus on the khan's erudition, spiritual introspection, and generosity rather than simply to be overawed by his might and power. Such character virtues were, after all, ones that anyone could emulate, and if they did so, the thinking appears to have been, the entire society would be better for it.

A good wazir, in Chandar Bhan's view, also had to be always open to new ways of improving the administration. The next passage thus emphasizes Afzal Khan's willingness to innovate, written in prose that strongly echoes the language used earlier to eulogize Raja Todar Mal. The khan's dedication to maximizing "economic productivity and the affluence of the people" (kifäyat $i$ māl wa rafähat- $i$ ra'ìyat), Chandar Bhan was confident, would definitely earn him "a good name for himself in the present and next life" (CC, 52-53). 
At this point, Chandar Bhan relates two anecdotes that appear to have nothing whatsoever to do with governance and thus at first seem almost like non sequiturs. But on closer reading it becomes clear that they are specifically designed to emphasize Afzal Khan's virtuous character and to highlight the notion that a truly great wazir must also have the humility and ascetic ethos born out of a mystical sensibility:

\section{AN INTERESTING STORY}

One day the Plato-esque scholar Afzal Khan was sitting on the throne of wizārat. This lowest of servants, who had been nurtured and trained by that eminent scholar of the age and the empire, and had acquired prosperity in the copiously generous service of that pillar of nobles of the world, and has since gained renown [ishtihär dāsht] as a disciple of that wise master-this faqì $r$, then, I myself brought an interesting passage from a book for his analysis. [It concerned the notion] that the moment of actual physical death requires a more violent exertion than the moment of separation of the soul [from the body], because the former demands fleeing from creation, whereas the latter is [a moment of] arrival at the Creator. As one familiar with ecstatic moods, when the 'Allama heard this he was transported to another mental state and spontaneously bolted up from the dìwān's dais to go be in private, overcome by compassion. When he regained his senses, his happy pen wrote the following letter to Aqa Rashid, who was among the sagacious khan's most respected and intimate friends. ${ }^{16}$

COPY OF THE DEAR MISSIVE (RAQ $\bar{I} M A-Y I$ GIRĀMI $)$ THAT THE WISE SCHOLAR AFZAL KHAN WROTE TO AQA RASHID

One can only hope that God on high, upon gladly and gently severing the likes of you and me from these worldly attachments ['alā'iq-i dunyawī], may grace us with awareness of himself. May He banish our hearts from the pursuit of worldly status, which directly threatens those actions which attract us to the Divine. Whenever $\mathrm{He}$ wants to guide one of His servants on the path to Himself, He creates in them an aversion to this world. And it is precisely through such aversion that [people] can be content with their life's achievements, and count their situation as a blessing.

Now this friend of yours also feels that calling [da'ciyat] which you know so well-that, having engaged in all sorts of activities, and now grown lukewarm toward worldly affairs [dil-sardī az umūr-i dunyawī ba ham rasīda], at seventy years of age I am entering the final stages of life. And just as there is no limit to this kind of talk, one does ultimately run out of paper [chūn ìn chunìn sukhan rā pāyānī nìst ba itmām-i kāghhaz tamām namūd].

\section{ANOTHER ANECDOTE}

One day [Mir Musá] Mu'izz al-Mulk, the mutaṣaddī of the port of Surat, had sent a novel eyeglass ['ainak] [as a gift] for that 'Alläma of the age who is in the highest echelon of men of understanding. ${ }^{17}$ Since it did not pertain to official financial business, out of courtesy [Afzal Khan] accepted it [chūn māliyatì nadāsht az rū-yi ahlīyat qabül farmüdand] and wrote this letter [ruq'a] to $\mathrm{Mu}^{\prime} \mathrm{izz}$ al-Mulk. 
COPY OF THE MISSIVE ( $R A Q \bar{I} M A$ ) THAT THE LEARNED, ARISTOTLE-LIKE AFZAL KHAN WROTE TO MU'IZZ AL-MULK

One can only hope that Allah on high will grant our ilk deliverance from the prison of this illusory existence [hastī-yi mauhūm] and from the contemplation of this ephemeral multiplicity. The viewing glass that you sent-which shows one thing as a multiplicity-has arrived. [But] this inmate of the prison of multiplicity is looking, rather, for a viewing glass that will turn such panoply into a unity. If you come across anyone who has such a glass, do give me some indication so that I can enlighten my eye by meeting him, and, having gotten hold of such a glass, can look through it and deliver myself from the prison of all this multiplicity. (CC, 53-55)

It's not entirely clear what kind of "eyeglass" ('ainak) Chandar Bhan is referring to here. It could refer to some sort of kaleidoscope-which would explain the comments about seeing "multiplicity" upon looking through it—or maybe a telescope, which is just the sort of novel item that Europeans were beginning to use in the seventeenth century as maritime aids, and bringing to India as gifts for local notables, patrons, and government officials. This would at least circumstantially explain how the gift originally came into the possession of $\mathrm{Mu}$ 'izz al-Mulk, who was the chief official at the bustling port of Surat on the western Indian coast and would have interacted with newly arriving Europeans on a regular basis. But the 'ainak could also have simply been a set of spectacles, which were a known technology in early modern India, but were nevertheless items of enough relative curiosity that they became the subject of occasional philosophical discussion. Indeed, Nilakantha Chaturdhara, the great seventeenth-century Sanskrit philosopher and commentator on the Mahābhārata, specifically used the example of eyeglasses (upanetra) in his Bhäratabhāvadipa (Light on the inner significance of the Mahābhärata) to explain the workings of cosmic illusion $(m \bar{a} y \bar{a})$, because of their power to make the invisible visible, or the illegible legible. In other words, for Nilakantha too the eyeglass's ability to heighten a certain kind of visible perception was-perhaps paradoxically-for that very reason an example of cosmic illusion, because it was only a means to enhanced physical eyesight, not the kind of spiritual or esoteric insight necessary for glimpsing ultimate Truth. ${ }^{18}$

Whatever the precise nature of the "glass" in question, the anecdote's significance for Chandar Bhan clearly lies more in the way that it highlights several valued aspects of Mughal gentlemanliness that he wanted to bring to his readers' attention. The rejection of a gift that could be perceived as a bribe, for instance, highlights Afzal Khan's incorruptibility in the course of his duties. The wry sense of humor used to respond to Mu'izz al-Mulk displays the sort of wit that was an essential part of the lively literary and epistolary cultures of the day. And of course the mystical interpretation of an everyday object highlights Afzal Khan's powers of esoteric gnosis. 
These examples of Afzal Khan's mystical bent are followed by a lengthy discussion directly out of the nașinat-nàma tradition, recounting the "Plato-esque" (Aflàțūn-kirdār) minister's advice on the art of wizärat and the duties and obligations of imperial servants-including munshiss-to king and empire:

\section{AN ACCOUNT OF SOME OF THE LEARNED WAZİR AFZAL KHAN'S EXPRESSIONS OF KNOWLEDGE AND WISDOM}

Now, the late and deceased khan used to say that wazirs are of two kinds: first, the one who correctly comprehends whatever the emperor says and acts accordingly; second, the one upon whose counsel and advice the emperor acts. Alas, we wazirs of the current era do not [even] have the [former] capability for correctly comprehending the bādshāh's commands and then executing the blessed will and temperament, much less making it into the second category [hālat-i dìgar].

Also, the late Afzal Khan used to say that truly, in consulting [kangāyish] with kings one should never utter a word unless asked. And if he should ever ask, one should never deviate from the truth [simply to appease the ruler]; for one should fear God more than one fears the bādshāh.

Also, one should never blurt out in public [dar kassrat] that which could be counseled in private. For kings have a proud [ghayūr] nature, and God forbid the king should repudiate you in front of so many people. On the other hand, if he doesn't accept private [advice], a well-wisher [daulat-khwäh] can always raise the matter with him again later.

Also, since the wisdom channeled through royal succession ['ilm-i khiläfat] transcends [mere] administrative expertise ['ilm-i wizärat], the science of wizārat should never be used to subvert the policies of kings. For whatever inspiration illuminates the minds of this illustrious group [i.e., kings], that will be the true reality. Still, if a specific proposal that is beneficial to the state comes to mind that is based on your administrative expertise, never offer it with an arrogant attitude, for one must always give due deference to the king's wisdom [mașlahat].

Also, if an important problem presents itself but one is too daunted by the king's grandeur and majesty to raise it with him [openly], the need to seek good advice and guidance demands that one should still search for an opportune moment when the king will not be perturbed, whereupon [you can ask and] he can reveal his own insights to you. At that time, if you have come up with a suggestion that benefits the empire, you should offer it. If the king agrees, well and good-if not, then at least by advancing a proposal for the good of the empire you will have fulfilled your basic responsibility [as an adviser].

Also, when the time comes to counsel [a king] you should make sure first to have considered every potentiality and pitfall, whether powerful or trifling, and to have swept clean the prudent corner of your mind with the broom of sound intellect so that nothing will be left out. Then begin by explaining whatever is of primary importance; anything following from that can be deferred until the appropriate time.

Also among the late khan's sayings was that, to ensure the strength and firm foundation of the empire, a wise and visionary king requires four pillars-that is, four wise advisers ${ }^{19}-$ so that whichever way he turns, from whichever of them he 
may inquire, there will be someone to offer unveiled truth in any matters that require clear advice. Then the $b \bar{a} d s h \bar{a} h$, having taken each of their words to heart and weighed them with the scales of his wisdom, can decide which counsel is most sound in word and meaning [muttafiq al-lafz wa'l-ma'nī] and can proceed to enact it.

More than anything, a powerful monarch requires an abundant treasury. If he does not have wealth, he cannot mobilize an army. If he does not have an army, there can be no law and order $[z a b t]$ in the realm. If there is no law and order, wealth cannot accumulate, and the state's treasury can grow only if the country itself is prosperous. The realm can therefore flourish only if it has a capable administrator [șähib-i mu'àmala] who is attentive to imperial business and derives a sense of personal satisfaction from it. ${ }^{20}$

Also, even though one can build an army using wealth alone, the real management and conquest of the hearts of soldiers is not possible without the stewardship of a commander who is authoritative [zābiț], well-mannered [khwush-sulük], unenvious [ser-chashm], open-minded [wasī-mashrab], courageous [șāhib-i hauṣala], tolerant [mutahammil], sincere [durust-ikhhlāṣ], experienced [āzmūda$k \bar{a} r$ ], and of pleasant demeanor [shigufta-peshānī]. Such a person must be so reliable that he can be absolutely independent [mukntär-i muțlaq] in matters of promotion, demotion, bonuses, supervision, and hiring and firing. And his salary must be sufficient to support a large enough retinue that other elites and pillars of the empire will consider him someone to reckon with.

Finally, [a king requires] an aide who can be candid in both private and public [khalā' wa malà'], without calculating whether it may please or anger ['itāb wa khit $\bar{a} b$ ] [the king]. Such a person must be both truthful and discreet, so that whatever he says and hears will not be divulged elsewhere. Although such men are rare and difficult to find, they are definitely available for the king who seeks them. $(C C, 55-57)$

A detailed breakdown of all the elements of political wisdom covered in this passage could easily take up a whole chapter unto itself. But here let us simply reiterate the obvious general takeaway-namely, that in Chandar Bhan's opinion (albeit channeling Afzal Khan), the role of the ideal minister (and secretary) involved much more than mere administrative competence. It involved a certain demeanor, a certain understanding of human nature, a certain discretion, trustworthiness, and humility in the face of the extraordinary opportunities for material gain (and, potentially, corruption) that being a Mughal court insider afforded one.

For his part, Afzal Khan's wisdom regarding such matters made him one of the most widely admired men of the era. Even Emperor Shah Jahan was deeply distraught when the wazìr's health began to fail and, as Chandar Bhan put it, "The noble humors and graceful essence of that wise role model veered away from equilibrium." Our munshi adds that the emperor even took a personal interest in tending to the convalescing wazir, noting that "His Most Exalted Majesty the Sovereign of the Times betook his own noble and precious self to that peerless wazìr's mansion, where he personally tended to and lavished all manner of kindness and 
affection [on him] [anwā'-i talattuf wa mihrbānī mar'ì wa mabžūl gardānīdand]” $(C C, 53)$.

Following Afzal Khan's death, the position of prime minister went to Mir 'Abd al-Salam Mashhadi, aka Islam Khan (d. 1647). Islam Khan was a prominent noble with a decorated military record, but, as we saw in the previous chapter, he also possessed a connoisseur's literary sensibility, and he figures prominently in Chandar Bhan's discussions of the literary atmosphere of the court, as well as the munsh $\vec{\imath}$ s collected letters. ${ }^{21}$ When he was officially appointed wazìr, however, Islam Khan was serving as governor of Bengal, and thus there was a period of nearly a year, from January until October of 1639, between his official appointment and his arrival at court to assume his new responsibilities. In the interim, as we also noted in the previous chapter, virtually the entire administrative apparatus of the central Mughal dìwānì was overseen by another of Chandar Bhan's Hindu contemporaries, Diyanat Ray, who was promoted to the title rāy-i rāyān. ${ }^{22}$

Diyanat Ray had been in the Mughal administrative service since Jahangir's time, with many of those years being spent, like Chandar Bhan, in the offices of Afzal Khan. Indeed, Afzal Khan's dependence on Diyanat Ray became the stuff of minor legend. Despite his many talents, apparently Afzal Khan was known to be somewhat hopeless in accounts (siyāq), or, as the eighteenth-century text $M a$ 'àșir al-Umarā put it, had a tendency because of his immense intellect to refuse to write things down (bā in hama 'ilm-o-dānish așlan ba kāghaz namīrasīd wa siyāq-dān $n a b \bar{u} d)$, leaving such quotidian matters to his assistants. Thus for decades after his death an anecdote continued to circulate in which a wag at his funeral had eulogized the khan by suggesting that when the angels of death, Munkar and Nakir, appeared at his grave to ask him to account for his life and deeds, he had simply replied: "Ask Diyanat Ray, he'll be able to answer" (az Diyānat Rāy bapursad, ù jawāb khhwāhad dād). ${ }^{23}$

Jokes aside, Afzal Khan's mentorship clearly served Diyanat Ray well. According to Chandar Bhan, during his time as interim dīwān Diyanat Ray "supervised all the activities usually managed by the grand wazi $r$, such as the salaries [tan], unassigned imperial lands [ $\underline{k} \underline{h} \bar{a} l i s \underline{a}$ ], and other important fiscal responsibilities," adding that "it was he who performed the chief diwān's job of signing the dols and siyāhas recording jāgìr assignments, and then affixing the imperial seal to memoranda and circulars sent to various finance ministers and revenue collectors [dīwāniyān wa karoriyān]" (CC, 57). On certain documents he was, however, specifically instructed by Shah Jahan to leave the space designated for the wazi $r$ 's signature blank. But this was probably more to preserve formal appearances and hierarchy than an indictment of Diyanat Ray's capabilities.

Interestingly enough, though, there does seem to have been a bit of friction during this period between Diyanat Ray and yet another high-placed Hindu administrator named Sabha Chand, a fellow munshi who had once served in the 
Lahore dīwānī, and later as faujdār of Dāman chakla, Sialkot (a district in northeastern Punjab, located in present-day Pakistan). ${ }^{24}$ Sabha Chand was now serving as the dīwān $\vec{\imath}$ s fiscal auditor (mustaufî), and Chandar Bhan describes him as "well known for his rectitude and integrity [diyānat wa bì-gharazī]" (CC, 57-58).25 Thus, when Diyanat Ray tried to discharge certain of the wazir's responsibilities for which he had not been specifically authorized, it was Sabha Chand, not the emperor, who blocked him.

More revealing, even, than such quibbling over official protocols is the clear sense one gets from reading between the lines of Chandar Bhan's account that once Islam Khan arrived at court to begin his tenure as wazir, the efficiency and morale of the dìwāni began to falter a bit. To begin with, Islam Khan and Diyanat Ray seem to have rubbed each other the wrong way. On the one hand, Islam Khan did have certain traits that might have endeared him to the elite munshis in the dìwānī for instance, Chandar Bhan draws particular attention to the khan's flair for the secretarial arts: "He wrote beautiful shikasta calligraphy and composed well-expressed triplicate verses [mușallașin]. He was at the head of the class of calligraphers and munshis of the age, with a proud nature and a high intellect; indeed, one of the sayings of that khan of sweet expression used to be 'All the world's work is the job of one perfect man' [tamām kār-i dunyā kār-i yak mard$i$ kāmil ast]." But Chandar Bhan also describes Islam Khan as having a somewhat "martial mentality" (dimāgh $\underline{h}-i$ imārat), a man who, though highly gifted, was also strong-willed (qawi-nafs) and had a tendency to be quite demanding

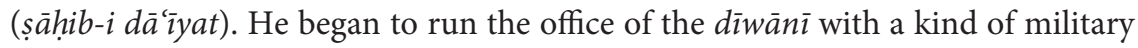
discipline-"joining," as Chandar Bhan puts it, "the principles of wizärat with the rules of command" (bā dastūr-i wizārat rā qawā'id-i imārat jam 'sāknht)-and thus, though Chandar Bhan never comes right out and says it, he strongly hints that the khan's ego got in the way of him and Diyanat Ray working together. As our munshi delicately put it, "The need to coordinate with him did not sit well with the aforementioned khan" (naqsh-i șuhbat-i $\bar{u} b \bar{a}$ kh hān-i mashārun-ilaih durust na-nishast). As a result, Diyanat Ray was "honorably reassigned" (iftikhāor $y \bar{a} f t$ ) to oversee the dīwān-i khālișa, while Islam Khan, "became the unquestioned dìwān" (dìwān-i mustaqil gardīd). "His martial mentality notwithstanding," Chandar Bhan adds in a telling aside, Islam Khan "managed the affairs of wizārat well enough" ( $b \bar{a}$ wujūd-i dimāgh $\underline{h}-i$ imārat ba umūr-i wizārat pardāk $\underline{h} t)(C C, 58)$.

The explicit contrast here between the authority of command (imärat) and Chandar Bhan's ideal of true governmental leadership (wizārat) could not be starker. And, as if it weren't plain enough, Chandar Bhan reiterates the point a few lines later. Just a few years after Islam Khan became wazir -in July 1645, to be exact - the eminent noble Khan-i Dauran Bahadur Nusrat Jang, who had been assigned to govern the Deccan, was murdered by one of his servants before he could travel south. ${ }^{26}$ In the wake of this awful news, Shah Jahan, needing someone 
to take over the crucial Deccan governorship_and perhaps recognizing that his new wazir was not a terribly effective administrator in any case-turned to Islam Khan, "upon whose resolute stature," in Chandar Bhan's revealing words, "the robe of command was a much better fit than the office of wizārat" (khil'at-i imārat bar qāmat-i khwāhhish-i $\bar{u}$ chust-tar az tashrîf-i wizārat būd) $(C C, 58)$.

This contrast between imārat and wizärat is again recapitulated in Chandar Bhan's portrayal of the careers of the next two prime ministers, Sa'd Allah Khan (d. 1656) and Mir Muhammad Sa'id Ardastani "Mu'azzam Khan," better known simply as "Mir Jumla II" (1591-1663). Sa'd Allah Khan took over when Islam Khan left for the Deccan in 1645 and was widely respected for having quickly worked his way up the ranks of Mughal nobility through his intelligence and talent, rather than political connections or birth. ${ }^{27}$ Sa'd Allah Khan also quickly emerged as one of the most effective military commanders of Shah Jahan's reign, which of course only increased the respect with which most seventeenth-century commentators regarded him. As we will see below, Chandar Bhan had occasion to observe Sa'd Allah Khan's martial capabilities firsthand, having accompanied the khan for at least part of the military campaigns in Balkh and Badakhshan in the 1640s-campaigns that the munshi describes at length later in Chahār Chaman. ${ }^{28}$ But as we have seen, great military ability alone was not enough to make a great administrative leader as far as Chandar Bhan was concerned. Rather, it was Sa'd Allah Khan's managerial acumen, generous disposition, and spiritual awareness that made him truly great in our munsh $\vec{\imath}$ s estimation. Like Afzal Khan and Abu al-Fazl before him, he was typically saluted as 'Allāmī, or "Learned One," and Chandar Bhan explicitly compares his "Aristotle-like" intellect to that of "the peerless and inimitable Shaikh Abu al-Fazl” (CC, 6o).

Chandar Bhan was especially impressed with Sa'd Allah Khan's mastery of secretarial arts such as accounting and prose composition, which allowed him to oversee the Mughal administration in a deft, hands-on way: "He drafted exquisite letters [nāma-hā-yi wāla $]$ on His Majesty's behalf to the rulers of Turan and Iran, doing true justice to eloquence and verbal artistry. . . . In addition to Arabic and Persian, he was completely fluent in Turkish, and whenever conversing with eloquent men of Arabia or 'Ajam his superiority was on display. In drafting replies to the revenue and property officers he had no need of accountants and auditors [peshkārān wa mustaufiyān]; in fact, there was hardly any matter in which he needed anyone's assistance" $(C C, 60)$. His ability and willingness to do some of the elite secretarial work himself, in other words, clearly endeared Sa'd Allah Khan to assistants like Chandar Bhan, who found in him someone they could respect as a fellow expert in the funūn-i dabīin. His managerial style, too, seems to have been much more appreciative of his staff's efforts, for Chandar Bhan repeatedly describes him as qadar-shinās, someone who "appreciates the talents of others." 
Finally, though he was indisputably one of the great military commanders of the entire Mughal era, Sa'd Allah Khan's demeanor was nevertheless considerably more genteel, spiritual, and humanistic than that of his generalissimo predecessor. "Many times," Chandar Bhan recalls, "I conversed from dusk until dawn with that khan who had an appreciation for talent, as if we were of one mind," adding that "even though his business was worldly, he also had a penchant for mystical introspection, and right there in the epicenter of worldly affairs he breathed an air

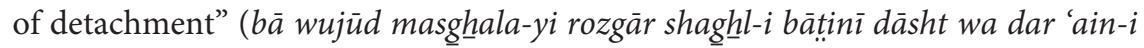
ta'alluq dam az bì-ta'alluqī mìzad) (CC, 60).

Virtually their entire extant correspondence, in fact, deals with mystical and literary themes. ${ }^{29}$ And, like his account of Afzal Khan, Chandar Bhan's account of Sa'd Allah Khan includes one of the khan's mystically themed letters to a friend, as well as another extended passage in the nașinat-nāma tradition-this time, in the form of a dialogue in which the wazìr summarizes his precepts on the responsibilities of governance for his munshi . Chandar Bhan begins the conversation with a fundamental question: "Should one's own interests [irāda-yi k khwud] take precedence over the will of the public [irāda-yi khalq], or should one rather give preference to the public interest over one's own?" As any ideal wazìr would, Sa'd Allah Khan answers unequivocally that "to the best of one's ability" ( $t \bar{a}$ maqdūr bāshad) public benefit should always override an administrator's desire for personal gain.

What follows is an extended meditation on the type of sound character that those who wield power must cultivate in order to best serve the public interest, for instance: "One should strive to the extent possible for the public good

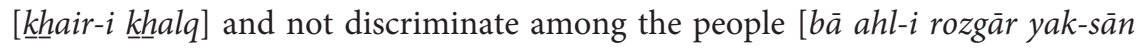
wa yak-rang bāshad], whether they are in your presence or not"; an imperial servant must "cast aside his own emotional and physical desires [agh $\underline{h} \bar{a} z$ - $i$ nafsānī wa jismānī] and have an eye toward the safeguarding of truth [haqq] in every matter"; in worldly matters he should be "deliberate, calm, and free of rancor and malevolence" (ähista wa àramìda wa bì-shor-o-sharr) rather than "impatient,

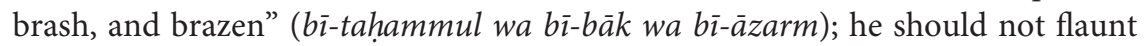
his position, for "doing and not saying is far superior to talking and not doing"; he should not use his power to usurp other people's wealth (tașarruf dar māl-i dìgarī nakardan); he should be humble, and avoid jealousy toward others (hâsid wa mu'ānid-i kasī nabāyad būd), even those who display such bad behavior toward him; and, perhaps most importantly, he should continue to emulate the great mystics (buzurgān) of the past, even in worldly service to kings, so long as he transforms the engagement with politics into an opportunity to accomplish "the work of God's servants" (kār-i banda-hā-yi khudā) (CC, 62-64).

Patience, humility, piety, a strong work ethic, a strong sense of duty in service of the greater good-these are the values Chandar Bhan acknowledges having learned from Sa'd Allah Khan, qualities he himself sought to emulate and 
hoped his readers would, too. It should come as little surprise, then, that Chandar Bhan, like many of his contemporaries, was deeply saddened by Sa'd Allah Khan's death. In fact, he takes the unusual step of including in Chahār Chaman the full text of an ornate eulogy circulated by Shah Jahan to announce the sad news, in which the khan is lauded, among other things, for being singular among the erudite men of the world (yagāna-yi dānishwarān-i jahān); the model for wise men of the times (qidwa-yi khiradmandān-i zamān); the textbook for scholars of the age (dastūr al-'amal-i dānāyān-i rozgār); the arbiter of visible and hidden perfections (mazhar-i kamālāt-i șuwari wa ma'nawī); the touchstone of the sciences (mihakk-i 'ulüm); the assayer of eloquence (naqqād-i sukhan); the penetrator of truths (darrāk-i haqä'iq); the unveiler of subtleties (kashshäf-i daqä'iq); and the treasure of knowledge (ganj-i 'ilm) (CC, 61-62). As above, with Chandar Bhan's praise of Afzal Khan, such strings of panegyric compliments were clearly intended to have a hyperbolic rhetorical effect, but that did not mean that they were random; in this case, note especially the fact that even in the emperor's opinion what was worth remembering about Sa'd Allah Khan, what elevated him to greatness, was his intellectual talents and accomplishments rather than his distinguished military record, which is barely alluded to in the entire eulogy.

After Sa'd Allah Khan's death in 1656, while "the dust of grief was still settled on the mirror of [Shah Jahan's] heart," once again there was a period during which an official wazir was yet to be named. During that time, as noted above in chapter 1, much of the fiscal administration was overseen by Chandar Bhan's colleague Raghunath Ray Kayastha, with both Hindu administrators receiving promotions commensurate with their added responsibilities.

Eventually, however, the official post of grand wazir was awarded to another military man, the aforementioned Mir Jumla (II), who had originally come to India as a diamond merchant, gotten involved in Deccan politics, and become incorporated into the Mughal hierarchy through his connections to Prince Aurangzeb..$^{\circ}$ Chandar Bhan begins his account of Mir Jumla's tenure by noting the latter's superior skill (mahārat-i tamām) in the various arts and sciences of war (ādāb wa funūn-i sipāhgirī) $(C C, 66)$. Of course, in almost any other context this would surely be viewed as a compliment, but given what Chandar Bhan has already told us about the subtle difference between imārat and true wizārat we cannot take this praise entirely at face value.

Sure enough, less than a year after Mir Jumla's appointment in 1656 he was sent back south to accompany Prince Aurangzeb in the ongoing Deccan campaigns. ${ }^{31}$ Chandar Bhan notes this quick turnaround in Chahär Chaman and also includes the gracious farewell letter that he wrote to Mir Jumla in his Munsha' $\bar{a} t(M B, 39){ }^{32}$ He also explains, however, that even though Mir Jumla had left the court for the Deccan, he retained his official title in absentia, while his son, Muhammad Amin Khan, was assigned to take over the prime ministerial duties in his father's absence. 
Administrative authority was thus split for a time "between the seal of Mu'azzam Khan [i.e. Mir Jumla] and the signature of Muhammad Amin Khan" $(C C, 66)$.

The suggestion, clearly, is that Mir Jumla was for all intents and purposes a wazir in name only. Even after his practical authority was transferred to Muhammad Amin Khan, Chandar Bhan tells us, "[Raghunath] Ray-i Rayan continued overseeing his own administrative operation [dar kār-i khhwud istiqlāl dāsht].” Chandar Bhan then gripes that "because [Mir Jumla's] sojourn in the Deccan grew extended," the accounting work of the dìwāni grew increasingly "clogged with delays" (dar 'uqda-yi ta'wìq uftād), leading Shah Jahan to assign nearly all of the wazìr's actual administrative duties_running the finance ministry, keeping revenue accounts, drafting orders, and so on-to Raghunath Ray-i Rayan in any case. Considering Chandar Bhan's earlier praise for the ability of a wazīr like Sa'd Allah Khan to run his own departments, keep track of accounts, and draft his own jawābs to provincial administrators, it seems difficult to read this as anything but a rebuke of Mir Jumla's appointment, absentee status, and general hands-off approach to wizārat. From the career civil servant's perspective, figurehead wazìrs like Mir Jumla and his son, whose skill sets were almost entirely military, only caused delays and disrupted the administration. Even worse, it turned out that Muhammad Amin Khan was so inexperienced in administrative practices that Shah Jahan had to reassign Chandar Bhan completely, remanding him to work as a special liaison between the wazir's office and that of Raghunath Ray so that he could "train Muhammad Amin Khan in such matters [az in ma'nī muttali" sāzad]” (CC, 67). . $^{33}$

Despite this tension, Chandar Bhan appears to have remained cordial toward Muhammad Amin Khan, and we do know that at least at some point in their acquaintance he wrote a very respectful letter to the khan asking if he would offer a job to a certain munshi by the name of Surat Singh, who may well have been the same Punjabi Brahman mentioned in the previous chapter in connection with a literary salon held in Agra, and whom Chandar Bhan affectionately refers to as "this faqi $r$ 's brother and student" $(M B, 27)$. Of course, helping to find gainful employment for a friend is one thing, but it appears clearly from the account in Chahār Chaman that Chandar Bhan didn't feel that either Mir Jumla or Muhammad Amin Khan fully lived up to his ideal of the learned Mughal wazìr.

Finally, in late 1657, in order to settle down the dīwāni, Shah Jahan appointed another respected noble and longtime servant of the court, Ja'far Khan (d. 1670), to take over officially for Mir Jumla. ${ }^{34}$ Chandar Bhan has great praise for the new wazìr's "dignity, eminence, forbearance, prudence, civility, ability, and talent" (shān wa shaukat wa burdbārī wa hoshyārī wa husn-i k̂hulq wa qābiliyat wa isti'dād) $(C C, 67)$-so fulsome that it's a bit hard not to read it as an implicit repudiation of Ja'far Khan's predecessor. Chandar Bhan also includes a number of letters to Ja'far Khan in his collected letters, including one specifically 
congratulating him on his promotion to the wizärat $(M B, 44-45)$. Meanwhile, he also notes that Raghunath Ray kept his title, office, and responsibilities overseeing financial affairs, as a kind of dual administration co-superintended by him and Ja'far Khan was eventually settled upon. By that time, however, Shah Jahan's reign was already basically at an end, and by early 1658 he had been imprisoned in Agra Fort and replaced by his son Aurangzeb 'Alamgir, the victor in a four-way struggle for the Mughal throne.

As we have noted several times, Aurangzeb's reputation in modern historiography is almost universally negative, and anyone familiar with this modern image could be forgiven for assuming that Hindus like Raghunath Ray (and Chandar Bhan, for that matter) would fare poorly once such an orthodox "zealot" came to power. Yet in fact the opposite is true-as we saw in the previous chapter, Chandar Bhan continued to serve Aurangzeb for nearly a decade following the war of succession, and in Raghunath's case it was Aurangzeb who gave him the highest promotion of all.

Chandar Bhan says nothing of the war of succession by way of details, saying only that "[Raghunath] Ray-i Rayan was appointed to the full prime ministership" after Ja 'far Khan was appointed governor of Malwa-an event that we know, from other sources, happened right at the beginning of Aurangzeb's reign. It was then that Aurangzeb also promoted Raghunath to the title of raja, perhaps partially in recognition of the fact that-again, quite contrary to the expectation that Hindus would automatically reject Aurangzeb's claim to power-Raghunath had not only supported Aurangzeb's effort to win the throne but also participated in the later battles against Dara Shukoh and Shah Shuja'. Once Aurangzeb's power was secure, Raja Raghunath continued as chief of the dìw $\bar{a} n \bar{\imath}$ for over half a decade, right up to his death in the sixth year of Aurangzeb's reign (1664). ${ }^{35}$

Later in life, Aurangzeb wrote fondly of Raja Raghunath in letters to others, praising the raja's abilities and even quoting his sage advice on how to appoint good administrators. ${ }^{36}$ Chandar Bhan, for his part, closes the dastūr al-wizärat section of Chahār Chaman's first garden by eulogizing Raghunath Ray in a way that resonates with all the virtues we have encountered above-erudition, selfreliance, a good work ethic, and excellent gentlemanly manners:

Numerous other ministers, despite ostensibly being skilled enough in the art of wizärat that they needed no help, had always approached the raja for corrections and a discerning eye, whether with regard to concluding or deciding some business or assessing and confirming the account ledgers. But whatever work the raja did, he did it himself, with no need of anyone else's help. Along with great skill in the art of penmanship, he had a true talent for prose style and usage [inshä'-o-imla'] and is famous for his excellent manners, politeness, and civility [husn-i sulük wa murūwat wa mudārā]. (CC, 68) 
As we noted in the previous chapter, Chandar Bhan too continued to serve in the administration of "the kind, merciful, just, and loving emperor" Aurangzeb for a number of years, even after his official retirement from the daily rigors of bureaucratic service. According to the surviving letter to Aurangzeb in which he requested the opportunity to spend his twilight years as caretaker of the Taj Mahal complex, in fact, Chandar Bhan saw this continued service to the Mughal court not as a form of blind loyalty but in quite grandiose spiritual terms, explaining that the Taj "is situated between this world and the hereafter and thus will gain me favor in the present life and the next." He openly expressed his continuing dedication to the royal family, including Aurangzeb himself, to whom Chandar Bhan offered "prayers for your long life and continued prosperity" $(M B, 12-13)$.

Little did Chandar Bhan realize that Aurangzeb would rule for another four decades after the munsh $\vec{\imath}$ s death or that the new emperor would wind up as one of the most vilified men in Indian history. Be that as it may, the totality of Chandar Bhan's perspective on imperial governance clearly suggests that for secretaries, wazirs, and others entrusted with the economic and administrative health of the empire, intellect, competence, and civility were valued above all. A penchant for humility born of a mystical attitude ( $m a^{\text {' }}$ rifat) and expertise in the secretarial arts ( funūn-i dabīin) were also considered vital character assets, not simply to make one a better person, but also to augment one's basic aptitude for the governmental tasks at hand. The contrast between Afzal Khan and Sa'd Allah Khan's tenures as wazìr versus those of Islam Khan and Mir Jumla, at least in Chandar Bhan's version of events, amply demonstrates this set of principles-principles that he, like many others, observed, in practice and in person, throughout his career.

Meanwhile, it is worth noting that for more than a few contemporary observers Chandar Bhan himself emerged as a model of exemplary civility and conduct. Thus we have the comments of a certain Bal Krishan, another notable Hindu munshi from Aurangzeb's reign who consciously modeled his own grand prose treatise Chahār Bahār on Chandar Bhan's Chahār Chaman and who singled out Chandar Bhan as one of the great gentlemen and literati of the era. Among Chahār Bahār's many varied contents-including praise for Aurangzeb and some of the author's other patrons and teachers, such as Shaikh Jalal Hisari (d. 1660), as well as learned disquisitions on topics like Sufism, akhlāqi ethical principles, asceticism, and the nature of good and evil-Bal Krishan also expounds at length upon the skills and virtues required of a great secretary, a section that culminates with special praise for Chandar Bhan:

Today among the word magicians of the land of Hindustan [sahr-țarāzān-i 'arṣa-yi hindūstān] and literary savants of this young age [i.e., Aurangzeb's reign] is that Mercury-quick secretary Ray Chandar Bhan, whose happy nature has been decorated and adorned with excellences and perfections and whose fame and reputation for good qualities has spread across the land. 
Though it is true that he is an intimate and close confidant in the service of great sovereigns and sultans, nevertheless the phoenix of his spirit is not at all fettered by worldly status and wealth, and he maintains cordial relationships with the faqirs, mendicants, and pious people of every community [humā-yi himmat-ash ba jāho-daulat-i dunyā muqaiyad nīst wa bā fuqarā wa ghurabā wa șulaḥ̄-yi har țā'ifa sari-yi khwush dārad].

He has such a courteous way with everyone, whether familiar or stranger, elite or peon, that even another whole essay or treatise on his civility and good manners would be insufficient. ${ }^{37}$

In other words, if a large part of Chandar Bhan's message was that aspiring officers and gentlemen should model their behavior on the great wazirs of the day such as Afzal Khan and Sa'd Allah Khan, then along the way our munshi had himself clearly emerged as a powerful model of good conduct among the contemporary Indo-Persian cognoscenti.

\section{THE MUNSHI IN WAR AND DIPLOMACY}

After his discussion of the theory and practice of ministerial conduct, Chandar Bhan turns in the last third of the first "garden" of Chahār Chaman to a new topic entirely - namely, the art of war and diplomacy_in a section entitled "An Account of Some of the Conquests of This Eternal Reign" (zikr-i ba'zī az futūhāt dar 'ahd-i abad-qarin). He does not propose to tell us the details of every aspect of Mughal foreign policy, or even every military engagement undertaken during the nearly three decades that he worked in Shah Jahan's central administration. This would take far too long, for, as he insists, "The victorious warriors [ $g h \bar{a} z \bar{i} \mathrm{~s}$ ] and conquering royal forces are always busy in every direction and quadrant of the imperial dominions subduing the skyscraping citadels and incorporating the wealth and territory of the tyrannical and recalcitrant, overcoming worthy opposition." Thus, "although fresh victories beyond measure are the constant good fortune of the friends of this conquering dynasty, [only] a few of the great conquests that were most difficult to achieve [ki wuqū'-i $\bar{a} n$ ishkāl-i tamām dāsht] are described here with a sincere pen" $(C C, 69)$.

What we notice immediately upon examining this chronicle of historical events, however, is that it is not really a chronicle at all-at least, not in any conventional sense of narrating the military and political history of Shah Jahan's reign "as it happened." Indeed, Chandar Bhan merely alludes in passing to a good number of the "great conquests" in question, dispensing with quite a number of them in barely a couple of pages of Chahār Chaman's printed edition. By contrast, he spends roughly the next eleven pages on a single campaign, the Mughal invasion of Balkh and Badakhshan launched in early 1646, followed by another two full pages on the resolution of a crisis in Mughal-Mewari relations that occurred in 
1654, and a brief closing note on Mughal relations with Bijapur. In other words, virtually the entirety of Chandar Bhan's account of Mughal military activity under Shah Jahan is focused on just two events, with the campaign in Balkh and Badakhshan figuring most prominently.

This somewhat curious narrative strategy makes much more sense, however, when we recall that for all its episodic format and blithe disregard for linear chronology Chahār Chaman is, at its heart, a kind of memoir. Of all the military campaigns that Chandar Bhan discusses in this section, the action in Central Asia and the diplomatic crisis in Mewar were the only two in which he appears to have played a personal role, as a member of the administrative support staff in the case of the former, and in the role of Shah Jahan's personal envoy to the court of Rana Raj Singh in the case of the latter. Thus his emphasis here on these two particular campaigns is intended, not to suggest that these two events were necessarily the focal points of Mughal foreign policy as such during this period, but rather to describe his own involvement in that policy-the moments when, in Alam and Subrahmanyan's elegant formulation, he was not merely a "witness" to empire but also its "agent." 38

This does not mean, however, that Chandar Bhan has nothing interesting to say in his relatively brief remarks on the other campaigns. He begins by drawing our attention to the Mughal conquest of Daulatabad Fort, which, he informs us, "is renowned as one of the most sturdy and well fortified strongholds in the world, the ramparts of which are so sturdy and high that the tops of them seem to reach the Wheel of Atlas" $(C C, 68)$. Here once again we see an example of how references to figures from the Greco-Hellenic tradition-such as Plato, Aristotle, Galen, or in this case Atlas-are woven seamlessly into Chandar Bhan's descriptive vocabulary, albeit filtered through a Persianate literary and political idiom. But we also see that although most of the content of Chahär Chaman is concerned with Chandar Bhan's own personal experiences in the Mughal heartlands of northern India, he was certainly aware, and even supportive, of the empire's expansionary efforts in the Deccan during the middle part of the seventeenth century.

Several other military encounters from the early years of Shah Jahan's reign are quickly passed over in similar summary fashion. Next up is the conquest of "various forts along the frontiers of Bijapur and Golconda by the servants of this court of celestial station," after which, Chandar Bhan tells us, "Adil Khan, Qutb al-Mulk, and other rulers [dunyā-dārān] of the Deccan, having draped the saddle-cloth of fidelity and allegiance over their shoulders, became submissive and obedient" (CC, 68-69). Chandar Bhan does not feel obliged to give us any details of the larger political implications of these events, or the diplomatic machinations and military tactics required to bring them about, or even, for that matter, the dates of the campaign (roughly the first half of 1636)-again, this is not our 
author's aim, and besides, as Chandar Bhan himself would have recognized, those details are easily available in other historical chronicles of Shah Jahan's reign. ${ }^{39}$

He does make sure, however, that we understand what such conquests meant in terms of the projection of Mughal power across the subcontinent and, perhaps even more importantly, the ability of the Mughal imperial apparatus to incorporate defeated rivals with grace and civility. This capacity of the Mughal state to be gracious in victory is a theme that runs throughout the Chahär Chaman and is clearly something that Chandar Bhan wants to advertise to the entire Persianate world as a feature of the overall ideology of șulh-i kull-in particular to audiences in the realms of the Mughals' great rivals, the Ottomans and Safavids (the latter of which had important direct ties to many of the very Deccan sultanates whose subjugation Chandar Bhan is writing about here). Hence, he emphasizes: "Everywhere in that region it became routine to read the khuttba and strike coins in His Highness's name of names, and eloquent ambassadors [from the Deccan] conveyed precious gifts, presents, and protestations of sincere fealty to the foot of the throne wherein the Caliphate resides ['arāiz-i bandagī wa iḳhlās ba pāya-i sarìr-i khiläfat-mașìr rasānīdand]" (CC, 69).

But Chandar Bhan is also not afraid to emphasize the empire's capacity for vengeful ruthlessness. He reminds us, therefore, of Shah Jahan's uncompromising response to two significant rebellions that occurred very early in his reign, the first by an Afghan noble named Khan Jahan Lodi, also known as "Pir Khan" or "Pir Afghan," who had been a stalwart at the Mughal court since the time of Akbar, and the second by a Rajput chieftain named Jujhar Singh Bundela. Those who might expect, on the basis of modern assumptions about the nature of religious community in South Asia, that Chandar Bhan would somehow be sympathetic to Jujhar Singh's insurrection simply because they were coreligionists would be sorely mistaken. Indeed, Chandar Bhan reserves some of the harshest language in all of Chahär Chaman for Jujhar Singh, calling him an "ill-starred wretch" (badakhtar) whose actions stemmed in part from "the ignominy that resides at the core of his powerful clan" (az rū-yi jahālatì ki dar nihād-i in jamā'at mutamakkin ast $)(C C, 69) .^{40}$

This may of course be an allusion to the fact that it was Jujhar Singh's own father, Bir Singh Bundela (d. 1627), who in 1602 had personally assassinated Akbar's celebrated courtier Abu al-Fazl ibn Mubarak (1551-1602), arguably the most revered intellectual in the history of the Mughal court. This was one of the most infamous acts of political treachery in all of Mughal history, and Chandar Bhan and most of his readers would surely have been familiar with it. Clearly it informed his judgment of Jujhar Singh's character as well.

Moreover, the entire chain of events leading to Jujhar Singh's rebellion-his second, actually-was initiated when he had attacked, murdered, and appropriated the lands of the Hindu zamindār of Chauragarh, a Gond chieftain named Prem 
Narayan. ${ }^{41}$ When Shah Jahan attempted to discipline Jujhar Singh for these crimes and to force the Bundela ruler to make some restitution for the lands and money he had expropriated, Jujhar Singh chose defiance instead. The point is, none of the people who figure here-not the author Chandar Bhan (whom we see vehemently criticizing a fellow Hindu for his political crimes), not Jujhar Singh (who brazenly murdered a prominent fellow Hindu, Prem Narayan), and not Shah Jahan (who took the side of a provincial Hindu zamindār against his own manșabdār) appear to have made their decisions on the basis of religious sentiment alone, much less some sort of general communal or "national" solidarity. On the contrary, except to the extent that one may deduce the various figures' religions on the basis of their names, their sectarian identities appear to have been totally moot as far as Chandar Bhan was concerned.

In any event, Chandar Bhan gives relatively few details of what was, in fact, a nearly eight-month-long counterinsurgency. He also declines to report on the grisly details of Jujhar Singh's death at the hands of a band of vengeful Gonds who discovered him and his son hiding in the forests of the central Indian region of Chanda, after which both were summarily beheaded by the Mughal commander Khan-i Dauran-lurid accounts of which are available in other contemporary sources. ${ }^{42}$ Chandar Bhan does, however, indirectly allude to this unceremonious end to the recalcitrant Rajput's career, citing the chronogram said to have been composed on the spot by a fellow munshi named Nand Rai: "The head and territory and possessions of the Bundela are now in hand" (ämad sar wa mulk wa $m \bar{a}$ - $i$ Bundela ba-dast $=1045 \mathrm{AH}=1635-36 \mathrm{CE})(C C, 70)$. The point, one suspects, had less to do with the triumphalism of a Mughal propagandist than with taking every opportunity to reiterate the centrality of the munshi in Mughal affairs, and the capabilities required of such munshis - in this case, the literary expertise necessary to extemporaneously mark a significant event with an apt chronogram. Nand Rai was also a fellow veteran of Afzal Khan Shirazi's circle, so he and Chandar Bhan were presumably known to one another. And calling attention to Nand Rai's munshi-on-the-spot participation in these military activities would have also highlighted Chandar Bhan's larger theme in this section, namely that the elite munshi wasn't someone who just sat in an office ghostwriting letters and reviewing accounts all day, he was also expected to get out in the field.

Chandar Bhan closes this survey of the early campaigns of Shah Jahan's reign with the Mughal action against the Portuguese at Hugli, about which all he says is that it was "among the famous ports of Bengal, conquered thanks to the excellent effort and leadership of Qasim Khan, the governor (șübadār) of Bengal” (CC, 70). He does not allude to the sharp sectarian overtones of this confrontation, which took place in 1632, and which most sources agree was launched after Shah Jahan began receiving complaints that the European traders there were raiding local villages, taking residents captive, and forcibly converting many of them to 
Christianity. There was also, of course, an economic dimension. Besides the fact that the Portuguese commercial activity at Hugli was taking business away from other nearby ports, some sources accused the Portuguese of engaging in disruptive maritime piracy, ${ }^{43}$ while others, such as 'Inayat Khan's Shäh Jahān Nāma, intimate that they were illegally seizing control of "all the villages and parganas surrounding the port on both sides of the estuary," adding insult to injury by not paying the appropriate taxes or rent on those lands. ${ }^{44}$

Chandar Bhan does, however, use some fairly colorful language to briefly mention the Mughal campaigns in Assam (ca. 1636-38), the subjugation of which, he tells us, "came about under the management and command of the Pillar of State, Islam Khan," and in which "countless Assamese more numerous than a swarm of ants or locusts became fodder for the swords of the victorious imperial ghäzis" (āshāmiyān-i bì-shumār ziyāda az mor-o-malakh 'alaf-i teghh-i ghàziyān-i nușratfarjäm gardìdand) (CC, 70). ${ }^{45}$ After this there is a brief discussion of Mughal efforts in the late 163os to win back from the Safavids the strategic fort of Qandahar, which once again gave the Mughals-albeit only temporarily-control of a crucial gateway to the lucrative overland trading routes to Central and Inner Asia.

Again, Chandar Bhan does not give extensive details about any of these campaigns, merely registering them as great victories, touting Shah Jahan's strategic wisdom, and occasionally noting some of the important commanders who led the efforts. Clearly, then, the point is not to offer a comprehensive history of Shah Jahan's foreign policy but to showcase another domain of imperial life in which the munshi had to be prepared to engage, namely war making, politics, and diplomacy.

This becomes especially clear in the two lengthy sections that follow, both of which deal with major military-diplomatic campaigns in which Chandar Bhan himself participated. The first was a massive, difficult, and expensive campaign in Balkh and Badakhshan. The Mughals had always looked to these areas of Central Asia as the ancestral lands of their illustrious forefathers, and, as a number of scholars have noted, one can find a strain of nostalgia regarding Balkh and Badakhshan running throughout a great deal of Mughal writing and cultural symbology throughout the sixteenth and seventeenth centuries. ${ }^{46}$ As one of the historians of Shah Jahan's reign put it: "From the time of the last Emperor Jahangir's death, when [the Uzbek ruler] Nazar Muhammad Khan had vainly attempted to seize Kabul, the mighty soul of the world-subduing monarch [Shah Jahan] had been bent upon the conquest of the countries of Balkh and Badakhshan, which were properly his hereditary dominions." ${ }^{47}$

Despite some early successes, though, there were immediate challenges to sustaining the Mughal presence in Balkh and Badakhshan. One, of course, was the infamously difficult terrain of these regions, which has been a source of exasperation for invading armies ever since ancient times and of course remains so even 
today. There were also the various local tribes to deal with, who somehow had to be pacified, recruited to the Mughal cause, or otherwise disciplined. Sometimes these groups acted independently, raiding Mughal advance parties and supply chains through the steep passes and narrow defiles of the Hindu Kush Mountains, and sometimes they acted in concert with the Uzbek contingents that continued to harass Mughal forces from the north.

Another logistical challenge of these campaigns-one that would have involved Chandar Bhan directly - was the payment of soldiers. When a military campaign like this was launched, the Mughal armies did not just pick up and go; there were all manner of issues to be worked out regarding the differential salaries, rights, and duties of those involved, and the bureaucracy that handled the Mughal information order had to be mobile and supple enough to handle these transactions, even far from home. At the time of the 1646 campaign in Balkh and Badakhshan, such administrative matters were usually handled by Sa'd Allah Khan, who had become prime minister barely a year earlier, and in whose office Chandar Bhan himself was one of the chief bureaucrats.

Thus Chandar Bhan reports that once Balkh was initially conquered it was Sa'd Allah Khan who was sent to manage the logistics (band-o-bast) of the transition to Mughal control $(C C, 78)$. But even before the imperial army had originally set out under the command of Prince Murad Bakhsh, Sa'd Allah Khan had been dispatched to Kabul in advance of the royal party to ensure the smooth disbursement of funds and to address certain grievances among the soldiers, many of whom had not received a promised three months of advance pay, as well as other subsidiary incentives, and were thus refusing to march onward. Once these issues were resolved, Sa'd Allah Khan was also authorized as a further incentive to reduce the typical muster obligations of the various mansabdärs taking part in the campaign, meaning that the officers' individual contributions to the imperial cause in the form of troops and horses would be less of a burden on their personal households. ${ }^{48}$

This relatively minor episode of bureaucratic messiness actually reveals a much larger truth about Mughal administration-and Mughal power-as a whole. However "absolute" the emperor's authority may have been in the abstract, when it came time for him to exercise that authority, particularly in a major undertaking like the Central Asian campaigns of the 1640s, he couldn't just wave his hand and expect the entire politico-military apparatus to fall into line by fiat. Soldiers, even the rank and file, had certain expectations; and it was even possible in a case like this for them to, in effect, strike for better pay and benefits. Meanwhile, there was an entire bureaucratic machinery in place to work out the details of how the Mughal state and treasury could meet those expectations, calculate the necessary balances of payments, disburse funds, and integrate whatever concessions the state had to make to its soldiers into the larger calculus of the Mughal political economy. 
While Sa'd Allah Khan would have had the overall authority as prime minister to manage these contingencies, someone actually had to keep the physical records of all these arrangements-the rosters of various classes of soldiers, the relative pay scales they were entitled to, the amounts of their wartime bonuses according to rank, the effect on overall manpower of reducing the mansabdārs' troop and cavalry obligations, and so on-and this is precisely where imperial munshis like Chandar Bhan came in. This is also why they were often required to travel with the Mughal army, even in the thick of an arduous military campaign. An elite grandee of the court like Sa'd Allah Khan would have had little need of technocratic assistants like Chandar Bhan in his specific capacity as a military commander; but in his larger governmental role as a manager of imperial finances and logistics, access to his best munshīs was essential, even on the front lines. Thus the administrative arm of the Mughal government had to be not only flexible enough to send teams of technocrats to travel with the imperial army but also expert and sophisticated enough to multitask even while they were on the move. Indeed, it is not as if the management of the rest of the empire was suspended simply because the emperor and a large percentage of the nobility were away on a campaign. To the contrary, the expectation was that routine business of the empire would continue basically as usual. ${ }^{49}$

In any event, it was largely because Chandar Bhan personally traveled with the Mughal army as part of Sa'd Allah Khan's retinue, and was intimately involved in the bureaucratic logistics of the Central Asian campaign, that "this lowest of servants" was, as he himself tells us, "[so] well-acquainted with the events that transpired there" (kamtarīn-i bandagān ... az sawānih -i ān jā wāqif ast) (CC, 79). He provides a list of all those "illustrious amìrs who gained top honors in contributing to the tumultuous contest for Balkh and Badakhshan" (CC, 79-80), both Hindu and Muslim. He also gives a lengthy description of the diplomatic negotiations and lavish ceremonies surrounding the defection of the Uzbek prince Khusrau Sultan to the Mughal cause. Parts of this section read almost like a primer on Mughal court ceremonial, and Chandar Bhan repeatedly emphasizes that Khusrau Sultan behaved "with perfect courtesy" (ba adab-i tamām), adding interesting details about the literary ambience of the proceedings-there was, apparently, always time for good poetry, even in the midst of a grueling military campaignand the exorbitant gifts that Shah Jahan doled out to his new ally.

Once again, then, the munsh $\vec{\imath}$ s personal experience organizes what would otherwise appear to be a straightforward narration of historical events. But however personalized the narrative, the larger politics and transregional audience of Chandar Bhan's account appear never to have been far from our munshîs mind. Rehearsing the august ceremonial minutiae of the assembly down to every last detail provides Chandar Bhan with a clear opportunity to flaunt not only his expressive prose but also the wealth and grandeur of Shah Jahan's court. Indeed, as an adver- 
tisement to far-flung Persianate literati, intellectuals, and even freelance soldiers who might find themselves in need of patronage one could hardly do better.

Even more significant, the framing of this entire episode allows Chandar Bhan once again to reiterate for a wider Persianate audience one of the central themes of Mughal ideology, namely, the great courtesy and hospitality that they prided themselves on extending to defeated rivals. The entire logic of Mughal imperial power held that those who submitted to it graciously, even after hard-fought wars, were not to be punished but rather to be incorporated into the imperial apparatus, given a rank and status commensurate with their character and capabilities, and subsequently honored for their loyalty regardless of their regional, ethnic, or sectarian identity. The system was never foolproof, of course; but as part of the broader logic of sulh-i kull it had clearly served the Mughals very well over the years and had been the ideological glue that had held the empire together and facilitated its expansion for generations. From the entire campaign in Balkh and Badakhshan, which, for all the fuss, ultimately wound up accomplishing very little, Khusrau Sultan's submission was perhaps the one shining exemplification of this larger principle. Hence Chandar Bhan's repeated emphasis on "civility" and "courtesy" ( $\bar{a} \bar{d} \bar{a} b)$ throughout Khusrau Sultan's audience, especially Shah Jahan's own hospitality and generosity. The message, loud and clear, was that whatever you brought to the table as a prospective servant of the Mughal empire, the court would give back many times over.

The same underlying themes also seem to animate the penultimate part of this section of Chahār Chaman, in which Chandar Bhan describes his part in helping to resolve a deepening crisis between Shah Jahan's imperial court and that of the Rajput king of Mewar, Rana Raj Singh (r. 1652-80). The house of Mewar had been one of the few Rajput kingdoms to never fully acquiesce to Mughal overlordship, and it remained extremely proud of this fact even if a relatively stable détente had prevailed since the negotiation of a 1615 truce between Jahangir and Rana Amar Singh (d. 1620), the ruler at the time. Over the course of the 1640 ond '5os, however, a series of what could be described as misunderstandings or outright provocations-depending on whose side you were on-had begun to raise tensions, culminating in the Mewar court's decision to renovate, reoccupy, and refortify the massive citadel at Chittor, a key stronghold that lay directly between the Mughal capitals of Delhi and Agra and the lucrative commercial trading areas of coastal Gujarat. This was a direct contravention of the 1615 treaty and a direct threat to Mughal strategic interests in the region. And thus, though the friction between the Mughal court and Mewar had been building for a number of years, things finally came to a head in $1654 .^{5^{\circ}}$

In response, Shah Jahan relocated his entire court from Delhi to Ajmer in order to be closer to Mewar, and from there he engaged in a two-pronged militarydiplomatic approach. On the diplomatic front, he sent our own munshī Chandar 
Bhan to the Mewari capital of Udaipur as his personal envoy, with instructions to convey directly to Rana Raj Singh the emperor's chagrin over recent events and to dangle certain diplomatic "carrots" in hopes that the rana would desist from these provocations-Chandar Bhan refers to them as "errors," "offenses," or even outright "crimes" (taqșir) - and come back into the imperial fold. At the same time-the "stick" - Shah Jahan dispatched the wazir Sa'd Allah Khan to lay siege to Chittor with an army of some thirty thousand soldiers, with instructions to raze it if Chandar Bhan's diplomacy should fail.

The strategy worked. Rana Raj Singh received Chandar Bhan's embassy with all due courtesy, and after hearing what the munshi had to say he relented. "The rana," Chandar Bhan tells us, "whose determination had been shaken by the menace of the conquering imperial armies and the singularity of the pādshāh's censures, listened to my prudent advice and valuable counsels and pulled back from his untoward intentions." As a further sign of good faith, Rana Raj Singh even sent his son, who, Chandar Bhan tells us, "was like a piece of his own liver, and only six years old at the time," to accompany Chandar Bhan's retinue back to Ajmer "so that he could be trained in the ways of sublime service to the exalted court." No doubt this appears at first glance like a menacingly heavy personal price for the imperial court to exact for peace. But the young man was treated extremely well and, exactly according to the logic of hospitality toward defeated rivals as a core component of șulh-i kull discussed above, was immediately lavished with gifts and accorded considerable status within the Mughal nobility. After they had returned to Ajmer, Chandar Bhan tells us, "he was brought graciously into the sublime imperial service [ba mulāzamat-i ashraf-a lá mustas'ad gardìd], and with an abundance of favor was granted the new moniker Subhag Chand and was honored with the gift of an elephant and a robe [khil'at]." "The members of his personal retinue," Chandar Bhan adds, "were also each ennobled by gifts of horses and robes of honor" (CC, 82-83).

Chandar Bhan's description of these events in Chahār Chaman is actually relatively concise, especially considering that the munshi himself gives a much more detailed account of his activities in Udaipur in a series of letters and reports to Shah Jahan that he includes in Munsha'ät-i Brahman. But for present purposes, the central point is the way in which participating in war and diplomacy were clearly recognized parts of Chandar Bhan's portfolio of duties as a munshī and an agent of the empire. In the case of the Balkh campaign, Chandar Bhan was expected to travel with the imperial army and perform a number of executive functions directly from the front. And in the case of the Udaipur mission, Chandar Bhan himself was raised to the level of imperial representative and sent to negotiate directly with a subordinate-and somewhat hostile-power.

But why, specifically, did Shah Jahan tap Chandar Bhan for this particular mission? On the face of it, there is little doubt that the religious identity had 
something to do with the emperor's decision. Chandar Bhan was a Brahman, after all, a status that would have commanded respect in any Rajput court regardless of the simmering political tensions involved. Moreover, there was at least some precedent for Shah Jahan choosing to send a notable Hindu from his court as an envoy to a hostile or refractory Hindu client state. As Allison Busch has noted in her extensive study of the Braj-Hindi literary culture of the period (including at Shah Jahan's court), we know from Persian chronicles of the period like 'Amal-i Șālih and Shāh Jahān Nāma of several occasions earlier in his reign when Shah Jahan had sent the Hindi poet Sundar Kaviray on sensitive diplomatic missions, for instance in dealing with the recalcitrant Bundela Rajputs who were based in Sundar's home region of Gwalior. ${ }^{52}$ This gesture on Shah Jahan's part, of deploying high-profile Hindu literati to serve as diplomatic envoys to Rajput courts, does not appear to have received much specific scholarly attention. But as we have just seen, we have an almost exact parallel to Sundar's case in our own Chandar Bhan's 1654 mission to Mewar.

Yet religion alone does not-indeed cannot-fully explain the choice of Chandar Bhan for this mission. After all, there were plenty of high-status Hindus at Shah Jahan's court, any number of whom were Chandar Bhan's social superiors, and many of whom were themselves Rajputs who would have commanded royal prestige on a par with that of Rana Raj Singh of Mewar. So why did Shah Jahan not send one of them?

The answer, I believe, lies in Chandar Bhan's particular mix of training, background, and skills. In particular, we must recall that Chandar Bhan was well known as a protégé of the great wazir Afzal Khan Shirazi, who himself had a great reputation as an expert in the art of diplomacy and moreover had a specific history as mediator between Mewar and the Mughal court. Decades earlier it had been none other than Afzal Khan, still newly arrived in India, who had negotiated the terms of the 1615 truce between Jahangir and Rana Amar Singh. In those days Afzal Khan was already a part of Shah Jahan's inner circle, while the latter was still a prince. And it should be noted, too, that in those same 1615 negotiations Afzal Khan had worked in tandem with a Brahman aide named Sundar Das (d. 1623), another close confidant of Prince Khurram / Shah Jahan who was himself promoted to the lofty title of ray-i rayan at the conclusion of the Mewar affair. ${ }^{53}$

Surely there would have been a memory of these events at Shah Jahan's court in later years; thus, when tensions with Mewar flared up again in the 1650s, who better to turn to than one of the most esteemed protégés of the man who had negotiated the terms of the original 1615 truce? As we have seen above, Chandar Bhan had clearly learned to emulate Afzal Khan's refined habits and demeanor, and one can assume that some lessons in the art of diplomacy-and maybe even the specific history of Mughal-Mewar relations-had also passed to the munshi from his erstwhile mentor. Thus, while Chandar Bhan's most recent mentor and 
the current wazir Sa'd Allah Khan was sent to handle the military side of the problem by commanding the siege of Chittor, Chandar Bhan himself turned out to be an especially apt choice to handle the diplomatic maneuvering at the rana's court in Udaipur.

In short, if part of the Mughal wazìr's job was to function as a kind of "secretary of state," then here, in Sa'd Allah Khan's absence, a highly trained and respected munshi like Chandar Bhan could be tapped to serve as a kind of "undersecretary of state" - speaking on the court's behalf and negotiating directly with a rival power. Just as Chandar Bhan's colleagues Diyanat Ray and Raja Raghunath had once stepped in to fulfill the wazir's duties when political exigencies and administrative necessity had required, here too Shah Jahan was perfectly comfortable having Chandar Bhan serve as his political agent in what was, after all, an extremely delicate matter where war and peace hung in the balance. An expert Mughal munshi, it would seem, had to be not only a secretary, an administrator, an accountant, a poet, and a mystic but also a diplomat.

Moreover, beyond the narrow question of the elite Mughal munshìs mentalité that lies at the heart of this chapter, we see too in the Mewar affair yet another powerful illustration of an important theme from the previous chapter-namely, the fact that in early modern South Asia a common religious identity did not necessarily translate into automatic political solidarity, just as religious difference did not automatically produce social and political antipathy. At no point during the entire sequence of events in 1654 did Chandar Bhan's loyalty to the Mughal cause waver, something we would surely have expected if Shah Jahan had been even half as sectarian and "orthodox" as he has been made out to be in modern historiography. Clearly, the munsh $\vec{\imath}$ s commitment to Shah Jahan's sovereignty transcended any affinity he may have had toward Rana Raj Singh simply because they both happened to be Hindus.

But this observation only raises yet another set of questions that we have yet to address. What did someone like Chandar Bhan actually think of Shah Jahan's legitimacy as a ruler, and of Mughal sovereignty in general? It is to these questions that we turn in the next chapter. 


\title{
King of Delhi, King of the World
}

\author{
Chandar Bhan's Perspective on Shah Jahan, \\ the Mughal Court, and the Realm
}

In the previous chapters we examined myriad facets of Chandar Bhan's experience as a prominent Hindu, secretary, and poet at the Mughal court-his literary self, his administrative self, and his political self, in particular. But what was Chandar Bhan's view of the emperor whom he served in all these capacities, and of Mughal sovereignty generally? There has been some notable scholarship in recent years on the general question of Mughal theories of sovereignty and royal legitimacy. ${ }^{1}$ But how did Chandar Bhan, as a Hindu, and a Brahman no less, treat the question of the legitimacy of Muslim rule in India, and how did he connect it with traditions of Indic rulership that predated the Mughal Empire and the Delhi Sultanate before it? What were his observations of Mughal court culture, both when the court was in residence at one of its major urban centers and when it was on the move, either in transit from one city to another or on a military campaign? What was his view of the larger expanse of the empire, beyond the privileged space of the court? What was his understanding of the horizons, both physical and conceptual, of the Mughal imperium?

\section{THE MYTHICAL GENEALOGY OF MUGHAL RULE}

We get some insight into the first of these questions from one of Chandar Bhan's lesser-known works, known as Tärîk $\underline{h}-i$ Rajahā-yi Dihlī (A history of the kings of Delhi). It is a relatively short work, of which only one manuscript is known to have survived; yet in just under twenty folios Chandar Bhan manages to trace, one by one, the entire chain of rulers who had sat on the throne of Delhi from mythical times right up to his own day-up to and including Shah Jahan himself. ${ }^{2}$ 
Chandar Bhan appears to have done a considerable amount of research in preparing the text, explaining that he got his information from various "Hindi books and other historical tomes" (az kutub-i hindī wa dìgar jarā'id-i tawārīknh). Despite its name, though, the Täri kn is not quite a "history" of Delhi, as such, but rather a chronology of rulership. Thus for most of the monarchs in question Chandar Bhan gives scant details other than their name and the number of years, months, and even days that they ruled. Sometimes he gives the length of time that particular dynasties ruled, before listing the individual kings. And as he gets closer to the kings of his own era, he begins to give a little more information, presumably because he had access to more sources and more recent cultural memories.

But in at least a few instances Chandar Bhan does insert brief bits of commentary even for some of the ancient kings. For instance, of King Yuddhishtira, one of the heroes of the Sanskrit epic Mahābhärata, and the first king of Delhi whom he treats individually, Chandar Bhan explains: "He was among the greatest kings of Hindustan [az buzurg-tarin rāja-hā-yi hindūstān būda], and it is known that every day he used to sit down to eat himself only after having fed ten thousand people; he ruled [hukümat karda] for a period of thirty-three years, eight months, and twenty-five days before departing his residence in this perishable world" (TRD, fol. 2b). Of the legendary King Janamajeya, said to be a descendant of Yuddhishtira's heroic brother Arjuna, Chandar Bhan tells us that "Janamajeya ruled [saltanat karda] for a period of eighty-four years, five months, and seventeen days; it was during his reign that the book Mahäbhärata, which concerns the exploits of the Pandavas [wāqi'ät-i pāndawān], was compiled by the sage Veda Vyasa; and in its entirety this book is composed of one hundred thousand verses" (TRD, fol. 3a). Of the tenth-century Tomar king Raja Suraj Pal, besides telling us that he ruled (farmān-dihi karda) for fifty-eight years, two months, and five days, Chandar Bhan notes with admiration that the celebrated monarch "was among the greatest kings of Hind; he owned no less than six thousand elephants, and in the domain of world conquest he was singular in his era [dar 'älamgìrì yagāna-yi rozgār būda]" (TRD, fol. 5a). Of one Raja Jiwan Jit, who "raised the banners of victory in the realm of Hindustan for a period of twenty-six years, nine months, and twenty-seven days," Chandar Bhan adds the tantalizing comment that the king "had a complete mastery over esoteric mystical practices" (dar ma'rifat-i wäjib sa'y maufūra dāsht) (TRD, fol. 6a). Alas, he does not elaborate and tell us what sort of gnosis ( $m a^{\prime}$ rifat) the king engaged in. But Chandar Bhan does report with a touch of wonder that the eleventh-century ruler Raja Anand Pal, who famously tussled on several occasions with the Central Asian conqueror Mahmud of Ghazni, "had seven thousand women in his harem and would be busy cavorting with all of them for two days at a stretch" (TRD, fol. $7 \mathrm{a})$.

This list of mythical, ancient, and medieval Hindu rulers then transitions directly into a discussion of India's medieval Muslim rulers-a transition that is 
made virtually without comment, other than a subheading denoting the advent of "the era of kingship by the just emperors and ocean-hearted monarchs who ruled from the imperial throne of Delhi” (muddat-i saltanat-i pādshāhān-i 'àdil wa shahryārān-i daryā-dil ki bar takht-gāh-i dihlī pādshāhī kardand) (TRD, fol. 11b). The mere fact that Chandar Bhan felt the need to include this heading suggests that he did perceive that some sort of new phase of Indian history had begun with the introduction of Muslim rule in the subcontinent and that he did have some vague sense that a kind of religio-cultural difference existed between Delhi's pre-Muslim rulers and their later Muslim counterparts. Yet nowhere does he actually code this new type of ruler as specifically "Muslim" or even "other." The difference is implied, at best, perhaps meant to be intuited simply from the use of the term $p \bar{a} d s h \bar{a} h$ rather than $r \bar{a} j \bar{a}$, and of course the fact that the new rulers' religion could obviously be distinguished by their names. But our author gives no indication whatsoever that this "new" period augured any sort of large-scale civilizational shift, much less outright decline (as British colonial and Hindu nationalist historiography would have us believe), or even any sort of disruption whatsoever. He simply moves on to a new set of names, and even the terms that he uses to denote the act of rulership (e.g., hukümat kardan, saltanat kardan, farmān-dihi kardan) are the very same verbs that he used for the earlier Hindu kings.

Likewise, the very fact that these later rulers are all also included under the same larger umbrella category denoted by the work's title - "the rājās of Delhi" gives us further reason to complicate any simplistic narrative suggesting that the arrival of Muslim kings in India represented some sort of radical rupture, essentially foreign and incommensurable with Hindu cultural memory and ideas about kingship. For Chandar Bhan, at least, the sovereignty emanating from the bodies of Delhi's medieval and early modern Muslim rulers was simply a continuation of that which existed in earlier eras, in a line extending deep into the mythical past and continuing right into his seventeenth-century present.

It should be noted, too, that Chandar Bhan also displays plenty of admiration for the various Muslim rulers whom he mentions along the way. Thus he says of Ghiyas al-Din Balban (r. 1266-87) that "they say that he possessed uncommonly great courage" (mīgūyand ki khailī 'àlì himmat dāsht) (TRD, fol. 12a-12b). He says of Balban's successor Mu'izz al-Din Qaiqubad that he was a connoisseur of poetry and "a man of great generosity" (șähib-i saknhāwat) (TRD, fol. 12b), who, Chandar Bhan reminds us, was also one of the key patrons of the great Indo-Persian poet Amir Khusrau. " 'Ala al-Din Khalji is described as "among the greatest sultans of Hindustan” (az buzurg-tarìn saläțin-i hindūstān) (TRD, fol. 13b), whose campaigns in southern India are also mentioned by Chandar Bhan without reproach, simply as part of the business of conquest. Note too the exact parallel with the language he used to describe Yuddhishtira, simply replacing raja with sultan. 
It would perhaps be easy for a cynic to dismiss all this as so much sycophantic pandering. Chandar Bhan is not, however, above criticizing Muslim rulers whom he judges to be particularly unjust, sectarian, or otherwise not fulfilling their duty as kings. Regarding one of the later Tughlaq princes named Ahmed Shah, for instance, Chandar Bhan says that he "gave his father a lot of trouble" by rebelling, and "struggled mightily to promote the religion of Muhammad" (afzāyish-i dìn-i muhammadi jahd-i baligh dāsht) (TRD, fol. 14a). ${ }^{4}$ He offers an even more explicit censure of the very next king he lists, Shah Tughlaq: though he credits him with having built many mosques, wells, traveler's inns (sarais), and Sufi centers (khkanaqās), he also notes that the king "rattled the foundations and destroyed many houses of worship [ $i b \bar{a} d a t-k h \bar{a} n a-h \bar{a}]$ that were among the monuments of the great rajas, collected the protection tax [jizya] from the people of India, and made great efforts to promote the shari' $a$ through his edicts" (TRD, fol. 14a-14b).

Chandar Bhan does not, in other words, simply offer blanket praise of India's Muslim rulers across the board. He has done his homework and appears perfectly willing to criticize those who deserved it. But those who do come in for criticism aren't chided merely for being rulers who happened to be Muslim, or othered as somehow "foreign" to India. Rather, they are singled out for specific excesses, usually for the crime of being unjustly sectarian or of going out of their way to try and impose Islam. Indeed, when read in the larger context of the work as a whole, the two sultans mentioned in the previous paragraph whom Chandar Bhan criticizes for such behavior actually serve as exceptions that prove the rule-minor, isolated instances of sectarian excess in an otherwise unbroken chain of rulers, both Hindu and Muslim, whom he considered to have been perfectly acceptable and legitimate.

Sure enough, Chandar Bhan goes on to explain that "Sultan 'Ala al-Din" (presumably, 'Ala al-Din Sikandar Shah, d. 1394?), besides having an improbable ten thousand lovelies (șähib-i husn) in his harem, had the more important distinction of having undone some of the unjust practices of his predecessor and "set aside the jizya throughout all the lands of Hindustan" (jizya az kull-i mamālik-i hindūstān bar taraf sāk $\underline{h} t)$ (TRD, fol. 15b). Likewise, Bahlul Lodi (r. 1451-89), whom Chandar Bhan hails as "one of the great Afghans of Thatta" (i.e., Sindh), is praised not only for being very brave and building many forts but also for having "erased every trace of tyranny from the face of the earth" (āssār-i zulm az șafha-yi 'ālam pāk namūda) (TRD, fol. 15b).

Overall, the message is clear: Delhi is the site from which political power in northern India emanates, passed on from dynasty to dynasty in a chain of kings whose individual reigns (their "natural bodies," in Kantorowicz's terms) are recognized as mortal, impermanent, and even sometimes imperfect, but also where the institution of Delhi kingship itself ("the body politic") is lasting, permanent, and continuous. The Mughals, and the Delhi sultans before them, are just the latest in this eternal genealogy going back to mythological times. ${ }^{5}$ 
When it comes to the Mughals themselves, Chandar Bhan gives, as might be expected, considerably more information than he provided for most of the earlier rulers of Delhi. With regard to the founder of the Mughal Empire Zahir al-Din Muhammad Babur, for instance, he provides Babur's entire personal family genealogy going back to the famed Central Asian conqueror Amir Timur (d. 1405). In an interesting aside, he also notes pointedly that Timur himself "cannot be counted among the chain of rulers of India" (dar silsila-yi saläțin-i hind munsalik nīst) (TRD, fol. 16a-16b) because, even though he conquered northern India late in the fourteenth century, he did not stay and rule from Delhi. Of Babur's successor Humayun he says, somewhat counter to that ruler's reputation for ineffectuality in modern historiography, that although he spent a good part of his reign tied up in struggles with the Sur Afghans, who would eventually defeat and send him into a fifteen-year exile he also "spent much of his reign occupied by administrative matters, and that ocean-hearted king is to be credited with many [governmental] innovations" (wāqi'āt-i khhwud rā dar silk-i nazm kashìda-and wa mukhhtara'ät-i $\bar{a}$ shāh-i daryā-dil bisyār ast) (TRD, fol. 16b).

Chandar Bhan then lists each of those very same Sur sultans, beginning with Sher Shah (1486-1545) - a bit of a surprise, perhaps, for a Mughal propagandistbefore providing another brief entry on Humayun's triumphant return from exile in 1555. This is followed by an entry on Hemu (1501-56), another significant challenger to Mughal rule who claimed the throne after Humayun's death in 1556 and won a series of important battles before finally being defeated and killed by the young Akbar's forces under the command of the regent Bairam Khan.

In short, though Chandar Bhan's accounts of all these kings are extremely concise, he has made every effort to be comprehensive, even if it means acknowledging the reigns of the Mughals' rivals for power. It should be reiterated, too, that a considerable amount of research would have gone into the compilation of a work like this. We mentioned above that Chandar Bhan notes in the preface that he consulted many works of history in "Hindi" and other languages, and in his notices of the individual Mughal emperors Chandar Bhan also refers his readers more specifically in a couple of cases to other histories for further reading, such as Akbar Nāma (fol. 18a) and Shāh Jahān Nāma (TRD, fol. 19a). But the overall logic of Tārîkn-i Rājahā-yi Dehlī is clearly to situate the Mughals, and specifically Shah Jahan, within an institutional genealogy of Indian kingship.

\section{THE KING, THE COURT, AND THE ROUTINE OF IMPERIAL GOVERNANCE}

If one purpose of Chandar Bhan's History of the Kings of Delhi was to establish a genealogy of legitimate Hindustani kingship for the Mughal emperors, when it came to his magnum opus Chahār Chaman that legitimacy was entirely taken 
for granted. The whole work is shot through with effusive praise for the grandeur of the empire and its reigning monarch, but perhaps nowhere so much as in the text's second "garden," an extended meditation on daily life at the court of Shah Jahan, including a great many details about the daily routine of the emperor himself.

As we noted in the Introduction, this section of the text is, relatively speaking, perhaps the best known in all of Chandar Bhan's oeuvre among English readers, having been partially excerpted and translated in the Orientalist Francis Gladwin's compendium The Persian Moonshee under the title "Kowayid us Sultanet Shahjehan; or Rules Observed at Court during the Reign of Shahjehan." Intended to help mitigate East India Company officers' dependency on native South Asian munshis and other tutors-whom they typically viewed as unreliable and untrustworthy-Gladwin's work functioned largely as an introductory textbook that would, at least in theory, instruct the British in the various forms of linguistic and cultural expertise necessary to do business in late Mughal India in the same way that a real-life "Persian munsh $\vec{\imath}$ " would. The text quickly emerged as required reading for nearly all aspiring British officials and administrators who hoped to pass the new Persian-language exams instituted by the company in the late eighteenth century, and thus The Persian Moonshee went through numerous printings and became a very well known and widely circulated text well into the early decades of the nineteenth century. A copy of it was found, for instance, among the possessions of the British veterinarian, horse trader, and adventurer William Moorcroft when he died of a fever in northern Afghanistan in $1825 .{ }^{8}$

This portion of Chandar Bhan's oeuvre thus played a significant role in shaping the early British colonial state's image of the opulence of the Mughal court in its seventeenth-century heyday. Gladwin, however, never names Chandar Bhan as the author of these "rules observed at court," nor does he alert his readers to the fact that the text itself was actually an excerpt of a much longer work, much less one written by a high-caste Hindu. It is possible that he was simply unaware or confused, given that this section of Chahär Chaman had in fact circulated widely as a separate text among the early modern Indo-Persian intelligentsia. One reason that it was so popular was, in part, simply that it was a memorable firsthand account of the activities at Shah Jahan's court. But another very important reason was that Chandar Bhan's reputation as a literary stylist made it an exemplary model of expressive Persian prose (inshä') that other aspiring munshīs and early modern literati sought to emulate.

In a list of his own works provided in the preface to his collected letters, Chandar Bhan himself referred to the extract by the title of Guldasta (a "bouquet," plucked as it were from the "four gardens" of the work as a whole). ${ }^{9}$ But as it circulated and was copied and recopied over time it also acquired secondary and 
even tertiary names, a composite of which would be something like (Guldasta-i) Qawā'id al-Salțanat (-i Shāh Jahān). Eventually, it appears that scribes and archivists began simply to drop the original, perhaps vaguer, title of Guldasta entirely, preferring instead the more specific Qawā'id al-Salțanat-i Shāh Jahān (which we may more accurately translate as "The Routines of Governance under Shah Jahan")- and this is probably the form in which Gladwin actually encountered the text. But there remained great variation, and thus, for instance, in the collection housed in Aligarh's Azad library alone there are at least six manuscripts of the text, nearly every one of which refers to it by a different title (and sometimes by different titles within the same copy!). ${ }^{10}$ There is no exhaustive catalog of Chandar Bhan manuscripts worldwide, but one suspects that a similar variation would be found in the many versions of this text housed in archives elsewhere in India, in England, and around the world.

If specificity in terms of actually naming the content was one reason that the secondary title of Qawāid al-Saltanat-i Shāh Jahān grew in popularity among seventeenth- and eighteenth-century scribes, another might have been the fact that the text evoked the memory of a deep tradition of other writings on IndoPersian political culture such as some of those mentioned in the previous chapter, as well as other texts like the Ahkām al-Sultaninya of Abu al-Hasan al-Mawardi (d. 1058), or the Zakhìrat al-Mulük of Mir Sayyid 'Ali Hamadani (d. 1384), which specifically uses the phrase qawa' $i d-i$ saltanat in discussing "the principles of the form and substance of power and governance" (lawäzim-i qawā'id-i salțanat- $i$ șuwari-o-ma'nawī). ${ }^{11}$ As we will see, however, Chandar Bhan's observations on these questions deal less with abstract principles and norms than they do with the day-to-day business of governance, with the focus in the early passages on activities of the emperor himself and those in his immediate presence. What did the emperor do when he woke up? What time did he usually have his first public audience? What was the setting like? When did he pray? When did he legislate? When did he deal with the business of revenue administration? When did he take a break for entertainment? When did he receive guests with special access in the privy chamber? And so on.

In short, Guldasta / Qawā'id al-Saltanat and the corresponding portion of Chahär Chaman are not meant to be an account of a single, specific "day in the life of the emperor" but rather a composite image of the typical routine and of the sorts of things that could potentially happen on any given day. ${ }^{12}$ This part of the text, at least, is similar to an account of the emperor's daily routine found in another chronicle of the period, the Pādshāh Nāma of 'Abd al-Hamid Lahori (d. 1654). ${ }^{13}$ But after the early subsections dealing with the emperor's personal routine, Chandar Bhan widens his gaze to include the general atmosphere of the court, both while it was in residence in one of the trio of grand Mughal capital cities of 
Delhi, Agra, and Lahore and when it traveled as a massive, mobile tent city. This is where the text of the extract Guldasta / Qawā'id al-Saltanat typically ends. But in the second garden of Chahär Chaman this expansion of perspective-from the body of the king himself to the "body" of the imperial cities and the peripatetic imperial camp-leads directly into an even further widening of Chandar Bhan's gaze, as he ends the second chaman with a long excursus on the various provinces of the empire, the "body" of the Mughal dominion as a whole. Let us examine this progression a bit more closely, paying special attention to Chandar Bhan's own words and the specific language that he uses to describe the king, the court, and the empire.

\section{The King}

The version of the text that appears in Chahär Chaman begins, as all four "gardens" do, with a preface explaining Chandar Bhan's reasons for writing it. Thus, while the bulk of what is to follow centers on his general observations of the emperor, the courtly milieu, and the imperial metageography, the narrative itself is framed, like the first chaman, once again as a form of self-expression and selfexamination-not just any old information about Shah Jahan's court but an account of what Chandar Bhan himself has personally seen and heard. As we saw in the previous chapter, Chandar Bhan was intimately involved in the day-to-day administration of the empire for nearly three decades, often working out of the prime minister's office. But we also know that he spent at least some amount of time working in the personal presence of the emperor as Shah Jahan's private diarist, or wāqi'a-nawīs, giving him a consistency and intimacy of access that would have been uncommon even for many in the upper nobility. It is this personal perspective that Chandar Bhan wants to share with his readers.

Even his opening lament regarding the incapacity of language to fully capture the splendor of the court strikes this inward-looking tone: "Since a true expression of gratitude for the generosity of His Royal Highness and a true description of the lofty positions and virtues of the elite members of this heavenly court are above and beyond the narrative powers of this meager slave and Brahman of the Hindi tongue, after searching my mind and the deficiency of my talents, I had become resigned to impotence and failure." ${ }^{14}$ Chandar Bhan immediately explains, however, that the thought of the emperor's great qualities inspired him to proceed nonetheless, despite the impossibility of words- his words - to convey those very qualities.

But what sort of language, specifically, does he use to eulogize the emperor? I quote Chandar Bhan's own words in full, having taken the liberty of bracketing the praise for the emperor that comes midway through the sentence and placing it in a column, to make the syntax a bit easier to follow. I have also placed some of the original Persian words in bold text, in order to highlight the rhythm and rhyme of Chandar Bhan's prose: 
I had become resigned to impotence and failure. But the verdant flower in the garden of eloquence became infused with the hue and fragrance of eulogy and praise for the angelic qualities of the universe-conquering emperor-

the Asylum of the Entire World ('älam-panāh)

the King of World-Conquering Kings (shähinshāh-i gìtī-sitān)

the Subduer of the Heavens (falak-dastgäh)

the Truth-Knowing Sovereign (khidev-i haqq-shinäs)

the Lord Whose Foundation Is Truth (khhudäwand-i haqiqat-asās)

the Friend to Truth (haqq-pasand)

the Seeker of Truth (haqq-talab)

the Desirer of Truth (haqq-khwāh)

the Chooser of What Is Right (haqiqat-guzin)

the Way Station of Reason (maurid-i ' $a q l$ )

the Impetus for the Primal Element/Essence (nashä'-i jauhar-i awwal)

the Perfect Guide (murshid-i kämil)

the Just Sovereign (k $k \bar{h} \bar{a} q \bar{a} n-i$ ' $\bar{a} d i l)$

the Manifestation/Embodiment of Power (mazhar-i qudrat)

the Wellspring of Excellence (mașdar-i khair)

the Unalloyed Bounty (faiz-i mahz)

the Total Intelligence (tamām-khirad)

the Complete Civility (hama-lutf)

the Utter Munificence (jumla-karm)

[the One] Whose Mystery Is His Intellect (ramz-ash 'ilm)

Whose Intellect Is His Art ('ilm-ash hunar)

Whose Art Is His Wisdom (hunar-ash hikmat)

the Jewel in the Span of the Universe (jauhar-i'arșa-yi kā'ināt)

the Binding on the Book of Existence (shìrāza-yi nuskha-yi maujūdāt)

the Epitome of the Qualities of Truth (maușüf ba șifät-i haqq)

the Shadow of the Ultimate Being (sāya-i zāt-i mutlaq)

the Decipherer of the Signs of Wisdom (shināsā-yi rumūz-i hikmat)

the Pearl Diver in the Ocean of Reality (ghauwāṣ-i bahr-i haqīqat)

the Brilliance on the Gemstone of Plenty (ābrū-yi gauhar-i futūwat)

the Pupil in the Eye of Masculinity (mardumak-i dìda-yi murūwat)

[the One] Whose Oaths Are Firm ('ahd-ash ustuwär)

Whose Purpose Is Resolute ('azm-ash bar qarär)

Who [gives with] an Open Hand (abr-dast)

Whose Heart Is an Ocean (daryā-dil)

the Morning of the Soul [of humanity] (șubh-i nafs)

the Sun on the Forehead [of mankind] (aftāb-i jabīn)

the Knower of Hidden Mysteries (dānāa -yi rāz-i nihānn̄)

the Witness to Divine Splendor (binnā-yi jilwa-i rabbānāi)

the Shadow of God (žill-i șubhān̄in)

the Merciful caliph (khaliffat al-rahmmānī)

the Second Lord of the Celestial Conjunction (șāhib-i qirān-i șānn̄i)

May God keep his realm intact forever (khhallad-allähu mulkahu)

- and so out of divine inspiration I have named this garden in the eternal spring of meaning the Chahär Chaman of Brahman. I hope that it will be refreshed and 
invigorated by showers of kindness and appreciation emanating from the clouds of His Blessed Majesty's bountiful heart and discerning intellect.

I trust that wherever the generous spirits of the masters of knowledge and visionaries of the intellect may find one of those mistakes and errors that all ignorant mere mortals are prone to, perhaps they will do this humble supplicant the courtesy of fixing it with the pen of correction. $(C C, 85)$

This is exactly the sort of flourish of ornamental insh $\bar{a}$ ' that has given many modern historians fits. It contains no specific new information that is particularly "useful" (i.e. no names, dates, events, etc.), and its syntax appears purposefully convoluted, with the main sentence interrupted by some ten lines (in the printed edition) of "artificial" praise for the emperor.

But no one forced Chandar Bhan to write in this way-so to dismiss such passages as meaningless verbiage, as so many modern scholars have done, is to take the easy way out and perhaps to miss the entire point. The basic content is straightforward enough, along the lines of: "I was having doubts about whether my linguistic abilities were up to the task of effectively depicting the splendors of Shah Jahan's court, but my pen was inspired by the emperor's many qualities, which are like a resplendent garden, to go ahead and give it a try; I have called my account 'The Four Gardens' (Chahär Chaman) and hope that he and other readers like it and forgive me for any errors of style or substance." Merely understanding this basic content, however, does not fully capture the surplus "meaning" conveyed by the passage's prose style.

The first thing to notice is that Chandar Bhan does not merely list the emperor's virtues. He turns that mundane act of listing into an aesthetic event, deploying all the tools of rhyme, consonance, and assonance that good poetry typically displays, and introducing a consciously performative quality to the prose whereby the pleasure of reading (or better yet, reciting) the words is itself a key part of the text's "meaning." There is an almost percussive rhythm to the list of Shah Jahan's virtues, a cadence that is next to impossible to recreate in English, and difficult even to replicate in Persian without reading aloud. But this parade of rhymes and parallel constructions is quite consciously designed to trip along the tongue, impelling the reader's eye forward and bringing delight to the connoisseur. Far from being stilted, the words flow almost effortlessly when one knows what they mean and how to read them properly, as most of Chandar Bhan's early modern Persophone contemporaries certainly would have. (Translating them effectively is, of course, another matter entirely.)

Aside from purely aesthetic considerations, there is also actual historical insight to be gleaned from reading a panegyric litany like this carefully, modern historiography's biases to the contrary notwithstanding. That modern bias would have us believe that this is all merely the perfunctory verbiage of a lackey who was cowed by the emperor's despotic power into sycophantic hyperbole or 
constrained by courtly literary convention into ostentatious verbosity, or both. Hence, it is not to be taken seriously when it comes to questions of how we interpret Shah Jahan's reign, or Hindu-Muslim relations during that reign, or any number of other topics of interest for the history of early modern India generally. But to accept this interpretation means accepting the conclusion that the words themselves, and the author's agency in writing those words, do not matter. It means taking as our analytical starting point the unfounded premise that it was impossible for someone like Chandar Bhan to actually mean what he said about the emperor, or to have crafted his words with a specific message about the nature of Mughal power in mind.

Yet surely it matters that in this lengthy list of Shah Jahan's virtues hardly any-only three, by my count-speak specifically of the emperor's capabilities as a warrior and conqueror. Given all the tired clichés about the intrinsic violence of Muslim rule in India, and Shah Jahan's own martial severity in particular, this in itself is a noteworthy absence. Did it simply go without saying to Chandar Bhan's way of thinking that Shah Jahan was the greatest conqueror in the world? Or was it rather that conquest alone was not necessarily as worthy of his praise as we might be inclined to assume?

By the same token, surely it matters that Chandar Bhan, who could have chosen any set of imperial characteristics to eulogize, focuses nearly all of his rhetorical energies on praising Shah Jahan's justice, wisdom, intellect, reason, sense of fairness, yearning for Truth, and even esoteric mystical knowledge. Indeed, any specialists reading this will have surely noted that a good deal of the idiom here is infused with a generic Sufi mystical sensibility and idiom-the emperor as a "knower of Truth" (haqq-shinās), a "seeker of Truth" (haqq-talab), "the Perfect Guide" (murshid-i kāmil), "the Decipherer of the Signs of Wisdom" (shināsāyi rumūz-i hikmat), "the Pearl Diver in the Ocean of Reality" (ghauwās-i bahr-i haqiqqat), "the Knower of Hidden Mysteries" (dānā-yi rāz-i nihānī), and so on. These are humanist virtues of the intellect and esoteric spirituality, about as far from the thundering bombast of worldly power or even the shrill hectoring of clerical orthodoxy as one can imagine.

In other words, even if we make allowances for the fact that Chandar Bhan is intentionally laying it on a bit thick, and even if we recognize that some of these forms of praise are at least partly formulaic and that we don't have to take every word literally, it does not necessarily follow that the underlying sentiment is not genuine-which, in turn, means that there is still something telling about the manner of praise on display here. For one thing, it gives us a powerful glimpse of the Mughal ideology and value system, one in which the legitimacy of a king was judged less on the monarch's brute ability to conquer and hold territory-though that too was obviously important - than on the justice, fairness, equitability, and even spirituality of his rule. For another, it tells us something about what 
Chandar Bhan thought mattered to his readers in the wider Persianate world when it came to kingship, and about what he thought distinguished Mughal rule from that of rivals like the Ottomans and Safavids. Remember, Chandar Bhan's effusive praise of Shah Jahan was not just meant for local Hindustani consumption; it was also clearly intended to advertise the Mughal court's justice and generosity to readers in Anatolia, the Iranian plateau, Central Asia, and even the Deccan, and in so doing perhaps to lure away artists, intellectuals, mystics, traders, and other talented individuals from those rival locales who might be in search of patronage and might further add to the luster of Shah Jahan's court.

In the next few pages, Chandar Bhan reiterates and builds on many of these same themes. In the section immediately following the one we have just discussed, for instance, he draws our attention to another important quality that he admires in the emperor, namely, the latter's administrative acumen:

Ever since the prosperous throne of governance and conquest that is the envy of heaven was beautified and adorned by the accession of His Majesty the Emperor of the Age, the Sovereign of the World, the Ruler of the Land and Sea, and the King of Kings of the Seven Climes, the four gardens of the world [chahār chaman-i rozgār] have grown even more verdant and lush, and the gardens of hope and serenity have become green and succulent.

Since His Majesty the Emperor's lofty and discerning intellect is an innovator in the precepts of government and politics [qawānīn-i jahāndārì wa jahānbānī] , and the establisher of norms of rule and conquest [ādāb-i mulkgìrì wa kishwar-sitānī], he has cultivated in the lands of Hindustan a sense of conscientiousness and attentiveness to the proper principles of governance and management, the creation of new laws and statutes, and regulations for the revenue, administration, and smooth running of this great empire for the safeguarding of land and property [dar mamālik-i hindūstān nasaq-o-nizām dar nishast-o-bar-khāst wa qawā'id-o-qawānīn-țarāzì wa $\bar{a}$ '̀n̄i dar zabt-o-rabț-o-band-o-bast-i umūr-i daulat-i wālā ba muhāfizat-i mulk-omāl hazmì-o-ihtiyāțī padìd āmad]. (CC, 86)

The prose may well be florid, and it may not exactly be hard evidence, but at the very least this is suggestive testimony from a contemporary witness insisting thatagain, contrary to so much modern historiography-Mughal administrative practices were far from static after Akbar's death in 1605. We saw in the previous chapter that Chandar Bhan reserved special praise for prime ministers like Afzal Khan and Sa'd Allah Khan who, in his opinion, had made an effort to improve the Mughal administrative and revenue system - not just for the empire's own extractive benefit, but also, at least in Chandar Bhan's view, for the benefit of the peasants and cultivators themselves. And here he makes a similar claim for the emperor himself, and for the emperor's hands-on approach to administration and governance.

This theme will recur a number of times in the pages that follow, but first Chandar Bhan once again inserts himself into the narrative, making a point of 
reminding us that his long service to the court is what gives his testimony credibility, and reiterating that this is a firsthand account of what he has personally seen:

Since this humblest servant of the celestial court has been among the followers [talmizan] of the victorious royal stirrup ever since the beginning of [the emperor's] august accession to the throne, whether the royal camp was in residence or on the move, I have enjoyed the special benefit of the privilege of longtime service, friendship, and appreciativeness of the kind, generous, affectionate, and discerning emperor.

With a hopeful pen I have thus selected and set down in this compilation [nuskha-yi jāmia] some of the particulars of life at this eternal court that I have witnessed with my very own objective eyes [ $k i$ ba dìda-yi haqq-bin mushāhida namüda]. May this depiction of the daily life and most happy and blessed events be like a bouquet in the assembly of the masters of expression [guldasta-yi bazm-i arbäb-i sukh han]! (CC, 86)

This is followed by yet another panegyric to the emperor, this time in verse:

The tongue of whosoever's mouth has words

Is a singer of praise for the King of Kings of the World,

The fortunate emperor who possesses the earth,

Who has the sun for a crown, the heavens for a throne.

Every morning the sky opens up its heart

And showers its pearls upon the dust of his path.

The shade of his umbrella [chatr] spreads across the universe,

More majestic even than the celestial wheel.

Under the shade of that august parasol, the auspicious Huma ${ }^{15}$

Augurs wealth for the empire.

The heavens are a mere vestibule in his mansion;

The lamp of the sky merely a moth [to his flame].

The legendary steed of his courage [burāq-i himmat-ash] is so fleet of foot

That it needs all of Anatolia and the Levant [rüm-o-shām] just to go for a gallop.

The number of his dominions is impossible to reckon,

For in conquest [mulk-giri $\overline{]}$ he is the sun.

His effusive heart is boundless as the ocean;

For earrings he uses Pisces [māhī] and the moon.

O heaven [falak], you are but a tent in his realm;

O celestial dome [gumbad-i gardūn], you are but a castle in his country.

Everyone you see has prospered in his domain;

The foundations of tyranny [bina $\vec{a}-y i z u l m]$ have crumbled in his reign. 
His knowledge ['ilm] can fairly be measured against that of a scholar ['älim], For he is wise in every science and every matter [dar har 'ilm-o-dar har kār].

When he spreads his jewel-scattering hands He empties the ocean and mine of his heart.

The dust of his path is a balm of kohl for troubled eyes, The brilliance of his intellect a guiding light for sight.

The world-displaying mirror, the heart with knowledge of the unseen:

These are the interpreters of the wisdom emanating from his tongue of magical expression.

[zabān-i har ki goyā dar dahān ast șanā-khwān-i shahinshāh-i jahān ast shahinshāh-i jahāndār-o-jawān-baknht ki khwwurshed-ash sazad tāj āsmān takht falak har șubh sāzad az bar-i knhwesh nișār-i khāke-i rāh-ash gauhar-i k̂hwesh bar āfāq ast chatr-ash sāya-gustar ki bāshad dar shukoh az charkh bar-tar Humā dar sāya-yi ān chatr-i wālā kunad sarmāya-yi daulat muhaiyā falak tāqì-st dar kāshāna-yi $\bar{u}$ chirāgh-i āsmān parwāna-yi $\bar{u}$

Burāq-i himmat-ash ān tez-gām ast ki jaulān-gāh-i ghurrish Rūm-o-Shām ast shumār-i mulk-ash afzūn az hisāōb ast ki ū dar mulk-gìrī âftāb ast dil-ash daryā-yi bī-pāyān-i pur-josh zi māhì tā ba māh-ash halqa dar gosh falak az bārgāh-ash k̂haima dārī zi mulk-ash gumbad-i gardūn hisārī ba daur-ash har ki bìnī kāmyāb ast binä'-yi zulm dar 'ahd-ash kharāb ast ba 'ilm andāza-yi 'àlam kunad rāst ki dar har 'ilm-o-dar har kār dānā-st chu afshānad kaf-i gauhar-fishān rā tahī sāzad dil-i daryāa-o-kān rā 
ghubār-i rāh-i ù kuhl-i baṣar-hā

furogh-i rāy-i ù nūr-i nazar-hā

ayīnā-yi jahān-numā dil-i ghaib-dānish

tarjumān-i 'ilm zabān-i mu'jiz bayān-ash]

(CC, 86-87)

Again, while Shah Jahan's greatness as a conqueror is of course celebrated here, there is a near-equal emphasis on his intellect, generosity, and wisdomon knowledge ( $\mathrm{ilm}$ ) triumphing over the "foundations of tyranny" (zulm), as Chandar Bhan suggests in couplets 11 and 12.

After a few more lines of praise for the emperor (this time once again in prose), Chandar Bhan finally begins his description of the daily routine at court, and this is the spot where most manuscripts of the digest Guldasta / Qawā'id al-Saltanat begin. He opens with a series of celestial metaphors, comparing the emperor to the moon and the rising sun before explaining that Shah Jahan would typically rise very early at the break of dawn to pray and spend some time reading the Qur'an. Notably, this hint of Muslim piety on the emperor's part does not seem to perturb our Brahman commentator in the least. On the contrary, Chandar Bhan frames Shah Jahan's prayerful routine as a reflection of the emperor's virtue and humility rather than as a threatening harbinger of orthodoxy and indeed barely comments on it before moving on to other topics.

Next we are taken on an intimate tour of the palace's inner quarters during the early morning hours. Here we learn, for instance, that breakfast in the royal apartments usually consisted of a variety of juices and other drinks, as well as a bountiful selection of fruits from all over India and the surrounding regions. Chandar Bhan's description of this assortment of fruits serves not only to highlight the rare and luxurious comestibles available in the palace but also to remind readers of the territorial extent of Mughal power, which assured access to such exotic fruits in the first place and provided a safe network of roads and territories through which to transport them. Indeed, the multiplicity of fruits on offer at the court is itself arguably intended to serve as a metaphor for the inclusive ethos of empire as a whole: ${ }^{16}$

Since the Emperor's bounteous generosity is as deep as the ocean, the key that throws open the gates of kindness and favors, every morning he distributes a rich array of delicious food, aromatic drinks, amber-scented confections [nuqlät], sweets of various colors, and fruits of every variety: melons from Balkh and Kariz, ${ }^{17}$ plums from Kashghar and Ghur, black and purple Habshi and Sahibi varieties of grapes, Samarqandi pears and apples, pomegranates from Yazd and Jalalabad, Kardi peaches, ${ }^{18}$ and various other fruits of Persia and Central Asia [mewa-hā-yi wilàyat] that are always arriving at the court that is the asylum of the world. There are also Hindustani fruits [fawäkih-i Hindūstān] such as mangoes from Gujarat and the Deccan, pomegranates from Thatta, watermelons from Kashmir, delicious pineapples and juicy sugarcane, delightful figs, seedless mulberries, oranges of every shape and size, and many other 
kinds of juicy and fresh fruit that are delivered daily in baskets from the provinces and gardens throughout the empire-all generously shared on silver and gold trays among the princes $[n \bar{u} b \bar{a} n]$ of this great and magnificent court, the nobles of the everlasting state, and other familiar servants of the court.

Even breakfast, it would appear, was intended to be a display of Mughal cosmopolitanism, a chance to show that the fruits of the whole world were available at the court and generously shared with its denizens. In material terms, this inventory of delicacies shows just how hooked into the circulatory trade networks of Asia the Mughal court really was. But there is also little doubt that Chandar Bhan was trying to use all this sumptuous bounty as a kind of metaphor for the court's pluralism and generosity more generally. In some manuscripts of the text, moreover, he adds an interesting aside noting that in addition to the organized networks of fruit delivery, there was a coordinated system for bringing ice down from the mountains (presumably, the lower Himalayas) in the blistering heat of the summer months, whereupon it would be distributed "among the principal officers, according to their respective ranks." ${ }^{19}$

After breakfast, the emperor dispensed certain special favors in private and then made his way to the public viewing gallery, or jharoka-darshan, "according to the long-standing practice of this great empire and magnificent caliphate" (mutābiq-i qā'ida-yi qadìm-i daulat-i 'uzmá wa khiläfat-i kubrá). Chandar Bhan explains that in all three major Mughal cities-Agra, Delhi, and Lahore-the jharoka-darshan was situated alongside the riverbank facing out onto a wide-open space where the

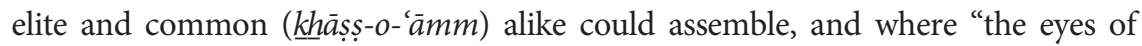
the hopeful and expectant could be lit up by contact with the luminous imperial gaze" (dìda-yi umedwārān wa muntazirān rā ba dīdār-i fā'iz al-anwār munawwar mìsāzand). The same gallery and attached field were also sometimes used for other kinds of entertainment, such as elephant fights_-"a marvelous spectacle," according to Chandar Bhan, "as if two mountains were crashing into one another" - as well as performances by "a variety of master players, dancers, and jugglers from every region" (ijtimā'-yi arbāb-i la'b wa raqqāṣān wa bāzìgarān-i har diyār) (CC, 89). But the jharoka-darshan was not meant solely for the passive visual experience of beholding the emperor, or the morning's imperial entertainment. It was also a space, Chandar Bhan tells us, where petitions for charity, the redress of some grievance, or some other form of justice ( $a d l-o-d \bar{a} d$ ) could be lodged directly with the emperor himself and could "reach the blessed ear of the just emperor unmediated" (ba wasätat-i ghairi ba sam'-i mubārak-i pādshah-i 'ādil firyād-ras mìrasad) $(C C, 89) .^{20}$

After this session the emperor usually proceeded directly to a much more formal assembly in another part of the palace known as the Hall of Special and Public Audience (jharoka-yi khhāṣs-o-'ām) (CC, 90-95). It was here that the main daily business of the court was conducted-audiences with officers who were being posted to a new assignment, or perhaps returning from a campaign; the reading of 
imperial edicts, newsletters, and memoranda; the receiving of diplomats and other distinguished visitors; the dispensing of patronage for artists, literati, scientists, and other intellectuals; and so on. In Akbar's day, this public audience could last up to four and a half hours, and according to the contemporary historian Badayuni (1540-1615) "Huge crowds assembled and there was much bustle." ${ }^{21}$ This seems clearly to have still been the case under Shah Jahan, if Chandar Bhan's account is any indication, though it would appear that the ceremonial aspects of such assemblies had become much more regimented by our author's time. The emperor made his entrance to the booming of kettledrums, which, according to Chandar Bhan, resounded for miles around, whereupon he was received by "the assembled servants of this court that is the asylum for kings, who are blessed and graced with the opportunity to bow before him." The first order of business was a kind of military review, beginning with a parade of horses and elephants in full regalia, creating a spectacular commotion that Chandar Bhan acknowledges (with characteristic modesty) was "entirely beyond the capacity of words to describe" $(C C, 90)$.

Shah Jahan's court is well known in modern historiography for the strict formality of its ceremonial, and this impression is at least partly confirmed by Chandar Bhan, who notes that the assembled nobility and other courtiers like himself were required to stand and were typically arranged in rows according to their rank. But here he also treats us to a lengthy excursus on the rich diversity of regional, ethnic, and religious identities that might be represented in the audience of the jharoka-yi khāṣs-o-'ām on a typical day. First the various princes and members of the royal family were "permitted to sit, rank by rank, according to their status, near the throne of the caliphate and sultanate." (Note that there was an explicit official hierarchy even within the extended royal family, one that was embodied in practice during Mughal assemblies through proximity to the royal person.) Next came the upper echelon of the Mughal nobility: "khhāns, sulțāns, mīrs, and mīrzās hailing from the lands of Iran and Turan, followed by illustrious wazìrs who are masters of the sword and the pen, nobles of high rank and their sons who served the court." ${ }^{22}$ Alongside these were arrayed various other types of military subalterns, arranged in groups for maximum effect: swordsmen, armorers (qūrchiyān), archers, mace bearers, matchlockmen, and so on. Next to these were another set of "estimable" (wājib al-ihtirām) denizens of the court: "Sayyids of lofty status, great [Sufi] shaikhs, eminent men of learning, ingenious doctors, and other able courtiers" (CC, 90).

Various ethnic and regional identities were represented among these generic categories of courtiers and those to follow. Thus, Chandar Bhan explains, the rest of the Hall of Public Audience was filled out with attendees of "various ethnicities” (tabaqāt-i mukhtalif):

from Arabia and 'Ajam, Turks, Tajiks, Kurds, [Lurs], Tatars, Russians, Africans [habash], Circassians, and various others from the lands of Anatolia, Egypt, the Levant, 'Iraq, Arabia, 'Ajam, Persia, Gilan, Mazandaran, Khurasan, Transoxiana, 
the Qipchaq steppes, Turkistan, Georgia, and Kurdistan, each in their turn; so too with the various communities [aqwām] of Hindustan, from among the masters of learning and perfect wisdom, to men of the sword and the pen, such as sayyids of pure ancestry, martial shaik $\underline{h}-z \bar{a} d a s$, Afghan tribes [alūsāt] like the Lodis, Rohillas, Khweshgis, Yusufza'is, and others, not to mention various classes of Rajputs, ranas, rājās, raos, and rays, among them the Rathors, [Sisodias], Kachwahas, Hadas, Kurus, Chauhans, Jhalas, Chandrawats, Jadauns, Tonwars, Baghelas, [Maheshwars], Gujars, [Panwars], Bhadauriyas, Sanghis, Bundelas, Shagarwals, and other attendees from the rest of India, arranged in descending order from ranks of 7,000 to 1,000, and then 1,000 to 100 , and then 100 to individual troopers [ahadìs]. (CC, 90-91)

[Several of the toponyms and ethnonyms in this list are quite unclear in Ja'fery's printed edition of Chahär Chaman (2007), but I have clarified some of them by consulting various manuscripts of the text, and indicated these by placing the names in brackets. Cf. Guldasta, Mausūm ba Qawāìd al-Salțanat, MS, Azad Library, AMU, Aligarh (Suleiman Collection \#664/42: fol. 5a); Guldasta / Qawā'id al-Saltanat, MS, Azad Library, AMU, Aligarh (Suleiman Collection \#664/44: fol. 5a); Qawā'id al-Saltanat-i Shāh Jahān, MS, Azad Library, AMU, Aligarh (Habib Ganj Collection, \#56/1:4-5).]

We may pause here to note that when discussing the various classes of Muslim elites such as sayyids and shaik $\underline{h}-z \bar{a} d a s$, and even the various Afghan tribes represented at the Mughal court, Chandar Bhan is perfectly comfortable considering them to be among the "communities of Hindustan" (aqwām-i Hindustān). Being a Muslim-even one such as a "sayyid" whose entire claim to elevated social status was based on an avowed pride in Arabian origin and direct descent from the prophet Muhammad-simply did not make one "foreign" in Chandar Bhan's eyes, and certainly not in the modern nationalist sense. As for the Afghan tribes, Chandar Bhan's comments here are a powerful reminder that the premodern South Asian geographical imagination often included much of modern-day Afghanistan, which, far from representing a cultural space that was incommensurably other, had been a recognized part of the zone of political, cultural, and commercial circulation along the trans-Indus corridor since antiquity.

In any event, Chandar Bhan's parade of diversity is not done. Lest we think that his metageographical horizons - and those of the Mughal court generally-are limited to northern India and Central Asia, he proceeds to tell us about yet more cultural and ethnic groups from further afield that were usually present in Mughal assemblies, including "landed gentry [zamindārs] from the plains and the mountains, from the countries of Karnataka, Magadha, Assam, Udaipur, Srinagar, Kumaun, Bandhu, Tibet, Kishtvar, and other countries of the realm, who rank by rank according to their status were ennobled by the honor of kissing the threshold of the Saturnal court [dargāh-i kaiwān-jāh]." Here Chandar Bhan reiterates that all of these groups were dressed in their best finery and arranged according to their ranks, adding that "no one moved without permission" and that "even though all were standing very close to one another, they were expected to maintain strict silence" (CC, 91-92). 
Such ceremonial discipline notwithstanding, it is nevertheless striking the degree to which the religio-ethnic diversity of the empire, personified by the attendants at such assemblies, is framed by Chandar Bhan as something not merely to be tolerated by the Mughal state but in fact to be celebrated and promoted among the primary virtues of Mughal dominion-as if the very purpose of Mughal power was to maintain the conditions of possibility for such plurality.

Chandar Bhan also seems to have recognized quite clearly that tolerance was, as it were, good for business, and he makes a clear connection between Mughal pluralism and the empire's political economic health. Thus as he continues this extraordinary excursus on the participants and routine of the jharoka-yi kh $o$-' $\bar{a} m$ he frames his next set of comments specifically around various forms of Mughal hospitality toward outsiders. There was geopolitical hospitality: "Likewise multilingual ambassadors from the Caesar of Rum [i.e., the Ottoman Sultan] and the rulers of Iran and Turan arrive with letters and gifts-the crucial implements of diplomatic concord-and are given permission to stand in the palace audience according to their status. Ministers and lords from the Deccan, too, such as the representatives of the 'Adil Shah, Qutb al-Mulk, and the people of Karnataka, exposed to the munificent light of the Imperial Presence, also demonstrate their loyalty with petitions and gifts" $(C C, 92)$. There was also commercial hospitality:

And the class of captains of commerce [malik al-tujjär] — represented by various merchants, profiteers, and suppliers from every quarter of 'Iraq, Khurasan, Anatolia, the Levant, China [chīn], Greater China [mā-chìn], Cathay [khatā], Hotan [khutan], Turkistan, Europe [farangistān], and various other far-off countries [mamālik-i $\left.b a^{'} \bar{i} d a\right]$ and famous islands and ports-visit the world-protecting court carrying expensive jewels, finery, curios, exotica, and other wares and display their cargo in the spacious audience hall.

Then, made prosperous and delighted by their lavish profits and gains [fawä'id wa munāfa' $i$ kullī], they carry testimonial evidence of the kindness and good name of this eternal empire in every direction and to every far corner of the world, [spreading the word] that this magnificent and majestic court is the qibla of the hopes of this world and its inhabitants. $(C C, 92)$

\section{And cultural hospitality:}

There is a surfeit of experts in the sword and the pen, men of excellence and perfection, masters of wisdom and intellection, authors of elegance and eloquence, and various other classes of masterful artists, artisans, and other skilled people from all over the civilized world [az ma'mūra-yi 'àlam]_including Istanbul, Aleppo [hal$a b$ ], Egypt, Basra, Baghdad, Hamadan, Shirwan, Shamakhi, Gilan, Mazandaran, Astarabad, Ganja, Barda', Tabriz, Ardabil, Qazwin, Qom, Savgan, Tehran, Yazd, Isfahan, Simnan, Damghan, Bastam, Sabzawar, Nishapur, Merv, Mashhad, Tus, Tabas, Qayin, Tun, Isfarayin, Jam, Herat, Khwaf, Bakhtar, Sistan, Farwan, Qandahar, Balkh, Badakhshan, Bukhara, Samarqand, Andijan, Tibet, Kashghar, other parts of Turkistan, and various other far-off cities. 
For all manner of men come to this court of global refuge, the central axis of the world's turning quadrants, bringing their hopes and dreams with them, which are in turn fulfilled by their attaching themselves to the bounteous court that is a refuge for the world and its inhabitants. (CC, 92-93)

As I have noted above, there is no doubt that this is all a form of propaganda, an advertisement for the benefits of Mughal rule. But this in itself does not mean that Chandar Bhan's pride in the court's posture of universal civility (sulh-i kull) is not genuine.

Tolerance, moreover, is far from the only theme that Chandar Bhan addresses in this account of the routine at Shah Jahan's main public audience, or darbār. He explains, for instance, some of the intricacies of Mughal court ceremonial and further notes that it was in this type of public assembly that official titles of nobility and bureaucratic assignments were usually handed out personally by the emperor: "Royal titles such as shah, general [sipah-sālār], commander of commanders [amīr al-umarā], khan of khans, sultan, maharaja, raja, ray, ray-i rayan, rana, and various other epithets suitable to individual capabilities were bestowed by His Majesty the Caliph, while the important governmental posts relating to the provinces such as the regional and city qāzīs, judges, inspectors [ihtisābs], qānūn-gos, chaudhrīs, and other officers were also appointed by the luminous Imperial Presence" (CC, 93). Mughal bureaucracy, in other words, did not simply run on autopilot. Keeping the central, provincial, and local administrative positions filled and supervised required constant attention from the court, including the direct intervention of the emperor himself on an almost daily basis. There was, moreover, a good deal of turnover in such positions, and Chandar Bhan notes that many of these provincial and local officers were subjected to a kind of institutionalized formal review process, one that took place out in the open for all to see during such public assemblies: "On one side stood the various governors [șübadārs], administrative heads [dīwāns], amīns, and 'āmils who had been [newly?] assigned by His Great and Magnificent Majesty to the various provinces, districts, cities, and towns of the realm, while on another side stood those who had been in charge of this or that governmental post but had been relieved of duty [ma'zūl shuda]. Having arrived at the court that is the refuge of the world, they were there to reap the appropriate reward or punishment resulting from their good or bad performance" (CC, 93-94). Some of those whose performance was approved by the emperor were specially favored with the opportunity to approach the throne and were literally given a "blessed pat on the back" (dast-i muqaddas bar pusht mīguzarānand), while others were acknowledged more subtly, perhaps only with a glance or a nod of approval from the emperor.

But behind all the ceremony, the main point for Chandar Bhan definitely seems to be that the administration of the empire was an ongoing process, one in which the emperor was personally interested and engaged. Thus, he continues:

Because of [His Majesty's] resolve to vouchsafe the obligations of governance, all edicts concerning matters related to land, property, manșab rankings, jāgīr assign- 
ments, monthly stipends, per diem allowances, gifts, charitable land grants, and various other matters are submitted to His Highness for review. Also submitted to the blessed gaze are reports of events in every land and territory, outlined in memoranda ['arä'iz] sent by the officials, governors, intelligence agents, watchmen, and news reporters of each locality.

In turn, inviolable orders are issued for enhancing the well-being of the people [rafāhat-i aḥwāl-i khhalā'iq], promoting cultivation, building infrastructure, policing bandits and rebels, and safeguarding the guarantees of utmost justice and fairness [pās-i marāsim-i 'adl-o-dād-i arfa ]. (CC, 94)

Chandar Bhan goes on to explain that during the darbār various types of officials were given the opportunity to consult directly with the emperor on important matters of state and were usually given answers right then and there. This observation once again affords him the opportunity to offer an extended praise of Shah Jahan's reason, intellect, and humane approach to governance, a point that Chandar Bhan punctuates by noting that another important activity during the assemblies of the jharoka-yi khasass-o-'ām was the public distribution of various types of charity-including gold-for the poor and the indigent, as well as charitable land grants (madad-i ma'āsh) for religious institutions. As Chandar Bhan notes, these gifts were managed through an officer known as the șadr al-șudūr, but what he wants to convey here is that the emperor did not simply delegate these matters to a functionary but took an active role in supervising their administration.

This theme is revisited repeatedly in the subsequent sections. After the assembly in the jharoka-yi knhāṣs-o-'ām has concluded, Chandar Bhan brings us along as the emperor retires to his privy chamber, or ghusl-khāna, for further consultations with his most trusted advisers in a more intimate, relaxed setting. Officially, this part of the palace was known as the dīwān-khāna-yi knhāṣs (or sometimes

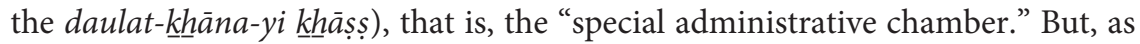
Chandar Bhan reminds us, it was better known by the colloquial name of "the bathhouse" (ghusl-khāna) because it was situated directly between the royal apartments and the baths. The important point to note, however, is not the etymology of the term but simply the fact that this was an area of extremely limited access for all but the most trusted advisers, or those with special permission. There is thus a hint of self-promotion here by Chandar Bhan, always mindful of his status as an insider eyewitness and never shy about using his narrative perch to remind us of the privileged access he enjoyed. (As we will see in the final chapter, this penchant for flaunting his insider status, and specifically his claim to special access to the emperor's ghusl-khāna, will eventually be turned on its head and used against our munsh $\bar{\imath}$ in the construction of a collective memory about his exploits in later generations. But let us not get ahead of ourselves.)

Shah Jahan typically conducted business in the ghusl-khāna until just after midday, according to Chandar Bhan. It was a setting for various different types of activities, but the first order of business - and the one that Chandar Bhan spends 
the most time telling us about-was to continue the administrative work of managing the empire that had begun earlier in the day during the public darba $r$. A "summary agenda" (khhulāṣa-yi mațālib) prepared by a council of ministers was presented to the emperor, who began by reviewing and giving directions with regard to all the most pressing matters (mahāmm-i lāzim al-anjām). This was also his time to consider any new or pending written requests ('arā'iz) from highlevel princes, nobles, provincial governors, and the like, which "were read by him with careful attention from beginning to end," while the gist of some other general requests was summarized for him orally. Any orders and edicts that in turn needed to be issued to the princes and various other officials- "șūbadārs, army commanders, provincial administrative officials, and the like"-were "presented first in the form of a rough draft [musauwada] to [the emperor's] alchemical gaze for blessed editorial corrections," and only after the emperor's personal approval did Chandar Bhan and the other "munshis as fast as Mercury" copy out the orders in final draft form $(C C, 95-96)$.

Here yet another theme from the previous chapter resurfaces: Chandar Bhan's special admiration for those members of the royal family and the ruling classes who cultivated expertise in the secretarial arts and thus were able to perform certain types of administrative and managerial tasks on their own. As we saw with regard to Chandar Bhan's assessment of the various prime ministers of Shah Jahan's reign, he clearly felt that some competence in skills such as penmanship, composition, and accounting was an essential quality of an effective leader of government because it made such a leader much more competent to keep the bureaucracy functioning efficiently, to manage and assure the quality of his assistants' work, and even, in some cases, to set the standard for quality workmanship himself. And so it is with Chandar Bhan's view of the emperor: "Often the imperial edicts as effective as Fate [manāshìr-i qaża'-ta'șìr] on important subjects addressed to the renowned and successful princes or powerful nobles were set down in the blessed writing of [His Majesty's] own amber-scented pen, in a shikasta or nasta 'liq script that displayed the highest quality and the utmost grace and refinement, with pithy, concise content delivered in a bold, vivid prose style that could serve as a template [dastür al-'amal] for even the most knowledgeable people, leaving the ministers, officials, and secretaries nothing to add" $(C C, 96)$. Chandar Bhan notes that the emperor also personally inspected the accounts and receipts relating to all manner of imperial business, such as provincial agricultural production and revenue, and kept handy a ledger listing the names and ranks of all the high-profile members of the Mughal administrative apparatus who held positions of responsibility "for the care and well-being of the soldiery and cultivators" (barā-yi pardākht wa rafāhiyat-i hạl-i sipāh wa ra'ìyat) $(C C, 96)$.

Chandar Bhan goes on to note that in order to stimulate provincial trade Shah Jahan at some point suspended the collection of certain commercial taxes and 
levies such as the tamgh $\bar{a}$ (a kind of sales tax aimed specifically at merchants) and the rāhdārī (the "road tax," a levy on the transport of goods). This was part of a wider set of policies relating to the Mughal provincial economies, one that included a very high standard for maintaining law and order expected of local officials ('āmils). In particular, Shah Jahan continued the established Mughal practice of holding such officials responsible for any property lost to theft or robbery in their jurisdiction, for which they were expected not only to pay restitution (tāwān) to the victim of the crime but also to pay a fine (jarima) as punishment for their institutional negligence. "It is because of these very same just laws and policies," Chandar Bhan adds, "that the sense of security on the roads, highways, and rest stops in this grand dominion is so great that the merchants, traders, and other wayfarers do not hesitate to travel from place to place with hearts at ease and peace of mind" $(C C, 96)$.

The ghusl-khāna was more than a place for transacting imperial business, however. It was also a kind of salon where various types of private entertainment could be staged for the emperor and his inner circle. At times it served as a sort of boutique showroom, where especially luxurious or exotic merchandise such as fine jewelry was brought in for private browsing. Chandar Bhan gives a number of examples of such items and dwells at length on the particular interest Shah Jahan took in rare and fine books, for the perusal of which the ghusl-khāna often served as a convenient setting.

Celebrated books in Arabic and Persian, often in the author's own handwriting, were brought in from the royal library and displayed for the hair-splitting and discerning critical gaze of the Emperor of Form and Content, the King of Kings of Aesthetic Appreciation, along with miscellaneous albums of art and calligraphy in a variety of scripts such as șulus, naskh ta ta liq, nasta'li q, and shikasta.

Many of these albums included samples penned by some of the great calligraphers of the world, such as Yaqut [al-Musta'simi? (d. 1298)], ['Abd Allah] Seyrafi [14th cent.], Mulla Mir 'Ali [Haravi? (d. ca. 1550)], Sultan 'Ali [Mashhadi (d. 1620)], Mir 'Imad [al-Hasani (d. 1615)], Mulla Darwish, [Mir Muhammad Asghar] Ashraf Khan [d. 1575], Muhammad Khan, and Muhammad Husain Isfahani, as well as images by some of the most talented painters, for instance Mani [3rd cent.!], [Kamal al-Din] Behzad [d. ca. 1535], [Abu al-Hasan] Nadir al-Zaman [d. ca. 1630], and the like. $(C C, 96-97)$

Granted, for most readers today the names of these master painters and calligraphers from the medieval and early modern Persianate world will not mean very much. But to the cosmopolitan Indo-Persian intelligentsia of Chandar Bhan's day the mere mention of many of these artists, let alone the idea that so many samples of their exquisite works would be available for viewing in one private collection, would surely have induced a sense of envy and awe. ${ }^{23}$ Indeed, this was precisely the intention. After all, we must always remember that Chandar Bhan was writing with the wider Persianate audience in mind, on the one hand simply to 
burnish his own literary credentials, but also with the avowed goal of advertising the wealth, splendor, and aura of luxurious possibility that he felt was characteristic of the Mughal court and might attract the interest of other talented intellectuals in the wider Indo-Persian cosmopolis.

This cosmopolitan outlook is of course a consistent, if intermittent, feature of Chahār Chaman as a whole, and it is one that Chandar Bhan expands upon here as he continues his account of the goings-on in the ghusl-khāna. He tells, for instance, of the "masters of perfect learning and intellect from Iraq, Khurasan, Transoxiana, and Hindustan [who] debate intellectual questions in elegant discourses" in one part of the room, discussions that were moderated by "His Majesty the perfect guide and complete teacher" (hazrat murshid-i kāmil wa ustād- $i$ mukammal) $(C C, 97)$. Meanwhile, on another side of the room there might be "eloquent poets reciting panegyrics and epics [qașā'id wa mașnawī] in eulogy and praise for the angelic nature of the generous and ocean-hearted emperor, and receiving bounteous rewards for their efforts." Because of the emperor's good taste and "appreciation for talent" (qadar-dānī), Chandar Bhan boasts, many celebrated poets (shu'arā-yi nāmdār) "have received their weight in red and white gold" (CC, 97). (I.e., if you are an aspiring poet, this is the place for you.)

In another part of the room munshis and calligraphers showed off their exquisite penmanship, and in still another "physicians of the Perso-Hellenic [yūnānī] tradition and doctors of the Hindi tradition test[ed] each other's skills and methods for applying proper remedies and courses of treatment." Astronomers and astrologers, including "Brahmans, hindīs, and Zoroastrians," were also regularly in attendance, "while other accomplished and talented intellectuals of every discipline engaged in all manner of theoretical and practical discussion" (wa digar dānāyān-i hunarwar wa hunarmandān-i har hunar ba muqaddamāt-i 'ilmī wa 'amalī bar zabān dārand) (CC, 97). ${ }^{24}$ Among these on any given day might be painters and other artists, mathematicians, and designers.

Chandar Bhan closes his account of the typical activities in the ghusl-khāna by noting that it was also a space for private performances. Sometimes these were quasi-gladiatorial displays of hand-to-hand combat among "dexterous youths" (jawānān-i sabuk-dast), and on such occasions the ghusl-khhāna also turned into a kind of showroom for exquisite hand-crafted military implements_ "glistening swords of Indian steel," some of them inlaid and jewel-encrusted, matchlocks, armor, and so on - "that to describe them all in detail would require an entirely separate volume" $(C C, 97)$. On other occasions exotic animals, such as "eastern and Punjabi antelopes" (ăhuwān-i pūrabì wa panjābì), were brought in to lock horns in combat with one another as the emperor and his guests looked on, "a sight that is second to none" (tamāshā-yi ghair-mukarrar) according to our author (CC, 98). But most often the afternoon's entertainment consisted of storytelling, singing, and dance performances by troupes of "melodious crooners, musicians, and other 
performers of exquisite style from places like Iraq, Khurasan, and Kashmir, as well as kalāwants and courtesans [tawä'if] from Hindustan, some of which were employed as resident artists by this bounteous government, while others had traveled from other courts in every country and region" $(C C, 98)$.

Such diversions notwithstanding, the real business of governance was never far from Chandar Bhan's mind-or, if he is to be believed, from the emperor's mind either. He thus returns to this topic again and again in the next few sections of the text. In introducing the next section on the administration of justice, for instance, he insists that on some days Shah Jahan would remain busy with administrative matters "from the crack of dawn until the middle of the night," adding that such "dedication to the important matters of governance and justice is the essence of devotion" (ba ishtighāl-i umūr-i salțanat-o-'adālat ki 'ain- $i$ 'ibādat ast) (CC, 98).

He further explains that even though there were many institutions and officials in place to ensure fairness and the rule of law throughout the realm, Shah Jahan made a special point of setting aside at least one day during the week when, "for the greater ease of the people" (ba wāsța-yi wufūr-i àsānī-yi khhalā'iq), he would personally hold court and hear the complaints of "the oppressed and the seekers of justice" (mazlūmān wa dād-khhwāhān), whereupon he would issue immediate rulings "in conformity with the splendid rule of law and the supreme principles of justice” (bar tabq-i sharī'at-i gharrā' wa 'adālat-i 'uzmá) (CC, 99). Here he goes out of his way to praise not only Shah Jahan's justice but also his inclination to be merciful (lazzzat-i 'afūw wa bak $\underline{h}$ shish) whenever possible, and humane when the occasion unavoidably called for some form of punishment (CC, 99-100). ${ }^{25}$

Chandar Bhan also adds here an observation of some significance for how we interpret even some of the court's leisure and recreational activities, noting that they were often undertaken with a commendable ulterior motive. "On many occasions," he tells us, "royal excursions that appeared to be for the mere purpose of recreation or hunting were actually designed to glean information about the state of governance and the object of people's desires, so that the most needy [arbāb-i $i$ thiyāj] could have unhindered and unfettered access to the royal person, and so have their needs addressed" (CC, 100).

After a morning filled with attention to these "various important matters of state" (iqsām-i umūr-i daulat), the emperor typically went from the ghusl-khanna to the most secluded part of the palace, the royal apartments (haram-saräi). Here Shah Jahan would rest, enjoy some private time, and perform his afternoon prayers "with the kind of humility that is fitting for emperors who seek an understanding of Truth and an acquaintance with Reality" (bā niyāz ki $\bar{a}$ '̀n-i pādshāhān-i haqq-shinās wa haqīqat-guzīn ast) (CC, 100). After that, lunch was served, and the emperor took a nap before returning to the ghusl-khāna for another round of attending to imperial business. 
During these afternoon sessions, Chandar Bhan tells us, Shah Jahan used to meet with his principal administrative officers, such as the prime minister (dīwān-i a'lá), the chief army record keepers and paymasters (bak $\underline{k} \operatorname{sh} i y \bar{a} n-i$ ' $i z \bar{a} m$ ), the head of equipment and matériel ( $m \bar{i} r-i$ sāmān), the superintendent of imperial infrastructure (roads, buildings, irrigation, etc.) (dīwān-i buyūtāt), and "all the other accounting officers [mutașaddiyān] responsible for important matters of revenue and land administration" $(C C, 101)$. These officials were expected to submit financial reports on various matters ranging from the general health of the Mughal economy to the details of expenditures from the treasury for military salaries, the account balances with respect to land-tenure assignments (jāgìrs), the inventories of imperial supplies and infrastructure, and so forth. If any bureaucratic or administrative actions required the approval of the emperor, this was the time and place for such requests to be submitted. Meanwhile, Chandar Bhan again stresses the emperor's personal interest in "facilitating the productivity, cultivation, and settlement of the land for the benefit of the common soldiers and peasant-cultivators" $(C C, 101)$.

Having all of his chief economic advisers assembled in one meeting was also, apparently, a good opportunity for the emperor to consider and organize the various types of charitable expenditures that the court routinely doled out. Thus, Chandar Bhan tells us, "the gates of charity and good works [abwāb-i khairāt wa mabarrāt] of this empire remain forever open, so that their blessings may be experienced universally by the world and its inhabitants" $(C C, 101)$. Even so, however, there were particular types of charity on which the court tended to focus its energies. For instance, during particularly holy days and months-Chandar Bhan does not specify of which tradition(s) - the court would make special donations to "men of learning and intellect, masters of piety and virtue, and various classes of darweshes, holy men, and the poor and needy masses of every region," many of which, he adds, were personally "granted audience with the noble and sublime Imperial Presence before having the skirts of their hopes and well-being overflow [dāman-i àmāl wa àmānì rā lab-rez mìsāzand] with the gift of red and white gold" $(C C, 101)$.

One did not have to have direct access to the emperor's person to benefit from the court's philanthropy, however. The emperor was also weighed periodically during the year, for instance in well-known ceremonies on his solar or lunar birthdays, and Chandar Bhan tells us that "the equivalent of the blessed weight was issued from the royal treasury and sent to the provinces for the purposes of charity and the support of the people who were most deserving and needy" (CC, 101-2). He mentions, too, that beyond such cash donations the court also financed various types of public works projects. Thus, in addition to mosques, "schools, Sufi centers, traveler's inns, hospitals [dār al-shifā'], and other useful buildings and structures have been and continue to be built through funding 
from the generous government" $(C C, 102)$. "Specific sums were also designated," he adds, "for the daily support of poorhouses and food kitchens [langar wa ghalül-khanna] in every village and town, the benefit of which was intended to reach the poor, the indigent, widows, and other sheltered women" $(C C, 102)$. Finally, Chandar Bhan notes that in addition to regularly sending large cash donations to the holy sites in Mecca "for offerings and alms" (ba țariq-i nazzr wa khairät), Shah Jahan used to collect and send along some of the "precious rarities of Hindustan" (nafä'is-i hindūstān) as gifts (CC, 102).

As evening approached, the emperor would wind up these afternoon meetings with his financial advisers and then head out from the ghusl-khanna to attend the twilight congregational prayers in the company of some of the 'ulamia, as well as other "learned men" (fuzalā) and notable courtiers. Once again, our Hindu author uses this moment not as an opportunity to express-or even hint at-any reservations about Shah Jahan's piety but rather to laud the emperor's "emotional poise, interior and exterior grace, and utter humility and adherence to the norms of prayer" (jam 'ìyat-i kh hătir wa lațāfat-i bāțin-o-zūhir ba ādāb-o-niyāz-i tāmm). Once the evening congregational prayer services were completed, the impressive sight of thousands of city lights being lit all around the palace and the surrounding neighborhoods would begin, a spectacle so grand, we are told, that "the heavens themselves with all their eyes would be amazed at the sight of it." Meanwhile, the reciters of public prayers (șalawät-khhwānann) turned their attention to reciting lyrical odes and quatrains (ghazal wa $r u b \bar{a}^{\hat{\imath}} \bar{i}$ ) wishing for the continued success of the empire and for the continued "peace and tranquility of the world and its inhabitants, in eloquent language, before pronouncing 'Amen" (CC, 102).

At this stage, Shah Jahan typically retired to the private royal apartments for a predictably sumptuous dinner, during and after which various forms of entertainment were staged. First among these, according to Chandar Bhan, was "the hearing of marvelous tales and interesting anecdotes" (iṣgh $\bar{a}^{\prime}-y i$ hikāyāt-i badì $a$ wa nikāt-i gharība), as well as the reading aloud of selections from "reliable books of history [tawārîkh-i mu'tabar] such as Rauzat al-Ṣafā, Zafar Nāma, Wāqi'āt-i Bāburī, and Akbar Nāma, by eloquent courtiers who were knowledgeable about historical matters" $(C C, 103)$. None of the texts listed here suggest any particular ideological or sectarian predilections on Shah Jahan's part, though a couple of them do provide further evidence of the emperor's keen interest in his Timurid heritage and the legacy of Timurid kingship in Mughal politics. ${ }^{26}$

This sensibility was, moreover, consciously historicist in nature, basing itself on the study of sources that were deemed "reliable" (mu'tabar) and transmitted by courtiers who were "tawāri $\underline{k} \underline{h}-d \bar{a} n$ " - that is, specialized in historical knowledge. One of the texts listed, Mir Khwand's fifteenth-century Rauzat al-Ṣafā (Garden of purity), was an influential Persian history of the "kings, prophets, and caliphs" of the Muslim world that also included the stories of many widely respected figures 
from the Greco-Hellenic and Christian traditions such as Alexander the Great, Kings David and Solomon, and Jesus. ${ }^{27}$ Rauzat al-Ṣafā thus also included abundant discussions of the norms, theory, and practice of kingship, as well as an extended historicist disquisition on the specific benefits-especially for kings-of studying and learning from history generally. Another of the texts on the list, Sharaf al-Din Yazdi's Zafar Nāma (1424-25), was a historical synthesis of the life and times of Shah Jahan's ancestor Timur, drawn from multiple earlier sources. According to the modern historian John Woods, Yazdi's Zafar Nāma "has long been the best-known representative of early Tīmūrid historiography in Persian ... widely acclaimed as a model of elegance and style for historical writing in Iran, Central Asia, and India." ${ }^{28}$

We also cannot fail to note the specific mention here of the memoirs and chronicles from the reigns of Shah Jahan's own immediate Mughal ancestors, Babur and Akbar. In other words, what we have here is an open cultivation of an appreciation for the history of Shah Jahan's dynastic lineage, as well as the precedents, norms, and traditions of Timurid-Mughal kingship more generally-not exactly the curriculum one might expect from an emperor who is thought to have initiated the process of consciously veering away from the Akbari cultural and political dispensation.

The evening's entertainment also usually included "listening to captivating and delightful Kashmiri and Hindi songs until well into the night." These songs were accompanied, according to Chandar Bhan, by a variety of regional musicians, as well as jugglers and "Hindustani dancers" who in their speed and agility, and the deftness of their eye, hand, and footwork, had such an inimitable style that "they appeared more lively than even the wind and the lightning" (teztar as barq-o-bād minumāyand $(C C, 103)$. One suspects, perhaps, that this is yet another passage intended more to impress the audience in the wider Persianate world than, say, the audience in South Asia itself-who would, presumably, have been more than familiar with the sounds and styles of Indian dance. Indeed, Chandar Bhan punctuates his lavish praise of the dancers themselves with a burst of four short couplets that deftly reframes the beauty and grace of the Hindustani musicians' and dancers' art as a metaphor of the greatness of the empire as a whole:

The melodists in the assembly of the King of the World

Carry off with their tunes the sorrows of my heart.

The musicians strike such a chord on the strings

That they animate the very paintings on the wall.

Sing, O minstrel, of how so long as time continues to pass

Shah Jahan will remain the King of Kings of the World.

Bless him with long life,

And a thousand new victories with every refrain. 
[nawā-sāzān-i bazm-i shāh-i 'ālam

barand az dast-i dil rā w'az dil-am gham

zanad z'ān gūna muțrib zaḳhma bar tār

ki dar jumbish dar āyad naqsh-i dīwār

bi-gū muțrib ki tā daur-i zamān ast

shahinshāh-i jahān shāh-i jahān ast

mubārak bād bar wai jāwidāna

hazārān fatḥ-i nau dar har tarāna]

$(C C, 103-4)$

This transition leads Chandar Bhan to return once more to the theme of governance, specifically to the emperor's vigilance about matters of state and public safety even during moments of entertainment and recreation such as the evening performances. "His Blessed Highness is so intent on remaining aware, informed, vigilant, and alert," we are told, "that every incident or event that transpires, at whatever time of day, from morning to night and likewise from night until morning, is reported to him without delay or procrastination, and the emperor gives it the immediate attention of his penetrating intellect." Meanwhile, outside the palace, Chandar Bhan reports that various official cadres of night watchmen, sentinels, police, spies, and other agents of public order guard the city "in front, back, and all around the imperial palace, as well as in every lane and market, throughout the night" $(C C, 104)$. Because of these robust security measures, Chandar Bhan insists:

The people of the city and even the shopkeepers in the bazaars pass the night with the doors to their houses and shops unlocked, free from worry. Throughout the whole city, in all the lanes and markets, there is so much light from the municipal lamps that the darkness of night is transformed practically into the light of day. And in the areas surrounding the palace of celestial foundation there are also the households of so many renowned gentlemen with their own trusted followers, auxiliaries, and devoted subalterns such as mace bearers, servants, slaves, and sons of the house, always armed and prepared to intervene [in any disturbance]. Thus, if there is even so much as an unusually loud noise, it is reported within minutes to the alert ears of the emperor who hears the Truth. $(C C, 104)$

Obviously, Chandar Bhan has a proclivity toward gilding the lily in both style and substance, so one may be forgiven for treating these assertions of an utterly crime- and care-free urban milieu with due skepticism. But the important thing for us to recognize is the larger truth underlying his admittedly somewhat exaggerated characterization of the degree of public safety and order: namely, that the Mughal bureaucracy under Shah Jahan took such matters seriously in the first place and that there was a vast, centrally organized network and hierarchy of urban police set up to maintain law and order. 
Indeed, it may not have been the Weberian ideal of a modern bureaucratic state, but it was clearly far more than the decadent, orthodox, insulated, and aloof court that one continues to find even in twenty-first-century portrayals. Consider, for instance, the recent and much-ballyhooed British Library exhibition catalog (The Lives of the Mughal Emperors, 2012), which tells us, quite matter-of-factly, and without any supporting evidence, that the problem with the post-Akbar court was simply that "alcohol and drugs such as opium were constant temptations for many members of the Mughal dynasty, and there was always the danger of enjoying court life and the harem too much and neglecting state affairs, as was the case with Shah Jahan later in life." ${ }^{29}$ Besides being an unfortunate perpetuation of all the old stereotypes, such characterizations also do little to help us understand basic questions of how most people actually lived, or, in this case, how law and order were actually maintained in a Mughal city like Delhi or Lahore on a day-to-day basis (while the emperor and his circle were so busy "enjoying court life and the harem ... neglecting state affairs"). Chandar Bhan's account may well be short on details, but it nevertheless gives us at least a glimpse of a much more active administrative culture, not to mention the direct involvement of Shah Jahan's court in keeping tabs on such regulatory matters. ${ }^{30}$

At this point, Chandar Bhan's tour through the typical day in the life of the emperor comes to a close, but not before he adds a few more words about Shah Jahan's active interest in administrative matters. Here our munshī is again characteristically effusive, but there is still something to be learned from the specific qualities he praises in the emperor. Once again, there is almost zero discussion of Shah Jahan's martial capabilities, with the emperor's erudition and intellectual talents instead taking center stage. In particular, Chandar Bhan revives his insistence that one of Shah Jahan's chief merits as a ruler was his ability to perform many of the necessary administrative and secretarial tasks on his own, and to do so effectively. This was not mere idle praise. For Chandar Bhan, it was also a matter of optimizing bureaucratic efficiency, something that was possible only with effective management from the top. Thus, he explains:

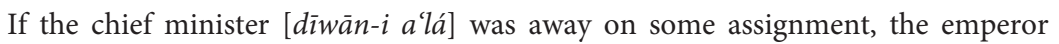
would oversee the business of the wazir's office himself, whether in part or in whole. He would closely review all the invoices and expenses relating to the crown lands with his own penetrating and world-illuminating intellect and would examine the status of accounts relating to the various provinces, districts, cities, towns, villages, and neighborhoods.

Whatever action regarding promotions or increases in expenditure entered the emperor's mind, as boundless as the ocean, on the basis of these audits [tahqi $q$ ], was entered into the official registers. The ledgers and accounts connected with land assignments and cash salaries [jägīr wa naqdī] were also balanced in the emperor's exalted presence, and the drafts of the happy farmāns that were distributed in all directions to various regions of the realm were adorned by his august personal corrections. 
He inspected the requests and petitions from regional ministers and other officials and answered each one himself according to the proper protocols and regulations. $(C C, 104-5)$

Chandar Bhan goes on to explain that the emperor made a point of knowing the manșab rankings of all the important officials in the state apparatus by heart, along with the jāgi $r$ assignments, the length of imperial service, and the time of promotions for many more servants of the court. But even so, as a precaution to avoid mistakes, he made sure that "seasoned clerks were always present with the relevant records."

In other words, when the career administrative officers were away, or otherwise indisposed, Shah Jahan himself would step in and personally oversee the business side of the Mughal imperial enterprise. His skill in such matters, in fact, is probably a large part of what so endeared him to someone like Chandar Bhan. Remember, this is coming from a professional, career civil servant with a lifetime of expertise in Mughal administrative and accounting procedures. He is praising the emperor not for his heroism or manly virtues but rather for the relatively unglamorous-but no less important, in Chandar Bhan's eyes-ability to engage in quotidian administrative and secretarial functions, and to do so competently, so that the bureaucratic machinery could continue operating smoothly even in the absence of a prime minister or other top official.

As evidence of this principle, Chandar Bhan reminds us here of the interim period in 1656, after Sa'd Allah Khan's death but before Mir Jumla could take over as prime minister (discussed in greater detail above, in the previous chapter), during which "all the important commercial and administrative business was reported directly to the blessed royal ear, and he was kept informed of all the details and accounts relating to the boundless empire" $(C C, 105)$. Let us also recall that during that time it was a fellow Hindu administrator, Raghunath Ray-i Rayan, who stepped in to oversee the logistics in the central dīwāni office, answering directly to the emperor himself. Meanwhile Chandar Bhan, who by his own account was working with Raghunath Ray in the dīwānī during those days, was presumably among the many "auditors, financial supervisors, deputies, munshīs, and assessors in the central $d \bar{\imath} w \bar{a} n \bar{\imath}$ ” whose work on "various particulars relating to official matters like the administration of unassigned crown lands [ǩhāliṣa-yi sharifa], imperial salaries, and the apportioning of lands within the realm" was conveyed to the emperor by the ray-i rayan and was personally scrutinized by the former's "alchemical gaze" $(C C, 106)$.

Here again, Chandar Bhan insists that Shah Jahan's agricultural policies were designed not merely to be extractive but to improve productivity, and in so doing also to improve the lives of the cultivating classes (ba rafāhat-i ra'ìyat). Nor were they arbitrary, being based rather on a series of established "rules, regulations, and policies" (zawābiț wa qawā'id wa dastūr al-'amal), some of them 
inherited from previous Mughal administrations and others newly formulated by Shah Jahan and his chief administrators. The officials "in every district and province" were thus under specific imperial orders "to engage in whatever improvements were necessary to facilitate the productivity and satisfaction of the cultivators" (dar ān chi kașrat-i ma'mūrī wa rizāmandī-yi ri'āyā bāshad 'amal numāyand) (CC, 106).

Many such improvements involved upgrades to canals, wells, and other means of irrigation because, Chandar Bhan explains, "despite the vastness of Hindustan, much of the suitable agricultural land is already under cultivation or designated for cultivation after lying fallow" (CC, 106), and thus new production could occur only with successful water management. Finally, he mentions once again in this connection that often the emperor's recreational journeys and hunting trips were really just a ruse, the true purpose of which was to give Shah Jahan an opportunity to observe firsthand the performance of his provincial officials and the circumstances of the peasants and other cultivators in the countryside so that he could take any necessary action to improve their condition or the management of the court's agricultural policy.

Even during periods when the regular administrative chain of command remained intact, Shah Jahan apparently continued to be actively engaged in the running of the empire. Chandar Bhan explains, for instance, that the emperor routinely gave written advice and instructions to the princes with regard to their conduct and their management of the domains for which they were responsible $(C C, 106-7)$. He also consulted routinely with his chief fiscal secretaries and advisers, as we have seen throughout this chapter. Here Chandar Bhan seizes the opportunity to once again extol the emperor's wisdom in various worldly and esoteric domains, repeatedly lauding the "gravity of his thoughts" (matānat-i an-

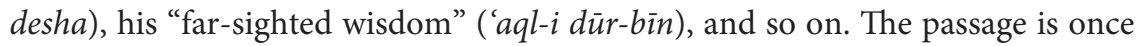
again infused with a Sufi mystical idiom, casting the emperor also as the perfect spiritual guide, and occasionally Chandar Bhan punctuates these observations with verses to that effect. For instance:

His mind is the manifestation of god's light,

The knower of what is black and what is white.

His heart is the lucid mirror of meanings

In which all the hidden secrets are revealed.

[zamīr-ash mazhar-i nūr-i ilāhī

shināsa-yi safedī-o-siyāhī

dil-ash āyīna-yi șāf-i ma'ānī

dar ū paidā hama rāz-i nihānī]

$(C C, 107)$ 
The minds of ordinary knowledgeable people (ahl-i dānish) were no match for the emperor's "otherworldly intellect" (k khäțir-i malakūt), Chandar Bhan continues, because the emperor was "acquainted with the Real" (haqq-shinās); thus, "when he directed his gaze toward ordinary visible things, he endowed the material world of attachments ['älam-i ta'alluq] with the brilliance and color of fresh insight [āb-o-rang-i hikmat-i tāza].” Even wise men "as knowledgeable as Plato" (dānāyān-i aflätūn-manish) were routinely baffled by the emperor's degree of insight and superior intellect, Chandar Bhan insists $(C C, 107)$.

Our munshi does not close this section on Shah Jahan's personality and personal routine, however, without one last dip into the well of praise for the emperor's mastery of the finer points of the secretarial arts. It is almost as if, as an elite secretary himself, Chandar Bhan simply cannot resist the urge to repeatedly impress upon his readers the importance of such skills in the makeup of the complete Mughal gentleman. Thus the emperor's "fine penmanship" (husn-i khatt) and the "boldness of his expressions" (matānat-i 'ibārat) both "light up the eyes of expert calligraphers and scribes, and set the standard for the masters of prose style and diction [inshä'-o-imla']' (CC, 108). The emperor also understood numbers: "Even the pens of expert accountants and record keepers tremble in their hands when exposed to the emperor's nuanced and hair-splitting abilities in the practices of accounting, bookkeeping, and annotation, while their papers shuffle across the lap of ignorance as they confess their comparative ineptitude" $(C C, 108)$.

\section{THE COSMOPOLITAN TRAPPINGS OF SHAH JAHAN'S COURT}

At this point, still only midway through the second chaman of the "Four Gardens," Chandar Bhan begins to expand his gaze outward, from his intense focus on the body and person of the emperor to the wider social and cultural life of the court, and then beyond even the court to the various districts and provinces of the empire as a whole. The section begins with a detailed description of the lavish decorations used to adorn the court and its environs on festival days and other types of public celebrations (dar aiyām-i sharif wa roz-hā-yi jashn). Among these was the famed "jeweled throne" (takht-i murașsa)-later commonly referred to as the "Peacock Throne"- the precious ornamentation of which Chandar Bhan describes in some detail, adding that it cost a gaudy one crore (i.e., 10 million) rupees to produce. This, Chandar Bhan helpfully translates for his audience outside India, was equivalent to "more than 300,000 Iraqi tumans, or 50,000,000 khānīs in Transoxiana," and in a set of verses that accompanies this observation he goes on to boast somewhat improbably that the cost of the throne alone would have exhausted the entire annual budget of rival polities in Iran and Central Asia (kharāj-i kishwar-i ìrān-o-tūrān) (CC, 109). 
Clearly, we have arrived at a portion of the text that was expressly designed to reach - and to impress-cosmopolitan readers in the wider transregional Persianate world. Chandar Bhan goes on to describe in exquisite detail the various types of jewels, precious stones, and inlay work that adorned the decorative canopy (shāmiyāna) above the throne, the surrounding pavilions, the pillars, and even the incense burners. He tells us of the smooth velvets and rich silk fabrics that were used for the Mughal festival tents and the intricate embroidery and brocade work that went into each one. He tells, too, of the gorgeous carpets and luxurious shawls that helped make denizens of the court comfortable and the fragrant scents that perfumed the bodies of the emperor and his courtiers. For their mouths, there were trays of $p \bar{a} n-a$ mouth-freshening Indian delicacy wrapped in a betel-leaf-carefully bound in silk string. For their eyes and ears, there were performances by singers, musicians, and "Mughal, Hindi, and Afghan dancers so colorfully dressed, and with melodies so graceful and voices so enchanting that they would stop a bird in flight, or water in its tracks." These performers were, of course, dutifully and handsomely rewarded for their efforts by the "treasuredispensing emperor" ( $p a \bar{d} d s h a ̄ h-i$ ganj-bakhhsh). And during special occasions like the Persian New Year's festival (nauroz), Chandar Bhan continues, "the usual fun and entertainment reaches another level entirely" ('aish-o-'ishrat rā rawāj-i dìgar mìbäshad) (CC, 110). Chandar Bhan also mentions that in addition to nauroz, various Hindustani festivals were also celebrated at Shah Jahan's court, such as the spring festivals of Basant and Holi, which he refers to as 'ìd-i guläbi.

It would appear, then, Shah Jahan's court regularly celebrated not only "proper" Muslim ceremonial occasions but also various Persian and Indian festivals that were far from orthodox. From our present vantage point, however, perhaps the most interesting thing about Chandar Bhan's descriptions of all these festivities is less the sportive atmosphere than the cosmopolitan perspective implied by the material culture on display during such occasions and the global origins of many of the most valued commodities. During nauroz, for instance, Chandar Bhan specifically mentions that the palace walls were decorated with, among other things, "velvets from Kashan" (makhmal-i kāshānī) and "Gujarati brocades" (țās-i gujarātī) $(C C, 110)$. In the next section of the text, on the various types of luxury commodities one might typically see at Shah Jahan's court, he mentions "rubies from Badakhshan" (la'l-i badakhshān), "Chinese porcelain"

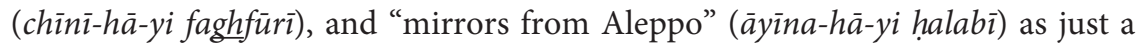
few of the deluxe accouterments of life in the palace originating "from every land and region" of the world $(C C, 111)$. The most highly prized horses were Arabian, with those bred in Iraq and Khurasan fetching prices of "thousands of tumans." But the royal stables also included horses bred in Turkistan and Hindustanwhich, Chandar Bhan insists, "in their build, temperament, stride, and gait are on a par with the horses of Iraq" (CC, 111-12) - as well as colts and mares from other 
parts of India such as Kutch, which was well known for its fine horses, and the breed known as Sunūjīs, which came from western Punjab. ${ }^{31}$

Here, in a charming moment of levity, Chandar Bhan tells us that the finest equine specimens in the royal stables were regularly given affectionate pet names such as "King's Favorite" (pādshāh-pasand), "Super Standard" (tamām 'iyār), "Blessed Victory" (zafar-i mubārak), "World's Sweetheart" (mahbūb-i 'ālam), "White Elephant" (fil-i safed), and the like. This was also true of the many battle elephants "sturdy as mountains and swift as the heavens" (koh-mișal [wa] falakraftār) that were bred for the court and were given names like "World Elephant King" ('ālam gaj rāj), "Splendor of the Universe” (jagat sobha), "Majestic Mountain" (koh-i shukoh), "War Hero" (jang jodha), "Ganesh Incarnate" (ganesh awatār), and so on $(C C, 112) .{ }^{32}$ Chandar Bhan does not tell us the names of any camels, but he does inform us that the court maintained huge populations of particular breeds, such as Boghdis, dromedaries, and Jamazas. There were also plenty of donkeys and other beasts of burden, including "thousands upon thousands of sturdy oxen" pulling "Gujarati chariots" (bahlì-hā-yi gujarātì).

A good deal of Mughal military hardware and matériel was also sourced from all over South Asia and the surrounding regions. Chandar Bhan tells us that "western, southern, and 'Hindi' swords" were all commonly used by Mughal gentlemen and warriors, and he describes the intricate inlay work and other decorations that often adorned their blades, daggers, and other fighting implements. Some of these were produced in official imperial workshops and foundries (kār-khhānas), while others were imported. He specifically mentions "Gujarati arrows" ( $t \bar{i} r-h \bar{a}-y i$ gujarātī) (CC, 111-12), ${ }^{33}$ bows from Central Asia, Lahore, and Multan (kamān-hāyi wilāyatī wa lahorī wa multānì), European spears (neza-hā-yi farangīi), a kind of chain mail known as "Dawudi" (zirih-i dāwudī), and various other types of weaponry.

Like military animals, sometimes these weapons, too, were given amusing nicknames. Swords were called things like "King Akbar" (akbar shāh), "The Blood Spiller" (khiūn-rez), “The Splitter” (do-pāra), and so on. Mughal guns and artillery also commonly had nicknames, such as "The Beast" (dhūrdhānī), "The Hummer" (gung), "The Fort Buster" (qil'a-gushā), "The Enemy Slayer” (dushman-kush), "The Fire Breather" (ätish-dam), and other colorful epithets (CC, 112). These armaments, Chandar Bhan adds, were forged and maintained "under the supervision of artillery specialists from Europe and the Deccan" (ba ihtimān-i top-sāzān-i farangi wa dakhanī) who were specially employed by the Mughal court for that purpose (CC, 113).

Much of this finery and firepower went on full public display during the festival parades and other ceremonial occasions that Chandar Bhan proceeds to describe in the next section. Indeed, if Chandar Bhan is to be believed, massive crowds used to come out to see the imperial processions pass through Delhi and other 
Mughal cities not only on specific festival days but also on days when the court was in transit from one city to another and arrived at a new location with full pomp and éclat. Crews would clear and clean all the boulevards, lanes, and markets beforehand, and then during the processions themselves the streets would be lined with horsemen, mace bearers, and other soldiers. Meanwhile, Chandar Bhan tells us, "Throughout the city people decorated their doors, walls, and shops along the streets and in the bazaars with bright, beautiful, and colorful fabrics," and as the processions themselves passed by, "innumerable throngs of people converged from all over the city and suburbs, congregating on balconies, verandahs, and the rooftops of houses three or four stories high, while in the markets, boulevards, and shops it was as though the whole world had crowded in together" $(C C, 113)$.

The emperor would pass by on his way to the festival grounds (' $\bar{i} d-g \bar{a} h$ ) with his cortège, sometimes mounted on a horse, other times seated atop an elephant, "showering heaps of gold on the fortunate multitudes in every direction" (CC, 114). Following behind the emperor himself would usually be the princes, followed by the upper nobility with their own retinues of attendants, chelas, and other servants, and Chandar Bhan goes into considerable detail about all the decorations, fashions, sights and sounds of such occasions. Often, we are told, all the pomp and circumstance notwithstanding, such processions would end with the emperor himself and his inner circle attending the evening's public congregational prayer services, joining "elite and common alike" (khawāṣs-o-'awāmm) in prostrating themselves "in the place of prayer on the ground of humility to the true Lord of Grandeur” (dar sijda-yi hazrat-i rabb al-'izzat bar jā-yi namāz bar zamīn-i niyāz guzāshta) (CC, 115).

Everyone loves a parade, it would seem, then as now. But this vision of crowds of ordinary people decorating their shops and homes and coming from all over the city and environs just to catch a glimpse of the royal procession is precisely the sort of simple detail from Mughal daily life that is so often left out of most modern historiography. Clearly, if Chandar Bhan is to be believed, there was quite a bit of public interest and enthusiasm for the chance to come out and see the royal family and its entourage pass through the streets of Delhi, to cheer as they passed by, and to bask in the carnivalesque spectacle. These processions, which happened multiple times during the year, served as a way of connecting the court with the wider population and of giving the latter an emotional stake in the splendor and success of the court. Indeed, let us not forget that for most people in early modern Mughal cities the court and its denizens represented not just an abstraction called "the nobility" but also the closest thing they had to socialites and public celebrities. Thus, in addition to the kind of adulation Chandar Bhan describes here, many Mughal elites were also the subject of plenty of salacious gossip that was rampant among common folk in the bazaars, cafes, literary salons, and other pockets of the urban Mughal public sphere-a kind of public fascination with the "lifestyles of 
the Mughal rich and famous," as it were. ${ }^{34}$ As we will see below, Chandar Bhan also paints a vivid portrait of the hustle and bustle of life in such high-traffic urban locales, where the sight of this or that nobleman or courtier out for a stroll would not have been uncommon.

\section{COSMOPOLITANISM ON THE MOVE: \\ THE MOBILE IMPERIAL CAMP}

Meanwhile, when the imperial court was on the move from one city to another, it resembled a giant floating urban space all on its own, creating a vast spectacle and logistical operation to which Chandar Bhan devotes the next three sections of the text. He begins by describing the extensive advance personnel necessary to convey the imperial equipage to the next stage of the journey-quartermasters, water bearers, equipment haulers, and other logistical teams. This advance party would journey ahead to select a suitable spot for the royal encampment, bringing crews with them to fill and patch holes so that the ground would be as level as possible, after which the tents and pavilions of the mobile court were pitched in a configuration similar to the layout of the palaces in Delhi, Lahore, and Agra.

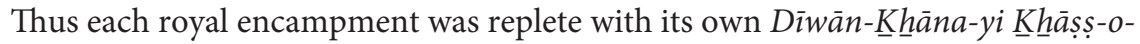
'A $m m$, a set of private royal tents, a privy area meant to serve the same function as the ghusl-khāna, and so on, all of it set up before the imperial retinue even arrived. Some of the tents had built-in windows, and all of those in the royal areas of the camp would have been well appointed with silk carpets and deluxe wall hangings made of fine materials like "Kashani velvet" (maknhmal-i kāshānī), "European satin” (ațlas-i farangī), "chintz from Masulipatnam” (chīnt-i machlì-patan), and other luxurious exotic fabrics $(C C, 115-16)$.

All in all, the tents and other structures of this mobile city were said by Chandar Bhan to take up a space of nearly two square miles (ba tū bar $p \bar{a}$ mishawad), in part because the central area containing the official residences and pavilions of the "court" was surrounded on all sides by several mobile markets ( $b \bar{a} z \bar{a} r-h \bar{a}-y i$ muta'addid) that traveled with the imperial retinue wherever it went, "well stocked with every type of good and every variety of commodity imaginable" $(C C, 116)$. In this, the mobile imperial camp really did resemble an urban settlement, with all sorts of satellite populations and commercial economies constantly traveling with it. There was even a system of urban planning of sorts, whereby the tent residences of the princes and other nobility were laid out according to a specifically designated pattern, according to their official rank, with different flags and banners used to designate each residence "so that each one could be distinguished at a distance."

Meanwhile, Chandar Bhan explains, the elite ladies' tents constituted another entire wing of the encampment, with its own stable of horses and elephants and 
its own community of guards, servants, ladies-in-waiting, and other attendants. These tents were guarded, as was the common practice in the palace as well, by a contingent of eunuchs, who, along with the others, kept the women's area of the camp so secure that "even the morning zephyr could not pass through" without permission $(C C, 116-17)$. Those familiar with the stock imagery of Indo-Persian literature may detect a bit of playfulness here on Chandar Bhan's part, given that the morning breeze, or $b \bar{a} d-i s a b \bar{a}$, which was of course able to come and go freely and discreetly through even the strictest households, was often anthropomorphized by romantic ghazal poets as the ideal courier for conveying desperate messages of love to otherwise inaccessible beloveds. But in this case, our munshi somewhat cheekily turns the classic trope on its head, as if to say: "Don't bother falling for a Mughal princess, because even the morning breeze won't be able to help you get a message to her!”

While the camp was on the move, Chandar Bhan adds, the ladies of the court were further protected by "multiple contingents of Rajputs, so famous for their bravery and loyalty [shujā'at wa ikhlās], who rode alongside the ladies' retinue encircling it like a cordon of iron" $(C C, 117)$. It is yet another reminder that, for all the talk of orthodoxy and a so-called "return to Islamic political culture" at Shah Jahan's court, Hindu bureaucrats like Chandar Bhan and aristocrats like Rajput warriors remained as invested in, and essential to, the imperial enterprise under Shah Jahan as they had ever been and were even routinely trusted with some of the royal house's most sensitive tasks.

We are also reminded, in the very next sentence, that Shah Jahan and his officials were far more attentive to the needs of ordinary subjects than some of the clinical modern analytical terms often used to describe the Mughal political system-its "autocratic centralism," its "patrimonial-bureaucracy," and so oncan possibly hope to capture..$^{35}$ Specifically, Chandar Bhan addresses the issue of the potential inconvenience to local populations that could arise when the imperial camp was passing through their district. Beyond the brute fact of thousands upon thousands of people, animals, carts, wagons, and so forth trampling the ground and taking up space for the actual royal encampment, there was of course the potential for denizens of the imperial camp to misbehave, either directly by treating the locals badly or even indirectly by, for instance, taking fruits and other crops from local orchards and fields. One can imagine how disruptive the royal progress could wind up being for the locals if members of the vast imperial retinue were even slightly undisciplined, much less got out of hand. Shah Jahan and his officials were apparently very mindful of this potential, as Chandar Bhan explains:

Despite such a huge crowd of both nobility and commoners on the move, including the many workers and laborers of the workshops, and all the multitudes and vicissitudes of the camp, there is such a degree of fear and respect for the emperor's authority, as well as dread and awe of his justice, that not a single person [associated 
with the royal retinue] can so much as lay a hand on a piece of fruit or the crops [belonging to the local people], lest he wash his hands of his own life or become his own executioner.

There is also a special corps of officers, ranking men, and troopers designated for protecting the roads and the crops, and on every journey there are specific officials [darogha wa äminn-i pāy-mālì] in charge of making sure the local fields don't get trampled along the way. But if in spite of these policies and precautions it so happens that the people's crops ever get damaged, the officials are authorized to pay compensation to them directly from the royal treasury. $(C C, 117)$

The logistical difficulties of operating such a massive mobile camp were not limited to the land, moreover. While in transit from one city or region to another, or on military campaign, the camp routinely encountered sizable bodies of water that needed to be crossed. There was thus an entire department, Chandar Bhan tells us, for transporting, maintaining, and operating the many portable bridges, rowboats, ferries, and other equipment required to help the camp ford large rivers, or for the use of the emperor for fishing or other pleasure boating. He adds that in some cases royal boats were maintained permanently at major crossings along the more common routes taken by the court $(C C, 118)$.

In short, Chandar Bhan sums up, “The world-traversing camp was like entire city on the move, indeed a whole civilized realm unto itself." There were even whole communities of "tradesmen and artisans for whom the camp's bazaar was like their native country [wațan-i ma'lüfa], a class of people for whom the expression 'a whole house on their shoulders' [k khāna ba-dosh] was coined." Some in these communities, according to Chandar Bhan, lived out much of their lives in the imperial camp and experienced the full range of human existence while on the move:

With their bundles, loads, families, and entire households, they enthusiastically and contentedly pass the time from one stage to the next telling tales and singing songs. Whether in transit or encamped, they marry, get pregnant, and give birth to sons and daughters right there in the exalted camp [urdü-i mu'allá]. They put the children in baskets slung across their shoulders and in this way carry them to the next stage.

And because both divine protection and imperial justice [hifz-i ilāhī wa 'adālat-i shāhinshāhī] extend to all people, despite the immense throngs and multitudes of people [on the move], everyone from a child born yesterday [tifl-i yak roza] to an old man of a hundred years can carry on safely, even from the feet of the horses and elephants. $(C C, 118)$

Even away from the elite royal and noble quarters, Chandar Bhan continues, the entire camp was imbued with a festive atmosphere, constantly humming with the sounds of "musicians, dancers, and jugglers from every region" (mutribān wa raqqāṣān wa bāzīgarān-i har diyār) singing, playing drums, and ringing bells, cre- 
ating a commotion that, when added to the general bustle of people and animals, "could be heard for miles around" (CC, 118).

Not everything about life in the imperial camp was easy. Yet the emperor and his officials appear to have been attentive to some of the potential problems, and they tried to address them through policy. For instance, Chandar Bhan points out that when the imperial caravan had to cross rivers, narrow mountain defiles, or other constrained terrain the press of the crowd was enormous. But there were crews specially assigned to facilitate these crossings, as well as "officers posted at intervals to supervise and make the crossing easier for the people." The crowds at such bottlenecks were such that "people were sometimes held up for two or three days on the side of a river," and in some cases Shah Jahan would even halt the caravan entirely in order to make things easier on the residents of the camp (barā-yi rafähiyat-i mardum) (CC, 118-19). When the imperial camp traveled through mountainous areas like Kashmir and Kabul, it often hired local porters (muzdūr) to help convey the people and equipment through the difficult terrain. "Thousands of such porters were available for hire" in these areas, Chandar Bhan notes, with the "Hindustani porters" (muzdūr-i hindustānī) possessing uncommon strength, "enough even to carry a sick man over the mountains in a harness slung onto their back" (CC, 119).

Children sometimes got lost, too, apparently, amid all the bustle and confusion of so many people on the move. But again, there were officials specifically charged with handling such cases and ensuring that lost children were reunited with their parents. And sometimes things worked out simply because of the kindness of fellow members of the camp population. For instance, Chandar Bhan tells us the following anecdote: "One night a young girl got lost and separated from her poor mother. [Believing her dead,] the distraught mother hired some professional mourners [nauha-kunān] in the camp to sing laments in the daughter's name. One of the men in the camp heard sounds coming from under his tent and realized it was the lost girl, who had fallen under while it was being pitched. He pulled her out and returned her into the arms of her mother, who gave thanks to God and said a prayer for the soul of the emperor as well" $(C C, 119)$.

One can wonder why the emperor would deserve any credit in such a circumstance, but I think that Chandar Bhan's point is that Shah Jahan set a tone of law, order, and civic duty from the top down within the environs of the imperial camp, for which its population was clearly grateful. There were "patrols, sentries, police, and watchmen" ( 'asasān wa chaukīdārān wa jāsūsān wa nažr-bāzān) charged with maintaining order in the camp, facilitating the recovery of lost or stolen property, and returning it to its rightful owners $(C C, 119)$. There was even a kind of motel area specially set up-right next to the royal tents, no less (nazdik-i daulat-khāna-yi wālā)-where "anyone who reached the exalted camp at night after a long day's journey and could not find the accommodations of someone 
familiar to him" could pass the night and "make any necessary inquiries so that he could eventually locate his destination" $(C C, 119)$. These temporary quarters were usually set up directly under a giant torch that went by the Sanskrit name of "ākāsh-divia," or "lamp of the heavens," which Chandar Bhan also helpfully translates for his Persian readers as chirägh-i $\bar{a} s m \bar{a} n$. This appellation will be familiar to many South Asians even today as a common name for the decorative homemade lanterns people use during the annual Diwali festival in order to light the way for Lakshmi, the Hindu goddess of good fortune, to enter their homes. From a Mughal institutional perspective, then, the metaphor and the message are equally striking: even traveling wayfarers and strangers in the night were to be not only accommodated and treated with hospitality but in fact welcomed as potential boons to Mughal society, like the wealth that Goddess Lakshmi showers on her devotees.

Perhaps because of such open access, Chandar Bhan gushes, "even many articles that are unobtainable in some great cities and countries are available in the exalted camp, which is a refuge for all sorts of people and a point of convergence for many of the finer things in the world" $(C C, 119)$. He goes on to list some of the many types of merchants, businessmen, commercial brokers, booksellers, tailors, grocers, artisans, animal trainers, and others who set up shop or otherwise plied their trade right there in the camp, creating "an extraordinary degree of cheapness and variety for every type of commodity" (arzānī wa farāwānī-yi har jins wa har chìz ba martaba-yi a lá mīshawad) (CC, 119-20). In the evenings, the bustle in the camp bazaar picked up even more as the various soldiers and other people finished their daily occupations and went around to do their shopping, or strolled around simply to do some people watching (ba kharīd-o-firosh nishasta wa istāda tamāshā mìkunand). "Everyone was busy with some activity," our munshī reports, "and every shop had a lamp lit in front of it, so that the entire camp and bazaar were lit up." Meanwhile, "there were storytellers, musicians, dancers, and jugglers everywhere, energetically showing off their skills.” And, as in an ordinary city, there were apparently even accommodations for the poor, the needy, and holy men within the camp. As Chandar Bhan explains, "The front of practically every amir's tent was frequented by some faqi r," many of whom resided in special hostels set up at the edges of the camp complex $(C C, 120)$.

\section{URBANITY AND PUBLIC CULTURE IN THE MUGHAL METROPOLIS}

Here Chandar Bhan offers a brief digression regarding the emperor's preferred modes of hunting, and some of the many varieties of game that were commonly hunted at the time, followed by another small excursus on the extraordinary sight of the lighting of lamps around the court pavilions at the end of each day, as well 
as the official firework displays that the court sometimes put on throughout the year $(C C, 120-23)$.

But for our munshi the cosmopolitan exuberance of life in the mobile royal camp was merely a synecdoche for that of the empire as a whole, particularly for the three bustling urban metropolises of Mughal North India: Delhi, Agra, and Lahore. Thus the next major section of Chahär Chaman, a survey of the "various provinces of happy Hindustan" (ta'dād-i șubajāt-i hindūstān-i bahjat-nishān), is unsurprisingly dominated by Chandar Bhan's urban perspective, with nearly twothirds of the overall account being taken up with his entries on these three cities. He begins, however, by laying out the extent of the empire as a whole before moving on to descriptions of specific cities and provinces:

Although the territories and lands of our sovereign imperial king extend from the [eastern] frontier in Bengal all the way [west] to Qandahar, and from Bijapur [in the south] up to Balkh [in the north]; and in every region [zila] there are major provinces [șübajāt-i 'umda], such as

Shahjahanabad, the Abode of the Caliphate [dār al-khiläfat]

Akbarabad, the Dwelling of the Caliphate [mustaqarr al-khiläfat]

Lahore, the Abode of the Sultanate [dār al-saltanat]

Kashmir, the Equal of Paradise [jannat-nazir

Kabul, the Abode of the Realm [dār al-mulk]

Multan, the Abode of Peace [dāral-aman]

Thatta, the Joy-Increasing Province [șüba-yi nishāt-afzāy]

Ajmer, the Abode of Blessing [dār al-barakat]

and Gujarat, the Land of Delight [ $\left.n u z^{\prime} h a t-\bar{a} b \bar{a} d\right]$,

and although there are also the Deccan provinces such as Berar, Daulatabad, Khandes, and Tilangana, as well as

the dominion of Baklana

Malwa, the province of lovely water and weather

Awadh, the cream of plentiful provinces

the broad and spacious district of Allahabad

the excellent province of Bengal

and the pleasant province of Orissa

—each of which contains excellent and prominent cities, qaṣbas, villages, and countless districts [mahäll], not to mention renowned fortresses like Daulatabad, Asir, and various forts of the Deccan, as well as the citadels at Gwalior, Chittor, Kalanjar, Chanadha, Rohtas, Junagarh, and so on, and famous ports like Surat, Lahiri, Khambayat [Cambay], Hughli, and so on; and in each of these regions and cities many splendid buildings and pleasant gardens have been constructed; verse:

The emperor's provinces are beyond count,

For in conquering territory he is the sun;

The mighty steed [burāq] of his power is so fleet of foot

That it needs all of Anatolia and the Levant [rūm-o-shām] just for an

exercise pitch 
-nevertheless, on account of its myriad special charms and features, the Abode of the Caliphate, the capital Shahjahanabad-which has been completed in this eternal and felicitous reign of His Most Exalted Majesty the Emperor, the Ocean of Justice and Benevolence, after whose most celebrated name of names it has received its own name-is beyond description [mustaghnni al-auṣäfast]. As the [famous] couplet [usually attributed to Amir Khusrau (d. 1325), and also inscribed on the walls of the Red Fort's dīwān-i khhāṣṣ] goes:

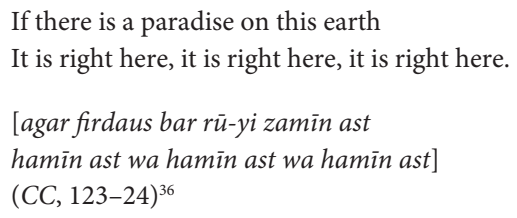

Here once again, one suspects that Chandar Bhan is writing primarily with the wider Persophone audience beyond Hindustan in mind. The listing of Mughal territories, the explanation of the importance of Delhi as the political center of the Mughal world, and the advertisement for Shah Jahan's outstanding power and rule all would have been somewhat superfluous for the core Mughal audience except as an exercise in pure rhetoric. But to readers beyond Hindustan, whether they were in Persia, or Central Asia, or the Deccan, or even someplace further afield in the Indian Ocean world, it would have functioned almost like an inviting guidebook for tourists, entrepreneurs, intellectuals, and other adventurers.

Thus in each section that follows, Chandar Bhan provides his readers with many of the details that a first-time visitor to India in the seventeenth century might find interesting or useful. For the major urban centers like Delhi, Agra, and Lahore, this includes extended descriptions of the cultural life of the markets and bazaars. But he is also very attentive to India's sacred, spiritual, and political geography. For instance, wherever it is relevant he makes sure to list the important Sufi shrines and other spiritual centers that might be of interest to religious pilgrims coming from abroad. He also tends to mention each city or territory's most noteworthy tourist attractions-monuments, public parks, gardens, and the like-many of which were built by, or otherwise connected to, prominent members of the Mughal nobility or even the royal family. Thus, in the process of mentioning each city's most noteworthy sights, Chandar Bhan is also able to construct a cultural memory of the continuity and stability of Mughal rule, as evidenced by a tour through its built environment.

Some examples should make this a bit clearer. Continuing with his description of Shahjahanabad, Chandar Bhan explains that "this great city has two citadels," the first being the "imperial palace of celestial foundation," what is now commonly called the Red Fort. Because of its "impregnability, towering height, and sturdy fortifications," he explains, it was "like a second vault of the heavens"-an observation punctuated with a bit of verse: 
The firmament has spread stars on its battlements

And it is but one step from its pinnacle to the sky;

The heavens circle and spiral all around it

And the sun comes to rest right on its towers on high.

[falak bar kungur-ash aḳhtar fishānda

az ù tā āsmān yak rutba mānda

ba gird-i u falak dar pech-o-tāb ast

ba burj-i ù nuzūl-i äftāb ast]

$(C C, 124)$

For readers who may not know Delhi, Chandar Bhan goes on to explain that the fort is situated alongside the banks of the Jumna river, adding that the palace is really composed of an entire neighborhood complex replete with "handsome, impressive mansions, recreational grounds, and revivifying, enchanting, and pleasant gardens," as well as various waterways, streams, ponds, reservoirs, and fountains, all of which "remind one of paradise" because of the "overwhelming pleasantness and beauty at every step and every spot" $(C C, 124)$. Here again, he resorts to poetry to capture his feelings:

I take such pride in the emperor's palace

From where it is only one step to the sky;

Its lofty nobility transcends the firmament

The sun and moon arise from its threshold;

So much pure gold [tilia -yi nāb] was spent on it

That it couldn't be counted even in a cosmic ledger;

So how could I use mere words to describe its jewels and stones,

Which polish the rust $[z a n g]$ off the mirror of [dejected] hearts?

Every house is like a sublime heaven [firdaus-i barin],

And every building has a paradisiacal garden;

Its avenues are so utterly delightful ['ishrat-sirisht]

You might say they're bylanes off the road to paradise;

Its breezes find their way into your heart,

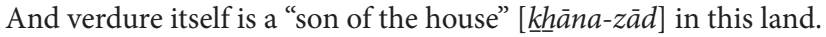

$(C C, 125)$

Note the first-person perspective in these lines. It is Chandar Bhan himself who "takes pride" ( $n \bar{a} z)$ in the city, its rulers, and its architecture. It is he himself who asks, "What sort of words can I use" (chi sān gūyam sukhan) to capture Shahjahanabad's charms. Once again, in other words, it is the eyewitness perspective that animates his narrative.

But perhaps more important, for present purposes, is the cosmopolitan nature of that perspective. Thus Chandar Bhan goes on to describe the bustling multiplicity of the city's commercial life: 
Within this impregnable fort complex [hiṣn-i hașinn], on one side a grand, impressively long covered bazaar has been arranged, containing shops, coffeehouses [ $q a$ -

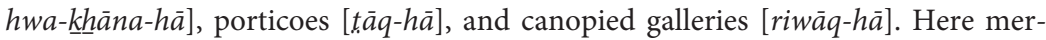
chants [tājirān], traders [saudagarān], impresarios [mutamauwilān], and jewelers [sunār] from every city and region ply their stocks of all manner of colorful merchandise for a comfortable livelihood.

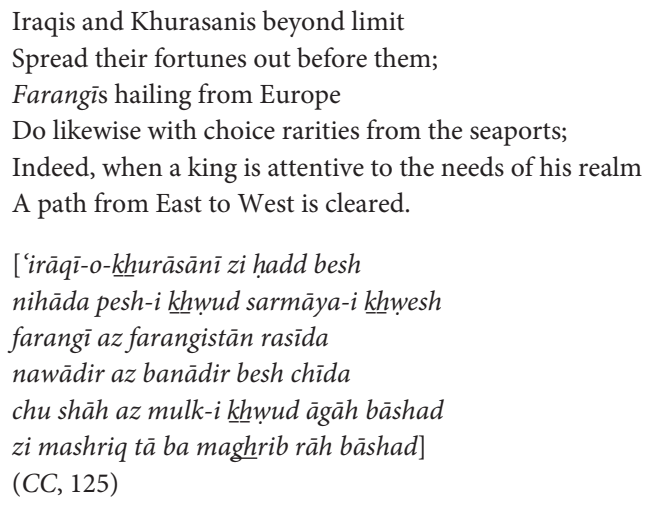

Iraqis, Khurasanis, and Europeans-all are welcome and able to ply their trade because the Mughal emperor is "attentive to the needs of the realm" (az mulk-i khwuud āgāh bāshad). As a result, Chandar Bhan continues, the shops of Delhi "burst with capital, jewels, commodities, silks, and choice rarities from every region," while the streets, bazaars, and specialty markets are all "enriched and adorned by the bustle of people coming and going" $(C C, 125)$.

These public commercial spaces, moreover, were also prime real estate for the city's lively public literary and artistic culture. Thus, Chandar Bhan adds, "On every patch of open space there is some entertainer or performer, and there are ghazal singers, melody makers, storytellers, and expert musicians and revelers sitting and standing all over the place" $(C C, 125)$. Once more, this prompts Chandar Bhan to muse in verse about Delhi's distinctive place in a much grander cosmopolitan metageography, outdoing even great metropolises like Cairo, Herat, and Isfahan in both commercial and literary vitality:

What a city, of which all of Cairo would be just a part

And Herat just a fable in one of its lanes;

It has such architecture and cultivation

That there are a hundred Isfahans in its every alley;

There are so many pearl vendors in every direction, That the seas heave a bereaved sigh of lamentation; At every turn a hundred glittering rubies are strewn As if every shop was a mine of Badakhshan; 
And popping up for your perusal,

The wares of seven continents abound in every shop.

[chi shahrī ān ki Miṣr az ān nishānī

Herāt az kūcha-yi ū dāstānī

ba ma'mūrī-o-ābādì chunān ast

ki dar har kūcha-ash șad Ișfahān ast

nishasta har taraf gauhar-faroshī

bar āwurda zi daryā-hā kh huroshī

fitāda har țaraf șad la'l-i rakhhshān

buwad dar har dukān kān-i Badakhshs̄ān

bar āyad az barā-yi imtih̄̄āì

matā'-i haft kishwar az dukānī]

(CC, 125-26)

This wider cosmopolitan perspective is an undercurrent even in Chandar Bhan's descriptions of Mughal monumentality. For instance, his description of Shahjahanabad's jāma' masjid, or great mosque, begins conventionally enough with praise for the structure's "height so towering that it brushes up against the sky" (ki az ghāayat-i rif'at sar ba falak mìsāyad), its expansive dimensions, soaring porticoes, great domes, and so on- "all with such glorious open-aired spaces," he gushes, "that even the denizens of heaven lower their heads and pray there, while mere mortals will not want to lift their own heads up from prostration." Meanwhile, in those days Delhi's jāma' masjid also had a huge attached public reservoir that was, he tells us, "brimming with pure water and finished with an inlay of marble and red stone in a pattern and design the likes of which have never been seen even by worldly and experienced men" $(C C, 126)$.

Such wonderful architecture did not come cheaply, however, and thus Chandar Bhan goes on to boast that "a total cost of 12 lakh [i.e., 1.2 million] rupees was spent on it by the imperial government" - an eye-popping sum that, he helpfully translates once again for his non-Indian audience, "comes to 40,000 "Iraqi tūmāns, or 60 lakh [i.e., 6 million] Transoxanian khhānīs" $(C C, 126)$. These reflections are punctuated yet again with a few lines of Chandar Bhan's own verse, in which he compares Delhi's grand mosque favorably with, among other things, the iconic Al-Aqsa Mosque in Jerusalem:

Each one of its columns is as high as the sky;

Under its shadow is where the moon and the sun fly.

For people of faith its galleries are the Qibla,

For this is the very equal of the masjid-i aqsá.

Just by entering its courtyard, one gains a special grace

And from its reservoir imbibes the water of paradise.

[ba rif'at āsmān yak pāya-i $\bar{u}$

mah-o-khhwurshed zīr-i sāya-i $\bar{u}$ 
riwāq-ash qibla-i ahl-i yaqīn ast

naziri-i masjid-i aqsá hamīn ast

ba șahn-ash faiz-i dīgar mītuwān yāft

zi ḥauz-ash āb-i kaușar mìtuwān yäft]

$(C C, 126)$

At this point we are treated to an extended dilation on the loveliness of Delhi's

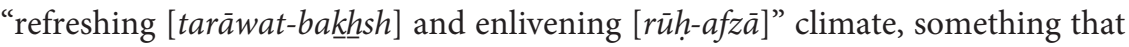
will perhaps come as a surprise to modern residents and visitors to that notoriously scorching city. One might even be tempted to scoff at Chandar Bhan's panegyric to idyllic Delhi weather as pure fantasy, but we should also remember: he was writing not only long before the city's modern population boom and industrial development, when there was much more cooling greenery throughout the city, but also at the height of the so-called "Little Ice Age," when the peak annual temperatures around the early modern world were considerably lower than they are today. Thus, while we may find it difficult to believe that there was ever a summer in Delhi when, as Chandar Bhan insists, "the weather feels so moderate along the bazaars and city streets that there's no need of retreating to a cooled bungalow

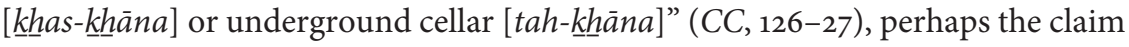
is not so outrageous as it first appears.

He reminds us, too, as he did above during his account of the daily activities of the court, that there was a steady traffic in "plenty of ice and melted snow-water arriving from the mountains" $(C C, 127)$ to help keep Delhi residents cool. The yearly monsoons, he adds, also brought heavy downpours that cooled the city considerably, albeit only seasonally. The monsoons also helped Shahjahanabad's many royal and public gardens to thrive, and Chandar Bhan closes his description of the city with a brief description of A'azzabad Park, one of the most well known such spaces, which was often visited by Emperor Shah Jahan himself, and which, our munshī tells us, "on account of the beauty of its various buildings, its waterways, ponds, and lakes, and its general freshness, verdure, pleasantness, and luscious foliage augments the flower bouquet in the mind's eye of all who appreciate beauty" $(C C, 127)$.

Next up, Chandar Bhan gives us "some particulars regarding the Abode of the Realm, Old Delhi" (kaifiyat-i dàr al-mulk dihli-yi kuhna), by which he means basically the area known today as Nizamuddin, just southeast of India Gate and Khan Market. Though the entire area is one continuous settlement today, for most of the period prior to the construction of British "New Delhi" in the twentieth century there would have been a vast plain separating the Mughal "new Delhi" of Shahjahanabad from "old Delhi" (dihli-yi kuhna) and its surrounding province to the south. And for Chandar Bhan and his contemporaries, "old Delhi" appears to have served mainly as a repository for a certain idealized spiritual and cultural memory. 
Thus he begins by noting the "many gnostics and other holy men ['ārifān wa darweshān] [who] have their final resting place in this area, such as that wise knower of truth, Khwaja Qutb al-Din [Bakhtiyar Kaki], the essence of eminent saints, as well as Shaikh Nizam al-Din Auliya, Shaikh Nasir al-Din 'the Lamp of Delhi' [chirägh-i dehlī], and Shaikh Hamid al-Din Nagauri." ${ }^{77}$ Chandar Bhan also includes among his list of saintly tombs of old Delhi that of the celebrated poet Amir Khusrau (d. 1325) — "the parrot in the rose garden of eloquence," according to our munshī-as well as those of Mulla Hamid bin Fazl Allah Jamali (d. 1535) and that of Shaikh Sharaf al-Din 'Bu 'Ali Qalandar (d. 1324) on the outskirts of Delhi in the suburb of Panipat, which "was permanently ennobled by the eternal presence of Shaikh Sharaf's overflowing munificence" (ba wujūd-i fấ'iz al-jūd-i Shaikh Sharaf sharaf dārad) (CC, 127-28).

Mentioning such spiritual landmarks served not only the esoteric function of including India within the wider sacred geography of the Perso-Islamicate world but also the practical function of alerting potential travelers to India to what they ought to see when they visited particular cities. Indeed, this is not idle speculation on my part. We know, for instance, that major Sufi shrines were often among the first tourist destinations of newly arrived visitors even in early modern India, as, for instance, several of the tombs mentioned here by Chandar Bhan-such as those of Nizam al-Din Auliya, Khwaja Qutbuddin, and a number of others, as well as the nearby tombs of many of the erstwhile Delhi sultans-were all among the first sites visited by Babur upon his conquest of northern India. ${ }^{38}$ We know, too, from other roughly contemporary accounts such as Dargah Quli Khan's early eighteenth-century Muraqqa' $i$ Dihlì (A Delhi scrapbook) that the city's Sufi shrines, in particular, and even those of prominent poets like Khusrau or 'Abd al-Qadir Bedil (1642-1720), were very popular destinations for tourists and pilgrims traveling even within India. ${ }^{39}$ It has recently been proposed that "sightseeing in India" did not begin until the late eighteenth century, but this is clearly not the case. ${ }^{40}$

Of course, the tombs of the Mughal emperors themselves, as well as some of their most celebrated nobles, also in turn emerged as major tourist attractions of early modern India. The most prominent such site in Delhi in Chandar Bhan's day-and even in today's south Delhi-was the tomb of Shah Jahan's great-grandfather, Emperor Humayun:

The ancient buildings of Old Delhi fill the eyes of tourists and sightseers [tamāshāiyān wa nazzāragiyān] with wonder and amazement, particularly the luminescent tomb complex of His Majesty of Celestial Station, Whose Resting Place Is in Eternal Heaven, and Who Is Nestled in the Garden of Paradise, Emperor Humayun, which is also situated in this seat of the region [dār al-mulk].

'Abd al-Rahim Khan-i Khanan and the great military commander Mahabat Khan, who were among the most celebrated nobles of this era, have also laid their heads for eternal sleep in this same patch of land. $(C C, 128)$ 
There is, in other words, the creation of a kind of monumental geography at work here, both sacred and political. If you travel to Delhi, Chandar Bhan seems to be saying, these are the major religious and architectural landmarks you should see. Then, as now, "monuments mattered." ${ }^{41}$ And Chandar Bhan's purpose here seems not simply to produce a handbook for potential tourists but also, by repeatedly alerting us here and in subsequent pages to the final resting places of Shah Jahan's ancestors, to reinforce a culture of appreciation for the Mughal dynastic heritage, using a tour through the built environment of Delhi and other locales as an advertisement for the very genealogical prestige with which we began this chapter.

Also important to our munshī, it would appear, was an appreciation for a kind of administrative institutional memory. Thus he closes his entry on Delhi with a note about the province's geographical borders, along with a list of those who had served as its governor:

Other important districts and counties [chakla-hā wa sarkār-hā] are also associated with this $s \bar{u} b a$, for instance the chakla spanning the $d o-\bar{a} b$ [alluvial plain between the Ganges and Jumna rivers] and the sarkār of Hisar [in modern-day Haryana], which is the epitome of breadth and cultivation, or the chakla of Sirhind, the governance and safekeeping of which were at one time entrusted to Raja Todar Mal, right up to the border with Multan.

Past governors of the șüba of Old Delhi have included Mahabat Khan, I'tiqad Khan, Baqir Khan, Asalat Khan, Allah Wardi Khan, Makramat Khan, Khalil-Allah Khan, and Siyadat Khan.

At present it is the site where the ever-victorious imperial camp is pitched. $(C C, 128)$

The intended audience and exact purpose of this list of the province's former governors are not entirely clear. Without more specific details, especially dates, the list is practically useless as historical "evidence" from the modern scholarly perspective and would require an extensive cross-check of other contemporary archival and administrative records - many of which have not even survivedeven to corroborate its accuracy. Yet it indicates a desire on our munsh $\vec{\imath}$ s part to call attention to the institutional history of the province, even if it is short on specific detail. In fact, he closes his account of each and every subsequent province with a similar list of governors, so it cannot be accidental. Perhaps the explanation is simply that he wanted to include such lists because he could do so. As a career secretary who, as we have seen, spent much of his time working either in the Mughal prime minister's office or directly for the emperor, he would have had easy access to all the ledgers and other records necessary to compile such lists, even if we cannot always do so today. It suggests an implicit self-reflexiveness on Chandar Bhan's part regarding his own role as a maintainer of Mughal administrative records, and thus, too, his role as a bearer of a certain kind of institutional memory. 
Chandar Bhan next tells us about Agra, the "Seat of the Caliphate" (dār alkhiläfat), which had officially been renamed "Akbarabad" in honor of Shah Jahan's grandfather early in the latter's reign. ${ }^{42}$ Agra had been the Mughal capital city for over a hundred years by the time Shah Jahan acceded the throne, except for a relatively brief interlude when Akbar had tried to relocate the court to a newly built "City of Victory" ( fathpür) centered at the nearby village Sikri-a project that was eventually abandoned after barely a dozen years (for reasons that need not detain us here). Thus until the official relocation of the court to Shahjahanabad in 1648, Agra/Akbarabad had been the political and symbolic epicenter of the Mughal Empire practically since its inception, a fact that is reflected in the rich variety of its surviving monuments, gardens, mansions, and other visible reminders of its former heyday (the Taj Mahal being only the most famous example).

For Chandar Bhan, Agra was "among the most important provinces and best places in all of heavenly Hindustan," not least for its impressive architecture and planning. "The towering, sky-scraping buildings of the imperial palace complex ['imārāt-i buland-i falak-farsā-yi daulat-khhānah-i shāhinshāhī]," he tells us, "present a vision of beautiful dwellings, heavenly mansions, and attractive, enchanting locales that is reminiscent of the garden of paradise." Like the Red Fort in Shahjahanabad, the palace at Agra was "situated on the banks of the [Jumna] river," and the surrounding area on both sides of the river was also home to many private mansions and estates owned by members of the royal family and nobility, such as the official residences of various Mughal princes and those of esteemed courtiers like Asaf Khan, Shayista Khan, and other "notable amīrs" (umarā-yi nāmdār) (CC, 128-29).

These residences were not just put up willy-nilly, anywhere there was room to build. As the modern architectural historian Ebba Koch (2008) has shown, there was a specific plan to the Mughals' "riverfront garden city," which was organized mainly around the waterfront of the River Jumna and radiated outward from the central location of the imperial palace-a fact corroborated by Chandar Bhan, who specifically comments that the mansions and hawelis of most of the royal family and nobility were all clustered together and "situated, by design, next to one another along the riverbank" (ba qawā'id-o-tartīb-i tamām yak-dìgar bar kinār-i daryā husn-i anjām wa șūrat-i itmām yāfta) (CC, 129).

As with Delhi, Chandar Bhan also has high praise for Agra's gardens, which he lauds as "earthly vestiges of the celestial garden." He explains that there are "verdant and lush gardens throughout the city" but that among his favorites are the Jahan Ara Garden, the lawns of the Moti Mahal, and especially the Bägh- $i$ $N \bar{u} r-A f \operatorname{sh} \bar{n}$ (the light-scattering garden), which is nowadays referred to as Ram Bagh or Aram Bagh, but which Chandar Bhan refers to as the "Nur Mahal Garden." Of course, the fact that the planning and maintenance of such gardens was an important feature of the Mughal lifestyle is well known, but perhaps not so 
well appreciated is the fact that, as the names of several of these gardens indicate, the design and patronage of a great many of them were financed by the women of the court. The Jahan Ara Garden, named for Shah Jahan's eldest daughter, was actually originally built by her mother, Empress Mumtaz Mahal, though the princess took over responsibility for its maintenance after her mother's death. ${ }^{43}$ And the garden that Chandar Bhan refers to as the "Nur Mahal Garden" and lavishly praises for its "boundless expanse and immeasurable breadth, its freshness, lushness, succulence, and verdure, the beauty of its pavilions, as well as its various ponds, lakes, streams, creeks, and other distinguishing features" $(C C, 129)$ was designed and patronized by Empress Nur Jahan (1577-1645), the wife of Shah Jahan's predecessor Jahangir. ${ }^{44}$

Here Chandar Bhan returns to the theme of dynastic memory, noting that the impressive citadel surrounding the imperial palace complex at Agra was originally built by Emperor Akbar. He also briefly commends the impressive bazaars in the city and surrounding suburbs, which, he says, like those of Delhi, were practically "bursting with gems, jewels, fine merchandise, and all types of rarities that simply boggle the mind of anyone who sees them all displayed" $(C C, 129)$. The mention of all these glistening jewels, apparently, was the perfect transition for him to at last mention the Taj Mahal, the world-famous structure with which Agra is practically synonymous today.

Interestingly enough, particularly for a man who ended up as the caretaker of the complex toward the end of his life, Chandar Bhan has surprisingly little to say about the Taj. About all he tells us is that even though Akbar's tomb is one of the great monuments of the city, "the sacred tomb [maqbara-yi mutahhara] of that Rabi'a of the Age, the Fatima of the Times [i.e., Empress Mumtaz Mahal], completed during this eternal bounteous reign under the supervision of Makramat Khan and Mir 'Abd al-Karim, has an especially mesmerizing quality [kaifiyat-i digar dārad]" (CC, 129). From our present vantage point it may seem quite odd that apart from a brief additional remark about the Taj's cost-so exorbitant, he exclaims, "that it couldn't be matched even by the revenue of some entire countries, or the spoils from some great kingdoms"-this is all that the loquacious Chandar Bhan has to say about the single most famous architectural landmark of Mughal India. But one also has to remember, when the Taj was originally built it was, however distinctive and "mesmerizing," only one among many extraordinary structures all clustered together as part of a continuous monumental, urban, and garden landscape. As Koch points out, "No individual or prominent site was chosen for the Taj Mahal"; rather, it was simply "integrated into the riverfront scheme" in the nucleus of the planned cityscape. Perhaps, then, in its original built environment it did not stand out as much as it appears to nowadays, when so many of the impressive structures that originally would have surrounded it are no longer standing. Meanwhile, the true focal point of the city was meant to be the 
overall plan itself, radiating out from the palace and the surrounding gardens as a microcosm meant "[to reflect] the concept of the garden as primordial residence of the Mughal dynasty, and in a wider ideological sense [to serve] as a symbol of the bloom of Hindustan under the just rule of Shah Jahan." 45

Another important symbol of the justness and liberality of Mughal rulers was the patronage, protection, and devotion they offered to various Sufi orders and other mystical religious institutions. Among the most prominent of these were the community of Sufis centered on the shrine of the celebrated saint Salim Chishti (1478-1572) in the nearby town of Sikri, which, as Chandar Bhan notes, fell within Agra's provincial boundaries. As many readers will recall, it was from Salim Chishti that Akbar sought counsel early in his reign when he had yet to produce a male heir; thus, when the long-awaited son (who would later become Emperor Jahangir) was born, he named him Salim, after the saint, and decided moreover to build his new capital (the aforementioned Fathpur Sikri) in the saint's village in order to increase the court's physical proximity to this auspicious site.

Chandar Bhan does not get into all these details, perhaps because he assumed that contemporary readers would already be familiar with the site's historical and religio-political significance, but also, as I mentioned above, because by Shah Jahan's time the new capital at Fathpur Sikri had in any case long since been abandoned as an expensive boondoggle. Our munshi does, however, take special note of the Sufi complex in Sikri, reminding his readers that

emperors of great stature like their majesties 'Arsh-Āshiyānī [Akbar] and JannatMakānī [Jahangir], as well as His Majesty the Second Lord of the Celestial Conjunction [Shah Jahan], have traveled many times to that firm house of goodly foundation [buq'a-i mustahkam-i knhair-asās] to demonstrate their devotion.

In the town itself and the surrounding villages there are many mystics, religious figures, free spirits, hermits, Sufis, and clerics [darweshān wa dìn-dārān wa àzādagān wa gosha-nishīnān wa șūfiyān wa zāhidān] busily engaged in their devotion and spiritual exercises. There are also many local literati and intellectuals [fuzalā wa 'ulamā] busy spending their time practicing teaching and learning. $(C C, 129-30)$

Again, this was not just a way of touting the Mughal dynastic practice of protecting Sufi mystical communities-a practice that continued under Shah Jahan-but also of advertising points of interest within India's larger cultural and sacred geography that might be of interest to curious readers in the wider Persophone world, both within and beyond Hindustan. After briefly noting that "the famously impregnable fortress of Gwalior" fell within the same administrative province, Chandar Bhan closes his description of Agra/ Akbarabad with a list of former governors and officials similar to the one he provided for Delhi-one of whom, a certain Girdhar Das, may well have been 
the kāyastha of the same name who had translated the Ramāyanā into Persian in 1626-27, toward the end of Jahangir's reign.

Chandar Bhan then turns his attention to his native city of Lahore, in his estimation "among the grandest and most magnificent cities in all of Hindustan." Many of the themes that characterize his descriptions of Delhi and Agra recur here, as he takes us on a tour through Lahore's architectural landmarks, its commercial and intellectual culture, its gardens, and its sacred geography. He praises the delightfulness of Lahore's weather (latāafat-i $\bar{a} b$-o-hawā), and, along with the obligatory adulation for the city's impressive palace architecture, mentions a number of the grand estates and mansions of members of the extended royal family and the nobility that "all add to the beauty of this city that is the peer of paradise." As in the case of Agra, there was an organized plan to Lahore's layout in Chandar Bhan's day, for he explains that "the houses of the people, from the lowest up to the most noble, were arranged in proximity to one another by design, in accordance with each individual's taste and status" ( $\underline{k} h \bar{a} n a-h \bar{a}-y i$ ahl-i shahr az

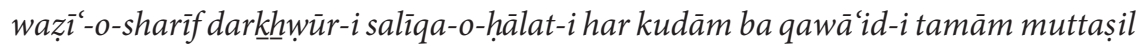
ba-ham tartīb yāfta) (CC, 131). Among these, Asaf Khan's estate was especially grand according to our author, "like another city within the city, a description of which completely exceeds the limitations of writing." He tells his readers, too, that "this feeble ant, the author of these artful pages, also maintains a residence in this city" (CC, 133), and elsewhere he praises a number of Lahore's marvelous gardens, with their fabulous flora, waterways, ponds, and reservoirs, all of which also "lend freshness to the garden of men's hearts" (CC, 130-31).

But perhaps the most memorable portions of Chandar Bhan's discussion of Lahore are those that deal with the city's mystical and literary culture. The city "has an inner beauty that exceeds even its superficial beauty" (husn-i ma'nī ziyāda az husn-i șurat dārad), he explains, largely because of the abundance of "deeply learned scholars ['ulamā'-yi mutabahhir], erudite intellectuals, masters of asceticism and self-control, men of ecstasy and spiritual transcendence, mystics acquainted with truth, hermits seeking the basis of Reality, pure-hearted Sufis, and free-spirited recluses, [who] all lend an added flair to this city of bounteous foundation." Meanwhile, according to our resident munshī and poet, Lahore had a plentiful supply of "poets of exquisite language and sweet expression [who] heat up the bustling literary scene in every corner and every direction with the gift of scintillating and exciting meanings." Even the young literati of this eminently literary city were top-notch, Chandar Bhan explains with a bit of playful punning: "Even precocious youths and adolescents, faces marked by new lines [ $k \underline{h} a t t]$ [of facial hair], practice their [calligraphic] lines [ $k$ hatt] and recitations, doing able justice to [the standards of] graceful and elegant penmanship, and to the smooth flowing of literary expression [salāsat-i rawānī-yi sukhan ]" $(C C, 131)$. 
Chandar Bhan's tour through Lahore reminds us, too, of the degree to which Indo-Persian mystical and literary cultures were inextricably intertwined, often even sharing the same physical space within the urban landscape. Thus, for instance, he describes the hubbub of the public culture in the vicinity of two of Lahore's most famous spiritual landmarks, the tomb of the eleventhcentury saint Pir 'Ali Hujwiri and the eponymous Wazir Khan mosque, built in $1634-35$ by the widely admired Mughal physician and governor of Lahore under Shah Jahan:

Even though there are yearly and monthly impromptu performances throughout the city's precincts, especially at the tombs and shrines of the giants along the path of esoteric Truth [buzurgān-i rāh-i haqiqqat], the Thursday gatherings at the blessed tomb of that knower of mystical stages, Pir 'Ali Hujwiri, create an especially remarkable commotion. Darvishes and other free spirits, literati, poets, and all manner of people gather there to observe the spectacle of Divine Creation.

Then on Fridays the masters of literary perfection, eloquent men of pleasing expression, and poets of linguistic delectation, group after group of eloquents from Iran, Turan, and Hindustan gather in that house of firm foundation [buq'a-i khairasās], the Wazir Khan mosque complex-one of the most exemplary buildings in the world-and heat up the literary and poetic action.

Meanwhile, countless Persian and Arabic books, and manuscripts of reliable histories, epic romances, dīwāns of the classical and the latest poets [mutaqaddimin$o-m u t a ' a ̄ k \underline{k} \underline{k} \underline{h} i \bar{i} \bar{n}]$, letter collections [munsha'ät], anthologies [fiqrāt], epistolary primers [ruq'a $t$ t], biographies, chapbooks, samples of the calligraphers of the times, and all the other tools and equipment for practicing every genre and course of study are widely available for sale or purchase in this wonderful place.

And, since this is also the day when schoolchildren have the most free time, from every street and lane young boys with notebooks in hand and flowers in their hair [bayāz dar dast wa gul bar sar] come strutting around the bazaar [khhirāmān ba sair- $i$ $b \bar{a} z \bar{a} r m \bar{i}-\bar{a} y a n d]$, in keeping with ways of youth. This bustle of activity continues until well after midday and is a delight to the eyes of all the urbane onlookers [arbā $b-i$ bașîrat $]$. (CC, 132-33)

These observations, perhaps especially the mention of the poets "from Iran, Turan, and Hindustan," remind us that Lahore was yet another cosmopolitan Mughal city, with people and populations from all over the surrounding regions participating in its vibrant commercial and cultural life. Indeed, for centuries Lahore had been the main urban contact zone at the frontier of South, Central, and West Asia, with the traffic in people and goods flowing in from all three directions. In fact, in terms of its Persianate literary culture Lahore and its surrounding area could arguably boast a tradition even older than that of Delhi, dating back at least to the eleventh-century heyday of medieval Ghaznawid frontier poets like Mas'ud Sa'd Salman and Abu al-Faraj Runi, not to mention Pir 'Ali b. Usman Hujwiri (d. after 1089), the Sufi saint whose shrine Chandar Bhan mentions here, 
and who authored perhaps the earliest prose treatise on Sufism ever written in Persian, the famed Kashf al-Mahjüb (Revelation of the veiled). ${ }^{46}$

Chandar Bhan gives some inkling of this kinetic frontier atmosphere when he describes the city walls and gates. Lahore's citadel, he explains, "has twelve gates, the first of which is the 'Roshana'i Gate' located near the palace, and it is precisely because of this association that it has gotten this name, the 'Gate of Light."' This northern gate, he adds, was "the main entry point to the city for sojourners from places like Qandahar, Kabul, and Kashmir." Meanwhile, "the most famous of the city's entry points" was the so-called "Delhi Gate," which was situated on the eastern side of the walled city and thus served as a convenient entry point for the heavy commercial traffic to Lahore from other parts of India like "Bengal, Orissa, Bihar, Gujarat, the Deccan, Akbarabad, and many other cities and towns" $(C C, 133)$.

Here in a side note Chandar Bhan adds that Kangra Fort, which was "among the most celebrated fortifications in Hindustan," and which is nowadays located in the mountainous modern Indian state of Himachal Pradesh (about 250 kilometers east of Lahore, as the crow flies), actually fell under the administrative jurisdiction of Lahore province during his own time. But this was noteworthy not so much because of the fort itself as because the Kangra district was also home to the popular Hindu temple of Jwalamukhi, to which, Chandar Bhan explains, "it is a custom that every year people from all over India flock for pilgrimage" $(C C, 133)$.

At this point in the text, after listing seventeen of Lahore's former governors, Chandar Bhan offers an extended digression about Shah Jahan's connection to a number of prominent Sufi saints of the time. The most important of these, as those familiar with the history of the period will know, was the celebrated mystic of the Qadiri order known as Miyan Mir (ca. 1531-1635), to whose "isolated corner of reclusiveness and liberation" (zāwiya-i kh humūl wa àzādī) Shah Jahan directed the imperial camp while en route from Kashmir to Punjab so that the two could hold "spiritual discussions" (șuhbat-i rūhānn̄). ${ }^{47}$ Chandar Bhan notes the spiritual depth of their conversations, describing Shah Jahan and Miyan Mir as "two great masters of form and meaning," one of whom "bangs the drum of the Shadow of God" (kos-i zill-i ilāhi nawākhta) while the other "raises knowledge of devotion to its acme" ( $i l m-i$ 'ibādat bar afrāshta). He adds that it was "around the same time" that the emperor visited the knhānqāh of another "ocean-hearted pīr, Shaikh Bala'ul [d. 1636-37], with whom he discussed numerous matters of gnosis and esoteric meaning" $(C C, 134) \cdot \cdot^{8}$

Meanwhile, on another occasion, "in heavenly Kashmir that great knower of mystical Truths, Mulla Shah, visited the assembly of the emperor-who is himself acquainted with Truth and is a friend to holy men-where they held a vibrant discussion" (CC, 134). Mulla Shah (d. 1661), another prominent Sufi of the Qadiri order, was Miyan Mir's most celebrated disciple, and in modern historiography the 
two saints are most often associated with Prince Dara Shukoh. ${ }^{49}$ But as Chandar Bhan reminds us, Shah Jahan also had an important relationship with both Miyan Mir and Mulla Shah. In fact, it was Shah Jahan who introduced Prince Dara to these Qadiri saints in the first place, a fact that routinely goes unacknowledged in modern scholarship..$^{50}$ Shah Jahan also provided the home in Lahore to which Mulla Shah retired, not long before the saint died, which gives some inkling as to the lasting nature of their relationship..$^{51}$

Chandar Bhan notes, too, that it was not just the emperor himself who made a habit of consulting with spiritual and mystical adepts but also his officials. Thus he tells us of an occasion when the wazir Sa'd Allah Khan sought and received permission to leave the imperial presence while en route to Kabul so that he could visit a darwesh named Shaikh Muhammad Sharif Rasa'i. Chandar Bhan adds that "despite the fact that on one side there was a pinnacle of erudition, and on the other side the height of asceticism, their conversation was very down-to-earth [șuhbat-i bì-gharazāna wāqi'shud].” A short time later, in Kabul itself, Sa'd Allah Khan also took a tour of a nearby village called Manji, "which was ablaze with arghawān blossoms, and where he met with a local darwesh named Sayyid 'Alam" $(C C, 134)$.

By way of a concluding thought on this relationship between Shah Jahan's court and the prominent Sufi saints of the era, Chandar Bhan explains that the patronage and protection of holy men was an essential feature of good kingship-and thus, "because of their lofty natures, all great and glorious emperors have had an affinity for the company of holy men acquainted with Truth [șuhbat- $i$ darweshān-i haqq-shinās], the trappings of empire and the state notwithstanding [bā wujūd-i asbāb-i daulat-o-jahāndārī]" (CC, 134). In other words, Shah Jahan's good relationship with the mystical personalities of his time was not simply a matter of the emperor's own personal spiritual well-being, it was a crucial index of the well-being of the state and the realm as a whole.

"Such masters of renunciation," Chandar Bhan adds, "turn up for most of the festivals and assemblies at court and contribute to the grand audience by holding spiritual discussions." Shah Jahan himself, "a friend to all holy men," apparently became particularly fond of conversing with "a man at an advanced stage of Truth named Khwaja Jawid Mahmud, who hailed from charming Kashmir and was given a seat right next to the imperial throne." Another Sufi saint named Shaikh Nazir, "the details of whose career are beyond description," was, according to our munshi, "a fixture at the palace both day and night." Chandar Bhan notes that Shah Jahan was particularly fond of another figure named Khwaja 'Abd al-Razzaq, "whose material position was that of a Hindustani ahadi [a freelance soldier in the emperor's personal security detail] but who in fact trod the path of [mystical] precedents [ba-țariq-i salaf mī-guzarānīd].” And he mentions three other figures by name-one Mir 'Arif, one Mir Fakhr al-Din, and 
Sayyid Muhammad Qanauji-all of whom were treated as "honored and revered guests" of the court and who held dialogues with the emperor, "who knows all the finer points of intellectual matters" $(C C, 134-35) .^{52}$

"Indeed," Chandar Bhan concludes, "elite shaikhs who had achieved a level of divine friendship were constantly arriving at the sublime mahfil, where they were the featured members of the assembly" $(C C, 135)$. But they were also important cornerstones of the South Asian spiritual landscape writ large, as we will see in the next and final section of this chapter.

\section{THE CONCEPTUAL HORIZONS OF THE REALM}

As our author returns his attention to the various provinces of the realm, there is a repeated emphasis on the noteworthy population of saintly figures associated with each locality. The province surrounding the city of Multan, for instance, is described by Chandar Bhan as "one of the most blessed ancient locales in the world," thanks in large part to the "many great men, gnostics, and mystics acquainted with Truth [who] have been laid to rest in that land, such as that 'ārif acquainted with God, Shaikh Baha' al-Din Zakariya [ca. 1182-1262], Shaikh Sadr al-Din ['Arif] [d. 1286], and Shaikh Rukn-i 'Alam [aka Rukn alDin]." ${ }_{53}$ Among the other notable saints from Multan, Chandar Bhan specifically mentions Sayyid Yusuf Gardezi, Shaikh Jalal Khoka, and Bibi Rasti. But he reserves special reverence for "the refulgent mausoleum of that treader on the path of Truth and gnosis, Shaikh Farid [al-Din] Ganj-i Shakkar" (d. 1265), which, Chandar Bhan reminds his readers, "is located in the local qașba of Pattan." ${ }^{54}$ Meanwhile, he notes that in the nearby town of Ucch "the great spiritual master [maknhdūm] Shaikh Jalal Makhdum-i Jahaniyan [1308-84] and several other great men" $(C C, 135)$ are also buried.55

We cannot possibly delve into the biographies and spiritual careers of all the many saints whom Chandar Bhan mentions here and in subsequent pages, which would probably require another entire chapter, maybe even a whole book. (I have tried to direct the interested reader to basic information and resources in the footnotes.) The important point for present purposes, however, is not so much the details of the individual Sufis themselves but rather the fact that Chandar Bhan is so particular about mentioning them at all. Remember, our author proudly self-identifies as a high-caste Hindu; his deep familiarity with the spiritual landscape and personalities of Sufi Islam is thus, in itself, fairly noteworthy. But it also speaks to the larger question of the continuing salience of the "mystical dimensions of Islam," in Annemarie Schimmel's famous formulation, for Mughal ideology generally and for the Mughals' understanding of political Islam in the post-Akbar period. Over and over again, Chandar Bhan emphasizes that in the grand cosmic scheme of things power and renunciation go hand in hand, and 
that kings, including Shah Jahan, are great only to the extent that they afford protection to the poor, the weak, and the vessels of spirituality-even esoteric and unorthodox spirituality-in their dominions. The king's quest for worldly power was, of course, always in tension with the mystical ideal of spiritual renunciation. But this is precisely why Shah Jahan and his officials placed so much emphasis on promoting, surrounding themselves with, and seeking the counsel of a broad cross section of India's mystical population.

Chandar Bhan closes his entry on the șüba of Multan with a brief mention of its excellent irrigation system, along with, as usual, a list of its recent and former governors-which in this case included two princes of the royal house: "the illustrious prince Sultan Murad Bakhsh" as well as "the great, famous, successful and victorious prince Muhammad Aurangzeb Bahadur" (CC, 135).

Next up is Kashmir, "the equivalent of paradise," the gorgeous scenery and pleasant environs of which made it, in Chandar Bhan's words, "the ruler of all the gardens in the land of Hindustan" (dar mamālik-i hindūstān hukm-i bāgh därad). He does acknowledge that Kashmir's "steep mountains and peaks that brush the sky, around which even the bird of the imagination could not possibly wrap the wings of desire," made the journey there extremely arduous. But this, in a sense, is precisely what made the enjoyment of Kashmir's delights so rewarding, "rubbing away the rust of melancholy from the mirror of hearts" (zang az a'ina-i dil$h \bar{a}$ mìbarad). Kashmir was-and remains-also famously home to many scenic valleys, lush gardens, and lakes and ponds on many of which one could, even in Mughal times, enjoy boat and gondola rides. And, in keeping with the theme we have just discussed, Chandar Bhan explains that "many mystics and other liberated souls have emerged from this region," drawing our attention in particular to the khānqāh of "that soaring falcon of gnosis" (shāhbāz-i auj-i ma'rifat), Mir Sayyid 'Ali Hamadani (1314-84), a renowned fourteenth-century saint of the Kubrawi Sufi order $(C C, 136)$.

The province of Kabul, too, is praised by Chandar Bhan for its lovely climate and scenery, as well as for the fact that "every house there has running water, abundant fruit, and colorful flowers." He points out that strategically speaking it is "among the most important" șübas in the empire, whose boundaries stretch "from the River Atak [aka "Attock"] to the Hindu Kush Mountains, which form the frontier with Hindustan, and which [are so high that they] present a tremendous challenge even for birds to cross" $(C C, 137)$. Careful readers will note that these boundaries bear no relationship to the modern nation-state of Afghanistan, straddling as they do the modern boundary between that country and Pakistan. Be that as it may, for Chandar Bhan the important thing is that Kabul served as a crucial buffer between Mughal South Asia and the empires of the Uzbeks and other Central Asian rivals to the north. It could also serve, as we saw in the previous chapter, as the key staging ground for Mughal campaigns in the opposite direction, in particular the 
campaigns in Balkh and Badakhshan in the 1640s. Thus, Chandar Bhan explains in his list of governors, it was important that "many sword-wielding imperial servants-Mughals, sayyids, Afghans, and Rajputs-have all been stationed in this șüba." Moreover, he explains, Kabul represented a hugely important symbolic site in the sacred geography of Mughal dynastic heritage, given that the founder of the empire, "His Majesty Whose Dwelling Is in Heaven, Emperor Babur, has also been laid to rest in this same blessed land" $(C C, 137) .{ }^{56}$

The nexus between Mughal commercial, literary, and mystical cultures also figures in Chandar Bhan's next two geographical entries, on Thatta (Sindh) and Ahmedabad (Gujarat). Often overshadowed by some of the more famous ports down the western coast of India, such as Bombay, Goa, Calicut, Mangalore, and especially Surat, the coastal Sindhi city of Thatta and its associated port of Lahiri have nevertheless served as a major entrepôt in the vigorous triangular trade between the Middle East, Central Asia, and India since antiquity. Situated just inland off the Arabian "salt sea" (daryā- $i$ shor) at the mouth of the Indus river delta, Thatta was ideally suited to commercial exchange of all kinds. But in addition to this bustling commercial atmosphere, or perhaps indeed because of it, Thatta was also, in Chandar Bhan's words, well known for being "a place where all manner of faqirs, free spirits, literati, and other intellectuals made their entry [into the subcontinent]" (mahal-i wurūd-o-nuzūl-i fuqarā'-o-āzādagān, wa makān-i zuhūr-i fuzalā-o-fuṣahā ast) (CC, 137-38).

Similarly Ahmedabad-which in Mughal parlance meant the entire region of Gujarat-is described by Chandar Bhan as being "among the most important provinces in Hindustan," in large part because it was home to "world-famous ports like Surat, Khambayat [Cambay], and Bahruch.” As a result of this status as a cosmopolitan contact zone between India and the larger Indian Ocean world, Gujarat was, in Chandar Bhan's view, not only "a mine of rarities from around the world" but also "an area from which many great mystics and holy men have hailed” (CC, 138). In particular Chandar Bhan mentions Shaikh Ahmed Khattu (1336-1445) and Shah 'Alam Bukhari (1414-76), both of whose shrines remain important sites of religious activity and pilgrimage to this day. ${ }^{57}$

We can see that after beginning with the three urban capitals at the core of the Mughal realm, Chandar Bhan starts tracing a circle of Mughal dominion around South Asia. First he made his way northwest via Multan and Kashmir all the way up to Kabul, and now he is working his way back down the western coast of India, whence he will eventually circle all the way back around.

Thus, continuing down the western coast from Gujarat, the next entry is on the Deccan, the large swath of territory south of the Vindhya Mountains that stretched across the subcontinent from coastal Maharashtra on the Indian Ocean side to Golconda (modern Andhra Pradesh and Telangana) on the Bay of Bengal side. Though the entire Deccan was considered a single province from the 
Mughals' administrative point of view, they were of course well aware that this "vast territory" (mamlakat-i wasī), as Chandar Bhan describes it, actually comprised numerous subregions and political formations, all vying both with each other and with the Mughals for control of the lucrative coastal trading zones and fertile agricultural plains in the interior hinterlands of the plateau. Among these, the centrally situated city of Burhanpur (at the southern edge of the modern state of Madhya Pradesh), which had long served as an important staging area for Mughal campaigns further south, is described by Chandar Bhan as "the seat of power for the entire region" (häkim-nishīn-i ān mulk ast), while other areas like Khandes, Birar, Ahmadnagar, Daulatabad, and Telangana were, according to our author, "among the important șübas of that frontier region" (șübajāt-i 'umda ba àn marzubūm) (CC, 138).

Chandar Bhan gives a few snippets of Mughal political history in the region, particularly pertaining to Mughal relations with the Qutb Shahi sultans of Golconda and the 'Adil Shahi sultans of Bijapur. He also lists the series of Mughal viceroys in the Deccan, among whom the most notable were two of Shah Jahan's own sons- "His Highness Prince Sultan Murad Bakhsh," and then later "the renowned and successful prince, the Subduer of the World and Conqueror of the Universe, Muhammad Aurangzeb Bahadur" $(C C, 139)$. Chandar Bhan also draws his readers' attention to the "many great and famous forts located in this territory." Among these were "two of the most celebrated citadels in all of Hindustan"namely, Daulatabad Fort, the Nizam Shahi capital subdued by Shah Jahan's forces in 1633, "which is among the fresh conquests [futūhāt-i tāza] of this perpetual empire"; and Asir Fort, just north of Burhanpur, which Chandar Bhan explains "was conquered during the reign of His Majesty Whose Nest Is Now in Heaven, Emperor Akbar" $(C C, 139)$. Again, Mughal dynastic memory is given a featured place in the landscape of Chandar Bhan's geographical imagination. So too, again, the sacred geography of Sufism enters into the picture, as he closes his account of the Deccan by reminding his readers that "many great spiritual leaders and mystics are also laid to rest there, such as Sayyid Muhammad Gisu Daraz, Shah Zain al-Din, and Shah Burhan al-Din" (CC, 139).

The remaining entries in Chandar Bhan's geographical tour of the empire are, for the most part, quite brief. Regarding Malwa, for instance, besides the list of that province's Mughal governors, and a list of important cities such as Ujjain, Saronj, Sarangpur, and Chanderi, he does not have much to add other than to extol the architecture of Mandu, "the length and breadth of whose fort cannot be captured by a mere written description" (CC, 139-40). We may recall, of course, that many of the structures in Mandu's fort complex had been renovated in Emperor Jahangir's time by none other than Chandar Bhan's own first employer, the architect Mir 'Abd al-Karim. ${ }^{58}$ But Chandar Bhan himself does not deem it necessary to mention it here, for whatever reason. 
The entry on Ajmer, meanwhile, focuses primarily on its political and spiritual significance. It is "among the most exquisite provinces in all of Hindustan," Chandar Bhan tells us, adding that "it is the homeland of various Rajput clans, ranas, raos, and rajas." But the province's luster did not rest solely upon its importance as the native land of certain Hindu chieftains who were among the Mughals' most crucial military and strategic allies. It also "garnered added prestige" because it was home to "the beneficent shrine of that Pillar of Spiritual Pillars, the Revealer of Secrets, Khwaja Mu'in al-Din Chishti" $(C C, 140)$. Here Chandar Bhan is referring to the dargāh, or shrine complex, of the celebrated medieval Sufi saint Mu'in al-Din Chishti (d. 1236), a site of immense significance in the spiritual and mystical geography of South Asia generally, of course, but also, in particular, for the Mughal dynasty, which had very close ties to the keepers of the shrine complex. ${ }^{59}$

Thus Chandar Bhan's consistently twinned themes of Mughal dynastic memory and South Asian sacred geography converge here as he explains that "exalted emperors like His Majesty of Celestial Station 'Arsh-Āshiyāni [Akbar], His Majesty Jannat-Makānī [Jahangir], and His Majesty the Second Lord of the Celestial Conjunction [Shah Jahan] have all repeatedly betaken themselves to that auspicious abode" (CC, 140). Meanwhile, we learn from at least one other source that after he had outmaneuvered his brothers in the struggle to succeed Shah Jahan, among the first orders of business for the newly crowned emperor Aurangzeb "Alamgir was a visit to the Chishti shrine at Ajmer, "where he bestowed offerings of thanksgiving." "60

Chandar Bhan also mentions that Ajmer is home to the tomb of Miran Sayyid Husain Khing Suwar (the White Horseman), a thirteenth-century military commander under the first Delhi Sultan, Qutb al-Din Aibak, who emerged as another important figure in the history of medieval Sufism in South Asia. Sayyid Husain Khing Suwar had been a contemporary and possibly even a disciple of $\mathrm{Mu}$ in alDin Chishti, but, as the modern architectural historian Catherine Asher points out, the shrine dedicated to his mystical exploits did not actually become a major pilgrimage site until early modern times, when it became the beneficiary of substantial patronage from the Mughal emperors and nobility, especially among the "lesser elite." ${ }_{11}$

The provinces of Awadh and Allahabad are both dealt with in short order. Regarding the former, Chandar Bhan does note that Awadh contains "several important urban centers such as Khairabad and Lucknow" and that "a number of important darweshes and hermits reside in Khairabad and environs" (CC, 141), but in this case he does not elaborate. As for Allahabad, he notes that it is among the most well-known provinces in Hindustan, thanks largely to its being the home of the city of Banaras- "one of the most impressive and sacred sites and one of the most enchanting and captivating places [in the world]" (CC, 141). But again, he does not elaborate. ${ }^{62}$ 
Meanwhile, the eastern provinces of Bihar, Bengal, and Orissa are also dispatched fairly quickly. Chandar Bhan notes that Bihar is "a very blessed place" (jā-yi mutabarraka), in which the major urban center is Patna, and the most important regional fort is Rohtas. He also lists a few of the officials who have served as Bihar's Mughal governors and states that "several great spiritual men of the world are laid to rest there, such as Hazrat Shaikh Yahyá Maneri [also pron. "Munyari"], Hazrat Makhdum-i Jahaniyan, and others of their ilk" (CC, 141-42). ${ }^{63}$ Bengal, he continues, "is among the remotest provinces in Hindustan," but it is also extremely large, he adds, "and one cannot get a true sense of its vast length and breadth from a mere written account" $(C C, 142)$.

Chandar Bhan praises the pleasantness of the Bengali climate and notes for his readers that the two major urban centers (hākim-nishin) are "Jahangir Nagar, also known as Dhaka, and Akbar Nagar, better known as Raj Mahal." He also lists the various prominent Mughal officials who had governed Bengal since its conquest by Akbar in the late sixteenth century, including Shah Jahan's second son, Prince Shah Shuja', "who has served two tenures in that capacity." Meanwhile, with a nod to the importance of Bengal to the Mughal commercial economy, Chandar Bhan also notes that "many fertile tracts and important districts, as well as ports and peninsulas, are associated with this șüba," reminding any would-be travelers that "the chief means of commercial transport in that province is by boat" $(C C, 142-43)$. As for Orissa, about all he has to say-perhaps simply by way of situating it geographically for readers outside South Asia-is that "it neighbors Bengal, and in fact is connected to Bengal," that it is "a delightful place with a lovely climate," and that "its frontier extends right alongside the borders of Golconda" (CC, 143).

From these eastern environs, Chandar Bhan circles back again to the northwest frontier for two final entries. First up is the "Abode of Stability" ( $d \bar{a} r$ alqarār), Qandahar, whose stately epithet in Mughal parlance is belied by the fact that it was a city of great strategic importance, at the crossroads of a number of major commercial routes, over which the Mughals and their Safavid Persian rivals had struggled almost constantly over the first half of the seventeenth century. ${ }^{64}$ Chandar Bhan does allude to this situation, explaining that the province "came under the jurisdiction of imperial territories earlier in [Shah Jahan's] infinitely successful reign" (in 1638), but he comes just short of acknowledging the subsequent disastrous failure of the Mughals' Qandahar policy, specifically their loss of the fort city once again to the Safavids in 1648-49 and their inability to retake it despite numerous attempts thereafter. Regarding all of this Chandar Bhan is willing only to say, somewhat diplomatically, that "repeated heroic battles have taken place there between the victorious imperial forces and the army of Iran" $(C C, 143)$. But he does add that the important satellite fortresses of Bust, Zamindawar, and Shahr-i Safa were also situated in Qandahar province, and, striking a note that is familiar by now, he calls our attention to the local sacred geography-specifi- 
cally, "the luminous shrine of Baba Wali, which is situated on the outskirts of Qandahar city." "It has a beautiful and spacious courtyard in front," Chandar Bhan adds, "and on Fridays the people of the city and suburbs make pilgrimages there" $(C C, 143)$.

Chandar Bhan closes his geography of the empire with an entry on the Central Asian territories of Balkh and Badakhshan, the Mughal campaigns in which during the 1640 s were discussed in the previous chapter. Chandar Bhan revisits some of those events briefly here and lists many of the important cities and towns of both provinces. He notes that Badakhshan, in particular, was "well known for its deposits of gold, silver, lapis lazuli, and iron" (kān-i țila wa naqra wa lājaward wa $\bar{a}$ han), and he mentions that Shafiq Balkhi and Khwaja Abu al-Nasr Parsa Naqshbandi, "the cream of experts in Truth and Faith" (zubda-i arbāb-i șidq-o-yaqin), were among the many important Sufi mystics who "are laid to rest in this land." He reminds us, too, of the importance of his status as an eyewitness narrator, stating that "this humblest of imperial servants, the author of this exquisite book [nuskha-i badi'], has traveled to that land, and is therefore very well acquainted with the quality of its climate," even if the region's special features "are so famous as to require no publicity" (CC, 143-44).

With this, our author concludes, "the second chaman recounted by Chandar Bhan Brahman is at an end." But what, exactly, is going on with this tour through the Mughal imperial geography? At one level, it is simply a gazetteer of sorts, meant to introduce readers to the main provinces of the empire and to offer some interesting particulars about each locale. Perhaps, too, it was meant as a kind of echo or update of the much more famous gazetteer penned by Chandar Bhan's celebrated predecessor at Akbar's court, the magisterial $\bar{A}$ 'inn-i Akbarì of Abu alFazl ibn Mubarak. But if so, Chandar Bhan's version is not nearly as exhaustiveit is not even in the same league, really-and for that matter it is not particularly "useful," from an empirical standpoint. One suspects, then, that this may be part of the reason that this section of Chahär Chaman has received almost no attention in modern scholarship.

But as I've tried to suggest, Chandar Bhan's survey of the various provinces of the empire was clearly aimed at a wide cosmopolitan readership among the mobile intellectual populations of the Persianate and Indian Ocean worlds, a fact that accounts for some of its "tourist guidebook" qualities-especially its emphasis on the bustling mercantile and cultural life of Mughal India's major urban centers, as well as the consistent reference to the must-see landmarks of India's political and sacred geography. Coming on the heels of the earlier portions of the chaman, in which Chandar Bhan paints such a vivid portrait of the welcoming atmosphere at Shah Jahan's court and the just and humane rule of the emperor himself, it would 
not be too far to speculate that this section was intended not just as a gazetteer, or as a general advertisement for Mughal dynastic grandeur, but also as a clear invitation to traders, poets, mystics, and other talented people across the Persianate world to travel to India and settle there-so that they too could, in turn, add to the existing dynamism of the empire's commercial and religio-cultural life. Wherever you come from, and whatever your religious persuasion, Chandar Bhan seems to be saying, come to India and Shah Jahan will protect you.

Another tantalizing way to interpret Chandar Bhan's minigazetteer of the empire would be to see it as a kind of Mughal version of the classical Indic narrative of the just king's triumphal "conquest of the directions," or digvijaya. The most famous, and possibly earliest, such narrative is that which appears toward the end of the Sanskrit epic Mahābhärata, in which King Yuddhishtira, the eldest of the five heroic Pandava brothers, sends each of his other four brothers out to conquer a different quadrant of the world. After having done so, they all perform another tour of the four directions together to consecrate and legitimate their just rule.

This distant echo of an epic text like Mahäbhārata brings us right back, in fact, to where we began this lengthy chapter, with Chandar Bhan's attempt to situate the Mughal rulers as part of a classical genealogy of legitimate Indian kingship emanating from Delhi, one that went all the way back to none other than Yuddhishtira. In Chandar Bhan's Mughal version, however, we are presented with an updated imagining of Indian imperial and religio-political space-a new tour through the conquered dominions of another "King of the World" (shāh-i jahān), with special attention drawn at every turn to the monuments of his dynasty and the sacred geography that not only helps to consecrate his rule but also demonstrates that it is tolerant, benevolent, and just. 


\title{
4 \\ Writing the Mughal Self
}

\author{
Chandar Bhan's Life and Letters
}

In the previous chapters, I have from time to time called attention to the firstperson perspective that our seventeenth-century Mughal informant, munshi Chandar Bhan Brahman, cultivates in his magnum opus, "The Four Gardens" (Chahār Chaman). As I have tried to suggest, for all its fragmentary nature, Chahär Chaman is quite consciously constructed as a memoir of the secretary's own personal experiences in the wider panoply of Mughal courtly and cultural life. In this chapter, we will examine this feature of the text in its most explicit form, namely, the third and fourth "gardens" (chamans), in which Chandar Bhan gives us a brief autobiography and supplements it with a selection of his personal letters and philosophical speculations.

\section{AUTOBIOGRAPHY OF A WELL-KNOWN MUNSHI}

Chandar Bhan begins the third chaman, as he does the earlier two, with a brief introductory note. The heading explains that this "garden" of the text "is composed of an orchard of colorful trees bearing sweet fruit [ashjār-i rangīn wa așmār-i shìinn]; that is, a narration [izhār] of various stages in the author's life, illustrated by certain events and sample writings." ${ }^{\prime \prime}$ As we will see, the events (wāqi $i^{i} \bar{t}$ ) in question are mainly the highlights of Chandar Bhan's professional career, but he does give some very intriguing details about his family as well. The "sample writings" (niwishtajät), meanwhile, consist mainly of a series of his personal letters, arranged in categories according to the recipient's status and relationship to our munshi. The last batch of these, most of which are to his brothers, are extremely concise and informal, many of them just a handful of lines, often dealing with 
themes of a mystical nature. This running mystical "conversation" with Chandar Bhan's brothers will, in turn, serve as the perfect transition to the fourth and final chaman, which is almost entirely composed of brief notes and miniessays on a range of philosophical and mystical themes.

Chandar Bhan is clearly conscious, in other words, of a kind of convergence between the twin vectors of autobiographical and epistolary self-fashioning, placing his life story and his personal letters in direct physical proximity within the text. He is also quite explicit about the fact that this dual self-presentation is intended for public consumption, directly addressing his "discerning" (mushkilpasand) readers in characteristically florid prose:

Even as the ambience and fragrance of the second of Brahman's Four Gardens is yet fresh $[t \bar{a} z a]$ with the perfume of his musk-diffusing pen and the jewels scattered by his flowing soul, the keeper of the garden of creative literary temperament has already planted a Third Garden of colorful trees, all bearing sweet fruit.

I am hopeful that it will be acceptable in the eyes of those who have discerning taste, and agreeable to those who delight in delectable literature. $(C C, 145)$

At this point, he begins the most explicitly autobiographical portion of Chahār Chaman, under the heading: "Some Brief Particulars about the Author of This Ornate Text." We have already discussed some of these basic details of Chandar Bhan's biography above, in chapters 1 and 2, but let us review them here and look a bit more closely at the specific language Chandar Bhan uses to narrate his life.

"This broken-hearted and rightly faithful Chandar Bhan Brahman, the brokenness of whose heart is the very foundation of his upright character," he tells us, "is a Brahman born of the country [mulk] of Punjab" $(C C, 145)$. Right away, then, Chandar Bhan not only tells us where he was born but also gives us some insight into his existential outlook. But what, exactly, is he telling us?

One thing to note at the outset is that he does not mean "broken-hearted" (shikasta-khātir) here merely in the modern romantic sense of one who has suffered in love. That sort of worldly distress and affliction is certainly captured by the literal sense of the term shikasta-khattir, and the image of the thwarted lover suffering from a "broken heart" (khätitir-i shikasta, or also commonly dil-i shikasta) was of course a common enough trope in the romantic Indo-Persian poetry of Chandar Bhan's day, not to mention the Bollywood songs of our own. But in classical Indo-Persian poetry, of course, the depiction of the suffering undergone by those who are unsuccessful in physical worldly love has also almost always been susceptible to a more spiritual and metaphysical reading, wherein the romantic lover ('äshiq) pining for his unattainable beloved ( $m a$ 'sh $\bar{u} q$ ) is merely a metaphor (majāz) for the human being's existential angst and yearning for connection with an aloof divinity. Sufis and Indo-Persian poets alike tended to consider the latter 
to be "true love" ( $i s h q-i$ haqiq $\bar{i}$ ), as opposed to the "metaphorical love" ( $i s h q$ $i$ majāzi $)$ experienced by human beings in their physical existence-which was thought to be nothing but a pale imitation, transient and ephemeral, of the real Love that was cosmic, eternal, and divine. ${ }^{2}$

Chandar Bhan's "broken-heartedness," in other words, had little to do with mere lovesickness. It was, rather, an existential or even a spiritual condition. Hence the fact that it goes hand in hand with what he calls "proper faith" (durust i'tiqād). We should hasten to add, however, that this was not an endorsement of total renunciation, for as we have seen Chandar Bhan remained a man of the world, immersed in the politics and affairs of the day. Rather, he is talking here about what he will later repeatedly describe as a kind of "detachedness" (bi-ta'alluqī)—what in Sanskrit would be referred to as vairägya, or "dispassion"-even in the thick of worldly affairs, and even surrounded by the power and lavish material wealth on display in the Mughal court. Such an attitude was a check on greed, breeding spiritual humility even in those who achieved great worldly power, success, and influence. Indeed, as we saw in chapter 2, it was exactly this quality of mystical civility that Chandar Bhan admired in those whom he considered to be the great wazìrs of the day, such as Afzal Khan Shirazi and Sa'd Allah Khan. And here he reiterates that such "broken-hearted"-that is, dispassionate-detachment was the key to his own ethical sensibility, being the "foundation of my upright character" ( $b \bar{a}$ 'is $-i$ durustī-yi hāl-i khwud).

I dwell on these opening lines at such length because they signal the degree to which Chandar Bhan appears in these pages to have been attempting to craft a vision of the ethical Mughal subject that was, as it were, community neutral-one that could draw on the spiritual and mystical idioms of both Hinduism and Islam but without ever being tied explicitly to one or the other, and thus, by the same token, one that could be equally comfortable in either. The trope of being existentially "broken-hearted" may well have had roots in a Sufi or Indo-Persian literary idiom, but the term itself, and the condition it described, was not "Islamic" as such but rather human and universal. In fact, especially in the Indian context it is hard not to see an echo of the Bhagavad Gita's message of "action without regard for personal desire" (niṣkāma karma) in Chandar Bhan's own notion of worldly "detachment" (bì-ta'alluqī).

Similarly, even when Chandar Bhan describes himself as a man of "proper faith" (durust i'tiqād), he never clarifies: Faith in what? Faith in whom? It could be a certain divinity, or it could even mean dedication and loyalty to his patron, and in turn the emperor and empire. But the fact that he does not feel obligated to specify is telling in and of itself and appears to have been intentional-as if to say to the reader, "Whether you are a Muslim or a Hindu like me, spiritual devotion is an important component of an ethical life, a life of humility and good character." It is a way of speaking about shared values across community lines without 
necessarily trying to flatten the differences-a way of harmonizing, but respecting and even preserving difference.

Indeed, despite his immersion in the Persianate literary and political idiom and his affinities for some of the spiritual lessons of Sufism, Chandar Bhan remained adamant throughout his oeuvre that he was a practicing Hindu, expressing consistent pride in his status as a Brahman. Thus he continues, "I have earned distinction and admiration among the cream of the Brahmans, the people of sacred thread" $(C C, 145)$. But as we noted above in chapter 1 , his vision of caste may surprise some modern readers, especially those who assume that "traditional" caste identities were always fixed and immutable, or who have an image of Brahmanism as being solely about ritual purity and the protection of status. On the contrary, he clarifies immediately that not all Brahmans are priests or ritual specialists by trade; many, like him, "earn their livelihood through various worldly professions" $(C C, 145)$. This participation of Brahmans in worldly pursuits is commonly accepted today, of course, as part of the practical reality of living in the modern, globalized, capitalist world. But for some reason people have a harder time believing that the same might have been true in seventeenth-century South Asia; and yet, at least as far as Chandar Bhan was concerned, it was a perfectly ordinary phenomenon.

This does not mean, of course, that Chandar Bhan believed there was nothing distinctive about Brahmans as a community. Significantly, though, he frames their prestige as being the result of their cultivation of certain generalized ethical and intellectual values, rather than any narrow obsessions with social hierarchy or ritual purity. Thus he tells us that despite the worldliness of some Brahmans, "Nevertheless, the greatest characteristic of this class [t $\left.\bar{a}^{\prime} i f a\right]$ is that they have retained the ability to discern visible and hidden meanings [ $p \bar{a} s-i$ marātib- $i$ șuwari wa ma'nawi $\bar{\imath} \bar{a} s h t a]$ and continue to live in conformity with the ways prescribed for their community in reliable ancient books [ ba wajhì ki dar kutub-i mu'tabari qadìm dar bāra-yi in guroh șabt shuda 'amal numāyand], and make a habit of fashioning their outer and inner selves in a manner detached from their worldly commitments [ārāstagi-yi žăhir wa bāțin rā 'unwān-i jarīda-yi a'māl-i khhwesh sāzand]" (CC, 145).

In light of such comments one could, perhaps, plausibly argue that this was all just Chandar Bhan's way of trying to rationalize his own family's worldliness and that it can hardly be taken as representative of the state of caste relations in early modern India. Fair enough. But if nothing else Chandar Bhan was speaking for a growing population of early modern Hindus who were experiencing new possibilities of social and financial mobility under the protective umbrella of Mughal pluralism. Some of them, like Chandar Bhan's family, had learned Persian and were working as bureaucrats and administrative officials in the imperial state apparatus-but certainly not all. The issue of such communities working for the state, when analyzed in modern scholarship, has often been framed solely 
as a question of religious difference, for instance, their need to justify working for the "Muslim" state of the Mughals. But, especially for Brahmans, the issue would also have been one of whether some in the community could or should work at all, in any worldly profession. Many who took on commercial trades in the bustling and increasingly globalized early modern Indian economy would have faced the same questions, ritually speaking. So too with those of the subsequent century who began working for the East India Company. In other words, these were not questions unique to the "secretarial castes" who worked for the $\mathrm{Mu}$ ghals; they were shared and contested among many upper-caste and upwardly mobile communities across early modern South Asia.

We should caution too that any generalizations about "caste in India" are always at risk of overstating the case, in the seventeenth century no less than today. For one thing, generally speaking, whether in theory or in practice, the very phenomenon of the premodern caste "system" has always been far more complex than most modern commentary allows. For another, attitudes about caste and other forms of social status varied immensely from region to region. Thus in this case Chandar Bhan's observations may have been tied to a particularly Punjabi, or Mughal North Indian viewpoint that would have found little traction in, say, Maharashtra or Bengal. More research on such questions is definitely needed, but recent scholarship on caste relations among service elites in early modern Maharashtra by scholars like Rosalind O'Hanlon, Christopher Minkowski, and Sumit Guha, and work on some of Chandar Bhan's scribal counterparts in Bengal by Kumkum Chatterjee, suggest that there were significant regional variations in how the identities of Brahmans and other scribal communities like kāyasthas and khattrīs were fashioned-and in some cases reconfigured-during this period. ${ }^{3}$

In point of fact, Chandar Bhan himself was quite aware that there was something relatively "new"-modern, even-about his own family's place in Indian society and that it was specifically their literacy and expertise in the domain of the secretarial arts that made it possible for them to take advantage of the possibilities afforded by the Mughal cultural and political world to move beyond a more "traditional" Brahmanical role. After mentioning that he was born in Lahore, he makes a point of telling us that "the ancestors of this rightly faithful Brahman remained engaged in our ancient ways" (ba tarz-i qadìm-i khwud 'amal minumàyand) until his father Dharam Das's generation $(C C, 145-46)$. This was sometime toward the end of the sixteenth century, as we discussed above in chapter 1, and we may recall here that Chandar Bhan goes on to explain that his father was "an accomplished scribe" (nawisandayi kārdānī), a skill through which he was able to enter the Mughal administrative service as an officially recognized "rank-holder" (manșabdār).

After a successful career as a low-level Mughal bureaucrat, Dharam Das "retired to a quiet corner" (CC, 146). Meanwhile, Dharam Das's path was followed not only by Chandar Bhan but also by at least one of his two brothers. We may 
remember from the discussion in chapter 1 that his brother Ray Bhan was apparently a yogi or sadhu of some sort, and about him Chandar Bhan says here only that he had "a passion for self-liberation" and that he had "developed an antipathy toward all earthly attachments" $(C C, 146)$. But his other brother, Uday Bhan, did establish a career as a skilled munshi in his own right and served in the office of 'Aqil Khan, a Mughal official who was also, incidentally, the nephew and foster son of Chandar Bhan's own early patron, the powerful minister Afzal Khan Shirazi. Uday Bhan appears to have had a very close relationship with 'Aqil Khan, for after the latter's death, Chandar Bhan tells us, Uday Bhan was so emotionally devastated that he withdrew entirely from social life, joining their brother Ray Bhan as some sort of renunciant and becoming "a complete stranger to the ways of worldly people" (CC, 146).

Chandar Bhan will revisit his relationship with his brothers a bit later in the text, in a series of letters, but at this point he returns to the account of his own career trajectory. It is here that he tells us about his early relationship with the architect 'Abd al-Karim Ma'mur Khan, whom he credits with launching his career as a munshi and setting a fine example as a man of erudition and principle. After this he gives us the most detailed account anywhere of "how I entered the most gracious service of that great intellectual of the age and the world, an Aristotle in stature, the pinnacle of the state, the wise scholar Afzal Khan" $(C C, 146)$. Chandar Bhan frames this crucial turning point in his life as the result of a combination of good fortune, Afzal Khan's keen appreciation for talent, and the munshìs own ability to make the most of the opportunity once it presented itself:

When the Divine Creator casts a look of grace upon someone it elicits the attention of visionary men, thus delivering one to the care of those influential people whose alchemical gaze can transform sand into gold, or copper into a philosopher's stone. [Thus it so happened that] when this insignificant speck had the honor, through various fortunate circumstances, to enter the service of that great scholar of the age and the world, Afzal Khan, I did so with tremendous eagerness and enthusiasm. Because of his keen ability to recognize talent, he nurtured and supported me with a grace and generosity far greater than this supplicant's status and abilities merited. Right from the start, he produced a pen from his own pencase and said: "Write with this pen." After that he demonstrated, saying: "These are the proper writing techniques." Little by little, because of my great constancy of faith [rusūk $\underline{k}-i$ 'aqìdat],

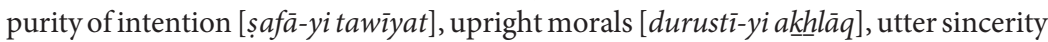
[rāstī-yi mahz], and lasting service [dawām-i khidmat], our professional relationship reached a level of trusting intimacy [mahramiyat]. $(C C, 146)$

Chandar Bhan clearly had great admiration for Afzal Khan, and it is here that he mentions some of the details of their relationship that we discussed in chapter 2 above: the khan's kindness and generosity; the fairness of his managerial style; the special interest that he took in promoting Chandar Bhan's career; his personal 
introduction of the munshi to Emperor Shah Jahan; and his gift of an elephant, so that Chandar Bhan "could always travel alongside that illustrious khan in his personal company" $(C C, 147)$ - as he once did, for instance, while accompanying Afzal Khan on some imperial business in Daulatabad. ${ }^{4}$ The two also appear to have shared a similar work ethic, about which Chandar Bhan proudly boasts: "From the break of dawn right up until midnight I had my place among the attendants at his public and private assemblies, and the drafting of his beneficent orders was especially entrusted to my expertise in the shikasta script" $(C C, 147)$.

Here Chandar Bhan reminds us yet again that the literary facets of his persona were critical to his career success, as a shared appreciation for good poetry formed an important part of his comfortable relationship with the wazir. Thus he continues, "On many occasions [Afzal Khan] requested that the poems of this lowly author be conveyed to his forgiving ear, among which this couplet [of mine] was particularly dear to his heart: 'With the heart's eye I catch a glimpse of the witness to true Meaning / The veil is [actually] a looking glass for the man of real vision' [nazar ba shāhid-i ma'ni ba chashm-i dil dāram / hijāb 'ainak-i chashm ast mard-i binna $r \bar{a}$." In other words, to gain true mystical insight one must use "the heart's eye" (chashm-i dil), rather than ordinary physical perception (which is inevitably flawed). Thus the veil (hijāb), by occluding one's mundane faculty of sight, actually heightens one's access to esoteric Truth by forcing one to focus inward and thus serves, paradoxically, almost as a magnifying glass ('ainak) for one who has real "vision" (bīnā).

It is hard not to see an echo here of Afzal Khan's similar response to the gift of a "glass" ('ainak) from a port official in Surat, which we discussed above in chapter 2. Perhaps Chandar Bhan had that encounter in mind when he composed this verse, and that's what made it resonate so powerfully with his employer? Then again, it's equally possible that the reverse is true: that Afzal Khan, presented with an 'ainak in real life, had occasion to recall his own munsh $\vec{\imath}$ s powerful verse, and this sent him into a spell of philosophical musing. We can probably never know for sure one way or the other. Still, one can see just how powerfully interwoven the literary, mystical, and professional personae of these Mughal administrators actually were in their day-to-day interactions-not to mention here, specifically, in Chandar Bhan's crafting of his public persona. One can also see, moreover, why Chandar Bhan played such an active role in Afzal Khan's salon "whenever the conversation turned to spiritual matters or intellectual discussions." On such occasions, he tells us, "This meager speck had his designated corner among the assembled learned men, literati, and other intellectuals gathered in the majlis, and I noted down with the nib of my pen whatever crossed anyone's tongue" $(C C, 147)$.

We saw above in chapter 2 the extent to which Chandar Bhan viewed such mystical civility, as I call it, as a crucial feature of Mughal political culture generally, 
and here we see how important it was to the cultivation of his own public persona as a successful, upwardly mobile bureaucrat and munshì. Just as he learned to emulate Afzal Khan's admirable qualities as a gentleman and administrator and thus improved his own lot in life, so too can his readers, he seems to be telling them, if they will cultivate those same qualities. He goes on to praise Afzal Khan's "innate

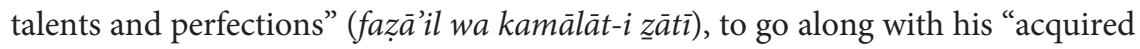

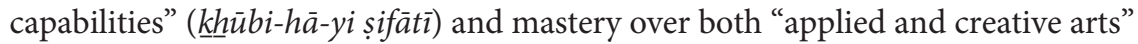
(funūn-i kasbi wa wahbi). He was a man who "could display the universe of [hidden] meaning in visible garb"; but perhaps even more importantly, "though immersed in the world of multiplicity, he remained focused on the vision of Unity." In support of this observation, Chandar Bhan remarks that the following verse quatrain $\left(r u b \bar{a}^{\prime} \bar{i}\right)$ "was often on the tip of that khan of sweet expression's tongue."

So long as I have yet to see the Friend with the eyes in my head

I will not rest from searching for even a breath.

They say that Truth is not visible to the physical eye,

But body's eye is not the [sum of] the human, while I am the eye embodied

[tā dost ba chashm-i sar nabīnam har dam

az pāy-i talab naminishinam har dam

gūyand ki haqq ba chashm-i sar natuwān dìd

ān insān nai wa man chashm-am har dam]

(CC, 147-48)

Remember, Afzal Khan was not some Sufi hermit in a cave, but the chief minister and an elite military commander of one of the most powerful empires on earth. Yet to one who knew him well the most impressive thing about him was the tone of gentility, civility, and spiritual humility that he consistently struck and that those around him clearly admired and strove to emulate.

We get further indication of just how widely admired Afzal Khan was in Mughal court society from Chandar Bhan's account of his illness and death in 1639, which also represented a crucial turning point in our munsh $\vec{\imath}$ s own life journey. Losing his primary mentor and benefactor was a devastating blow for Chandar Bhan, of course, but from the way he describes it the death of such an accomplished and well-respected minister was also a cause for grieving among many in the wider Mughal aristocracy, including Emperor Shah Jahan himself. We don't often hear much about basic human emotions like friendship, loss, and grief in modern scholarship about the Mughal court, so Chandar Bhan's reflections on these final weeks of Afzal Khan's life-as the khan "was making his way from this ephemeral abode $[d \bar{a} r-i f \bar{a} n \bar{\imath}]$ and turning his attention to the eternal world ['ālam-i jāwidānī]" (CC, 148)-are especially noteworthy and offer a brief yet powerful glimpse of the inner lives and personal relationships cultivated by the Mughal political elite. 
Chandar Bhan begins this passage by telling us that in those final weeks and days Afzal Khan "often spoke eloquently of the fickleness of fate [ $b \bar{i}-s a b \bar{a} t \bar{i}-y i$ rozgār]" and in his final breaths recited these two couplets:

If Death himself shows up, tell him "Come hither!"

So that I can embrace him tightly, so tightly;

From him I will receive a soul eternal,

And from me he will get only this cloak patched brightly, so brightly

[ gar ajal mard ast gū pesh-i man $\bar{a} ' \bar{\imath}$

tā dar äghosh-ash bagìram tang tang

man az ù jānī sitānam jāwidān

$\bar{u}$ zi man dalqī bagìrad rang rang]

$(C C, 148)$

The "patched garment" (dalq) here refers to the typical cloak of a Sufi darwesh, which often had a colorful appearance on account of being stitched together from multiple scraps of cloth. Thus the message of the two couplets is that Afzal Khan views all his worldly status and finery as nothing but the humble garb of a mendicant, and moreover, that when the appointed hour of his death comes he will happily give up even that in order to join with the cosmic soul-again, a stirring sentiment coming from one of the most powerful men in South Asia.

But perhaps even more compelling is Chandar Bhan's narration of the reaction of others to Afzal Khan's illness and death. As his condition worsened, Afzal Khan received personal visits not only from the emperor but also from "many elite nobles of the eternal empire." In fact, according to Chandar Bhan, at some point the emperor himself took personal charge of overseeing the palliative care of his friend and confidant:

Whatever was necessary to tend to his convalescing servant, he arranged to have it produced [ba manașșa zuhūr āwurdand]. And when His Majesty the caliph of the age, out of an abundance of affection and respect, laid his blessed hand across the hand of that scholar of the world and asked after the latter's condition, the gentle khan was unable to muster the words, but, recalling their longtime connection and bond of service, expressed his thanks for His Highness's generosity, and then suddenly lost control of his emotions and began to weep.

Upon seeing this, the affectionate and considerate emperor used his inspired tongue to speak many words of encouragement for the improvement of that illustrious khan's condition. $(C C, 148)$

Of course, even if the "King of the World" himself is in charge of your medical care, time catches up with everyone-a sentiment that Chandar Bhan proceeds to express with quite a flourish: "But, because it is a peculiar feature of the wine of destiny that ultimately it inebriates those who imbibe at the tavern 
of existence with the empty gulp of nonexistence at the bottom of the cup, and hurls the rock of fragmentation against the glass of desire, that wise man of the world abandoned the trappings of existence in this decentered world and became a sojourner bound for the path to eternal sanctity" (CC, 148). Again, however, when it came to the evaluation of what made Afzal Khan so great in the eyes of his contemporaries - the emperor included-it had far more to do with his humanity and civility than with his military might or political influence, at least in Chandar Bhan's assessment: "Since he had lived a wellfashioned life, indeed in every way, the emperor of the world and its inhabitants, recalling the laudable ethics, habits, and manners [husn-i aḳhlāq wa auz $\bar{a}^{\prime}$ wa ațwār] of that scholar of the age, who had spent nearly a decade as the standard bearer for governance and administration [imārat-o-wizärat] in the land of Hindustan, earning fame for his kindness, wisdom, and good character, made known to the entire world the special esteem in which he had held his knowledgeable wazìr" $(C C, 148-49)$. Accordingly, a royal proclamation bearing the "dreadful news" of Afzal Khan's death was read throughout the city of Lahore, where Afzal Khan not only had his private residence but had also served for a number of years as the provincial governor. Meanwhile, during his funeral procession, the bier was accompanied by a number of high-profile members of the Mughal nobility, including Wazir Khan, the governor of the Punjab; Mu'tamad Khan, the chief army paymaster (mīr baknhshī); Makramat Khan, the chief of equipment and matériel (mīr sāmān); "and several other notables ... who conveyed his corpse toward the eternal country, showing their grief in sobs amid the throng of onlookers who remained behind in this transient world" (CC, 149).

For Chandar Bhan, however, what happened after Afzal Khan's funeral turned out to be perhaps the most pivotal moment in his life. He has alluded to these events in passing a couple of times earlier in Chahär Chaman, but here he recapitulates them once again, filling in some of the missing details. First he offers a brief note on the fate of some of Afzal Khan's relatives following the wazi r's demise, beginning with the latter's brother 'Abd al-Haqq Shirazi (d. 1644-45), better known by his official title of "Amanat Khan." According to Chandar Bhan, Amanat Khan was so distraught after his brother's death that he "retired from service and gave up his manșab, betaking himself to a secluded corner and becoming a complete renunciant." Chandar Bhan also reports that Amanat Khan built a "charming hostel" (sarāy-i dilgushāy) one day's journey from Lahore that became "a notable architectural curiosity" (mauza'i-yi ihdās. $)$, and where Amanat Khan himself was eventually interred $(C C, 149){ }^{5}$

Meanwhile, Amanat Khan's own son 'Aqil Khan, who had also been mentored by Afzal Khan and who had, as we have noted, also been Chandar Bhan's own brother's employer, went on to have a very promising military and political career until, as our munshī puts it, "while he was en route to Kabul, still in the prime of 
his youth, the tender shoot of his future success was cut down by the fierce winds of doom" (CC, 149). The entire discussion of Chandar Bhan's patron, mentor, and benefactor Afzal Khan thus ends on a rather melancholy note. Chandar Bhan closes by remarking that "now, apart from his good name there is no one to carry on the memory of the 'allama's family line except for 'Aqil Khan's brother Faiz Allah" $(C C, 149)$. The latter, though, was apparently some sort of eccentric, or possibly even mentally disturbed. All Chandar Bhan will say about him, somewhat enigmatically, is that "he lives according to his own manner" (ba taur-i khwud zindagī mìkunad) (CC, 149).

This discussion of the fate of Afzal Khan's family was not, however, merely an opportunity for Chandar Bhan to express pathos, for it also explains something about our munshìs own fortuitous career trajectory. Indeed, under the circumstances, it would not have been out of the ordinary for a service professional like Chandar Bhan to have remained a fixture in Afzal Khan's household, had there been any member of the wazir's family able and willing to take over its fortunes. But as Chandar Bhan reminds us, 'Aqil Khan, the most viable candidate, died young; and no other family member stepped forward to assume Afzal Khan's role, either as a Mughal manșabdār or even as head of the family estate.

Meanwhile it would certainly have been possible, had things turned out differently, for someone with Chandar Bhan's skills to attach himself to some other notable family or commercial concern with a base in Lahore, and simply to live out the rest of his days in his native city. But a stroke of good fortune made all that moot, and Afzal Khan's own nephew 'Aqil Khan was instrumental in creating the opportunity for Chandar Bhan, as he tells us in the title of the next section of the text, to "enter directly into the most benevolent service of His Highness the Emperor and Shadow of God, the Lord of the Planetary Conjunction" (bayan- $i$ idrāk-i mulāzamat-i sar-ā-sar-i sa'ādat-i bandagān-i a 'ì-hazrat-i khāāānì zill-i subhānī șāhib-i qirānī) (CC, 149). He explains:

When Divine favor ['ināyat-i ilāhi] presents an opportunity to improve one's circumstances, those moments [in life] become allies until step by step, and moment by moment, one's ultimate goals are reached.

After the passing of that kind patron Afzal Khan from this bodily dustbin over to the spiritual world, that most distinguished of amirs 'Aqil Khan presented all the munshis and others connected with the late khan whose abode is now in heaven in an audience before His Highness the Emperor. Each was honored with a promotion to some new position, in accordance with his status and lot.

When this faqir's turn came, a sample of this supplicant's expertise in the broken [shikasta] script, which is not devoid of correctness, entered into [the emperor's] alchemical gaze, and a ghazal produced by my humble nature also reached the august and magnificent imperial ear, earning a measure of appreciation and even delighting his discerning taste. $(C C, 149-50)$ 
The message is clear: Chandar Bhan got his position at the imperial court not because of any generalized caste or community affiliation, or even solely through his fortuitous connection to Afzal Khan's household, but through his own individual merit and capabilities. When the opportune moment in his life arrived, he seized it to advance his career, and it was his lifelong industry and cultivation of certain qualities - scribal and literary skills, in particular, but also good character and other gentlemanly values - that had prepared him for this singularly transformative moment. A Horatio Alger character he may not have been, but the idea that in the Mughal world an individual's talent, character, and work ethic could enable social mobility is certainly there nonetheless.

Once Chandar Bhan was recruited into the emperor's personal circle, he applied his skills to a variety of tasks. Among these, initially, was the job of wäqi'anawiss, or personal diarist to the emperor, in which capacity Chandar Bhan kept "the king's special journal" (bayāz-i k̂hāṣsa-yi pādshāhī). Accordingly, he explains, "I was expected to report daily to His Royal Highness, for instance while en route to Kashmir or Kabul, on the condition of every stage [manzil] and the features of every noteworthy place along the way, detailing the particulars of the journey, the climate, the hunting areas, and so on, and recording it in the diary" $(C C, 150)$.

Now, our munshi is obviously biased, but it would appear from his account that Shah Jahan took quite a liking to him and was impressed enough with his literacy and erudition that, according to Chandar Bhan, "His Majesty was inspired to dub this faithful Brahman his 'Hindu expert in Persian' [hind $\bar{u}-y i$ fārsi-dān]" $(C C, 150)$. Taken out of context, it may be tempting to read into this comment the idea that Chandar Bhan's Persian literacy was somehow exceptional among Hindus, but as we have seen throughout this book this was clearly not the case, even in his own family and social circle-and Shah Jahan, with plenty of other Hindus serving in both his military aristocracy and his bureaucratic administration who were also "Persian-knowing" (a more literal translation of "fārsī-dān"), would surely have known this.

So what was it that made Chandar Bhan especially fluent in Persian, according to the emperor? One reason, clearly, was that Chandar Bhan's erudition in the various classical canons of Indo-Persian literature, history, and mysticism went far beyond what we merely necessary for the average clerk or bureaucrat. Chandar Bhan's literary talents, in particular, which were notable by any standard, made him stand out in a way that went beyond routine literacy, and in fact, as we have seen above, were precisely what got him a position in Shah Jahan's service in the first place. And when all was said and done, Chandar Bhan's artful expression in lyric forms such as the ghazal and ruba $\bar{a}^{-} \bar{\imath}$ would give him a notable status among some of the greatest, "freshest" poets in a century of great Indo-Persian poets (of any background). Chandar Bhan himself clearly recognized how critical his flair for literary expression was in his own career trajectory, reminding us here once 
again that "on festival days and other blessed events, although the verses of many famous poets were presented for His Highness's luminous gaze, the quatrains of this supplicant also reached the magnificent and grand imperial ear, as a result of which I obtained a number of promotions and rewards" (CC, 150).

At this point, Chandar Bhan moves fairly quickly through the rest of his autobiography and in fact skips over a lot of details that we have learned earlier in Chahär Chaman. He reminds us, for instance, that when Islam Khan Mashhadi was assigned to replace Afzal Khan as grand wazir in 1639, Shah Jahan, "considering this supplicant to be well trained in the workings of the finance ministry [maṣaliḥ-i kār-i dīwān-i a lá] reassigned me to the office of that greatest of elite khans" (CC, 150). Interestingly, however, in this version of those events Chandar Bhan leaves out almost all the details regarding Islam Khan himself, and the matters pertaining to the latter's character and stewardship of the finance ministry that featured so prominently in the section on ministerial conduct and ethics earlier in the text. He also leaves out any discussion of figures like his colleague Diyanat Ray, the fellow munsh $\bar{\imath}$ who had served as interim chief minister during the nearly yearlong interval between Islam Khan's promotion and actual assumption of his duties as head of the dīwānì. Instead, the focus at this stage is primarily on his own role as a munshi and administrator; he explains only that "besides my work in the imperial secretariat [dār al-insh $\bar{a}$ '], this well-wisher was also entrusted with overseeing the distribution [of funds] and balancing [of accounts] [khidmat- $i$ taqsīm wa muwāzana] in coordination with the finance officers throughout the imperial dominions, and working with them suited me well [naqsh-i șuhbat durust nishast]" (CC, 150).

The explanation for these curious absences of detail at this stage in the text lies, I think, in certain genre considerations peculiar to Mughal inshà'. In this case Chandar Bhan is intentionally covering the same set of experiences and series of events for a second time, but from an entirely different perspective. The first time, in the parts of the first chaman discussed above in chapter 2, he did so almost as an essay on the norms of governance, from the perspective of an eyewitness to the chain of executives who administered Mughal power during his own tenure in Shah Jahan's government, written in the didactic form of the subgenre of inshä' known as "manuals for wazìrs" (dastūr al-wizārat). In that version, though Chandar Bhan himself is always lurking as one of the bit players in the narrative and even pops up explicitly from time to time in moments of first-person awareness, he himself is not the "main character," as it were. Rather, the focus of the narrative is on the careers of others, especially the wazìrs in charge of the dìwaini and their most trusted associates, and on the norms, ideals, and ethics of competent governance that they embody-or in some cases, fail to embody.

Here in the third chaman, however, the perspective is entirely and explicitly autobiographical. Thus the details of the lives of others in the Mughal administration 
matter only insofar as they are relevant to the narration of our own munsh $\vec{\imath}$ s personal career, especially at the key moments in that career. In other words, Islam Khan's promotion to the office of prime minister is relevant to this narrative not as a random factoid but as an event that represented a key moment of reshuffling in the overall Mughal administrative machinery, one in which Chandar Bhan himself was promoted and given added responsibilities that he would retain for the rest of his tenure at court.

A similar turning point in our munsh $\vec{\imath}$ s career occurred, Chandar Bhan continues, "when that axis of important affairs, the aforementioned [Islam] Khan, was reassigned during one of the court's sojourns in beautiful Kashmir to serve as the governor of the Deccan, and the daily administration of imperial affairs was handed over to that great role model, the grand wazi $r$, the scholar of the age and the times, Sa'd Allah Khan" $(C C, 150)$. This reshuffling of the political and administrative hierarchy happened in July 1645 , as we may remember from the discussion in chapter 2, at which point "His Majesty the Caliph of the Age and Emperor of the World, out of his affection and high regard for me, assigned this insignificant speck to assist that illustrious khan" (CC, 150). Sa'd Allah Khan would serve as prime minister for over a decade, until his death in 1656, and as far as we can discern Chandar Bhan served directly under him for virtually that entire period. This decade represented in many ways the acme of our munsh $\vec{\imath}$ s career, as he "enjoyed the best of times working on the imperial business in the company of that khan of great stature" (CC, 150), and the two appear, at least from Chandar Bhan's perspective, to have enjoyed a tremendously close relationship. "Often," he explains, "we carried on as if of one mind, from early morning until evening, and from evening right up until the next morning" (CC, 150-51). It was also while working in Sa'd Allah Khan's office that Chandar Bhan got his most extensive firsthand military experience-or at least, proximity to the action-reminding us here that "when that most elite khan of high status was dispatched to see to the critical imperial agenda in Balkh, this lowest of servants, per His Highness's orders, was sent to accompany that magnificent pillar of state so that I might draft the necessary letters and progress reports from the front" $(C C, 151)$.

Chandar Bhan closes the explicitly autobiographical section of the text with Sa'd Allah Khan's death in April 1656. But again, whereas in the first chaman our munshi had provided a number of details regarding the circumstances of the wazir's demise, the period of mourning it ushered in for the entire court, the affection and grief displayed by the emperor himself during that time, and the reshuffling of the administrative hierarchy that resulted, all from the third-person perspective of a participant-observer, here Chandar Bhan mentions it only in passing, and mainly from the perspective of what it meant for him personally. "When that illustrious khan passed on from this world," he tells us, "His Majesty the Emperor, who was a keen evaluator of talent with respect to every trade and 
every class of people [har tâ'ifa], bestowed on this faithful and rightly loyal servant, who had spent years perfecting my craft in the service of the most illustrious wazirs, a promotion to the title of rāy." "By entrusting me with the task of drafting the imperial farmāns acknowledged and obeyed by the entire world," he adds by way of closing, "[the emperor] gave me one of the most distinct honors in the world" $(C C, 151)$.

From our present-day vantage point, it can admittedly be a bit frustrating that Chandar Bhan ends his autobiography here, of all places, for we know in hindsight that there is much more to the story. Indeed, the ensuing years were a period of intense volatility at the court, not only because of high turnover in the dìwāni, to which Chandar Bhan was still ostensibly assigned, but also because of the looming succession crisis instigated by reports of Shah Jahan's own ill health beginning just a year later, in September-October 1657. Chandar Bhan's narrative of his career trails off just on the eve of some of the most momentous-and many would argue, calamitous-events in the entire Mughal era. One wonders in vain what he really thought of all that went on over the next few years, a period when, let us remember, he continued working in the Mughal administration and would have had an excellent vantage point from which to observe the war of succession and its aftermath.

But perhaps the simplest, and most likely, explanation for why Chandar Bhan did not feel it necessary to include the tumultuous events of these years is simply that Chahär Chaman is not that kind of book. Historical events, as such, do not drive the narrative. Even in the one section late in the first chaman that deals largely with military and political events, Chandar Bhan glosses over many details, preferring to stick instead to questions specific to the secretarial domain. So we should not be entirely surprised that he is not much interested in recording them here. Moreover, as we have just seen, even in the most explicitly autobiographical part of Chahār Chaman our munshì tends to focus largely on transformative moments and relationships in his career, rather than on a narration of his entire life story. Since there was no real qualitative change in his position in the years following Sa'd Allah Khan's death, so far as we know, even after Aurangzeb acceded the throne, perhaps he simply didn't see the need to dwell on the details. Moreover, if our munshi had any inkling that he was a living witness to the beginning of the end for Mughal imperial success, he certainly doesn't give any indication of it. Maybe, just maybe, he did not see the transition to Aurangzeb's rule as the kind of civilizational calamity it has later come to represent.

Chandar Bhan also, unfortunately, tells us virtually nothing about his family and domestic life. We get no details of his wedding, nor that of any of his children. We do not even know, for that matter, if he had any children other than his son Tej Bhan, or whether any of them were daughters. ${ }^{6}$ We learn about Chandar Bhan's father's death, but only because it is mentioned in one of the collected let- 
ters discussed below-Chandar Bhan did not see even this milestone as suitable or necessary content for his "autobiography."

Straightforward autobiography, however, is only one possible form of selffashioning. Indeed, much scholarship on the intellectual history of the early modern world has focused on the degree to which epistolography and other forms of informal "life writing" were crucial to the construction of private individual self-consciousness. To catch a glimpse of what that process might have looked like from an Indo-Persian perspective, we move now to Chandar Bhan's personal letters, and his construction of an epistolary self.

\section{LETTER WRITING AND SOCIAL INTIMACY}

Before we examine the letters that conclude the autobiographical section of Chahär Chaman a bit more closely, however, perhaps a brief preliminary excursus about Chandar Bhan's epistolary oeuvre, his correspondents, and his letterwriting style is in order. There are three main sources for Chandar Bhan's letters. The most extensive collection is usually referred to in most manuscripts as Munsha'ät-i Brahman, the title under which a printed text edited by S. H. Qasemi and W. H. Siddiqi was published in 2005 . $^{7}$ The exact contents of some of the manuscripts of this text vary somewhat, and some of them have different titles (e.g., Ruq'ät-i Brahman, Inshā'-yi Brahman), but there is enough consistency that we can be confident that Chandar Bhan himself purposefully selected the letters for inclusion in at least one collection produced in his lifetime. We know, moreover, that he collected these letters after he had already compiled his two other major works, Chahār Chaman and his dīwān of poetry, for he mentions both of these latter works (along with a handful of others, most of which are now lost) in a preface to the Munsha'ät. There he goes on to explain:

From the time that this supplicant first took up a pen in my hand I had written such a variety of letters $\left[r^{\prime} q^{\prime} \bar{a} t\right]$ on just about every topic, especially on happy matters, that I knew that if the opportunity arose they could be arranged in a separate volume.

Now I have finally given the nib of my pen permission to write some of them out and have named the collection Munsha'ät-i Brahman, which contains copies of reports ['arā'iz] dispatched to the celestial court, as well as letters and epistles [raqā'im wa kh hut $\bar{u} t$ t] written out with my broken pen [qalam-i shikasta] and sent to notable wazirs, great men of the age, and other friends and literati. $(M B, 1)$

The collection is far too long for us to examine in any detail here, but let us note a few features before returning to the parallel set of letters included in Chahār Chaman.

Like many such collections from this period, the letters in Chandar Bhan's Munsha'àt are organized into sections according to the recipient's social status 
and relationship to the author. Thus Part One (qism-i awwal) contains only letters to recipients of the highest status possible, the royal family. There are four letters to "His Majesty the Emperor" (ba janāb-i hazrat kh which Chandar Bhan reports on his diplomatic mission to Mewar in 1654 (discussed above at the end of chapter 2) $(M B, 2-11)$. These are followed by another three letters to Aurangzeb 'Alamgir, all of them penned sometime after the latter became emperor in 1658 .

Part Two (qism-i șānī) contains letters written to "great and elite nobles of the age" ('umda wa zubda-yi amìrān-i rozgār), including many that we have encountered already in this book, as well as a number of others that we have not $(M B, 14-53)$. This section also includes a handful of letters to notable Sufi mystics of the time, and the names on this list are a powerful reminder of just how wide Chandar Bhan's circle of friends and acquaintances in the Mughal nobility actually was.

These letters also further demonstrate the remarkably rich literary life of even the most aristocratic nobles and hardened warriors of the Mughal military and political elite, as we noted above in chapter 1. In the printed edition of the Munsha'at, there are forty-four letters in this section; and of those some twentysix-more than half-include our munsh $\vec{\imath}$ s own poetry, usually short lyrical odes (ghazals) or quatrains ( $r u b \bar{a}^{\text {cis }}$ ), either appended as a simple courtesy or in many cases newly composed with a specific request for suggested improvements. Poetry was also routinely used in such letters simply to provide a literary flourish to otherwise mundane correspondence. A good example is the following letter to Islam Khan Mashhadi, which, we may infer from the contents, was perhaps written sometime in early 1639 , after Islam Khan had been named prime minister and had been ordered to return to court from Bengal, where he had been serving as the provincial governor, but had yet to arrive $(M B, 31)$. The letter clearly suggests that the two had been acquainted for some time, long before Islam Khan was appointed wazì and our munshī began working as his direct subordinate:

To the Pillar of Pillars of the Exalted State, the Expert of All Things Superficial and Esoteric, Islam Khan:

How can the eyes of the lover lined with eyeblack be bright?

Come, for only your arrival can light up my eye.

The dust of your lane works as pearly collyrium for my sight, And through that ointment benighted eyes will be set alight.

[zi surma dìda-yi 'āshiq kujā shawad raushan

biyā ki z'ämadan-at chashm-i mā shawad raushan

ghubār-i kū-yi tu kuhl al-jawāhir-i bașr ast

ki chashm-i tìra ba àn tūtiyà shawad raushan]

Greetings, My Dear Nawab, the Gracious Connoisseur! It has been ages since this faqì has served as a disciple to you, the true master [ustād-i haqīīi $]$. Although in 
that time I have been deprived of the special alchemical grace of your company [az sa'ādat-i șuhbat-i kimiyā-ḳhāsșiyat mahrūm būd], nevertheless I have never let go of the precious tie of fidelity that connects us. And now that the wonderful news of your impending arrival has reached this hermit's ear, my afflicted heart has spontaneously burst with joy. Quatrain:

The pleasure of nightly wine I know, The tales of romance I know,

Though my hands and feet are paralyzed, my heart starts to dance,

For the pulsing of this melody, too, I know.

[ mā żauq-i mai-yi shabāna rā mìdānìm afsāna-yi 'āshiqāna rā mì̄ānīm

bì-jumbish-i dast-o-pā ba raqș āyad dil

mà shorish-i ìn tarāna rā mìdānìm]

Here the new wazir, one of the most powerful and august personalities in the entire Mughal aristocracy, is cast in the conventional role of the cruel romantic beloved familiar to connoisseurs of Indo-Persian literature, while Chandar Bhan assumes the guise of the tormented lover pining for a glimpse of her (or sometimes, as in this case, him). The verses function not just as a light touch or a literary flourish but also as a means of flattening the otherwise pronounced difference in the two men's social and political status, providing the correspondents with an idiom of friendship and epistolary intimacy that could transcend the ostensibly wide gulf separating their respective places in the overall social order. The personal letter was, in other words, a space in which the notoriously rigorous formalism of dress, gesture, and hierarchy of Mughal courtly life under Shah Jahan could melt away, replaced by amiable bursts of literary wit and fond individual sentiment.

We should note, too, the relative brevity and familiarity of the letter's opening salutation. Indeed, the conventional image of Mughal epistolary insh $\bar{a}$ ' is exactly the opposite, namely that it is encrusted with fussy ornament, unwilling and unable to get to the point. It has even been argued, perhaps most notably by the late nineteenth-century Urdu writer and critic Altaf Husain Hali (1837-1914), that one of the key features that distinguished modern Indo-Persian letter-writing practices from their more "artificial" courtly antecedents was the dropping of longwinded salutations ( $a l q \bar{a} b-o-\bar{a} d \bar{a} b)$, which were said by modern reform-minded critics to be dripping with sycophantic courtesy but ultimately devoid of content. Perhaps nowhere did Hali make this argument more explicitly than in Yādgār-i Ghālib (A memoir of Ghalib; 1897), his biography of the celebrated nineteenthcentury poet Mirza Asadullah Khan Ghalib (1797-1869), who, he argued, was perhaps the first modern epistolographer in Indo-Persian letters-precisely on 
the grounds that Ghalib had boldly renounced such unnecessary verbosity and often began his letters with brief salutations of just a few words. ${ }^{8}$ Hali also singled out Ghalib's conversational prose style as being new and inimitable, it should be noted. But the main structural innovation he credited the poet with was his abandonment of extended epistolary salutations: “Mirza [Ghalib's] Urdu epistolary style was in reality utterly unique. Neither has anyone written letters in this style before Ghalib, nor will anyone after him ever be able to fully emulate his style. He completely abandoned the old and decrepit manner of address [alqāa-o-ädāb $k \bar{a}$ purāna aur farsūda tarīqa], as well as many stylistic features that epistolographers had considered essential to letter writing, but which, in truth, were useless and beside the point [fuzūl aur dūr az kār]." This critical stance has been so influential among Urdu literary critics that it remains almost universally accepted, as does the presumption that the entire earlier Indo-Persian letter-writing style was weighed down by excessive, fatuous, and insincere formality - a blanket assertion that is usually taken simply on faith, without any attempt at critical investigation. Indeed, barely two years ago the Pakistani newspaper Dawn ran an essay commemorating Ghalib's death anniversary (February 15), in which the author does little more than restate Hali's claims from over a century ago: "Before Ghalib, in the subcontinent letters were normally written in Persian. Letters occasionally written in Urdu were laden with highly ornamental language and long and tortuous salutations and formalities. . . But Ghalib entirely changed the way letters were written. Aside from being in Urdu, Ghalib's letters are spontaneous, candid, and in a language that is chaste and literary. He bade farewell to the formal style of letter writing that was in vogue in those days and began writing letters quite an informal way."9

And yet here we have Chandar Bhan doing exactly that, nearly two centuries earlier, in a great many of his own letters, even those addressed to eminent Mughal officials and other clear social superiors. For instance the very next letter after the one just cited, also to Islam Khan, begins simply: "Greetings, true teacher!" (ustād-i haqīqì salāmat) $(M B, 31-32)$. A letter to Sa'd Allah Khan later in the collection begins in similar fashion: "Greetings, O Scholar of Aristotelian Genius!" ('allāma-yi aristo-fițat salāmat) (MB, 41-42). To be sure, many of Chandar Bhan's letters do begin a bit more formally than this, particularly those addressed to the emperor and others who commanded great respect. But there are dozens of examples of more conversational openings in Munsha'ät-i Brahman alone, and the letters become increasingly informal and to-the-point as one gets into the later sections, especially the letters to Chandar Bhan's brothers-some of which abandon the opening salutation altogether.

What, then, are we to make of Hali's suggestion that a core feature of modernist epistolary authenticity is the absence of stilted and verbose opening greetings? Clearly, as Chandar Bhan's letters demonstrate, Ghalib was not the first 
Indo-Persian epistolographer to use such relatively informal salutations. Perhaps, we might be tempted to muse, our munshi was the real pioneer in this regard-but I doubt it. Far more likely is that the elements of such conversational and informal epistolography were already becoming established parts of the epistolary landscape in Chandar Bhan's day, just not in the type of "official" courtly documents and diplomatic correspondence that modern scholars have tended to treat as the only part of the corpus worth perusing. Indeed, the perceptive reader may have already noted that the letters from Afzal Khan and Sa'd Allah Khan that Chandar Bhan records in Chahär Chaman (discussed above in chapters 1 and 2) are also concise and conversational in tone, certainly by the standards of contemporary seventeenth-century Indo-Persian prose style, even though they deal with highly recondite subject matter. But how pervasive was the trend? And was the trend even new, or did it have its own antecedents in even earlier letter-writing practices, whether Indic or Perso-Arabic? Did vernacularization have an influence on the Persian epistolary sensibility? Was it the spread of literacy, coupled with a boom in informal personal correspondence facilitated by the growing sophistication of the Mughal postal system? Are we even asking the right questions?

The honest answer to all these questions is: it is difficult to say. Indeed, absent a major collective scholarly effort to recover, preserve, and actually study the many such collections of epistolary and other inshä' that sit unread in manuscript archives, it is difficult to know even how to pose the right questions, much less begin to answer them. Already by Hali's time scholarly attention to Mughal-era Persian insh $\bar{a}$ ' had waned to a point of considerable institutional neglect, both in the British colonial-Orientalist scholarship and in the emergent nationalist historiography. But therein lies the conundrum. Because so few in India can actually read Persian any more, documents that were once thought to be not worth reading are now nearly forgotten to have existed in the first place. Thus the very types of personal correspondence that would allow us to at least begin the type of prosopographical analysis that could bring such Indo-Persian letter-writing practices into a more global cultural historical conversation about early modern self-fashioning have fallen into such a musty linguistic and archival purgatory that they are barely even available to be read any more.

Things have gotten a bit better since the onset of the digital age, as more and more archives are being made available online. But we are still a long way off from the day when those who are interested in such things can even ask, much less provide a serious answer to, such a simple question as: "What was the typical mode of address in personal letters exchanged between friends in Mughal India, and how would the answer inform our understanding of epistolary self-fashioning in early modern India more generally?" At this stage we can at least draw attention to the analytical problem by pointing to Chandar Bhan's way of doing things, but beyond that we can only await further research. 
In any event, to return to the letters themselves, Chandar Bhan also exchanged letters and verse with a number of professional poets, some of which are collected in Part Three (qism-i siwum) of Munsha'ät-i Brahman. In a brief preface to this section he apologizes to the reader for not including all the letters he has exchanged over the years with various "masters of learning and intellect and men of fluency and eloquence" (arbāb-i fazl-o-kamāl wa ahl-i fașāhat-o-balāghat), but he insists that "there simply wasn't enough space in this brief compilation, and thus a few samples will have to suffice" $(M B, 53-62)$. This is followed in Part Four (qism-i chahärum) by a fascinating set of letters of "recommendation" (sifärish), which seem to have functioned, just as they do today, as reference letters testifying to the professional competence of Chandar Bhan's friends and acquaintances-and sometimes their children-mostly addressed to influential members of the $\mathrm{Mu}$ ghal and Rajput nobility with whom he had connections (marbūt wa manüt. $)(M B$, 62-73). Chandar Bhan's own secretarial skills and success were thus, it would appear, also a conduit for the social mobility of others, most of them Persian-literate fellow Hindus who were looking for positions as scribes and accountants in the imperial and subimperial bureaucracies.

This is followed in the fifth, final, and longest section of Munsha'ät-i Brahman by Chandar Bhan's letters to "my esteemed father, the qibla of truth" (qibla-yi haqiqi pidar-i buzurgwär), along with those addressed to his son, brothers, friends, and literary disciples $(M B, 73-120)$. Here too Chandar Bhan apologizes that his readers will have to be content with only a sampling of such letters, because if had he included all the many letters he had written since "the exuberant days of my youth and the first stirrings of literary activity" (shorish-i aiyām-i jawānì wa garmī-yi hangāma-yi sukhandānī) it would have required another volume entirely.

Beyond his own works, another small set of letters to and from Chandar Bhan is scattered in various insh $\bar{a}^{\prime}$ collections from the period. For instance, the contemporary historian of Shah Jahan's reign Muhammad Salih Kambuh included a letter to our munshī in his unpublished collection of miscellaneous writings Bahār-i Sukhan (The springtime of expression; 1655). ${ }^{10}$ The preface to Bahār-i Sukhan was written by Salih's friend, the celebrated poet Abu al-Barakat Munir Lahori (d. 1644), who was himself also a friend and correspondent of Chandar Bhan. At least one of Munir's letters to Chandar Bhan has survived and is reproduced in Lachmi Narayan Shafiq's eighteenth-century literary biographical compendium, Tazkira-yi Gul-i Ra'na. ${ }^{11}$ There is also a letter addressed to Chandar Bhan by an unknown author in an unpublished notebook (bayāz) of Mughal epistolography called Maktübät-i Mukhtalifa, housed in the manuscript archive of the Bombay University library. ${ }^{12}$ We do not know when it was written, but the letter, which deals mostly with the themes of friendship and mystical longing, was probably penned sometime in the 1630s, as it is addressed to "Chandar Bhan, the munshi 
of Afzal Khan, from myself" (ba Chandar Bhān munshī-yi Afzal Kূhān az jānib-i $\underline{k}$ wud -alas, since it is not entirely clear who made the collection, we don't know who that "myself" actually refers to.

Another massive, hitherto unpublished, collection of Mughal insha' known as Majma' al-Afkār (A collection of thoughts) contains three letters from Chandar Bhan. ${ }^{13}$ The first is to the architect Mir 'Abd al-Karim, his first patron, and appears unique to this manuscript. Another lengthy letter, also unique to this collection, is addressed to one Khwaja Bhag Mal, in which Chandar Bhan discourses on a number of literary, spiritual, and ethical subjects but also reflects on the ways he has matured since the days of his headstrong youth, when, he explains, "I was adrift in the roiling seas of adolescence, and had plugged my ears with the cotton of carelessness" (dar āghāz-i hăl ki daryā-i jawānì dar josh wa pumba-yi ghaflat dar gosh büd) (fol. 207b). The third is to Muhammad Jan Qudsi (1582-1640), one of the preeminent poets of the era, who had come to India in 1632, at the age of fifty, and immediately established himself as a fixture at Shah Jahan's court. ${ }^{14}$ Unlike the other two epistolary specimens in Majma' al-Afkār, this one is actually included by Chandar Bhan himself in both Munsha'ät-i Brahman and Chahār Chaman (see below).

One imagines that a perusal of more of the dozens of unpublished collections of miscellaneous insh $\bar{a}$ ' produced during this period might turn up even more letters to our munshī-but only further research can tell us for sure. What we do know, even from this handful of examples, is that the seventeenth-century Mughal culture of personal letter writing was extremely robust and that intellectuals across the spectrum of Mughal social and cultural life not only were availing themselves of new opportunities to transmit their "epistolary selves" via the Mughal postal system but also had a kind of meta-awareness of letters themselves as important cultural artifacts that ought to be collected and preserved. Whether all this represents a shift toward a more "early modern" sensibility among the Indo-Persian intelligentsia, however, remains to be seen.

\section{PATRONS, POETS, AND PARENTS}

All this brings us back to Chandar Bhan's own sense of self-fashioning in Chahār Chaman, another good source for understanding his epistolary practice. Again, the autobiographical essay that opens the third chaman segues directly into a compilation of his letters, followed by a fourth and final chaman dealing with his mystical, spiritual, literary, and ethical musings. In other words, our munsh $\vec{\imath}$ autobiographical impulse, his epistolary practice, and his views on mystical civility were all three clearly related in the construction of his public persona.

Though far fewer than those collected in the Munsha'att, the letters compiled in Chahär Chaman are arranged according to a similar pattern, albeit not explicitly. 
Thus the first five letters are to important nobles with whom Chandar Bhan corresponded over the course of his career, with one each addressed to the wazirs Asaf Khan, Afzal Khan, Islam Khan, Sa'd Allah Khan, and Ja'far Khan. Oddly enough, though, especially in a text so much of which is dominated by Chandar Bhan's views of Shah Jahan and his court, he does not include here any of his letters to the emperor, or to Aurangzeb 'Alamgir for that matter, that we find in the Munsha'àt. Be that as it may, these first few letters are nevertheless revealing, not just for the raw information they provide us, but also for what they tell us about how Chandar Bhan presented his epistolary self to his superiors. Note too that they are arranged chronologically in the order of their recipients' respective tenures as prime minister, which was also, of course, the order in which Chandar Bhan himself worked for each of them. He thus subtly recapitulates the linear arc of his career simply by the arrangement of letters in the compilation.

The first letter is a thank-you note of sorts to the celebrated noble and member of the extended royal family Abu al-Hasan Asaf Khan (d. 1641), whom we discussed briefly in chapter 1. As we noted there, Chandar Bhan never worked for Asaf Khan directly, but the latter did have an important indirect influence on the course of Chandar Bhan's early career. Our munshi was then still in Lahore, working on the fringes of the Mughal bureaucracy in the closing years of Emperor Jahangir's reign (1605-28), and spent much of this period working with the noted architect Mir 'Abd al-Karim Ma'muri. But at some point Chandar Bhan also developed some sort of working relationship with one 'Inayat Khan, an official who was at the time serving as governor of Lahore province.

'Inayat Khan had himself had been a protégé of Asaf Khan, whose training Chandar Bhan credits with instilling such a high ethical standard in 'Inayat Khan that "he had neither peer nor equal in terms of rectitude and integrity" (dar rāstī wa durustī 'adīl wa nażì nadāsht). Meanwhile, 'Inayat Khan had apparently promised to recommend Chandar Bhan's services to his mentor, who was of course one of the most powerful and respected members of Mughal courtly society. But, as Chandar Bhan explains in the letter, "the vicissitudes of fate" (ittifāqāt-i rozgār) had prevented this from coming to pass, and our munshi eventually wound up in Afzal Khan's employ rather than that of Asaf Khan himself. Nevertheless, he explains, since Chandar Bhan had learned so much from 'Inayat Khan, who was himself Asaf Khan's protégé, our munshī considered himself already "in reality a part of the eminent Nawab's network" and hoped that now that he had become a part of the central Mughal bureaucracy he would benefit from Asaf Khan's direct tutelage and "alchemical gaze" (nazar-i kimiyā-așar) $(C C, 151){ }^{15}$

This letter to Asaf Khan, probably written in the early 1630 , is followed by a single letter to Afzal Khan (d. 1639), who was, as we have seen, arguably the most important early patron of Chandar Bhan's career. It is introduced by a subheading explaining that it is "a faithful epistle addressed to that magnanimous scholar of the age, the 
illustrious, erudite, and magnificent exemplar, the grand wazir and illustrious khan, Afzal Khan, the gentleman par excellence" $(C C, 152-53){ }^{16}$ This is followed by one of the more extended opening salutations in our munsh $\widehat{\imath}$ s epistolary repertoire, beginning: "The humblest of devoted servants and hopeful well-wishers, Chandar Bhan Brahman, who wears the thread of servitude around his sincere neck, and the sandal paste of bondage on his loyal forehead, like an insignificant speck submits this letter to the master, the qibla of truth and the ka'ba of erudition, and relates that..." and so on.

Like the letter to Asaf Khan, this letter too is undated-alas, almost all of them are-but we may intuit from the contents that it may have been written sometime toward the end of Afzal Khan's life, because in it Chandar Bhan explains that after obtaining leave from the emperor to travel to Lahore on personal business, the first thing he did upon arrival in his home town was offer prayers for the eminent khan's health and long life at the "shrine of the gift-giver" (dargāh-i wähib al-'ațāyā). This could be a generic reference to God (i.e., the divine "gift-giver"; wāhib al-'atāyā) on Chandar Bhan's part, or, perhaps even an oblique reference to the tomb complex of the eleventh-century Sufi saint Pir 'Ali Hujwiri, who is known colloquially as Dāta Ganj-Bakhsh (The Giver of [Divine] Treasures), and who is buried in Lahore. At any rate, as he made his way around touring various buildings and palaces, Chandar Bhan continues, "I was constantly reminded of the litany of the exalted Nawab's virtues and good works." Chandar Bhan also reports that one Ishwar Das, then the province's minister of architecture (mutașaddi-yi 'imärät), "had demonstrated his great competence and excellent taste with respect to every heavenly building" in the area, including, presumably, Hujwiri's tomb complex. In other words, to reiterate a theme from earlier in the book, not only was Chandar Bhan himself perfectly comfortable visiting the shrine of a Sufi saint for blessings, but under Shah Jahan it was also possible for a Hindu administrator to be placed in charge of regulating the upkeep of all Mughal monuments and other landmarks in Lahore, including specifically Muslim sites like Pir 'Ali Hujwiri's tomb, which, as we noted in the previous chapter, was one of the most notable spiritual and tourist attractions in the entire region.

The next two letters in the collection provide Chandar Bhan with opportunities to display his poetic virtuosity, as each contains one of the munsh $\vec{\imath}$ s own ghazals at the end. The first is to Islam Khan, with whom we have already seen Chandar Bhan exchange verses, and is marked off by an elaborate heading similar to the one that introduced Chandar Bhan's sample of his correspondence with Afzal Khan. This was, it should be said, only appropriate for a subordinate like Chandar Bhan writing to the prime minister of the empire. But the two men were also clearly good friends, and the letter itself begins simply: "Greetings, great sir, the qibla of connoisseurs!" (nawāb șāhib qibla-yi qadr-dān salāmat) (CC, 153-54)-a drop in formality that is likely to indicate, not necessarily that he thinks any less of Islam Khan than of his predecessor as wazir, Afzal Khan, but rather that this is simply a different type of letter, on a less sober topic. ${ }^{18}$ 
In it, Chandar Bhan complains that he has been so busy lately that "these days I can barely even remember myself, or keep track of what I myself have

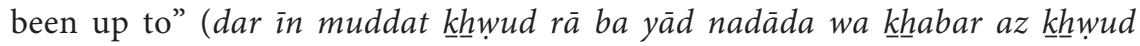
nadāshta). But when he finally had some free time "and had a brief respite to recover my senses," he explains, he realized that it was a good opportunity to rekindle his correspondence with "the affectionate sir" (sāhib-i mihrbān) and wondered, too, "why my esteemed mentor appears to have forgotten me, his complete and sincere well-wisher." In such a situation, he asks with an almost cheeky rhetorical flourish, "From whom can I expect justice, from whom can I beg for fairness?” (man inșāf az kai knhwāham wa dād az kai țalbam). Chandar Bhan goes on to explain that he has been working night and day on imperial business, and hopes that Islam Khan will remember him fondly to the emperor, as well as to the other members of the imperial assembly. He closes the letter with "a ghazal that immediately sprang to mind with the thought of the pleasure of your company," adding that he hopes it will be "agreeable to your discerning taste":

No one knows my condition in this solitude;

No one knows the condition of an indigent stranger.

My eager hands so small, your skirt so great;

These insufficient arms cannot attain their objective.

I come madly with my passionate forehead prostrate on the path to you, ${ }^{19}$

For one does not journey the path of love on erect legs.

The dust of your lane is a pearly collyrium for the eye;

Mere ointment brings no relief to the lover's sight.

What will be the fate of Brahman's frail heart

If the medicine from your charm factory fails to arrive?

[kasī zi bì-kasī-yi mā ba hāl-i mā narasad

kasì ba hạl-i gharībān-i bì-nawā narasad

marā-st dast-i țalab past-o-dāman-i tu buland

zi kūtahì-st ki dast-am ba mudda'ā narasad

jabīn-i shauq ba rāh-i tu sauda mīyāyam

ki țai-yi marhala-yi 'àshiqī ba pā narasad

ghubār-i kū-yi tu kuhl al-jawāhir-i baṣar ast

'ilāj-i dìda-yi 'āshiq ba tūtiyā narasad

buwad chi ḥāl-i dil-i knhasta-yi barahman rā

zi kār-khānna-yi luțf-i tu gar dawā narasad]

(CC, 153-44) 
Once again, Chandar Bhan casts Islam Khan in the role of absent beloved and himself in the part of tormented lover hoping for a glimpse of her to relieve his suffering.

There is a slightly different tone, however, to Chandar Bhan's next letter, described in the heading as "a letter seeking corrections, addressed to the pillar of pillars of the age, the cream of learned men of the world, the scholar of Platonic vision, the grand wazir of Hindustan, Sa'd Allah Khan, written with the pen of sincerity" (CC, 154-55). ${ }^{20}$ The letter appears to have been written sometime soon after Chandar Bhan was initially assigned to work with Sa'd Allah Khan, when the latter was appointed to take over as prime minister for Islam Khan in 1645; and the "corrections" (ișlāh) in question refer specifically to literary guidance. Chandar Bhan explains that previously, "when this humblest of servants had the good fortune to be employed in the service of the lately deceased most eminent scholar and intellectual of the age, Afzal Khan, I sent a fresh ghazal to him every day for suggestions, that it might be transformed under the examination of the late khan's alchemical gaze."

It would appear, then, that Afzal Khan's death had deprived Chandar Bhan not only of his first great patron but also of one of his most important literary interlocutors, and he therefore hoped to cultivate a similar relationship with his new boss, Sa'd Allah Khan. Thus, he explains, "I have decided for myself that from now on I will submit whatever poetry or prose emanates from my defective character for review and corrections by the Nawab, who is a kind and a keen judge of quality." Accordingly, the letter concludes with "a freshly composed ghazal written with my broken pen, which I hope will be agreeable to your most gracious and discerning eye":

We crafted our tales by the candlelight of the friend's face;

We burned like the flame, but turned ourselves into the moth.

How nice to be like the comb, silent despite a hundred tongues;

I too have learned, like the comb, to live with the twists and turns of your curls.

May the land of the civilized flourish! For I, in my solitude,

Have made my nook of sorrow into a treasure in the wilderness.

The principles of far-sighted reason are of no use to me!

I have been set loose, and make do with a heart gone mad.

Until we've become truly acquainted with ourselves, Brahman,

We have as yet encountered only the heart of a stranger.

[bā sham'-rū-yi dost ba afsāna sā $\underline{k} \underline{h} t \bar{i} m$

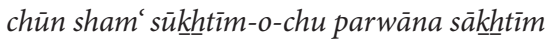

bā șad zabān chu shāna k̂hamoshī nikū buwad

bā pech-o-tāb-i zulf-i tu chū shāna sāknhtīm 
$\bar{a} b \bar{a} d$ bād mulk-i murūwat ki mā ba klhwesh

dar kunj-i gham chu ganj ba wīrāna sākhhtìm

bā mā nasākhht qā'ida-yi 'aql-i dūr-bīn

fārigh shudìm-o-bā dil-i dìwāna sāḳhtìm

tā āshnā shudīm barahman ba kl khweshtan

bā āshnā'i-yi dil-i begāna sākhhtīm]

An analysis of the literary delights packed into this short ghazal-not to mention translational challenges-could occupy us for many pages, but for present purposes what is important is that it is there at all. Sa'd Allah Khan was not only the newly minted prime minister of one of the most powerful empires on earth; he was, even more so than Afzal Khan, one of that empire's most capable and feared military commanders. Indeed, if he is remembered at all by modern historiography, it is, for good or ill, depending on one's perspective, almost entirely for these military exploits. And yet here we see him engaged in a private correspondence with his Brahman munshi, in which the secretary makes clear that a cornerstone of their working relationship will be the friendly exchange, discussion, and revision of poetry suffused with mystical and romantic themes-about being struck dumb by the beauty of the beloved, challenging orthodox pieties, glamorizing antisocial behavior, and celebrating the quest for individual self-knowledge. It is difficult to imagine a glimpse of everyday human, indeed humanist, cultural interaction more at odds with the commonly held image of Shah Jahan's era than this.

In this case the correspondence between the content of the letter and the metaphors in the appended poem is not as direct as it was in the letters to Islam Khan that we have quoted above. But it is nevertheless important to take note that the rich everyday literary and mystical cultures on display here were transmitted and circulated through private epistolary networks of which Chandar Bhan is able to provide only a glimpse, but that extended throughout the literate Mughal elite. Our modern image of Mughal poetic culture is largely that of professional poets in august courtly assemblies, reciting florid and elegant panegyrics in exchange for handsome rewards, or else plying their trade in exclusive private mahfils and literary salons. And it is true that those were obviously crucial domains of literary life in Mughal India. What we see here in Chandar Bhan's letters, however, is a far less conspicuous, but arguably even more pervasive, forum for everyday Mughal poetic culture, one that allowed for a seamless fusion of the idioms of literature, mysticism, and personal intimacy in one epistolary space, through exchanges between friends and colleagues that were entirely outside the public eye.

The final letter in this set is to Ja 'far Khan, in which Chandar Bhan updates the wazir on the progress of his recovery from an illness that apparently caused our munsh $\bar{i}$ to suffer an extended absence from court, and thus also from his duties in the dìwāni $(C C, 155) .{ }^{21}$ Remember, Ja'far Khan did not become prime minister 
until the late 1650s, by which time Chandar Bhan too was already getting on in years and was only a few years removed from his own retirement. One thus detects a hint of self-awareness regarding the onset of old age here, a tone that also dominates Chandar Bhan's letter to Aurangzeb announcing his retirement just a few years later $(M B, 12-13)$. Apparently, the illness had completely disrupted our munsh $\vec{\imath}$ s occupational routine of spending "night and day" working on the imperial business, and thus, he explains, for one who prided himself on his work ethic the effect of boredom caused by the inability to work had grown "most difficult" (sakht dushwār). Chandar Bhan goes on to explain that, "although I am beginning to recover thanks to the grace of God, the emperor's kindness, and the Nawab's own solicitude, nevertheless my body is still quite weak." Still, he closes the letter by noting that he hopes to be back at court soon, and he requests in the interim that Ja'far Khan convey his affectionate regards to the emperor, his fellow courtiers, and his colleagues in the dìwāni.

With the clever selection of just a handful of letters, then, Chandar Bhan provides his readers with a snapshot of his entire professional bildung-from the early years of his career, when he had to prove himself and work every connection possible just to break into the upper echelons of Mughal administrative and courtly society, through the middle years, when he developed lasting friendships and professional relationships with elite members of the nobility like Afzal Khan and Sa'd Allah Khan, right up to the period when he could reflect on a lifetime of hard work with the growing realization that he could no longer put the energy into his administrative duties that he once had as a younger man.

Along the way, Chandar Bhan had also befriended a good number of professional poets, letters to two of whom are the next to be included here. The first is to Muhammad Jan Qudsi (1582-1640) (CC, 155-56), a letter that is also included not only in Chandar Bhan's own Munsha'ät-i Brahman $(M B, 61-62)$ but also, as we mentioned above, in the miscellaneous compilation of Mughal insha $\vec{a}$ known as Majma' al-Afkār. ${ }^{22}$ The letter is fairly short-only eight lines, in the printed edition of Chahār Chaman-but it also has appended to it a seven-couplet ghazal, among the longest verse selections in the entire work.

Qudsi was originally from the holy city of Mashhad, in the northeastern corner of modern Iran-near the borders with Afghanistan to the east and Turkmenistan to the north-and in his early life he had had a successful commercial career as a grocer. ${ }^{23}$ These business skills, along with Qudsi's good reputation in the community, came in handy when he was appointed as the administrator of the important local shrine of the revered early shi' $a$ imam 'Ali Reza (765-818). Eventually, however, Qudsi's poetry began eliciting the interest of important patrons, and, after a brief stint at the court of Hasan Khan Shamlu, the Safavid governor in Herat-during which Qudsi was devastated to learn of his son's death back home in Mashhad and decided not to return-he made his way in 1632 to 
the Mughal court in India. He is remembered among critics and literary historians as one of the great all-around poets of the age, but it was perhaps in panegyric that he excelled the most, renowned for his exquisite poems in praise of not only various patrons but also the $\operatorname{sh}^{-} a$ imams and other religious figures. And it was precisely for such panegyrics that Qudsi was rewarded by Shah Jahan on more than one occasion with his weight in silver and gold. Twenty of his verses in praise of the emperor were even inscribed on the Mughal monarch's celebrated Peacock Throne. ${ }^{24}$

Chandar Bhan may have had these two features of Qudsi's biography in mind-his business background and his reputation for writing lucrative prizewinning panegyrics-when writing the letter included here in Chahär Chaman, because one of its most distinctive features is the clever way that the language of trade, money, and commerce courses through it:

A Bouquet from the Garden of Unity, sent to the Banquet of Purest Intellect, Mulla Muhammad Jan Qudsi

Nightingale of a Thousand Tales, may your gracious character, nestled amid the orchards of melody makers' expression, be forever loquacious and full of ghazals and sweet songs! In this bountiful age, which is among the most rarefied and distinguished eras [in history], the one who most delights in literary capital [naqd-i sukhan $]^{25}$ and best evaluates the masters of expression [qadr-i arbāb-i sukhan] is none other than your angelic self, that mine of eloquence and good taste [ma'dan-i fașāhat-o-baläghat]. Accordingly, it is incumbent upon all wayfarers in the land of meaning and wanderers through the valleys of poetry to remit their literary wares [matā'-i sukhan] from every region to the bounteous assembly of that great sophisticate of the world. Although the worthless poetic merchandise of this insignificant speck [matā'-i suknhan-i kāsid-i in zarra-yi bīmiqdār] is not nearly so fine that I may dare venture to offer it for such a purpose, nevertheless, in hopes of editorial guidance, I have set down a freshly composed ghazal here with my broken pen. I can only hope that the benefit of your revision will raise it to another level.

My heart is forever jealous of the breeze

Wondering why it too cannot caress the tips of her tresses.

One who possesses even a passing acquaintance with your veil

Would weave from that cloth a spectacular tale of epic beauty.

An uncanny new light blazes in the eye of whoever enters your lane

Where the dust of the road, [instead of blinding], is a healing collyrium.

A hundred times you have come crookedly down the path of love-

Otherwise the straightness of the road would have easily shown you the way. ${ }^{26}$

To seek forgiveness for past sins is simple enough;

To use past forgiveness as an excuse to err again, that is truly a crime. 
It produces no commodity of knowledge, nor any monetary benefit:

But why would you expect a return on investment from empty-handed prayer?

Brahman, it is best to detach and consign yourself to a corner,

For the highest achievement, after all, is in renouncing the very idea of achievement.

[ma rā hamesha ba dil ghairat-i șabā bäshad

ki āshnā-yi sar-i zulf-i ù chirā bāshad

kunad zi parda tamāshā-yi kārnāma-yi ḥusn agar kasī ba hijā̄b-i tu äshnā bāshad

ba chashm-i har ki rasad nūr-i dīgar afzāyad ghubār-i kū-yi tu ham-rang-i tūtiyā bāshad

tu dar tarīq-i muhabbat kaj āmadī șad bār w'agar na rāstì-yi rāh-i rahnumā bāshad

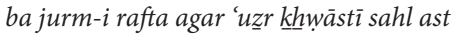

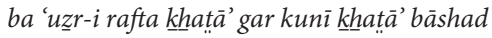

na jins-i 'ilm ba dast āmad-o-na naqd-i 'amal aṣar kujā ba tahī-dastīi du'à bāshad

barahman az tu hamān bih ki gosha-gìr shawi ki mudda'ā hama dar tark-i mudda'à bāshad]

$(C C, 155-56)$

It may not be as obvious in my paltry attempt at an English translation as it is in the original Persian, but there is a running play on the idiom of business transactions throughout this letter. Meanwhile, the commercial connotations of words like naqd (money, capital), ma'dan (mine, quarry, i.e., for precious metals and other valuable objects of exchange), matä (merchandise, goods, wares), and irsāl (dispatch, remittance, e.g., of a bill or invoice) all dovetail nicely too with the association of travelers (saiyārān and rah-rawān) with traders-in this case, wandering merchants of literary taste displaying and exchanging their wares for Qudsi's expert evaluation. Given Qudsi's background, it therefore appears to have been not just any play on words but rather one specifically crafted with the former businessman in mind. One suspects, too, that it was precisely this clever wordplay that made the letter stand out to the compiler of Majma' al-Afkār as a notable morsel of skilled Mughal insh $\bar{a}$.

The next letter, addressed to the poet, literary critic, and Chandar Bhan's good friend Abu al-Barakat Munir Lahori (1610-44), is roughly similar in substance to the letter to Qudsi, albeit without all the elaborate extended metaphors. Like Qudsi, Munir is widely considered to have been one of the great Indo-Persian poets of the seventeenth century and is considered by some even to have been somewhat 
of a literary prodigy, having reportedly begun his professional poetic career at the age of fourteen, and having claimed to have penned over one hundred thousand verses during his relatively short life. ${ }^{27}$ Munir also gained a reputation even in his own lifetime as a fierce critic, launching attacks in both satirical verse and independent essays against the perceived aesthetic flaws and violations of good taste of a number of high-profile contemporaries (see the next chapter for details). But as far as we can tell, his relationship with Chandar Bhan was excellent, and the two almost surely exchanged far more letters than the two that have survived. In this one, Chandar Bhan begins by praising Munir's poetic virtuosity and then follows the typical courtesy by humbling himself as a mere literary amateur and begging for the guidance of his esteemed colleague, appending yet another ghazal for Munir's-and our-perusal.

A heightened literary sensibility also figured prominently in Chandar Bhan's letters to his family members, to which he now turns with a letter to his father. This letter also includes a ghazal of nine couplets; notably, however, it is not part of a new section but rather a continuation of the section on letters to great nobles and literati. It is addressed "to that man of gracious stature, the qibla of truth, the $k a ' b a$ of erudition, my esteemed father, a man of all manner of affection, composed with the pen of fidelity" (CC, 157-58) ${ }^{28}$ —epithets that almost precisely echo those Chandar Bhan uses in his letters to Afzal Khan, whom he also refers to with salutations like "qibla of truth" (qibla-yi haqīqi) and "ka'ba of erudition" (ka'ba-yi tahqi $\bar{q} \bar{i})$ (e.g., in CC, 152).

Obviously there is an element of convention here that could neutralize any overinterpretation. But the use of "Muslim" terms like qibla and ka 'ba to describe the virtuous character of a Brahman, by a fellow Brahman, is nevertheless quite notable. Religion aside, moreover, the similarity of language suggests something about the parallels between how Chandar Bhan viewed his relationships with his father and with the erstwhile wazir, respectively. On the one hand, we may see it as the broader norms of Mughal social hierarchy being recapitulated in the microcosm of the family-a son using the norms of epistolary etiquette to show his father, the family patriarch, the same respect that he shows for his social and political superiors in the Mughal courtly elite. On the other hand, the reverse interpretation is also available to us, alerting us in retrospect to the fact that the emotional range of Chandar Bhan's relationship with Afzal Khan included not just professional courtesy, friendship, and the admiration of a servant for his patron but also a degree of almost filial devotion-even love.

The letter itself begins with lofty expressions of service and devotion that are also similar to those Chandar Bhan used in writing to Afzal Khan: "May this humble offering, expressing the earnest supplication and prayers incumbent upon those with the bond of service around their neck and the șandal-mark of duty on their forehead meet with a high degree of satisfaction; greetings, true qibla!' If the 
conventions of epistolary prose are any indication, in other words, Chandar Bhan seems to have viewed his father Dharam Das to be in the same social category of recipient as his erstwhile patron, Afzal Khan, entitled to be addressed with the same idiom of submission, courtesy, and respect. This is perhaps why the letter is placed in the same group as the letters to wazirs and respected literary mentors, rather than the subsequent group of letters to Chandar Bhan's son and brothers. In Chandar Bhan's view, his father's authority matched that of the prime minister of the empire.

In fact, a variant version of the letter found in some manuscripts (as well as Sayyid Muhammad Murtazá Qadiri's Urdu translation [1992: 148-51]) begins by saying that "the ties and bonds between a father and son are so great that if thought and imagination could try to comprehend them it would ignite a fire of passion from each direction." But, as Chandar Bhan goes on to explain, a son's love for his father is a complicated thing, neither a given nor constant. "Although it has been heard," he writes, "that a father's natural affection ['utüfat-i jibilli-yi pidar] for his son is always greater [beshtar] 29 than what the son reciprocates with devotion to the father, nevertheless, in light of my own example, I firmly believe that if a son is truly fortunate he will gather within himself a level of sincerity and trust toward his father that is far greater than the kindness his father could possibly show him." Our munshi did not come to this judgment easily, however, for he goes on to admit to his father that he has not always felt this way and that he had to mature from a somewhat headstrong youth before he learned to appreciate his father's wisdom. The same variant version of the letter adds:

Earlier, when my head was drunk with the pride and arrogance of youth, I kept a veil over the eyes of my heart that masked both my outward self-assurance and my inner [turmoil] and regarded whatever was contrary to prudence as the right course of action. But eventually, as I became more acquainted with various life experiences that introduced me to the subtleties of the meaning of life [ba-idrāk-i daqā'iq wa haq $\left.\bar{a}^{\prime} i q-i m a^{\prime} n \bar{i}\right]$, my purpose shifted toward polishing my inner self like the surface

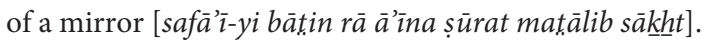

I now understand with clarity that the rewards of this world and the next come to those who put their heart and soul into serving their parents, [because] he who has the hand of his father on his head wears a crown of joy. The attainment of such happiness is the very aim of one's livelihood and the reward for having lived a good life..$^{30}$

The sentiments are expressed in somewhat high-flown prose, no doubt, but it is hard to think of a more universal human experience than the realization, after a rebellious youth, that one's parents were not nearly as obtuse as one thought they were, followed by the respect and admiration for them that such insight brings. One is almost tempted to speculate that perhaps Chandar Bhan wrote this letter sometime after becoming a father himself, but there is no way to know for sure. What 
we do know is that these broader philosophical ruminations on the volatile nature of father-son relationships give way to a much more mundane, yet also universal, sentiment-Chandar Bhan misses his father and wishes that they could meet:

Having made my eyes red from yearning, I now long for the happiness of actually seeing you - what more can I say? Maintaining the proper etiquette [demands that I] suppress the cry in my throat and the sigh of my heart, squeeze up the blood of my liver like a bud, and not say a word. [But] out of an abundance of love, I have said so many times, and say again, that I am a son who idolizes his father [man pisar-i pidarparast-am] and considers my service to this metaphorical god to be the highest form of devotion to the [universal] God of magnificence and grandeur ['ibādat-i $\underline{k} \underline{h} u d \bar{a}-y i$ 'azz-o-jall rā dar knhidmat-i ìn khhudāwand-i majāzī mīdānam].

The letter closes, as so many of Chandar Bhan's letters do, with "a freshly composed ghazal [that] has been written out with the pen of supplication." It is nine couplets long, among the lengthiest in Chandar Bhan's entire oeuvre, and it is with these nine couplets that he closes the section of Chahär Chaman containing his epistles to the authority figures in his life.

\section{THE MYSTICAL DIMENSIONS OF EVERYDAY MUGHAL CORRESPONDENCE}

Nearly all of the twenty-three remaining letters in the latter part of Chahär Chaman are addressed either to Chandar Bhan's brothers, Ray Bhan and Uday Bhan, or to his son Tej Bhan. Most of them deal with mystical themes or moral and ethical principles, but a couple of them do venture into more worldly matters-the most notable example being, perhaps, the poignant letter Chandar Bhan writes to his son concerning the death of his father, Dharam Das $(C C, 170-71)$. But before getting to the letters themselves, our author alerts us to the general mystical and moral tone of these epistles with an intriguing autobiographical aside:

In [earlier] days when this wayfarer through the valley of submission and acquiescence [rah-naward-i wādī-yi taslìm wa riz̄̄] was consumed with a passion for liberation, a mysterious tumult found its way into my heart and mind. But when I began to seek out the company of some of the wise men possessed of great equanimity [fuqarā-yi șâhibib-i jam ‘ìyat], a newfound freedom, quietude, and composure settled in my heart-even amid the hot commotion of the prime of my youth, passion, and excitement-and I developed an inner and outer calm.

Since poverty and wandering are among the ancient practices of Brahmans [az $\bar{a} n$ jā ki faqr wa sulūk à'inn-i qadìm-i brahmanān ast], the father of this faqìr was a faqi $r$, and my two brothers Ray Bhan and Uday Bhan are also faqìrs, who step by step have surpassed even their spiritual masters, and little by little have elevated their understanding of the states of mystical consciousness and ecstasy [jazzba-o-hāal] beyond even the level of great masters of consciousness [arbāb-i jażba]. 
These brothers have completely abandoned the ways of worldly employment and awareness of self in the world of material attachments ['älam-i ta'alluq]. A few of the letters that this servant of darweshes occasionally wrote to these two brothers, who are so familiar with Reality, have been copied out below. $(C C, 159)$

Here again, Chandar Bhan expresses his admiration for mystics and other holy men, and especially for those, like his brothers, who manage to distance themselves entirely from the "world of attachments" ('ālam-i ta'alluq), even if he himself was never able to do so completely. Note too that even though Chandar Bhan describes himself, his father, and his brothers using terms like faqì and darwesh-Persian terms that would generally be associated in India primarily with "Muslim" mysticism - he is at pains to emphasize that his family's mystical sensibility is in perfect harmony with "the ancient practices of Brahmans" ( $\bar{a}$ ' $\bar{n}$ - $i$ qadim-i brahmanān), for whom lives of poverty and wandering were considered not only appropriate but, in some ways, ideal.

Most of the "letters" that follow are really just short notes, many of them just a few lines long. A good number of them, moreover, lack any kind of salutation at all, making it hard to identify the recipient. And even where we are able to cross-reference the letters with the versions that sometimes also appear in sources like Munsha'at-i Brahman, they will often only say things like "to my brother," without specifying which one. We may surmise, then, that even if in their original composition these were intended as personal letters addressed to specific individuals, in their publicly circulated form they served a different function, perhaps simply as a vehicle through which Chandar Bhan could explore his understanding of a broad range of mystical themes.

Thus the first letter in this section, introduced by the subheading "A Note on Reality" (raqima-yi haqīat-āyinn), goes as follows:

May you be graced with special blessings. The root of prosperity lies in striving for the gnosis of Truth [ma'rifat-i haqq], and the apprehension of the condition of the self [dar-yāft-i hâal-i khwud], after the awareness of which comes the recognition that one's self is merely like a drop in the ocean, or a speck of dust floating in the sunlight of Reality [äftāb-i haqīqat], and [after this] the understanding and contemplation of the eternal and unending nature of the essence of the Real [żat-i haqq]. Quatrain:

You have kept on making us aware of the state of our own selves,

You have made a rose out of the thorn, and an entire ocean from a single drop;

Once we have fulfilled our debt of thanks to you,

We finally understand what you have done for us.

[mā rā chu ba hạl-i khhwud shināsā kardī

az khār gul-o-zi qatra daryā kardī

az 'uhda-yi shukr-i tu chu bìrūn āyìm

mà mìdānìm àn chi tu bā mā kārdī]

$(C C, 159)$ 
The echoes of William Blake notwithstanding ("To see a World in a grain of sand / And a heaven in a wild flower / Hold infinity in the palm of your hand / And Eternity in an hour"), as it turns out the version of this letter that appears in Munsha'ät-i Brahman is considerably longer and includes an extended dilation on the far less philosophical topic of Chandar Bhan's relationship with Afzal Khan, followed by a complete-and completely different-ghazal rather than the $r u b \bar{a} ' \bar{\imath}$ that is given here $(M B, 75-76)$. Clearly, then, Chandar Bhan was exercising some form of editorial discretion as he compiled these letters, consciously varying his self-presentation from one text to another. Unfortunately, he does not give us much clue as to the criteria upon which he based these editorial decisions. It could be that in Munsha'at-i Brahman he wanted to present his readers with the letters themselves, as he originally wrote them (or at least close to it), whereas in Chahär Chaman he was so conscious of organizing the text thematically that he decided to prune some of the letters in order to maintain the focus on the topic at hand and avoid digressions. In this case, that meant excising the more mundane content of the letter as it appears in Munsha'ät-i Brahman, leaving only the mystical kernel. But, absent a more exhaustive line-by-line comparison of the two texts, not to mention a collation of the many manuscript versions of the text, we cannot know for sure.

What we do know is that, at least in the selection compiled for Chahär Chaman, such mystical and moral themes dominate this part of the work. In the next letter he insists, among other things, that "the best habit one can cultivate in this world is to keep the company of the virtuous [șuhbat-i nekān]" $(C C, 160) . .^{31}$ And in the letter after that he extols the virtue of refining one's character, saying that "the first condition of this oasis of civilized manners [wādì-yi tahzīb-i akhlāq] is that when a person improves his manners [muhazzab al-akhlāq gardad] all phenomena become manifest in their desired form on the mirror of his heart [bar āyina-yi zamīr-ash har āyina șūrat-i mațlūb jilwa-gar shawad]." "Although this supplicant is still a prisoner of worldly attachments [giriftār-i qaid-i ta'alluq]," he adds, "nevertheless I never rest from the cultivation of praiseworthy manners [akhlāq-i hamìda]," and he punctuates the sentiment with a couplet urging the recipient (and the reader, presumably) to seize the day:

It is morning, time to rise from the sleep of heedlessness.

The chance to achieve your purpose is fleeting, wake up!

[șubh shud az knhwāb-i ghaflat sā'atì bìdār bāsh

furșat az andāza bìrūn mìrawad hoshyār bāsh]

$(C C, 160)^{32}$

Worldly virtue and civility, in other words, were intimately tied in Chandar Bhan's moral universe to the need to awake from the "sleep of heedlessness"

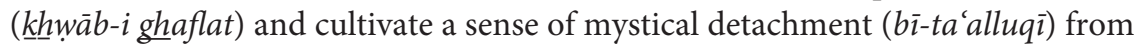
the everyday material world. 
As we noted above, one did not necessarily have to be a practicing Sufi or yogi, much less a complete renunciant, in order to benefit from these principles of mystical civility. On the contrary, in Chandar Bhan's vision of the ethical Mughal subject a certain familiarity with them was essential for anyone who aspired to a life of virtuous character and gentlemanly conduct. Thus in another letter he openly laments his inability to truly embrace the mystical path but reassures himself that: "at least by maintaining as a token the society of great men who are the guardians of these [mystical] stages [șuhbat-i buzurgān-i pās-i in marātib], this supplicant manages to cling to a certain equipoise [i'tidāl]; perhaps with the passage of time I can rise above this stage [sar az maqāmi bar äwarad] and reach my desired goal" - a thought he punctuates with the following couplet.

At last we have lifted ourselves above our place and station;

The discipline of our quest was not in vain.

[ākhhir sar az maqāmi-o-jā'̀̄ bar-āwurìm

bì-hüda nìst qā'ida-yi just-o-jū-yi mā]

$(C C, 160-61)^{33}$

In most cases, the verses that accompany these meditative epistles are clearly Chandar Bhan's own, and they often correspond to ghazals or rubāìs in his own Dìwān of poetry. There are others, however, like the one just quoted, that do not seem appear anywhere else in his oeuvre. These could perhaps be verses that he composed extemporaneously while writing the letter in question, or simply verses from poems that he composed over the course of his life and career but that were never included in the published Dìwān. But in a handful of cases Chandar Bhan also uses the poetry of others for an emphatic flourish.

A good example comes from another short letter to his brother Ray Bhan, in which Chandar Bhan comments on the difficulty, for most people, of subduing their physical desires (lazzat-i jismānī) in favor of spiritual pursuits (lazzzat-i rūhānin) $(C C, 161) .{ }^{34}$ This only increases his admiration for what he describes as "that special class of people" (țā'ifa-yi khāṣs) who can transcend the distinction altogether and arrive at true spiritual awareness. He ends this thought with a single cryptic line of verse:

Just see the distance on the way from where to where!

[babìn tafāwut-i rah [k-]az kujā-st tā ba kujā]

The tone of self-critique implicit here may be clear enough even if one does not know the source of this line, but Chandar Bhan clearly expected his brother (and his readers) to recognize these as the words of the celebrated fourteenth-century Persian poet Hafiz Shirazi (1325-90) and to read his own observations in light of the full couplet: 
Where is the do-gooder, and where a degenerate like me?

Just see the distance on the way from where [I am] to where [he has already reached]!

[șalāḥ-kār kujā wa man-i kharāb kujā

babìn tafāwut-i rah k-az kujā-st tā ba kujā]

Besides alerting us once again to the fact that a mastery of the classical IndoPersian literary canon was considered a staple of educated discourse in Chandar Bhan's intellectual world, the allusion to this particular verse is yet another indication of our munsh $\vec{\imath}$ s vision of the ethical Mughal subject. Even for a man at the center of worldly power and influence, such as Chandar Bhan himself, or the patrons and nobles he worked with, a certain humility was in order. One may not find the strength of character to overcome one's personal ambition, material desires, and so forth, but a recognition that one should strive to do so, and that it was possible to do so-as demonstrated by that "special class" of people who possessed such spiritual discipline-was nevertheless an important check on hubris and greed. Such awareness was thus not only a virtue in and of itself but also, in turn, an important factor in promoting the larger set of ak $\underline{h} l \bar{a} q \bar{\imath}$ virtues such as justice, moderation, and tolerance that were so essential to Mughal civility.

Chandar Bhan's letters to his brothers continue in this vein for some time, reiterating this same basic didactic message, that the cultivation of the ethical self requires an awareness of mystical civility. But such precepts could also lend comfort in a time of crisis or emotional distress, as we see from the first letter to Chandar Bhan's son included in Chahär Chaman, in which he conveys the news of his father's death $(C C, 170-71) .{ }^{35} \mathrm{He}$ explains that the news, which Chandar Bhan himself learned from a letter from his "grief-stricken brother," transformed the loveliness of spring into an autumnal misery, as though "a caravan of pain and anguish from the land of hopelessness had dumped its entire cargo in the city of my afflicted heart and saddened mind." He goes on to describe at some length his own efforts to control his grief once "the cotton had been yanked from my heedless ears." Once he accepted the news, he continues, "I entered such a stupor that I was frozen like a painting on the wall, and even though I was cognizant of the world around me I quickly descended into a world of madness and derangement, to the point that since my hands were incapable of reaching my soul I grew crazed and tore at my shirt instead." He found himself weeping uncontrollably and cursing the heavens, as if "there was no longer any brain in my head, nor any sense in my mind," before finally entering a kind of daze in which "my mouth, though like a rosebud with its hundred tongues, had gone silent, and the excessive stupor had silenced the ability of my lips to speak."

Despite these tribulations, Chandar Bhan goes on to reassure Tej Bhan with some consoling words. "Still," he explains, "since it is a principle among those who cultivate the habit of equanimity to place the string of acquiescence in the 
hands of providence, and to avoid placing themselves at the center of things, I wrapped up my sadness in the hem of the tunic of resignation and, giving my acceptance over to fate, made the bitterness of this heartbreaking calamity, the mere thought of which still makes my pen gush with tears of black blood, more palatable with the sherbet of forbearance [ba sharbat-i șabr k khwush-guwārā sākh ht]." The healing of Chandar Bhan's shattered psyche was also aided, incidentally, by affectionate gestures of condolence from none other than Emperor Shah Jahan himself-who, he explains, upon hearing the sad news of Dharam Das's death "elevated this insignificant speck, this frail ant, in this world and the next by publicly gracing me with a robe of honor in his Solomonic assembly." "With just one benevolent word," Chandar Bhan adds, "[the emperor] gave some respite to my afflicted heart."

This touching moment of overlap between the public world of the court and the intimate world of Chandar Bhan's family then segues directly into the longest, and in some ways the most intriguing, letter in the munsh $\vec{\imath}$ s entire oeuvre: the "letter of advice" (nașihat-nāma) to his son Tej Bhan that we referenced briefly at the beginning of chapter 2 (CC, 171-77). ${ }^{36}$ The letter is replete with guidance for Tej Bhan (and of course Chandar Bhan's readers) on the kinds of upright character and professional skills required of the successful imperial munshi, providing, as Muzaffar Alam and Sanjay Subrahmanyam have noted, a kind of "syllabus" for how to cultivate the right knowledge and necessary skills. But the letter also dwells at length on how to cultivate the kind of habits, temperament, and civility that Chandar Bhan considered to be essential traits of any successful Mughal gentleman. Once more, he expounds at length upon the moral necessity of treating the material world with an air of detachment (bi-ta'alluqī), but he also urges Tej Bhan to "maintain his hold on the reins of proper Reason ['aql-i durust] at all times, in every place, while sleeping and awake, in a stupor and while alert" $(C C, 172)$.

But as the third chaman ends and gives way to the fourth and last, a somewhat different perspective begins to dominate the final pages of the work. Here we are treated to a repeated display of our munsh $\vec{\imath}$ s deepest and most esoteric thoughts on various philosophical topics, from the nature of language (sukhan), to Chandar Bhan's favorite theme of the desire for spiritual detachment (lazzat-i tark-i ta'alluq). Other miniessays and aphorisms in this section concern things like "constancy along the path of acceptance of divine fate" (istiqāmat bar jāda-yi tawakkul), or simply, the nature of Truth (kaifiyat-i așl-i haqiqat), among other matters.

A running theme throughout these esoteric reflections is the tension between the individual's experience of the material world of phenomena perceptible through the physical and rational senses versus the deeper experience of existential, mystical, and cosmic meaning. A good example is the following passage on the "Nature of [Mystical] Ecstasy" (kaifiyat-i hāl), in which Chandar Bhan appears 
to be advocating precisely the opposite state of mind to what he has just advocated to his son Tej Bhan in terms of cultivating "proper Reason" ('aql-i durust):

\section{Kaifiyat-i Hāl}

Once the veil of obliviousness [hijāb-i ghaflat] is lifted from in front of the eyes of the heart, the fire of True Love [ätish-i muhabbat-i ma'nawī], which was hidden and concealed in the ashes of existence, instantly sets ablaze the flame that had been suppressed there. The longing for that special object that had been cast aside to the edges of the intellect and the outskirts of the soul is refreshed anew.

The imagination and contemplation that are necessary at the very outset in order to rouse one's passion toward achieving the goal [imbi'äș-i shauq bar nail-i $m a q s \bar{u} d]$, and that stiffen the seeker's resolve to tread the path of desire and the way of searching [eventually] produce a fresh radiance that gathers at the forefront of the heart.

Thereafter, once the image of True Beauty [șürat-i shähid-i ma'nī] is transformed into a refulgent manifestation in the assembly of singularity, the spark of passion [shauq] engulfs the hem of the heart and the collar of the soul-regardless of whether one is in a state of dreaming, wakefulness, oblivion, or alertness. The head looks up and around from every direction, and the mystery of Love that had been annihilated by the repression of that old man Reason sounds a great alarm [gosh$m \bar{a} l$ mìdād], and [the seeker's] visage begins to beam with a visible splendor [bar manașşa-yi zuhūur jilwagarī namūd].

The breeze from this springtime of passion causes the previously pursed lips of the buds of desire to blossom, while in the mirror of thought [āyina-yi khiyāl] the pageant of the multiplicity of forms and meanings becomes comprehensible, and from out of the darkness of anxiety the true objective is obtained, as if the water of life. $(C C, 195-96)$

In these cryptic thoughts on the nature of perception versus reality, the irrational and ecstatic are clearly privileged over the rational perception available to the senses. The latter, in fact, represent an illusion, and it is only after one lifts this "veil of obliviousness" (hijāb-i ghaflat) that one can experience the triumph of Love over Reason, and the ultimate oneness of the universe. In another passage, described simply as "an observation" (nukta), Chandar Bhan argues, in fact, that what we typically perceive to be reality is in fact nothing but an illusion, a dream state from which we can only awake with esoteric gnosis.

Nukta

O you who have the sleep of heedlessness [ $\underline{k} \underline{h} w \bar{a} b$-i ghaflat] pulled up over your head, [know that] time has a stone up its sleeve, and a glass in hand. How long will you be intoxicated by the cheap wine of wakefulness [ $k \underline{h} \bar{a} m-i$ hosh]? How long can you continue deluding yourself with the sleep of heedlessness? The sun has crossed the zenith, and the goblet has been drained of wine. While you were still busy with the cheap wine [of material attachments], the morning of desire has already turned to evening. Couplet: 
From the first time you blinked your eyes, life was already at the beginning of the end; We have tread this path without producing so much as the sound of a footfall.

[chashm tā bar ham zadī anjām shud āghāz-i 'umr tai shud ìn rah ān chunān k'āwäz-i pāy bar nakh hāst] $(C C, 199)$

The final pages of Chahār Chaman are replete with such esoteric passages, many of which would be perfectly at home in any discussion of arcane Sufi interpretations of the "unity of being" (wahdat al-wujūd), or the speculative traditions of influential medieval and early modern philosophers like the great Andalusian thinker Ibn al-'Arabi (1165-1240) or the celebrated Persian illuminationist philosopher Mulla Sadra (1572-1640).

Mulla Sadra, in fact, may be particularly relevant here given that he was part of a new wave of early modern philosophers and other intellectuals that has come to be known as the "Isfahan school" and that also included luminaries such as Mir Findarski (d. 1641), Shaikh Baha al-Din Muhammad al-'Amili (aka "Shaikh Baha'i"; 1547-1621), and Mir Muhammad Baqir al-Astarabadi (aka "Mir Damad"; d. 1631). Deeply influenced by the ishrāqi illuminationism of the medieval Sufi saint Shihab al-Din Suhrawardi (1171-1208), as well as the neo-Platonic and neo-Aristotelian metaphysics of Ibn al-'Arabi (1163-1240) and the thought of other, even earlier figures such as Ibn-i Sina (979-1037), their works were also meant to revive, revise, and synthesize these various strands of the Hellenic and Perso-Islamic philosophical traditions. ${ }^{37}$ Needless to say, their works were also widely read in India, quite possibly by Chandar Bhan as well. And, in turn, many of the "Isfahan school" thinkers were themselves fascinated with India and Indian thought. Mir Findarski, in particular, not only traveled to the subcontinent but also wrote extensively on Indian religions, most notably in a commentary on a Persian translation of the Yoga Vasistha prepared by Nizam Panipati and originally commissioned by Jahangir while the latter was still a prince. ${ }^{8}$ So there is little doubt that the robust traffic in such philosophical ideas across the IndoPersian world would have had some influence on our erudite and intellectually curious munshi.

When we recall, however, that Chahär Chaman as a whole was intended as a didactic text, carefully crafted to display the exemplary skills and attributes of a successful imperial secretary to the wider Indo-Persian reading public, we must ask: What are these esoteric passages even doing in this work? One answer, of course, is that Chandar Bhan simply wanted to show that such metaphysical conversations were an important part of his everyday life, and especially his relationship with his brothers. In so doing, however, he also communicates to his 
readers - and to us - the fact that brief notes like this (he often refers to them simply as nuktas, or "points") were an important genre of Mughal writing unto themselves, a common, informal vehicle for the circulation of esoteric ideas via the epistolary networks of the day.

But there is another interpretation as well, one that I believe lies in Chandar Bhan's more general views on the ideals of humility and self-control incumbent upon those who were given the privilege and responsibility of governance. At the philosophical level, Chandar Bhan valorizes a certain mystical epistemology, reflected for instance in his exaltation of the dream state $(\underline{k} \underline{h} w \bar{a} b)$ over the more quotidian "reality" of wakefulness ( $b \bar{i} d \bar{a} r \bar{i})$ and the allure of worldly desires and attachments ( ta $^{\prime}$ alluqāt), which to him were mere illusions that distracted one from the true, cosmic Reality. These are common enough themes in Sufi and Vedantic thought, of course. But it is precisely in his repeated calls to abnegate the self that Chandar Bhan winds up, ironically enough, giving us powerful insight not only into his own personality but also into his wider views on the nature of Mughal service and the ideal attributes of those charged-as he was for much of his life-with the day-to-day exercise of Mughal power, administration, and governance.

Indeed, for Chandar Bhan, recognizing the dreamlike, illusory nature of empirical reality was not an excuse to withdraw entirely, as the hermit does, but rather an ethical demand placed on the Mughal gentleman-to avoid greed, to work hard, to cultivate one's moral self, and to make the most of life. Perhaps nowhere is this ethos voiced more explicitly than in one of the last passages of Chahār Chaman, "A Vision of the Morning Garden," in which Chandar Bhan urges his readers to remember that life is short, so they had best make the most of the time that they have:

\section{"A Glimpse of the Morning Garden" [Nazzāra-yi Gulshan-i Șubh]}

Before the rays of the great illuminating sun overspread the earth and the day; and before the chatter of the morning birds claws at the hearts of meditative people [arbāb-i hâll]; you should rise up from your dreams together with the heartblossoming and perfume-scent-scattering breeze of the morning garden and take in the panoply of sights and smells of this colorful garden [of the world].

Lucky is he who, taking time's rope [sar-rishta] in hand, understands that this state of wakefulness and the people who are currently alive [to enjoy it] are ever more ephemeral than those that have already passed by, and thus treats each breath as though it might be his last.

Take care not to take your breath for granted for even a single breath,

For it could well be that this very breath may be your very last.

[ghaflat zi ihtiyāt-i nafas yak nafas makun

shāyad hamīn nafas nafas-i wāpasīn buwad]

$(C C, 196)$ 
It is precisely in his insistence on the ephemerality and transience of life, in other words, that Chandar Bhan produces, not fatalism and withdrawal, but rather a call to action-a sense of urgency that he, his brothers, and of course his readers should make the most of their this-worldly potential-even if it does all turn out to be one big dreamy illusion.

It would be a mistake, therefore, to read the contents of this fourth chaman simply as an afterthought, or as a random assortment of philosophical musings completely detached from the themes of the earlier parts of Chahār Chaman. When viewed in light of the overall ethical message of the text, these metaphysical epistles emerge as yet one more among the many varieties of life writing that Chandar Bhan used to craft his public persona-a persona that reflected, in every way possible, his understanding of the ideally fashioned Mughal self. 


\title{
Making Indo-Persian Literature Fresh
}

\author{
Chandar Bhan's Poetic World
}

All poets, in all ages, have placed a premium on timely themes, verbal dexterity, and aesthetic innovation, but in sixteenth- and seventeenth-century India there was a heightened sense of newness in the air. By the end of Emperor Akbar's long reign (1556-1605), the Mughal Empire was well established, and, as we discussed above in chapter 2, the ensuing years that coincided with Chandar Bhan's life and career saw the consolidation of a number of composite cultural trends that had, in many cases, been centuries in the making but now received a more explicit political and administrative formulation than ever before. An atmosphere of religious tolerance, a respect for scholarly inquiry and the arts, the rationalization of bureaucratic and administrative policies, and a welcoming respect not only for the cultural diversity of the subcontinent itself but also for the intellectual and commercial capital brought by travelers from around the world were all hallmarks of the Mughal state ideology of "universal civility" (șulh-i kull).

The sense of being on the cusp of a new historical era permeated the atmosphere of the Mughal court. Meanwhile, as one of the world's most wealthy, welcoming, and tolerant locales, early modern India had become a prime destination for an extraordinarily multicultural cast of global traders, artists, service professionals, and adventurers seeking commercial opportunity and artistic patronage-Turks, Afghans, Iranians, Armenians, Yemenis, Africans, Europeans, and many others besides. This multicultural influx didn't just add to the existing diversity of the subcontinent; the very fact that such radical pluralism was even possible fed the widespread belief among many intellectuals at the Mughal court and in the wider Indo-Persian world that a new age of social and political potential had arrived. The remarkable commercial and intellectual mobility throughout Asia and 
the Indian Ocean world during this period, both overland and by sea, produced ever-newer types of encounters that were transforming intellectuals' worldviews, giving many a palpable sense that an epochal change was under way, not just in South Asia, but across Eurasia.

One important factor in this early modern sense of epochal change across many parts of Eurasia and the Indian Ocean world was the turning of the Islamic calendar's new millennium in 1591-92 CE, which was itself only one calendrical signpost in what has been described as a much broader "millenarian conjuncture that operated over a good part of the Old World in the sixteenth century," from the Iberian peninsula all the way to South Asia and beyond. ${ }^{1}$ A giddy anticipation of new human possibilities accompanied this historical moment, in Mughal India no less than elsewhere, even as the excitement was accompanied in some quarters by an equally potent revival of messianic cults, visions of impending apocalypse, and omens of the end of days. ${ }^{2}$ It has even been argued recently that a certain form of millenarianism, in which the king represented the earthly embodiment of divine astrological conjunctures, was the dominant mode of understanding sovereignty in the early Mughal world, and indeed in much of South, Central, and West Asia in the post-Timurid era. ${ }^{3}$

But the sense of temporal transition was not limited to the eschatological, as a number of South Asian knowledge systems were undergoing unprecedented internal changes in the sixteenth and seventeenth centuries. It was around this same time, for instance, that Sanskrit intellectuals first began drawing sharp contrasts between the work of "new" (navya) thinkers and that of "antiquated" (jīrna) scholars of generations past, inaugurating a self-consciously "new historicality by which intellectuals began to organize their discourses." 4 The "New Grammar," the "New Poetics," the "New Logic," and so on remained largely in conversation with the classical Sanskrit tradition, but the navya discourse nevertheless opened up a space for novel forms of poetic and scholarly self-expression, including robust new idioms of regionalized Sanskrit literature, or kāvya. ${ }^{5}$

Meanwhile, by the sixteenth century South Asia's "vernacular millennium" was well under way, as poets and other literati increasingly began to use spoken, regional, and other demotic languages for their compositions instead of-or in some cases in addition to-the more "classical" cosmopolitan languages like Sanskrit and Persian. ${ }^{6}$ The two centuries before the Mughal consolidation of power thus witnessed the emergence of flourishing new genres and literary practices in northern India, from the writings of antiestablishment devotional (bhaktī) saints like Kabir, Mirabai, Caitanya, Guru Nanak, and others, to Sufi romances in the Awadhi register of Hindi such as Maulana Da'ud's Candāyan (1379), Shaikh Qutban Suhrawardi’s Mirigāvatī (1503), Malik Muhammad Jayasi’s Padmāvat (1540), and Mir Sayyid Manjhan's Madhumālatī (1545), all of which drew on multiple linguistic and religio-cultural traditions to produce almost entirely new forms of 
literary expression. The famed Rāmcaritmānas (ca. 1574), an Awadhi version of the Sanskrit epic Rāmāyana by the celebrated poet Tulsidas (1532-1623), emerged out of this same mix of generic and linguistic dialogism, as did one of the first early modern autobiographies ever produced in South Asia, the Ardhakathanaka (Half a tale; 1641) by Banarasidas, a Jain merchant from Jaunpur who was an almost exact contemporary of our own Chandar Bhan Brahman. ${ }^{8}$

Banarasidas's witty memoir was written in Brajbhasha, another regional idiom that underwent a significant transformation during this period. Braj had long been known as a medium for regional devotional poetry, especially Vaishnava songs in praise of the Hindu deity Krishna and his consort Radha. ${ }^{9}$ But in the late sixteenth and early seventeenth centuries, Brajbhasha also began to emerge as the preeminent "courtly vernacular" of early modern North India. As Allison Busch has argued, Braj literati during this period such as Gang (d. ca. 1608), Keshavdas (ca. 1555-1617), and others engaged in a self-conscious and unprecedented effort to reinvent high classical Sanskrit tropes, poetics, and thematic topoi for their own compositions. ${ }^{10}$ The resulting riti style also included elements of the classical Persian literary idiom and became the darling of various Mughal, Rajput, and regional courts - an efflorescence that continued right up to the late nineteenth century, when such ornamental literary elegance in Hindi fell out of favor, as also happened with many early modern Persian, Urdu, and Sanskrit literary traditions that came under a withering critique from postromantic colonial and nationalist critics who viewed them as too "artificial" and "decadent" to be suitable for a modern national literature. ${ }^{11}$

Against this larger historical backdrop, it is perhaps not so surprising that IndoPersian poets like Chandar Bhan, too, would begin giving voice to a powerful sense of epochal transition in their compositions. Sure enough, over the course of the sixteenth and seventeenth centuries many early modern Mughal and Safavid poets and other literati across the transregional Indo-Persian ecumene articulated an unprecedented break with their literary past, a temporal distantiation most often invoked through calls for ingenuity and "freshness" (tāzagì) in poetic expression. It was not a complete break, though, in that even the most inventive "speakers of the fresh" (tāza-gūyān) - Chandar Bhan included-never went so far as to completely renounce the Persianate literary tradition that they had inherited. Rather, they continued to see themselves in a dynamic relationship with their poetic forebears, a relationship in which they, as the "latest" generation (muta'ak $\underline{k} \underline{k}$ hirin), took up the classical precedents of "the ancients" (mutaqaddimin) and brought them to new and transcendent levels through poetic ingenuity and imaginative effort (khayāl-bandī). ${ }^{12}$ Thus even though for the most part poets continued to adhere to the same basic set of norms that had been developing in Persophone literature for centuries-the Persian language itself, obviously, but also its rhymes, meters, prosody, and conventional poetic tropology - they did so in very 
self-conscious and formally innovative new ways. The goal, as the celebrated Mughal poet Abu al-Faiz "Faizi" Fayyazi (1547-95) put it, was to use the same "old words" (lafz-i kuhan) to generate "new meanings" (ma'ni-yi nau), and thereby to create an updated, "fresh" (tāza) sensibility for a new era in an increasingly interconnected new world. ${ }^{13}$

This nearly universal urge to "make it new" emerged some three full centuries before Ezra Pound would issue his own famous modernist dictum and would thus-or so one would think-be of considerable interest to scholars of literary modernity generally. ${ }^{14}$ Strangely, though, this has not really been the case. In fact, just as the various aspects of seventeenth-century political culture that we have been examining in previous chapters have received far too little scholarly attention, so too has the era's entire literary culture been virtually banished from modern Indo-Persian literary historiography. Indeed, one of the strangest things about the $t \bar{a} z a-g \bar{u} ' \bar{\imath}$ movement and this era of Indo-Persian literary culture generally is that its history, for all intents and purposes, has yet to be written in any proper sense of the word. This may seem like a stunning claim, especially considering that we are talking about the period that arguably witnessed the most prolific overall production of Persian literature worldwide. And yet it really is hard to argue otherwise, particularly when it comes to English-language scholarship.

The reasons for this scholarly neglect are quite complex, and I have examined them in some detail elsewhere..$^{15}$ Most famously-or rather infamously, depending on your point of view-modern critics have dismissed virtually the entire literary output of the sixteenth-eighteenth century Persianate world as suffering from some sort of flawed "Indian Style" (sabk-i hindī). Some have argued that this Indian influence on Persian literature diluted the "pure Persian" idiom of earlier classical eras, in some cases specifically citing the alleged ineptitude of Mughalera Hindu munshīs like Chandar Bhan for this defect. Others have argued that the real problem with the Indian Style was not linguistic dilution per se but rather the "Indian mind," which has often been essentialized in this scholarly literature as somehow more prone to abstract, recondite, and abstruse subject matter than that of other places. In this sense, sabk-i hindi simply refers to what modern scholars consider to have been an unwelcome excess of "artificial" complexity in the poetry of the period, for which they blame India alone. In other words, according to this line of thinking-which, incidentally, was not formulated until the twentieth century-just about any poets in the early modern Persianate world who showed any hint of novelty, eccentricity, or formal experimentation in their compositions were doing so under the spell of the "Indian style," whether or not they themselves were Indian, and indeed whether or not they had any connection to India at all.

Of course, these two positions are somewhat at odds, for it is hard to see how the alleged ineptitude of Persophone literati in India could simultaneously produce a literature so complex as to be not only unappealing but unintelligible (as 
more than one commentator has characterized the poetry of the so-called sabk-i hind $\bar{\imath}$ ). Be that as it may, the real problem from the perspective of literary and cultural history is that the entire notion of a characteristically "Indian Style" is an anachronistic and purely modern invention, one that would have been completely foreign to Chandar Bhan and any other poet of his era. This is not just a quibble about nomenclature, moreover. By treating certain features of the era's poetry as somehow essentially and timelessly "Indian," modern scholarship has approached these cultural phenomena far too ahistorically and in the process has almost completely forgotten that what the fresh poets-be they from India, Iran, Central Asia, Turkey, or somewhere else in the Persianate world-were really expressing was an exuberant sense of the novelty of the historical moment, one that cries out for examination as part of a larger conjuncture of global early modern literary consciousness.

The problem with the entire sabk-i hindi paradigm, in other words, is not necessarily its essentialism and its implicit—and sometimes explicit-cultural chauvinism, though that too is unfortunate. The real problem, analytically, is that it distracts us from the actual social, cultural, and historical dynamics that animated the Indo-Persian literati of the early modern period, nearly all of whom were far more interested in questions of newness and literary ingenuity than in "Indianness" as such. To see what this meant in practice, let us return to the poets and poetry of the period and try to see how they might have been viewed by someone with Chandar Bhan's sense of literary style.

\section{THE POETICS OF LITERARY REFRESHMENT}

Given how neglected this period of Indo-Persian literary culture has been in modern scholarship, it is difficult to know where to begin in terms of how to introduce readers to Chandar Bhan's perspective on such matters. Let us recall that Chandar Bhan was born in late sixteenth-century Lahore and that he most likely died in the late 1660 s, that is, about a decade into Aurangzeb 'Alamgir's reign. Throughout his upwardly mobile administrative career trajectory, Chandar Bhan also gained a reputation as a poet of some distinction, and like most poets of his day he collected his substantial body of Persian verse into a volume normally referred to simply as the Dīwān-i Brahman. ${ }^{16}$ His prose works, as we have seen in previous chapters, are also peppered with various ghazals (lyrics), rubāiss (quatrains), and individual couplets, some of which correspond to verses in the Diwwān, while others appear to have been stand-alone compositions. His poetic style has generally been praised by his immediate contemporaries for both its fluid elegance and its searching mystical temperament. But Chandar Bhan was also highly conscious, like most poets of the era, that he was living in what many saw as a new age, and he sought to inject that exuberant sense of newness directly into his verse. 
Where did this idiom of "speaking the fresh," of reinvigorating the classical Persian canon, actually come from? As we have seen from the discussion in previous chapters, Chandar Bhan lived and worked at a time when Persian language and literature flourished all over India, both as a courtly medium of elite literary expression (as it had already done for upwards of half a millennium), and as the official language through which the administration of the Mughal imperium was conducted. ${ }^{17}$ State policy encouraged Persian-medium education throughout the Mughal territories, not just for the literary and courtly nobility, but across the social and religious spectrum. Chandar Bhan's father, both brothers, and son Tej Bhan all appear to have been accomplished Persian writers, and the addressees of his letter collection, the Munsha'ät-i Brahman, are representative of a variety of demographics, as we have amply seen in earlier chapters.

Meanwhile, the lavish patronage available to poets and other literati at the $\mathrm{Mu}-$ ghal court, as well as the Persianized courts of the Deccan, attracted a steady flow of Persophone poets and other litterateurs from Central and West Asia to India, where they often found a congenial and lucrative haven in which to practice their craft. This was in stark contrast, often, to the political unrest in much of Central Asia during this period, which had made consistent patronage difficult to secure. Thus, as one poet of the times, 'Abd al-Razzaq Fayyaz Lahiji, put it: "Great is India, the Mecca for all in need / particularly for those who seek safety." ${ }^{18}$ Another "push" factor that made India an appealing destination for Persianate literati of this period was the Safavid Empire's increasingly restrictive vision of a $\operatorname{sh}^{-1} a$ state, a development accompanied by a considerably more censorious atmosphere that was generally inhospitable to overly provocative and antinomian poetry.

Ghazali of Mashhad (b. 1527), for instance, was a well-traveled and well-known Iranian literary figure long before he ever came to India. But in the sectarian political climate of Safavid Iran, Ghazali's poetry gained a reputation for "immodest"

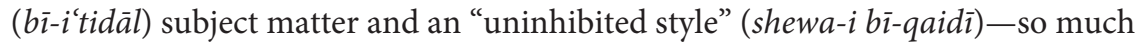
so that a group of "ulamā actually issued a fatwá calling for his execution. It was fear that this fatwá would be carried out that led him to leave for India, where, no longer fearing for his life, he eventually thrived as the emperor Akbar's first poet laureate (malik al-shu'arā). ${ }^{19}$

Indeed, Mughal India came to be viewed all over the wider Persianate world as a haven for intellectual freedom and literary genius, a place of such bounteous opportunity that, according to a verse of Talib Amuli (d. 1626) - another Iranian expatriate in India, who at one time served as Jahangir's poet laureate-any Iranian traveler who got homesick while sojourning there "should be ashamed of himself" (sharm bād-ash). ${ }^{20}$ For poets in particular, Mughal India developed a reputation as one of the few remaining places where sufficient patronage and institutional appreciation were available with which to perfect one's craft-a sentiment neatly summed up by 'Ali Quli Salim's famous couplet: 
The means of acquiring perfection do not exist in the land of Iran,

[Just as] henna has no true color, until it comes to Hindustan.

[nīst dar ìrān-zamīn sāmān-i taḥ̂ìl-i kamāl

tā nayāmad sū-yi hindūstān hịnā rangīn nashud $]^{21}$

As with henna, so too with poets, and thus there was a kind of double infusion of Persophone intellectual production into India under the Mughals: one homegrown and "grassroots," made up of relatively new South Asian demographics (represented by intellectuals like Chandar Bhan and his family) who were mastering Persian and deploying that mastery within the ambit of $\mathrm{Mu}-$ ghal imperial and subimperial administration, commerce, art, and culture; and the other transregional and cosmopolitan, made up of expatriates from across the Persophone world who came to India in search of asylum, patronage, commerce, employment, or plain old adventure. Some of these travelers wound up settling in the subcontinent permanently, while others, like the celebrated poet Sa'ib Tabrizi (ca. 1592-1676), stayed only for a relatively short time-in Sa'ib's case, barely seven to eight years-before returning home or continuing their peripatetic careers elsewhere. ${ }^{22}$

One crucial figure for the present discussion who did settle in India for good was Masih al-Din "Hakim" Abu al-Fath Gilani (d. 1589), whose intellectual circle appears to have been the first to actually begin using the expression tāza-gu' $\bar{\imath}$. We can, in other words, actually trace the usage of the term tāza as a marker of poetic value with relative historical precision, to about one or two generations before Chandar Bhan's own professional heyday. Abu al-Fath's father had been a local ecclesiastical authority in northern Iran but had fallen out of favor and had eventually died in prison after Shah Tahmasp I (r. 1524-76) conquered his home province of Gilan in 1566-67. Fearing similar treatment, Abu al-Fath, together with his brothers Hakim Hamam and Hakim Nur al-Din, sought refuge in India, where all three managed to gain appointments in Emperor Akbar's service.

Abu al-Fath never achieved an especially illustrious rank at the Mughal court, though the emperor was apparently quite fond of him, and he did distinguish himself in various governmental and military capacities before his death in 1589 . But it would appear, in any case, that his most lasting influence was clearly in the realm of literary culture, and the timing here is not insignificant for our purposes-Abu al-Fath died right about the time that Chandar Bhan was born, meaning that our own munshi would have received his education and literary training at exactly the time when the notion of tāza-gu' $\bar{\imath}$ was first becoming fashionable. Meanwhile, the earliest source to specifically credit Abu al-Fath

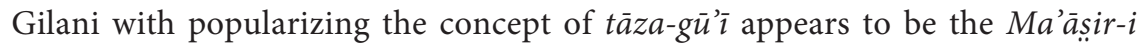
Rahimin (ca. 1616-17), a chronicle of the court of the celebrated Mughal grandee 'Abd al-Rahim Khan-i Khanan (1556-1627) by the Iranian émigré 'Abd al-Baqi 
Nahawandi (1570-1637). 'Abd al-Rahim's court was renowned for its literary and artistic patronage, and almost the entirety of the third volume of $M a$ 'a Rahim $\bar{\imath} \bar{i}$ is taken up with biographies of the many notable poets, artists, mystics, and others who enjoyed his patronage at one time or another. It is there that $\mathrm{Na}$ hawandi notes that the first literati to use such "fresh" terminology were those in Abu al-Fath Gilani's literary circle. "To the poets and literati of today," Nahawandi explains, "it is well known that tāza-gü' among the elegant poets of this era, such as Shaikh Faizi, Maulana 'Urfi Shirazi, etc., who all composed in this mode [rawish]—was introduced and promoted by [Abu al-Fath Gilani]." ${ }^{23}$

"Shaikh Faizi" refers, of course, to the renowned Indian poet and intellectual Abu al-Faiz "Faizi" Fayyazi (1547-95), who remains widely regarded as one of the greatest Indo-Persian literati of all time and was also the elder brother of Akbar's even more famous minister Abu al-Fazl.24 "Maulana” Jamal al-Din Muhammad 'Urfi Shirazi (1555-91), on the other hand, was an émigré from Iran who had gone to India in 1584, where he became a friend and sometime rival of Faizi, and is also usually lauded-or condemned, depending on the critic's vantage point-as one of the most formidable poets of the era. ${ }^{25}$ Both Faizi and 'Urfi are among the

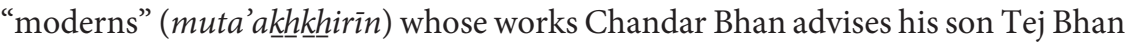
to study $(C C, 177)$, while Nahawandi describes 'Urfi, in particular, as the "inventor of the fresh style" (mukhtara'-yi tarz-i tāza). Significantly, Nahawandi also calls attention to 'Urfi's considerable success in the literary salons of Shiraz even before he came to India at age twenty-nine, adding that "he has won accolades for his

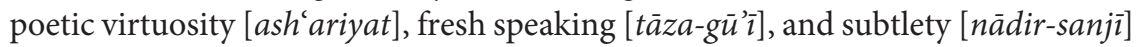
among the people of Iraq, Fars, Khurasan, Turkistan, Hindustan, and the far corners of the world." ${ }^{26}$ Indeed, it was perhaps because he lived in an age of such unprecedented cosmopolitan mobility that, according to Nahawandi, 'Urfi was able to achieve a level of fame that his "peers and equals, namely the master literati of the past such as Khaqani, Anwari, Sa 'di, and Shaikh Nizami," were unable to experience in their own lifetimes. ${ }^{27}$

Within the trio, then, Abu al-Fath Gilani seems clearly to have acted as more of a facilitator, patron, and intellectual inspiration than a prolific litterateur himself. Apart from a collection of letters, he has not left behind much of a literary oeuvre, although he was known as a talented physician (hence the epithet "Hakim") and is credited with writing a handful of notable treatises, including a commentary on Ibn Sina, as well as a manual for physicians called Mujarrabāt (Proven remedies).$^{28}$ (He is also popularly credited, incidentally, with introducing the hookah to India.) Abu al-Fath Gilani obviously had an eye for literary talent, though, and Nahawandi mentions that he was among the first in India to recognize 'Urfi's genius and secure patronage for him, while Faizi, for his part, exalts the Hakim in one letter as a "second Plato" (aflātūun-i șānī). ${ }^{29}$ 
Prior to this historical moment no one seems to have ever used the term tãza$g \bar{u} ' \hat{\imath}$ to designate a poetic movement or particular era, much less both at once. One can find poetic precursors who influenced the täza poets, of course, like Baba Fighani of Shiraz (d. 1519), whose oeuvre and popularity among later early modern generations have been exhaustively analyzed by Paul Losensky. ${ }^{30}$ And many poets throughout the ages had obviously boasted of their own individual genius and originality, a gesture known as ta'alli (self-exaltation), or sometimes fak $\underline{h} r$ (pride, boasting) ${ }^{31}$ - but never before had there been such a collective expression of self-conscious literary newness across the Persophone world.

This does not mean, however, that literary periodization itself was new, as Indo-Persian literati had been distinguishing between the poetry of the "ancients"

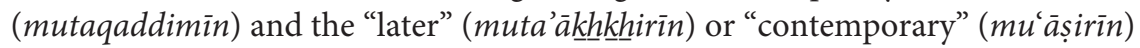
poets for quite some time. Differentiating among different poetic styles was also not new. For instance, in some cases earlier critics referred to regional "schools," or dabistāns, within the larger Persophone world. ${ }^{32}$ These were not abstract, geographically deterministic categories along the lines of modern sabk-theory, however; rather, they usually referred to the work of specific poets or groups of poets at specific courts, or in certain cosmopolitan regional centers like Isfahan, Shiraz, Herat, Samarqand, and Delhi, at particular historical moments. Thus, for instance, the great North Indian Chishti Sufi Nizam al-Din Auliya (d. 1325) is reported to have advised Amir Khusrau to write "in the manner of the Isfahanis" (bar tarz- $i$ işfahāniyān $)^{33}$ - not because Isfahan had some special claim to the authoritative Persian dialect, but because there was a clique of particularly talented poets from Isfahan during that era who were worth emulating.

There were also several common terms that critics used to distinguish the styles of master poets. The modern Urdu literary critic Shamsur Rahman Faruqi has noted, for instance, that the traditional way of classifying Indo-Persian literary styles could comfortably allow for multiple styles and fashions to coexist in any given era. Drawing on Amir Khusrau's literary critical essay prefacing his Dìwān-i Ghurrat al-Kamāl (The new moon of perfection), Faruqi shows that words like tarz ("manner"), shewa ("practice"), and rawish ("mode") - the term that Nahawandi uses above to denote the tāza-gu' '̄ movement-could all refer to subsets of conventional poetic style. ${ }^{34}$ These might emphasize different aspects of the versifier's craft or be further calibrated to the influence of particular canonical poets. But, as in almost all literary criticism the world over, the gradations among the compositional postures denoted by such terms could be very subjective, with considerable overlap across categories. Thus a poet might see himself as a follower of one earlier master's rawish in one genre and another's shewa in another genre. Amir Khusrau is a case in point: though he is renowned for boastful Indophilia is and considered a quintessential forerunner to the supposedly eccentric and overly intellectualized "Indian Style" (sabk-i hindī), the poets that Khusrau himself 
claims to have tried hardest to emulate were all paragons of the classical canon: he considered himself a disciple of Sana'i Ghaznawi and Khaqani in certain didactic genres but a follower of Nizami Ganjawi and Sa'di Shirazi in expressive forms like masnawi and ghazal. ${ }^{35}$

Much of this earlier critical vocabulary continued to be used even after tāza$g \bar{u} ' \bar{\imath}$ came into vogue, and commentators continued to refer to the early modern li-

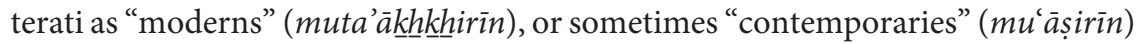
well into the nineteenth century. Even Chandar Bhan uses this terminology, for instance to distinguish between the volumes of classical versus contemporary poetry available in the book markets of Lahore. ${ }^{36}$ Later in Chahār Chaman, he again uses the same terms to classify the various poets whose works he advises his son Tej Bhan to study as either "ancients" (mutaqaddimin) like Firdausi, Rumi, Sa'di, Hafiz, and Nizami, or "moderns" (muta'ākh $\underline{k} \underline{k}$ irīn) like Faizi and 'Urfi (CC, 176-77). Notably, in Chandar Bhan's classificatory scheme Indian poets of earlier times like Mas'ud Sa'd Salman, Amir Khusrau, and Hasan Dehlavi are not listed separately as peculiarly "Indian" but rather fit comfortably alongside all the other canonical ancients, just as Faizi (an Indian) and 'Urfi (an Iranian) are classed together with the other moderns. Note too, moreover, that Chandar Bhan specifically cautions his son not to begin dabbling too much in more modern and contemporary works until after "you have completely finished your junior studies of the books of the ancients [mutaqaddimin]." Thereafter, he explains, "Your natural literary inclinations $\left[t a b^{c}-i\right.$ sukhan-dost $]$ will lead you to the poetry of the moderns [muta'äkhkhirin]" $(C C, 177) .^{37}$

But unlike a term like muta' $\bar{a} \underline{k} \underline{k} \underline{k} \underline{h} i \bar{i} n$, which was for the most part strictly a temporal designation for poets of recent vintage, whatever their stylistic orientation, the term tāza had a much more complicated dual sense, announcing both an epochal transition and an unprecedented-albeit somewhat ambiguousaesthetic claim: that the new age demanded a new, "refreshed" poetic sensibility, one that was, moreover, not merely the product of any individual genius but the product of a collective, "fresh" new worldview. Sixteenth- and seventeenthcentury commentators began increasingly to speak of the poetic now, and phrases drawing self-conscious attention to "the [literary] manner of our present age" (tarz-i zamān-i mā), or the "fresh mode of our era" (rawish-i tāza dar 'ahd-i mā), and so on, became ever more common across the Indo-Persian world..$^{38}$

This by itself represented a strikingly new way of talking about Indo-Persian literary historicality. But it is equally clear that "making it new" in this context did not mean completely exploding the existing formal and thematic conventions that had made for good literature. Indeed, Nahawandi never suggests that tāza-gūyān like Faizi and 'Urfi invented an entirely new form of poetry. Both were steeped in multiple classical traditions and continued using the established meters, drawing from the existing array of Indo-Persian poetic tropes and themes such as the rose, 
the nightingale, the wine of mystical and worldly intoxication, the poet-lover's angst at the unattainability of the B/beloved, the unreasonableness of orthodox clerics, and so on. ${ }^{39}$ 'Urfi was especially attuned to mystically speculative verse, a knack for expressing "gnostic yearning” ('ärifāna-yi 'āshiqāna) that, according to $M a$ 'àșir-i Rahīmī, led "all the eloquent literati and poetic craftsmen to keep his Dìwān of ghazals and qașidas with them day and night, attached to their bosoms as if it were a magic talisman." 40 Meanwhile, in his own verse "Urfi not only paid homage to the poetry of past masters like Kamal al-Din Isfahani and Khaqani but also was especially renowned for his innovative emulations of the panegyrics (qașidas) of the twelfth-century master of the form, Auhad al-Din Anwari. ${ }^{41}$

Such emulation of past masters from the classical tradition, often in an explicit attempt to outdo them, was itself-perhaps paradoxically-a common driver of poetic innovation in Indo-Persian literary culture. In fact, in his analysis of Baba Fighani's legacy Paul Losensky has amply demonstrated that it was common practice during this period for reputation-seeking poets to "greet" or "welcome" poets of earlier generations into their own oeuvre by writing "answers" (jawābs) to their predecessors' greatest works. ${ }^{42}$ Poets had been writing such jawābs for centuries. For instance, Nizami Ganjawi's collection of romantic epics (mașnavis) was so widely admired and imitated across the Indo-Persian world that the mere mention of their number had the force of a proper name- "The Five" (kㅡamsa). ${ }^{43}$ Amir Khusrau wrote five mașnavis attempting to outdo them, and 'Abd al-Rahman Jami (d. 1492), the great poet from Herat, had, in turn, tried to outdo Khusrau. Still later Faizi, 'Urfi, and numerous other tāza-gūyān all tried their hand at refreshing the same set of master texts.

Usually such jawābs were expected to be in the same rhyme and metrical pattern as the original poem, imposing significant formal constraints on later poets. This also meant that for each succeeding generation "the dialectic between innovation and tradition, between poetic intention and literary convention" grew ever more acute, as it grew increasingly difficult to distinguish one's self from the crowd of other imitators, past and present. ${ }^{44}$ Fellow connoisseurs, many of whom might be composing rival jawābs of their own, would be equally familiar with both the master text(s) and all the earlier attempts to answer them; and in such a competitive atmosphere clever manipulation of wordplay, tropes, and conventional themes came to be at an increasingly high premium. But all of this, it must be remembered, continued to take place within the formal and thematic parameters of classical meter, rhyme, and convention. The goal was not to renounce the canon but to "reevaluate, reform, and recreate the tradition in order to do it justice." ${ }^{45}$

The era thus witnessed what the modern Urdu scholar Shamsur Rahman Faruqi has aptly described as a widespread literary "treasure hunt for new themes and meanings." ${ }^{46}$ But it was one in which poets were expected to modulate, not 
overthrow, the cosmopolitan traditions they had inherited. One could do this by taking an established classical theme or trope (mazmūn) and reformulating it in a "fresh" or creative new way or by mixing and matching images to create an entirely new literary topos-a gesture that came to be known as "theme invention" (mazmūn-äfiriñ $)$. To the untrained eye, a verse with a novel theme might look just like any old verse from the Persian canon; but true connoisseurs prided themselves on not only composing but recognizing in the work of others verse that introduced new imagery to the stock of classical Persian tropes. A related concept that came to be known as "meaning creation" (ma'nī-äfirini $)$ usually involved the remixing of common tropes and idioms, or the subtle variation of old thematic patterns, to produce entirely new meanings out of shopworn conventions. ${ }^{47}$

Merely "Indianizing" one's verse in some obvious way was thus hardly enough to qualify one as a truly fresh poet. This is why most of the poets lauded in Ma'àsir-i Rahīmī as talented "fresh speakers" (tāza-gūyān) are noted not for tackling a particular subject matter, or for embodying a particular literary lineage, or for hailing from a particular place, but rather for contributing general traits and gestures of ingenuity that built on the classical canon. Naziri Nishapuri (ca. 1560-1614), for instance, is commended by Nahawandi for giving voice to "elusive meanings and complex themes" (ma'ānì-yi gharìba wa mazāminn-i mushkila), a talent that made him the "captain of eloquent poets and the commander of lovers of genuine expression." ${ }^{48}$ Naziri had made his poetic reputation in Kashan long before setting out for India, where he initially became attached to the court of 'Abd al-Rahim Khan-i Khanan and later emerged as one of Emperor Jahangir's favorite court poets before retiring to Gujarat, where he died. He is also, like 'Urfi and Faizi, included in Chandar Bhan's list of "modern" poets worth studying $(C C, 177)$. Despite his great success in India, though, and despite spending the bulk of his career during the peak era of tāza-gì $\bar{\imath}$, Naziri is actually best known for having self-consciously patterned his qașidas after those of the twelfth-century Khurasani master Anwari, as his great rival 'Urfi Shirazi had also often done. In turn, Naziri's lyrics have been compared favorably with those of both the modern Iranian poet Qa'ani (d. 1854) and the fourteenth-century master Hafiz Shirazi, whose ghazals he sometimes "welcomed" through emulation. ${ }^{49}$

Another Persian poet from the period who is often associated with India and sabk-i hindī was Nur al-Din "Zuhuri" Tarshizi (d. 1615)..$^{50}$ It is not entirely clear where he was born-possibly Tehran, but more likely a village called Khujand, in the Khurasani district of Tarshiz-but we do know a bit more about his travels later in life. After a basic education in topics like grammar, literature, prosody, and rational sciences, he had already gained quite a reputation as a poet while still a youth in Khurasan. This renown had clearly already spread to other localities, and when he traveled as a young man to Yazd his reputation preceded himsecuring him both the hospitality of one Nawab Mir Ghiyas al-Din Mir Miran 
and an almost immediate rivalry with the leading local poet, Wahshi (d. 1583) (who is, incidentally, also on Chandar Bhan's list of outstanding modern poets). From Yazd, Zuhuri traveled to Shiraz, where one of the many regular poetic assemblies he participated in was held in the shop of a local baker known simply as Mirza Husain. He stayed in Shiraz for seven years, continuing his poetic training and mastering the art of calligraphy under the tutelage of one Maulana Darwish Husain. Eventually he became affiliated with the court of the Safavid ruler Shah 'Abbas, but, feeling underappreciated and bereft of the necessary patronage, left for India. He first settled not at the Mughal court but at the court of Burhan Nizam Shah, the Sultan of Ahmadnagar, and thence made his way to the 'Adil Shahi court at Bijapur. It was during this sojourn in the Deccan that he first met Faizi, who was himself on a diplomatic assignment in the south.

Given this itinerary, assessing either credit or blame to "India," much less the Mughals, for Zuhuri's poetic style seems like more than a stretch. Meanwhile, Nahawandi's Ma'āșir-i Rahīmī says of him that "by raining down excellence and grace, the clouds of his lofty nature gushed artistry and accomplishment, as he made the springtime of words and meaning and the garden of eloquence and subtlety lush and verdant." Notably, however, Nahawandi adds that despite his ingenuity Zuhuri's verse was widely respected for being "free of formal excess and ostentation" (bī-ghà'ila-yi takalluf wa shä'iba-yi tașalluf)..$^{51}$

In short, each of these so-called "Indian Style" Iranian poets already had clearly established reputations before ever arriving in India, and in some cases did not even begin their Indian careers at the Mughal court. This is not meant to support the argument, put forward by some recent Iranian scholars, that sabk-i hindi should be renamed the sabk-i isfahāni or some such-for that would simply replace one flawed metageography with another. ${ }^{52}$ The point, rather, is that such static geographies are fundamentally inadequate in the first place, particularly when we are talking about a literary world in which poets rarely remained in one city for too long, much less one country. They traveled in circuits from one intellectual center to another, attaching themselves to a succession of local literary salons and patrons, sometimes moving out of need, and sometimes simply in search of a change of scenery.

That is a major reason why, for the poets of this period, geographical location was far less important as a marker of literary taste than location in time, vis-à-vis the canon of past masters whose works they so admired and struggled so hard to surpass. Far from requiring a mere shift to a new civilizational climate, the path of renewal required poets to refresh the "simple" ( $s \bar{a} d a)$ poetics of a tradition grown "cold" and stale (afsurda), an impulse reflected in this couplet by Jahangir's onetime poet laureate, Talib Amuli (d. 1626):

I am ashamed of stale simple-speak, Talib;

My poetry and I require a metaphoricity all their own. 
[zi sāda-gū'i-yi afsurda nādim-am Țālib

man-o-sukhan ba hamān țarz-i isti'āra-i k khwesh $]^{53}$

In other words, no matter where poets lived, the most important indicator of literary excellence was not Indianization but ingenuity-a fresh poetic voice that was "all their own." Stale and bland images were to be spiced up and given new flavors, as Chandar Bhan suggests in this vivid culinary image:

Brahman, the savoriness of this fresh ghazal is something else;

As if the thought of her lips has been sprinkled over my barbecued heart.

[barahman ìn ghazal-i tāza rā digar namakì-st

magar knhayāl-i lab-ash bar dil-i kabāb guzasht]

$(D B, 81.7)$

But the emphasis, as it is here, was on imaginative reinvention, not rejection, of the classic Persianate canon and conventions.

Faizi's oeuvre, which was perhaps even more wide-ranging than 'Urfi's and was similarly steeped in various classical traditions, is a case in point. Unfortunately, thanks to the sabk-i hindi paradigm, Faizi has often been viewed quite narrowly in a lot of modern scholarship simply as an "Indianizer" of Persian. At some level, this perhaps understandable, as even in his own time much of Faizi's fame rested on his talent for adapting classical Indic texts into Persian, such as the Mahābhärata, the Bhagavad Gìtā, Bhaskara's twelfth-century mathematical treatise Lìlāvatī, and the romantic legend of Nala and Damayanti. ${ }^{54}$ Faizi himself, however, was also one of the most accomplished Arabic savants of his day, something he tried to prove by penning an extensive commentary on the Qur'an. What made this routine exegesis "fresh," though, was the fact that Faizi managed to compose the entire text using only undotted letters. ${ }^{55}$ Then, as if to prove that this extraordinary feat was no fluke, Faizi also wrote an entire treatise on ethics in which he did exactly the reverse, using only letters with dots.

Meanwhile, in his more conventional Persian poetry, even when Faizi played with the concept of tāzagī, his ghazals were overwhelmingly imbued with classical Indo-Persian poetic conceits, particularly the anguish of mystical love, or 'ishq, as in these two couplets.

My heart burns from a fresh scar;

Once again, the house has caught fire.

[dil-am az dāgh-i tāza mīsozam

bāz dar ǩhāna ätish uftād ast $]^{56}$

The fresh martyrs of the beloved's wink gain new life;

For the sword of love reanimates the victims of sacrifice.

[jān yāftand tāza-shahīdān-i ghamza-'sh

shamshīr-i 'ishq zindagī-afzā-yi bismil ast $]^{57}$ 
It's a bit difficult to convey in English, but neither of these verses is eccentrically "Indianized" in any demonstrable way, nor does either contain any Hindi words that might make it difficult for an audience outside South Asia to understand. On the contrary, however clever the conceits of both might be, stylistically they are perfectly conventional.

To be sure, elsewhere in his oeuvre Faizi sometimes engaged in the art of "selfexaltation" ( ta $^{\prime}$ alli $\bar{l}$ ) vis-à-vis his cosmopolitan rivals, but even then he was apt to couch the boast in the language of a Sufi 'āshiq:

Do not seek the road to abstention from Faizi,

For the master of love [i.e. Faizi himself]

has shown the Persians the way to the tavern.

[țarīq-i zuhd zi Faizī majū ki murshid-i ‘ishq

namū rāh-i kharābāt pārsiyān rā̄ $]^{58}$

However assertive such boasting may appear on the surface, there is nothing in this couplet that reflects the sort of radical literary or linguistic Indianization postulated by the sabk-i hindi paradigm. Faizi had a clear sense of pride in his Indian identity, no doubt; but he also saw himself and India as full participants in the Persophone ecumene and considered tāza-gu' '̀ to be a movement generated by a transregional avant-garde, not just by poets who had some connection to India. Hence his praise for Muhtasham Kashani (d. 1588), the Safavid "sun of poets" (shams al-shu'arā) who apparently never left his hometown in central Iran, and thus never met Faizi, but about whom Faizi nevertheless exclaims:

The silk-spinner of expression is that great man [muhtasham] in Kashan,

Who embroiders his eloquence with a fresh technique.

[harīr-bāf-i sukhan muhtasham ki dar kāshān

ba tararzi tāza țarāz-i sukhanwari dārad $]^{59}$

Given Faizi's admiration for Kashani, it should come as no surprise that he too was included in Chandar Bhan's own list of essential modern poets a couple of generations later $(C C, 177)$. Meanwhile Faizi, for his part, drew confidently on the deep civilizational connection between India and ancient Persia to claim both traditions:

I might be Indian, but even so, through sheer talent,

I claim the championship

among those whose language is Pahlawi [i.e., ancient Persian].

[gar hindiyam wa lekin dāram ba zor-i qudrat

bā pahlawī-zabānān da'wá-yi pahlawānī $]^{60}$

Even Faizi's forays into explicitly Indic literary topoi were often framed in terms that a broad audience across the Persophone ecumene could make sense of. Thus in the epilogue to Nal-Daman he locates the tale as part of the universal 
"story of Love" (hadīs $i$ 'ishq), invokes the legendary mystical prophet Khizr as his guide, describes himself as a modern Barbud-the medieval Persian musician proverbial for his lilting melodies - and claims that a hundred nightingales would croon that "an "Iraqi rose has blossomed in India." ${ }_{11}$ The subject matter itself might be Indophilic, in other words, but the form is utterly classical, and the Indian elements are artfully transcreated for a transregional cosmopolitan audience. Indeed, Faizi insists in the same passage that his poetic character is drawn as much from Ganja as from Delhi, yet another clear indication that he, like Amir Khusrau and 'Abd al-Rahman Jami before him, and many others besides, sought to measure himself against the classical standard set by Nizami Ganjawi. ${ }^{62}$

In fact such Indophilia, while perhaps especially robust under the Mughals, was hardly new in Persianate literary and intellectual culture. As the research of Finbarr B. Flood and others has so well demonstrated, South, Central, and West Asia had been interconnected in a vast, transregional "mercantile cosmopolis" for centuries. ${ }^{63}$ People and ideas moved quite freely in this cosmopolitan world, unhindered by modern boundary and identity controls, and among the various classes of merchants, men of war, religious pilgrims, craftsmen, artisans, literati, and other men of the pen who made their way to and through the subcontinent the "wonders of India" ('ajä'ib al-hind) had always provided a fertile source of imaginative possibilities. It should not be surprising, then, that many early modern poets continued to use "exotic" aspects of Indian culture to expand their metaphorical repertoire, even when writing for Persianate audiences beyond the subcontinent. Moreover, by the literary standards of the age the mere act of incorporating Indic mythemes and cultural topoi into a Persian composition was not enough to make the work täza. It might lend a measure of superficial novelty to a composition, but the poetry itself still had to convey an ill-defined-but no less necessary-blend of classical (Persian) allusiveness, verbal artistry, and inventive meaning.

Faizi's Iranian contemporary Nau'i Khabushani (d. 1609), for instance, explored the trope of Hindu widow immolation (sati $)$ as a metaphor for the apotheosis of romantic love ( $i s h q$ ) in an epic called "Burning and Melting" (Soz-oGudāz). But even this "exotic" topos was hardly new, having served for some time as a common way for Sufis and other mystics to express wonder at what they considered to be an act of sublime devotion, the Hindu woman burning herself alive out of love for her husband. ${ }^{64}$ Besides, stylistically speaking Nau'i's text is composed in an extremely common Persian meter and is explicitly modeled not on anything "Hindi" but rather on a text of indisputable classical Persian credentials, Nizami's epic "Khusrau and Shirin." Such compositions always existed in multiple literary contexts, registers, and genealogies, in other words, and for many commentators in the Persian literary audience, specifically, the use of Indic literary topoi, or the occasional Hindi word, barely elicited comment. In this case, 
Nau'i is praised generally in $M a$ 'ạșir-i Rahīmī for the "colorful meanings [ $m a a^{\prime} \bar{a} n \bar{\imath}-$ yi ranginn] and heartfelt poems that sprang from his passionate nature," traits that made him "distinguished and exceptional among the fresh speakers of the current age [tāza-gūyān-i ìn zamān]."

Perhaps it should come as no surprise, then, that Nau'i was also on Chandar Bhan's syllabus of moderns worth studying $(C C, 177)$. But both Chandar Bhan and Nahawandi are notably silent on the "Indianness" of Nau'i's work. Chandar Bhan, in fact, doesn't mention it at all, while Nahawandi says of Soz-o-Gudāz only that "[Nau'i] has embellished the fabric of a mașnawi in the meter of [Nizami's] Kh $\underline{h} u s$ rau wa Shìrin, called 'Burning and Melting,' with glittering ornaments, and done it extremely well." ${ }^{65}$ For Nahawandi what was noteworthy about Soz-o-Gudāz, in other words, was not its ostensibly "exotic" Indian subject matter but rather its expert use of language and its location within the larger taxonomy of Persianate literary canonical precedents. Indeed, no matter which classical tradition one was attempting to rejuvenate, Faizi's goal of stretching the "old words" (lafz-i kuhan) so as to produce "new meanings" ( $m a^{\prime} n \bar{\imath}-y i$ nau) applied equally whether one was drawing from Indic or Perso-Islamic traditions.

\section{CHANDAR BHAN'S FRESH POETRY}

In Chandar Bhan's own verse, we see a blending of the fresh aesthetic with a deeply mystical sensibility similar to what we saw in Faizi's and some of the other verses quoted above. The historian of Shah Jahan's reign, Muhammad Salih Kambuh, for instance, observed that Chandar Bhan used to get so overcome with the pain of mystical yearning that he often wept while reciting his verse. Perhaps our munshi himself had this personality quirk in mind when he composed this playful couplet:

Pour forth such tears from your flowing eyes, O Brahman,

That you can fetch fresh water for the priests.

[birekht ashk chunān barhaman zi dìda-i tar

ki āb-i tāza ba rūy-i barahmanān āward]

$(D B, 174.5)$

There's quite a bit going on in this clever bit of verse. The first line is plain enough, drawing on a common trope of the poet crying floods of tears in the anguish of separation from the Beloved. These are mystical, Sufi tears. But Chandar Bhan adds a nice twist in the second hemistich (mișra'): cry so much, he tells himself, that you can collect enough "fresh water" ( $\bar{a} b-i t \bar{a} z a)$ to fetch and present ( $b a$ rüy awardan) to the class of Brahmans generally, presumably to use in their ritual bathing. The implied contrast, one could say, is between 
Chandar Bhan's own mystical and esoteric awareness as a poet-lover-mystic and the empty, formulaic, exoteric rituals of other "mere" Brahmans. Meanwhile, there is also a nice wordplay in the second line. $\bar{A} b-i$ ru $y$ literally means "face water," that is, perspiration, but idiomatically, presumably because of water's reflective properties, the expression can also be used to suggest a face that is bright, shining, glistening, or otherwise radiant-hence its further connotations of honor, dignity, and so on. Thus the second line can also be read as "so that you can restore fresh luster/dignity to the Brahmans," that is, by showing them a heightened degree of mystical awareness, the evidence for which is the very tears of existential yearning "poured forth" in the first line, and with which you can also-in yet a further connotation-quite literally wash, and thus brighten, their faces.

Such compact, inventive, and elegant wordplay was the essence of the fresh aesthetic. And in Chandar Bhan's case, his identity as a Brahman allowed him plenty of opportunity to toy with other poetic topoi that were commonly associated with Hindus, but had nevertheless been a part of the Persianate poetic tradition for ages, such as the "time-honored" Sufi and Indo-Persian literary trope of the unattainable beloved as an idol (sanam or but) and the poet-lover-mystic as an idol worshipper (sanam- / but-parast), "leaving the Ka'ba and going to the idol temple" - a play of concepts, that, as Annemarie Schimmel once noted, "[has] been part and parcel of the Persian tradition for the last millennium." ${ }^{\prime 66}$ It was surely this cluster of associations that led Salih to playfully describe Chandar Bhan as "the idol worshipper in the temple of poetic expression" (sanam-parast-i but-khāna-i sukhan). To Salih, in other words, Chandar Bhan was an idol worshipper not just as a member of the Hindu community, but also as a mystical poet always yearning for the perfect, unattainable, Reality that can only be imperfectly conceived through language. Thus one uses poetry as a substitute, a way to use linguistic form (șu rat) to at least try and approximate true Meaning $\left(m a^{\prime} n \bar{\imath}\right)$, just as the religious devotee uses an idol as a kind of imperfect metaphor for the transcendent, immanent God. It is precisely in this vein that the Mughal emperor Jahangir once accepted the explanation of a group of pundits that the use of idols in Hindu worship was not, in fact, an affront to monotheism but rather a subtle means to it. ${ }^{67}$ And this seems clearly to be what Salih has in mind when he insists that "even though [Chandar Bhan] appears to be a sacred thread-wearer, his intellect transcends infidelity; even though he has the form [șürat] of a Hindu, in essence [dar ma'nī] he [also] breathes Islam." 68

This reference to Chandar Bhan's "sacred thread" (zunnār), too, was no coincidence. At the literal level, it obviously drew attention to Chandar Bhan's identity as, in fact, a Brahman. But Salih was also simply invoking yet another long-standing trope in classical Persian literature wherein the trappings of non-Muslim ritual and devotion-be they Christian, Zoroastrian, or Hindu-were valorized as a rebuke to 
what many Muslim poets, Sufis, and bon vivants saw as the superficial and hypocritical pieties of orthodox clerics. Thus it was extremely common in medieval and early modern Indo-Persian poetry to find the zunnār, specifically, "contrasted to the rosary of law-bound, pious people ... [and] widely used as a metaphor for infidelity which was in reality a deeper faith." ${ }^{\circ 9}$ Chandar Bhan himself was quite fond of toying with this exact trope for expressive effect, at times even "reverse-engineering" it, as it were, to send up the superficialities of Hindu ritualists themselves. For instance, in one verse he confides:

I have an especially intimate bond with my sacred thread

Which keeps on reminding me that I come from [a line of] Brahmans.

[ $m a$ rā ba rishta-i zunnār ulfatī-yi khhāṣs ast

ki yādgār-i man az barhaman hamīdāram]

$(D B, 256.5)$

Like the verse we examined briefly above, this one is not so straightforward as it may first appear. On the one hand, we could read it as meaning: "I have a special respect for my traditions, and thus the sacred thread is especially important to me." But it could also mean: "I have so transcended superficial religious practices that the only thing that reminds me of my Brahmanical heritage is this slender thread." One could even read it in a more general sense of existential angst and alienation: "I have become so confused by all my religious experimentation, with Sufism and such, that I need this thread to remind me who I really am." There is also a clever play on the word rishta, which literally means "thread," as in "sacred thread" (rishta-i zunnār), but can also mean a social connection, especially a familial bond, thereby resonating with the first line's suggestion of a "special bond of endearment" (ulfatī-yi k̂hāṣs ș) as well as the second line's genealogical premise of coming "from [a line of] Brahmans" (az barhaman).

The subtle-and sometimes not so subtle-critique of orthodoxy contained in such verses notwithstanding, it is precisely this interplay of potential readings and clusters of meanings that gives the verse the kind of semantic "density" (rabt) that would have delighted a contemporary audience. ${ }^{70}$ We should also not discount the role of worldly wit and humor in the appeal of such verses. No doubt the poetry of the tāza era was sometimes obscurantist and recherché, as modern critics have endlessly carped. But we forget that sometimes it was also just meant to be funny. Thus in another verse Chandar Bhan warns, tongue-in-cheek:

The wine of monotheism tests a man, O Brahman;

A novice like you will get drunk off of just one cup!

[mard-āzmā-st bāda-i tauhì d barhaman

$n \bar{a}-\bar{a} z m \bar{u} d a$ mast ba yak jām mìshawī]

$(D B, 335.5)$ 
In another, he sounds a more defiant note, cleverly combining the idiom of Sufi antinomianism with a commitment to a different kind of devotion in order to produce a lovely poetic conceit:

I wash the robe of transgression with my tears, O Brahman;

But the mark on my forehead from prostration to the idol remains.

[dāman-i 'iṣyān ba āb-i dìda shustam barhaman

lek naqsh-i sijda-yi but bar jabìn dāram hanūz]

$(D B, 231.5)$

One could read this verse in a cheeky, humorous vein, as in: "I keep trying this monotheism business, and I've gotten to the mystical stage where, like the Sufis, my tears have washed away my earlier self; but, Lady Macbeth-like, I just can't seem to get that mark of my old idol-worshipping self off my forehead." Or one could read it almost as a defiant rebuke: "I may well dabble in Sufism, but don't think that means I'll abandon my traditions." There may even be other possible readings. But the more important observation, for present purposes, is to note that while these verses are almost always open to multiple interpretations (and translations), in none of them is the grammar or vocabulary particularly difficult from a stylistic point of view - again, quite contrary to the oft-heard modern complaint that what distinguished "Indian Style" poetry was its inordinate rhetorical complexity.

Salih, in fact, goes on to say that "[Chandar Bhan's character], like his poetry, is pure in its perfect lack of ostentation," and, while the point may seem obvious to some readers, it is important to note that he did not mean this pejoratively. For it seems clear that an effect of poetic tāzagì did not always have to involve complex, bombastic, and intricate formal experimentation; it could also, as was often the case with Chandar Bhan's poetry, simply mean taking a conventional theme and expressing it in a particularly elegant, new, and refreshing way, or recombining the old conventions to invent a new theme altogether. It also did not-or at least did not necessarily - require the poet to draw on exotic themes simply for the sake of being exotic. Thus even when Chandar Bhan exploits his interstitial subject position as a Brahman steeped in the Perso-Islamicate cultural world, or draws on "Indic" tropes, he almost always does so-much like Faizi-within the norms of existing poetic conventions, meters, vocabulary, and imagery, often in direct conversation with the work of other poets. Consider this verse, on the thirst for awareness being thwarted by the false water of the "mirage" of worldly existence-

What does one derive from the vivid shimmer of the world, Brahman?

He who dives into the mirage will remain thirsty.

[zi āb-o-rang-i jahān chī-st barhaman hạșil

ba-mānd tishna-lab ān kas ki bar sarāb nishast]

$(D B, 55.5)$ 
—which recalls 'Urfï's slightly different take on a similar theme (mazmūn):

Don't be so proud of your intellect; know that it is simply a lack of thirst;

Your mind is deceived if you don't [keep trying to] drink from the mirage.

[zi naqș-i tishna-labi dān ba-'aql-i khhwesh manāz

dil-at firì gar az jilwa-i saräb nakhwurd] $]^{71}$

Chandar Bhan has at least five verses in his Dìwān that play specifically on this classic mystical theme alone. Even when he invokes a theme like religious infidelity $(k u f r)$, he often couches it specifically within a Sufi idiom, as for instance in these two couplets from the same ghazal:

When the agony of love comes, the desire for a remedy is infidelity [ $k u f r]$;

In such affairs, having an objective in sight is itself infidelity.

[chu dard-i 'ishq rasad khwwāhish-i dawā kufr ast

dar in ma'āmla izhār-i mudda'ā kufr ast]

On this path do not exert anything but your tearful eyes;

To walk the journey to the Friend on earthly feet is itself infidelity.

[dar in țariq ba-juz chashm-i tar makun taklif

ki țai-yi marhala-yi dostī ba-pā kufr ast]

$(D B, 27.1,27.4)$

Again, these couplets, while certainly clever, are not "difficult" or opaque by any serious measure. Chandar Bhan has simply taken some relatively conventional images and redeployed them in a novel way to produce something unexpected and fun.

But another thing that helped to make some couplets "fresh" was, quite simply, the claim to freshness itself. On some level, saying was doing, and the claim to be modern, the self-awareness of participating in the newness of the moment, was often just as important as the actual demonstration of one's aesthetic virtuosity. Thus a poet might facetiously marvel at his own ability to create such "freshness," as in this couplet by Chandar Bhan:

Surely the words must have alighted from skies above

For such a fresh lyric to have found my tongue today.

[sukhan zi 'álam-i bālā magar firod āmad

ki āmad in ghazal-i tāza bar zabān imroz]

$(D B, 233.3)$

Or he might make the unending quest for novelty a structural feature of the verse itself, as he does here:

O Brahman, plant a fresh theme in a fresh refrain;

A new shoot always looks prettier in new sod. 
barahman dar radīf-i tāza mażmūn tāza bar bastī nihāl-i tāza zībā-tar numāyad nau-zamīnì rā

$(D B, 15.5)$

Besides the overt call to always be inventing new poetic themes (mazmūns), which is a clear sign of the times, the real delight of this couplet turns on a clever use of the word zamin, which literally means "earth," "ground," or "land" (and which I have translated here as "sod") but which also has a very specific technical meaning in the idiom of Persian poetry. Specifically, it refers to the prosodic "ground" that specifies a given ghazal's meter, rhyme (qäfiya), and refrain (radiff). So zamin works here not just on the literal level of the ground for planting new flowers, but also metaphorically in its reference to the formal structure into which the innovative mazmūn and radif called for in the first line will be inserted.

Needless to say, this meta-awareness and sense of literary play would not have been lost on Chandar Bhan's contemporary audience, and it is this aesthetic that allows him to boast repeatedly, and quite self-consciously, of his ability to produce an effect of freshness (tāzagī) in his literary expression (sukhan) throughout his poetic Dīwān. Indeed, by my rough count the words tāza and/or sukhan appear some eighty-five times in Farooqui's 1967 edition of Chandar Bhan's Dìwān. And it is this conscious effort to "make it fresh" that led so many of his contemporaries to express their appreciation for his verse, either by praising his literary abilities in their own works or by including his verses in their personal anthologies (bayāzes), as we have noted in earlier chapters.

Note too that the verse just quoted is in one of the most common traditional meters available to a Persian poet, and does not contain a single Hindi expression or neologism, though the entire logic of the sabk-i hindi paradigm in modern scholarship would certainly lead one to expect it. As Momin Mohiuddin, a modern Indian scholar who has written on the supposedly characteristic features of $s a b k$-i hindī, explains: "Although to introduce Hindawī words into pure Persian was considered unpleasant, it was an unforced necessity with Khusrau, Barani, 'Afif, and other writers [of the pre-Mughal Delhi Sultanate era], like the sufis. The ready access to Hindawi for homely expressions . . . was a natural process and more practicable than coining or neologism." ${ }^{72}$ Mohiuddin goes on to explain that the conceptual correlate to this capitulation to the Indian environment on the part of medieval Indo-Muslim literati was the supposedly active intervention of Hindus-like, say, Chandar Bhan-whom he presumes to have been somehow more Indian than their Indian Muslim brethren, and thus, by implication, even less capable of writing "pure Persian." Their effect on Persian language and literature was thus considered especially deleterious, according to Mohiuddin, who adds that the kind of Hindi expressions and neologisms he is talking about were 
"equally peculiar to the munshīs of the Moghul period, and reached their acme in the composition of the Hindu Munshīs."73

This line of thinking directly implicates a writer like Chandar Bhan in all the alleged flaws of the so-called sabk-i hindī (with nary a mention, by the way, of tāza$\left.g \bar{u}^{\prime} \bar{\imath}\right)$. But again, note the argument's essential contradiction. On the one hand, it is stipulated categorically that Hindu munshìs were, by definition, incapable of fully mastering Persian and thus had to resort to inserting Hindi words and expressions into their compositions. Yet this very same intellectually deficient species managed somehow to smuggle the hyperintellectual abstraction of the "Indian mind" into not only their own writings but the literature of the entire era-forcing even non-Indians like 'Urfi, Naziri, Nau'i, Sa'ib, and the like to "succumb" (a word that is often used in the scholarly literature on so-called sabk-i hindī) to the new fad for abstraction, experimentation, and excess. While Hindi words and expressions are indicted as the initial linguistic culprit, it is the entire civilization embodied by them that gets convicted. Thus Mohiuddin concludes: "Persian became more Indianised when the Hindus took to the study of Persian. . . . A great majority of Hindu Munshīs, all of whom flourished during the Moghul regime, enriched the Persian language with Indian vocabulary, homely metaphors and imageries drawn from the Hindu-Muslim beliefs. ... This Indianisation was complete when Persian succumbed to the influence of Indian customs and creeds, legends and mythology, romance and folk-lore. It was not only a change of form but a change in spirit and mood . . . the essentially pantheistic mind of Medieval India."74

If Mohiuddin's argument were valid, however, then we should expect Chandar Bhan, as one of the foremost Hindu munshis of his era, to have used Hindi words and "homely expressions" routinely throughout his oeuvre. Yet apart from place names and certain physical objects that have no real Persian equivalent-the betel-leaf confection " $p \bar{a} n$," for instance-we do not find much evidence of such "Hindi influence" on his word choice. ${ }^{75}$

In fact, there is hardly a trace of crude "Indianization" anywhere to be found in most of the verses cited above, apart, perhaps, from Chandar Bhan's use of the word Brahman. But this was of course the poet's pen name, which had to be included in the verse because ghazal conventions demand that a poet use his nom de plume somewhere in the final couplet of a composition. And even with regard to his own pen name, Chandar Bhan routinely alters the usual pronunciation of the Indian term Brahman (two long syllables) to ba-rah-man (short-long-long), or bar-ha-man (long-short-long), in order to fit the relevant Persian meter. In other words, if anything what we are actually seeing is not some sort of crude, incompetent, or hapless Indianization of the Persian language but rather a highly literate and sophisticated Indian poet's Persianizing of his very name in order to conform to the classical metrical conventions that remained the norm among the wider audience of the Persianate world. 
Generally speaking, then, even poets like Faizi and Chandar Bhan who were proud of their Indian heritage and status as elite Mughal literati wanted to advertise their poetic wares-not to mention the charms of Mughal rule-across the Persianate world. And there is almost nothing in most of the verses discussed above that would have been the least bit unintelligible to a contemporary Persophone audience in faraway Shiraz, Herat, Isfahan, or even Bukhara or Istanbul for that matter. Good poets simply assumed that their works would reach a wide transregional audience, as Chandar Bhan's occasional boasts to this effect suggest: for instance, his claim that "the books and writings of this supplicant have gained fame all over Iran and Turan, and have reached every corner of Hindustan, in every region and every district." 76

Such boasting was not some sort of defensive effort on the part of Indian poets to "fit in" or to prove their literary credentials to a skeptical audience of "proper Persian" literati. It was a claim to literary and cultural superiority, to the ability to outdo their poetic rivals, wherever they might be in the wider Persophone world. Of course, as noted above, there was a long tradition in Indo-Persian literature of such boasting ( $f a \underline{k} \underline{h} r)$, or "self-exaltation" (ta'allī). ${ }^{77}$ Perhaps the most famous example from an Indian Persian poet is the well-known boast of Amir Khusrau:

I don't have Egyptian candy with which to answer an Arab;

I am a Hindustani Turk, and so I reply in Hindawi.

[shakkar-i miṣrī nadāram k-az 'arab gūyam jawāb

turk-i hindūstāniyam dar hindawī gūyam jawāb] $]^{78}$

Even here, though, despite Khusrau's feisty protestations of "Hindawi” genius, in order to reach his desired cosmopolitan audience he had to play by cosmopolitan rules and pen his boast in Persian. The same is true of another famous bit of "Hindi" fak $\underline{h} r$ on Khusrau's part:

Since I am a parrot of Hind, if you want to inquire correctly,

Ask in hindawi $\bar{i}$, that I may reply correctly.

[chu man tūtuti-yī hind-am a'r rāst pursī

zi man hindawī purs tā rāst gūyam $]^{79}$

However much verses like this demonstrate Khusrau's pride in "Indianness," they are nonetheless intentionally couched in a cosmopolitan idiom that could be understood far beyond South Asia. And Khusrau was, in fact, read and generally respected all over the Persianate world, as was his contemporary Hasan Dehlavi (d. 1336-38), who was himself so renowned for his lyrical ghazals that he was sometimes referred to as the "Sa'di of Hindustan." ${ }^{\circ}$ Thus not only did Indian poets look outward across the Persian cosmopolis for inspiration, both before and during the so-called sabk-i hindi period, but other intellectuals across the ecumene, far from viewing Indian poets as harbingers of literary degeneration, 
tended to see them as equal and legitimate poetic interlocutors. Bear in mind, too, that by the fourteenth century, as one modern Indian scholar put it (with admittedly rather sweeping judgment): "The whole tract of land extending from the borders of Delhi to the centres of learning in Persia was one long connecting chain ... from the man in the street to the king on the throne, the distinction between Ghazni and Lahore or Khurasan and the Punjab was never felt." ${ }^{{ }_{1}}$

Even if this appraisal seems hyperbolic, the main point about the interconnectedness of medieval Persianate literary centers across vast swaths of territory, under numerous different political formations, cannot really be disputed. These different centers of poetic production might well have developed local fashions and even local superiority complexes. ${ }^{82}$ But it is precisely in these rivalries, in their constant imitations of and protestations of superiority over their poetic counterparts in far-off lands, that the Persophone intellectuals spread out across 'Ajam actually prove the underlying cosmopolitanism of their literary world, rather than the reverse. For instance, as noted above, Khusrau himself looked to the celebrated Shaikh Sa'di Shirazi (ca. 1213-92 CE) as an inspiration and fellow traveler in the art of ghazal, as we can see by his boast:

As far as they speak Persian

In this age two have shone forth:

One of them is Sadi, the other myself;

Each has brought the ghazal to its full potential.

[tā ba-jā'ì ki hadd-i pārsiyān

andar in 'ahd do tan gasht 'iyān

$z$-ān yakì sa'di-o-șāni-yash hamā-m

har do rā dar ghazal àìn tamām] $]^{83}$

Thus, instead of seeing the poets' rivalries and ubiquitous boasting as evidence of locally insular and parochial aesthetics, we could just as easily see them as trying to outdo one another in a vast transregional conversation. Chandar Bhan himself would echo Khusrau's boasts, with similar paradoxical force, some three centuries later:

This Brahman serves up his subtleties with Hindi lips;

He does not know Persian, Turkish, or Arabic.

[barahman az lab-i hindī-nizhādān nukta mīsanjad

zabān-i pārsī wa turkī wa tāzī namìdānad]

$(D B, 218.5)$

Just like Amir Khusrau before him, Chandar Bhan may well be bragging about his "Hindi" identity, but the verse is clearly addressed to readers beyond India and is meant to be intelligible to them-what's the point of a boast, after all, if no one in the intended audience can actually understand it? 
In purely aesthetic terms, then, if an earlier poet like Khusrau is to be posited as a forerunner, and Hindus like Chandar Bhan as the completers, of an "Indian Style" characterized by incomprehensible mannerism, thematic complexity, and so on, then these verses would actually seem to bear witness to an utterly contrary poetics. Not only are they written in the cosmopolitan idiom of Persian, but they are grammatically straightforward, contain no difficult vocabularyeither Hindi or Arabic-and are written in three of the most common meters in the entire Perso-Arabic prosodic system. ${ }^{84}$ In what sense, then, other than the ex post facto attribution to them of pseudonationalistic content, can we slot these verses as harbingers of the formal decadence so often associated with sabk-i hindi?

In fact, Chandar Bhan himself gives no indication in his writings that he is using anything but pure, fluent Persian in the tradition of all the past masters. Thus, even as the Mughal-Safavid political rivalry was heating up during his lifetime, and even though he might claim that his own melodious voice was proof positive of India's cultural superiority over Iran-

There's no doubt that India enjoys nobility over the land of Iran

When the King of the Age [Shah Jahan] has a sweet-singing parrot like me

[sharaf bar khitța-i ìrān-zamīn hindūstān dārad

ki shāh-i 'aṣr chūn man tūūtī-yi shakkar-fishān dārad]

$(D B, 220.12)$

-the poetics of his ta'alli were, like nearly all of his verse, incontrovertibly classical. ${ }^{85}$ Likewise in this verse:

Carry this message from Hindustan to Iran, O Nightingale:

That if they require a sugar-scattering Brahman, I am the one.

[ba ìrān mì-barad afsāna-yi hindūstān bulbul

barahman rā shakkar afshānī a’r bāshad hamīn bāshad]

$(D B, 206.5)$

The latter verse, in particular, plays on both Rumi's classical tale of the parrot who sent a message to India with a trader and Hafiz's famous verse boasting that all the "Indian parrots" would become "sugar-crunchers" as they echoed the "Persian candy" of his verse all the way to Bengal. On purely aesthetic grounds, then, not only are these verses thoroughly imbued with intertextual referents from the classical Persian canon, but also, even at the level of word choice, one would be hard pressed to see in them evidence of the type of linguistic degradation so often associated with sabk-i hindī, and with the Hindu munshis in particular. Rather, it makes far more sense to see Chandar Bhan and his rival poets, whether in Mughal India, Safavid Iran, or elsewhere further afield, as competing players, yes-but 
largely playing by the same cosmopolitan rules, with the same canonical literary equipment, on the same cultural playing field.

There is a striking parallel here with the dynamic described by the Sanskrit scholars Yigal Bronner and David Shulman, regarding what they call the "metapoetic awareness" of regional "Sanskrit of the place" in late medieval and early modern India: their description of the ways in which regional Sanskrit poets balanced their rootedness in particular localities with their commitment to participating in a much larger cosmopolitan ecumene. With few alterations, in fact, much of what Bronner and Shulman say of such regional Sanskrit literary cultures could apply equally to the Persophone ecumene in the same period:

We could postulate that as a rule, wherever we find a mature "Sanskrit of place," we will also find a commensurate body of literary theory unique to that area or at least some salient expression of metapoetic awareness. Such localized poetic theories inevitably engage with classical or normative schemes and categories, and with canonical theoreticians. ... This kind of intertextual conversation inevitably generates a certain intellectual or experiential depth. The same kind of complexity is an essential feature of what we are calling regional Sanskrit poetry. Local themes, conventions, genres, concepts, names and places are consistently plotted against the old, rich cosmopolitan set of images and patterns ... [but] Sanskrit still allows a poet to transcend his or her parochial context and reach out to a space shaped by a wider, inherited discourse. At the same time, Sanskrit enables a skilled poet to condense into the space of a single work - even a single verse - an entire world of specific associations, contents and meaning. ${ }^{86}$

Bronner and Shulman's recognition of the constant dialectic between the local and the cosmopolitan, and the "fundamental tension" that accompanies it, opens up a space for us to see that, as with Sanskrit, participation in the Persian literary cosmopolis, no matter how locally adamant-as in the case of Amir Khusrau's boasts, or Chandar Bhan's geopolitical ta'allī quoted above-always meant "positioning oneself in relation to wider literary universes" and enabled "a unique connectedness of the various domains ... all conveying a sense of worldwide potential [since even] a highly local milieu allows a skilled poet to dig deep, to tap into these underlying currents." ${ }^{87}$

Chandar Bhan's poetry provides an excellent example of this principle at work. Throughout most of his dīwān, one could argue that he was just as-if not more-likely to draw on the Perso-Arabic religious and folk traditions as the Indic. One would be hard-pressed, in fact, to find a single instance in all of Chandar Bhan's dīwān in which he refers, for instance, to a Hindu god. By contrast, he regularly invokes the names of many stock characters from the Persianate literary and mystical idiom such as Farhad and Shirin, Yusuf and Zulaikha, and so on. Here he is, for instance, boasting of his ability as a tear-jerking narrator of epic romance: 
Even the stones would begin to wail if I were to patiently recount

Farhad's bitter travails in pining for Shirin.

[zi talkhīi-hā-yi Shìrīn ān chi bar Farhād mì-āyad

agar āhista gūyam sang dar faryād mì-āyad]

$(D B, 107.1)$

In legend, of course, Farhad was famously exiled by King Khusrau, his rival for Shirin's affections, to work as a stonecutter on Mount Behistun-giving the conceit that "even the stones" would cry for the doomed lover if they heard Chandar Bhan's version of the story an added allusive density. Meanwhile, Chandar Bhan also uses a clever word choice to heighten the poetic effect, referring to Farhad's tribulations as talk $\underline{h} \bar{i}-h \bar{a}$ (lit. "bitternesses") in playful contrast to the literal meaning of "Shirin" (“sweet”).

Elsewhere Chandar Bhan liked to invoke the tortured lover Majnun, the quintessential "mad lover" of Persianate literary and mystical lore, for instance here:

It's been ages since there's been any trace of the ways of Majnun;

This ancient lifestyle shall be refreshed in my era.

['umrī-st k-az țarīqa-i Majnūn așar namānd

ìn rasm-i kuhna tāza shawad dar diyār-i man]

$(D B, 318.2)$

And again here:

I'll give just one whiff of the tips of your tresses to [today's] lunatics of love

And thus, through me, the ways of this lineage will be refreshed.

[bū'ì zi sar-i zulf-i tu k̂hwāham ba-junūn dād

tā tāza shawad rasm dar ìn silsila az man]

$(D B, 304.3)^{88}$

At one level, both of these couplets clearly echo canonical precedents such as, say, Jalal al-Din Rumi's verse on a similar theme:

Get your hands off of me, Reason,

For today I am too busy with Majnun.

[ bashawi ai 'aql dast-i khwesh az man

ki dar majnūn paiwastam man imroz] $]^{89}$

But the crucial point is that, without knowing beforehand that these four lines were Chandar Bhan's, one might struggle in vain to decipher where (and by whom) they could have been written, because really they could have been written anywhere in the entire Indo-Persian cosmopolis. However, given the poet's 
insistence on producing an effect of tāzagī, there can be little doubt about when they were written. Thus here again, on the most basic level of literary historical analysis, the term sabk-i hindi simply fails to account for the most salient feature of the verse in question, namely Chandar Bhan's claim to poetic renewal.

\section{MODULATING AND CONTESTING THE FRESH STYLE}

This buzz surrounding tāza-g $\bar{u}$ ' $\bar{\imath}$ continued throughout the seventeenth century and is reflected in many different types of sources. The historian Muhammad Salih Kambuh, for instance, lauds a number of his contemporaries for their fresh compositions in his chronicle of Shah Jahan's reign, the 'Amal-i Șalih...$^{\circ}$ A generation later, Muhammad Afzal Sarkhwush (d. 1714) also praises a great many poets as tāza-gūyān in his biographical compendium Kalimāt al-Shu'arā, a work that begins with Sarkhwush's own ode to "fresh" poetic expression (sukhan):

Sukhan is the soul, so listen, my dears, to the following discourse;

If you want a fresh soul [jān-i tāza] with every passing moment, hear now of sukhan..$^{91}$

Meanwhile, in his study of Mughal-Safavid poetics, Paul Losensky has cited scores of examples, from various poets, of the continuing emphasis on tāza-gū' $\bar{\imath}$ as the century went along. For instance these four couplets from Talib Amuli (d. ca. 1625-27), Sa'ib Tabrizi (d. 1676), and Kalim Kashani (d. 1651):

Like the garden of time,

I am an old rosebed, Talib.

My fresh spring [bahār-i tāza]

is my new meaning.

We are, Talib, the seeker

after the nightingale of melodious hymns.

The fresh manner [rawish-i tāza]

is our creation.

Whoever, like Sa'ib, is an old acquaintance

of the new style [tarz-i tāza]

speaks with the verve

of the nightingale of Amul [i.e., Talib Amuli]'s garden.

If the market for poetry's wares

is depressed these days, Kalim,

make the style fresh [tāza kun țarz]

so it catches the buyer's eye. ${ }^{92}$

Among these three, Sa'ib is probably the best known today and is widely regarded as someone in whom "the ingenuity and cerebral juggling of sufistic and 
pseudo-philosophical themes characteristic of the 'Indian' style reach their climax."93 But once again, a closer look reveals that Sa'ib's career is actually a perfect illustration of what is wrong with the sabk-i hindi paradigm. For one thing, as we have just seen, Sa'ib himself did not refer to the elements of his poetic style that usually get flagged as signs of sabk-i hindī as peculiarly "Indian," but rather as "fresh," without any particular geographical qualification. Moreover, Sa'ib was already in his thirties when he arrived in Mughal India, via Kabul, and stayed in the subcontinent for only seven years (ca. 1625-32) before returning to Isfahan where he lived out the rest of his life, a period of approximately four decades. ${ }^{94}$

It is quite a stretch, in other words, to give India either credit or blame for Sa' ib's poetic style, unless one is willing to believe that this relatively brief sojourn in the subcontinent as an already-established adult poet was enough somehow to strip him of virtually all intellectual agency. He not only was born in Iran but also spent the vast majority of his life in Iran, yet this apparently had nothing whatsoever to do with his penchant for "cerebral juggling," which is ascribed entirely and involuntarily to his encounter with India. It would be rather like arguing that Ernest Hemingway and F. Scott Fitzgerald should be banished from the canon of American literature because they spent a few formative years in Paris, or that James Joyce should not be considered Irish, much less studied in respectable departments of English literature, because so much of Ulysses was actually written in Paris, Zurich, and Trieste. Such a scenario is almost inconceivable-yet this is precisely how the bulk of modern Persian literary scholarship has treated not just Sa'ib but the entire tāza era, using the slippery, invented category of sabk-i hindī as an excuse.

Of course, this is not at all how early modern poets like Sa'ib (and Chandar Bhan, for that matter) thought about their place vis-à-vis the Indo-Persian literary canon. Indeed, one gets a far more realistic and concrete sense of the aesthetic commitments of someone like Sa'ib simply by looking at what he himself considered to be worthy poetry - as we are fortunately able to do, for he compiled a voluminous personal anthology (bayāz) of favorite poets and poetry that has survived in manuscript, though it has never been published. The first thing one notices while perusing the contents of Sa'ib's bayāz, and obviously the most relevant here, is that the overwhelming majority of entries are the work of established canonical masters, to each of whom several, in some cases many, folios are devoted. By contrast, in a manuscript hundreds of pages long, there are barely a handful of folios at the end dedicated to Sa'ib's own contemporaries, from each of whom only a few individual couplets are quoted. ${ }^{95}$

Among the latter group, incidentally, is a verse by none other than our own Chandar Bhan Brahman-a slight variation on the same verse quoted above

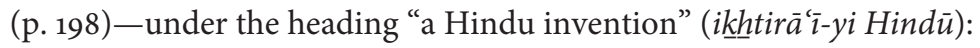

From the first time I blinked my eyes

life was already at the beginning of the end; 
We have tread this path without producing

so much as the sound of a footfall.

[chashm tā bar-ham zadam anjām shud āghāz-i 'umr

țai shud ìn rah ān-chunān $k-\bar{a} w \bar{a} z-i$ pāy bar naḳhāst $]^{96}$

But though Sa'ib was obviously keeping tabs on what his poetic contemporaries were up to, and was occasionally noting down particularly interesting couplets in his notebook, the main purpose and focus of the baya z was to anthologize the work of literary greats from previous eras, those whose poetry even the most committed täza poets would have agreed needed to be mastered before one went about trying to innovate. As if to underscore this point, in the front matter of one of the two known manuscripts of Sa'ib's bayāz is a note, probably penciled in by a cataloguer, describing the manuscript simply as an "anthology of poems of the ancients" (muntakhab-i ash 'àr-i mutaqaddimin). Far from rejecting the poetry of the classical tradition, in other words, even the most avant-garde poets of the tāza era saw it as the foundation upon which their fresh aesthetic was built.

This does not mean, however, that the aesthetic claims and commitments of the

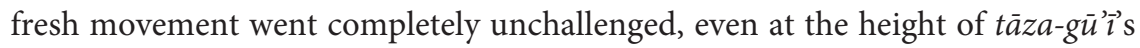
seventeenth-century vogue. Indeed, there is a notable hint of such contestation in a text called Tazkirat al-Safar wa Tuhfat al-Zafar (A memoir of travel and a gift of victory), the memoir of an accomplished Hindu munshi of Aurangzeb's reign named Nik Rai (b. 1670). Nik Rai explains at one point that he himself has closely studied the oeuvres of earlier generations of tāza poets like 'Urfi, Sa'ib, and Mirza Jalal Asir, and he includes some of his own verses that he says are in the mode of Sa'ib. But he points out that there were vigorous debates (munäzirāt) between the tāza-gūyan and some of their critics. ${ }^{77}$ Indeed, one of the most overlooked aspects of this entire era is that the critical reception of ta $\bar{a} a-g \bar{u} \bar{\imath}$ was far from uniform, even at the peak of its popularity.

For one thing, there were clearly multiple different styles within the parameters of tāza-giu' $\bar{\imath}$. Some commentators considered Sa'ib, for instance, to have created a whole new brand of poetry. Meanwhile, beginning around midcentury, contemporary critics started taking note of yet another new poetic idiom that some referred to as the "imaginative style" (tarz-i khayāl). These developments were summed up neatly by the noted eighteenth-century philologist and critic Siraj al-Din 'Ali Khan Arzu (1689-1756), in his biographical compendium Majma' al-Nafā'is:

When Mirza Muhammad 'Ali Sa'ib appeared on the scene, literary expression entered a whole new world. ... Many of his contemporaries like Mirza Jalal Asir Shahristani and Mulla Qasim Mashhadi, better known as "Diwana," took a new path,

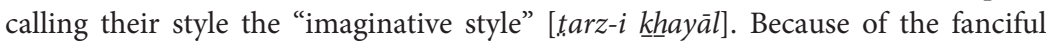
imaginative possibilities of the age, they produced many poems that are altogether meaningless $\left[b \bar{l}-m a^{\prime} n \bar{\imath}\right]$. 
When some of the Indian poets, such as Shah Nasir 'Ali [Sirhindi], Mirza 'Abd al-Qadir Bedil, and Iradat Khan Wazih, took a liking to Asir and Qasim, they added yet another hue [to this new style] and carved out many more fresh thoughts and

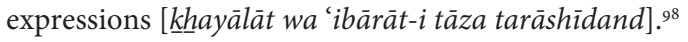

One of the poets who figures prominently here is Mirza 'Abd al-Qadir Bedil, yet another poet routinely touted in modern scholarship as representing the pinnacle of "Indian Style" abstraction. ${ }^{99}$ Yet clearly at least some of Bedil's contemporaries viewed him as part of a new movement, distinct from $t \bar{a} z a-g \bar{u} \bar{\imath}$, and distinct even from Sa'ib's neo-tāza style. Note, too, that whatever its eccentricities, the Indian poets were not even viewed as the progenitors of this new tarz-i khayal, at least not according to Arzu. ${ }^{100}$ We might also detect an echo of this imaginative turn in other late seventeenth-century works, for instance in the title of an important compendium of literary biographies and other essays compiled in 1690-91 by an Indian Afghan named Sher Khan Lodi, the "Mirror of the Imagination" (Mir'ät al-Khayāl) (1998), and possibly even in the name for the musical genre known as khayāl, which was emerging as a popular form at precisely this historical moment. ${ }^{101}$

Contrary to what the sabk-i hindi model would lead us to expect, in other words, there were multiple ways of classifying literary newness and imagination among seventeenth-century Indo-Persian cognoscenti, most of which hinged on stylistic judgments above all else. It is clear too that many early modern commentators, as if anticipating the complaints of later critics, seem to have agreed that there were limits to how far one should go in terms of verbal ostentation, as the line between ingenious "meaning creation" ( $\left.m a^{\prime} n \bar{\imath}-\bar{a} f r \bar{i} n \bar{\imath}\right)$ and trafficking in "meaningless" ( $\left.b \bar{i}-m a^{\prime} n \bar{\imath}\right)$ nonsense could be a fine one. In fact, the aesthetics of tāza-gu' '̄ were being contested all along, as some poets pushed the limits of metaphorical and semantic possibility, while other poets and critics chided them for overdoing it.

Already in Ma'äsir-i Rahīmī (1616), for instance, though the author admired the poet Husain Sana'i Khurasani's intricate expressions, he also noted that many contemporaries were often unable to understand Sana'i's strained verse, at times

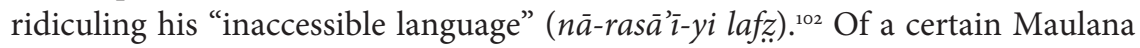
Haidari, Nahawandi gripes: "He used to just imitate the manner and mode of his mentor Maulana Lisani's expressions, and had no taste for the latest poetic fashion [rawish-i muta'a $\underline{k} \underline{h} \underline{k}$ irin ]." ${ }^{103}$ Kamal al-Din Jismi of Hamadan is said to have written too many "difficult and overly intricate verses" (ash'ār-i mushkila daqìqa bisyār) even for sophisticated contemporary audiences, and thus, though he liked Jismi personally, Nahawandi concedes that "his oeuvre must be excused for the immaturity, nonsensicality, and all the other flaws that the work of tāza-gūyann in this day and age may be prone to." ${ }^{104}$ 
In short, as in any age of literary ingenuity, not everyone was enamored of tāza$g \bar{u} ' \bar{l}$, and even aficionados like Nahawandi-or Chandar Bhan, for that matterdid not simply indulge bad poetry just because it was experimental or provocative. They too sometimes puzzled over particularly abstruse verses, as suggested, for instance, by Chandar Bhan's offhand observation that the entire court once spent an entire week discussing and pondering the meaning of a single couplet by a certain Hakim 'Abd al-Khaliq $(C C, 43)$. There was thus an ongoing negotiation, in the courts, the literary salons, and the bazaars, over what constituted the appropriate way(s) to deploy poetic originality. Nahawandi's comment about Jismi shows, moreover, that astute commentators recognized that the aesthetic logic of tāzagi was itself part of the problem. Taken to extremes, it always carried the potential, especially in less talented poets, to cross over into nonsense and absurdity.

Consider, moreover, that one of $t \bar{a} z a-g \bar{u} ' \vec{\imath}$ s harshest contemporary critics was, in fact, an Indian, namely Chandar Bhan's good friend Abu al-Barakat Munir Lahori (1610-44). In a sharply worded essay called Kārnāma (Book of deeds), Munir takes aim squarely at four literary titans of the previous generation, 'Urfi Shirazi (d. 1591), Talib Amuli (d. 1626), Mulla Zulali Khwansari (d. ca. 1615), and Nur al-Din Muhammad Zuhuri (d. 1616), all Iranian émigrés, three of whom we have already noted in our discussion thus far. Munir begins Kārnāma courteously enough, imagining a literary assembly in which he himself sits quietly in a corner, listening to the discussions, as the conversation turns to comparisons of the new poets with the literati of previous generations (sukhanwarān-i peshinn). ${ }^{105}$ Some praise "Urfi for being the "master of the fresh style" (șăhib-i tarz-i tāza), while others praise Talib Amuli for "having given new life to those who express fresh meanings" (tāza-guftār-i ma'nī rā jān dāda), and so on. ${ }^{106}$ The attendees go on to proclaim that earlier poets like Mir Razi Danish Mashhadi, Kamal al-Din Isfahani, Amir Khusrau, and Mas'ud Sa'd Salman-that is, two Iranians, two Indians-had they been alive in this era, would have been like mere students learning at the feet of these four modern masters. ${ }^{107}$

This is too much for Munir, who, as the "wielder of the mirror of justice" (āyina-dār-i insāj), finally speaks up and appeals to people of fair conscience (inșāf-zamīrān) to put a stop to such hubris. "Do not elevate these purveyors of the 'fresh' over the ancients," he implores, begging his colleagues not to continue such prideful "infidelity $[k u f r]$ against the path of justice." 108 Then, his plea falling on deaf ears, Munir decides to argue the case in writing. He acknowledges that some might see his attacks as a violation of "the norms of universal civility" (shewa-i sulh-i kull), but he hopes that "those who understand literature in In-

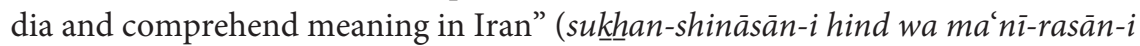
$\bar{i} r a \bar{n})$ will excuse his speaking the truth bluntly. ${ }^{109}$

What follows is a meticulous critique of various couplets by the four authors in question, framed as a classicist corrective against the excesses of tāza-gùu' $\bar{\imath}$. It is 
not that Munir is opposed to poetic ingenuity as such, so much as critical of innovation for its own sake, particularly when it produces verses so outré that they are ineffective or simply don't make sense. Thus he takes some to task for the same sin of "inaccessible language" (nārasā' $\bar{\imath}-y i$ lafż) that Nahawandi also cautioned against, while others are lampooned for having invented conceits so far-fetched that they are shutur-gurba-like comparing "camels to cats." In some cases $\mathrm{Mu}$ nir's objections concern usage and grammar, for instance the discussion of what he considers to be 'Urfi's incorrect use of the word nuqșānī. ${ }^{110}$ Elsewhere he quibbles about word choice, as when he suggests that the imagery of one of Zuhuri's verses would have been more powerful if he had used the phrase "world of water" ('älam-i $\bar{a} b$ ) instead of "torrent of wine" (sail-i sharāb). ${ }^{111}$ The approach, in other words, is detailed and scholarly, emphasizing the technical minutiae of the poet's craft in a witty, occasionally even sarcastic tone.

It has been suggested that what these complaints actually reflect is a growing "ethnic-professional" rivalry between Indian and Iranian intellectuals at the Mughal court as an ever larger number of Iranian émigrés "sought to advance their lot by questioning the linguistic competence of the poets of Indian descent," prompting a backlash among Indian poets and other literati. ${ }^{12}$ There is, undoubtedly, at least some truth to this assessment. In a short epilogue to Kārnāma, Munir complains openly of the way that, in his estimation, Mughal patrons fawned over Iranian émigrés at the expense of talented Indian poets like himself.

This complaint was not, however, as nativist as it might first appear. For one thing, the bulk of Munir's argument-which, let us remember, is explicitly addressed to the literati of both Iran and India-is framed not in ethnic terms but specifically in terms of defending classicalism against the excesses of tāza-g $\bar{u}$ ' $\bar{\imath}$, a trend for which he blames the Iranian poets, not the Indians. ${ }^{113}$ Nowhere does he even hint that classical poetic norms and conventions should be "Indianized" in the way imagined by the sabk-i hind $\bar{\imath}$ thesis; on the contrary, his point is precisely that literary competence in a cosmopolitan language like Persian is not region specific, and he cites as evidence the popularity and gracious reception of Indian poets like Mas'ud Sa'd Salman, Abu al-Faraj Runi, Amir Khusrau, Hasan Dehlavi, and Faizi in the wider Persianate world. ${ }^{114}$ The problem in his era, as Munir saw it, was that patrons were beginning to privilege Iranians as native speakers ( $a h l-i$ $z a b \bar{a} n$ ) in a historically unprecedented way and were thereby undermining the traditional hospitality of 'Ajam's cosmopolitan literary culture. Pointing out the errors of Iranian poets like 'Urfi was a way of illustrating that even Iranians were not infallible when it came to questions of grammar, usage, and aesthetic taste, while, concomitantly, erudite Indian poets and literati with classical training were perfectly competent to critique such errors. In short, while Munir's literary argument was conservative, his cultural argument represented a plea for cosmopolitan egalitarianism over parochial favoritism. 
In this light, while it is true that the growing rivalry between Indian and Iranian intellectuals during this period was a critical historical factor that still needs much more scholarly attention, it is equally clear that the larger contestation of the fresh style did not play out solely in those terms. Other, non-Indian literati also criticized tāza poets of various stripes for their "inaccessible language," while conversely plenty of Indian-born intellectuals like Chandar Bhan continued to express admiration for the tāza aesthetic in general and for Iranian poets like 'Urfi, Talib Amuli, Sa'ib, Kalim Kashani, and Muhammad Jan Qudsi in particular. Recall that Chandar Bhan's own verse was included in Sa'ib's bayāz and that our munshi was an epistolary correspondent of both Munir Lahori and the latter's sometime poetic rival Muhammad Jan Qudsi, with whom Munir and another Indian-born poet named Mulla Shaida (d. 1669) had a noted public feud.

Munir's complaints, therefore, though clearly significant, were hardly representative among all Indian-born intellectuals. Sure enough, Munir's position in Kārnāma was openly rebuked a few decades later by another Indian intellectual, Siraj al-Din 'Ali Khan Arzu (d. 1756), in an essay aptly titled Sirāj-i Munīr (A light on Munir). ${ }^{115}$ Arzu acknowledges that some of Munir's criticisms of "the latest poets" (shu'arā-yi muta'a $\underline{k} \underline{k} \underline{k} \underline{h} i r)$ are valid, ${ }^{116}$ but he faults his predecessor's repudiation of $t \bar{a} z a-g \bar{u}$ ' $\bar{l}$ as too sweeping and as a squeamish failure of imagination. The task of poets, after all, has always been to innovate and stretch the possibilities of linguistic meaning. Arzu makes a point, too, of scolding Munir's sarcastic tone as an unproductive breach of scholarly decorum, noting at one point that "no progress can be achieved through glibness [charb-zabānī]." ${ }_{117}$ More important, as Arzu painstakingly demonstrates, is the fact that many of the "fresh" usages and conceits that Munir criticized as outrageous crimes against poetic language can actually be supported by examples from the classical canon. In a bravura display of literary critical philology-all the while insisting, notably, that his methodology is entirely objective and "free of bias" (khâli az ta'așsub) ${ }^{118}$ - Arzu provides exhaustive rejoinders to every one of Munir's objections. Many of these run to several pages, as Arzu corroborates the contested tāza usages through authoritative attestations, or sanads, from past masters whose linguistic and aesthetic credentials were beyond dispute: Anwari, Rudaki, Kamal Isfahani, Khaqani, Nizami Ganjavi, Amir Khusrau, Sa'di, and Faizi, to name a few. Implicit in Arzu's argument, in fact, is a telling verdict: it is precisely Munir's imperfect mastery of the ancients that hinders his appreciation of the moderns.

Here, then, we have an Indian philologist wielding profound classical erudition to defend the modernist tendencies of Iranian tāza-gūy $\bar{a} n$ against a conservative attack lodged by another Indian who saw himself, ironically enough, as an avowed champion of the very same classical canon later employed to refute him. Given this tremendous deference to the earlier tradition, imagine the surprise of all concerned if they were somehow granted a glimpse into a future in which they 
were remembered simply as typical of an age characterized by mass "alienation of the poets from the old established masters." 119 Imagine the look on Munir's face, or that of contemporary readers like his friend Chandar Bhan, if he were to read in a modern reference work that his literary style and 'Urfi's were both of a piece, merely reflecting "standard features of the Persian lyrical style known as sabk-e hendī." ${ }^{120}$ And imagine how oddly it would strike Arzu to hear another of his essays, Tanbīh al-Ghäfilin, described as "an essay in defense of Sabk-e Hendī"-a term that wouldn't even be coined for nearly another century and a half. ${ }^{121}$ The fact that one has to conjure a different meaning of the term sabk-i hindi for each of these statements even to make sense is proof, if any more were needed, that the very category is inadequate for capturing the sophistication of these intellectuals' literary world.

\section{THE GLOBAL HISTORICAL CONTEXT OF TÁZA-G $\bar{U}^{\prime} \bar{I}$}

There is an uncanny synchronicity to the fact that 'Abd al-Rahman Jami of Herat"universally regarded as the last eminent figure in the history of classical Persian literature"122 - died in 1492, the year of Columbus's discovery of the New World. Several hundred years of vibrant, cosmopolitan Indo-Persian literary and intellectual production were yet to follow, much of which not only participated in, but also made potent contributions to, the "connected" intellectual histories of global early modernity. ${ }^{123}$ Yet for nearly a century this rich archive has all too often been walled off by a self-defeating scholarly embargo-not just in Iran, but also in Europe, in America, and even, surprisingly enough, in South Asia-under the flimsy pretext that it was all too "Indian," too Hindi, or too Hindu to be anything more than an embarrassment that should be repudiated when spoken of at all.

Chandar Bhan's own oeuvre has been a clear victim of this neglect. But it has also had devastating consequences not just for the study of Indian Persian literary culture, specifically, but also for the study of South, Central, and West Asian cultural modernity generally. And so, if we are ever to bring the vast Persophone literary tradition into the wider scholarly conversation about various "alternative modernities," then it is precisely such "homeless texts" from the age of tāza-gū' that call out for further scrutiny. ${ }^{124}$ For that to happen, needless to say, an entirely new critical vocabulary will be necessary, and, as I have tried to suggest, maybe taking a fresh look at the actual aesthetic claims and commitments of the fresh poets would be an ideal place to start.

Before bringing the discussion of Chandar Bhan's poetic world to a close, however, we should emphasize that there is a notable global and comparative dimension to all this, too. We do not know nearly enough, for instance, about the resonance of notions like tāza-gu' '̀ in places like the Ottoman cultural world, although it is noteworthy that the latter has been characterized by at least one 
eminent modern scholar as "remarkable for ... innovation that is often extreme," coupled with a pronounced millenarian ethos that inspired literary imagery "marked perhaps more by radical, even catastrophic, disjuncture with the past than by smooth continuity." 125 We know, too, that at least some of the tāza poets were very popular in the Ottoman world, such as Faizi, who has been described as having been among "the chief foreign influences on the development of Ottoman Turkish poetry." ${ }_{126}$ Meanwhile, Walter Andrews and Mehmet Kalpakh have demonstrated the striking degree to which early modern Ottoman literary and commercial cultures were integrated with those of Europe via the Mediterranean basin, particularly where philosophical ideas about romantic love were concerned. ${ }^{127}$ We can thus rightfully chart a set of cultural dots in an arc that connects the poetics of tāza-g $\bar{u}$ ' $\bar{\imath}$ - either directly or indirectly-to exactly contemporary fashions in Europe like the so-called "mannerist" movement and the "quarrel between ancients and moderns."

The term mannerism began as an art-historical designation for the trend toward stylized, self-conscious aesthetic formalism that became fashionable in sixteenthcentury Italy, roughly between the later Renaissance and the Baroque periods. It so happens, moreover, that like sabk-i hindi the term mannerism is a twentiethcentury invention, and the mannerists themselves have also suffered greatly at the hands of modern critics. ${ }^{128}$ Where critics of sabk-i hindi have been exasperated by its "abstract ideas, farfetched similes, quaint metaphors, queer fancybuilding and morbid imagery [that] had reduced the lyric to an absurdity," European critics have likewise seen in mannerism "a demand only to advance incomprehensible and dazzling remarks." ${ }^{129}$ Like the experimentalism and ingenuity of $t \bar{a} z a-g \bar{u}{ }^{\prime}$, , in other words, mannerism has been dismissed in much of modern scholarship and criticism merely as vain anticlassicism, a fad for artificial and empty formalism from which the arrival of the baroque's emotional sincerity has been considerednot unlike the so-called "cultural return" (bāzgasht-i adabi) movement in modern nationalist Iran-a welcome relief. ${ }^{130}$ Mannerism was nothing but a "stylish style," as the art historian John Shearman called it, one that lacked authenticity because its heightened artifice served as a barrier to the "overt passion, violent expression, [and] real energy" of the raw human condition. ${ }^{131}$

This modern response to mannerist style was of course largely a product of romanticism's cult of the personal experience of the individual creative genius-a stance that also, in the wake of British and French colonialism, deeply informed Indo-Persian literary historiography's modern critical idiom, especially the intense hostility toward the early modern $t \bar{a} z a-g \bar{u} \bar{\imath}$ (aka sabk-i hind $\bar{\imath}$ ) era. But just as Western scholars have begun more recently to see the mannerists in a more favorable light, and to view their interest in formal innovation less as an empty gesture and more as a dynamic response to the anxieties and exuberance of global early modernity, we must try to do the same for the cultural world of tāza-gūyān like 
Chandar Bhan and his contemporaries and to situate their ideas about cultural renewal in a larger global framework.

Indeed, on a purely literary theoretical level, it is hard not to notice the striking parallels between the two movements. Beyond the broad conceptual agreement between mannerist notions of "ingenuity" and the Indo-Persian idiom of "freshness," there is an uncanny harmony even in some of their theoretical minutiaefor example, mannerist ideas about the "acuteness" (acutezza) of expression vis-àvis tāza-gu' '̀े's "tightness" or "connectedness" ( $r a b t$ ); the mannerists' attention to metaphor as the staple of literary revivification vis-à-vis tāza-gü' $\vec{\imath}$ 's similar ideas about stretching metaphor (isti'āra) in the service of "meaning creation" (ma'nī$\bar{a}$ frini $\bar{\imath}$; or the mannerist sense that an artistic expression, as the seventeenthcentury mannerist theoretician Matteo Peregrini insisted, "must be rare and remote from the normal way of using the words in question" compared with Indo-Persian literary theorists' definitions of $\bar{\imath} \bar{a} m$, a kind of punning in which the poet intentionally thwarted readers' expectations by intending a word's "remote" meaning rather than the "near" one..$^{132}$

To my knowledge, no sustained comparative analysis of these cultural phenomena has ever been attempted. One thing we do know, however, is that for the mannerists too there was general agreement that a historically informed, cosmopolitan "sensus communis [was] of utmost importance" as a precondition for true ingenuity. ${ }^{133}$ In other words, as in the Indo-Persian world, one had to respect and master the existing canon and conventions before one could successfully innovate. Meanwhile, the Indo-Persian trope of Truth (haqq) as an immanent but veiled reality in a constant process of being disclosed anew by what Chandar Bhan himself once referred to as the "magical language" (jā $\bar{u} \bar{u}$-bay $\bar{a} n \bar{\imath})$ of poetry $(D B, 43.5)$ finds a striking parallel in Peregrini's assertion that "the intellect does not create, but only unveils and presents." 134 Or, as Chandar Bhan's contemporary Mirza 'Abd al-Qadir Bedil, perhaps the most celebrated metaphysical poet of the early modern Indo-Persian canon, put it:

If you tear asunder the veil on poetry's face

You get to things that are beyond imagining.

[gar niqūab-i sukhan shikāfta'ī

$\bar{a}$ chi dar wahm nìst yāfta'īi ${ }^{135}$

Whether or not we can connect these European and Indo-Persian cultural movements directly, it would certainly appear that an uncannily similar response to the historical moment was percolating globally, in various ways from the salons of Europe to the salons of Delhi and beyond-perhaps not with total "symmetry," but with undeniable "simultaneity." ${ }_{136}$ 
I should note in closing that I have not spent so much time in this chapter on tāza$g \bar{u}^{\prime} \bar{\imath}$ because it is the only or even necessarily the most dominant theme of Chandar Bhan's literary oeuvre. Indeed, while such notions of cultural refreshment and renewal were undoubtedly a crucial factor in animating Chandar Bhan's overall poetic sensibility, they were far from the only ones. But to have also offered a sustained analysis of the extraordinary range of mystical ideas, the often playful engagement with the preceding literary canon, and some of the other features of his poetry that are so fascinating on a purely literary level would have requiredas Chandar Bhan himself was so often fond of saying-at least another chapter, and maybe even another whole book. Such analysis will thus unfortunately have to wait for another occasion.

But given the overwhelming, indeed suffocating, dominance of the so-called $s a b k-i$ hindī paradigm in virtually all modern Indo-Persian literary historiography, the most important thing to me as a student of Chandar Bhan's poetry and cultural world seemed to be to try to recuperate some sense of the larger cultural context and idiom through which he and his contemporaries responded to the novelty of the age. Indeed, Jacques Barzun once observed that "cultural periods are united by their questions, not their answers." ${ }^{137}$ Perhaps, then, going forward we can return to asking with Chandar Bhan and the other early modern tāzagūyān:

Brahman, you have recited this fresh ghazal in such a fresh voice;

Where, and from whom, did you learn such a new style?

[guftì ba-tāzagì ghazal-i tāza barhaman

in țarh-i tāza tarz-i kudām-o-kaläm-i kì-st]

$(D B, 69.5)$ 


\title{
The Persistence of Gossip
}

\author{
Chandar Bhan and the Cultural Memory of Mughal \\ Decline
}

In the previous chapters, we have examined Chandar Bhan Brahman's life and career against the backdrop of multiple facets of seventeenth-century Mughal cultural and political life. Along the way, we have seen that he was patronized by, and often formed powerful and intimate friendships with, a veritable galaxy of Mughal notables, both Hindu and Muslim. He often recited his own poetry in palace gatherings and other occasions, both formal and informal, performances for which he was rewarded on numerous occasions by the emperor, with cash, or a robe of honor, or a promotion, or sometimes all of the above. He traveled with the court, serving for a time as Shah Jahan's personal diarist (wāqi'a-nawiss), and worked for nearly three decades in the office of the Mughal prime minister, most notably under the learned and widely admired wazirs Afzal Khan Shirazi and Sa'd Allah Khan. He was dispatched from time to time on sensitive matters of Mughal foreign policy, for instance assisting Sa'd Allah Khan with the organization of the campaign in Balkh and Badakhshan in the 1640s, or serving as the lead envoy to the court of the recalcitrant rana of Mewar during a crisis in Mughal-Rajput relations a few years later. And he even appears to have had a fairly cordial relationship with the notoriously "orthodox" emperor Aurangzeb "Alamgir once the latter came to power in 1658, at least if Chandar Bhan's letters to the new emperor are any indication.

Our munsh $\vec{\imath}$ s circle of friends, associates, and acquaintances also extended well beyond his immediate political patrons. As we have seen, Chandar Bhan carried on a rich epistolary correspondence with a wide network of Mughal cultural elites, including various mystical figures, minor officials who dabbled in literature, and even some of the most accomplished poets and other intellectuals of the era. He 
was good friends, for instance, with the historian Muhammad Salih Kambuh, as well as prominent poets like Abu al-Barakat Munir Lahori and Muhammad Jan Qudsi, all of whom appear to have reciprocated Chandar Bhan's friendship and admiration, as did many of the other mid-level Mughal officials and lower nobility with whom he exchanged letters.

One name that has been conspicuously absent from all of these discussions, however, has been that of Shah Jahan's famously liberal eldest son, Prince Dara Shukoh (1615-59). Given this, it will perhaps come as some surprise to readers of my account of Chandar Bhan's life and career that in the modern cultural memory of South Asia Chandar Bhan is more often than not remembered, if he is remembered at all, almost exclusively as an associate of Dara Shukoh-and Dara Shukoh alone. Our analysis of Chandar Bhan's life, career, and cultural world thus cannot be completed without telling the story of how this peculiar, though largely fanciful, memory of Chandar Bhan's relationship with Dara Shukoh came into being, and its crucial significance as a key building block in the larger modern historiography of Mughal imperial decline.

\section{DARA SHUKOH AND MODERN MUGHAL HISTORIOGRAPHY}

As a prelude to the discussion to follow, let us briefly examine a few salient aspects of Dara Shukoh's career and how he is remembered in modern times, so that the more detailed examination below of how it is all relevant to Chandar Bhan's story will be a bit clearer. Prince Dara was born in March of 1615, the first of Shah Jahan's sons. Being the eldest son of the Mughal emperor, of course, automatically made Dara a person of considerable status and influence, even as a young boy. Like the others in his family line, he was a direct descendant of the great conquerors Chingiz Khan and Amir Timur and was thus suitably trained in the arts of war and governance during his youth. But Dara's own bloodline was also quite cosmopolitan and was in many ways a microcosm of the cultural and ethnic diversity of Mughal India generally: through his father, he was descended from an illustrious line of Central Asian Turks; but through his mother, Mumtaz Mahal (d. 1631), the daughter of Iranian émigrés, he could also lay direct claim to the ancient cultural and political heritage of the Persianate world; and of course he was born in India and through his paternal grandmother Taj Bibi (d. 1619) was in fact one-fourth Rajput.

Already by his twenties Dara Shukoh had been given a generous military rank (manșab) and his first official command, and in 1642, when still a few years shy of thirty, Dara was given the title "Prince of Great Fortune" (shāhzāda-yi buland $i q b \bar{a} l)$. By this time, he was widely seen as the likely heir apparent (wali-'ahd) to Shah Jahan's throne. But Dara's "heir-apparency" also needs to be seen in its 
proper historical context. For one thing, Shah Jahan's public acknowledgment of Dara as his probable successor broke sharply with the existing traditions of Timurid succession, in which, as Munis Faruqui has persuasively argued, notions of primogeniture were largely subordinated to a culture of open princely competition. ${ }^{1}$ Every prince, including Dara himself, knew the rules of this game, the contemporary shorthand for which was $y \bar{a}$ tak $\underline{h} t y \bar{a} t \bar{a} b \bar{u} t$-for a Mughal prince, it was "either the throne or the grave." Such open competition for power put pressure on successful Mughal princes to expand their social and political networks and to build alliances beyond the existing frontiers of Mughal dominion. In so doing, Faruqui suggests, they also played a crucial role in Mughal state building generally, partly through princes serving as governors of strategically important frontier provinces, and thus also, in turn, laying a foundation for further imperial expansion. As one can imagine, such independent princely networks and alliances became crucial when the time came to fight for the throne upon the sitting ruler's death.

In other words, while we might consider Dara's public status as heir-apparent to have conferred a kind of royal legitimacy, his fraternal competitors for the throne and many other contemporary elites would have seen it as nothing more than a hollow, even insulting, token gesture. It should come as no surprise, then, that when rumors of Shah Jahan's ill health began to circulate in late 1657, not one of Dara's brothers deferred to his supposed right to rule, and an intense four-way struggle for the throne ensued. Shah Shuja', who had a distinguished record of military service and was then serving as the governor of Bengal, was the first to declare himself the new ruler. He was quickly followed by Murad Bakhsh, who was then serving as the governor of Gujarat, and then, in turn, by Aurangzeb, who was at the time posted to his second stint as the Mughal viceroy in the Deccan. Aurangzeb and Murad Bakhsh quickly formed an alliance and began advancing toward Agra from the southwest, while Shah Shuja' was closing in from the east. But by the time everyone realized that Shah Jahan had, in fact, not died, it was too late-the armies had already been mobilized and were on the march. War was inevitable.

As all this was happening, Dara Shukoh was with his father in Agra, and any neutral assessment of the events leading up to and during the war of succession would be hard-pressed not to conclude that he was relatively ill prepared to seize the moment. Though he certainly had an illustrious military rank, and had led a handful of campaigns - most notably, the failed attempt to retake Qandahar in 1653-he had far less actual martial experience than any of his three brothers, especially Shah Shuja' and Aurangzeb, who both had extremely distinguished and hard-won reputations as battle-tested leaders with loyal followings. Dara also had almost no experience as an independent governor or administrator. On the contrary, precisely because of his status as likely heir, Dara had spent most of his 
life at court under the watchful eye of his father. He was thus largely insulatedsome might even say sheltered-from much of the actual day-to-day business of Mughal politics and governance, especially the art of independently managing armies, building provincial networks, and forging the kind of strategic alliances that his brothers had to cultivate over the course of their princely careers. As a result, even though he had the backing of the imperial army in Agra, and the support of his father Shah Jahan and many in the Mughal nobility (at least initially), when things came to a head Dara proved unable to use these strengths to his advantage and made a number of crucial errors - both strategic choices and tactical mistakes on the battlefield - that wound up costing him the throne and eventually his life. Aurangzeb, a wily tactician and a hardened warrior, emerged as the winner of the four-way struggle, eventually dispatching not only Dara but also Shah Shuja' and even his erstwhile ally Murad Bakhsh.

Now, from the perspective of these practical realities, it is perhaps not so difficult to see why Dara was unsuccessful in his bid for the throne. It is also not especially hard to believe that for many Mughal observers at the time like, say, Chandar Bhan Brahman, Aurangzeb's victory in the war of succession was not only a plausible potential outcome but in fact a fairly predictable one that did not appear to change the basic nature of Mughal rule, at least not right away. This, at any rate, would be one possible explanation for why Chandar Bhan did not really dwell on the war of succession anywhere in his oeuvre, and even, as we have seen in earlier chapters, maintained a good relationship with Aurangzeb in the first decade or so after the latter's accession. Whatever contemporary observers may have thought of Aurangzeb's personal piety and austere personality, in other words, in 1658 at the very least they would have had little doubt about his basic competence as a ruler and conqueror. After all, the vetting process of the war of succession had itself proven those capabilities.

Meanwhile, with few exceptions the vast majority of Mughal nobles and other officials-even many who had supported other contenders for the throneretained their privileges and titles once Aurangzeb was in power, giving them little incentive to reject his claim. But even when questions about his right to rule did arise, as they did in certain quarters, it is important to remember that they arose mainly because Shah Jahan, the legitimate sitting monarch, was in fact still alivenot because of any significant groundswell of enthusiasm for Dara Shukoh. Some contemporary reports do suggest that when the prince was finally captured and paraded through the streets of Delhi on the way to his imprisonment and eventual execution, the people of Delhi came out en masse to watch, many of them bemoaning Dara's fate. But among the nobility and other influential circles, there appears to have been pretty widespread acceptance of the outcome of the war and Aurangzeb's accession to the throne. As we saw above in chapters 1 and 2, Chandar Bhan even wrote a letter of congratulations to the new emperor, and 
in Chahār Chaman he also praised Aurangzeb's decision to promote his fellow munshī Raghunath Ray to the position of chief financial officer of the realm.

Yet in modern historiography and cultural memory these events have been fairly consistently viewed as nothing less than a utter catastrophe for India. Why is this so? The short answer, as with a good deal of modern colonial and nationalist historiography in South Asia, is religion-specifically, the idea that Dara and Aurangzeb's competing attitudes toward religion not only helped determine the outcome of the war of succession but were, in fact, reliable indicators of their respective fitness to rule. Dara, who is seen as by far the more tolerant and open-minded of the two, is almost universally adored in modern historiography, where he is hailed as a champion of Mughal pluralism in the mold of his great-grandfather Akbar; Aurangzeb, on the other hand, is almost uniformly reviled, cast as a religious zealot driven solely by a hatred of Hindus and a desire to Islamize the subcontinent at all costs, or at least to use the state to terrorize its non-Muslim populations with every waking breath. Dara's execution in 1659 has thus turned out to be one of the most overdetermined events in all of South Asian historiography. It is the quintessential "What if?" moment, often viewed with modern (not to mention postmodern) hindsight as a kind of civilizational tipping point away from Akbar's laudably pluralist policies toward a more austerely pious-many would say outright bigoted - set of imperial policies under Aurangzeb. This Islamist turn is said to have alienated Hindus, incited a "Rajput rebellion," fractured political coalitions, drained the treasury, and thus hastened the disintegration of the empire, in turn setting the subcontinent on an inexorable path (with the aid of British colonial mischief) to partition in 1947. As one modern critic colorfully put it, this was not merely a moment of import for seventeenth-century Mughal politics, but "India's War of Succession, without exaggeration an almost Shakespearean tragedy [that would] unwind, through crisis after crisis of towering implication involving not only Shah Jahan and his children but their children and their children's children and millions of anonymous participants. When a concatenation of ruin begins, nothing can stop it." ${ }^{2}$ In this modern formulation of Dara the "good Muslim" falling victim to Aurangzeb the "bad Muslim," both men's personalities, and all the complexities of seventeenth-century Mughal culture, politics, and society generally, are distilled into one simple proposition-that Aurangzeb's greater piety was the main cause of Mughal decline, whereas Dara's tolerance would have somehow prevented all that "concatenation of ruin."

Now, there is absolutely no doubt that on balance Dara Shukoh was a more open-minded and intellectually curious person than Aurangzeb, who by all accounts was a much more conventionally pious Muslim than his older brother. Dara was a practicing Sufi of the Qadiri order, for instance, but he was also known to frequent the company of Hindu yogis, scholars, and other intellectuals. As Shah Jahan's eldest son, Dara had immense power and resources at his disposal 
with which to patronize the scholars, poets, mystics, and other intellectuals who shared his wide-ranging interest in the study of mysticism and comparative religions, and in these fields Dara's accomplishments are virtually beyond question. He himself composed highly regarded mystical poetry, several important Sufi hagiographies such as Safinat al-Auliyā (1640), Sakinat al-Auliyā (1642), and Hasanāt al-'Árifīn (1652-54), and general treatises on the mystical path like Tarīqat al-Haqīqat and Risāla-i Haqq-numā (1646), along with perhaps his most famous work, a profound meditation on the potential for conceptual rapprochement between Vedantic and Islamic metaphysical doctrines, known as the "Confluence of Two Oceans" (Majma al-Bahrain, 1655). ${ }^{3}$ This text was later translated into Sanskrit as Samudrasangama. ${ }^{4}$ And, as if this weren't enough of a contribution to early modern South Asian intellectual history, Dara is also responsible for commissioning several groundbreaking translations of Sanskrit philosophy, including a new translation of the Yoga-Vasishta (though it is important to note that there were already at least three Persian translations in existence before Dara's) and, perhaps most ambitiously, the Upanishads. ${ }^{5}$

All this knowledge production has left an important legacy, not just in South Asia, but indeed for the entire modern world. As many scholars have noted, for instance, it was Dara's Persian translation of the Upanishads as "The Great Secret" (Sirr-i Akbar) — not the Sanskrit original-that found its way into the hands of the eighteenth-century French Orientalist Abraham Hyacinthe Anquetil-Duperron (1731-1805) and, via the latter's Latin version, into the libraries of so many luminaries of Europe's "Oriental Renaissance" (Schopenhauer is said to have kept a copy of the text by his bedside, and even to have gone so far as to name one of his poodles "Atma" as an homage to the Upanishads' notion of the transcendant cosmic soul). ${ }^{6}$ Such intellectual genealogies can be a potent reminder of the degree to which colonized Asian scholarship and knowledge systems often lurk repressed behind many landmark "discoveries" of European intellectual modernity. ${ }^{7}$ But even as we must do more, generally speaking, to recuperate such genealogies and integrate them into a more truly global intellectual history of early modernity, for South Asian historiography specifically an eclectic figure like Dara Shukoh can actually present somewhat of a problem, particularly where our understanding of the larger issue of tolerance is concerned.

This is because there are at least two implicit assumptions in the conventional narrative charted above that deserve a bit of scrutiny. The first is that Dara's tolerance and intellectual curiosity necessarily made him a kinder, gentler, more virtuous person than his brother. But why should we assume this? It may well be true on some abstract level that a person who displays great religious tolerance and intellectual curiosity will be more inclined to be generous, loving, and kind. But there are also plenty of examples of brilliant writers, scholars, and artists over the years who were tolerant in their politics and intellectual pursuits but prickly, 
arrogant, and antisocial in their personal life. It is generally assumed in modern South Asian scholarship that Dara was more like the former caricature, but what if it turns out that he was more like the latter? How would that affect our view of his legacy?

Indeed, though Dara's most vehement antagonists in the immediate wake of the war of succession were certain members of the conservative Muslim 'ulamā and various partisans of Aurangzeb, these were hardly Dara's only critics. The European travelers Francois Bernier and Niccolao Manucci, who were both in India during the war of succession, also both suggest numerous reasons why Dara's personality and general comportment may have played a part in his downfall, irrespective of spiritual matters. Manucci's version is especially revealing, since he was an avowed partisan of Dara and fought beside him as an artillery specialist during the war of succession. Note, though, how his praise for some of Dara's good qualities quickly segues into a rather scathing indictment of the prince's arrogance, not to mention his sometimes insufferable behavior toward others:

The first-born son of King Shahjahan was the prince Dara, a man of dignified manners, of a comely countenance, joyous and polite in conversation, ready and gracious of speech, of most extraordinary liberality, kindly and compassionate, but over-confident in his opinion of himself, considering himself competent in all things and having no need of advisers. He despised those who gave him counsel. Thus it was that his dearest friends never ventured to inform him of the most essential things. . . He assumed that fortune would invariably favour him, and imagined that everybody loved him. ... [But] the haughty Dara scorned the nobles, both in word and deed, making no account of them.... [He] depreciated all the nobles at the court, above all the generals and commanders ... [who] showed themselves aggrieved and disgusted. All these things united were the chief causes of Dara's ruin and death. He might have been King of Hindustan if he had known how to control himself. $^{8}$

These observations from Manucci point to a certain discontent with Dara festering among the Mughal nobility, many of whom clearly found the prince's arrogant airs to be off-putting, boorish, immature, and downright unseemly for one with pretensions to the throne. To be sure, readers familiar with Mughal history will note that Manucci's testimony should be treated with a certain amount of due skepticism, not least because his memoir was not actually penned until several decades after the events themselves, and he often had his own agenda in writing it. ${ }^{9}$ But even if Manucci exaggerated certain details as he recalled these events years later, let us not forget: he had been an ally of Dara's, not a critic, and thus was trying to paint the prince in the best possible light. Even so, the general tenor of his remarks regarding Dara's relationships with members of the Mughal nobility is inescapable-that the prince routinely spurned sincere counsel and had difficulty 
"controlling himself," resulting in fairly consistent breaches of etiquette and civility that "aggrieved and disgusted" many important and influential potential allies.

Little if any of this grumbling had anything to do, apparently, with Dara's eclectic religious proclivities or intellectual pursuits, but it did prove exceedingly consequential when the time came to choose sides-and change sides-during the war of succession. Rajputs such as Jai Singh were just as likely as Muslims like Mahabat Khan and Shaista Khan to have been rankled by Dara's behavior, and all three of these influential officers turned on Dara at one point or another during the events of $1657-58$, each for personal grievances that had nothing to do with religion. Rumor had it, too, that the notorious traitor Khalil Allah betrayed Dara at the battle of Samugarh not because of any lofty ideals or principled stance against the crown prince's eclectic religious pursuits, but rather for the oldest and most banal reason there is: jealousy produced by Dara's intimacy with the man's wife. ${ }^{10}$ In other words, despite the great admiration in some circles for Dara's intellect and cultural patronage, there was also a significantly large and important constituency of contemporary Mughal elites, both Hindu and Muslim, who disliked him for purely nonsectarian reasons, in some cases out of personal enmity, and in some cases, no doubt, because of a sincere belief that Dara's narcissistic arrogance simply made him unfit for the throne.

This brings us to the second major assumption implicit in the modern conventional wisdom about these events: namely, the notion that because Dara was more intellectually curious and tolerant of heterodox religiosity he necessarily would have made a better emperor than Aurangzeb, and somehow could have prevented the Mughal decline and the "concatenation of ruin" said to go with it. It is certainly a possibility; but it is also a purely counterfactual one that takes no account whatsoever of all the many complex economic, political, and social transformations taking place in seventeenth- and eighteenth-century India that had little or nothing to do with the emperor's personal religious proclivities. Nor does it take any account, of course, of the kind of friction between Dara and some of the $\mathrm{Mu}$ ghal nobility just discussed, or the role that his own actions, personal foibles, and human frailties may have played in his failure to win the throne.

Even before the war of succession, there are indications that problems were brewing between Dara and those whom he would presume to lead. Munis Faruqui has noted, for instance, that during the 1653 Qandahar campaign Dara's leadership style became a source of great tension with some of his most important commanders. In a harsh but telling verdict, Faruqui concludes that Dara's failure in Qandahar "threw a spotlight on [his] military inexperience ... [and] revealed the prince's reliance on soothsayers and charlatans for important military decisions, his naïveté, his callousness toward individual suffering, and his inability to work with any nobles assigned to his command." Even if we admit the potential for partisan hyperbole in the Persian sources Faruqui has relied on for making 
this judgment, the fact remains that such behavior was likely to be far more consequential to Dara's ultimate doom than any of his religious investigations, particularly at the key moment "when the time came to marshal the Mughal nobility against his brother in $1658 .{ }^{\prime 11}$

We even occasionally find evidence of some of these character flaws on Dara's part in the modern colonial and nationalist historiography, despite the overall favoritism toward him in most such works. For instance, even the eminent early twentieth-century historian Jadunath Sarkar, who was definitely no fan of Aurangzeb, couldn't help acknowledging that Dara's ultimate failure had been, in some measure, a failure of character. Sarkar praises Dara for having "taken after his great-grandfather Akbar," especially in his thirst for religious knowledge and his efforts "to find a meeting-point for Hinduism and Islam in those universal truths which form the common basis of all true religions and which fanatics are too apt to ignore in their zeal for the mere externals of faith." ${ }^{12}$ But despite Sarkar's admiration for these spiritual pursuits and intellectual virtues, when it comes to describing Dara's actual preparedness and fitness to rule he strikes a far more ambivalent note and admits that some of Dara's less redeeming qualities played a key role in his downfall:

His father's excessive love did him a distinct harm. He was always kept at Court and never, except at the third siege of Qandahar, sent to conduct campaigns or administer provinces. Thus, he never acquired experience in the arts of war and government; he never learnt to judge men by the crucial test of danger and difficulty; and he lost touch with the active army. Hence, he was rendered unfit for that war of succession which among the Mughals served as a practical test for the survival of the fittest. His unrivalled wealth and influence were not likely to develop moderation, self-restraint, or foresight in him, while the fulsome flattery which he received from all must have aggravated the natural pride and arrogance of an heir to the throne of Delhi. Evidently, he was no judge of character. Men of ability and self-respect must have kept away from such a vain and injudicious master. Dara was a loving husband, a doting father, and a devoted son; but as a ruler of men in troubled times he must have proved a failure. Long continued prosperity had unnerved his character and made him incapable of planning wisely, daring boldly, and achieving strenuously, or, if need be, of wresting victory from the jaws of defeat by desperate effort or heroic endurance. Military organization and tactical combination were beyond his power. And he had never learnt by practice how to guide the varying tides of a battle with the coolness and judgment of a true general. This novice in the art of war was destined to meet a practised veteran as his rival for the throne. ${ }^{13}$

However much Sarkar tries to deflect the blame-onto Shah Jahan, for overindulging and sheltering Dara, or onto the "excess wealth" that prevented Dara from learning humility and moderation, or onto the culture of "fulsome flattery" that poisoned Dara's judgment by inflating his pride and arrogance-here again, 
if we read between the lines there is no escaping the conclusion that however tolerant Dara may have been in the religio-intellectual domain, in day-to-day courtly life he had a tendency to rub many people the wrong way.

One can surmise, too, that some of these problems would have persisted even if Dara had become emperor, leaving one to wonder whether he would have made such a great emperor after all. Indeed, given his overall lack of military experience and administrative acumen, it is just as plausible to suppose that he would have been a terrible ruler, one who might even have hastened the decline in the Mughal imperial fortunes. It is impossible to say either way. But modern scholarship almost never even considers the latter possibility, much less ponders the implications for how we interpret these events and their significance within the larger context of seventeenth- and eighteenth-century Mughal culture and politics. Indeed, far from holding Dara at least partially responsible for his own poor showing in the war of succession, modern commentators are far more likely to perform an ironic reversal of the usual epithet for Dara in Mughal sources-the "Prince of Great Fortune" (shāhzāda-i buland-iqbāl)—and describe him instead as the "ill-fated, lovable Dara Shikoh."14

It is as if, pace Shakespeare's Cassius (Julius Caesar 1.2), all fault emanated from his stars rather than himself. Meanwhile, the routine juxtaposition of Dara with Akbar (of which one can also see numerous examples in the previous note), to the exclusion of all other Indo-Muslim monarchs, nobles, and intellectuals who might have shared a similar "admiration for Hindu culture," creates an effect in modern South Asian historiography whereby the two are treated not only as exceptional individuals but in fact as exceptions to an implied default position of Islamic orthodoxy to which Aurangzeb is viewed as some sort of logical "return." Whatever their basis in some kernel of historical reality, the sharp dichotomies of this model could use considerable reconsideration. Indeed, as I've tried to show throughout this book, a great many seventeenth-century $\mathrm{Mu}$ ghal nobles and members of the Indo-Muslim intelligentsia besides Dara Shukoh showed plenty of civility and courtesy toward the Hindus in their midst and even, like Asaf Khan and several others, patronized the kinds of literary and scientific works of cultural translation for which only Dara and Akbar usually get credit. ${ }^{15}$ Moreover, a fair amount of recent scholarship has shown that, if nothing else, there was a great deal of complexity to both Dara's and Aurangzeb's personalities and career trajectories. Thus, while their respective religious perspectives certainly informed their worldviews-how could they not? - these perspectives were far from determinative, politically speaking, in any kind of straightforward way. Politics still mattered, as did personalities and a great many regional, socioeconomic, and historical contingencies that had little if anything to do with some final palace showdown between intellectually liberal tolerance and implacable orthodoxy. ${ }^{16}$ 
None of this, it should be emphasized, is intended to diminish the profound importance of Dara's intellectual patronage, or to suggest that his openness to cultural translation and pluralism does not matter. It most certainly does matter, and as I myself noted above, we need more scholarship on such topics, not less. But given how one-sided the portrayal of Dara has been in modern scholarship and commentary, and given the related assumptions that characterization has engendered - that Dara was lovable, kind, and universally admired and that he would have definitely made a better emperor than Aurangzeb-it is nevertheless equally important to show that he was not necessarily the saint he has often been made out to be. To draw once more on Shakespeare's Julius Caesar (3.2), it is as though Antony's famous proposition-that "the evil that men do lives after them; / the good is oft interred with their bones"-has been inverted in Dara's case, to such an extent that most mentions of him today focus almost exclusively on the nobility of his spiritual pursuits, while any flaws he may have had were buried with him. Thus, somewhat ironically, one of the key challenges facing any intellectually honest reappraisal of Dara Shukoh's cultural and political legacy will be to grapple with the negative image of him among certain early modern audiences.

Of course, the most obvious form of critique against Dara after the war of succession was charges of heresy and/or apostasy, leveled toward the end of his own life and in some of the historical chronicles composed during Aurangzeb's reign to justify Dara's execution. ${ }^{17}$ But even the deployment of this "weapon of heresy," as Craig Davis has rightly noted, has to be seen in the context of Dara's threat to Aurangzeb's nascent imperial authority while he was still alive, and thus as a political act-one that merely helped rationalize what was, after all, a standard Timurid practice of eliminating political rivals for raisons d'état. While heresy may well have been Aurangzeb's public excuse for eliminating Dara, let us not forget that the new emperor also imprisoned his father-the supposedly "orthodox" Shah Jahan-and eliminated both of his other brothers for good measure. Even if we make allowances for the charges of heresy against Dara being a product of Aurangzeb's imperial propaganda, however, an undercurrent in other early modern sources suggests he was a rather immature, unkingly figure. The origins of this latter discourse are no doubt to be found in the kinds of brash, uncouth behavior we have noted above, which seem to have seeped into the popular memory of Dara well beyond the immediate precincts of the court, in the emergent Mughal public sphere. Thus, by the end of the eighteenth century, one even finds Hindu literati like Anandaghana "Khwash” depicting Dara in his Mașnawī-yi Kaj-Kulāh (ca. 1794-95) less as an august but ill-fated sovereign who represented the last lost hope for tolerant Hindustan than as a precocious, oversexed, and sophomoric youth in desperate need of good guidance. ${ }^{18}$ Not all sources depict him this way, but there was nevertheless a noticeable strain of critique in the quasi-popular image of Dara that emerged in the generations after his death, partly in court chron- 
icles, but also in literary texts that were themselves informed by the gossip and chatter in the bazaars, coffeehouses (qahwa-khānas), huqqa stalls, literary salons (mushä'iras), and other sites of urban mingling in seventeenth- and eighteenthcentury North India.

One crucial site for the textualization of this somewhat amorphous critical discourse was the genre of literary biographical compendia, or tazkiras, which saw an efflorescence in India beginning in the last decades of the seventeenth century and continuing on through the eighteenth. Such tazkiras provide an important, if underappreciated, window onto the sort of political critiques that were possible in the emergent Mughal public sphere, in which criticism of prominent public figures was often subtly encoded in wry anecdotes, jokes, satirical poetry, and other forms of urban "gossip." ${ }^{19}$ The genre reflects an interesting synergy between the oral and textual cultures of late Mughal India, blending information compiled from written sources with what the author himself claims to have heard from reliable sources ("they say that one day, etc."; "I heard from so-and-so that, etc."). This feature of the genre often gives the tazkira literature an amusing, conversational feel. But it is also precisely by allowing this space for the oral, or one might even say the testimonial, that such texts-unlike their historical chronicle counterparts-were able to transmit alternative discourses that may well have been "true" at some level, though not always, and in any case were often empirically unverifiable. Reliable or not, these tazkiras circulated extremely widely and have exercised a powerful role in shaping the modern cultural memory of many members of the early modern Indo-Persian intelligentsia.

In Dara's case, interestingly enough, most of this alternative critical discourse is expressed obliquely, not so much in direct accounts of Dara himself as through narratives about other prominent figures said to have been associated with him. This is, perhaps, one reason that the strain of criticism of the prince found in such anecdotes has not really been examined carefully by modern social and political historians. But-and here we are finally coming full circle-it is precisely where someone like munshī Chandar Bhan Brahman comes into the picture and is conscripted to serve as a corroborating witness.

\section{THE MUNSHI AND THE PRINCE}

To see how all this relates to Chandar Bhan, and to get a sense of just how far removed the modern image of him has become from what we have encountered in the previous five chapters, let us try a thought experiment. Imagine, if you will, a student looking for information on Chandar Bhan Brahman in the Encyclopedia Britannica. She will not find a separate entry for him, but maybe, if she knew where to look, she just might happen across our munsh $\vec{\imath}$ s name in a passage located in the section "Islamic Arts," subsection "New Importance of Indian Litera- 
ture," under the sub-sub-heading "Indian Literature in Persian," in a paragraph that deals specifically with Dara Shukoh. There she will be told the following:

The heir apparent of the Mughal Empire, Dārā Shikōh (executed 1659), also followed Akbar's path. His inclination to mysticism is reflected in both his prose and poetry. The Persian translation of the Upanishads, which he sponsored (and in part wrote himself), enriched Persian religious prose and made a deep impression on European idealistic philosophy in the 19th century. A group of interesting poets gathered about him, none of them acceptable to orthodoxy. They included the convert Persian Jew Sarmad (executed 1661), author of mystical roba' $\bar{\imath} y \bar{a} t$, and the Hindu [Chandar Bhan] Brahman (died 1662), whose prose work Chahār chaman (Four Meadows) gives an interesting insight into life at court.

With the long rule of Dārā Shikōh's brother, the austere Aurangzeb (died 1707), the heyday of both poetry and historical writing in Muslim India was over. Once more, orthodox religious literature gained preeminence, while poets tried to escape into a fantasy world of dreams. ${ }^{20}$

Here we have a concise, yet potent, recapitulation of the typical narrative of Mughal golden age and decline available in most modern historiography. Akbar was great in every way, while nothing worth mentioning happened under his immediate successors Jahangir and Shah Jahan. Only Dara Shukoh truly "followed Akbar's path," a phrasing that also suggests that nothing related to the larger Islamic world, or Indo-Muslim political or intellectual history prior to Akbar's reign, need be considered germane to Dara's worldview, while it literally goes without saying that no one else in the era's Indo-Muslim cultural elite did anything to help nurture, much less advance, the Mughal cultures of civility and sulh-i kull that Dara is thought to have epitomized.

Special praise for Dara's "inclination to mysticism" only further reinforces this exceptionalist subtext, giving the impression that Dara must have been somehow unique in this regard, when in fact, as we have seen clearly in previous chapters, nothing could be further from the truth-Jahangir, Shah Jahan, and even Aurangzeb, like many other figures in the Mughal nobility and broader intelligentsia, all exhibited powerful mystical inclinations that to this day go largely unacknowledged. But, when framed in this way, even the just acknowledgment of Dara's achievements as an intellectual and a patron, admitted to have "enriched Persian religious prose and made a deep impression on European idealistic philosophy," winds up having a wistful, ominous ring to it-as if he were the only person other than Akbar to have done so, the last lost hope for a pluralistic, uncolonized, and unpartitioned Hindustan.

Meanwhile "the austere" Aurangzeb 'Alamgir (r. 1658-1707), besides being cast one-dimensionally as a fanatical bigot, is also, for good measure, tarred with the brush of illegitimacy for having executed the supposed rightful "heir apparent" to the throne. As noted above, this insinuation is more than a bit misleading. 
Nevertheless, we are told, Aurangzeb's usurpation was a cultural disaster, causing "the heyday of both poetry and historical writing" to come crashing to a halt, not just for the Mughal era, but for all Muslim India. His particular brand of piety, moreover, is seen, not as a new and historically specific phenomenon, but rather as a return to an orthodoxy that is implied to have been lurking there all along, riding out the Akbar and Dara moment until "once more, orthodox religious literature gained preeminence," leaving poets and other "interesting" people no recourse but the "fantasy world of dreams."

Among these "interesting" people who gathered around Dara, we find none other than our munshi Chandar Bhan Brahman, along with the eccentric wayfarer Muhammad Sa id Hakim Sarmad “(executed 1661)," who is the only other specific example given. Of course, it is hard to quibble with Sarmad's inclusion in a list of "interesting" Mughal intellectuals, for he was arguably one of the most fascinating people in all of seventeenth-century India. A Jew from Armenia, Sarmad was later educated in Persia, converted to Islam, and then came to the subcontinent via the port of Thatta (Sindh) in the 1632. There he fell madly in love with a Hindu boy named Abhay Chand, and had some sort of rapturous mystical epiphany, after which he and Abhay Chand spent roughly the next twenty-five years wandering the subcontinent, usually naked, before finally landing up in Delhi in the 1650 s. Once in Delhi, Sarmad appears to have developed quite a local following, which drew the attention of not only Dara, but also Shah Jahan, who is reported to have made inquiries about him as well. But once the war of succession began, Sarmad is said to have publicly predicted Dara's victory. This, for obvious reasons, put him at odds with Aurangzeb, who ultimately executed him-ostensibly for obscenity, under the pretense of Sarmad's refusal to wear clothes, but also clearly as a political vendetta. There is a fairly sizable scholarly literature on Sarmad, and I myself have also discussed some aspects of his peripatetic career and its relevance to the larger cultural memory of Dara Shukoh elsewhere. ${ }^{21}$ But here let us simply note that his two main distinguishing characteristics according to the Encyclopedia Britannica entry quoted above are apparently that he was a "convert Persian Jew" (though a convert to what is not entirely clear, if one reads Sarmad's poetry and the sources that mention him) and that he wrote mystical quatrains (though this was of course hardly unique in Mughal India).

Chandar Bhan, for his part, appears to have been the only "interesting" person in this circle to have escaped execution, while it would seem that in the eyes of the late Annemarie Schimmel, the editor of this Encyclopedia Britannica entry and one of the most highly esteemed modern scholars of the Indo-Islamicate world, his most pertinent contributions to all this eclecticism were simply that he was a Hindu and that he wrote an account of court life containing "interesting insights." Such were the trivial transgressions-having once been a Jew, writing mystical poetry, merely being a Hindu who wrote notable works in Persian-that 
could, apparently, make one "unacceptable to orthodoxy" and even endanger one's life in mid-seventeenth-century Mughal India if one lacked the protection of heroically tolerant patrons like Akbar and Dara Shukoh.

But if Chandar Bhan's experience and broad network of friends, associates, and patrons proves anything, it is that Dara was clearly not the only Muslim with whom a prominent Hindu administrator and intellectual could find camaraderie. Indeed, perhaps the biggest irony in all this, as the reader of the previous chapters will recognize, is the fact that Chandar Bhan had had a long and remarkable career already before there is any record of his having even met Dara Shukoh. (The same, incidentally, is true of Sarmad, who came to India in 1632 and had already spent nearly three decades wandering the subcontinent and interacting with all manner of nobles, intellectuals, and others before coming to Delhi and becoming part of "Dara's circle.") That career was facilitated by plenty of other Muslim patrons, interlocutors, and supporters. Thus, besides completely ignoring these other relationships, the version of our modern historiographical collective wisdom that is reflected in the Encyclopedia Britannica entry quoted above short-changes Dara's own "circle"-as if these intellectuals' passing acquaintance with Dara Shukoh were the only notable aspect of their lives and careers. The prince's patronage and accomplishments are presented as somehow so singular and unique that there were simply no other powerful contemporaries toward whom non-Muslims and "interesting" Muslims could gravitate.

What we see crystallized in this passage, in other words, are some of the ways in which Dara's power, intellectual charisma, and tragic end have exerted a kind of centripetal pull in the construction of historical narratives about Mughal tolerance generally, exaggerating the degree to which figures like Sarmad and Chandar Bhan depended on his support for their livelihood, and almost certainly also exaggerating the prince's own counterfactual role in the eventual decline of the Mughals. Meanwhile, this bright spotlight on Dara has obscured in almost total darkness the contributions of numerous other patrons, interlocutors, and supporters - a great many of them also Muslim - whose tolerance was equally critical to the successful careers of these and many other fascinating Mughal intellectuals, Muslim and non-Muslim alike. Given all this, as I mentioned above, it is of course telling that Chandar Bhan himself hardly even mentions Dara Shukoh in his entire oeuvre-there are no letters to Dara, no poems in praise of Dara (such as we have for both Shah Jahan and Aurangzeb), and no discussions of any kind of relationship they might have had. In fact, there are only a handful of brief references in contemporary seventeenth-century sources to indicate that the two of them had any relationship at all, and nearly all of these refer to events that took place in the 1650s, roughly four decades into Chandar Bhan's career in Mughal service. The most we can really say is that at some point very late in his career Chandar Bhan did have some kind of relationship with Dara Shukoh. But there is 
very little concrete evidence regarding the exact nature or extent of that relationship, and in any case Chandar Bhan's status at the Mughal court would have been firmly established by then.

Let us briefly examine this concrete evidence before demonstrating why all this is so important. One context in which Chandar Bhan's and Dara's names come up together is the political crisis with Mewar in autumn 1654 (discussed in the last section of chapter 2 above), where Chandar Bhan served as Shah Jahan's chief envoy to the court of Rana Raj Singh (r. 1652-80) in Udaipur. Though Chandar Bhan himself never mentions Dara Shukoh in connection with this crisis or its resolution, either in Chahär Chaman or in the series of letters to Shah Jahan collected in Munsha'ät-i Brahman, one wrinkle in this entire episode does appear to have involved the prince. One of the main Mughal complaints had been that in addition to other provocations like refortifying the citadel at Chittor, Rana Raj Singh had refrained from sending any troops in support of Dara Shukoh's Qandahar campaign the previous year, an effort that ended in embarrassing failure. Despite this humiliation, Dara for some reason agreed-it is not entirely clear why-to intercede with Shah Jahan on the rana's behalf during the Chittor crisis, urging a diplomatic rather than a military solution. ${ }^{22}$ And when Chandar Bhan was selected as one of the two representatives dispatched by the Mughal court to negotiate the final settlement, at least two contemporary sources-'Inayat Khan's Shāh Jahān Nāma and Muhammad Salih Kambuh's 'Amal-i Șāliḥ-both referred to Chandar Bhan in their respective accounts of these events as Dara's "dīwān." ${ }^{23}$

This would appear to be definitive enough evidence that there was some sort of working relationship between Chandar Bhan and the prince. But neither of our sources gives any further details regarding precisely what the nature of that relationship was, or what, specifically, being Dara's "dīwān" meant in this context. It could certainly mean that Chandar Bhan was assigned at some point to work as one of the prince's secretaries, but we have no other corroboration of this, either from these sources or from Chandar Bhan himself. On the contrary, as we saw above in chapters 1 and 2, Chandar Bhan's own account of these years places him in the central dīwānī working under Sa'd Allah Khan during this period. This would not necessarily preclude him from also doing some work for Dara on the side, of course. But whatever Chandar Bhan's relationship with the prince may have been in the early 1650 s, one thing we can say almost categorically is that as an official emissary from the Mughal court he was acting as Emperor Shah Jahan's representative, not Dara's. Moreover, even if we grant the possibility that our munshi got reassigned to work for Dara as a secretary at some point in the 1650 s, there is not a single reference in any contemporary source (including the two just mentioned) connecting him to the prince any earlier than this, whereas we know he had extensive connections with many other Mughal officials, including Emperor Shah Jahan himself, for several decades. 
The only other reliable contemporary evidence explicitly connecting Chandar Bhan to Dara Shukoh comes from roughly the same time frame and again involves our munshi apparently doing a bit of secretarial work for the prince. Specifically, it was Chandar Bhan who translated Dara's dialogues with a Punjabi spiritual divine, commonly known as Baba Lal, into Persian. The conversations were originally conducted in some unspecified form of "Hindi," according to a preface to the Persian version of the work. ${ }^{24}$ But Dara clearly wanted the text to reach a wider audience both in South Asia and beyond, hence Chandar Bhan's translation. This written version of the dialogues did indeed circulate very widely in early modern India and has come down to us under a variety of names-Nādir al-Nikāt, Mukālama-yi Bābā Lāl wa Dārā Shukoh, Gosht-i Bābā Lāl, Sawāl-o-Jawāb-i Dārā Shukoh wa Bāba $L \bar{a} l$, among others-and even seems to have been translated into Sanskrit with the title Praśnottarāvalì (A series of questions and answers) sometime toward the end of the seventeenth century. ${ }^{25}$

Once again, at first glance this would seem to indicate that Chandar Bhan was indeed a part of Dara's inner intellectual circle. But here too, the larger context matters. The dialogues took place in the autumn of 1653, as Dara Shukoh was on his way back to Delhi following the disastrous Qandahar campaign-that is, the very same campaign for which Rana Raj Singh had failed to send support troops. The Mughals had already made a couple of unsuccessful attempts to retake this important frontier outpost in Shah Jahan's later years, efforts that had been commanded by such notable stalwarts of the Mughal military apparatus as Aurangzeb and Sa'd Allah Khan. The 1653 campaign thus represented an opportunity for Dara to prove his martial mettle, not only to his indulgent father, but also to some of the factions at court that were skeptical of his prowess on the field of battle. In this, the prince appears to have failed spectacularly, and Dara's resounding loss in Qandahar may well have been the most humiliating defeat on an already flimsy military résumé. ${ }^{26}$ And yet, despite the dismal failure of this mission-or indeed, perhaps because of it-Dara appears to have been in no great hurry to return directly to his father's court. Instead, the prince broke journey somewhere on the outskirts of Lahore, where the dialogues with Baba Lal were held.

At least one modern source has suggested that Chandar Bhan accompanied the Qandahar campaign, while others have even suggested that Dara's conversations with Baba Lal were actually hosted in the munsh $\vec{\imath}$ s own Lahore household. These details are difficult to corroborate one way or the other. But either way, in keeping with the modern image of Dara, one thing that most modern commentators seem to agree on is that the dialogues were yet further evidence of Dara's singularly tolerant disposition-part of his "experiment in Hindu-Muslim unity," as the French Orientalist Louis Massignon once called it. ${ }^{27}$ But given all the evidence of everyday Hindu-Muslim interaction during Shah Jahan's era discussed in the previous chapters, the idea that such a dialogue (however profound) was a com- 
plete novelty, or some sort of heroically tolerant gesture on Dara's part, is simply not supported by the evidence.

One near-contemporary Persian source that mentions the dialogues rather matter-of-factly, for instance, is Sujan Rai Bhandari's K Khulāṣat al-Tawārī $\underline{k} \underline{h}$ (1696), in a description of a town called Dhyanpur (literally, "City of Contemplation"):

Dhyanpur is the place where Baba Lal, a genius of mystical experience and discourse [sar-āmad-i arbāb-i hāl-o-qāl] who acted as a portal to the bounties of glorious God [maurid-i fuȳuzāt-i izad-i zzu al-jalāl], had his residence. In life he was a master of erudition and godly knowledge, and in the explication [guzāirish] of divine Truth and gnosis he was a captain on a vast ocean of multiplicitous waves of eloquence [marzbān-i baḥr-i amwāj-i gūnā-gūn sukhhanān büd].

Many classes of men, both elite and common, have become his disciple or devotee, and incorporated his Hindi poetry on matters of spiritual Truth, mystical gnosis, and divine unity into their regular prayer litanies [wird-wazîfa-i k $\underline{h} w u d$ dàrand]. On several occasions during his life the Imperial Prince Dara Shukoh met with that celebrated saint and discussed the gnosis of God [ma'rifat-i ilāhī], whereupon Shah Jahan's munshi Chandar Bhan committed their dialogues to the prison of the pen in an elegantly expressed Persian text. ${ }^{28}$

Readers familiar with such terminology will note that the language Sujan Rai uses to praise Baba Lal, even though by a Hindu, about a Hindu, is almost entirely drawn from Indo-Persianate Sufi idioms and that the topic of the dialogues themselves is described as "spiritual gnosis" ( $m a$ 'rifat-i ilāhì). Even the prayers of his devotees are described not with what we would consider to be typical "Hindu" terms but rather as wird-wazifa litanies. It would appear, then, that for at least some early modern writers such terminology was not necessarily always coded as "Muslim" but rather had become, especially in Mughal Persian texts written in certain circles, a kind of neutral idiom available for describing mystics, and mystical experience, of all types. ${ }^{29}$

But more importantly for present purposes, note too that the author describes Chandar Bhan specifically as a munshī-yi shāh jahānī, which can be translated as "Shah Jahan's munshī," or perhaps more generally as “a munshī of Shah Jahan's time." There is no indication whatsoever that Chandar Bhan had some sort of special relationship with the prince beyond his general service to the court. It could be that he was simply the person commissioned to do the translation, nothing more. In terms of content, much of the dialogue concerns what I've been calling "mystical civility" - questions of ethics, humility, and maintaining a spiritual perspective even as a person engaged with worldly pursuits. One could even argue that the dominant theme of the dialogues is not spiritual matters as such but rather kingship_specifically, Dara's desire to resolve the tension between the worldly demands of kingship and the otherworldly yearnings of the spiritual adept. This preoccupation is evident in some of the prince's earlier works, too, such as Sakinat 
al-Auliyā, where he had noted that "he who is called by God a faqìr, though he appears to be an amìr, remains a faqīr" (ān ki nām-ash az haqq faqīr ast agar chi amīr ast faqir ast)..$^{30}$ Dara is not simply asking Baba Lal to explain Hinduism to him, in other words, but in fact asking for advice on how to be a better king and, even more significantly, how to be a better Muslim. In one especially revealing passage, Baba Lal advises Dara to make sure that as a king he continues to seek out "people of God" (ahl-i allāh). ${ }^{31} \mathrm{He}$ - or at least Chandar Bhan's incarnation of him-also demonstrates a robust familiarity with all manner of Islamicate theological concepts, not just through his consistent deployment of Sufi terminology, but also, for instance, in an exchange on the question of whether or not the Prophet $\mathrm{Mu}$ hammad had a visible shadow. ${ }^{32}$ As if that weren't enough, he also occasionally sprinkles his answers to the prince's questions with Persian poetry, including direct quotations from the ghazals of Hafiz Shirazi.

Having just lost the battle for Qandahar, perhaps Dara was feeling the tension between his intellectual endeavors and the demands of rulership all too acutely, lending an even greater real-world seriousness to such recondite subject matter. There is evidence to suggest, moreover, that at least some early modern readers viewed Chandar Bhan's Persian version of the dialogues in precisely this way-not merely as an inquiry into Hindu religion but as a text that fit comfortably within a whole spectrum of genres pertaining to political philosophy, rulership, and moral wisdom ( $a \underline{k} \underline{h} l \bar{a} q)$. One eighteenth-century manuscript miscellany, for instance, directly juxtaposes Chandar Bhan's text with what the compiler describes in the colophon as "some intriguing and wonderful extracts from miscellaneous books" (ba 'żi naql-hā-yi gharì̄b-o- 'ajīb az kutub-i mutafarriqa), including specific excerpts from works on political

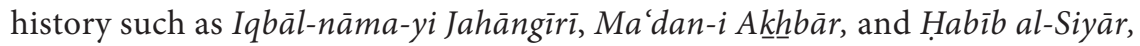
as well as others that come directly out of the $\bar{a} d \bar{a} b$ and $a \underline{k} \underline{h} l \bar{a} q$ tradition, such as Abu al-Fazl's 'Iyār-i Dānish and Sa'di Shirazi's Nașihat al-Mulūk, and Sufi treatises on Hindu cosmology such as 'Abd al-Rahman Chishti's Mir'ät alMaḱhlūqāt and Mir'āt al-Haqà'iq..$^{33}$

Seen in this light, Dara's dialogues with Baba Lal appear less an "experiment in Hindu-Muslim unity," as Massignon put it, than simply one contribution to a much broader Mughal curriculum of texts designed to teach the wise exercise of worldly power.

\section{FROM INNOCENCE TO INSOLENCE: THE CURIOUS BEGINNINGS OF THE MODERN MEMORY OF CHANDAR BHAN}

The larger significance of all this will become a bit clearer in the remainder of this chapter, as we trace the evolution of the somewhat peculiar memory of Chandar Bhan's career that emerged in the ensuing decades and centuries. Much of this 
cultural memory was initially formulated and refined in the many works of literary biography, or tazkiras, and other miscellaneous literary compendia that were produced in seventeenth- and eighteenth-century Indo-Persian cultural world, most of which have brief and in some cases quite extensive entries on Chandar Bhan. The explosion of Persian writings in this genre during this period has not really received much modern scholarly attention and thus no theory explaining why the commemoration of famous literary careers became such a powerful impulse among early modern Indo-Persian literati at this particular historical moment. But it is clear that such texts worked on many levels, and some of the politico-cultural "work" that they performed involved far more than mere scholarly inquiry.

Among the first stand-alone tazkiras to contain an entry on Chandar Bhan was Muhammad Afzal Sarkhwush's "Words of the Poets" (Kalimāt al-Shu'arā; 1682), compiled roughly ten to fifteen years after the munsh $\vec{\imath}$ s death. Sarkhwush acknowledges that Chandar Bhan "was of sound character" (tab'-i rasā) that he "was a treasure among the Hindus" (dar hindū'ān ghanimat būd), and that "he composed poems that were clear and elegant in the style of the ancients [ba tarz-i qudamā]." This last comment, of course, could easily be seen as damning the munsh $\bar{\imath}$ with faint praise, especially in a literary cultural context where, as we saw in the previous chapter, "speaking the fresh" (tāza-g $\bar{u}$ ' $)$ was considered the summum bonum of the poetic craft. Indeed, though Sarkhwush does acknowledge that Chandar Bhan "also had a knack for composing artful prose" (dar insh $\bar{a}$ 'pardāzì nìz salīqa dāsht), his rather less enthusiastic endorsement of Chandar Bhan's poetry hints at a curious antipathy toward the munshi that he then illustrates with a vivid anecdote:

One day, an order summoning him [Chandar Bhan] to recite a poem was issued directly from the Seat of the Imperial Caliphate [i.e., from Shah Jahan]. He recited this couplet:

I have a heart so acquainted with infidelity that, however many times

I took it to the Ka'ba I brought it back still a Brahman.

[ma-rā dilī-st ba-kufr äshnā ki chandīn bār

ba ka'ba burdam-o-bāz-ash barahman āwurdam]

Emperor Shah Jahan, the protector of the faith, became angry and declared: "This illstarred infidel is a heretic. He should be executed.” Afzal Khan suggested [instead] that "the following couplet of Hazrat Shaikh Sa'di is an appropriate rejoinder":

[Even] If Jesus's donkey goes to Mecca

It's still just a jackass when it comes back.

[khar-i î̃sá agar ba makka rawad

chūn biyāyad hanūz khhar bāshad]

The emperor smiled and turned his attention elsewhere. Meanwhile, they quickly escorted him [i.e., Chandar Bhan] out of the privy chamber [dīwān-i khhāsș]. ${ }^{34}$ 
Now, there is no evidence, either from Chandar Bhan's own extensive writings, or from any other contemporary source composed during his lifetime, to corroborate that an encounter like this ever actually took place. Indeed, until Kalimät alShu'arā, Chandar Bhan's relationship with Shah Jahan had never been described by any source as anything but friendly and affectionate. Moreover, Sarkhwush's chronology simply doesn't work-we saw above in chapter 1 that although Chandar Bhan had been presented to Shah Jahan by Afzal Khan at least once during his early career, technically he did not begin his tenure at court until after Afzal Khan died in 1639. In fact, if anything the anecdote seems to be a clever inversion of Chandar Bhan's own autobiographical account in which quite the opposite happened: far from offending the emperor with an impertinent verse, the munsh $\bar{\imath}$ made a great impression on the $b \bar{a} d s h \bar{a} h$, at Afzal Khan's funeral no less, with a witty panegyric quatrain in praise of the emperor himself!

Of course, it is also possible to read the anecdote in such a way that Afzal Khan is the real hero, using his wit to protect his naive protégé from the emperor's dangerous temper. This interpretation would certainly comport better with the known historical evidence. But since Sarkhwush makes no mention of the wazir's and the munsh $\vec{\imath}$ s prior relationship, it is difficult to draw a conclusion either way. Regardless, though, there is nothing in Sarkhwush's version of the story that can really be disproved. The fact that Chandar Bhan himself never mentions an encounter like this does not necessarily mean that it never happened. Indeed, had such an unpleasant audience actually taken place one can certainly imagine that our munshi would have been embarrassed and reluctant to write about it.

Yet something about the story flies in the face of everything we know about Chandar Bhan's personality and his relationship with the emperor. Virtually everything we know from Chandar Bhan's own writings and other contemporary sources suggests that both Afzal Khan and the emperor were very cordial toward him. There is not a single mention in any source prior to Sarkhwush's account of Shah Jahan ever getting so much as annoyed with his "Persian-knowing Hindu"

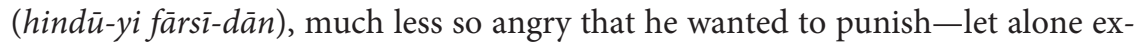
ecute-the munshī. Nor do we ever hear of a single occasion where Brahman's religious background is raised as an issue of concern with respect to his ability to do his job. The overriding impression one gets is that Chandar Bhan was well liked, went about his business, impressed everyone with his talent and civility, and never, ever, ruffled any feathers whatsoever, much less those of the bādshāh.

In other words, nowhere among sources from Chandar Bhan's actual lifetime do we find evidence of the type of brazenly cheeky attitude on display in this anecdote. On the contrary, in his own writings Chandar Bhan's tone is without fail one of extreme-some might even argue obsequious - deference to the emperor's majesty, and, as we detailed above in chapter 1 , he had numerous occasions on which he had the opportunity to recite poetry for Shah Jahan (and later Aurangzeb, for that 
matter), or had his verse communicated to them by some nobleman. In every single known instance Chandar Bhan followed the usual Mughal etiquette of praising the emperor with grandiloquent hyperbole. Not once in such a situation does he offer so much as a single couplet on even an innocuous nonpanegyric theme, much less something so "inflammatory" as we have in Sarkhwush's anecdote.

We should add, too, that as M. A. H. Farooqui, the modern editor of Chandar Bhan's dīwān, has pointed out, the verse in question does not seem to appear in any extant manuscript of Chandar Bhan's collected verse, or even among the prodigious amount of poetry contained in his other surviving works. Nor, for that matter, is there a single ghazal in his entire dīwān with the right metrical and rhyme scheme to match this verse, or ending in the correct refrain "āwardam." ${ }_{35}$ True, such counterpositive evidence is not definitive-it is of course possible, however unlikely, that Chandar Bhan composed such a verse and then left it out of his dìwān - but it certainly is compelling.

With all that said, let us nevertheless suppose for argument's sake that Chandar Bhan had in fact recited such a verse before the emperor. Given all we know about the antinomian tendencies in Persian poetry generally, and during Mughal times in particular, the idea that Shah Jahan would be so naive as to be offended by this verse simply strains credulity. After all, Mughal India was the place regularly hailed by early modern Indo-Persian literati as a land where one not only was free to think-and poeticize-unorthodox thoughts but could actually make a great living doing so. Playful, esoteric, and heterodox themes had been the heartbeat of Indo-Persian literary culture, in which ostensibly heretical practices such as idol worship were routinely valorized as metaphors for love of the divine, while orthodoxy of all kinds was dismissed as hypocritical.

We saw several examples of such verse in the previous chapter, but let us consider a few more. Long before Chandar Bhan came along, for instance, Amir Khusrau (d. 1325) had defiantly said in the fourteenth century:

Some say to me, 'O idol worshipper, why don't you just wear the Hindu's sacred thread?'

But tell me, which of Khusrau's blood vessels is not already a sacred thread?

[chand gūyand ki rau zunnār band ai but-parast az tan-i Khusrau kudāmīn rag ki ān zunnār nīst]

Elsewhere, Khusrau turn's the cleric's puritanism on its head, asking him to bless his dabbling in idol worship as a virtue rather condemn it as heresy:

If you have any prayer for me, $\mathrm{O}$ preacher, make it this:

That this wanderer on idol street goes even further astray!

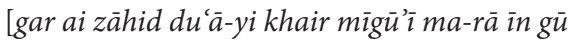

ki ān àwāra az kū-yi butān āwāra-tar bādāa ${ }^{36}$ 
And long after Chandar Bhan had gone, the eighteenth-century Urdu poet Khwaja Mir Dard (1721-1785) wrote:

The idols that made you turn the temple desolate

O Shaikh! They've chosen my heart for their home.

[jin ke sabab se dair ko tū ne kiyā knharāb

ai shaikh un buton ne mere dil meinghar kiyā $]^{37}$

Comparable verses from Chandar Bhan's own contemporaries can easily be found, including this couplet from Talib Amuli (d. 1626-27), an Iranian émigré who, after a peripatetic career, wound up in India and served for a time as Jahangir's poet laureate (malik al-shu'arā):

I do not condemn infidelity, I am not a bigoted believer;

I laugh at both, the Shaikh and the Brahman.

[na malāmat-gar-i kufr-am na ta'așṣub-kash-i dīn

khanda-hā bar jadl-i shaikh $\underline{h}-o$-barhaman dāram $]^{38}$

Even such basic tenets of Islamic religiosity as the importance of Mecca as the Muslim sacred space par excellence were not off limits, and poets throughout the centuries played with this type of insouciant rejection of orthodox strictures, finding cleverer and cleverer-or, in light of the previous chapter, we might say "fresher and fresher"-ways to express such imagery. In fact Shah Jahan's own poet laureate Abu Talib Kalim (1585-1651), a man on whom the emperor famously and repeatedly lavished heaps of wealth and patronage, routinely explored such themes in his verse. For instance this couplet:

The same fire illuminates the congregations of both Muslim and infidel.

The very same spark resides in the stones of the Kaba and the temple.

[majlis-furoz-i gabr-o-musalmān yak ätish ast

dar sang-i dair-o-ka'ba ba-juz yak sharār nīst $]^{39}$

Or this one:

The sandal mark on the forehead of the Hindu idols is made with Kalim's blood Like dawn's colorful glow adorns the resplendent brow of the morning sky

[șandal-i hindū butān zi khhūn-i Kalìm ast

$z$-ìn shafaq ārāstand șubh-jabīn rā $]^{40}$

Beyond the ethical and theological issues, as we saw in the previous chapter there was a virtually ubiquitous streak of inventiveness, jocularity, performative excess, and recitational gamesmanship to such poetry that has been well documented, if rarely praised in modern scholarly works that view Mughal poetry only as decadent $s a b k-i$ hindi. This antinomian strain continued even after the 
transition to rekhta (i.e., Urdu) as a poetic medium in the eighteenth century, a literary culture in which poetic satire and subversive expressions were "not only made explicit but ... carried to an extreme." ${ }^{41}$ In fact, at least one modern scholar has gone so far as to suggest that such "dissent" against orthodoxy was the dominant thematic topos of early modern Urdu poetry. ${ }^{42}$

Seen in this context, the verse attributed to Chandar Bhan by Sarkhwush appears downright conventional, and memorable largely for its witty use of the existing theme rather than its alleged "heresy." Sure enough, virtually the identical trope was deployed about a hundred years later in at least two verses by the celebrated Urdu poet Mir Taqi Mir (1723-1810):

I went to Mecca, went to Madina, and went to Karbala

And after all that gadding about came back the same as when I left.

[makke gayā madìne gayā karbalā gayā

jaisā gayā thā waisā hì chal phir ke à gaȳ̄]

If going on Hajj made one a man,

then the whole world would go;

Thus Mr. Shaikh has returned from Mecca,

still the same ass of asses as before.

[hajj se ko’i ādmì ho to sārā 'ālam hajj hi kare

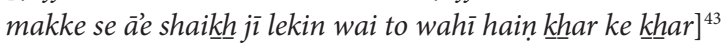

Clearly, then, the verse that allegedly caused so much offense to Shah Jahan was very much within the parameters of commonly acceptable poetic themes and imagery.

But knowing this, as the extremely literate Sarkhwush himself surely would have known, in some ways only deepens the mystery. Why portray the munsh $\bar{\imath}$ in this way, as a cheeky, heretical upstart who lacks the most basic courtly manners, and utterly contrary to his reputation as a learned and refined gentleman? And why, for that matter, portray the emperor in this way, as a hotheaded zealot unable to take even a relatively mild expression of heterodox wit in stride? It is difficult to put one's finger on it empirically, but it is hard to resist speculating that the image contained in this anecdote-of the emperor as "protector of the faith," as a strong force for Islam in India, meting out exemplary punishment to the insolent Brahman poet-is especially powerful precisely because it goes against the grain of everything sources tell us about Chandar Bhan's character and relationship with Shah Jahan. Ironically, this projected image of Shah Jahan maps so perfectly onto the archetype of the Muslim despot as a quick-tempered dispenser of harsh justice that, had it been penned by a European, we might be quick to denounce it as shamelessly Orientalist. The fact that the anecdote comes from a precolonial Persian source thus creates quite an interpretive conundrum. 
We don't know, moreover, whether Sarkhwush himself invented the story or if this sort of inversion of Chandar Bhan's image was already circulating as gossip in the decade or so after his death and Sarkhwush was simply the first to write it down. He does, however, also go on to provide the earliest known written account of another verse often attributed to Chandar Bhan, in which the poet openly satirizes the orthodox impulse to tear down temples and build mosques in their place. In this case, though, there is an interesting twist. Sarkhwush knows that this second verse is not by Chandar Bhan, yet he records it in connection with the munshi anyway, seemingly for the sole purpose of furthering the mnemonic association of Chandar Bhan with antinomian verse and poor manners.

The following couplet is widely attributed to him [Chandar Bhan], but a bit of research $[$ tahqi $q$ ] shows that it was composed by some other Hindu:

Just see the miraculous power of our idol-house, O Shaikh-

When it gets destroyed, it becomes a house of Allah!

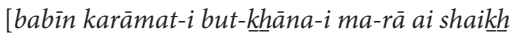

ki gar tabāh shawad khāna-i khudā gardad]

Mirza Muhammad 'Ali Mahir [Sarkhwush's own literary mentor] asked him: "Is this verse yours?” He said, "Perhaps I composed it, I don’t remember.” This had to be some kind of ruse, because if it had really been his own verse that he "didn't remember" [chūn shi'r-i bar-jasta az wai ba-khātitir nabūd], then the mere mention of it should have sufficed to remind him. This faqir [i.e., the author] prefers the writing of poems with honesty and integrity [ash'ār rāst ba-rāst niwishtan faqì r rā khwush mī-äyad]..$^{44}$

Here Sarkhwush seems to be suggesting that Chandar Bhan has slyly accepted credit for a verse that he might not have composed, by being cagey without actually lying about it. Thus, on top of having two potentially offensive verses associated with him, in Sarkhwush's eyes Chandar Bhan has compounded the problem by committing a serious breach of literary etiquette, affecting nonchalance where a forthright admission of what was sometimes known as "accidental plagiarism" (tawārud) would have been more appropriate. ${ }^{45}$

\section{THE POLITICS OF ANECDOTAL TRUTH}

Whether any of what Sarkhwush has to say is empirically true, however, is in some ways beside the point. His image of Chandar Bhan as the cheeky Hindu poet who, whether out of naïveté or outright insolence, once recited an ill-mannered verse before the emperor and almost paid for it with his life, emerged over the ensuing decades as the single most commonly remembered moment our munsh $\vec{\imath}$ s career. This process only picked up steam when the memory of Prince Dara Shukoh got attached to the anecdote as well, thanks in large part to Sher Khan Lodi, another 
late seventeenth-century author who included Sarkhwush's anecdote about Chandar Bhan in his expansive compendium Mir'ät al-Kh hayāl (completed in 1690-91 CE) but made some very telling additions. ${ }^{46}$ Lodi's most significant intervention was not only to insert Dara Shukoh into the narrative but also to recast virtually the entirety of Chandar Bhan's career as nothing but a lucky result of the prince's largesse. He begins:

Chandar Bhan, the sacred thread-wearer [zunnar-dār], was among the residents of Akbarabad [i.e., Agra], and took "Brahman" as his pen-name. He had a fairly mystical temperament [ $\underline{k} \bar{a} \bar{l}$ i az wā-rastagi nabüda] and got started in the office of munshis under the auspices of the Prince of Great Fortune, Sultan Dara Shukoh. He advanced in association with the prince through the gift of a glib tongue [ba-dast$\bar{a} w e z-i$ charb-zabānī $]$, and his poetry and prose became a joy to the prince's heart. Among his writings, the work Chahār Chaman gives evidence of his rhetorical skill and clarity of expression [mațlab-nawīsì wa sādagī-yi 'ibärat] and cannot mask the silkiness of his verse.

Here too, even more overtly than Sarkhwush, Lodi seems to be damning Chandar Bhan with faint praise, incorrectly crediting Dara with starting and advancing his career but at least acknowledging that Chandar Bhan did indeed have a modicum of literary skill. Lodi is, however, nonetheless suspicious of this Hindu munsh $\vec{\imath}$ s success, explicitly wondering how Dara could have favored Chandar Bhan over the more "capable men" (musta'iddān) at the Mughal court. To this mystery, he can only venture to suggest that "either the prince had a special affinity for his simple style [sukhan-i sāda], or [Chandar Bhan] achieved this status through sheer luck."

Even though Chandar Bhan is the overt target here, however, no savvy reader could miss the fact that Dara is implicated too. Lodi's chauvinistic assumption that Hindus a priori cannot achieve true mastery of literary Persian collides squarely with the otherwise indisputable fact of Chandar Bhan's successful administrative and literary career, and thus he resorts to deftly insinuating that there was some kind of Brahman trickery lurking behind Chandar Bhan's success. Concomitantly, he virtually takes for granted that Dara was in fact a naive, gullible, and ultimately unwise personality, susceptible to the malign influence of mediocre, irreligious, and ignoble charmers. Just as Dara's ungentlemanly behavior in real life rankled many members of the nobility, so too in Lodi's depiction he rebuffs the "capable men" of the court in favor of Chandar Bhan's "simple style" (sukhan-i $s \bar{a} d a)$ - which again, as with Sarkhwush, has to be taken in pejorative contrast to the tāza-gu' 's that was all the rage. Lodi then continues the theme with a subtle retelling of the same anecdote first penned by Sarkhwush:

They say that once one of [Chandar Bhan's] couplets greatly impressed the prince. One day, in the heart of the privy chamber [ghusl-khāna], where talented men from all the seven climes congregate, he mentioned to [Shah Jahan] that "a wonderful 
new couplet has been composed by Chandar Bhan Munshi. With permission, I will call him to your presence." Through this tactic Dara Shukoh had an eye toward demonstrating [Chandar Bhan's] talent and ability. The emperor ordered him to present himself, and when [Chandar Bhan] arrived [the emperor] commanded: "Recite that couplet of yours that Baba [Dara] liked so much today." Chandar Bhan recited this verse:

I have a heart so acquainted with infidelity that, however many times I took it to Mecca I brought it back still a Brahman.

[ma-rā dilī-st ba-kufr äshnā ki chandīn bār ba ka'ba burdam-o-bāz-ash barahman āwardam]

Upon hearing this, the faith-protecting, sharī'a-following emperor [bādshāh-i mutasharri' dīn-dār] became angry, wrung his hands, and said: "Can anyone answer this infidel?"

Among the esteemed gentlemen Afzal Khan, who was known for being quick with an answer, came forward and said: "With permission, I will respond with a couplet from the master." The emperor nodded, and Afzal Khan recited this couplet of Hazrat Shaikh [Sa'di] , which had refuted him four hundred years in advance:

[Even] If Jesus's donkey goes to Mecca

It's still just a jackass when it comes back.

[ khhar-i î̀sá agar ba makka rawad

chūn biyāyad hanūz khhar bāshad]

The emperor's blessed heart relaxed and, thanking [Afzal Khan], he said: "It was by the power of the faith, may Allah be propitious and bless it, that you offered this sort of rejoinder, otherwise I might have killed him in anger." He [the emperor] ordered gifts for Afzal Khan, warned the prince not to bring such undignified chatter [muzakhrafät] into his presence again, and had Chandar Bhan removed from the privy chamber.

The basic structure and elements of the anecdote are the same as that of Sarkhwush, but by casting Dara as the overeager facilitator of Chandar Bhan's alleged transgression Lodi throws a spotlight on Dara's willingness to flout-indeed, his total cluelessness about-a certain presumed standard of acceptable decorum. Surely this would have resonated with a readership that had a living memory of the prince's occasional bad behavior, hints of which are reinforced at every stage of Lodi's version of the story, from infantilizing the prince as "Baba" to the patronizing warning not to traffic in such muzakhrafät. Indeed, by framing the anecdote in this way Lodi subtly shifts much of the story's attention to Dara, making Chandar Bhan himself into almost an afterthought.

At this point Lodi adds another twist to the story that would also become part of the standard repertoire of mnemonic images of Chandar Bhan, and, by 
extension, of Dara as well. "At any rate," Lodi continues, "the aforementioned [Chandar Bhan], having renounced his employment after the death of Dara Shukoh, went to the city of Banaras and busied himself there with his own [i.e., 'Hindu'] ways and customs, until finally in the year 1073 [1662-63 CE] he became ash in the fire-temple of annihilation."

This is simply, patently false. As we discussed at length above in chapters 1 and 2, Chandar Bhan's own extant writings and various other bits of reliable evidence indicate clearly that he continued to serve Aurangzeb for a number of years even after Dara's execution before finally retiring to Agra, where he and his son Tej Bhan maintained their connection to the court by managing the Taj Mahal complex until at least the autumn of 1666 (i.e., some four years after the date Lodi gives for his death), when they were both honored by Aurangzeb with robes (khil'ats). Thus the idea that Chandar Bhan retired instead to Banaras appears entirely to have been Lodi's own invention. No source prior to Mir'ät al-Kh hayāl, to my knowledge, had ever mentioned Chandar Bhan even visiting Banaras, much less renouncing his imperial service and moving there permanently so that he could mourn Dara's death. This little epilogue thus appears very clearly calculated to further reinforce a certain image of Chandar Bhan, not as a long-serving member of the Mughal administrative elite in good standing, but rather as a kind of imaginary, idealized, generic Hindu - the sort of devoted Hindu for whom a final pilgrimage to Banaras, a city inextricably linked to the religio-cultural imagination of and about Hinduism, was the logical next move after his liberal benefactor was no longer around to advance his career.

The fact that this portrayal of Chandar Bhan and his relationship with Dara can, for the most part, be debunked on strictly empirical grounds does not in any way undercut its long-term historical importance, however, because some version of Lodi's narrative gets transmitted by virtually every eighteenth-century tazkira that includes an entry on Chandar Bhan. In most cases, the central encounter between Chandar Bhan, Dara Shukoh, and Shah Jahan is reported as the most salient-often the only salient - thing worth remembering about the munsh $\vec{\imath}$ s career. Most of these later reports borrowed explicitly from Lodi's ur-version of the event, sometimes acknowledging him as a source, often reproducing his exact words, and along the way transmitting a potent cultural memory of "Baba" Dara as well. In the process, this almost certainly fictional encounter becomes absolutely critical for how not just Chandar Bhan but also Dara Shukoh was remembered by early modern audiences.

What exactly is going on here culturally and politically? Simply proving that Lodi got it wrong is not much help in answering this question. And perhaps the real question in any case is why, in the face of so much easily available contradictory evidence, Lodi and Sarkhwush felt so comfortable telling these tales, less than a generation after Chandar Bhan's death. 
One interpretation could be that Lodi is trying to use Chandar Bhan as a kind of synecdoche for Hindus in general, particularly in terms of their interactions with imperial power. The modern scholars Bruce Lawrence and Marcia Hermansen have argued that the tazkira as a genre was notable for its use of "memorative communication" to sacralize a certain Muslim cultural space in South Asia by invoking the memory of past and present Muslim "heroes" like Sufi saints, prominent nobles, excellent poets, and so on. This narrow view of the function of such texts in Indo-Persian literary and mystical culture breaks down somewhat when one considers that a great many eighteenth-century tazkiras were also written by Hindus. But Lodi's portrayal of Chandar Bhan does nevertheless at least provide some evidence for the more general notion that tazkiras could be used to circulate stories and anecdotes with important cultural and political symbolic value beyond their mere usefulness as sources for biographies and other information about poets. ${ }^{47}$

Indeed, one is hard pressed here not to detect a certain culturally conservative attitude on Lodi's part regarding the threat of Hindus such as Chandar Bhan who would attempt to encroach on urbane Indo-Persian society by insinuating themselves into elite literary and cultural circles. The emperor is valorized for upholding good taste and taking due offense to the perceived affront to Islam contained in the verse, while Afzal Khan is on hand not only to put Chandar Bhan in his place but to do so in just the right way, using a precedent from a canonical Persian master to counter the upstart's moral (and literary) transgression. Afzal Khan's wit was a weapon, but it was also a means to neutralize the emperor's anger and defuse the tension. This in turn allows for the image of the emperor to be doubled: he is both ideally uncompromising in his defense of the faith and ideally merciful for not punishing Chandar Bhan once an appropriate literary rejoinder has undercut him. But it is an ambiguous mercy-the threat of his power still lurks, hence they must usher the offending munshi out of the room while Shah Jahan's now bemused attention is distracted, that is, before his mood changes again. The entire moment can be read a parable about necessity for royal power to safeguard certain cultural norms, even as one must always beware the volatility of that power.

But one could also read it as a parable about the Persian language itself and the cultural anxiety of some intellectuals, like Lodi, regarding the domestication of Persian as an Indian language accessible to Hindus as well as Muslims. Though Persian had long been a kind of "secular" language of Indo-Muslim literary and administrative culture, by the time Lodi was writing Mir'ät al-Khayāl Hindus had begun to dominate the Mughal secretarial and bureaucratic classes, and more and more Hindus were participating at all levels of Indo-Persian literary and intellectual culture. ${ }^{48}$ Their presence was also increasingly being felt socially in elite literary salons and urbane cultural forums, not only as participants but also as patrons, as seen for instance in the career of the famed "Lord of Traders" Anand 
Ram Mukhlis (1695-1758), a poet himself who also became a major patron of IndoPersian literary culture in the early eighteenth century. ${ }^{49}$ In other words, far from a socially insular world produced by an age of widespread orthodox retrenchment, late seventeenth-century South Asia arguably witnessed more Hindu-Muslim cultural interaction than ever before. But this did not mean that everyone always got along, or that there was no cultural anxiety about such developments, particularly among more conservative critics like Lodi. And perhaps what we are really seeing here is an example of such anxiety, filtered through the prism of a seemingly isolated anecdote about munshī Chandar Bhan Brahman.

As we discussed in the previous chapter, moreover, this was also a period in which India's rivalry with Iran was taking a particularly interesting turn, perhaps leading Lodi and some of his fellow Indian Muslim intellectuals to feel squeezed between two kinds of pressure, one regional and "horizontal," and the other social and "vertical." Horizontally, Indian poets and other intellectuals' long-standing claim to a status as equal participants in the cosmopolitan Persianate ecumene was coming under fire from Iranian critics who claimed to be the only true "native speakers" (ahl-i zabān) with linguistic and cultural authority. Meanwhile vertically, from "below," the elite status of certain Indo-Muslim intellectual communities within India was being trespassed upon by an upwardly mobile and newly prominent class of Hindu bureaucrats and literati, many of whom, like Chandar Bhan, could advance their own claims to Persian linguistic and literary mastery.

What better way, then, to alleviate some of the cultural anxiety of the moment than by putting such upstarts in their place-in this case, by revisiting the memory of the most famous of their ilk, Chandar Bhan, and lampooning him? Better yet, by also lampooning the patron saint of syncretism, Dara Shukoh, right along with him, and doing it in such a way that recasts Shah Jahan as resistant to the prince's liberal and eclectic agenda, and therefore by extension politically resistant to Dara himself in favor of the eventual successor, and Lodi's own emperor, Aurangzeb?

None of this, unfortunately, really tells us any more about where the anecdote originally came from. But it certainly gives us a more historicized context in which to read the story and to understand why it made anecdotal-if not empiricalsense to some intellectuals like Lodi and Sarkhwush and found such a receptive audience among other Indo-Muslim elites of succeeding generations throughout the eighteenth century.

\section{FROM GOSSIP TO CONVENTIONAL WISDOM}

In an interesting twist to all this, it was a member of that very class of "upstart" Hindu Persianists who composed the next major tazkira of this period, the Hamisha Bahār (Eternal spring) of Kishan Chand "Ikhlas" (d. 1754). Ikhlas was a khattri and resident of Delhi, the son of one Achal Das Dehlavi, who by 
all accounts was quite an intellectual gadabout himself and an avid follower of various Sufi darweshes in and around Delhi toward the end of the seventeenth century..$^{50}$ According to its author, Hamisha Bahār was completed in $1136 \mathrm{AH} /$ 1723-4 CE, about thirty years after Lodi's Mir'āt al-Kh hayāl.

Given the timing, it is likely that Ikhlas's father had frequented some of the same Delhi literary circles as Lodi and Sarkhwush, and Ikhlas himself might well have been familiar with oral versions of some of the anecdotes about Chandar Bhan that these earlier writers had included in their tazkiras. In fact, Ikhlas acknowledges Kalimāt al-Shu'arā as one of his major sources, especially for poets with whom he was not personally acquainted. ${ }^{51}$ Chandar Bhan would certainly have fallen into this category, making it all the more intriguing that Ikhlas completely bypasses both Sarkhwush and Lodi's accounts of the munsh $\vec{\imath}$ s encounter with Shah Jahan and instead adds his own curious anecdote to the mix. His account is as follows ${ }^{52}$ :

Rai Chandar Bhan Brahman was a native of Lahore; he resided in the Abode of Tranquility and Universal Civility [dar dār al-amn-i șulh-i kull āramīda] and was very genteel; he had a compassionate disposition and was a friend to poverty (i.e. to mystics) [bisyār pasandīda waz'-o-dardmand wa faqr-dost būd].

It has been heard from the mouths of many a knower of secrets and many skilled historians in this ancient land that, from the beginning of the Timurid era up to the present, such a great Hindu had not appeared in the realm [hindu'i ba-in k $k \bar{h} \bar{u} b \bar{\imath}$ ba-'arșa-i zuhūr nayāmada] —even though, compared to Raja Todar Mal and some other Hindus, he was neither blessed with such a degree of worldly resources nor quite so accomplished in terms of rank and status. There had been many other preeminent Hindus [hindu'ān-i șăhib-i kamāl] who demonstrated the acquisition of rational ['aqli], practical [naqli], natural [țab'ì], and spiritual [ilähi] sciences, and so on. But insofar as he placed great faith in highly distinguished holy men [i'tiqād ba-firqa-i 'āliya-i fuqrā bisyār dāsht], he was able to inhale an extra whiff of Truth.

He was the beauty worshipper in the idol-house of Meaning and also wrote the broken script [shikasta] well. In the discipline [ $\left.\bar{a}^{\prime} \bar{\imath} n\right]$ of $i n s h \bar{a}^{\prime}$ he emulated the excellent master Shaikh Abu al-Fazl..$^{53}$ When reciting poems, tears flowed from his eyes, and he used to sigh with the lamentation of [mystical] searching. In the beginning of his career he worked for Mir 'Abd al-Karim, the superintendent of buildings in Lahore; after that he was attached to the exemplar of pure character Afzal Khan and then entered the service of Emperor Shah Jahan.

This passage clearly suggests that unlike Sarkhwush and Lodi, who mention Chandar Bhan's works but don't give any clear indication one way or the other that they've actually read them, Ikhlas is familiar not only with Chandar Bhan's own oeuvre but also some of the other contemporary sources that talk about him (for instance, the work of the historian Muhammad Salih Kambuh, some of whose description of Chandar Bhan in 'Amal-i Șäliḥ Ikhlas has lifted practically verbatim). In any event, Ikhlas continues: 
Praise God! How fortunate is he who is remembered fondly after his death! If one spends all day and night like dogs and jackals engaging in wolfish deceit and dirty tricks, then what's the use? As the melodist in the rose garden of mystical meanings, Mirza Mu'izz Musawi Khan, has put it:

Live so that when calamity comes and you are obliterated from this world

You didn't abandon the finer virtues

lest you fade from memory.

[ān chunān zī ki chu az hạdișa bar-bād rawī

husn-i ma'nī naguzārad ki tu az yād rawī]

From among Brahman's glistening verses [six verses follow, of which I quote only the last]:

Just see the miraculous power of our idol-house, O Shaikh-

When it gets destroyed, it becomes a house of Allāh!

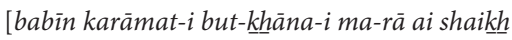

ki chūn kharāb shawad kn̄āna-i khudā gardad]

This last couplet, which has become inscribed at the front of the niche of fame in the opinion of elite and common alike, is attributed to him, but this is simply a mistake. I have heard firsthand from [Bhupat Rai] Bi-Gham that it was composed by Dayal Das Parasruri [a.k.a. "Pasruri"]. ${ }^{54}$

They say that one day the rai [Chandar Bhan] was passing through the bazaar of Akbarabad [i.e., Agra] riding in a chariot with his disciple Shiv Ram-who, in the time of Emperor 'Alamgir, was assigned to serve as a draftsman for Nawab Fazil Khan, the head of supplies, and who, being in the onset of youth, captivated the heart with flirtatiousness and coquetry through every expression of his mind and body. Suddenly, the rai's gaze fell on a beautiful woman dressed in a ravishing outfit who was sitting in a storefront selling pipefuls [chillums] of tobacco to her customers for one rupee apiece. These enchanted customers of the peerless beauty were heatedly bartering and crowding around her [dar dād-o-gìr sar-garm büdand]. Stopping the chariot, the rai handed Shiv Ram a rupee and said: "You also buy a chillum from her." When the youth approached this beloved, the saucy lady looked toward them and said: "This strange old man is so bashful [ablah], that he gave you money, sent you before me, and thus placed me in your hands." ${ }_{55}$ Exposed on hearing these words [ba-mujarrad-i shanidan-i in harf], they both remained too flabbergasted to answer, and simply went on their way.

The first thing to notice about this passage is its appropriation of several lines, not from Sarkhwush, but from Muhammad Salih Kambuh's account of Chandar Bhan at the end of his historical chronicle 'Amal-i șälih. This might not seem so odd, except for the fact that Sarkhwush was by far Ikhlas's primary source, so much so that Wahid Qureshi, the modern editor of Hamisha Bahār, feels compelled to note every instance in the text where Ikhlas has borrowed from 
Sarkhwush, sometimes almost word for word. Given this overwhelming reliance on Kalimāt al-Shu'arā, it is certainly a bit curious to find no mention of Chandar Bhan's alleged encounter with Shah Jahan here. In a footnote, Qureshi states simply that Ikhlas "didn't take anything from Kalimāt al-Shu'arä" for the section on Chandar Bhan-but he does not address the more vexing question of why Ikhlas would or wouldn't follow Sarkhwush in any given instance. Sarkhwush has been a perfectly valid source for him throughout Hamisha Bahār, so what causes Ikhlas to avoid Kalimàt al-Shu'arā here?

It may well have simply been a question of scholarly methodology. Perhaps, having read Chandar Bhan's own works and other sources like Salih carefully, Ikhlas-like me-simply found Sarkhwush's information less reliable for Chandar Bhan than for some of the other poets he deals with in Hamisha Bahār. But Ikhlas presumably would have also sensed the same subtext in Lodi and Sarkhwush's accounts of Chandar Bhan that I have adduced above. And, as a Hindu himself, he might have had his own experience with the social and literary controversies of the day, making him especially attuned to Sarkhwush and Lodi's biases and their implications. In other words, though it would be far too simplistic to suggest that Ikhlas ignores Sarkhwush's and Lodi's portrayals of Chandar Bhan solely because, as a Hindu, he found them distasteful and demeaning, it is hard to resist speculating along those lines. He therefore bypasses their versions, turning instead to the testimony of Chandar Bhan's own friend and contemporary, Salih.

Besides illustrating at least one way that social and religious biases could play a subtle part in certain types of knowledge transmission, Ikhlas's account raises the question of how early modern intellectuals like him actually conducted research. He clearly seems to sense the limitations of his main source, Kalimāt al-Shu'arā. But what types of methodological choices did writers like him make actually in constructing their texts? How did they distinguish between valid and invalid sources, and what were their criteria for sifting reliable from unreliable sources? How did they negotiate the sometimes conflicting claims of oral history versus textual archives? And how did the tension between these various types of sources factor into their narrative choices?

Modern scholarship has not yet even begun to address these sorts of questions, in part because, like the inshä' canon, such tazkiras have generally been read in modern times simply as sources of data, rather than as a textual tradition with its own set of internal norms. But it is in this context that we might read Ikhlas's story of Chandar Bhan and his shägird Shiv Ram riding through the market and being embarrassed by a local woman. Perhaps Ikhlas is attempting to insert his own alternative memorable anecdote into the tradition, in an attempt to provide a more innocuous narrative to compete with the one offered by Sarkhwush and Lodi. But if this was indeed Ikhlas's goal, then he was ultimately unsuccessful. 
Only one other tazkira writer-ironically enough, another of Sarkhwush's acolytes, Brindaban Das Khwushgu (d. 1756), in his Safina-yi Kh $\underline{h} w$ ushgū-took up this vignette about Chandar Bhan and Shiv Ram riding through the market, and that too slightly altered. Thus, despite Ikhlas's best efforts, and despite Hamisha Bahār's considerable influence on later writers, it was Sarkhwush's and Lodi's versions of Chandar Bhan's personality that came to dominate accounts of him for the remainder of the eighteenth century and beyond.

This triumph is clearly evident in the notice about Chandar Bhan in another influential eighteenth-century tazkira, 'Ali Quli Khan "Walih” Daghistani's Riyāz al-Shu'arā (The garden of poets; 1748). Born in Isfahan to a distinguished family, Walih had moved around quite a bit in early life as a result of disturbances caused by the Afghan invasions of Iran in the early 1720 s before winding up in India and finally reaching Delhi in 1734-35. He served under various Mughal rulers, beginning with Muhammad Shah (r. 1719-48), and eventually achieved the notable manșab ranking of 7000 under 'Alamgir II (r. 1754-59) before dying in Delhi in $1756 . .^{56}$

Walih's entry on Chandar Bhan in Riyāz al-Shu'arā basically follows Sarkhwush's seminal account in Kalimàt al-Shu'arā to the letter, but perhaps the most noticeable feature of this later version is that, for Walih, it seems that Chandar Bhan's encounter with Shah Jahan has by now become practically the only thing worth mentioning about the munshì. Here is the entry in full:

Chandar Bhan, pen-named "Brahman," was among the Brahmans of Hind and the munshis of Shah Jahan Badshah. One day the order came from the Court of the Caliphate [pesh-gāh-i khiläfat] that he recite one of his poems. He delivered this couplet:

I have a heart so acquainted with infidelity that however many times

I took it to Mecca I brought it back still a Brahman.

[marā dilī-st ba-kufr āshnā ki chandīn bār

ba ka'ba burdam-o-bāz-ash barahman āwardam]

According to the demands of piety [ba muqtaz $\bar{a}-y i$ din-dārī], the enraged emperor declaimed: "This insolent wretch [shaqī] should be killed." Afzal Khan replied, "This verse of Sa'dī suits his [i.e., Chandar Bhan's impudent] character" [mișdāq-i $h \bar{a} l-i \bar{u}-s t]$ :

Even if Jesus's donkey goes to Mecca,

He's still just a jackass when he comes back.

[khhar-i īsá agar ba-makka rawad

chūn biyāyad hanūz khar bāshad]

The emperor smiled and turned his attention elsewhere, and those assembled at the foot of the exalted throne removed him [Chandar Bhan] from the eminent chamber. ${ }^{57}$ 
This is all Walih has to say about Chandar Bhan, despite, by his own profession, having had numerous sources available to him besides Sarkhwush. He claims to have studied over seventy poetic collections and numerous biographical and historical texts-including the tazkiras of Aufi, Taqi Auhadi, and (significantly for our purposes) Sarkhwush and Lodi as well-in preparing his work..$^{8}$ Moreover, as several scholars have pointed out, Walih was, generally speaking, very attentive to these sources' credibility, even going so far as to see himself as adjudicating the matter when his sources disagreed. As Paul Losensky has marveled, "Vālih deploys all his resources. ... He gathers new material, critiques his sources, and brings some older material up to date." 59 It would appear, however, that in the case of Chandar Bhan he has deployed few if any of these scholarly resources. He does not examine any of Chandar Bhan's own writings, and he leaves out a fair amount of Sarkhwush's account, including the notorious "babīn karāmat" verse. He also ignores Lodi's many additions, such as Dara's alleged role in the matter, and he says nothing of Chandar Bhan's supposed retirement to Benares. Nor does he seem to be aware of Ikhlas's revisions and additions.

Again, we are faced with the question of how the authors of such tazkiras used, abused, and adapted their sources. There is very little scholarship on the topic, unfortunately, but Losensky, in his excellent treatment of how the tradition slowly revised the biography of the great Timurid poet Baba Fighani Shirazi (d. 1519), observes that one technique writers used was simply to insert "undisguised repetitions" of earlier works into their biographical accounts (indeed, we saw a perfect example of this technique above, with Ikhlas's unattributed borrowing from Salih). Losensky ponders whether such wholesale borrowing reflects a form of casual "indifference to [their] subject matter" on the part of early modern critics or rather the opposite-a way of referencing earlier sources "without the convenience of footnotes." 60 In the case of the tazkira sources that deal with Baba Fighani, Losensky concludes that "the obviousness of [the] borrowing suggests the latter." But Chandar Bhan's case does not appear to be so clear-cut, and we might even be forced to come to the opposite conclusion-that Walih was so curtly distilling the Chandar Bhan story down to its most memorable part simply out of indifference.

If he was, even this indifference has a kind of proactive logic to it. Walih is making scholarly choices here about what is or isn't worth being passed on to posterity. The contrast with his treatment of Fighani is instructive. Whereas Walih "finalizes Fighani's literary and saintly canonization" by going to great lengths to "[evaluate] Fighani's importance in terms of the entire Safavid-Mughal literary tradition and his own personal poetic development," he seems to perform the opposite operation on Chandar Bhan. ${ }^{61} \mathrm{He}$ excises all other competing information and cements the memorative image of Chandar Bhan: not as the affable "Persian-knowing Hindu"

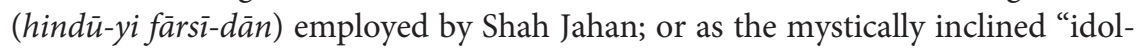
worshipper in the temple of expression" (șanam-parast-i but-khānah-i sukhan) of 
Muhammad Salih Kambuh's contemporary account; or as the master epistolographer in the tradition of Abu al-Fazl; or as the author of numerous Persian works of which Chahār Chaman, Munsha'āt-i Brahman, and Dīwān-i Brahman were only the most famous; or even as the synoptic image of the Hindu envisioned by Lodi as detrimental to Prince Dara's character. Rather, in Walih Daghistani's hands Chandar Bhan becomes, simply, the impudent Brahman who one day angered the emperor with a heretical verse and nearly paid for it with his life.

\section{THE AFTERLIFE OF A MUGHAL ANECDOTE}

Within a century of Chandar Bhan's death, then, a complex process of negotiating the parameters within which remembrance (literally, tazkira) of the celebrated munsh $\bar{\imath}$ would be defined in literary circles had already been consolidated. This is not to say that all writers after Walih simply followed Riyāz al-Shu'arā or that no one after him ever questioned the story's veracity. Of course, this is not the case. The image has been doubted by several scholars and has even been openly questioned by some. ${ }^{62}$ But even those who have been most vehement in refuting the possibility of the encounter have failed to account for its persistence or to offer some explanation of why it was even told in the first place. Thus the fact remains that after Walih virtually no one (including myself) has been able to write about Chandar Bhan without dealing with this story in one way or another. It frames the entire context within which he is remembered and has dominated the memory of him right down to the present day.

In fact, in some cases the image has become even more exaggerated. For instance, the early nineteenth-century tazkira of Shaikh Ahmad 'Ali Hashimi Sandelvi, Makhzan al-Gharä'ib (Treasury of wonders; completed 1803-4), basically follows Lodi's account of the incident. ${ }^{63}$ Thus Sandelvi too mistakenly states that Chandar Bhan was from Akbarabad (Agra) and argues that Chandar Bhan retired to Banaras after Dara's death. But Sandelvi doesn't simply copy Lodi's account. In some cases, he clarifies passages that were either implied or ambiguous in Lodi's wording, thus creating almost a gloss or commentary on Lodi's master text. ${ }^{64}$ But Sandelvi is also uses a noticeably sharper, more acerbic tone toward our munshi . Writing at the tail end of the debates on Iranian Persian versus Indian Persian, and being a vigorous partisan of the Iranian side, perhaps Sandelvi found it even more urgent than Lodi did to paint Chandar Bhan as emblematic of the negative effects of Hindu (and by extension Indian) influence on Persian literary culture. In Sandelvi's account Chandar Bhan is not simply an infidel but a boorish one at that: an "uncultured sacred-thread-wearer" (zunnār-dār-i bī-adab). And whereas Lodi had reported that Dara was warned at the end of the incident not to engage in such "undignified chatter" (muzakn hrafāt), Sandelvi takes it a step further and tells us that the emperor warns the young prince not to bring "such people" (i.e., 
insolent Hindus?) into his presence again (ba shāhzāda mana' farmūd ki bār-i dìgar chunīn kasān rā dar huzūur nayārad).

In certain later texts, in other words, the subtext of the earlier accounts was becoming much more explicit. Long forgotten, meanwhile, is the perspective of Chandar Bhan's seventeenth-century contemporaries like Muhammad Salih Kambuh, Munir Lahori, and others, for whom the fact that Chandar Bhan was a Hindu might have remained worth noting as a marker of religio-cultural difference but did not preclude his ability to master the etiquette and comportment $(\bar{a} d \bar{a} b)$ of an urbane Indo-Persian gentleman. In its place, Sandelvi anchors his entire account to a determinist framework where religious identity is a critical factor in achieving certain kinds of linguistic expertise, something that Lodi and Sarkhwush had merely hinted at. Of course, this type of determinist view would only gain momentum as the nineteenth century progressed, as modern communal interpretations of South Asia's history and culture came into their own in British colonial and Indian nationalist historiography, and the equations "Persian/Urdu = Muslim languages" and "Hindi = Hindu language" gained wider and wider currency.

Over the course of the nineteenth century, moreover, the status of these earlier tazkiras as reliable sources of collective cultural knowledge began to undergo a change, as did the value judgment implicit in Sarkhwush and Lodi's original anecdotes. While some of these shifts are definitely attributable to the growing British colonial influence on Indian intellectuals, it is not always easy to pin down exactly how that influence manifested itself in actual scholarly practices.

For instance, consider Nishtar-i 'Ishq (Lancet of love), the voluminous tazkira written by Aqa Husain Quli Khan “Ashiqi” "Azimabadi over the course of nearly a decade and completed in 1233 AH / 1818 CE.65 'Ashiqi's main motivation in writing Nishtar-i 'Ishq appears to have had far less to do with ingratiating himself among the Europeans than with contesting the received literary canon. Though he was born in Patna, it is reported that 'Ashiqi gained most of his poetic knowledge during the numerous visits to Agra and Delhi that he made over the course of his life. (This pattern, it should be noted, was true for Sandelvi as well, who was not a native of Delhi but who credits his conversations with various expatriate Khurasani and Iraqi poets living in Delhi for teaching him the true fundamentals and ethos of Persian literary culture.) But upon reading Walih's Riyāz al-Shu'arā, 'Ashiqi seems to have awoken from his dogmatic slumbers, for he claims that he was so unimpressed by Walih's selection of poets and insipid characterizations that he decided to write his own alternative. His entire tazkira can thus be read in dialogic relation to Riyāz al-Shu'arā, as a direct contestation of the earlier work's vision of what constituted the Indo-Persian literary canon, and moreover of what constituted the best scholarly approach to representing the writers and works who populated that canon. 
It is no coincidence, then, that 'Ashiqi's portrayal of Chandar Bhan represents the most sustained attempt to provide an alternative to Walih's version-or rather, if not quite to counter Walih's version, then at least to expand on it by providing multiple versions of the infamous anecdote we have been discussing here. ${ }^{66}$ 'Ashiqi also self-consciously foregrounds his methodology, quoting from source material and providing full attributions to those sources. Thus, after providing some introductory background on Chandar Bhan, mostly taken from Salih, he goes on to quote the notices of both Sarkhwush and Lodi in their entirety and in succession. He does not comment on whether either source is reliable, but he obviously has some doubts, and the fact that he assembles his sources in this way suggests clearly that he is thinking chronologically, as well as critically distancing his own scholarly judgment from that of sources he deems suspect. In other words, drawing his readers' attention so self-consciously to the fact that he is quoting them is also a way of bracketing them as part of a past archive rather than an ongoing conversation-a clear move, it would seem, to a kind of modern scholarly disciplinarity.

'Ashiqi also adds what appears to be an entirely new anecdote to the store of memories about Chandar Bhan, but in this case he tellingly does not reveal his source. Recall that Chandar Bhan claims in his Munsha'ät (quoted in chapter 5 above) that his writings had achieved fame throughout Iran and Turan, and all over Hindustan. 'Ashiqi, perhaps wishing to highlight what he considered to be the bad manners [ $b \bar{i}-a d a b \bar{i}]$ of Iranian and Central Asian rivals in his own day, turns Chandar Bhan's boast on its head. He reports that Chandar Bhan once sent a gilt, ornamented, and beautifully bound copy of his Dìwān to the master poets of Iran and Turan (specifically which ones, however, we are suspiciously not told). In turn these rude Iranian and Turanian poets abroad-all of them, apparentlyare said to have kept the expensive bindings and sent Chandar Bhan's poems back to him. For 'Ashiqi, then, at a historical moment of heightened Indo-Iranian rivalry, Chandar Bhan seems to stand as a symbol, not of the "Hindu" encounter with Mughal rule, but rather as a symbol of Indian resistance to perceived slights coming from other parts of the Persianate world.

In the grand sweep of modern Indo-Persian historiography, however, 'Ashiqi's interpretation of Chandar Bhan's cultural significance has become something of an outlier, for there were still more cultural shifts on the horizon that would have an even greater impact on the memory of our munshi. One immensely important shift was the change in attitudes about the Mughal Empire itself. As we have noted several times earlier in this book, over the course of the nineteenth century the Mughals (especially the post-Akbar Mughals) underwent a withering critique in British Orientalist and Hindu nationalist historiography. Shah Jahan and Aurangzeb, in particular, were increasingly viewed through the lens of "orthodoxy" and despotism and were given much of the blame for the 
empire's ultimate demise. All the tangled complexity of early modern India's social, ethnic, linguistic, religious, cultural, economic, and political worlds got reduced, eventually, to a simple tale of "Muslim rule" versus "Hindu resistance." And as the larger colonial discourse of rescuing India from Muslim despotism was increasingly deployed to justify all manner of modern political agendasBritish colonialism itself, the promotion of "Hindi" over "Urdu," cow protection, Hindu majoritarianism, Partition, and even postcolonial Hindu nationalismthe memory of many minor figures like Chandar Bhan, and even major figures like Dara Shukoh, was similarly transformed.

Dara Shukoh, for instance, had no doubt been widely admired among many seventeenth- and eighteenth-century commentators. But as I noted above, there was also a consistent undercurrent of doubt in early modern sources about the prince's actual fitness to rule, even if many evinced great respect for his learning, scholarly endeavors, and patronage. This strain of critique is clearly evident in some of the anecdotes discussed above, as well as several others from the eighteenth century that I have discussed elsewhere. ${ }^{67}$ But over the course of the nineteenth century, and continuing on to the present day, any doubts about Dara's character, political savvy, and kingship have been filtered away, and he has emerged simply as the heroic post-Akbar "good Muslim" par excellence, the sole bright light in an otherwise darkening cultural and political landscape.

As a result, anecdotes like the ones about Dara and Chandar Bhan found in early modern tazkiras have been read completely differently in modern times than they appear to have been read in many seventeenth- and eighteenth-century circles. In Chandar Bhan's case, whereas writers like Sarkhwush and Lodi clearly intended to paint the munshi in a somewhat negative light, repeatedly insinuating that he was uncultured and ill-mannered, many modern commentators have completely inverted the message of these anecdotes. In other words, though they appear to have been originally and specifically designed to tarnish Chandar Bhan's reputation with the stigma of impudence, they have instead been transformed into tales of heroic "Hindu" resistance to "Muslim" rule. What once was read as Chandar Bhan's ignorance of Mughal decorum and cultural norms is now seen as a kind of protonationalist political dissent.

Meanwhile, the modern politics of language in South Asia have added yet another fascinating layer to Chandar Bhan's journey through modern historiography. As the various registers of northern India's dominant spoken idiom became standardized, along with their attendant scripts, into modern "Hindi" and "Urdu" over the course of the nineteenth century, those two languages-which aren't really distinct languages at all in any proper linguistic or grammatical sense-also got mapped along religious lines. The idea that Hindus spoke "Hindi," while Indian Muslims spoke a supposedly different language called "Urdu," became all too 
common conventional wisdom in modern South Asia. Meanwhile Persian, too, began to lose its Mughal-era aura as a neutral pan-Indian idiom of culture, power, and diplomacy, irrespective of religious persuasion, and instead came to be specifically coded in British colonial and Indian nationalist writings as a "Muslim" language of conquest.

The story of how all this unfolded, and the devastating ramifications of these language politics for modern South Asian political history more generally, have been explored extensively in postcolonial scholarship. ${ }^{68}$ But they are especially relevant here because these language debates probably wound up coloring the specific memory of munshī Chandar Bhan as well. Since the late eighteenth century, British colonial scholars had argued that Urdu was the "camp" language of India's medieval Muslim conquerors, a mix of "their" Turko-Persian idiom and the "Hindi" of their Hindu subjects. The essentialist underpinnings of this origin story have been thoroughly debunked in a number of recent studies, most notably by the literary scholar Shamsur Rahman Faruqi. But for most of the nineteenth and twentieth centuries it was still fairly common for serious commentators to speak of an odd sort of equation whereby "Hindi + Persian $=$ Urdu," and it was in those heady days of debates about the religious determinants of India's linguistic identities that someone like Chandar Bhan could emerge as a powerful, even paradigmatic, exemplar of this phenomenon. He was a Hindu, after all, which meant by definition that his "natural" language would have been "Hindi." But he was also arguably the most celebrated Hindu Persian savant ever, one who was, moreover, a denizen of the Mughals' royal "camp." Intuitively, then, he must have also known and dabbled in "Urdu" too, if the modern theories of India's historical linguistics were to hold true. The only problem, of course, is that there is not a shred of contemporary evidence, whether from Chandar Bhan's own writings or from any other contemporary source, that our munshi ever wrote a single line of vernacular poetry or prose.

Or did he? It would appear that the symbolic need for an origin story for Urdu literature that conformed with the modern equation "Hindi + Persian = Urdu" had to be met, and symbolically, at least, if not empirically, Chandar Bhan fit the bill quite nicely. Thus, sure enough, around the turn of the twentieth century what appears to be a previously unattested Urdu ghazal attributed to him mysteriously began to circulate. Just like the two Persian verses made so famous by Sarkhwush and the other tazkira writers, there is no evidence from Chandar Bhan's surviving oeuvre to corroborate his authorship of this or any other Urdu ghazal. Nevertheless, beginning with Sri Ram Lala’s K $\underline{h} u m \underline{k} \underline{h} \bar{a} n a-i$ Jawed (1908), and carrying forth in later decades to Brij Mohan Dittatriyah Kaifi Dihlavi's Kaifiyyah (1942), Jigar Barelvi's Yādgār-i Raftagān (1943), and as recently as Jamil Jalibi’s Tārīknh-i Adab-i Urdū (2000), this mystery ghazal has been offered up as a way to make the case for Chandar Bhan as the progenitor of modern Urdu literature. The text of this ghazal 
has also been included in other works without comment, for instance at the end of Shahid Naukhez Azmi's recent edition of Chandar Bhan's poetry, where it is the sole entry in a section on Chandar Bhan's "Urdu oeuvre" (urdü kalām). ${ }^{69}$ But Kaifi puts it most explicitly when he says: "Urdu's first poet was Amir Khusrau, and its first prose writer was [the great Chishti Sufi] Hazrat Gisu-Daraz; but the oldest Urdu ghazal that is still available is that of a Hindu writer named Brahman."7o Kaifi had explained this a bit earlier in the text:

Thinking that on hearing Wali's poetry north India developed a sudden taste for Urdu poetry is a violent injustice to history. A ghazal by a poet of Shah Jahan's reign is offered here as proof. The poet was Rai Pandit Chandar Bhan, takkhallus Brahman, whose birth was nearly a century before Wali's (Wali was born in $1079 \mathrm{AH}$, Brahman in $982 \mathrm{AH})$. Brahman was the mìr munshī in Shah Jahan's darbār, and was a powerful poet and prose stylist in Persian. He passed away in $1073 \mathrm{AH}$. Along with Persian, he also used Urdu, and several scholars agree that the ghazal copied below is the first Urdu ghazal ever written. ${ }^{71}$

Multiple dynamics are in play here. On the one hand, there is an attempt to reclaim Urdu for North India, away from the trajectory that posits Wali Deccani (1667-1707) as the founder of modern Urdu (another story entirely). But there is also an unmistakable-albeit implicit-way in which it simply makes sense to a certain type of modern audience that Chandar Bhan, who combined the Indic and Persianate traditions so effectively, would have written in Urdu. Kaifi does not name any of the "several scholars" (ba'z muhaqqiq) who agree with him that this is the first Urdu ghazal aver written, nor is it even really clear where the poem came from. As I mentioned above, the earliest reference to it that I can find is in Sri Lam Lala's Kh humkhāna-i Jawed (1908). Lala doesn't tell us where he came across the poem either, saying only that Chandar Bhan "also composed melodious verse in rek $\underline{h} t a$ [i.e., Urdu]" and adding that "although the language is somewhat archaic and mixed with Hindi, nevertheless the beauty and exquisiteness of its themes shine through clearly" (zabān agar chi qadìm aur mak $\underline{\text { hlu }}$ ț ba hindī hai magar mazāmīn kī nafāsat-o-khhūbī șâf jhamak rahī hai). Again, note the emphasis on Chandar Bhan's idiom being "mixed with Hindi" to produce "Urdu." As for the rest of Lala's appraisal of the quality of the ghazal, I leave it to the reader to judge:

What is this city that God has gone and dumped us in?

There is no friend, no cup-bearer, no glass, no cup.

Friends, what manner of splendor could there be in the garden of beauties?

Where are the daisies, the marjoram, the lilies, the tulips?

Even if I wanted to meditate on the name of God, how could I?

I have no rosary, no beads, no necklace, no garland. 
It seems so strange, the Lover slain for the sake of the Beloved When there is no sword, no knife, no dagger, no spear.

Brahman has returned from the garden for his bath; But there is no Ganges, no Jumna, no river, no stream.

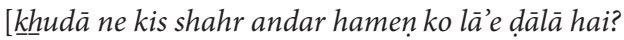
na dilbar hai na sāqì hai na shīshä hai na piyāla hai khubān kì bāgh meṇ raunaq ho ve to kis țarah yārān? na donā hai na marwā hai na sūsan hai na lāla hai piyā ke nā'oṇ kī sumran kiyā chāhūṇ karūṇ kaiseṇ? na tasbī hai na sumran hai na kanțhì hai na mālā hai piyā ke nā'oṇ 'äshiq kon qatl bā 'ajab dekhe hün na barchhī hai na karchhī hai na kֵhanjar hai na bhālā hai

barahman wāsțe aśnān ke phirtā hai bagiyā sen na Gangā hai na Jumnā hai na nadì hai na nālā hai ${ }^{72}$

Whether or not one thinks this is a particularly good ghazal (or, for that matter, translation) is, for present purposes, somewhat beside the point. What interests me most is that as a historical matter it is simply impossible to prove or disprove its authenticity. But the fact that Lala and so many scholars after him have felt the need for there to be a founding ghazal for Urdu poetry, and for Chandar Bhan to be its author, is itself indicative of a certain modern framing not only of our own munsh $\vec{\imath}$ s legacy but of the memory of the entire Mughal literary, linguistic, social, and political milieu.

\section{THE TREACHERY OF MEMORY}

Despite these modest attempts to posit Chandar Bhan as a sort of godfather of modern Urdu literature, in the end he is far better remembered for having been the Hindu sidekick of Dara Shukoh who once made the near-fatal mistake of reciting a subversive verse in front of Emperor Shah Jahan. And as I have suggested above, this received tradition of Chandar Bhan's place in Mughal society transforms him, from the dutiful and amiable state secretary loyally serving Shah Jahan, a series of Mughal prime ministers, and ultimately even Aurangzeb 'Alamgir, into a symbol rather of anti-Mughal sentiment-in some cases, as a symbol of perceived Hindu insolence who managed to corrupt the gullible Dara Shukoh along the way; in other cases, as a champion of Hindu-Muslim rapprochement, standing up for composite Indo-Muslim culture in the face of orthodoxy and imminent Mughal imperial decline.

A couple of very recent examples bear this out. One comes from popular memory, as evidenced in a 2002 article published in the Chandigarh Tribune 
newspaper. Quite sensibly opining on the immoral futility of communal attacks on rival religious institutions, the author refers his readers to our very own munshī Chandar Bhan:

Is there any wisdom in hurting the religious susceptibilities of the people by desecrating or destroying their places of worship? When Aurangzeb decided to demolish the famous temple of Benaras and build a mosque on its site, poet Chandar Bhān Brahman, who had held many important posts under the inexorable emperor, said in a satirical verse:

O' Shaikh! See the miracle of my idol-temple.

Even after its demolition it becomes the abode of God [i.e., a mosque].

[Ba-been karaamat-e-butkhaana-e-mara ai Shaikh

Agar kharaab shavad khaana-e-Khuda gardad $]^{73}$

The image of Chandar Bhan as the rude, defiant Brahman standing up to orthodoxy is here transvalued, from Sarkhwush and Lodi's derision to a postNehruvian, secular admiration for Chandar Bhan's willingness to speak truth to power.

But such persistence of tazkira knowledge does not have to be explicitly sociopolitical. Shamsur Rahman Faruqi, one of the most eminent scholars of Urdu and Persian in India today, recently released a delightful collection of Persian verses called Shadow of a Bird in Flight. In it, the verse from Chandar Bhan's infamous encounter with Shah Jahan is one of only two couplets which he quotes from the celebrated munshī, which he translates as

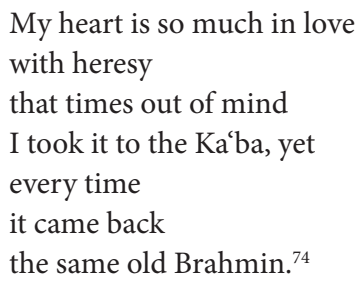

Faruqi seems completely unaware that there could be some doubt about the verse's authenticity, and who can blame him? There is almost nothing in the tazkira tradition itself that casts specific doubt on the verse or the occasion on which it is said to have been recited. Thus no one who wasn't either doing specific research on Chandar Bhan or actively scouring the archives in a targeted effort to authenticate it would have any reason to doubt. It is by far his "most famous" verse, and it is, after all, a very good one at that. It is thus, in a very real sense, worth remembering, and it has gone from the oral public space of the seventeenth century to the oral (and printed) public space of the twenty-first century, kept alive in the intervening years by its inscription in innumerable tazkiras 
and modern literary histories. The anecdote vividly encapsulates a moment of encounter-between Hinduism and Islam, and between ordinary subject and emperor-that lends an added symbolic power and provides a context in which to frame the memory of an already memorable and clever verse.

As V. S. Narayana Rao and David Shulman have noted in another context, with respect to the transmission of another tradition of oral poems that sometimes wend their way through written canons, the cātu verse of South India: "Most poems have a story that goes with them, and each is invariably memorable, a perfectly worked-out expression of skilled composition, though often disarmingly simple... Together, they represent a literary culture and a tradition built up for centuries. They bring to mind, in addition to aesthetic judgment, a host of literary, political, and cultural contexts, indeed a whole world view."75

Here too, the supposed moment of encounter and the verse associated with it are so deeply entrenched in the collective memory of Chandar Bhan (not to mention Shah Jahan and Dara Shukoh) that they have both found their way into the only known pictorial depiction of the munshi (see figure 1). The picture is reproduced in the first modern but nevertheless quite obscure twentieth-century edition of Chandar Bhan's poetic dìwān, the Gulzār-i Bahār, Ma'rūf ba-Bazm-i Nazm-i Brahman, compiled by a certain Bhagwant Rai Sunnami. The painting is clearly a modern work, despite the vague claim that it is "an exact reproduction of the ancient painting." But even if it is a complete fabrication, perhaps drawn or commissioned by Sunnami himself, it only further reinforces the argument being made above.

The painting's Persian caption should, by now, strike a familiar note: "Prince Dara Shukoh's introduction of Munshi Chandar Bhan Brahman to the Presence of Emperor Shah Jahan in the Blessed Privy Chamber at Shahjahanabad." Shah Jahan is seated to the left, being fanned by an attendant. He is faced on the right-hand side by Dara Shukoh (bearded) and Chandar Bhan (mustachioed), with heads deferentially bowed. The painting cannot speak to us, obviously, but the artist has employed an ingenious device with which to transmit Sarkhwush and Lodi's anecdote through visual, rather than a narrative, representation. In his hands, Chandar Bhan is holding a tablet (lauh), on which is written our infamous verse: "I have a heart so acquainted with infidelity that however many times / I took it to Mecca I brought it back a Brahman" (see figure 2 for detail). ${ }^{76}$ It is a fitting image, not least because of the strong connection between the writing tablet (lauh) as a symbol of primordial memory in the Perso-Islamicate philosophical imagination. It is the primordial preserved-tablet (lauh al-mahfüz) "on which the destinies of men have been engraved since the beginning of time." But there is a double meaning to this symbolism, because that which has been "preserved" has also been "memorized" through "a sequence of articulations of what has been preserved on this primordial tablet." 77 


\section{THIS PHOTO IS THE EXACT REPRODUCTION OF THE ANCIENT PAINTING.}

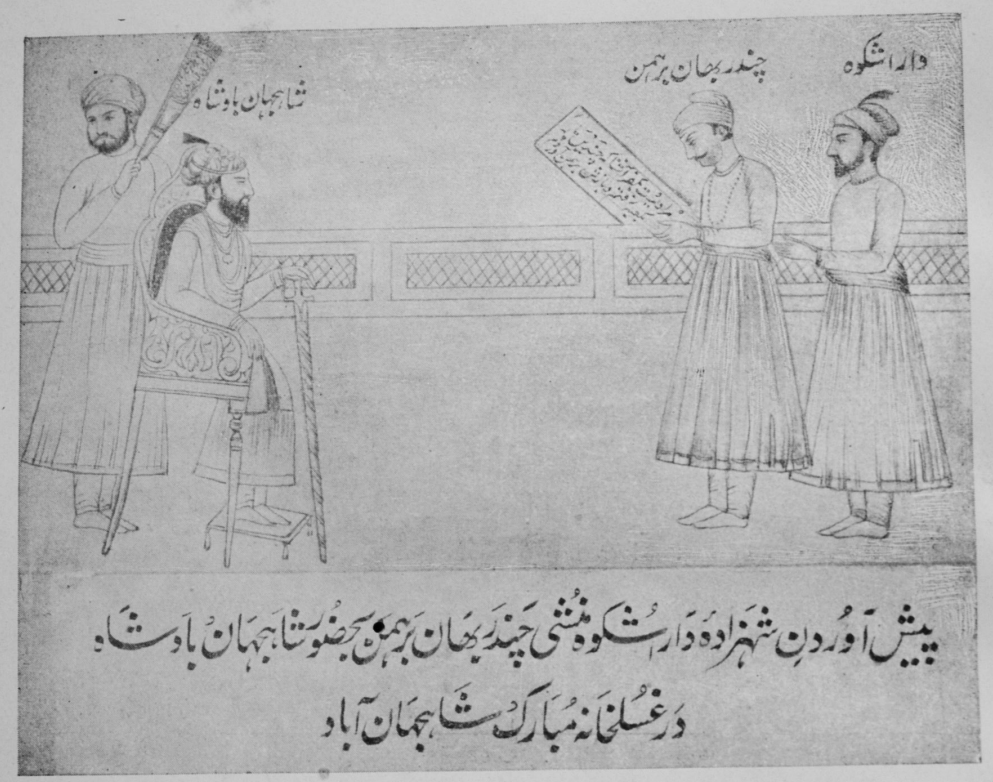

Presenting of Munshi Chander Bhan Brahman by Prince

Dara SHaKOH before SHAHJAHAN in DEWAN-I-AM at Shahjahanbad (Delhi).

(The block of this picture is specially made for the Proprietor, Rais-i-Hind, Delhi, who has special arrangement of making all kinds of blocks).

FIGURE 1. Depiction of the Mughal Prince Dara Shukoh presenting Chandar Bhan Brahman to Emperor Shah Jahan.

In a way, then, we might end by suggesting that the tazkira as a genre presents us with a similar sequence of articulations that are bound up with received memories and the inscription of those memories. Indeed, the image that first appears in Sunnami's (1930s?) edition of Chandar Bhan's Dìwān, a text in which the notorious couplet never appears, has in turn gained a new afterlife as the cover image on the dust jacket of the recent printed edition of Chandar Bhan's letters, the Munsha'att-i Brahman (2005) - yet another text in which the anecdote's miseen-scène and the accompanying verse also do not appear-like a visual palimpsest canceling out the actual contents of the book and replacing them with a more anecdotal, symbolic memory of the munshìs life and career. 


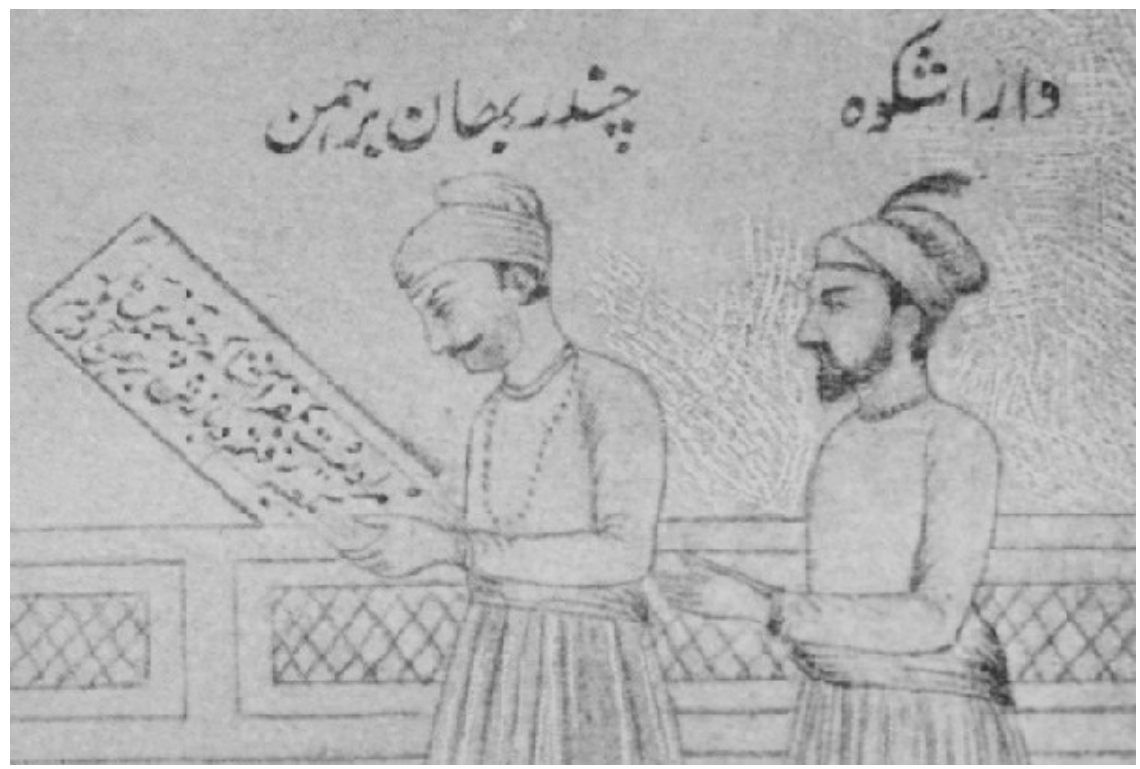

FIGURE 2. Detail of Figure 1, close up on Dara Shukoh, Chandar Bhan Brahman, and a writing tablet.

And thus in the case of Chandar Bhan it is not the recorded texts of history or even his own writings that have served as the primary reference point for the remembrance of him. Rather, it is this "sequence of articulations" in the tazkiras that have come to be preserved, and memorized, on the imaginative tablet upon which much of his legacy has been written for him. 


\section{Ending at Just the Beginning}

A colleague of mine who studies ancient and medieval South India once asked me: "Aren't you worried that the Mughals have been studied to death, and there won't be anything new to say as you get older?" I chuckled. To someone like my friend, who works on a time and place for which the surviving archival and archaeological evidence is admittedly much thinner than what I have to work with, I suppose it is easy to look on the Mughal specialist's embarrassment of riches with a touch of envy. From the outside looking in, one could easily get the impression that the Mughals have been studied endlessly, certainly in comparison with some of the other important political formations of medieval and early modern South Asia like the Cholas, the Delhi Sultanate, the Bahmani Sultanate, Vijayanagara, and the Deccan Sultanates, to name just a few. If one goes to a good university library, the shelves and shelves of books on the Mughals must look imposing indeed.

But as I hope to have shown in this book, we do have quite a lot more to learn about the Mughal Empire, especially where its cultural history is concerned-and I confess now to my chagrin that in the preceding pages I have barely scratched the surface even in Chandar Bhan's case, much less that of Mughal cultural history writ large. In fact, all those imposing shelves of musty tomes notwithstanding, one could easily argue that until very recently, beginning largely with the extraordinary contributions of Muzaffar Alam and Sanjay Subrahmanyam in the last couple of decades, we have barely begun to grapple seriously with Mughal cultural history.

How can this be true? After all, the reader might be asking him- or herself, don't I see endless coffee-table books with the Taj Mahal on them down at the Barnes \& Noble? Aren't big museums always doing opulent shows on Mughal art, 
especially all those gorgeous miniatures? Don't I hear constantly about Akbar the Great as a model of tolerance and understanding for the modern Muslim world? Even Thomas Friedman wrote about him in the New York Times. ${ }^{1}$ How can it really be that the cultural history of that empire has yet to be written?

The beginnings of an answer would be to admit that yes, it is true that on the surface the Mughals get a lot of attention, particularly where the art and architectural history of the empire are concerned. But in terms of the remaining components of cultural history-literature, literary criticism, letters, essays, memoirs, music, and the like-the dropoff in knowledge is swift and steep. Forget about Chandar Bhan for a moment and just imagine: as best I can tell, there has not been a single scholarly monograph in English on Jahangir's poet laureate Talib Amuli since Nabi Hadi's Talib-i-Amuli: The Poet Laureate of Jehangir, His Life and Times (1962). Meanwhile, apart from a handful of encyclopedia entries and scattered notices in general literary histories, there does not appear to be even a single booklength study of Shah Jahan's poet laureate Abu Talib Kalim (d. 1651) ever written in English (much less currently available); and even in Persian and Urdu there doesn't appear to have been much work on him in the last fifty years, perhaps not since Shareefunnisa Begum Ansari's Hayāt-o-Taṣnīfāt-i Mirzā Abū Tạālib Kalìm Hamadāni (1961). If no one is even studying the poets laureate, then what chance do the other literati have? And if we as a twenty-first century postcolonial readership have so little understanding of the literary culture that saturated the Mughal intelligentsia's social world, animated their lives, and informed their politics, how can we understand what made them tick? How can we understand their views on religion, or, say, something like "political Islam," when we are not even familiar with their basic cultural idiom? It would be like claiming to understand the Elizabethan Age without ever having read a word of Shakespeare.

At its most basic level, then, this book has simply been a modest attempt to address a tiny part of this gap in our knowledge by reintroducing the life, writings, and cultural outlook of a major Mughal intellectual of the seventeenth century to current conversations about early modern South Asian history. Persian literacy has dwindled considerably in India since its heyday in the seventeenth-nineteenth centuries, putting the works of countless Mughal poets, scholars, and intellectuals like Talib Amuli, Abu Talib Kalim, and our own Chandar Bhan out of reach even for otherwise very well educated Indians today. In fact, even among professional scholars of South Asia, access to Persian texts-especially the many texts from the Mughal archive that remain unpublished and are available only in manuscriptsis quite limited. As a result, the vast majority of scholars and other commentators are at the mercy of whatever primary texts and secondary works are available in English. And in many cases, despite tremendous advances in Mughal scholarship just in the last couple of decades, too often this means that they are forced by necessity to turn to dusty old relics of the colonial archive, the narrative framework 
and cultural assumptions of which-at least where the Mughals are concernedhave had a tenacious afterlife in a good deal of postcolonial South Asian scholarship and commentary.

Even where scholars have explicitly reacted against the old-fashioned Orientalist narratives of British colonial historiography, the results, though often extremely illuminating in some ways, have not necessarily done much to advance our understanding of Mughal cultural and intellectual history. One reason for this is that it was precisely the desire among many modern South Asian scholars to prove the classic Orientalist narrative about Indian history wrong - to prove, in other words, that India's so-called "Muhammadan period" was not simply an unvarnished tale of eight centuries of stagnation, atavistic carnage, serial absolutism, and capricious tyranny - that led them to move away from cultural history toward an emphasis on topics like state formation and socioeconomic institutions. Many of the historians in this new structuralist tradition lodged their response to the colonial historiography from a decidedly Marxist point of view, and thus, as one might expect, their general approach has greatly privileged the analysis of social and economic institutions, structures, and systems over the niceties of poetry, letters, and biography, or the larger mentalités exhibited by individual personalities like Chandar Bhan. Attempts to read class formations and relations back into the Mughal structures of social power have loomed large in this body of scholarship, as has the desire to understand the markers of status, privilege, and authority that featured in the composition of the Mughal nobility, allowing the latter to perpetuate their control over India's economic surplus, particularly the agrarian surplus that was the foundation of Mughal wealth.

In the process, many nationalist and postcolonial scholars, especially those of the so-called "Aligarh school," have over the years marshaled a veritable mountain of evidence to show the exceeding complexity of, and diffusion of power within, the Mughal state, bureaucracy, manșabdāri system, and political economy writ large. One cannot help but admire the amazing intricacy and detail of this body of scholarship, even if one has reason at times to debate some of the particulars. ${ }^{2}$ The classic volume in this genre is of course Irfan Habib's seminal Agrarian System of Mughal India ([1963] 1999), an exhaustive technical overview of the details of Mughal land measurement techniques, the features of their agrarian bureaucracy, and the trifold relationships among Mughal rulers, local potentates (zamindārs), and peasant producers in rural village communities. Habib viewed the Mughal state almost exclusively in terms of its capacity for revenue extraction and economic exploitation, a view that was largely consistent with the broader anti-"Muhammadan" message of colonial historiography, even if Habib's own intention as a radical secularist was largely to counter the colonial discourse of premodern South Asian society's ineluctable stagnation with a stagist Marxian revision. 
But the main point here is that culture, broadly conceived, has been almost entirely absent from the discussion. ${ }^{3}$ This is true, too, of most of the very fine surveys of the composition of the Mughal nobility that have emerged from basically the same school of historiography. There are a number of notable works in this genre, ${ }^{4}$ but by far the most comprehensive and ambitious is M. Athar Ali's Apparatus of Empire (1985), an extraordinary tabular almanac of virtually every member of the Mughal nobility's "ranks, offices, and titles" for the entire period of 1574-1658. It is a truly impressive tome, the product of decades of painstaking research. But it also highlights some of the limitations of viewing the Mughal state simply as a hierarchical series of points on a spreadsheet of ranks and titles. Chandar Bhan, for instance, exists in The Apparatus of Empire solely as "S6404: 1066; 1655-6; Chandra Bhān Munshī (now Rāi) (H); 500/100; Wāriṣ, 229(a)" — that is, as a serial number (the "S" in S6404 stands for "Shah Jahan"); two corresponding dates in the Hijri Era (1066) and the Common Era (1655-66); a name; an "H" to indicate that Chandar Bhan was a Hindu; his manșab ranking (500/100) as of his promotion to the title rāi in 1655; and finally a nod to the chronicler Muhammad Wāriṣ for providing the data. ${ }^{5}$

The larger historical meaning of these bits of data is left entirely to the reader's imagination, as is any sense that the careers of people like Chandar Bhan, or, say, those of wazirs like Afzal Khan and Sa'd Allah Khan, had narrative trajectories all on their own, beyond the specific points in time when they happened to get promotions. The idea that their careers may have transcended the sharp demarcation between the reigns of the (multiple) emperors they served, or that they were not simply cogs in a self-replicating state machinery but in fact part of the dynamic and ongoing process of making that entire Mughal "apparatus" actually continue to function, is simply absent from the discussion.

In this context, too, there is a resilient strain of Akbar exceptionalism, one that Athar Ali gives voice to right from the very first lines of The Apparatus of Empire: "Modern students of the Mughal empire have shown increasing awareness of the immense degree of systematization that was a characteristic feature of the empire. In the main that systematization was the work of its greatest emperor, Akbar (A.D. 1556-1605). The Mughal polity, so long as it functioned with any effectiveness, say, until the early years of the eighteenth century, continued basically with the organizational forms that Akbar instituted." 6 This sense that all that is needed to understand the Mughal state is to make sense of the basic "organizational forms that Akbar instituted" has contributed mightily to the ongoing diminution, noted above, of the seventeenth and eighteenth centuries in early modern South Asian historiography generally. But it has also had a very specific, direct, and sharply negative impact on the approach to all manner of Mughal prose genres. In point of fact, the usual materials that one typically considers the building blocks of cultural and intellectual history-including letters, essays, 
memoirs, biographical compendia, travelogues, and even more basic historical sources like chronicles-have been specifically targeted for exclusion from the category of "historical relevance" except insofar as they can "serve" the modern historian by providing raw data.

This assumption that writers like Chandar Bhan were somehow writing for the modern historian - and if they weren't, that they should have been-is generally presented politely enough or, more often, simply implied, as in the formulation of one recent scholar who mentions Chandar Bhan's Chahār Chaman in passing among a list of sources that "extend valuable help in constructing the biographical details of various leading nobles, and throw light on the political, economic and social conditions of this period." it nevertheless seems to suggest that the true purpose of a text like Chahär Chaman is somehow external to the text itself. It is a call simply to document, and any questions about what Dominick Lacapra (following Heidegger) once described as the text's "worklike" properties—the author's subject position, his aim in writing it, the literary and intellectual genealogies to which it is heir, the possible reasons for its textual architectonics, the ways in which it might have been received by its potential contemporary audience, or the sociocultural conditions of possibility that might have been necessary for a text like this even to have been producedare all set aside in favor of the extrinsic expectation that the work "extend help" to later generations of historians by providing empirical data that "throw light" on the structure of Mughal institutions.

So long as a text could do this without too much interference from ornate compositional norms and the "affectation of style" so vehemently decried by the British historian H. M. Elliot, then it might be considered useful to the modern historian. But until very recently the authors themselves, and the worldviews that informed the writing of their texts, have by and large been deemed almost entirely irrelevant to the project of modern Mughal history. How else is one to explain the fact that neither of Chandar Bhan's two main prose works, Chahār Chaman and Munsha'ät-i Brahman, was even available in a printed edition until the twentyfirst century? Or that no part of either of them has, to this date, been translated into English since Gladwin's brief excerpt of Chahār Chaman was included in The Persian Moonshee all the way back in 1795 ? Or that neither text was even translated into a local South Asian language until Sayyid Muhammad Murtazá Qadiri's 1992 Urdu edition of Chahār Chaman?

The classic formulation of this dismissive attitude toward such works of $\mathrm{Mu}$ ghal insh $\bar{a}$ ' was that of Jadunath Sarkar, whose perspective on Indian history has been the focus of considerable renewed interest of late. ${ }^{8}$ In a study entitled Mughal Administration, Sarkar acknowledged that the wealth of details contained in the epistolography and belles lettres of munshis like Chandar Bhan renders them "of inestimable service to the modern student of Mughal history."9 Again, the trope 
of "service" to the modern scholar is invoked; but very quickly we see that Sarkar's praise for the archive left behind by Mughal munshis is, in fact, both faint and damning:

But the main wealth of historical information regarding Aurangzib lies in the contemporary letters, which together with the above äkhbārs [i.e., imperial circulars and news memoranda] form the very raw materials or the most authentic source for the history of his reign. The preservation of these letters we owe not to any action on the part of the Emperor, nor to the practice of any secretariat archive, but to a private source, namely, the literary vanity of the secretaries (munshis) who drafted them.... The munshis had not the future historian of the Mughal empire before their mind's eye, but the polished society of their own days. Their aim was not to leave historical records for posterity, but to show their own mastery of style and to set models of composition before students of rhetoric and epistolary prose. ... Such letter-books, however, belonged to a decadent age, when the Court had ceased to make history. ${ }^{10}$

Here again, the arc of decline sketched above is recapitulated. By Aurangzeb's time "the Court had ceased to make history." And here too we find repeated the notion that literary "style" automatically equals "decadence." Sarkar is grateful that some of the Mughal letter collections have been preserved, but he winces at the "vanity" of the secretaries themselves; he laments that the secretaries did not think to compose their texts in a manner more suitable to a modern audience, rather than the "polished society" of their own day; indeed, as far as Sarkar is concerned it is precisely the munshīs' neglect of "posterity" in favor of their own will to "mastery of style" that represents the truest indication of their, and their entire era's, essential decadence-a decadence that is formulated specifically in terms that place them and their works outside the realm of the properly historical. Ironically, then, this sense that Mughal prose works should exist solely to serve the interests of what modern historians deem relevant is precisely what tends to dehistoricize them, as the emphasis on texts' documentary "raw materials" trumps nearly all other considerations.

Of course it is true, as we have seen in this book, that a text like Chandar Bhan's Chahär Chaman may not be especially helpful in corroborating certain types of empirical data, historical dates, the details of war and peace, the precise tabulation of numerical indices of social power and rank, and so on. But neither is it pure ornament, however much it may be written in what Sarkar chided as "the vicious style" of Mughal prose after Abu al-Fazl. ${ }^{11}$ Note, too, Sarkar's insertion of an explicit form of socioreligious determinism into the matter of when, precisely, this viciousness entered Mughal Persian prose and caused it to lose its historical utility:

From the middle of the $17^{\text {th }}$ century onwards, most of the munshis were Hindus, and their proportion rapidly increased. The Hindus had made a monopoly of the lower ranks of the revenue department (diwānì) from long before the time of Todar Mal 
(Akbar's revenue minister), probably from the very dawn of Muslim rule in India. Todar Mal's [late sixteenth-century] order to have all their papers written in Persian (instead of one set in Persian and a duplicate set in Hindi, as under Sher Shah [d. 1545]), compelled all the Hindu officials of State to master the Persian language, and the effect of this change became manifest in the next century, when the Hindus filled the accounts department (hisāb) of the State, and even rose to be deputies and personal assistants (näibs and pesh-dasts) to the heads of many departments. Most of the nobles and even princes in the late $17^{\text {th }}$ century engaged Hindu munshis to write their Persian letters. The docile abstemious hardworking and clever Hindu did the work well and cheaply. A Persia-born or Persia-trained Muslim clerk would have been cleverer and would have written a purer idiom, but he was too costly a luxury in India, and the supply of such men from the Persian home-land was dried up at its source by the political disorders in that country at the close of the $17^{\text {th }}$ century. Indian Muhammadans, as a rule, were unsatisfactory for clerical work.

However "hardworking and clever" the seventeenth-century Hindu munshīs might have been, according to Sarkar the "purer idiom" of Persian simply eluded them. Clearly, Sarkar had internalized the same set of assumptions that had led Elliot to decry the Hindu munshīs' excess "affectation of style"-Hindus and Muslims are from totally incommensurable cultures; Persian is a Muslim language; ergo, Hindus by definition cannot achieve true competence in the language and must overcompensate with mimicry and forced affectation.

Perversely, rather than commend the relatively nonsectarian ethos that made such cosmopolitan amicability possible, even under Aurangzeb, under whom more Hindus worked in the Mughal administration than at any previous time, Sarkar simply echoes the canard once propounded by Elliott in the preface to his notorious anthology, The History of India as Told by Its Own Historians: The Muhammadan Period, that Indo-Persian prose ceased to have "historical value" as soon as Hindus began to write it. In making this point, he specifically singled out Chandar Bhan: "The earliest Hindu munshi of note (after Harkarn Itibarkhani, c. 1624), known to me was Chandrabhan (poetical name Brahman), a protégé of Shah Jahan's wazir Sadullah Khan, who has left works in elegant prose and conventional verse besides some letters of little historical value." ${ }^{12}$ In Sarkar's formulation, then, the entire archive of Mughal prose produced by writers like Chandar Bhan could be written out of history not, as with subalterns, because they could not speak to us, but rather because they were thought to have nothing to say.

As I've tried to show in the chapters above, however, writers like Chandar Bhan did have something to say, and their letters, other inshä, and even poetry are of more than a little "historical value." Indeed, they are precisely the kind of voices we should listen to if we ever want to reconstruct a truly postcolonial version of Mughal cultural and political history. Chandar Bhan has shown us, for instance, good reason to treat the classic narrative of growing post-Akbar "orthodoxy" in Mughal culture 
and society with new skepticism. The ideals of sulh-i kull did not simply vanish, and many of the nobles, administrators, and other intellectuals in Chandar Bhan's midst remained committed to a relatively nonsectarian ethos of civility and gentlemanly conduct that crossed communal boundaries, creating a space for forms of friendship, emotional intimacy, and everyday civility. Chandar Bhan has also shown us the high value that continued to be placed on secretarial skills, a good work ethic, a commitment to the public good, and the benefits of bureaucratic innovation and efficiency among the administrators at Shah Jahan's court.

We have seen, too, that Chandar Bhan clearly saw Shah Jahan as an Indian ruler who happened to be Muslim, rather than as a "Muslim ruler"-an important distinction that allowed the munshi to locate Shah Jahan, and the Mughal dynasty more generally, within a genealogy of Delhi kingship going back to mythical times. To Chandar Bhan, in other words, the Mughals were not "foreign conquerors" bearing alien values but rather Indian kings who were continuing an ancient legacy and promoting Indian values of kingship. Thus, as we saw, while our munsh $\vec{\imath}$ s explication of the emperor's typical day-to-day routine is certainly full of the type of glowing panegyric that in modern scholarship has been derided as mere sycophancy, it is nonetheless illuminating that Chandar Bhan's emphasis is almost entirely on Shah Jahan's wisdom, his learning, his mystical intuition, and his commitment to justice in the $a \underline{k} \underline{h} l \bar{a} q \bar{i}$ tradition, rather than merely on the emperor's worldly power, wealth, and glory. Chandar Bhan's Shah Jahan is not the stern, orthodox, and aloof caricature depicted in so much modern historiography. On the contrary, in Chandar Bhan's telling Shah Jahan could be a man of great kindness, affection, and even warmth, whether in his concern for a convalescing Jahan Ara Begum, his grief at the deaths of his wazirs Afzal Khan and Sa'd Allah Khan, or even in his expression of personal condolences when our munsh $\vec{\imath}$ s own father died. Quite appropriately for a person who valued the benefits of training in the secretarial arts, Chandar Bhan also saw the king as a kind of super munshi, a capable and hands-on administrator who was competent in all the requisite instruments of Mughal bureaucracy and governmentality. It was precisely these characteristics and capabilities, above and beyond his military might, that made Shah Jahan such an able and effective ruler in Chandar Bhan's eyes.

Chandar Bhan has also given us a glimpse of the bustling commercial and cultural cosmopolitanism of life at Shah Jahan's court, in urban centers like Delhi, Lahore, and Agra, and even in the mobile imperial camp. Not only did one encounter people from just about every part of the world in such locales, but these sites were also important points of contact for multiple Mughal publics-traders, artisans, literati, intellectuals, mystics, and ordinary people from all walks of life who made their living as service professionals of various kinds. There is a liveliness and kinetic energy to these scenes of social and cultural interaction that modern Mughal historiography has often simply failed to capture. And that liveliness 
surely contributed to many Mughal intellectuals' feeling that they were living in a "fresh" new era, and to work that sense of renewal into the kind of literary modernism that we examined in chapter 5 .

Here yet again, in trying to recover the literary sensibility of Chandar Bhan's age, we run up against generations of modern Indo-Persian literary historiography that has completely erased the modernist tendencies of the tāza-gū' $\bar{\imath}$ movement from our collective memory. As a result, the potential significance of the Indo-Persian "quarrel between ancients and moderns" has remained almost completely invisible in wider scholarly conversations about global early modernity. Imagine, though, how the views of Western scholars and students alike with respect to the cultural history of places like India, Iran, Pakistan, and Afghanistan would change if they were made aware that intellectuals in those places, too, struggled with the tension between tradition and modernity, the classical and the new, in ways that had nothing to do with Islam or Islamicate political culture as such. Imagine how commentators who simply assume that "the modern" as a conceptual category is unique to Europe, or that it came to South Asia exclusively via European colonialism, might have to adjust their theories if they were actually presented with the overwhelming evidence that seventeenth-century IndoPersian literati and other intellectuals, like their European counterparts, also drew increasingly sharp distinctions between the "ancients" (mutaqaddimin) and the moderns (muta'ākhkhhirīn / mu'āṣirīn).

Similarly, the type of autobiographical and epistolary self-fashioning that we examined in chapter 4 needs much further investigation. Chandar Bhan was just one author, but he was clearly participating in a much wider culture of letter writing through which Mughal intellectuals of all stripes constructed their "epistolary selves." This rich archive of Mughal epistolography has gone unexamined for so long that many nonspecialists probably don't even realize that it ever existed in the first place-making it that much easier to perpetuate, even if only unconsciously, the same old Eurocentric shibboleths about the "self" and early modern forms of self-fashioning being exclusively European phenomena, diffused to the rest of the world only belatedly via colonialism.

Taking someone like Chandar Bhan's intellectual legacy seriously has even shown us-albeit indirectly-that empirically unreliable sources from the period can be quite "useful" and informative, too, if read with a bit of context and critical scrutiny. It would be all too easy simply to dismiss the "false" image of Chandar Bhan that percolated in the bazaar gossip and literary salons after his death, only to be further inscribed in the Indo-Persian cultural memory and circulated via literary biographical compendia (tazkiras), as a worthless collection of clever lies. But it is precisely the power of these fascinating falsehoods that allows for a reconsideration of crucial features of late Mughal cultural life, and even political critique, just prior to the onset of British colonial hegemony. Clearly, certain anxi- 
eties about the complex and rapidly changing cultural, political, and commercial world of South Asia that are on display in the tazkira archive were also attended by vigorous debates about good taste, literary etiquette, and canonicity. Meanwhile, many of these texts, like Sher Khan Lodi's Mir'ät al-Khayal, shared a palpable sense of urgency to recover and conserve the classical Indo-Persian literary tradition before it was lost-a staple modern anxiety if ever there was one. And thus, at virtually the exact historical moment when Samuel Johnson began writing his "Lives of the Poets," Indo-Persian literati were engaged in an analogous effort to compile the biographies of important literary figures, exemplary samples of their literary oeuvres, and anecdotes about their wit and ways of being in the world.

Why all this was happening, and what it all means, are questions that remain to be answered. I have tried to give some provisional suggestions above, but much work remains to be done. Even after our examination of Chandar Bhan's small part in all of this, we still do not know exactly why, for instance, Indo-Persian poets and other intellectuals began to articulate such an unprecedented vision of literary newness at the precise moment that they did, at the tail end of the sixteenth century. Why then? And how did the collective wisdom about what constituted literary "freshness," and cultural newness generally, change over the next two centuries? Similarly, we do not know why, exactly, there was such a boom in letter writing and other forms of inshä' during precisely the same time frame, or to what extent other authors, like Chandar Bhan, used such genres as a vehicle to explore various modes of self-fashioning. We do not know why there was such a boom in the compilation of literary tazkiras at exactly the same historical moment. All we know is that these things did happen. And we haven't even begun to discuss the robust scholastic cultures of translation, comparative philology, and other disciplines that were also thriving during this period.

It is simply hard to imagine that all of this extraordinary Indo-Persian cultural production, authored by Hindus and Muslims alike, could have flourished during an era characterized by the type of wholesale decline, despotism, orthodoxy, and political chaos that the classic narrative of Mughal history has told us was the norm from 1605 onwards. Chandar Bhan certainly didn't see his world that way, so if we are willing to take his testimony seriously then we are left with a difficult conundrum: the old models have to go, but we still don't have a complete picture to replace them with because the very texts and genres that would be most useful in critiquing those old models-letters, other modes of insha', poetry, tazkirashave been consigned to such oblivion for so long that the bulk of the archive still sits unpublished, out of print, or otherwise barely accessible even for many of those who actively want to engage it.

So at this stage, even after such a lengthy book, it is hard to end on anything like a triumphal note. Despite my best efforts, time pressures and the limitations of space have kept me from offering as comprehensive account even of Chandar 
Bhan's own oeuvre as I had once hoped would be possible in this book. An exhaustive analysis of his letters awaits future work. A full literary analysis of his poetic dīwān likewise remains only a desideratum. There are a handful of other miscellaneous minor works attributed to him to which we were not even able to give cursory attention but that would surely yield many further insights into not only Chandar Bhan's own cultural sensibility but also the literary, political, and religious culture of the age more generally. Meanwhile, the lives and works of so many of his literary and intellectual contemporaries lie similarly in wait of renewed attention, translation, and critical scrutiny.

Perhaps, then, the most honest way to conclude would be to admit a simple reality: we still have no idea just how much we don't know. We don't even know, necessarily, that we actually know what we think we know. So for now, let us content ourselves with letting Chandar Bhan have the last word:

Spring has come, and the face of the garden is refreshed;

But alas, the fruit of my labors lingers there on the tree, as yet only half ripe.

[āmad bahār wa rū-yi chaman tāzagì girift

bar shākn mānda mewa-i mā nīm-ras hanūz] 
NOTES

\section{INTRODUCTION}

1. "Taj Mahal Emerges as Top Google Street View Destination," The Hindu, March 16, 2015, www.thehindu.com/news/national/taj-mahal-emerges-as-top-google-street-viewdestination/article6999989.ece?homepage $=$ true.

2. On these and other myths surrounding the Taj and its construction, see Koch (2006: 249-50).

3. From his poem $\hat{S} \bar{a} \operatorname{Jahān}(1916)$, quoted as translated by William Radice in Tagore (1987: 78-81).

4. McWhirter (1967: 60).

5. Cf. the title of Gascoigne ([1971] 2002): A Brief History of the Great Moguls: India's Most Flamboyant Rulers.

6. Subrahmanyam (2006: 67).

7. See, for instance, Yohannan (1977); Karimi-Hakkak (2002); and, for the larger context, Schwab (1984).

8. Richards (1984: 271).

9. For a recent analysis of this process, see Travers (2007). For further context, see, for instance, Bayly (1996); Cohn (1996).

10. In Gladwin's defense, however, we should point out that he had in fact already translated the $\bar{A}$ ' $\bar{n}$ - $i$ Akbari in 1783 , dedicating the publication to the Company's thengovernor-general, Warren Hastings (1732-1818).

11. For the Persian text of Muraqqa'-i Dihli with Khaliq Anjum's accompanying introduction, notes, and Urdu translation, see Dargah Quli Khan (1993). For Sunil Sharma's examination of "urban ethnography" in Indo-Persian literary and historical texts, see, for instance, Sharma $(2004,2011)$. 
12. The corpus of scholarship on the connection between epistolography, other forms of "informal writing," and early modern European (and American) self-fashioning is vast, but one might begin by examining, for instance, Redford (1986); Chartier, Boureau, and Dauphin (1997); Earle (1999); Gilroy and Verhoeven (2000); How (2003); Bannet (2005); Schneider (2005); Berg (2006); Brant (2006); Pearsall (2008); Whyman (2009); Smyth (2010); Daybell (2012).

13. Cf. the title of Earle (1999): Epistolary Selves: Letters and Letter-Writers, 1600-1945.

14. Cf. Smyth (2010): 55-62.

15. For an overview of the curious publication history of Pepys's diary, see Tomalin (2002): 378-86; "secret masterpiece" quote on 386.

16. For the most comprehensive available overview of these features of Mughal literary and political culture, see Alam (1998; 2003; 2004: 115-40).

17. On the "new" (navya) intellectuals of the early modern Sanskrit world, see, for instance, Pollock (2001b); Bronner (2002); McCrea (2002); Ganeri (2011). On the new wave of Braj intellectuals who flourished at the Mughal and Rajput courts of this period, see Busch (2011).

18. Mack (2009: 34).

19. Tavakoli-Targhi (2001a).

20. 'Abdullah (1928; 1992: 70-76, 79-83).

21. Marahravi (1910; 183-88).

22. Zaman (2007: 93-129).

23. Alam (2003: 164-65); Alam and Subrahmanyam (2004): 62-63.

\section{CHANDAR BHAN'S INTELLECTUAL WORLD}

1. For an overview of Sher Shah's life, career, and influence, see, for instance, Qanungo (1965); Aquil (2007).

2. Lane-Poole (1903: 237). For some more charitable, though still occasionally critical, reconsiderations of Humayun's court and career, see Anooshahr (2008), Orthmann (2011, 2014), and Moin (2012: 94-129).

3. For the basic ideas, background, and debates surrounding the notion of sulh-i kull, see, for instance, Athar Ali ([1980] 2006); Rizvi (1999); I. A. Khan (1992: esp. 22-25); A. Nizami (1972: esp. 131-42). For an overview of Akbar and Abu al-Fazl's religious and intellectual outlook more generally, Rizvi (1975) remains the most comprehensive study.

4. Richards (1993: 100-102).

5. For a complete biography of Nur Jahan, see Findly (1993). For a critique of the Nur Jahan “junta” theory, see S. Hasan ([1958] 2005).

6. For an overview and critique of these debates, see Alam and Subrahmanyam (1998: 1-71; 2012: 1-32).

7. Wink (2009: 107).

8. Koch (2009).

9. I. Qureshi (1985: 166-82, 183-217).

10. Richards (1993: 121-23).

11. The quoted phrases are from Smith (2003: 60). For other versions of this general approach to Aurangzeb's reign, see, for instance, Richards (1993: 151-84); Stein (1998: 17689); Wolpert (2009: 156-72). Of course, there are some notable exceptions to this general 
rule. The work of Muzaffar Alam (esp. 1986) and Satish Chandra (e.g., [1959] 2002; [1999] 2005: 267-357; and the various relevant essays reprinted in 2003: 71-127, 305-53, 485-94) comes especially to mind, along with more recent work by Katherine Butler Brown (2007) and Munis Faruqui (2009, 2013). But unfortunately, though a more nuanced approach to the complex relationship between Aurangzeb's personal piety and his actual policies is slowly beginning to emerge, the old conventional wisdom (not to mention its implicit Islamophobia) still tends to trickle down to many textbooks and other general works on South Asian and global history.

12. It is only through such willful embrace of the logical fallacy of post hoc ergo propter hoc ("after it, therefore because of it") that a modern commentator could write, in all seriousness, that under Aurangzeb "the Pakistan spirit gained strength" (M. A. Zafar, Pakistani Studies for Secondary Education [1986], quoted in Rosser 2004: 277). Another writes that the tension between Aurangzeb and Dara Shukoh, his famously liberal brother and chief rival for the throne, exhibited "those trends, which were to result finally in the partition of the subcontinent in 1947" (Schimmel 1980: 2). To another, "Aurangzeb's reign thus marks an anti-climax in the otherwise glorious era of medieval Indian history and culture. The virus of religious communalism which subsequently infested the body of India, leading to the Partition of the country in 1947, had sprouted in the diseased brain of Aurangzeb, the perverted genius of his age" (Mehta [1983] 1990: 300).

13. Parker (2010: 59).

14. Brahman (2007: 145). Subsequent citations of Chahär Chaman in this chapter refer, unless otherwise noted, to this printed edition edited by Yunus Ja'fery (hereafter CC) and are given parenthetically in the text with page numbers.

15. There was a well-known painter in Akbar's time also named Dharam Das, but it is unlikely that this was the same person as Chandar Bhan's father.

16. That is, because conventionally a ghazal's final verse, or maqta', always contains the poet's pen name. For some examples of the playfulness of Chandar Bhan's ghazals, see chapter 5 below.

17. See, for instance, Brahman (2005: 75-80, 82-93, 105, 107-8, 110-16). Subsequent citations of Munsha'āt-i Brahman refer, unless otherwise noted, to this printed edition edited by S. H. Qasemi and Waqarul Hasan Saddiqi (hereafter $M B$ ) and are given parenthetically in the text with page numbers. See also below, chapter 4 .

18. For an English translation of excerpts from one of these letters to Tej Bhan, see Alam (2003: 164-65); Alam and Subrahmanyam (2004: 62-63). For a more detailed discussion, see also below, chapter 4 .

19. The passage does not appear in the printed edition of Chahär Chaman but is in the manuscript housed in the National Museum, New Delhi, MS \#3340 (55043/2217), fol. 97aquite possibly the oldest extant manuscript of the text. (The Banarasi Das mentioned here is almost certainly not the famous author of Ardhakathānaka.)

20. Brahman, Chahār Chaman, MS, National Museum, New Delhi, \#3340 (55043/2217), fol. 97a-97b. Nath (1974: 9-10) also mentions two more of Chandar Bhan's early interlocutors, a certain Devi Das and one Arjun Mal Shudra.

21. For samples of both kinds of letters, see $M B, 62-73$.

22. Brahman, Chahār Chaman, MS, National Museum, New Delhi, \#3340 (55043/2217), fol. $87 a$. 
23. For Chandar Bhan's letters to 'Aqil Khan, see $M B$, 23-24. For an early mention of 'Aqil Khan in Jahangir's memoirs, see Jahangir (2007: 34 [Persian]); Jahangir (1999: 59 [English]).

24. Shahnawaz Khan (1888-96 [II]: 790-92).

25. Shahnawaz Khan (1888-96 [II]: 791-92). On Sati al-Nisa, see also Begam (1991[?]: 5-6); Mukherjee (2001: 37, 70, 177).

26. Further information on Amanat Khan's life, career, and architectural contributions is available in Begley and Desai (1989: xxxii-xl, 247-57), from which many of the details in this paragraph are taken.

27. Begley and Desai (1989): xxxiii.

28. Afzal Khan is regularly mentioned throughout Jahängìrnàma and the various chronicles of Shah Jahan's reign. For brief notices of his career, see also Shahnawaz Khan (1888-96 [I]: 145-51 [Persian]) and (1979 [I]: 149-53 [English]); Bhakkari 1961-74 [II]: 25556 [Persian]); and Nahawandi (2002: 23-26). For a more extensive overview of his career, see Kinra (forthcoming).

29. Nahawandi (2002: 23-26); Hamadani (1990: 36).

30. Koch (2006: 89); Begley and Desai (1989: 277-81).

31. Jahangir (1999: 169).

32. Jahangir (1999: 215).

33. Jahangir (1999: 219). We know from a surviving letter to one of Chandar Bhan's brothers that the munshi did visit Malwa at least once in his life-where he was able to take in the local sights and tour the "great fort at Mandu, whose dimensions exceed the descriptive capabilities of mere writing" (sair-i qil'a-yi 'umda-yi Māndū ki ihāta-yi ān az zabt-i tahrīr bìrūn wa afzūn ast)-but it appears from the context that this was several years later when he was working for Afzal Khan $(M B, 93)$.

34. Chaghtai (1981: 67-68); Chaudhry (2004: 77-78).

35. Jahangir (1999: 299, 351).

36. For details on I'tibar Khan's career, see Shahnawaz Khan (1888-96 [I]: 134-35 [Persian]; 1979 [I]: 704-5 [English]); Jahangir (1999: passim).

37. Indeed, neither I'tibar Khan nor Harkaran even appears in standard Mughal histories like Richards (1993), Habib ([1963] 1999), Mukhia (2004), Schimmel (2004), or Dale (2010).

38. Harkaran Das Kamboh (1781: 2-7) (I have amended Balfour's translation). Hatim was a sixth-century (i.e., pre-Islamic) Christian Arab poet proverbial for his generosity and kindness; "Anushirwan" refers of course to Khusrau I Anushirwan, the celebrated sixthcentury Persian king renowned for his justice and virtue.

39. "Inayat Khan" was a title, not a name, so this particular acquaintance of Chandar Bhan should not be confused with the more famous author of the Shah Jahan Nama, Muhammad Tahir 'Inayat Khan (d. 1670-71), who served for a time as Shah Jahan's royal librarian, and whose father (Zafar Khan Ahsan, d. 1663) and grandfather (Khwaja Abu al-Hasan Turbati) had both served in Mughal governmental circles for decades. The usual sources contain very few biographical details about the earlier 'Inayat Khan whom Chandar Bhan is discussing here, although Jahangir's account of his death from alcohol abuse is very moving (1999: 279-81 [English]; 2007: 247-48 [Persian]). The Thackston edition of Jahāngìrnàma also reproduces an excellent portrait of him ca. 1610 (1999: 104), as well as the famous Balchand painting of the dying, emaciated khan in his final days (1999: 280). 
For further details, and for a discussion of the art-historical significance of the latter painting, see also Smart (1999); Schimmel (2004: 195).

40. For details on Asaf Khan's life and political career, see A. Kumar (1986); Shahnawaz Khan (1888-96 [I]: 151-60).

41. Bhakkari (1961-74 [II]: 401-3); cf. also Shahnawaz Khan (1888-96 [II]: 237-38).

42. A. Kumar (1986: 108, 134-35).

43. For details, see Pingree (2003: 269-70). Unfortunately, Nityananda's efforts were not as well received in Sanskrit scholarly circles as they were among the various Mughal and Rajput courts where manuscripts were commissioned. In response, Nityananda wrote an elaborate defense of the Romaka (i.e., Greco-Roman) astronomical principles used by Muslim astronomers, aimed at his fellow pundits, and known as the Sarvasiddhāntarāja. For the larger context of traditional Sanskrit astronomy, or jyotihśástra, including the response to Perso-Arabic learning, during this period, see Minkowski (2002, 2014).

44. See Pingree (1999).

45. For the text of Asafa-vilāsa, see A. Kumar (1986: 241-43); Chaudhuri ([1942] 1981: 112-16). For details on Jagannatha Panditaraja's life, career, and place in early modern Sanskrit cultural history, see Pollock (2001a: 404-12).

46. Busch (2011: esp. 130-65); Brown (2007).

47. For details on Jahan Ara's life and influence on the court, see Begam (1991[?]); Bokhari (2009). For details on her accident and recovery specificially, see Begam (1991: 26-31); 'Inayat Khan (1990: 309-10, 312-14, 317-18).

48. Speziale (2009a). On Miyan Bhuwa, who besides his medical researches also served as a minister in Sikandar Lodi's government, see also Hadi (1995: 137).

49. For a general introduction to these thinkers' lasting influence on scientific progress not just in Asia and the Middle East but in Europe as well, see, for instance, al-Khalili (2010). For the specific reception of their ideas in early modern India, see Speziale (2009a, 2010b).

50. For details, see, for instance, Speziale (2003).

51. See Speziale (2009b), from which most of the details about Nur al-Din's career in the remainder of this paragraph are taken.

52. Speziale (2011; 2009a: 5).

53. Speziale (2009b; 2010a: 55 ).

54. For details on these poets, see, for instance, M. Lutfur Rahman (1970: 148-50).

55. For details on his career, see Shahnawaz Khan (1888-96 [III]: 441-42).

56. Chandar Bhan doesn't specify the timing of this expedition, but perhaps he is referring here to the imperial camp's departure from Lahore toward Kabul on March 6, 1639 (cf. 'Inayat Khan 1990: 256). That would, at any rate, be about the latest possible date for such an interaction, since Mu'tamad Khan died in $1049 \mathrm{AH}$, i.e., 1639-40 CE.

57. Richards (1993: 100).

58. Richards (1993: 144).

59. Nicoll (2009: 128, 160, 285 n.).

6o. According to Shah Jahan Nama, the imperial camp left Agra on January 24, 1645 ('Inayat Khan 1990: 321-23). The plan was to go by way of Ajmer so that the emperor could visit the shrine of Mu'in al-Din Chishti after having vowed to do so during Princess Jahan Ara's illness. But the princess had a relapse en route, and the imperial camp headed instead for Delhi. On the way, she was treated by "a mendicant named Hamun," whose medicinal 
plasters did indeed cure the reaggravation of Jahan Ara's burns-for which "the indigent Hamun" and his entire family were rewarded handsomely, both by the emperor himself and by the rest of the royal family, with gifts ranging from gold and robes of honor to horses, an elephant, and a land grant in perpetuity in his native village. Chandar Bhan doesn't mention any of these incidents, but 'Inayat Khan, the author of Shah Jahan Nama, remarks: "Although many famous physicians from among the Farangis, Musulmans, and Hindus had exerted themselves to the best of their ability in concocting plasters, they had produced no beneficial effect; but as the good stars of Hamun and the page "Arif Chela-of whom mention has been previously made-were in the ascendant, their efforts were crowned with success." At any rate, from Delhi the imperial camp proceeded toward Punjab via Sirhind, where it arrived on March 17, 1645. The Nauroz festival that Chandar Bhan describes here was held two days later.

61. For a discussion of the concept of khānazādagī, see, for instance, Richards (1984; 1993: 148-50).

62. Cf. Richards (1984: 263).

63. See, for instance, Koch $(1988,1994)$.

64. "The moon" is often shorthand in Persian poetry for the radiant face of the beloved, and the moon's dark spot-or in this verse technically its 'freckle(s)' (kalaf)-is seen as a beauty mark that only serves to highlight the brightness of the rest of its face. In the case of the moon, of course, that brightness comes from the sun. But even the sun, for all its brilliance, cannot fully remove the moon's kalaf. Thus what Chandar Bhan is really saying with this image is that Shah Jahan's face is so radiant that its light can overpower even the dark spots on the moon, something even the sun cannot achieve.

65. According to Shāh Jahān Nāma, this expedition, and the renaming of Mukhlispur as Faizabad, took place toward the end of Shah Jahan's reign in February-March 1657 (cf. 'Inayat Khan 1990: 535-37).

66. His dates are unknown, but for details on his career, see Shahnawaz Khan's entry in Ma'āșir al-Umarā (1888-96 [I]: 198-99), which I have relied on here.

67. Here, as elsewhere in much of his poetry, Chandar Bhan has adjusted the pronunciation of "Brahman" to conform with the requirements of Perso-Arabic meter-in this case, by changing it to "barahman" (short-long-long).

68. Saqi Musta'id Khan (1947: 47-78, 53).

69. Mehta (1984: 499-500). For a similar portrayal of 'Abd al-Nabi's character, see also Jadunath Sarkar (1920 [III]: 332-33).

70. Hadi (1995: 137-38). He does not appear to be the same Bhupat Rai (d. 1719) who composed poetry under the pen name of "Bigham Bairagi," the brief particulars of whose biography Hadi describes separately (1995: 130-31).

71. For details on his family and career, see Shahnawaz Khan (1888-96 [III]: 447-51).

72. For separate details on his career, see Shahnawaz Khan 1888-96 [II]: 307-9).

73. This is a reference to one of the most well-known topoi in all of Indo-Persian literature, that of the constellation of the Pleiades as a metaphor for the type of bejewelled necklace that a good poet might expect as a reward for a well-crafted verse.

74. On Mukhlis Khan's career, see Shahnawaz Khan (1888-96 [III]: 566-68).

75. For brief details on Qudsi's career, see A. Ahmad (1976: 123); M. Lutfur Rahman (1970: 141-46); Losensky (2006).

76. For details on Munir's career, see M. Lutfur Rahman (1970: 148); Memon (1983); Rashid (1967: 348-51). For a discussion of the historical significance of Munir's debates with 
contemporary poets and Kārnāma, his polemic against early modern tāza-gưu' Alam (2003: 182-84); Kinra (2011a: 28-31).

77. Quoted in Shafiq (n.d., 9). "Sahbān” refers to Sahbān Wā’il, the celebrated medieval Arab orator proverbial for his eloquence.

78. Bayāz-i Șāib, MS, Oriental Manuscript Library and Research Institute (OMLRI), Hyderabad, \#6170 (Dawāwìn \#344), fol. 193a (185a, according to the numbers penciled in the margin). The couplet in question is couplet 2 of ghazal 47 in the Dìwān-i Brahman 1967 printed edition edited by Farooqui (Brahman 1967). For an overview of Sa'ib's career generally, see Losensky (2004).

79. Bayāz-i Bedil, MS, British Library, Add. 16,802, fols. 283a, 286b-287a, and 315a, and Add. 16,803, fol. 73b. For details on Bedil's career, see A. Ghani (1960); M. Siddiqi (1989).

8o. Athar Ali (1972: 190).

81. The others were Mulla Shaida, Munir Lahori, and Hakim Haziq; see Salih Kambuh (1967-72 [III]: 305-44).

82. Salih Kambuh, Bahār-i Sukhan, MS, British Library, Or. 178, fol. $96 \mathrm{~b}$.

83. Salih Kambuh (1967-72 [III]: 336-38).

84. See, for instance, the notices in Shahnawaz Khan (1888-96 [II]: 282); Marahravi (1910: 233-37).

85. Shahnawaz Khan (1888-96 [II]: 282). His death is also mentioned in various chronicles of Aurangzeb's reign, such as Khafī Khan's Muntaknhab al-Lubāb, (1963 [III]: 166) and Saqi Musta'id Khan's Ma'ạșir -i 'Ālamgīrī (1947: 29).

86. Ruqa'āt-i 'Ālamgìrī (1880: 21, 46-47).

87. MS, $A \underline{k} \underline{h} b \bar{a} r$ papers (RAS Persian), entry 9/4, Royal Asiatic Society of Great Britain and Ireland. I am grateful to Munis Faruqui for originally bringing this reference to my attention and am especially grateful to Mr. Edward Weech, a librarian at the Royal Asiatic Society who provided me with digital images of the relevant pages.

88. Saqi Musta'id Khan (1947: 36).

89. Note that in the 2005 printed edition of Munsha'at-i Brahman $(M B, 14)$ this letter appears to be merely a continuation of the previous one, with no separate heading (probably the result of an earlier scribal error that in turn wound up being reproduced by the modern editors). But the context-and the content-make clear that it is a separate piece of correspondence.

\section{A MIRROR FOR MUNSHİS}

1. For background on the Indo-Persian secretarial culture generally, see, for instance, Mohiuddin (1971); Zilli (2000, 2007); Hanaway (2012); Alam and Subrahmanyam (2004); Kinra (2010).

2. Brahman (2007: 171-77); subsequent citations of Chahär Chaman refer, unless otherwise noted, to this printed edition edited by Yunus Ja'fery (hereafter $C C$ ) and are given parenthetically in the text with page numbers. Brahman (2005: 95-101); subsequent citations of Munsha'ät-i Brahman refer, unless otherwise noted, to this printed edition edited by S. H. Qasemi and Waqarul Hasan Saddiqi (hereafter $M B$ ) and are given parenthetically in the text with page numbers. A brief excerpt of this letter has previously been translated in Alam (2003: 164-65) and in Alam and Subrahmanyam (2004: 62). All translations here, and any errors in them, are, however, my own. 
3. Note that the version of the letter in the printed edition of Munsha'at-i Brahman $(M B, 95-101)$ does not contain this list of recommended poets at the end of the letter. It is not clear if this was an intentional omission on Chandar Bhan's part or if it is simply due to some quirk or variation in the particular manuscripts consulted. But this is a question that can be answered only by further research.

4. Arberry (1950: 18).

5. The scholarly literature on these and other texts in the genre, many of which have also been ably translated into English, is far too extensive to list here. But for an overview of their specific reception in India and influence on Mughal culture and politics, see Alam (2000; 2004: 26-80).

6. Kai Ka'us ibn Iskandar Qābūs-nāma (1967: 208).

7. Athar Ali (1985: x).

8. Richards (1993: 121-23). There is, however, a recent and growing body of work that is starting to take the continuing role of mysticism and religious dialogue in the seventeenthcentury Mughal culture, politics, and society of the post-Akbar period more seriously. See, for instance, Alam and Subrahmanyam (2009); Alam (2012); Lefèvre (2012); Moin (2012: 170-240); Kinra (2013); and the various relevant articles in Dalmia and Faruqui (2014).

9. For details on his life and career, see Das (1979); Marahravi (1910: 122-38); Shahnawaz Khan (1888-96 [II]: 123-29).

10. For details on the new land-revenue system implemented by Todar Mal, see Richards (1993: 83-86); Habib ([1963] 1999: 230-41).

11. For details on Abu al-Hasan Turbati's career and family connections, see Shahnawaz Khan (1888-96 [I]: 737-39).

12. Losensky (2003).

13. 'Inayat Khan (1990: 32; 2009: 78-79); Shahnawaz Khan (1888-96 [I]: 149). A chronogram is a verse or short phrase used to mark the date of an important occasion, the talent for composing which was highly esteemed among Indo-Persian literati. Each letter in the Perso-Arabic alphabet also has a corresponding numerical value; thus, to find the value of a simple chronogrammatic phrase like this requires one merely to add up the values of the various letters.

14. Chandar Bhan was clearly quite taken with his new mode of transportation and notes with pride in a separate letter to his brother Ray Bhan (undated) that he rode the elephant while accompanying Afzal Khan on a trip to Daulatabad $(M B, 75-76)$.

15. See, for instance, $C C, 152 ; M B, 16-17,55-57$.

16. This is very likely Aqa 'Abd al-Rashid Daylami (d. 1670-71), one of the most celebrated Persian calligraphers of the seventeenth century. He was Prince Dara Shukoh's personal calligraphy instructor (Hasrat 1982: 160-61) and is said to have made a copy of [Thattawi's?] Muntakhab al-Lughat personally dedicated to Shah Jahan. Details about his career are available in Ghulam Muhammad "Haft-Qalami” Dihlawi's Tazkkira-yi Kh hwwush-Nawīsān (1910: 95-100), where he is described as the "prophet of the empire of penmanship" (paighambar$i$ mulk-i khatțāțī). There is also a brief mention of him in Salih Kambuh's 'Amal-i Șālih, (1967-72 [III]: 344), where the author notes that "for exquisiteness of calligraphic line, loveliness of oeuvre, and gentility of character, he is famed throughout the world."

17. Mu'izz al-Mulk was governor of Surat from 1629 to 1636 , and again from 1639 to 1641. For details on his career, see Flores (2011); F. Hasan (2004: 31-43). 
18. For more on Nilakantha's Mahābhärata commentary, including his mention of eyeglasses, see, for instance, Christopher Minkowski (2010), to whom I am also grateful for bringing Nilakantha's work to my attention and clarifying its meaning in conversation and private correspondence.

19. Perhaps an allusion to the four "servants essential to kings" famously outlined in Nizami 'Aruzi's Chahār Maqāla, first among whom is none other than the imperial secretary, "for the maintenance of the administration" (1921: 12).

20. That is, he works for the justice and benefit of all, instead of using his position for personal gain. This passage bears a striking resemblance to an aphorism that appears in the Fārs-nāma of the eleventh-century Persian historian and political theorist Ibn Balkhiwho was, incidentally, himself part of a family of revenue administrators (mustaufiyān): "The Persians based their notion of kingship on justice [' $a d l]$, and their way of life on equity and liberality [dād-o-dishish]. Whenever [a king] designated his son heir, he advised him to ponder this saying: 'There is no dominion [mulk] without an army ['askar], and no army without wealth [ $m \bar{a} l]$, no wealth without development ['imārat], and no development without justice ['adl]'; and this maxim has been incorporated into the Arabic tongue from the the pahlawi language" (1921: 4-5). According to A. K. S. Lambton (1962: 99-101), the original source of this saying was al-Tha'âlibi, who attributed it to Ardashir, the celebrated founder of the Sasanian Empire; she adds that it "became one of the stock themes of the writers of mirrors [for princes]," appearing in the works of such widely read authors of nașihat-nāmas as Nizam al-Mulk, al-Ghazali, and Kay Ka'us ibn Iskandar.

21. On his life and career, see Shahnawaz Khan (1888-96 [I]: 162-67); Bhakkari (196174 [III]: 25-27).

22. Rāy (sometimes spelled $r \bar{a} \bar{\imath}$ ) was a Hindi variant of $r \bar{a} j \bar{a}$ that appears to have been used in Mughal parlance largely as a Hindu equivalent of khān. Thus a rāy who achieved special preeminence could be further promoted to the title of rāy-i rāyān (rāy of rāys), exactly analogous to the term khān-i khānān as used for elite Muslim notables. One suspects that this use of the term was a convenient way of assigning honorific titles to non-Rajput Hindus at court without creating confusion-but I don't believe anyone has actually studied the question systematically.

23. Bhakkari (1961-74 [II]: 255-56); Shahnawaz Khan (1888-96 [I]: 150); see also Marahravi (1910: 198-99).

24. Salih Kambuh (1967-72 [II]: 253 and [III]: 154).

25. The mustaufi was the chief auditor in the department of istifä', a kind of comptroller's office that worked under the direction of the Mughal state's chief financial officer

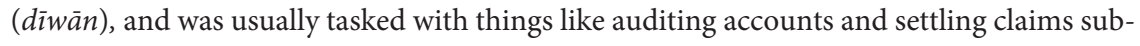
mitted by provincial estate holders (jāgīrdārs) and other revenue collectors (cf. Richards 1986: 25, 63-64).

26. The circumstances are somewhat mysterious, but for details see 'Inayat Khan (1990: 325 [English]; 2009: 299 [Persian]).

27. Cf. CC, 59-6o; Shahnawaz Khan (1888-96 [II]: 441-49).

28. See CC, 71-81; for the larger context, see also Richards (1993: 132-33); Foltz (1996, 1998).

29. Cf. $C C, 154-55 ; M B, 35-36,41$.

30. For details, see Jagadish Sarkar (1951); Shahnawaz Khan (1888-96 [III]: 530-55). 
31. 'Inayat Khan (1990: 533-34 [English]; 2009: 614-16 [Persian]).

32. The letter is addressed to "Mu'azzam Khan," Mir Jumla's official title following his promotion to wazir.

33. Chandar Bhan, incidentally, appears not to have been the only person with a low opinion of Muhammad Amin Khan, who according to several accounts seems to have been somewhat of a boor. See, for instance, the anecdotes of his bad behavior recounted in Shahnawaz Khan (1888-96 [III]: 531).

34. 'Inayat Khan (1990: 546). For details on Ja'far Khan's career, see also Shahnawaz Khan (1888-96 [I]: 531-35).

35. Shahnawaz Khan (1888-96 [II]: 282). His death is also mentioned in various chronicles of Aurangzeb's reign, such as Khafi Khan (1963 [III]: 166); Saqi Musta'id Khan (1947: 29).

36. Aurangzeb (1880: 21 [\#56], 46-47 [\#149]).

37. Quoted in S. H. Qasemi and W. H. Siddiqi's introduction to MB (Brahman 2005: ك - كز - For further details on Chahār Bahār and Bal Krishan munsh $\vec{\imath}$ s career, see A. Singh (1993).

38. Alam and Subrahmanyam (2010).

39. For general details on the campaigns in Bijapur and Golconda and a summary of the relevant sources, see, for instance, Saksena ([1932] 1962: 150-81). For a contemporary account available in English, see also 'Inayat Khan (1990: 166-89).

40. For details on the background and events surrounding Jujhar Singh's rebellion, see, for instance, Saksena ([1932] 1962: 79-91); Richards (1993: 129-30); Jadunath Sarkar (1920 [I]: 16-29).

41. 'Inayat Khan (1990: 149); note that Jadunath Sarkar, following 'Abd al-Hamid Lahori, gives the victim's name as Bhim Narayan, not Prem (1920 [I]: 18).

42. E.g., 'Inayat Khan (1990: 165).

43. Cf. Chandra ([1999] 2005: 259).

44. 'Inayat Khan (1990: 84-85).

45. For more details on this campaign, see 'Inayat Khan (1990: 233-43).

46. For extended discussions of the powerful effect of these strains of Mughal cultural memory on their imperial ideology, see, for instance, Foltz (1998: 12-51); Balabanlilar (2012); Moin (2012: 23-93).

47. 'Inayat Khan (1990: 335).

48. For details on these grievances and Sa'd Allah Khan's efforts to address them, see, for instance, 'Inayat Khan (1990: 339-40).

49. Even Mughal charity was kept up while the army was on campaign, as this moving anecdote from 'Inayat Khan's Shäh Jahān Näma indicates. In the same month that Murad Bakshsh and 'Ali Mardan Khan were dispatched for the campaign in Balkh and Badakhshan, the chronicler tells us, "It was reported that in consequence of the high price of food, some of the poorer classes of the province of the Punjab were selling their children. Accordingly, an edict was issued from the benevolent and indulgent threshold, directing that whosoever sold his child should receive the price out of the royal coffers, and have the child restored to him again. By this kindness, a great number were relieved from the anxiety of procuring food, the pangs of hunger, and the hardship of being separated from their offspring. A sublime farman was also promulgated to the effect that alms houses should be 
opened in different places, and that two hundred rupees' worth of meals should be distributed daily in charity among the poor and destitute" (1990: 337).

50. For details on all of these developments, see, for instance, G. Sharma (1954); Sri Ram Sharma (1971).

51. Note that while CC lists the boy's name as "Subhāg Chand," a number of other sources call him Subhāg Singh. See, for instance, Salih Kambuh (1967-72 [III]: 149).

52. Busch (2011: 147-48).

53. Jahangir (1999: 164-65). For further details on Afzal Khan's role in these earlier events, and his life and career generally, see Kinra (forthcoming).

\section{KING OF DELHI, KING OF THE WORLD}

1. Two classic examples of this branch of Mughal scholarship are R. P. Tripathi's "TurkoMongol Theory of Kingship" (1936) and J. F. Richards's "Formulation of Imperial Authority under Akbar and Jahangir" (1978). Both have been reprinted in Alam and Subrahmanyam (1998: 115-25 and 116-67, respectively). More recently, Lisa Balabanlilar (2007, 2012), for instance, has examined the continuing impact of the Central Asian Timurid tradition on Mughal politics; A. Azfar Moin (2012) has examined the role of astrology, millennial thinking, and the occult sciences in Mughal theories about the king as the semidivine embodiment of certain astrological phenomena; and Munis Faruqui (2012) has comprehensively established the crucial role of princely competition in the more mundane-but of course essential—quest for worldly power within the Mughal dynasty, through their role as frontier administrators and their efforts to build up princely households and networks of their own.

2. Tārīkn-i Rājahā-yi Dehlī-yi Hindūstān, MS, Gujarat Vidya Sabha, Ahmedabad (Main Catalog \#46). Subsequent citations of the Tãrīknh-i Rajahā-yi Dihlī in this chapter refer, unless otherwise noted, to this manuscript (hereafter TRD) and are given parenthetically in the text with folio numbers.

3. It should be noted, however, that Qaiqubad's reputation in many other Indo-Persian sources is not nearly so good as Chandar Bhan suggests. See, for instance, Khwajah Nizamuddin Ahmad's Ṭabaqāt-i Akbarī ([1927] 1973 [I]: 119-31).

4. Note that the word Chandar Bhan uses here is jahd- "toil, struggle, effort," etc.and not $j i h \bar{a} d$, the more infamous term usually (mis)translated as "holy war."

5. Several books examine Delhi's importance as a political center from ancient times through the Mughal period and down to the present. For a good distillation of the British colonial perspective on this history, see, for instance, Fanshawe (1902) or Hearn (1906). And for more recent considerations, see K. Nizami (1989); Blake (1991); S. Kumar (2010).

6. Gladwin (1795: 44-74).

7. For a discussion of The Persian Moonshee and a summary of its contents, see Kinra (2008: 134-54).

8. Lord (1839: 159). I am grateful to Manan Ahmed Asif for referring me to this inventory of Moorcroft's possessions. See also his note on Moorcroft in a blog post (Ahmed [Asif] 2007).

9. Brahman (2005: 1).

10. (1) 'Abd al-Salām Collection, \#289/59, copied in Bengal in 1209 AH (1794-95 CE), seems originally to have referred to the text as per the colophon, which gives the title Guldasta-yi Qawā'id al-Salțanat, with someone later adding “-i Shāh Jahān”; (2) 'Abd al-Salām 
Collection, \#291/61b, copied during Shah 'Alam's reign in $1194 \mathrm{AH}$ (1780 CE), lists it in the front matter as Guldasta-i Saltanat, while the colophon simply calls it Guldasta-i Chandar Bhān Munshī; (3) Subhān Allah Collection \#891'5528/20, copied in 1146 AH (1733-34 CE) or possibly 1126 (1714 CE), describes it variously in the front matter as Guldasta-i Munshi Chandar Bhān or Guldasta az Taṣnîf-i Chandar Bhān Munshī, and in the colophon as Guldasta az Tașnïf-i Chandar Bhān Brahman; (4) Suleiman Collection \#664/42, copied in $1196 \mathrm{AH}$ (1781-82 CE), refers to the text in the colophon as Guldasta, mausūm ba-Qawā'id al-Saltanat; (5) Suleiman Collection \#664/44, which is missing a colophon, also refers to the text by both names; and finally (6) Habib Ganj Collection, \#56/1, refers to the text in one place as Qawā'id al-Salțanat-i Shäh Jahān but notes that it has been copied from a fellow scribe's version of Chahār Chaman.

11. Quoted as translated in Alam (2004: 43).

12. This emphasis on the routine business of government on Chandar Bhan's part is the reason for my somewhat idiosyncratic translation of qawa' id (sing. $q \bar{a}^{-} i d a$ ), which Gladwin is technically correct in translating as "rules," instead as "routines." It may be unconventional, but I think it goes much further in capturing the sense of what Chandar Bhan is trying to convey in this text than any of the typical alternatives for translating $q \bar{a}^{\mathrm{a}} \mathrm{i} d a$, which Steingass (1892: 948), for instance, lists as "base, basis, foundation, ground-work; a pedestal; capital of a column; a metropolis, capital, seat of government; rule, custom, institution, mode, manner, style, etiquette; regulation; a rule of grammar; first reader, primer; construed with the verbs sust kardan, shikastan, nihädan, \&c." One gets closer to the sense in which I'm using it here, actually, with Steingass's subsequent definition of the related term $q \bar{a}$ 'ida-dān (i.e., "one who knows $\left.q \bar{a}^{\mathrm{a}} i d a \mathrm{~s}^{\prime}\right)$ as "one versed in rules of practice, or forms, or customs, or ceremonies; an expert, an authority" (948).

13. For an English translation of Lahori's version, see the appendix to 'Inayat Khan (1990: $567-73)$.

14. Brahman (2007: 85). Subsequent citations of Chahär Chaman in this chapter refer, unless otherwise noted, to this printed edition edited by Yunus Ja'fery (hereafter CC) and are given parenthetically in the text with page numbers.

15. The Huma is a legendary bird of fortune in ancient Persianate mythology. Merely catching sight of one was thought to be a good omen, but to have the Huma's shadow fall upon one, or to have it alight on one's head, was considered an especially auspicious sign of royal destiny. Here Chandar Bhan seems to be inverting the usual hierarchy, suggesting that Shah Jahan's kingly qualities are so magisterial that even the Huma bird, typically the creature that confers royal favor, actually seeks the shade of his royal parasol. For further details on the Huma, along with other examples of references to it in Persian literature, see for instance Schimmel (1992: esp. 187-88).

16. Like a number of manuscripts of Chahär Chaman and Guldasta, the text of this section of the 2007 printed edition of Chahär Chaman (CC, 88-89) skips over Chandar Bhan's full inventory of the fruits available at the palace breakfast, so here I have relied on the version in Gladwin's Persian Moonshee (1795: 45), though I have also revised Gladwin's English translation for accuracy and readability. Cf. also Guldasta / Qawā 'id al-Salțanat, MS, Azad Library, Aligarh Muslim University, Aligarh (Suleiman Collection \#664/44: fol. 3a-3b); and Qawā'id al-Salțanat-i Shāh Jahān, MS, Azad Library, Aligarh Muslim University, Aligarh (Habib Ganj Collection, \#56/1:1-2). 
17. Gladwin reads this as "musk-melons of Balk, and those cultivated near watercourses," presumably reading kārīz (or perhaps kārez) to mean the notable water regulation system developed among the Uighurs of ancient Turpan, an important Silk Road oasis on the edge of the Taklamakan desert. But Chandar Bhan was almost certainly referring, not to melons "cultivated near water-courses," but rather to those from Kariz, a town in Khurasan just inside modern Iran's northeastern border with Afghanistan (about midway between Mashhad and Herat), which was apparently famous for its delicious melons. Indeed, Joseph Pierre Ferrier, the nineteenth-century French adventurer who traveled across much of Central and West Asia, makes a special note in his memoir Caravan Journeys and Wanderings of Kariz's onetime reputation for great melons: "The melons of this locality were in ancient days considered the best in Asia, and were reserved for the courts of Teheran, Kabul, and Delhi: but the village having been destroyed at the close of the last century, and consequently deserted, the seed was lost, or degenerated from change of soil. Kariz had recently been repeopled by Hazarahs, who are taking pains to re-establish the reputation of its melons-judging by the two I ate, they have not yet succeeded" (1856: 138).

18. Here again, Gladwin's reading of shaftālū-yi kārdī as "apricots fit for the knife" is surely mistaken. The "Kardi" was a variety of peach common to Central and West Asia. Babur refers to them in his memoir by way of comparison with the Indian mango, which, he says, "resembles the kardi peach" (2002: 344). They are also clearly listed among the varieties of Persian peaches (Amygdalus persica) in Edward Balfour's Cyclopaedia of India (1885 [III]: 166-67).

19. Gladwin (1795: 45).

20. Satish Chandra has rightly noted that the Mughal ritual of jharoka-darshan was specifically intended to link their style of rule to the deeper practices of Indian kingship and to inculcate certain values among the nobility and bureaucracy: "Since the ruler was the centre of government his attitude towards public business set a standard and a norm. These, in turn, were widely emulated by the nobles... The morning appearance which was called jharoka darshan was an innovation of Akbar, and was designed to establish a personal bond between the ruler and his subjects. This was an occasion when people could submit their petitions and present their cases without hindrance. A decision could be taken on the spot, or, as under Shah Jahan, the clerks of the judicial department took notes, and placed them before the ruler in the open darbar, or in the private audience chamber. The jharoka darshan was sometimes used for witnessing animal fights, or reviewing the contingents of nobles. In course of time, as Akbar's prestige rose, some people made it a rule not to eat or drink till they had the darshan of the king. This was a practical demonstration of the old Indian traditions of attaching divinity to the office of the king" ([1999] 2005: 145-46).

21. 'Abd al-Qadir Badayuni, Muntakhab al-Tawārīkh, quoted in Chandra ([1999] 2005: 146).

22. Note that here the word sult țan does not mean "king" or "ruler," as it did in much of the larger Islamic world, including India in the pre-Mughal era. As Alam has noted, in Mughal parlance the meaning of sulțān by the seventeenth and eighteenth centuries "had expanded, or rather degenerated into denoting even cousins, distant cousins, and nephews of the reigning monarch - that is to say, even those with no plausible pretensions to power" (Alam 2004: 2). 
23. For details on some of their celebrated careers and works, see, for instance, Roxburgh (2005); Dihlawi (1910). Samples of the works of Sultan 'Ali Mashhadi, Mir 'Ali Haravi, and Mir 'Imad al-Hasani were also recently displayed in the exhibit "Nasta'liq: The Genius of Persian Calligraphy" at the Smithsonian's Arthur M. Sackler Gallery (September 13, 2014, to May 3, 2015); details of the calligraphers' lives, and specimens of their work, can still be viewed on the exhibit's website: www.asia.si.edu/explore/nastaliq/default.asp (accessed May 10, 2015).

24. It is not clear exactly what Chandar Bhan means by the distinction between brahmans and hindis - probably he just means to indicate that the astrologers whom Shah Jahan consulted were not exclusively Brahmans, that there were "other Indians" as well.

25. This discussion of justice leads directly into one of the strangest passages in all of Chahär Chaman (CC, 99), in which Chandar Bhan essentially narrates the famed biblical story of King Solomon and the baby of disputed identity (1 Kings 3:16-28) as if it had happened at Shah Jahan's court! It is not clear what to do with this passage, analytically speaking. Chandar Bhan was not in the habit of using parables, and this, as far as I can tell, is the only such passage in his entire surviving oeuvre. Whether he thought that his readers would not make the connection to the famous story, or he simply did not care, is not readily apparent. It is also not clear what his source for the story might have been. Perhaps he borrowed it from the version recounted in Mir Khwand's fifteenth-century compendium Rauzat al-Șafā (The garden of purity), which, as he tells us later in Chahār Chaman, was regularly read aloud as part of the evening entertainment at Shah Jahan's court (see below). For an English translation of Mir Khwand's version of the story, see Mir Khwand (1892 [pt. 1, II]: 73-74).

26. For extended discussions of this Timurid-Mughal genealogy, see, for instance, Anooshahr (2009: 15-57); Balabanlilar (2007, 2012); Moin (2012).

27. The text was translated into English in the nineteenth century by E. Rehatsek under the title Sacred and Profane History According to the Moslem Belief and then reedited by F. F. Arbuthnot and published by the Royal Asiatic Society in 1892 (Mir Khwand 1892).

28. Woods (1987: 99-100). For further details, as well as a general discussion of how such Timurid historical scholarship influenced later Mughal and Safavid historiography, see, for instance, Quinn (2003).

29. Reeve (2012: intro.).

30. Astonishingly, the very same exhibition catalog appears to reverse itself just a few lines later by describing Shah Jahan as "a very hands-on ruler." But the author, unlike Chandar Bhan, clearly does not see this as a good thing. Rather, according to him: "Shah Jahan emerges as a rather aloof perfectionist, put on a pedestal as a symbol of the just Islamic ruler. ... He was, however, a very hands-on ruler, travelling around his kingdom to be seen and to enforce Mughal authority and central control, not least on taxation. Unlike Akbar and Jahangir, he was an orthodox Islamic ruler" (Reeve 2012: pl. 18). Note that other than the English ambassador Sir Thomas Roe (who, by the way, had left India in 1618, some ten full years before Shah Jahan even became emperor) not a single contemporary seventeenthcentury source, in Persian or any other Indian language, is cited to support these assertions. Yet the author clearly feels confident characterizing Shah Jahan as an "orthodox" sectarian figure and further implying that even Shah Jahan's "hands-on" approach to governance was largely, if not entirely, in bad faith-cultivated solely for the self-serving purposes of van- 
ity ("to be seen"), intimidating his subjects ("to enforce Mughal authority") and extracting more taxes from them. In other words, the idea that Shah Jahan's "perfectionism" and belief in "justice" could actually have provided a sincere impetus to improve governance and the administration of "state affairs," or that they could have coexisted with a robust sense of Muslim piety, is apparently inconceivable. Shah Jahan could not actually be a "just Islamic ruler," he could only pose as a symbol of one in order to disguise his true nature as an "orthodox Islamic ruler" unlike his father and grandfather. Beyond this, Lives of the Mughal Emperors spends barely three pages on Shah Jahan's actual life and career, one of which is entirely on the Taj Mahal (pl. 19), and another of which is almost entirely focused not on Shah Jahan himself but on Dara Shukoh and Aurangzeb's struggle to succeed him (pl. 21) (completely neglecting to mention, incidentally, that there were two other princes, Shah Shuja' and Murad Bakhsh, who played major roles in that struggle).

31. For a detailed discussion of early modern horse trade and breeding practices in India, see Gommans (1995: 68-103), according to whom "the horses from Kutch were particularly celebrated and could not be easily distinguished from Arabians." In fact, there were even legends about the Arabian origin of the Kutch horses. According to the early nineteenthcentury European adventurer George Augustus Frederick Fitzclarence's Journal of a Route across India, through Egypt, to England: "The breed of horses in Kutch is very fine; they have a peculiar dip in the back, and their superiority over the other horses of India is accounted for in the Ayen Akbaree [sic], by the following anecdote. A long time ago an Arab merchant ship was wrecked on the coast of Kutch, and seven chosen Arab horses were saved from the wreck, which are reported to have been the progenitors of the present race" (Fitzclarence 1819: 144).

32. The reader familiar with South Asian languages will note that these elephant names were often Hindi, or a mix of Persian and Hindi, perhaps owing to the fact that, unlike the horses, they were bred and trained almost exclusively in India.

33. The printed text of Chahär Chaman has neza (spear) (نيزه) here, but Gladwin (1795: 66) is probably correct in reading it as tīr (arrow) (تير), since the latter would logically go with kamān (bow), the next thing on the list—not to mention the fact that neza appears again in the list just a few items later, which would be an odd redundancy.

34. For some interesting examples of such gossip, see, for instance, Mukhia (2004: 113-55); Naim (2004).

35. Pace Richards (1993) and Blake (1991), respectively.

36. Note that here again I have broken up some of Chandar Bhan's lists into columns, in order to make the syntax a bit clearer.

37. All three were eminent saints of the Chishti order, renowned for its tolerant disposition, and especially influential among the Mughal dynasty. For further details on the tombs specifically mentioned by Chandar Bhan, see, for instance, Blake (1991: 152-56). There is also an extensive bibliography on the Chishtis, but for basic details see, for instance, Rizvi (2002 [I]: 114-89); Ernst (1992: 5-93); Ernst and Lawrence (2002); K. Nizami (2002: $186-$ 280); Digby (1990); Suvorova (1999: 105-31).

38. Babur (2002: 327).

39. Dargah Quli Khan (1993: 51-58).

40. Pace Kavuri-Bauer (2011: 8).

41. Again, cf. the title of Kavuri-Bauer (2011): Monumental Matters, which treats such trends purely as a modern phenomenon. 
42. Koch (2008: 562). Again, not to beat a dead horse, but one has to wonder: If Shah Jahan had been so intent on rejecting the Akbari dispensation and replacing it with a more orthodox stance (as so much modern historiography seems to want to insist), then why would he so publicly exalt his illustrious grandfather by giving Agra Akbar's name?

43. Koch (2008: 571-72).

44. Koch (2008: 569-71).

45. Koch (2008: 556).

46. On Mas'ud Sa'd Salman and Abu al-Faraj Runi, see Sunil Sharma (200o); Alam (2003: 135-37, 142-43). On Pir 'Ali Hujwiri, see Reynold A. Nicholson's English translation of Kashfal-Mahjūb (Hujwiri 1911), and for basic details on his life and mystical career see also, for instance, Rizvi (2003 [I]: 112-13); Suvorova (1999: 35-58).

47. On Miyan Mir's life and career, see Rizvi (2002 [II]: 103-8).

48. Like Miyan Mir, Shaikh Bala'ul was a Sufi of the Qadiri order whose khhanqāh was just outside Lahore. For details, see Rizvi (2002 [II]: 66).

49. On Mulla Shah's career, see Rizvi (2002 [II]: 115-25).

50. Annemarie Schimmel, for instance, in her Empire of the Great Mughals (2004: 48, 135), goes so far as to describe Miyan Mir variously as Dara Shukoh's "guru" and spiritual "master" after the two "came into contact," without ever once even mentioning Shah Jahan's own relationship with the saint, much less pointing out that it was Shah Jahan who actually put them "into contact." Similarly, John Richards cites Dara's relationship with Miyan Mir and Mulla Shah as proof that, unlike his father, the prince was a "throwback" to the tolerant attitude of Akbar-again, without ever mentioning Shah Jahan's connection to the two Qadiri saints: "In his intellectual curiosity, his open-mindedness, and his mystical interests Dara was in many ways a throwback to his great-grandfather, Akbar. He was an active disciple of Mulla Mir (d. 1635) [i.e., Miyan Mir] and Mulla Shah Badakshi (d. 1661), two leading Shaikhs of the Qadiri order of Sufis" (1993: 151-52).

51. Rizvi (2002 [II]: 124).

52. These last three were all highly regarded Chishtis of the period, and among them Sayyid Muhammad Qanauji is probably the best known today. He was a disciple of the famous (though somewhat controversial) Chishti philosopher Shaikh Muhib Allah Allahabadi (ca. 1587-1648) (on whom see Rizvi [2002 [II]: 268-71]); and in addition to advising Shah Jahan on spiritual matters during his reign, he continued to do so even after the latter was imprisoned by Aurangzeb, and then served as one of the officiants at his funeral in 1666 (cf. Begley and Desai's epilogue to 'Inayat Khan [1990: 564-65]). Notably, he had also been one of Aurangzeb's childhood tutors, and he continued his connection to the court later in life, for example when he was recruited by Aurangzeb to assist in the compilation of Fatāwā-yi 'Ālamgìri (Faruqui [2012: $81 \mathrm{n}$.$] ), a massive and influential compilation of Hanafi jurisprudence.$

53. All three were very influential early saints of the Suhrawardi order. For details on their careers, see Rizvi (2003 [I]: 190-215).

54. "Baba" Farid al-Din Ganj-i Shakkar was one of the most popular Sufi saints of medieval India, and his shrine in Pattan became a well-known site of pilgrimage, and popular religious expression, among both Hindus and Muslims alike. For general details on his life, career, and influence, see, for instance, Rizvi (2003 [I]); K. Nizami (2002); Suvorova (1999: 81-104). For a study of the culture of popular religion surrounding Baba Farid's shrine, see also the classic article by Richard Eaton (1984). 
55. For basic details on Shaikh Jalal Makhdum Jahaniyan's life and spiritual career, see Rizvi (2003 [I]: esp. 277-82). For a recent analysis of his thought and philosophy, see Steinfels (2012). And for a poignant meditation on the continuing reverberations of both Baba Farid's and Shaikh Jalal's memory in the political landscape of Pakistan today, see Ahmed (Asif) (2013).

56. Though Babur died in India in 1530, his body was later transported for burial in Kabul, in accordance with his wishes.

57. Asher and Talbot (2006: 92). For the details of Khattu's life and career, see Rizvi (2003 [I]: 404-8). And for the larger context of Gujarati trade, commerce, and politics, including brief discussions of the influence and political connections of both of these two saints, see Shaikh (2010).

58. For details, see above, chapter 2.

59. For details, see, for instance, Currie (1989); Asher (1992: 77-80; 2009).

6o. 'Inayat Khan (1990: 558).

61. Asher (2009: 80-81).

62. The brevity of Chandar Bhan's discussion of Banaras is, perhaps, especially ironic because as we will see in the final chapter one of the most potent myths about the munshi in the later Indo-Persian cultural memory is that Banaras is the city to which he ultimately retired, supposedly in mourning over the execution of his alleged benefactor, Prince Dara Shukoh. This myth is completely unfounded, and is, in fact, easily refuted by evidence available in Chandar Bhan's own letters.

63. On Sharaf al-Din Ahmad Yahyá Maneri’s career, see Rizvi (2003 [I]: 228-40).

64. For details, see, for instance, Richards (1993: 133-35).

\section{WRITING THE MUGHAL SELF}

1. Brahman (2007: 145). Subsequent citations of Chahär Chaman in this chapter refer, unless otherwise noted, to this printed edition edited by Yunus Ja'fery (hereafter $C C$ ) and are given parenthetically in the text with page numbers.

2. For a basic overview of this distinction between 'ishq-i haqiq $\bar{\imath}$ and 'ishq-i majāzi, along with many examples of how it was deployed in late Mughal poetry (especially in Urdu), see, for instance, Russell and Islam ([1969] 1998: 169-231).

3. See, respectively, O’Hanlon and Minkowski (2008); O'Hanlon (2010); Guha (2010); and Chatterjee (2009, 2010).

4. Cf. the letter to his brother, $M B, 75-76$.

5. The building is situated just outside Amritsar, and though parts of it are crumbling it is still standing and still known locally today as the Sarai Amanat Khan. These curious architectural tastes appeared to run in the family, for Afzal Khan's own body was reportedly conveyed to Agra, where it was interred in a tomb of his own design that also had a number of novel structural features, leading the locals to refer to it as the Chinese Mausoleum (Chīnì kā Rauzāa). (For details, see Koch [2006: 43-45; 2008: 573].) The calligraphic inscriptions on Afzal Khan's tomb, like those on the Taj, also appear to have been designed by his brother Amanat Khan. For further details on his life and career, see Begley and Desai (1989: xxxii-xl) and above, chapter 1.

6. There are a handful of references to a certain "Indar Bhan" in a couple of Chandar Bhan's letters, some of which suggest that he may have also been the munsh's son. But the 
wording is ambiguous, and it is possible that he was some other kind of relation, or even just a disciple, who was "like a son" to him. Be that as it may, he does not figure prominently in Chandar Bhan's work, so there is not much more we can conclude about him.

7. Brahman (2005). Subsequent citations of Munsha'ät-i Brahman refer, unless otherwise noted, to this printed edition edited by S. H. Qasemi and Waqarul Hasan Saddiqi (hereafter $M B$ ) and are given parenthetically in the text with page numbers. Note that on the English title page of Qasemi and Siddiqi's edition the title is listed as "Munshi'at-e-Brahman."

8. Hali (1996: 176).

9. Parekh (2013).

10. Muhammad Salih Kambuh, Bahār-i Sukhan, MS, British Library, Or. 178, fols. 96b98a; cf. also MS, British Library, IO Islamic 3154, fols. 67a-68a.

11. Shafiq (n.d.: 9).

12. Maktūbāt-i Muknhtalifa, MS, Bombay University Library, \#82, fols. 6b-8a. For details on the other contents of this collection, see Sarfaraz (1935: 222-23; n.b., in Sarfaraz's catalog it is listed as Majmū'a-e-Khuțūt (A collection of letters), but the spine of the manuscript's actual binding calls it Maktūbāt-i Mukntalifa (Miscellaneous writings).

13. Majma'al-Afkār, MS, Khuda Bakhsh Oriental Public Library, \#872, fols. 207a-208a. I am very grateful to Arthur Dudney for sharing his digital copy of these folios with me, as I have not had the opportunity to travel to Patna to review the manuscript myself. An abridged selection of a few notable parts of Majma' al-Afkār was published some years ago (I. Siddiqi 1993), but it does not include Chandar Bhan's letters. For a detailed summary of the overall contents of Majma' al-Afkār, see Muqtadir (1925 [IX]: 82-100).

14. For details on Qudsi's career, see Losensky (2006).

15. Cf. the version of this letter in $M B, 15-16$.

16. Cf. $M B, 16-17$ (where it has a slightly different heading that describes Afzal Khan as a latter-day Plato or Aristotle).

17. Note that this was not the same Ishwar Das (ca. 1655-1750) who later served under Aurangzeb and composed the Futūhạtt-i 'Ālamgììi.

18. Cf. $M B, 34-35$.

19. I.e., it is impossible to go to the beloved except in complete submission and prostration. Thus the true lover ('áshiq) has the look of a madman as he makes his way to the beloved, because he is constantly hunched over, crawling, etc.

20. Cf. $M B, 35-36$.

21. Cf. $M B, 36-37$.

22. Majma' al-Afkār, MS, Khuda Bakhsh Oriental Public Library, \#872, fol. $208 \mathrm{a}$.

23. Losensky (2006).

24. For the verses, along with an English translation, see H. Hasan ([1951] 2008: 57-59).

25. The printed text reads $\underline{k}$ hurrami-yi naqd-i sukhan; but interestingly enough, the Khuda Bakhsh manuscript of Majma' al-Afkār has șairafi-yi naqd-i sukhan, i.e., "the broker of literary capital"-yet another commercial metaphor.

26. I would suggest that this means "It's not the road's fault that you came crookedly down the path of love."

27. For details on Munir's life and works, see Memon (1983). 
28. Cf. $M B, 74-75$. The translation here is a composite of the variants found in these two texts, along with those in Qadiri's dual Urdu-Persian edition (Brahman 1992: 148-51).

29. The printed edition of Chahar Chaman has niz ("also"), but virtually all the manuscripts, and the Urdu edition (Brahman 1992), have beshtar ("greater").

30. Brahman (1992: 149).

31. Cf. $M B, 77$.

32. Cf. $M B, 77$. The couplet itself does not appear in the version of this letter in the printed edition of Munsha'ät, nor does there appear to be any corresponding ghazal in the printed Dìwān of his poetry.

33. Cf. $M B, 77-78$.

34. Cf. $M B, 78-79$.

35. Cf. $M B, 93-95$.

36. Cf. $M B$, 95-101. Cf. also the excerpts from this letter translated in Alam (2003: 16465) and Alam and Subrahmanyam (2004: 62-63).

37. For details on the Isfahan school generally, and the four thinkers mentioned at the beginning of this paragraph, see, for instance, Kamal (2006) (esp. chap. 3, "The School of Isfahan and Mulla Sadra's Departure from Suhraward's Tradition," 24-41).

38. Kamal (2006: 29-30). For an extended discussion of Findarski's career in the wider context of South Asian literary and intellectual culture, see also Nair (2014).

\section{MAKING INDO-PERSIAN LITERATURE FRESH}

1. Subrahmanyam (2003: 134).

2. Some conservative Mughal intellectuals, like the historian 'Abd al-Qadir Badayuni (ca. 1540-1615), explicitly used such millenarian discourse to critique Akbar's humanistic policies of sulh-i kull as too open to heterodox influences. See, for instance, Moin (2009; 2012: 152-55). Others, like the famed Naqshbandi Sufi Shaikh Ahmad Sirhindi (d. 1624), who boldly cast himself as the "Renewer of the Second Millennium" (mujaddid-i alf-i șānī), drew energy from the moment to couch their own mystical visionary claims in terms of messianic reform. For a bibliography of further reading on Sirhindi and a recent reconsideration of his career and milieu, see Alam (2009). For comparison with the Safavid context, see, for instance, Babayan (2002). And for the Ottoman context, see Fleischer (1992, 1994b); Şahin (2010).

3. Moin (2012).

4. Pollock (2001b: 6). See also Bronner (2002); Bronner and Tubb (2008); McCrea (2002); Ganeri (2011).

5. See, for instance, Bronner and Shulman (2006).

6. On the concept of the "vernacular millennium," see Pollock (1998; 2006: 283-436).

7. For a general overview of developments in literary Hindi during this period, see, for instance, McGregor (2003). On Sufi romances (premākhyānas) in Awadhi Hindi, see Phukan (2000a, 2001); Behl (2012a, 2012b); Behl and Weightman (2000).

8. For Tulsidas's literary debt to the Sufi premākhyānas, see de Bruijn (2010). On Banarasidas, see Mukund Lath's and Rohini Chowdhury's introductions and notes to their respective English versions of his work (Banarasidas 2005, 2009). For a detailed analysis of the innovative "vernacular aesthetics" deployed throughout Banarasi's autobiography, see Snell (2005). 
9. On Brajbhasha devotional poetry, see McGregor (2003: 919-32).

10. Busch (2010a, 2010b, 2011).

11. For an extended discussion of riti-style poetry's marginalization in modern Hindi literary scholarship, see Busch (2011: 3-22, 202-48). For the similar fates of classical Persian and Urdu poetry, see Kinra (2011a); Faruqi (1998, 2001); Pritchett (1994); and Pritchett and Faruqi's respective introductions to their translation of Muhammad Husain Azad's $\bar{A}$ b-e Hayāt (2001: 1-17, 19-51). On the widespread modernist rejection and neglect of the śleșā (bitextual) tradition of classical Sanskrit, see Bronner (2010). To my knowledge, no comprehensive examination of the modern critique of classical Persian prose (insh $\bar{a}$ ) has been published to date, though I explore some aspects of the largely dismissive colonial and nationalist attitude toward the genre in my $\mathrm{PhD}$ dissertation (Kinra 2008) and touch on them briefly in the Conclusion below.

12. The most detailed recent assessments in English of the poetics and logic of tāza-gu' '̄ are found in Losensky (1998: esp. 193-249) and Faruqi (2004). In Urdu, see, for instance, S. M. 'Abdullah's (1977d) very informative article. For a more general historical overview of Indian Persian and its place within the wider culture and politics of South, Central, and West Asia, see Alam (2003).

13. Faizi's contrast between new and old (nau and kuhan) appears in multiple works throughout his oeuvre. See, for instance, the passage quoted in Losensky (1998: 195-96 [English], 355 [Persian]); or a similar passage quoted in Alam and Subrahmanyam (2006b: 111). For Faizi's life and career generally, see, for instance, Shibli Nu'mani (2002-4 [III]: 25-64); Desai (1963); Hadi (1978: 79-152); Munibur Rahman ([1999] 2012).

14. Of course, even Pound attributed the original formulation of his famous twentiethcentury dictum to a certain Tching Tang, who ruled China in the seventeenth century BCE (cf. Cantos, \#53). In other words, even for the quintessential modernist the ancient, classical, and exotic were not to be simply jettisoned but rather to be reconfigured and "made new" and relevant again.

15. Kinra (2007, 2011a).

16. There are scores of manuscripts of Chandar Bhan's Dìwān in archives all over the world, and there have also been at least four printed editions (though two of them are very recent). The first, published as Gulzār-i Bahār, Ma'rūf ba Bazm-i Nažm-i Brahman ("Spring's Bouquet, also known as the Banquet of Brahman's Verse"; n.d. [1930s?]), was compiled with accompanying biographical information in Urdu by a poetically inclined civil servant named Bhagwant Rai "Bahar" Sunnami, according to what he claims was a (now lost) manuscript in Chandar Bhan's own hand that he discovered in a private library in Lahore. It is extremely rare; in fact, in years of studying Chandar Bhan, I myself have only seen one actual copy of Sunnami's text. The second, which itself relies mainly on Sunnami's edition, has been edited with a nice English introduction by Muhammad 'Abdul Hamid Farooqui, under the title Ahwwāl-o-Āsār-i Chandra Bhān Brahman wa Dìwān-i Pārsī ("Life and Works of Chandra Bhan Brahman, along with His Persian Dīwān"; 1967). There are also two relatively new editions that have both appeared in the last decade. One was edited by Muhammad Amin 'Amir, under the title Dīwān-i-Brahman az Rā'i-yi Rāyān Munshì Pandit Chandar Bhān Brahman (Brahman 2008); the other was edited by Shahid Naukhez Azmi under the title Chandar Bhān Brahman kī Fārsī Shā'irī (Brahman 2012) with an Urdu introduction and, in addition to Chandar Bhan's ghazals and rubā'īs, 
reproduces much of the poetry found in his other works and even the (probably spurious) Urdu ghazal occasionally attributed to him in modern scholarship. Unfortunately, I was not able to access a copy of Azmi's edition until the final stages of editing the present work, so all citations of Dīwän-i Brahman in this chapter refer, unless otherwise noted, to Farooqui's edition (hereafter $D B$ ) and are given parenthetically in the text with a ghazal number followed by a period and then a couplet number.

17. For good overviews of the history of Persian in India, see, for instance, Alam (1998, 2003, 2004: 115-40).

18. Quoted as translated in Yarshater (1988: 251 n.).

19. For details on the fatwá and other particulars of Ghazali's life and poetry, many of which come from Badayuni's account, see Hadi (1978: 23-78).

20. Țālib ìn nashā'-i faiz̄i ki zi hindūstān yāft / sharm bād-ash ki digar yād zi ìrān ārad. Quoted in Hadi (1978: 178).

21. Quoted, among other places, in Shibli Nu'mani (2002-4 [III]: 8); W. Qureshi (1996: 19); Browne ([1924] 1959 [IV]: 166); Alam (1998: 322-23).

22. For details on Sa'ib's life and poetic career, see, for instance, M. Lutfur Rahman (1970: 135-41); Losensky (2004). For details on Iranian travel and migration to India more generally, see A. Ahmad (1976); Subrahmanyam (1992a); Alam and Subrahmanyam (2007).

23. Nahawandi (2002: 480). This passage is also quoted and discussed in 'Abdullāh (1977b: 114) and Losensky (1998: 206). Because they were never patronized directly by 'Abd al-Rahim Khan-i Khanan, there are no separate entries in Ma'assir-i Rahìmī for Abu al-Fath Gilani and his brothers, who are instead discussed under the heading of Abu al-Fath's nephew Hakim Haziq, who was himself a noted poet and prose stylist of the seventeenth century (Nahawandi 2002: 478-84). For further details on Abu al-Fath's career, see also Shahnawaz Khan (1888-96 [I]: 558-62) and Muhammad Bashir Husayn's introduction to the modern edition of Abu al-Fath's letters, Ruq'āt-i Hakìm Abū al-Fath Gìlānī (Gilani 1968).

24. For Faizi's life and career, see Shibli Nu'mani (2002-4 [III]: 25-64); Desai (1963); Hadi (1978: 79-152); Munibur Rahman ([1999] 2012).

25. For 'Urfî's life and career, see Shiblī Nu'mani (2002-4 [III]: 65-107); Ali (1929); M. Ansari (1974); Barq (1986); Losensky (2003).

26. Nahawandi (2002: 189-91).

27. Nahawandi (2002: 189).

28. Hadi (1995: 32-33). For the collection of letters, see Gilani (1968).

29. Nahawandi (2002: 190); Faizi (1973: 251-52).

3o. Indeed, Losensky's Welcoming Fighani (1998) is arguably the only modern booklength study in English that examines the poetics of tāza-g $\bar{u}$ ' $\bar{\imath}$ in terms of the fresh poets' own literary critical claims and vocabulary, rather than imposing the anachronistic sabk-i hindi model on them retroactively. There are a handful of other excellent recent analyses, most notably Shamsur Rahman Faruqi's "Stranger in the City: The Poetics of Sabk-e

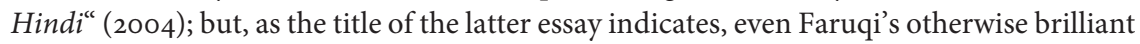
literary analysis remains committed to the notion of a discernible "Indian Style," generally sidestepping the poets" own claims that such inventiveness was "fresh" and new-rather than merely "Indian" - and thus largely bypassing the question of early modernity altogether. Meanwhile, Muzaffar Alam, in his "Culture and Politics of Persian in Precolonial 
Hindustan" (2003), generally splits the difference-noting in several instances the importance of the discourse of tāzagi in early modern Indo-Persian literary culture but also, like Faruqi, continuing to frame the overall question in terms of sabk-i hindì.

31. Faruqi (2004: 69).

32. For details, see 'Abdullah (1977d: 115-16).

33. As reported by Shaikh 'Abd al-Haqq Muhaddis Dihlavi, quoted in M. Ghani (1941: 391-92).

34. Faruqi (2004: 6-9).

35. Khusrau (1988: 59-60).

36. Brahman (2007: 132). Subsequent citations of Chahär Chaman in this chapter refer, unless otherwise noted, to this printed edition edited by Yunus Ja fery (hereafter CC) and are given parenthetically in the text with page numbers.

37. In a somewhat amusing afterthought, Chandar Bhan also addresses a practical dilemma faced by many bibliophiles, telling Tej Bhan that with so much studying, "in the course of time you will acquire a great many books; after you've finished studying them, just give them to your students" (CC, 177) [ba murūr-i aiyām nuskhha-yi bisyār ba dast āwarda ba'd az muțāla'a ba shāgirdān dād].

38. 'Abdullah (1977c: 133-34).

39. For an overview of these common tropes, see, for instance, Schimmel (1992).

40. Nahawandi (2002: 189).

41. Losensky (2003). For an analysis of one such poem, see Shackle (1996: esp. 207-12). For details on Anwari's career and later popularity at the Mughal court, see, for instance, Schimmel and Welch (1983: esp. 57-70).

42. Losensky (1998).

43. For some modern perspectives on Nizami Ganjawi's career, and a bibliography of sources, see, for instance, the various essays in Talatoff and Clinton (2000).

44. Losensky (1998: 211).

45. Losensky (1998: 212).

46. Faruqi (2004: 81).

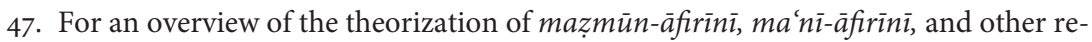
lated concepts, see Faruqi (2004: 25ff).

48. Nahawandi (2002: 91).

49. On Naziri's career, see, for instance, M. Ghani (1929-30 [III]: 67-103).

50. On whom, see M. Ghani (1929-30 [III]: 181-219).

51. Nahawandi (2002: 238-39). Nahawandi praises numerous poets along similar lines throughout $M a$ 'âșir-i Rahīmī, few of whom are even recognized today. See, for instance, his descriptions of Kami Sabzawari, Maulana Baqa'i, Mulla Shirazi, Tajalli, Saidi, Muhammad Yusuf Tab'i, and Nadim Gilani (2002: 487-508, 539-50, 573-86, 620-22, 662-68, 690-92).

52. Pace Yarshater (1988: 249-88).

53. Quoted in Thackston (2002: 95) (my translation).

54. For details on these and other works in this vein by Faizi, see, for instance, Desai (1963: 19-33); Athar Ali (1992); Alam and Subrahmanyam (2005, 2006b).

55. For example, as Hadi Hasan ([1951] 2008: 3-4) has noted, by rendering proper

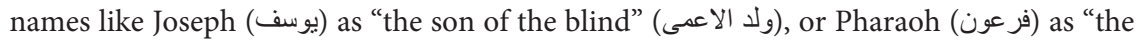
enemy of Moses” (عدو - موسى). To critics who claimed that such a work was an innovation 
bordering on blasphemy, Faizi is said to have blithely retorted that, after all, the Muslim confession of faith also contained no dotted letters (لا اله الا اله).

56. Faizi (1880: 25).

57. Faizi (1880: 41).

58. Faizi (1880: 15).

59. Quoted in Desai (1963: 18). For details on Kashani's life and career, see Losensky ([2004] 2014).

6o. Quoted in Desai (1963: 3).

61. Faizi (1889: 138-44).

62. Faizi (1889: 139). While it is certainly true, as Alam and Subrahmanyam have pointed out (2006b: 111-14), that Faizi's Nal-Daman quite proudly announces its emphasis on the "specific Indian manifestations" of the hadis $-i$ 'ishq - a form of what they call "Hindustani patriotism" akin to what I have been describing as Indophilia-they are equally quick to reiterate that Faizi's point of telling the tale in the first place was "quite clearly to make a statement that would extend beyond India to Iran, and to the Persian-speaking world more generally, of which he believed himself to be a part." They note too, incidentally, that the model for Nal-Daman was Nizami's Layla-Majnūn, "in terms of the metrical scheme utilized as well as a number of other features," and they remind us as well that Faizi's vision was not simply Indophilic but also epochal, a call to "tell that old tale anew" (nau sāz fasāna-i kuhan rā).

63. Flood (2009).

64. On sati and the analogous Rajput practice of jauhar as tropes for ultimate love in the Persianate literary imagination, see, for instance, Phukan (1996). For an analysis of Nau'i's specific approach in Soz-o-Gudāz, see Sunil Sharma (2007). On the popularity of Soz-o-Gudāz beyond India, particularly as a favorite text for Safavid painters to illustrate, see Farhad (2001).

65. Nahawandi (2002: 360-62).

66. Schimmel (1992: 35-36); see also the examples she gives on 62-63.

67. Jahangir (1999: 36).

68. Salih Kambuh (1967-72 [III]: 336-38, 343-44).

69. Schimmel (1992: 119-20).

70. Though it deals mainly with how the concept was applied in eighteenth- and nineteenth-century Urdu verse, one of the best scholarly analyses of the concept of rabt remains that of Pritchett (1994: 84-90).

71. When first writing this chapter I took the liberty of citing this couplet-which hung for years in a beautiful calligraphic rendering on the wall of my former Urdu teacher C. M. Naim's office, and which Naim, upon his retirement from the University of Chicago, left as a token for the room's next occupant, Muzaffar Alam, who as it turned out would eventually became my $\mathrm{PhD}$ adviser-from memory. Thus it was only while doing the final edits for this book that I actually tried to look it up and discovered that some modern editions of 'Urfi's dīwān (e.g., 1915: 112) actually have sharāb (wine) in the second line, instead of $s a r a \bar{b}$ (mirage). Needless to say, I couldn't help but stick with the reading I was so familiar with from Naim/Alam's office (and which, to me, makes more poetic sense in any case). But my instinct that "mirage" was indeed the correct reading was at least in some measure confirmed by consulting a 1620 manuscript of 'Urfi's verse (Dīvān-i 'Urfī, MS, University of 
Michigan, fol. 493) that has helpfully been digitized and made available online via the Hathi Trust Digital Library (http://catalog.hathitrust.org/Record/oo6816035), and in which the scribe has clearly written sarāb.

72. Mohiuddin (1960: 24).

73. Mohiuddin (1960: 24).

74. Mohiuddin (1960: 25).

75. At least one Hindi-Urdu ghazal has indeed been attributed to Chandar Bhan, but he himself never mentions it (or any other vernacular compositions), and I have not been able to trace any mention of it prior to Sri Ram Lala's Kh humknhāna-i Jāwed (Lala 1908: 574-75). It is safe to say, then, that unless further evidence comes to light, and beyond the possibility of it having being preserved in the oral tradition (apparently without being written down by anyone for over two hundred years), we can treat its authenticity with some skepticism.

76. Brahman (2005: 14-15).

77. On ta'allī, see Faruqi (2004: 69).

78. Khusrau (1988: 97).

79. Khusrau (1988: 97).

8o. There is also a well-known story, perhaps apocryphal but significant nonetheless in terms of cultural memory, that Prince Muhammad Sultan-aka Sultan Shahid, the son of Sultan Ghiyas al-Din Balban (r. 1266-86), and governor of Multan-bestowed lavish patronage and built up the cultural institutions of his court for the stated purpose of making it the "Shiraz of India." In pursuit of this goal, he tried repeatedly to invite none other than Shaikh Sa'di Shirazi to his court, only to have the latter demur. Sa'di cited his old age but also made a point of insisting that India didn't need Sa'di because "in India, Amir Khusrau was plenty" (dar hind khusrau bas ast). For further details, see M. Ghani (1941: 392-93); Alam (2003: 138-39).

81. M. Ghani (1941: xxii).

82. For instance, Aufi's Lubāb al-Albāb mentions the cultural rivalry between 'Iraq and Mawara' al-Nahr (Transoxiana), and Daulat Shah's Tazkirah describes numerous "schools" (dabistāns) in Khurasan, Mawara' al-Nahr, Samarqand, 'Iraq, Shiraz, etc. For details, see 'Abdullah (1977d: 115-16).

83. Khusrau, Nuh Sipihr, quoted in Shibli Nu'mani (2002-4 [II]:39).

84. The two from Khusrau are in Ramal (mussamman-i mahzūf) and Mutaqārib (musamman-i sālim), and respectively, while Chandar Bhan's is in Hazaj (mussamman-i sālim).

85. Specifically, there are no Hindi words, and the meter is utterly ordinary: Hazaj (mușamman-i sālim). Yes, Chandar Bhan projects himself as a parrot, a bird often associated with India even before Amir Khusrau, the paradigmatic poetic túți-yi hind. But this trope also has intertextual resonance with Hafiz, Rumi, 'Attar, and countless other classical poets. Likewise the notion of the poet as a sugar-scatterer (shakkar-fishān), strewing sweet turns of phrase with every utterance, was a common literary topos in every place where Persian was spoken or written. So even though this verse certainly provides superficial evidence of a growing Indo-Iranian rivalry, its language is nothing peculiar to India, or Hindus, or some kind of exclusively Indian literary style.

86. Bronner and Shulman (2006: 9).

87. Bronner and Shulman (2006: 5). 
88. The lineage in question being, of course, that of Majnun the prototypical lover. Note too the clever play on the word silsila. In this context it obviously refers to a "chain of transmission," i.e., a literary or especially mystical genealogy; but in poetry silsilas also refer to the "chains" made of the beloved's tresses-thus the "chain" of cultural genealogy is being refreshed by means of the perfumed scent of the very "chains" that the beloved uses to trap lovers like Majnun and drive mad.

89. Quoted (with slightly altered translation) in Mukhia (1999: 872).

90. Salih Kambuh (1967-72 [III]: 305-38).

91. Sarkhwush (1964: 1).

92. All four verses are quoted here as translated in Losensky (1998: 199) (the Persian texts, from which I have inserted the transliterated phrases, appear on 355-56).

93. Thackston (1994: 87). For similar associations of Sa'ib with sabk-i hindī, see, for instance, Barzegar (2000: 200); Yarshater (1988: 272); Robinson (1999: 275); Aini, Farhadi, and Habib (2003: 710).

94. For details on Sa'ib's life and poetic career, see, for instance, M. Lutfur Rahman (1970: 135-41); Losensky (2004).

95. Sa’ib Tabrizi, Bayāz-i Șā'ib, MS, Oriental Manuscript Library and Research Institute, Hyderabad, \#6170 (dawāwīn \#344) (formerly housed in the Asifiya Library).

96. Sa'ib Tabrizi, Bayāz-i Șā'ib, MS Oriental Manuscript Library and Research Instituted, \#6170 (dawāwìn \#344), fol. 193a (185a, according to the numbers penciled in the margin). The couplet in question corresponds to $D B, 47.2$.

97. On these and other aspects of Nik Rai's career and historical milieu, see Alam and Subrahmanyam (2004).

98. Arzu quoted in 'Abdullah (1977c: 134).

99. Moazzam Siddiqi, for instance, describes Bedil as "the foremost representative of the later phase of the 'Indian style"' (1989).

100. Some of my colleagues will no doubt object here, asking how I could ignore the clear gestures toward Indic philosophical traditions in Bedil's oeuvre. These clearly reflect "Indianization," do they not? In response, I would simply say that one can acknowledge these fascinating aspects of Bedil's thought without being beholden to the essentialism of the sabk-i hindi thesis. For instance, Walih Daghistani, who, as an acolyte of Arzu's great rival Shaikh 'Ali Hazin, was no stranger to eighteenth-century Indo-Iranian cultural rivalry, clearly differentiated between Bedil's sometimes quirky linguistic usages and the assessment of his poetic genius, saying in Riyāz al-Shu'arā: "Although many of his poems do not conform to the standard idiom of 'Ajam, and he has introduced strange expressions into the Persian language, nevertheless he has composed many great and outstanding verses, and the maturity of his soul was evident to anyone who conversed with him" (Walih Daghistani 2001: 133).

101. I am grateful to Hasan Siddiqui for pointing the possible connection with the

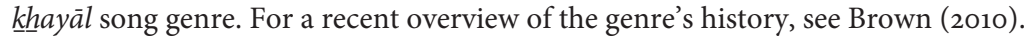

102. Nahawandi (2002: 220).

103. Nahawandi (2002: 722).

104. Nahawandi (2002: 524-25).

105. Munir Lahori (1977: 3).

106. Munir Lahori (1977: 4-5). 
107. It is true that Mas'ud Sa'd Salman was originally from Hamadan (in present-day northwestern Iran), but, especially because he spent the bulk of his life and poetic career in Lahore, he is considered by most modern commentators to have been an Indian poet, and, as we have noted above, a forerunner of the sabk-i hindī. For further details on his life, career, and poetry, see Sunil Sharma (2000); Alam (2003: 135-47).

108. Munir Lahori (1977: 6).

109. Munir Lahori (1977: 7).

110. Munir Lahori (1977: 9).

111. Munir Lahori (1977: 25).

112. Tavakoli-Targhi (2001b: 26-28); see also Alam (2003: 182-86).

113. Cf. Munir Lahori (1977: 4, 6, 7, 15, 23, 24, and 25).

114. Munir Lahori (1977: 26-29).

115. Arzu (1977).

116. Arzu (1977: 33).

117. Arzu (1977: 59). This critique of Munir's anti-tāza rhetoric was taken up even more systematically in another treatise that Arzu entitled Dād-i Sukhan [Poetic justice] (1974), in which Arzu took Munir to task for having joined Shaida in his feud with Muhammad Jan Qudsi. Dād-i Sukhan shows the same rigorous scholarly approach displayed in Siraj-i Munìr. (For further details, see S. M. Ikram's introduction to Arzu (1974), as well as Abdullah (1977a: 142-47).

118. Arzu (1977: 33).

119. Rypka (1968: 295-96).

120. Memon (1983).

121. M. Siddiqi (1987). Some will no doubt protest that in texts like Tanbìh al-Ghäfilin [A reprimand to the ignorant] Arzu was defending Indian poets against attacks from the Iranian émigré Shaikh 'Ali Hazin. Why should this not be seen as a "defense of $s a b k-i$ hind $\bar{\imath}$ "? I would reply, in the first instance, that the term sabk-i hindi was not known to Arzu, so we should not put words in his mouth. Second, there is a difference between Arzu defending Indian poets' basic linguistic-literary competence and defending Indophilia + linguistic Indianization + poetic complexity, or however one wants to define sabk-i hindī. Indeed, Arzu's approach in Tanbīh al- Ghäfilìn, just as in Sirāj-i Munīr and Dād-i Sukhan, was usually to draw his philological evidence from the established classical canon, not to authorize some sort of Hindi free-for-all.

122. Arberry ([1958] 1994: 425).

123. On the concept of 'connected histories,' see Subrahmanyam (1997).

124. Cf. Tavakoli-Targhi (2001a).

125. Fleischer (1992: 172).

126. E. J. W. Gibb, History of Ottoman Poetry, quoted in Browne ([1924] 1959 [IV]: 163).

127. Andrews and Kalpakh (2005).

128. Mirollo (1984: 5).

129. Farooqui (1967: 13); Catana (1999: 18).

130. Interestingly enough, though, mannerism too is undergoing somewhat of a favorable critical reappraisal of late, thanks no doubt to increased postmodern tolerance and respect for formal ingenuity. See, for instance, Catana (1999); Hauser (1986); Steadman (1990); Mirollo (1984); Zerner (1972). 
131. Zerner (1972: 106-7).

132. Peregrini quoted in Catana (1999: 18). Compare, for instance, the definition of îhàm given by the Central Asian literary theorist Rashid al-Din Vatvat (d. ca. 1183) in his Hadā'iq al-Sihr fì Daqā'iq al-Shi'r [A magical garden containing the subtleties of poetry]: "İhām in Persian means to create doubt. This is a literary device, also called takhyill [to make one suppose and fancy], whereby a writer [dabir $]$, in prose, or a poet, in verse, employs a word with two different meanings, one direct and immediate [qarīb] and the other remote and strange [gharīb], in such a manner that the listener, as soon as he hears that word, thinks of its direct meaning while in actuality the remote meaning is intended" (quoted in Alam 2003: 180).

133. Catana (1999: 18).

134. Peregrini quoted in Catana (1999: 19).

135. Quoted as translated in Faruqi (2004: 18 [English], 73 [Persian]).

136. Cf. Pollock (2007: 383).

137. Barzun (1961: xx).

\section{THE PERSISTENCE OF GOSSIP}

1. Faruqui $(2002,2012)$.

2. Hansen (1972: 192).

3. For details on all of these works, see, for instance, Hasrat (1982). For more recent treatments, see also T. Husain (2002); Davis (2002); Gandhi (2014).

4. See Filliozat (2003).

5. For details on Dara's Yoga-Vasishta, specifically, see Gandhi (2014). On the translation of the Upanishads, see D'Onofrio (2010); Ganeri (2011: 22-30; 2012).

6. On the general legacy of Dara's Sirr-i Akbar via Anquetil's Oupnek'hat, see, for instance, Schwab (1984); on Schopenhauer and his poodle, see, for instance, Cartwright (2010: 150-51); Durant (2005: 232).

7. For a more extensive elaboration of this point, see Tavakoli-Targhi (2003); Raj (2007); Pollock (2009); Kinra (2011b, 2015).

8. Manucci ([1907] 1981 [I]: 213-18).

9. For an overview of these and other reasons to be cautious in using Manucci as a source, see Subrahmanyam (2008).

10. Indeed, if we are to believe Manucci, she even warned Dara "to put no reliance on her husband, nor trust his soft speeches, for she knew him well, and given the occasion, he would inevitably engineer some treachery" (Manucci [1907] 2008 [I]: 255). It should be noted that Manucci's version of events has been sharply repudiated, on the basis of accounts from various other sources, by Jadunath Sarkar as idle "bazaar gossip" (e.g., in Jadunath Sarkar, [1930] 1979: 57-60). But even so, Sarkar's composite narration of the available sources makes it abundantly clear that Dara's tactical naïveté and lack of military experience were key factors in his decisive defeat at Samugarh.

11. Faruqui (2002: 298).

12. Jadunath Sarkar ([1930] 1979: 39).

13. Jadunath Sarkar ([1930] 1979: 39-40).

14. Chaitanya (1979: 46). Cf. also Chaitanya (1977: 31, quoted in B. B. Kachru [2008: 6]) ("But we must not forget that Akbar and that ill-fated son of Shah Jahan, Dara Shikoh, were 
great patrons of Sanskrit"); D. Smith (2003: 39) ("the ill-fated Dara Shukoh, who shared the admiration for Hindu culture of his great-grandfather, the Emperor Akbar"); Rawlinson (1937: 31) ("But the great Emperor Akbar, and after him that brilliant but ill-fated Prince, Dārā Shikoh, were both keenly interested in Hinduism”); Schimmel and Welch (1983: 9) ("Ill-fated Prince Dara Shikoh ... who was so spiritually akin to Akbar"); Fisher (2007: 116) ("[the] ill-fated Mughal imperial prince, Dara Shukoh ... was hospitable to Europeans and sympathetic to Hindus"); Johnston (1946: 102) (“Akbar's noblest and most ill-fated descendant, Dara Shukoh"); Hermansen and Lawrence (2000: 161) ("Let us consider the ill-fated older son of Shah Jahan, Dara Shikoh"); etc.

15. See above, chapter 1. For an even fuller treatment, see Kinra (2013).

16. For general discussions, see, for instance, Alam and Subrahmanyam (1998); Eaton (2005: 155-202); Asher and Talbot (2006: 225-86); Faruqui (2009, 2013). For a critique of the historiography surrounding Aurangzeb's supposed "ban on music," see Brown (2007); on the political calculations involved in Aurangzeb's use of the "weapon of heresy" against Dara, see Davis (2002); and on the culture and politics of Mughal princely competition generally, see Faruqui (2012).

17. For a detailed examination of these charges as described in contemporary sources, see Davis (2002).

18. For details, see Kinra (2009).

19. For some suggestive analyses of such phenomena, see, for instance, Naim (2004); Mukhia (2004: 113-71); F. Hasan (2005); Behl (2005).

20. "Islamic Arts: Indian Literature in Persian," Encyclopedia Britannica online edition, accessed July 10, 2012.

21. Kinra (2009).

22. For details, see 'Inayat Khan (1990: 501-4).

23. 'Inayat Khan (1990: 503); Salih Kambuh (1967-72 [III]: 148).

24. Gosht-i Bābā Lāl Dayāl hamrāh-i Shāhzāda Dārā Shukoh, MS, Aligarh Muslim University Azad Library, Jawahir Museum Collection, \#70, fol. 1 b.

25. I am grateful to Christopher Minkowski for drawing my attention to the Sanskrit version, an undated manuscript of which is housed in the City Palace Museum, Jaipur.

26. For details on all of these Qandahar campaigns, and their important political ramifications, see M. Faruqui (2002: 292-98).

27. Massignon (2003).

28. Sujan Rai Bhandari (aka Batalavi), Kh hulāṣat al-Tawārīknh (Bhandari 1918: 68-69). I am very grateful to Muzaffar Alam for drawing this passage to my attention. For further details on Sujan Rai, see Alam and Subrahmanyam (2010: esp. 398-406).

29. Cf. Alam (2004: 81-114).

30. Quoted in Davis (2002: 55).

31. Gosht-i Bābā Lāl Dayāl hamrāh-i Shāhzāda Dārā Shukoh, MS, Aligarh Muslim University Azad Library, Jawahir Museum Collection, \#70, fol. 6b.

32. This exchange is notably absent from Massignon's version of the dialogues, but is there in Gosht-i Bābā Lāl Dayāl hamrāh-i Shāhzāda Dārā Shukoh, MS, Aligarh Muslim University Azad Library, Jawahir Museum Collection, \#70, fol. 2 a.

33. A Volume of Miscellaneous Extracts, MS, British Library, Or. 1883. Cf. Rieu (1879-83 [III]: 1033-34). The Sawāl-o-Jawāb-i Dārā Shukoh wa Bābā Lāl appears on fols. (169b-175a). 
34. Here I have used the text in Sarkhwush, Kalimāt al-Shu'arā, Aligarh Muslim University Azad Library, University Collection \#95 (Farsiya Akhbar), fol. 8a-b. Compare also the modern printed edition, which has some minor variations (Sarkhwush 1964: 18).

35. There is one with the refrain āwarda-ìm (\#287 in Farooqui's 1967 edition), but that is the closest potential match.

36. Khusrau (1972: 142, 363).

37. Quoted as translated in Alam (2004: 178).

38. Quoted as translated in Alam (2004: 138).

39. S. Ansari (1961: 278).

40. S. Ansari (1961: 215).

41. Russell and Islam ([1969] 1998: 171).

42. Mukhia (1999).

43. Quoted in Russell and Islam ([1969] 1998: 171-72) (translations slightly modified).

44. Kalimāt al-Shu'arā, MS, Azad Library, Aligarh Muslim University, Aligarh, University Collection \#95 (Farsiya Akhbar), fol. 8a-8b. Cf. Sarkhwush (1964: 18-19). Muhammad 'Ali Mahir, a prominent poet himself, was Sarkhwush's mentor (ustād); and Sarkhwush himself was in turn the ustād of Brindaban Das Khwushgu (author of Safina-i kh $\underline{h} w \bar{u} s h g \bar{u})$ and Bhupat Rai Bigham Bairagi, whom we will encounter later in this chapter. For details, see Naqvi (1964: 210-12).

45. Indeed, in some manuscripts of Kalimāt al-Shu'arā Sarkhwush explains further that he himself was once the victim of such "accidental plagiarism" (tawārud) when another poet named Mir Hashmati began reciting a verse very similar to one of his own in public. The unlikely coincidence was brought to his attention by a friend, none other than the renowned poet Mirza Bedil, but Sarkhwush assures his readers that he was genteel enough to shrug it off as "probably just a case of tawārud" (Sarkhwush 1964: 19 n.). No doubt, however, this is why he was so sensitive on the subject.

46. Lodi (1998: 122-23). Cf. Sher Khan Lodi, Mir'āt al-Khhayāl, MS, British Library, Or. 231, fol. 92a-92b, and MS, Azad Library, Aligarh Muslim University, Aligarh, Zakhira-i Ehsan Collection \#920/3, fol. 38a-38b.

47. Hermansen and Lawrence (2000).

48. For details, see Alam (2003: 165-66); 'Abdullah (1992).

49. For details on Mukhlis's commercial, cultural, and political career, see, for instance, 'Abdullah (1992: 150-68); Alam and Subrahmanyam (1996); Phukan (200ob); James (2007).

50. For available details on Ikhlas's life, see Wahid Qureshi's Urdu introduction to Hamīsha Bahār (Ikhlas 1973: 22-52); Naqvi (1964: 229-30).

51. Cf. W. Qureshi's introduction to Ikhlas (1973: 19-20).

52. This translation is based on my own collation of the Persian text as it appears in MS, Azad Library, Aligarh Muslim University, University Collection \#181, fols. 17a-18a, and W. Qureshi's printed edition (Ikhlas 1973: 41-42).

53. Ikhlas, following Salih, is using a pun here on the word $\bar{a}^{\prime} \bar{i}$ ("institutes" or, perhaps better here, "precepts" or "principles"), and the whole sentence plays on the notion that Chandar Bhan is the successor to Abu al-Fazl's stylistic mastery: "In the $\overline{\boldsymbol{a}} \boldsymbol{i} \boldsymbol{i}$ of $\boldsymbol{i n s h} \bar{a}$ ' he is the follower of the arbāb-i fazl Shaikh Abu al-Fazl”" (whose most famous book is the $\bar{A}$ 'ìn-i Akbari).

54. Bhupat Rai Bigham Bairagi was another well-known poet of the period and was, as noted above, Sarkhwush's own pupil. 
55. I believe the implication is: "If he wanted to flirt with me he should have come himself instead of sending such a handsome young man, with whom I might fall in love instead of him."

56. For more complete biographical details on Walih Daghistani's fascinating life story, see, for instance, Naqvi (1964: 293-310); Bland (1848: 143-47); Storey (1953: 830-33).

57. Walih Daghistani (2001: 133-34).

58. For details of Walih's sources, see, for instance, Naqvi (1964: 304); Bland (1848: $144,147)$.

59. Losensky (1998: 45).

6o. Losensky (1998: 45).

61. Losensky (1998: 45-46).

62. For instance, Farooqui (1967: 56-57).

63. Shaikh Ahmad 'Ali Hashimi Sandelvi, Maknkzan al-Gharā'ib, MS, Habib Ganj Collection \#51/6-5/(3-2-1), vol. 1, fol. 59, Azad Library, Aligarh Muslim University, Aligarh.

64. For instance, where Lodi said that when Chandar Bhan retired to Banaras he "busied himself there with his own [i.e., 'Hindu'] ways and customs” (ba rāh-o-rasm-i khwwesh mashgh ūl mībūd) (Lodi 1998: 123), Sandelvi states much more plainly, "He went to the city of Banaras and became a hermit after the manner of the Hindus" (dar shahr-i banāras batarz-i hinduwān gosha-gìr gashta). It's a relatively minor change, obviously, but it shows that Sandelvi was not just mindlessly parroting Lodi's text but in fact actively trying to gloss it in the process.

65. 'Ashiqi Azimabadi (1981).

66. 'Ashiqi Azimabadi (1981: 256-61).

67. Kinra (2009).

68. See, for instance, Lelyveld (1993); Sengupta (1994); King (1994); Dalmia (1997); Faruqi (1998, 2001); Orsini (2002).

69. Brahman (2012: 216).

70. Kaifi Dihlavi (1942: 59).

71. Kaifi (1942: 24-25).

72. Lala (1908: 574-75).

73. B. Singh (2002).

74. Faruqi (1994: 82-83).

75. Rao and Shulman (1998: 4).

76. The tablet actually uses a minor variant, with the second line reading " $b a-k a$ 'ba raftam wa bäz-ash barahman āwardam" (I went to Mecca, and brought it back a Brahman).

77. Schimmel (1975: 414); see also Hermansen and Lawrence (2000: 153).

\section{CONCLUSION}

1. Friedman (2007). (“Akbar wasn't just tolerant. He was embracing of other faiths and ideas, which is why his empire was probably the most powerful in Indian history. Pakistan, which has as much human talent as India, could use an Akbar. Ditto the Arab world.")

2. For an exhaustive critique, see Subrahmanyam (1992b) and the introductions to Alam and Subrahmanyam $(1998,2011)$. 
3. Indeed, the idea that culture might have been at all relevant to Mughal history seems anathema to Habib, as he reiterates in the preface to the second edition: "The reader would find that I do not engage in debates with critics on such broad matters as the nature of the state (in respect of which since the early 1960s fashion has shifted from 'Oriental Despotism' to 'segmentary state' and 'ritual kingship'), or the Price Revolution (on whose possible occurrence in India the first edition had touched upon), or the agrarian factors behind the decline of the Mughal empire (dealt with in Chapter IX). I have thought it best to use the space available to me mainly for presenting the further evidence that I have gathered and letting it speak for itself." This posture might explain, at least in part, why Habib remained quite unwilling to give up on the colonial archive: "In the preface to the first edition [1963], I especially acknowledged my debt to W. H. Moreland and P. Saran, major precursors in the field. My consciousness of the debt to them and to others like H. M. Elliot, S. H. Hodivala, Jadunath Sarkar and Ibn Hasan, has only grown with time" (Habib 1999: xi).

4. See, e.g., Athar Ali (1966); Bedi (1985); Joshi (1985); A. Husain (1999); Anwar (2001).

5. Athar Ali (1985: 294).

6. Athar Ali (1985: x).

7. Anwar (2001: 16).

8. Cf. Chakrabarty (2011a; 2011b: 673-75; 2015).

9. Jadunath Sarkar ([1920] 1952: 216).

10. Jadunath Sarkar ([1920] 1952: 216-18).

11. Jadunath Sarkar ([1920] 1952: 219).

12. Jadunath Sarkar ([1920] 1952: 218-19). 



\section{B I B L I O G R A P H Y}

'Abdullah, Sayyid Muhammad. 1928. "Chandar Bhān Brahman.” Oriental College Magazine 4 (4): 2-12.

———. 1977a. "Dād-i Suknhan.” In 'Abdullah 1977b: 142-47.

-——. 1977b. Fārsī Zubān-o-Adab: Majmū'a-yi Maqālāt. Lahore: Majlis-i Taraqqi-yi Adab.

———. 1977c. "Sabk-i Hindī aur Isti'māl-i Hind.” In 'Abdullah 1977b: 133-34.

———. 1977d. “Tāza-Gū’ī: Ek Adabī Tahrīk.” In “Abdullah 1977b: 114-26.

- - . 1992. Adabiyāt-i Fārsī meṇ Hindu’oṇ kā Hiṣṣa. New Delhi: Anjuman-i Taraqqi-yi Urdu.

Abdur Rashid, Shaikh. 1949. "Shahjehan and the Rana of Udaipur." In Islamic Research Association Miscellany, vol. 1, 1948, edited by Asaf Ali Asghar Fyzee, 93-98. London: Oxford University Press.

Ahmad, Aziz. 1976. "Șafawid Poets and India.” Iran 14:117-32.

Ahmad, Khwajah Nizamuddin. [1927] 1973. The Tabaqāt-i Akbarī of Khwājah Nizāmuddìn Ahmad (A History of India from the Early Musalman Invasions to the Thirty-Sixth Year of the Reign of Akbar). 3 vols. Translated by Brajendranath De. Calcutta: Asiatic Society. Ahmed (Asif), Manan. 2007. "The Outsider." Chapati Mystery (blog), June 15.

-_—. 2013. "A Demon with Ruby Eyes." Medieval History Journal 16 (2): 1-35.

Aini, K., R. Farhadi, and Irfan Habib. 2003. "Literature in Persian and Other Indo-Iranian Languages." In History of Civilizations of Central Asia, vol. 5, Development in Contrast: From the Sixteenth to the Mid-nineteenth Century, edited by Chahryar Adle and Irfan Habib, 688-706. Paris: UNESCO.

A $\underline{k} h b a \bar{r} a \bar{t}-i$ Darbār-i Mu'allá. MS, RAS Persian, Royal Asiatic Society of Great Britain and Ireland, London. 
Alam, Muzaffar. 1986. The Crisis of Empire in Mughal North India: Awadh and the Punjab, 1707-1748. New Delhi: Oxford University Press.

- - . 1998. "The Pursuit of Persian: Language in Mughal Politics." Modern Asian Studies 32 (2): 317-49.

- - . 2000. "Akhlāqī Norms and Mughal Governance." In The Making of Indo-Persian Culture: Indian and French Studies, edited by Muzaffar Alam, Francoise "Nalini" Delvoye, and Marc Gaborieau, 67-95. New Delhi: Manohar; Centre de Sciences Humaines.

- - . 2003. "The Culture and Politics of Persian in Precolonial Hindustan." In Literary Cultures in History: Reconstructions from South Asia, edited by Sheldon Pollock, 131-98. Berkeley: University of California Press.

- - . 2004. The Languages of Political Islam in India, c. 1200-180o. Delhi: Permanent Black.

- - . 2009. "The Mughals, the Sufi Shaikhs, and the Formation of the Akbari Dispensation." Modern Asian Studies 43 (1): 135-74.

- - - 2011. "The Debate Within: A Sufi Critique of Religious Law, Tasawwuf, and Politics in Mughal India." South Asian History and Culture 2 (2): 138-59.

- - . 2012. "Strategy and Imagination in a Mughal Sufi Story of Creation." Indian Economic and Social History Review 49 (2): 151-95.

Alam, Muzaffar, and Sanjay Subrahmanyam, 1996. "Discovering the Familiar: Notes on the Travel-Account of Anand Ram Mukhlis, 1745." South Asia Research 16 (2): $131-54$.

- - , eds. 1998. The Mughal State, 1526-1750. Delhi: Oxford University Press.

- - 2004. "The Making of a Munshi." Comparative Studies in South Asia, Africa, and the Middle East 24 (2): 61-72.

- - . 2005. "The Afterlife of a Mughal Masnavĩ: The Tale of Nal and Daman in Urdu and Persian.” In A Wilderness of Possibilities: Urdu Studies in Transnational Perspective, edited by Kathryn Hansen and David Lelyveld, 46-73. New Delhi: Oxford University Press.

- - . 2006a. "Envisioning Power: The Political Thought of a Late Eighteenth-Century Mughal Prince." Indian Economic and Social History Review 43 (2): 131-61.

- - . 2006b. "Love, Passion, and Reason in Faizi's Nal-Daman." In Love in South Asia: A Cultural History, edited by Francesca Orsini, 109-41. Cambridge: Cambridge University Press.

- - . 2007. Indo-Persian Travels in the Age of Discoveries, 1400-180o. Cambridge: Cambridge University Press.

- - . 2009. "Frank Disputations: Catholics and Muslims in the Court of Jahangir (160811)." Indian Economic and Social History Review 46 (4): 457-511.

- - 2010. "Witnesses and Agents of Empire: Eighteenth-Century Historiography and the World of the Mughal Munshī." Journal of the Economic and Social History of the Orient 53:393-423.

- - - 2011. Writing the Mughal World: Studies on Culture and Politics. New York: Columbia University Press.

Ali, Muhammad. 1929. "Urfi of Shiraz." Islamic Culture 3:96-125.

al-Khalili, Jim. 2010. The House of Wisdom: How Arabic Science Saved Ancient Knowledge and Gave Us the Renaissance. New York: Penguin Press, 2011. 
Andrews, Walter G., and Mehmet Kalpakh. 2005. The Age of Beloveds: Love and the Beloved in Early-Modern Ottoman and European Culture and Society. Durham, NC: Duke University Press.

Anooshahr, Ali. 2008. “The King Who Would Be Man: The Gender Roles of the Warrior King in Early Mughal History." Journal of the Royal Asiatic Society of Great Britain \& Ireland 18 (3): 327-40.

- - 2009. The Ghazi Sultans and the Frontiers of Islam: A Comparative Study of the Late Medieval and Early Modern Periods. London: Routledge.

Ansari, Muhammad Wali al-Haqq. 1974. 'Urfi Shīrāzī. Lucknow: Milne ke pate, Dārulīmān. Ansari, Shareefunnisa Begum. 1961. Hayāt-o-Taṣnīfāt-i Mirzā Abū Țālib Kalīm Hamadānī, Malik al-Shu'arā-yi Darbār-i Shahinshāh Shāh Jahān. Hyderabad: Matba' Ibrahimiya. Anwar, Firdos. 2001. Nobility under the Mughals, 1628-1658. New Delhi: Manohar.

Aquil, Raziuddin. 2007. Sufism, Culture, and Politics: Afghans and Islam in Medieval North India. New Delhi: Oxford University Press.

Arberry, A. J. 1950. Sufism: An Account of the Mystics of Islam. London: George Allen and Unwin.

- - . [1958] 1994. Classical Persian Literature. Richmond, Surrey: Curzon Press.

'Aruzi, Nizami. 1921. Revised Translation of the Chahár Maqála ("Four Discourses") of Nizámí-i-'Arúdí of Samarqand, Followed by an Abridged Translation of Mírzá Muhammad's Notes to the Persian Text. Translated and edited by Edward G. Browne. London: Luzac; Cambridge: Cambridge University Press and E. J. W. Gibb Memorial Trust.

Arzu, Siraj al-Din 'Ali Khan. 1974. Dād-i Suknhan. Edited by S. M. Ikram. Rawalpindi: Markaz-i Tahqiqat-i Farsi-yi Iran-o-Pakistan.

———. 1977. Sirāj-i Munīr. Edited by S. M. Ikram. Islamabad: Markaz-i Tahqīqāt-i Fārsī-yi Iran-o-Pakistan.

Asher, Catherine B. 1992. Architecture of Mughal India. New Cambridge History of India 1, pt. 4. Cambridge: Cambridge University Press.

- - . 2009. "Pilgrimage to the Shrines in Ajmer." In Islam in South Asia in Practice, edited by Barbara D. Metcalf, 77-86. Princeton, NJ: Princeton University Press.

Asher, Catherine B., and Cynthia Talbot. 2006. India before Europe. Cambridge: Cambridge University Press.

'Ashiqi Azimabadi, Aqa Husain Quli Khan. 1981. Tazkira Nishtar-i 'Ishq. Edited by Asghar Janfida. Dushanbah: Nashriyat-i Danish.

Athar Ali, M. 1966. The Mughal Nobility under Aurangzeb. Aligarh: Aligarh Muslim University, Department of History.

- - . 1968. "The Objectives behind the Mughal Expedition in Balkh and Badakhshan, 1646-7." In Indian History Congress: Proceedings of the Twenty-Ninth Session, Patiala1967, Part I, 162-67. Patna: Indian History Congress.

- - . 1972. "Sidelights into Ideological and Religious Attitudes in the Punjab during the Seventeenth Century." In Medieval India: A Miscellany, vol. 2, 187-94. London: Asia Publishing House; Center for Advanced Study in History, Aligarh Muslim University.

- - . 1985. The Apparatus of Empire: Awards of Ranks, Offices and Titles to the Mughal Nobility (1574-1658). Delhi: Oxford University Press; Centre for Advanced Study in History, Aligarh Muslim University. 
. 1992. “Translations of Sanskrit Works at Akbar's Court.” Social Scientist 20 (9/10): $38-45$.

- - . [1980] 2006. "Sulh-i Kul and the Religious Ideas of Akbar." In Mughal India: Studies in Polity, Ideas, Society, and Culture, 158-72. New Delhi: Oxford University Press.

Aurangzeb 'Alamgir. 1880. Ruqa'āt-i 'Ālamgìrī. Kanpur: Nawal Kishore Press.

Azad, Muhammad Husain. 2001. Āb-e Hayāt: Shaping the Canon of Urdu Poetry. Translated by Frances Pritchett, with Shamsur Rahman Faruqi. New Delhi: Oxford University Press.

Babayan, Kathryn. 2002. Mystics, Monarchs, and Messiahs: Cultural Landscapes of Early Modern Iran. Cambridge, MA: Harvard University Press.

Babur, Zahir al-Din Muhammad. 2002. The Baburnama: Memoirs of Babur, Prince and Emperor. Translated, edited, and annotated by Wheeler M. Thackston. New York: Modern Library.

Bahar, Muhammad Taqi. 1942. Sabk-Shināsī: Yā, Tārīknh-i Tațawwur-i Nașr-i Fārsī. 3 vols. Tehran: Chapkhanah-yi Khẉudkār.

-_—. 1970-71. "Ṣā’ib va Shewa-yi ù." Yaghmā 23 (5): 264-65.

- - 1972. "Bāzgasht-i Adabī.” In Bahār wa Adab-i Fārsī: Majmū'a-i Yak-șad Maqāla az Malik al-Shu'arā Bahār, vol. 1, edited by Muhammad Gulban, 43-66. Tehran: Shirkat-i Sahami-yi Kitab-ha-yi Jibi.

Balabanlilar, Lisa. 2007. "Lords of the Auspicious Conjunction: Turco-Mongol Imperial Identity on the Subcontinent." Journal of World History 18 (1): 1-39.

- - 2 2012. Imperial Identity in the Mughal Empire: Memory and Dynastic Politics in Early Modern South and Central Asia. London: I. B. Tauris.

Balfour, Edward. 1885. The Cyclopeedia of India and of Eastern and Southern Asia, Commercial, Industrial, and Scientific; Products of the Mineral, Vegetable, and Animal Kingdoms, Useful Arts and Manufactures. 3rd edition. 3 vols. London: Bernard Quaritch.

Banarasidas. 2005. Half a Tale: A Study in the Interrelationship between Autobiography and History. Edited and translated by Mukund Lath. New Delhi: Rupa.

- - . 2009. Ardhakathanak (A Half a Story). Edited with parallel translation by Rohini Chowdhury. New Delhi: Penguin Classics.

Bannet, Eve Taylor. 2005. Empire of Letters: Letter Manuals and Transatlantic Correspondence, 1688-1820. Cambridge: Cambridge University Press.

Barelwi, Jigar. 1943. Yādgār-i Raftagān. Allahabad: Matbu'a Matba' Anwar.

Barq, Ahsan Karim. 1986. 'Urfì: Shā'irī wa Uslūb. Patna: Jami Publications.

Barzegar, Karim Najafi. 200o. Mughal-Iranian Relations during Sixteenth Century. Delhi: Indian Bibliographies Bureau.

Barzun, Jacques. 1961. Classic, Romantic, and Modern. 2nd, rev. ed. Garden City, NY: Anchor Books.

Bayly, C. A. 1996. Empire and Information: Intelligence Gathering and Social Communication in India, 1780-1870. Cambridge: Cambridge University Press.

Bedi, P. S. 1985. The Mughal Nobility under Akbar. Jalandhar: ABS Publications.

Bedil, 'Abd al-Qadir. Bayāz-i Bedil. MS, British Library, 2 vols., Add. 16,802 and Add. 16,803 .

Begam, Qamar Jahan. 1991[?]. Princess Jahān Ārā Begam: Her Life and Works. Karachi: S. M. Hamid 'Ali. 
Begley, W. E., and Z. A. Desai. 1989. Taj Mahal: The Illumined Tomb (An Anthology of Seventeenth-Century Mughal and European Documentary Sources). Cambridge, MA: Aga Khan Program for Islamic Architecture.

Behl, Aditya. 2005. "Poet of the Bazaars: Nazīir Akbarābādī, 1735-1830." In A Wilderness of Possibilities: Urdu Studies in Transnational Perspective, edited by Kathryn Hansen and David Lelyveld, 192-222. New Delhi: Oxford University Press.

- - . 2012a. Introduction to The Magic Doe: Qutban Suhravardī's Mirigāvatī, by Qutban Suhravardi, 9-38. Translated by Aditya Behl. Edited by Wendy Doniger. Oxford: Oxford University Press.

- - 2012b. Love's Subtle Magic: An Indian Islamic Literary Tradition, 1379-1545. Oxford: Oxford University Press.

Behl, Aditya, and Simon Weightman. 20oo. Introduction to Madhumālatī: An Indian Sufi Romance, by Mir Sayyid Manjhan Shațtāini Rājgīrī, xi-xlvi. Translated by Aditya Behl and Simon Weightman, with Shyam Manohar Pandey. Oxford: Oxford University Press.

Berg, Temma. 2006. The Lives and Letters of an Eighteenth-Century Circle of Acquaintance. Aldershot, UK: Ashgate.

Bernier, Francois. [1891] 1996. Travels in the Mogul Empire, 1656-1668. "Revised and improved edition based upon Irving Brock's translation." Edited by Archibald Constable. New Delhi: Asian Educational Services.

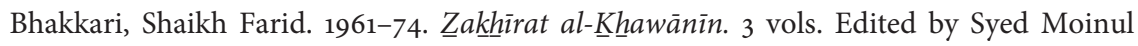
Haq. Karachi: Pakistan Historical Society.

- - . 1993. The Dhakirat ul-Khawanin of Shaikh Farid Bhakkari (A Biographical Dictionary of Mughal Noblemen). Part 1. Translated by Ziyaud-Din A. Desai. Delhi: Idarah-i Adabiyat-i Delli.

- - . 2003. Nobility under the Great Mughals: Based on Dhakhìratul Khawānin of Shaikh Farìd Bhakkari. Translated by Z. A. Desai. New Delhi: Sundeep Prakashan. Despite the different names, this is a combined volume containing Parts 2 and 3 of the previous entry.

Bhandari, Sujan Rai. 1918. The Khulasatu-t-Tawarikh, by Sujan Rai Bhandari of Batala. Edited by M. Zafar Hasan. Delhi: J. and Sons Press.

Blake, Stephen P. 1991. Shahjahanabad: The Sovereign City in Mughal India, 1639-1739. Cambridge: Cambridge University Press.

Bland, N. 1848. "On the Earliest Persian Biography of Poets, by Muhammad Aūfi, and Some Other Works of the Class Called Tazkirat ul-Shuārā." Journal of the Royal Asiatic Society 9:111-76.

Bokhari, Afshan. 2009. “Gendered Landscapes: Jahan Ara Begum’s (1614-1681) Patronage, Piety, and Self-Representation in 17th C. Mughal India." PhD diss., Universität Wien.

Brahman, Chandar Bhan. Chahār Chaman. MS, National Museum, New Delhi, \#3340 (55043/2217).

-——. Gosht-i Bābā Lāl Dayāl hamrāh-i Shāhzāda Dārā Shukoh. MS, Azad Library, Aligarh Muslim University, Aligarh (Jawāhir Museum Collection, \#70).

-_- Guldasta, Mausūm ba-Qawā'id al-Salțanat. MS, Azad Library, Aligarh Muslim University, Aligarh (Suleiman Collection, \#664/42). Copied in 1196 AH (1781-1782 CE).

- - - Guldasta / Qawāiid al-Salțanat. MS, Azad Library, Aligarh Muslim University, Aligarh (Suleiman Collection, \#664/44). 
-. Guldasta-yi Munshī Chandar Bhān / Guldasta az Taṣnīf-i Chandar Bhān Munshī

/ Guldasta az Tașnîf-i Chandar Bhān Brahman. MS, Azad Library, Aligarh Muslim University, Aligarh (Subhan Allah Collection, \#891'5528/20). Copied in 1146 AH (1733$1734 \mathrm{CE})$ or possibly 1126 (1714 CE).

- - - Guldasta-yi Qawā'id al-Salțanat (-i Shāh Jahān). MS, Azad Library, Aligarh Muslim University, Aligarh ('Abd al-Salam Collection, \#289/59). Copied in Bengal in 1209 AH (1794-1795 CE).

- - - Guldasta-yi Salțanat / Guldasta-i Chandar Bhān Munshī. MS, Azad Library, Aligarh Muslim University, Aligarh ('Abd al-Salam Collection, \#291/61b). Copied in $1194 \mathrm{AH}(1780 \mathrm{CE})$.

-—-. Qawā'id al-Salțanat-i Shāh Jahān. MS, Azad Library, Aligarh Muslim University, Aligarh (Habib Ganj Collection, \#56/1).

- - . Tārikh-i Rājahā-yi Dehlī-yi Hindūstān. MS, Gujarat Vidya Sabha, Ahmedabad (Main Catalog \#46).

- - 1967. Dìwān-i Brahman. Published in a single binding (separately paginated) with Ahwwāl-o-Āṣār-i Chandra Bhān Brahman wa Dīwān-i Pārsī (English title given as Chandra Bhān Brahman: Life and Works, with a Critical Edition of His Persian Dīwān), edited by Muhammad 'Abdul Hamid Farooqui. Ahmedabad: Khālid Shāhīn Fārooquī.

- - 1992. Chahār Chaman: Shahinshāh Shāh Jahān ke Darbār ke Roznāmcha Nigār, Chandar Bhān Brahman kī Fārsī Taṣnīf. Urdu translation by Sayyid Muhammad Murtazá Qadiri. Hyderabad: Chandan Printers.

- - . 2005. Munsha'àt-i Brahman. Edited by S. H. Qasemi and Waqarul Hasan Siddiqi. Rampur: Raza Library.

- - 2007. Chahār Chaman. Edited by Seyed Mohammad Yunus Ja'fery. New Delhi: Centre of Persian Research; Office of the Cultural Counsellor, Islamic Republic of Iran. - - 2008. Dīwān-i-Brahman az Rā’i-yi Rāyān Munshī Pandit Chandar Bhān Brahman. Edited by Muhammad Amin 'Amir. Kolkata: Asiatic Society.

- - . 2012. Chandar Bhān Brahman kī Fārsī Shā'irī. Edited by Shahid Naukhez Azmi. Delhi: Educational Publishing House.

Brant, Clare. 2006. Eighteenth-Century Letters and British Culture. Basingstoke, UK: Palgrave Macmillan.

Bronner, Yigal. 2002. "What Is New and What Is Navya: Sanskrit Poetics on the Eve of Colonialism." Journal of Indian Philosophy 30 (5): 441-62.

- - 2010. Extreme Poetry: The South Asian Movement of Simultaneous Narration. New York: Columbia University Press.

Bronner, Yigal, and David Shulman. 2006. “'A Cloud Turned Goose': Sanskrit in the Vernacular Millenium.” Indian Economic and Social History Review 43 (1): 1-30.

Bronner, Yigal, and Gary Tubb. 2008. "Vastutas tu: Methodology and the New School of Sanskrit Poetics." Journal of Indian Philosophy 36 (5-6): 619-32.

Brown, Katherine Butler. 2007. "Did Aurangzeb Ban Music? Questions for the Historiography of His Reign." Modern Asian Studies 41 (1): 77-120.

- - 2010. "The Origins and Early Development of Khayal." In Hindustani Music: Thirteenth to Twentieth Centuries, edited by Joep Bor, Francoise "Nalini" Delvoye, Jane Harvey, and Emmie TeNijenhuis, 159-91. New Delhi: Manohar. 
Browne, Edward Granville. [1924] 1959. A Literary History of Persia. 4 vols. Cambridge: Cambridge University Press.

Bruijn, Thomas de. 2010. "Dialogism in a Medieval Genre: The Case of the Awadhi Epics." In Before the Divide: Hindi and Urdu Literary Culture, edited by Francesca Orsini, 121-41. New Delhi: Orient Blackswan.

Busch, Allison. 2010a. "Hidden in Plain View: Brajbhasha Poets at the Mughal Court." Modern Asian Studies 44 (2): 267-309.

- - 2010b. "Riti and Register: Lexical Variation in Courtly Braj Bhasha Texts." In Before the Divide: Hindi and Urdu Literary Culture, edited by Francesca Orsini, 84-120. New Delhi: Orient Blackswan.

- - . 2011. Poetry of Kings: The Classical Hindi Literature of Mughal India. Oxford: Oxford University Press.

Cartwright, David E. 2010. Schopenhauer: A Biography. Cambridge: Cambridge University Press.

Catana, Leo. 1999. Vico and Literary Mannerism: A Study in the Early Vico and His Idea of Rhetoric and Ingenuity. New York: Peter Lang.

Chaghtai, Muhammad 'Abdullah. 1981. Tārīkh-i Amākin-i Lahaur. Lahore: Kitābkhāna-yi Nauras; Copy Book Shop, Urdu Bazaar.

Chaitanya, Krishna. 1977. A New History of Sanskrit Literature. New Delhi: Manohar Book Service.

- - 1979. A History of Indian Painting: Manuscript, Moghul, and Deccani Traditions. New Delhi: Abhinav Publications.

Chakrabarty, Dipesh. 2011a. "The Birth of Academic Historical Writing in India." In The Oxford History of Historical Writing, vol. 4, 180o-1945, edited by Stuart Macintyre, Juan Maiguiashca, and Attila Pok, 520-36. Oxford: Oxford University Press.

-_-. 2011b. "The Muddle of Modernity." American Historical Review 116 (3): 663-75.

- - 2015. The Calling of History: Sir Jadunath Sarkar and His Empire of Truth. Chicago: University of Chicago Press.

Chandra, Satish. [1959] 2002. Parties and Politics at the Mughal Court, 1707-1740. 4th ed. New Delhi: Oxford University Press.

- - . [1999] 2005. Medieval India: From Sultanat to the Mughals-Part Two: Mughal Empire (1526-1748). 3rd, rev. ed. New Delhi: Har-Anand Publications.

- - . 2003. Essays on Medieval Indian History. New Delhi: Oxford University Press.

Chartier, Roger, Alain Boureau, and Cécile Dauphin. 1997. Correspondence: Models of Letter-Writing from the Middle Ages to the Nineteenth Century. Translated by Christopher Woodall. Cambridge: Polity Press.

Chatterjee, Kumkum. 2009. The Cultures of History in Early Modern India: Persianization and Mughal Culture in Bengal. New Delhi: Oxford University Press.

- - . 2010. "Scribal Elites in Sultanate and Mughal Bengal." Indian Economic and Social History Review 47 (4): 445-72.

Chaudhry, Nazir Ahmad. 2004. A Guide to Lahore Fort. Lahore: Sang-e-Meel Publications. Chaudhuri, Jatindra Bimal. [1942] 1981. Muslim Patronage to Sanskritic Learning. Reprint, Delhi: Idarah-i Adabiyat.

Chopra, Hira Lall. 1956. Chandra Bhan Brahmin. Delhi: Kutub-khanah-i Anjuman-i Taraqqi-i Urdu. 
Cohn, Bernard S. 1996. Colonialism and Its Forms of Knowledge: The British in India. Princeton, NJ: Princeton University Press.

Currie, P. M. 1989. The Shrine and Cult of Mu'in al-Dīn Chishtī of Ajmer. Delhi: Oxford University Press.

Dale, Stephen F. 2010. The Muslim Empires of the Ottomans, Safavids, and Mughals. Cambridge: Cambridge University Press.

Dalmia, Vasudha. 1997. The Nationalization of Hindu Traditions: Bhāratendu Hariśchandra and Nineteenth-Century Banaras. New Delhi: Oxford University Press.

Dalmia, Vasudha, and Munis D. Faruqui, eds. 2014. Religious Interactions in Mughal India. New Delhi: Oxford University Press.

Das, Kumudranjan. 1979. Raja Todar Mal. Calcutta: Saraswat Library.

Davis, Craig. 2002. "Dara Shukuh and Aurangzib: Issues of Religion and Politics and Their Impact on Indo-Muslim Society." PhD diss., Indiana University.

Daybell, James. 2012. The Material Letter in Early Modern England: Manuscript Letters and the Culture and Practices of Letter-Writing, 1512-1635. Basingstoke, UK: Palgrave Macmillan.

Desai, Z. A. 1963 . "Life and Works of Faizī." Indo-Iranica 16 (3): 1-35.

Digby, Simon. 1990. "The Sufi Shaykh and the Sultan: A Conflict of Claims to Authority in Medieval India." Iran 28: 71-81.

Dihlawi, Ghulam Muhammad Haft-Qalami. 1910. The Tadhkira-i Khushnavisan of Mawlana Ghulam Muhammad Haft-Qalami Dihlawi. Bibliotheca Indica, 187. Edited by M. Hidayet Husain. Calcutta: Baptist Mission Press.

D’Onofrio, Svevo. 2010. “A Persian Commentary to the Upaniṣads: Dārā Šikōh’s «Sirr-i Akbar»." In Muslim Cultures in the Indo-Iranian World during the Early-Modern and Modern Periods, edited by Denis Hermann and Fabrizio Speziale, 533-63. Tehran: Institut français de recherche en Iran; Berlin: Klaus Schwarz.

Durant, Will. 2005. The Story of Philosophy. New York: Simon and Schuster.

Earle, Rebecca, ed. 1999. Epistolary Selves: Letters and Letter-Writers, 1600-1945. Aldershot, UK: Ashgate.

Eaton, Richard. 1984. "The Political and Religious Authority of the Shrine of Bābā Farīd." In Moral Conduct and Authority: The Place of Adab in South Asian Islam, edited by Barbara D. Metcalf, 333-56. Berkeley: University of California Press.

- - . 2005. A Social History of the Deccan, 1300-1761: Eight Indian Lives. Cambridge: Cambridge University Press.

Ernst, Carl. 1992. Eternal Garden: Mysticism, History, and Politics at a South Asian Sufi Center. Albany: State University of New York Press.

Ernst, Carl, and Bruce B. Lawrence. 2002. Sufi Martyrs of Love: The Chishti Order in South Asia and Beyond. New York: Palgrave Macmillan.

Faizi, Abu al-Faiz. 188o. Dīwān-i Faiz̄i. Delhi: Matba'-i Iftikhar-i Dehli-yi Muhammad Ibrahim.

-—-. 1889. Nal-Daman-i Fārsī. Kanpur: Nawal Kishore Press.

-——. 1973. Inshä'-yi Faizī. Edited by A. D. Arshad. Lahore: Majlis-i Taraqqi-yi Adab.

Fanshawe, H. C. 1902. Delhi: Past and Present. London: John Murray.

Farhad, Massumeh. 2001. "Searching for the New': Later Safavid Painting and the Suz u Gawdaz (Burning and Melting) by Nau'i Khabushani." Journal of the Walters Art Museum 59:115-30. 
Farooqui, Muhammad 'Abdul Hamid. 1967. Aḥwāl-o-Āșār-i Chandra Bhān Brahman wa Dìwān-i Pārsì [Chandra Bhan Brahman: Life and works, with a critical edition of his Persian Dìwān]. Ahmedabad: Khalid Shahin Farooqui.

Faruqi, Shamsur Rahman. 1994. Shadow of a Bird in Flight: A Collection of Persian Verses. New Delhi: Rupa.

- - . 1998. "Unprivileged Power: The Strange Case of Persian (and Urdu) in NineteenthCentury India." Annual of Urdu Studies 13:3-30.

- - . 2001. Early Urdu Literary Culture and History. New Delhi: Oxford University Press.

- - . 2004. "A Stranger in the City: The Poetics of Sabk-e Hindi." Annual of Urdu Studies 19:1-93.

Faruqui, Munis D. 2002. "Princes and Power in the Mughal Empire, 1569-1657." PhD diss., Duke University.

- - . 2009. "At Empire's End: The Nizam, Hyderabad and Eighteenth-Century India." Modern Asian Studies 43 (1): 5-43.

- - . 2011. “Awrangzīb.” In Encyclopaedia of Islam, THREE, edited by Gudrun Krämer, Denis Matringe, John Nawas, and Everett Rowson. Brill Online. Accessed May 23, 2015. http://referenceworks.brillonline.com/entries/encyclopaedia-of-islam-3/awrangzibCOM_23859.

- - . 2012. The Princes of the Mughal Empire, 1504-1719. Cambridge: Cambridge University Press.

Ferrier, Joseph Pierre. 1856. Caravan Journeys and Wanderings in Persia, Afghanistan, Turkistan, and Beloochistan; with Historical Notices of the Countries Lying between Russia and India. Translated by William Jesse. Edited by H. D. Seymour. London: John Murray.

Filliozat, Jean. 2003. "Dara Shikoh's Samudrasangama." In On Becoming an Indian Muslim: French Essays on Aspects of Syncretism, edited and translated by M. Waseem, 13144. New Delhi: Oxford University Press. Originally published as "Sur les contreparties indiennes du Soufisme," Journal Asiatique 268 (1980): 259-73.

Findly, Ellison Banks. 1993. Nur Jahan: Empress of Mughal India. Oxford: Oxford University Press.

Fisher, Michael H. 2007. Visions of Mughal India: An Anthology of European Travel Writing. New York: I. B. Tauris.

Fitzclarence, George Augustus Frederick (First Earl of Munster). 1819. Journal of a Route across India, through Egypt, to England, in the Latter End of the Year 1817, and the Beginning of 1818. London: John Murray, Albemarle-Street.

Fleischer, Cornell H. 1986. Bureaucrat and Intellectual in the Ottoman Empire: The Historian Mustafa Âli (1541-160o). Princeton Studies on the Near East. Princeton, NJ: Princeton University Press.

- - - 1992. "The Lawgiver as Messiah: The Making of the Imperial Image in the Reign of Süleymân.” In Soliman le Magnifique et son Temps, edited by Gilles Veinstein, 159-77. Paris: La Documentation Française.

- - - 1994a. "Between the Lines: Realities of Scribal Life in the Sixteenth Century." In Studies in Ottoman History in Honour of Professor V. L. Ménage, edited by Colin Heywood and Colin Imber, 45-61. İstanbul: İsis Press. 
- - 1994b. "Secretaries' Dreams: Augury and Angst in the Ottoman Scribal Service." In Armağan: Festschrift Fur Andreas Tietze, edited by Ingeborg Baldauf, 77-88. Prague: Enigma.

Flood, Finbarr B. 2009. Objects of Translation: Material Culture and Medieval "HinduMuslim" Encounter. Princeton, NJ: Princeton University Press.

Flores, Jorge. 2011. "The Sea and the World of the Mutasaddi: A Profile of Port Officials from Mughal Gujarat (c.160o-1650)." Journal of the Royal Asiatic Society, ser. 3, 21 (1): 55-71.

Foltz, Richard C. 1996. "The Mughal Occupation of Balkh, 1646-1647." Journal of Islamic Studies 7 (1): 49-61.

-_- 1998. Mughal India and Central Asia. Karachi: Oxford University Press.

Friedman, Thomas. 2007. "Democracy's Root: Diversity." Op-ed. New York Times, November 11, 2007.

Gandhi, Supriya. 2014. "The Prince and the Muvahhid: Dārā Shikoh and Mughal Engagements with Vedānta." In Religious Interactions in Mughal India, edited by Vasudha Dalmia and Munis D. Faruqui, 65-101. New Delhi: Oxford University Press.

Ganeri, Jonardon. 2011. The Lost Age of Reason: Philosophy in Early Modern India, 14501700. Oxford: Oxford University Press.

- - . 2012. "Dārā Shukoh and the Transmission of the Upanișads to Islam." In Migrating Texts and Traditions, edited by William Sweet, 151-61. Ottawa: University of Ottawa Press.

Gascoigne, Bamber. [1971] 2002. A Brief History of the Great Moguls: India's Most Flamboyant Rulers. New York: Carroll and Graf.

Ghani, Abdul. 196o. Life and Works of Abdul Qadir Bedil. Lahore: Publishers United.

Ghani, Muhammad 'Abdul. 1929-30. History of Persian Language and Literature at the Mughal Court, with a Brief Survey of the Growth of Urdu Language (Bābur to Akbar). 3 vols. Allahabad: Indian Press.

- - 1941. Pre-Mughal Persian in Hindustan; A Critical Survey of the Growth of Persian Language and Literature in India from the Earliest Times to the Advent of the Mughal Rule. Allahabad: Allahabad Law Journal Press.

Gilani, "Hakim” Abu al-Fath. 1968. Ruq'āt-i Hakìm Abū al-Fath Gìlānī. Edited by Muhammad Bashir Husayn. Lahore: Idarah-i Tahqiqat-i Pakistan; Danishgah-i Panjab.

Gilroy, Amanda, and W. M. Verhoeven, eds. 200o. Epistolary Histories: Letters, Fiction, Culture. Charlottesville: University Press of Virginia.

Gladwin, Francis. 1795. The Persian Moonshee. Calcutta: Chronicle Press.

Gommans, Jos J. L. 1995. The Rise of the Indo-Afghan Empire, c. 1710-1780. Leiden: E. J. Brill.

Guha, Sumit. 2010. "Serving the Barbarian to Preserve the Dharma: Scribal Ideology and Training in Peninsular India, c.1300-180o." Indian Economic and Social History Review 47 (4): 497-525.

Habib, Irfan. [1963] 1999. Agrarian System of Mughal India, 1556-1707. 2nd, rev. ed. New Delhi: Oxford University Press.

Hadi, Nabi. 1962. Talib-i-Amuli: The Poet Laureate of Jehangir, His Life and Times. Aligarh: Aligarh Muslim University.

- - . 1978. Mughaloṇ ke Malik al-Shu'arā. Allahabad: Shabistan.

- - . 1995. Dictionary of Indo-Persian Literature. New Delhi: Indira Gandhi National Centre for the Arts. 
Hali, Altaf Husain. 1996. Yādgār-i Ghāalib. New Delhi: Ghalib Institute.

Hamadani, Muhammad Sadiq. 1990.Ṭabaqāt-i Shāhjahānī: Țabaqa-yi 'Āshira. Edited by Muhammad Aslam Khan. Delhi: Bakhsh-i Farsi-yi Danishgah-i Dihli.

Hanaway, William L. 2012. "Secretaries, Poets, and the Literary Language." In Literacy in the Persianate World: Writing and the Social Order, edited by Brian Spooner and William L. Hanaway, 95-142. Philadelphia: University of Pennsylvania Museum of Archaeology and Anthropology.

Hansen, Waldemar. 1972. The Peacock Throne: The Drama of Mogul India. New York: Holt, Rinehart and Winston.

Harkaran Das Kamboh. 1781. Inshā-yi Harkaran = The Forms of Herkern Corrected from a Variety of Manuscripts, Supplied with the Distinguishing Marks of Construction, and Translated into English: With an Index of Arabic Words Explained, and Arranged under Their Proper Roots. Persian text edited and translated by Francis Balfour. Calcutta: Charles Wilkins.

Hasan, Farhat. 2004. State and Locality in Mughal India: Power Relations in Western India, c.1572-1730. Cambridge: Cambridge University Press, 2004.

- - 2005. "Forms of Civility and Publicness in Pre-British India." In Civil Society, Public Sphere, and Citizenship: Dialogues and Perceptions, edited by Rajeev Bhargava and Helmut Reifeld, 84-105. New Delhi: Sage Publications.

Hasan, Hadi. [1951] 2008. Mughal Poetry: Its Cultural and Historical Value. Madras: Islamic Literature Society.

Hasan, S. Nurul. [1958] 2005. “The Theory of the Nurjahan 'Junta': A Critical Examination." In Religion, State, and Society in Medieval India: Collected Works of S. Nurul Hasan, edited by Satish Chandra, 120-34. New Delhi: Oxford University Press.

Hasrat, Bikrama Jit. 1982. Dārā Shikūh: Life and Works. New Delhi: Munshiram Manoharlal.

Hauser, Arnold. 1986. Mannerism: The Crisis of the Renaissance and the Origin of Modern Art. Translated by Eric Mosbacher. Cambridge, MA: Belknap Press.

Hearn, Gordon Risley. 1906. The Seven Cities of Delhi. London: W. Thacker.

Hermansen, Marcia K., and Bruce B. Lawrence. 200o. "Indo-Persian Tazkiras as Memorative Communications." In Beyond Turk and Hindu: Rethinking Religious Identities in Islamicate South Asia, edited by David Gilmartin and Bruce B. Lawrence, 149-75. Gainesville: University of Florida Press.

How, James. 2003. Epistolary Spaces: English Letter Writing from the Foundation of the Post Office to Richardson's Clarissa. Aldershot, UK: Ashgate.

Hujwiri, Pir 'Ali bin Usman. 1911. The Kashf al-Mahjúb: The Oldest Persian Treatise on Súfiism [sic] by 'Alí b. 'Uthmán al-Jullábí al-Hujwirí, Translated from the Text of the Lahore Edition, Compared with Mss. in the India Office and British Museum. Translated by Reynold A. Nicholson. Leyden: E. J. Brill; London: Luzac.

Husain, Afzal. 1999. The Nobility under Akbar and Jahāngìr: A Study of Family Groups. New Delhi: Manohar.

Husain, Iqbal. 1945. "Chandar Bhan Brahman (A Hindu Writer of Persian Prose and Verse)." Islamic Culture 19:115-22.

Husain, Tasadduq. 2002. "The Spiritual Journey of Dara Shukoh.” Social Scientist 30 $(7-8): 54-66$. 
Ibn Balkhi. 1921. The Fársnáma of Ibnu'l Balkhí. Persian text edited by Guy le Strange and R. A. Nicholson. London: Cambridge University Press; E. J. W. Gibb Memorial Trust. Ibn Hasan. 1967. The Central Structure of the Mughal Empire, and Its Practical Working up to the Year 1657. Lahore: Oxford University Press.

Ikhlas, Kishan Chand. 1973. Hamīsha Bahār (Tazkira-i Shu'arā-yi Fārsī). Edited by Wahid Qureshi. Karachi: Anjuman-i Taraqqī-yi Urdū.

Ikram, S. M. 1974. Introduction to Dād-i Sukhan, by Siraj al-Din 'Ali Khan Arzu. Rawalpindi: Markaz-i Tahqiqat-i Farsi-yi Iran-o-Pakistan.

'Inayat Khan. 1990. The Shah Jahan Nama of 'Inayat Khan, an Abridged History of the Mughal Emperor Shah Jahan, Compiled by His Royal Librarian; The Nineteenth-Century Manuscript Translation of A. R. Fuller (British Library, Add. 30,777). Edited and completed by W. A. Begley and Z. A. Desai. Delhi: Oxford University Press.

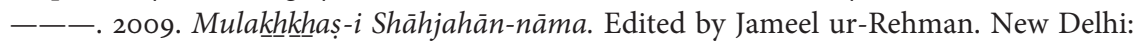
Centre for Persian Research; Office of the Cultural Counsellor, Embassy of the Islamic Republic of Iran.

Jahangir, Nur al-Din Muhammad. 1999. The Jahangirnama: Memoirs of Jahangir, Emperor of India. Translated by Wheeler M. Thackston. Washington, DC: Freer Gallery of Art and Arthur M. Sackler Gallery; New York: Oxford University Press.

- - . 2007. Tūzuk-i Jahāngīì̄. Edited by Sayyid Ahmad Khan. Aligarh: Sir Sayyid Academy, Aligarh Muslim University.

James, George McLeod. 2007. Anand Ram 'Mukhlis': His Life and Works, 1695-1758. Delhi: Henrietta Yasmin James.

Johnston, Charles. 1946. “The Heritage of the Brâhmans.” In The Crest-Jewel of Wisdom and Other Writings of Sankaracharya, translated by Charles Johnston, 93-103. Covina, CA: Theosophical University Press.

Joshi, Rita. 1985. The Afghan Nobility and the Mughals: 1526-1707. New Delhi: Vikas Publishing House.

Kachru, Braj. B. 2008. "Introduction: Languages, Contexts, and Constructs.” In Language in South Asia, edited by Braj. B. Kachru, Yamuna Kachru, and S. N. Sridhar, 1-28. Cambridge: Cambridge University Press.

Kaifi Dihlavi, Brij Mohan Dittatriyah. 1942. Kaifiyyah: Urdū Zabān kī Muḳhtașar Tārīkn aur us kī Inshä' aur Imlā' waghaira ke Muta'allaq har Qism ke Zarūrī aur Ahm Umūr se Bahs. Dilli: Anjuman-i Taraqqi-yi Urdu.

Kai Ka'us ibn Iskandar ibn Qabus, 'Unsur al-Ma'ali. 1967. Qābūs Namah, Ta'līf-i 'Unșur alMa'ālī Kaykāvūs ibn Qābūs ibn Vashamgīr ibn Ziyār. Edited by Ghulam Husayn Yusufi. 2nd ed. Majmu'a-yi Mutun-i Farsi, no. 34. Tehran: Bangah Tarjamah va-Nashr Kitab.

Kamal, Muhammad. 2006. Mulla Sadra's Transcendent Philosophy. Aldershot, UK: Ashgate. Karimi-Hakkak, Ahmad. 2002. "Beyond Translation: Interactions between English and Persian Poetry." In Iran and the Surrounding World: Interactions in Culture and Cultural Politics, edited by Nikki R. Keddie and Rudi Mathee, 36-6o. Seattle: University of Washington Press.

Kavuri-Bauer, Santhi. 2011. Monumental Matters: The Power, Subjectivity, and Space of India's Mughal Architecture. Durham, NC: Duke University Press.

Khafi Khan, aka Nizam al-Mulk Hashim 'Ali Khan. 1963. Muntaknhab al-Lubāb. 4 vols. Translated into Urdu by M. A. Faruqi. Karachi, n.p. 
Khan, Dargah Quli. 1993. Muraqqa'i Dihlī (Fārsī Matn aur Urdū Tarjuma). Edited and translated into Urdu by Khaliq Anjum. New Delhi: Anjuman-i Taraqqi-yi Urdu (Hind).

Khan, Iqtidar Alam. 1992. "Akbar's Personality Traits and World Outlook: A Critical Appraisal.” Social Scientist 20 (9-10): 16-30.

Khusrau, Amir. 1972. Kulliyāt-i Ghazaliyāt-i Khusrau. Vol. 1. Edited by Iqbal Salah al-Din. Lahore: Packages Limited.

Khusrau, Amir. 1988. Dībācha-i Dīwān-i Ghurrat al-Kamāl. Edited by Syed 'Ali Haidar. Patna: Idara-i Tahqiqat-i Arabi wa Farsi.

King, Christopher. 1994. One Language, Two Scripts: The Hindi Movement in NineteenthCentury North India. New Delhi: Oxford University Press.

Kinra, Rajeev. 2007. "Fresh Words for a Fresh World: Tàza-Gu'̀ $\bar{\imath}$ and the Poetics of Newness in Early Modern Indo-Persian Poetry." Sikh Formations 3 (2): 125-49.

- - . 2008. "Secretary-Poets in Mughal India and the Ethos of Persian: The Case of Chandar Bhān Brahman.” PhD diss., University of Chicago.

- - . 2009. "Infantilizing Bābā Dārā: The Cultural Memory of Dārā Shekuh and the Mughal Public Sphere.” Journal of Persianate Studies 2 (2): 165-93.

- - 2010. "Master and Munshì: A Brahman Secretary's Guide to Mughal Governance." Indian Economic and Social History Review 47 (4): 527-61.

- - . 2011a. "Make It Fresh: Time, Tradition, and Indo-Persian Literary Modernity." In Time, History, and the Religious Imaginary in South Asia, edited by Anne C. Murphy, 12-39. London: Routledge.

- - 2011b. "This Noble Science: Indo-Persian Comparative Philology, c. 1000-180o CE." In South Asian Texts in History: Critical Engagements with Sheldon Pollock, edited by Yigal Bronner, Whitney Cox, and Lawrence McCrea, 359-85. Ann Arbor, MI: Association of Asian Studies.

- - . 2013. "Handling Diversity with Absolute Civility: The Global Historical Legacy of Mughal Șulh-i Kull.” Medieval History Journal 16 (2): 251-95.

- - . 2015. "Cultures of Comparative Philology in the Early Modern Indo-Persian World." Philological Encounters 1: 1-63.

- - - Forthcoming. "The Learned Ideal of the Mughal Wazir: The Life and Intellectual World of Prime Minister Afzal Khan Shirazi (d. 1639)." In Secretaries and Statecraft in the Early Modern World, edited by Paul M. Dover. Edinburgh: Edinburgh University Press.

Koch, Ebba. 1988. Shah Jahan and Orpheus: The Pietre Dure Decoration and the Programme of the Throne in the Hall of Public Audiences at the Red Fort of Delhi. Graz: Akademische Druck-u. Verlagsanstalt.

- - - 1994. "Diwan-i 'Amm and Chihil Sutun: The Audience Halls of Shah Jahan." Muqarnas 11:143-65.

- - . 2006. The Complete Taj Mahal and the Riverfront Gardens of Agra. Drawings by Richard André Barraud. London: Thames and Hudson.

- - . 2008. "Mughal Agra: A Riverfront Garden City." In The City in the Islamic World, vol. 1, edited by Salma K. Jayyusi, Renata Holod, Attilio Petruccioli, and Andre Raymond, 555-88. Leiden: Brill.

- - 2009. "Jahangir as Francis Bacon's Ideal of the King as an Observer and Investigator of Nature." Journal of the Royal Asiatic Society of Great Britain and Ireland 19 (3): 293-338. 
Kulshreshtha, Jagdish Narayan. 1976. "A Critical Study of Chandra Bhan Brahman and His Works.” PhD diss., Aligarh Muslim University.

Kumar, Anil. 1986. Asaf Khan and His Times. Patna: Kashi Prasad Jayaswal Research Institute. Kumar, Sunil. 2010. The Present in Delhi's Past: Five Essays. Delhi: Three Essays Collective. Lala, Sri Ram. 1908. Kh̆humkhāna-yi Jāwed. Delhi: Nawal Kishore Press.

Lambton, A. K. S. 1962. "Justice in the Medieval Persian Theory of Kingship." Studia Islamica 17:91-119.

Lane-Poole, Stanley. 1903. Medioeval India under Mohammedan Rule, 712-1764. New York: G. P. Putnam's Sons; London: T. Fisher Unwin.

Lefèvre, Corinne. 2012. "The Majālis-i Jahāngìrī (1608-11): Dialogue and Asiatic Otherness at the Mughal Court." Journal of the Economic and Social History of the Orient $55(2-3)$ : $255-86$.

Lelyveld, David. 1993. "The Fate of Hindustani: Colonial Knowledge and the Project of a National Language." In Orientalism and the Postcolonial Predicament: Perspectives on South Asia, edited by Carol A. Breckenridge and Peter van der Veer, 189-214. Philadelphia: University of Pennsylvania Press.

Lodi, Sher 'Ali Khan. Mir'ät al-Khayāl. MS, British Library, Or. 231.

- - . Mir'āt al-Kh hayāl. MS, Azad Library, Aligarh Muslim University, Aligarh (Zakhirai Ehsan Collection \#920/3).

-—-. 1998. Tazkira Mir'at al-Khayal. Edited by Hamid Hasani, with Bihruz Safarzada. Tehran: Intisharat-i Rawzana.

Lord, Perceval Barton. 1839. "Memorandum Regarding Books and Papers of the Late Mr. Moorcroft." In Reports and Papers, Political, Geographical, \& Commercial Submitted to Government by Alexander Burnes, Lieutenant Leech, Doctor Lord, and Lieutenant Wood, Employed on Missions in the Years 1835-36-37 in Scinde, Affghanisthan, and Adjacent Countries, edited by Alexander Burnes, Robert Leech, Perceval Barton Lord, and John Wood, 156-6o. Calcutta: G. H. Huttmann, Bengal Military Orphan Press.

Losensky, Paul. 1998. Welcoming Fighānī: Imitation and Poetic Individuality in the SafavidMughal Ghazal. Costa Mesa, CA: Mazda.

- - . 2003. "'Orfi Širazi, Persian Poet of the Latter Half of the 16th Century (b. Shiraz, 1555; d. Lahore, Aug. 1591).” Encyclopedia Iranica, online ed. Accessed May 23, 2015. www.iranica.com/articles/orfi-of-shiraz.

- - . 2004. "Ṣā'eb Tabrizi, Mirzā Moḥammad 'Ali (b. Tabriz, ca. 100o/1592; d. Isfahan, 1086-87/1676), Celebrated Persian Poet of the Later Safavid Period.” Encyclopedia Iranica, online ed. Accessed May 23, 2015. www.iranica.com/articles/saeb-tabrizi.

- - . [2004] 2014. "Moḥtašam Kāšāni, Šams al-Šo'arā Kamāl-al-Din, Persian Poet of the Safavid Period (b. Kashan, 1528-29, d. Kashan, 1588)." Encyclopaedia Iranica. Accessed May 14, 2015. www.iranicaonline.org/articles/mohtasham-kashani.

-_-. 2006. "Qodsi Mašhadi, Hāji Moḥammad Jān (b. Mashad, ca. 1582; d. Lahore, 1646), Persian Poet of the First Half of the 17th Century." Encyclopaedia Iranica, online ed. Accessed May 23, 2015. www.iranicaonline.org/articles/qodsi-mashadi.

Mack, Ruth. 2009. Literary Historicity: Literature and Historical Experience in EighteenthCentury Britain. Stanford, CA: Stanford University Press.

Majma' al-Afkār. MS, Khuda Bakhsh Oriental Public Library, \#872. 
Maktūbāt-i Mukhtalifa. MS, Bombay University Library, \#82. (This is the title on the spine of the actual volume, but in the published catalog edited by Shaikh 'Abdu'l Kadir Sarfaraz [1935] this manuscript is referred to by the different title of Majmū' $a-e-\underline{K} \underline{h} u t \underline{u} t \underline{t .}$ )

Manucci, Niccolao. [1907] 1981. Storia do Mogor; or, Mogul India, 1653-1708. Translated by William Irvine. 4 vols. New Delhi: Oriental Books Reprint Corporation.

Marahravi, Muhammad Sa'id Ahmad. 1910. Umarā'-yi Hunūd: Ya'nī un Hindū Umarä' ke Hālāt jo ki Salțanat-i Mughaliya meṇ Mumtāz 'Ahdon par Sarfarāz Rahe. Kanpur: Nami Press.

Marshall, D. N. 1967. Mughals in India: A Bibliographical Survey. Vol. 1. Manuscripts. Bombay: Asia Publishing House.

Massignon, Louis. 2003. “An Experiment in Hindu-Muslim Unity: Dara Shikoh.” In On Becoming an Indian Muslim: French Essays on Aspects of Syncretism, edited by M. Waseem, 95-105. New Delhi: Oxford University Press. Originally published in Revue $d u$ Monde Musulman 63 (1926): 1-14.

McCrea, Lawrence. 2002. "Novelty of Form and Novelty of Substance in SeventeenthCentury Mimamsa." Journal of Indian Philosophy 30 (5): 481-94.

McGregor, Stuart. 2003. "The Progress of Hindi, Part 1: The Development of a Transregional Idiom." In Literary Cultures and History: Reconstructions from South Asia, edited by Sheldon Pollock, 912-57. Berkeley: University of California Press.

McWhirter, William A. 1967. "Its Beauty Veils a Mogul's Ruthless Whim.” Life, November $3,60-63$.

Mehta, J. L. [1983] 1990. Advanced Study in the History of Medieval India. Vol. 3. Medieval Indian Society and Culture. New Delhi: Sterling.

- - . 1984. Advanced Study in the History of Medieval India. Vol. 2. Mughal Empire (1526-1707). New Delhi: Sterling.

Memon, Muhammad Umar. 1983. "Abu'l Barakāt Lāhūrī, Indo-Persian Poet.” Encyclopedia Iranica, online ed. Accessed May 23, 2015. www.iranicaonline.org/articles/abulbarakat-monir-lahuri-indo-persian-poet-commonly-known-as-molla-monir-lahuri-b.

Minkowski, Christopher. 2002. "Astronomers and Their Reasons: Working Paper on Jyotihśāstra." Journal of Indian Philosophy 30 (5): 495-514.

- - . 2014. "Learned Brahmins and the Mughal Court: The Jyotișas." In Religious Interactions in Mughal India, edited by Vasudha Dalmia and Munis D. Faruqui, 102-34. New Delhi: Oxford University Press.

- - 2 2010. "Nilakantha's Mahābhārata." Seminar \#608, online ed. Special number: "The Enduring Epic: A Symposium on Some Concerns Raised in the Mahabharata." Accessed May 8, 2015. www.india-seminar.com/2010/608.htm.

Mir Khwand, Muhammad ibn Khwandshah. 1892. The Rauzat-us-Safa; or, Garden of Purity. Containing the Histories of Prophets, Kings, and Khalifs. By Muhammad bin Khvavendshah bin Mahmud, Commonly Called Mirkhond. Translated by E. Rehatsek, and Called by Him "Sacred and Profane History According to the Moslem Belief." Edited by F. F. Arbuthnot. London: Royal Asiatic Society.

Mirollo, James V. 1984. Mannerism and Renaissance Poetry: Concept, Mode, Inner Design. New Haven, CT: Yale University Press.

Mohiuddin, Momin. 1960. "Sabk-i Hindi (The Indian Style of Persian Prose), with Special Reference to Inshā'.” Indo-Iranica 13 (2): 19-30. 
1971. The Chancellery and Persian Epistolography under the Mughals, from Bábur to Sháh Jahán, 1526-1658: A Study on Inshá', Dár al-Inshá', and Munshīs Based on Original Documents. Calcutta: Iran Society.

Moin, A. Azfar. 2009. "Challenging the Mughal Emperor: The Islamic Millennium According to 'Abd al-Qadir Badayuni." In Islam in South Asia in Practice, edited by Barbara D. Metcalf, 390-402. Princeton, NJ: Princeton University Press.

- - . 2012. The Millenial Sovereign: Sacred Kingship and Sainthood in Islam. New York: Columbia University Press.

Mukherjee, Soma. 2001. Royal Mughal Ladies and Their Contributions. New Delhi: Gyan Publishing House.

Mukhia, Harbans. 1999. "The Celebration of Failure as Dissent in Urdu Ghazal." Modern Asian Studies 33 (4): 861-81.

- - . 2004. The Mughals of India. Malden, MA: Blackwell.

Munir Lahori, Abu al-Barakat. 1977. Kārnāma. Edited by S. M. Ikram. Islamabad: Markaz-i Tahqiqat-i Farsi-yi Iran-o-Pakistan.

Muqtadir, Maulavi Abdul. 1925. Catalogue of the Arabic and Persian Manuscripts in the Oriental Public Library at Bankipore. Vol. 9 (Persian Mss.), Philology and Sciences. Calcutta: Baptist Mission Press, Government of Bihar and Orissa; Patna: Superintendent, Government Printing.

Nadvi, Syed Sulaiman. 1947. "Rai Pandit Chandar Bhan Brahman.” Ma'ārif 59 (3): 215-28.

Nahawandi, 'Abd al-Baqi. 2002. Ma'āṣir-i Rahīmì: Baknhsh-i Siwum: Zindagī-nāma-hā. Edited by 'Abd al-Husain Nawa’i. Tehran: Anjuman-i Āsār wa Mufākhir-i Farhangī.

Naim, C. M. 2004. "Popular Jokes and Political History: The Case of Akbar, Birbal, and Mulla Do-Piyaza." In Urdu Texts and Contexts: The Selected Essays of C. M. Naim, 22549. New Delhi: Permanent Black.

Nair, Shankar. 2014. "Philosophy in Any Language: Interaction between Arabic, Sanskrit, and Persian Intellectual Cultures in Mughal South Asia." PhD diss., Harvard University.

Naqvi, Sayyid 'Ali Reza. 1964. Tažkira-Nawīsī-yi Fārsi dar Hind wa Pākistān. Tehran: Mu'assasa-i Matbu'at-i 'Ilmi.

Nath, Narindar. 1974. "Chandar Bhan Brahman: A Critical Edition of His Unknown Chahar Chaman.” PhD diss., University of Delhi.

Nicoll, Fergus. 2009. Shah Jahan: The Rise and Fall of the Mughal Emperor. London: Haus. Nizam Panipati. 1981. Jūg Bāsisht = Yoga Vasishta: Dar Falsafa wa 'Irfān-i Hind. Edited by Sayyid Muhammad Riza Jalali Na'ini and N. S. Shukla. Tehran: Iqbal.

Nizami, Azra. 1972. "Socio-Religious Outlook of Abul Fazl." In Medieval India: A Miscellany. Vol. 2. Centre for Advanced Study, Department of History, Aligarh Muslim University. London: Asia Publishing House.

Nizami, Khaliq Ahmad. 1989. Dillī: Tārīkn ke Ā'ìne meṇ. Delhi: Adam.

- - 2002. Religion and Politics in India during the Thirteenth Century. New Delhi: Oxford University Press.

O'Hanlon, Rosalind. 2010. “The Social Worth of Scribes: Brahmans, Kayasthas, and the Social Order in Early Modern India." Indian Economic and Social History Review 47 (4): 563-95.

O'Hanlon, Rosalind, and Christopher Minkowski. 2008. "What Makes People Who They Are? Pandit Networks and the Problem of Livelihoods in Early Modern Western India." Indian Economic and Social History Review 45 (3): 381-416. 
Orsini, Francesca. 2002. The Hindi Public Sphere, 1920-1940: Language and Literature in the Age of Nationalism. New Delhi: Oxford University Press.

Orthmann, Eva. 2011. "Court Culture and Cosmology in the Mughal Empire: Humāyūn and the Foundations of the Dinn-i Ilähī." In Court Cultures in the Muslim World: Seventh to Nineteenth Centuries, edited by Albrecht Fuess and Jan-Peter Hartung, 202-20. New York: Routledge.

- - . 2014. "Ideology and State-Building: Humāyūn's Search for Legitimacy in a HinduMuslim Environment." In Religious Interactions in Mughal India, edited by Vasudha Dalmia and Munis D. Faruqui, 3-29. New Delhi: Oxford University Press.

Parekh, Rauf. 2013. "Ghalib's Letters: An Important Historical and Biographical Source." Dawn, online ed., February 11, 2013. Accessed May 12, 2015. http://www.dawn.com/ news/785255/ghalibs-letters-an-important-historical-and-biographical-source.

Parker, Charles H. 2010. Global Interactions in the Early Modern Age, 1400-180o. Cambridge: Cambridge University Press.

Pearsall, Sarah M. S. 2008. Atlantic Families: Lives and Letters in the Later Eighteenth Century. Oxford: Oxford University Press.

Phukan, Shantanu. 1996. "'None Mad as a Hindu Woman': Contesting Communal Readings of Padmavat." Comparative Studies of South Asia, Africa, and the Middle East 16 (1): 41-54.

- - . 2000a. "Through a Persian Prism: Hindi and Padmavat in the Mughal Imagination.” PhD diss., University of Chicago.

- - . 20oob. “The Rustic Beloved: Ecology of Hindi in a Persianate World.” Annual of Urdu Studies 15:3-30.

- - 2 2001. "Through Throats Where Many Rivers Meet: The Ecology of Hindi in the World of Persian." Indian Economic and Social History Review 38 (1): 33-58.

Pingree, David. 1999. “An Astronomer's Progress.” Proceedings of the American Philosophical Society 143 (1): $73-85$.

- - 2003. "The Sarvasiddhāntarāja of Nityānanda." In The Enterprise of Science in Islam: New Perspectives, edited by J. P. Hogendijk and A. I. Sabra, 269-84. Cambridge, MA: MIT Press.

Podder, Tanushree. 2013. Escape from Harem: A Mughal Saga of Romance, Revenge, and Retribution. New Delhi: Roli Books.

Pollock, Sheldon. 1996. "The Sanskrit Cosmopolis, 300-1300: Transculturation, Vernacularization, and the Question of Ideology." In The Ideology and Status of Sanskrit in South and Southeast Asia, edited by Jan E. M. Houben, 197-247. Leiden: Brill.

- - . 1998. "India in the Vernacular Millenium: Literary Culture and Polity, 1000-150o." Daedalus 127 (3): 41-74.

- - . 2001a. "The Death of Sanskrit." Comparative Studies in Society and History 43 (2): $392-426$.

- - 2001b. "New Intellectuals in Seventeenth-Century India." Indian Economic and Social History Review 38 (1): 3-31.

- - 2006. The Language of the Gods in the World of Men: Sanskrit, Culture, and Power in Premodern India. Berkeley: University of California Press.

- - . 2007. "Pretextures of Time." History and Theory 46 (3): 366-83.

- - 2 2009. "Future Philology? The Fate of a Soft Science in a Hard World." Critical Inquiry 35 (4): 931-61. 
Pritchett, Frances. 1994. Nets of Awareness: Urdu Poetry and Its Critics. Berkeley: University of California Press.

Qanungo, Kalika Ranjan. 1935. Dara Shukoh. Calcutta: M. C. Sarkar and Sons.

- - . 1965. Sher Shah and His Times: An Old Story Retold by the Author after Decades from a Fresh Standpoint. Bombay: Orient Longmans.

Quinn, Sholeh A. 2003. "The Timurid Historiographical Legacy: A Comparative Study of Persianate Historical Writing." In Society and Culture in the Early Modern Middle East: Studies on Iran in the Safavid Period, edited by Andrew J. Newman, 19-31. Leiden: Brill.

Qureshi, Ishtiaq Husain. 1985. The Muslim Community of the Indo-Pakistan Subcontinent (610-1947): A Brief Historical Analysis. Delhi: Renaissance Publishing House.

Qureshi, Wahid. 1996. “The Indian Persian.” In Muțāli'ah-yi Adabiyāt-i Fārsī (Majmū'a-i Maqālāt), 1-33. Lahore: University Oriental College.

Rahman, M. Lutfur. 1970. Persian Literature in India during the Time of Jahangir and Shah Jahan. Baroda: Department of Persian and Urdu, M. S. University of Baroda.

Rahman, Munibur. [1999] 2012. “Fayżī, Abu’l Fayż., (b. Agra, 1547; d. Lahore, 1595), Mughal Court Poet, Also Known as Fayżī Fayyāżī, Who Wrote Mainly in Persian.” In Encyclopedia Iranica, online ed. Accessed May 23, 2015. www.iranica.com/articles/fayzi-abulfayz.

Raj, Kapil. 2007. Relocating Modern Science: Circulation and the Construction of Knowledge in South Asia and Europe, 1650-190o. Basingstoke: Palgrave Macmillan.

Rao, Velcheru Narayana, and David Shulman. 1998. A Poem at the Right Moment: Remembered Verses from Premodern South India. Berkeley: University of California Press.

Rashid, Khwaja 'Abdul. 1967. Tazkkira-i Shu'arā-yi Panjāb. Karachi: Iqbal Akadimi.

Rawlinson, H. G. 1937. "India in European Literature and Thought.” In The Legacy of India, edited by G. T. Garratt, $1-37$. Oxford: Clarendon Press.

Redford, Bruce. 1986. The Converse of the Pen: Acts of Intimacy in the Eighteenth-Century Familiar Letter. Chicago: University of Chicago Press.

Reeve, John. 2012. The Lives of the Mughal Emperors. London: British Library.

Richards, John F. 1984. "Norms of Comportment among Imperial Mughal Officers." In Moral Conduct and Authority: The Place of Adab in South Asian Islam, edited by Barbara D. Metcalf, 255-89. Berkeley: University of California Press.

- - 1986. Document Forms for Official Orders of Appointment in the Mughal Empire. Cambridge: E. J. W. Gibb Memorial Trust.

- - . 1993. The Mughal Empire. The New Cambridge History of India I.5. Cambridge: Cambridge University Press.

Rieu, Charles. 1879-83. Catalogue of the Persian Manuscripts in the British Museum. 3 vols. London: British Museum.

Rizvi, Saiyid Athar Abbas. 1975. Religious and Intellectual History of the Muslims in Akbar's Reign, with Special Reference to Abu'l Fazl, 1556-1605. New Delhi: Munshiram Manoharlal.

- - - 1999. "Dimensions of Sulh-i Kul (Universal Peace) in Akbar's Reign and the Sufi Theory of Perfect Man." In Akbar and His Age, edited by Iqtidar Alam Khan, 3-22. New Delhi: Indian Council for Historical Research; Northern Book Centre.

- - . 2002. A History of Sufism in India. Vol. 2. From Sixteenth Century to Modern Century. New Delhi: Munshiram Manoharlal. 
- 2003. A History of Sufism in India. Vol. 1.
AD 1600. New Delhi: Munshiram Manoharlal.

Robinson, Francis. 1999. Cambridge Illustrated History of the Islamic World. Cambridge: Cambridge University Press.

- - . 2007. The Mughal Emperors, and the Islamic Dynasties of India, Iran, and Central Asia, 1206-1925. London: Thames and Hudson.

Rosser, Yvette Claire. 2004. "Contesting Historiographies in South Asia: The Islamization of Pakistani Social Studies Textbooks." In Religious Fundamentalism in the Contemporary World: Critical Social and Political Issues, edited by Santosh C. Saha, 265-308. Lanham, MD: Lexington Books.

Roxburgh, David J. 2005. The Persian Album 1400-1600: From Dispersal to Collection. New Haven, CT: Yale University Press.

Russell, Ralph, and Khurshidul Islam. [1969] 1998. Three Mughal Poets: Mir, Sauda, Mir Hasan. Delhi: Oxford University Press.

Rypka, Jan, with Otakar Klíma et al. 1968. History of Iranian Literature. Edited by Karl Jahn. Dordrecht: D. Reidel.

Şahin, Kaya. 2010. "Constantinople and the End Time: The Ottoman Conquest as a Portent of the Last Hour." Journal of Early Modern History 14 (4): 317-54.

Sa'ib Tabrizi. Bayāz-i Șā'ib. MS, Oriental Manuscript Library and Research Institute (OMLRI), Hyderabad, \#6170 (Dawāwīn \#344).

Saksena, Banarsi Prasad. [1932] 1962. History of Shah Jahan of Dihli. Foreword by Wolseley Haig. Allahabad: Central Book Depot.

- - . 1942. "Chandrabhān on the Mewār Episode of 1654." In Indian Historical Records Commission: Proceedings of Meetings, vol. 18, Eleventh Meeting Held at Mysore, 104-7. New Delhi: Government of India Press.

Salih Kambuh, Muhammad. Bahār-i Sukhan. MS, British Library, Ethé \#2092 (IO Islamic \#3154).

-_- Bahār-i Sukhan. MS, British Library, Or. 178.

- - . 1967-72. 'Amal-i Șālih, al-Mausūm ba "Shāh Jahān Nāma." 3 vols. Edited by Ghulam Yazdani, revised by Wahid Qureshi. Lahore: Majlis-i Taraqqi-yi Adab.

Sandelvi, Shaikh Ahmad 'Ali Hashimi. Makkhzan al-Gharā'ib. MS, Habib Ganj Collection \#51/6-5/(3-2-1), Azad Library, Aligarh Muslim University.

Saqi Musta'id Khan. 1947. Maāsir-i-'Ālamgiri: A History of the Emperor Aurangzib 'Ālamgir (Reign 1658-1707 A.D.). Translated by Jadunath Sarkar. Calcutta: Asiatic Society.

Sarfaraz, Shaikh 'Abdu'l Kadir. 1935. A Descriptive Catalogue of the Arabic, Persian, and Urdu Manuscripts in the Library of the University of Bombay. Bombay: Qayyimah Press; University of Bombay.

Sarkar, Jadunath. 1920. History of Aurangzib: Based on Original Sources. 4 vols. London: Longmans, Green.

- - . [1920] 1952. Mughal Administration. 4th ed. Calcutta: M. C. Sarkar and Sons.

- - . [1930] 1979. A Short History of Aurangzib, 1618-1707. New Delhi: Orient Longman.

Sarkar, Jagadish Narayan. 1951. The Life of Mir Jumla: The General of Aurangzeb. With a foreword by Jadunath Sarkar. Calcutta: Thacker, Spink.

Sarkhwush. Muhammad Afzal. Kalimāt al-Shu'arā, MS, Azad Library, Aligarh Muslim University, Aligarh University Collection \#95 (Farsiya Akhbar). 
-——. 1964. Kalimāt al-Shu'arā: Mushtamil bar Żikr-i Shu'arā-yi 'Așr-i Jahāngīr tā 'Ahd-i

'Ālamgìr. Edited by Sadiq 'Ali Dilawari. Lahore: Alamgir Press.

Schimmel, Annemarie. 1975. Mystical Dimensions of Islam. Chapel Hill: University of North Carolina Press.

- - 1980. Islam in the Indian Subcontinent. Leiden: E. J. Brill.

- - . 1992. A Two-Colored Brocade: The Imagery of Persian Poetry. Chapel Hill: University of North Carolina Press.

- - 2004. The Empire of the Great Mughals: History, Art, and Culture. London: Reaktion Books.

Schimmel, Annemarie, and Stuart Cary Welch. 1983. Anvari's Divan: A Pocket Book for Akbar: A Dìvān of Auhaduddin Anvari, Copied for the Mughal Emperor Jalaluddin Akbar (r. 1556-1605) at Lahore in A.H. 996/A.D. 1588. Now in the Fogg Art Museum of Harvard University. New York: Metropolitan Museum of Art.

Schneider, Gary. 2005. The Culture of Epistolarity: Vernacular Letters and Letter Writing in Early Modern England, 1500-1700. Newark, NJ: University of Delaware Press.

Schwab, Raymond. 1984. The Oriental Renaissance: Europe's Rediscovery of India and the East, 1680-1880. Translated by Gene Patterson-Black and Victor Reinking. New York: Columbia University Press.

Sengupta, Sagaree. 1994. "Krsna the Cruel Beloved: Harishcandra and Urdu." Annual of Urdu Studies 9:82-102.

Shackle, Christopher. 1996. "Settings of Panegyric: The Secular Qasida in Mughal and British India." In Qasida Poetry in Islamic Asia and Africa, vol. 1, Classical Traditions and Modern Meanings, edited by Stefan Sperl and Christopher Shackle, 205-52. Leiden: Brill. Shafiq, Lachmi Narayan. N.d. Tazkira-yi Gul-i Ra'nā'. Hyderabad: 'Ahd Afarin Barqi Press. Shahnawaz Khan, Nawab Samsam al-Daula. 1888-96. Ma'ạșir al-Umarā. 3 vols. Edited by Maulavi Abd-ur-Rahim. Calcutta: Asiatic Society.

- - 1979. The Maāthir-ul-Umarā, Being Biographies of the Muhammadan and Hindu Officers of the Timurid Sovereigns of India from 1500 to about 1780 A.D. Translated by H. Beveridge; revised, annotated, and completed by Baini Prashad. 2 vols. Patna: Janaki Prakashan.

Shaikh, Samira. 2010. Forging a Region: Sultans, Traders, and Pilgrims in Gujarat, 12001500. New Delhi: Oxford University Press.

Sharma, G. N. 1954. Mewar and the Mughal Emperors (1526-1707 CE). Agra: Shiva Lal Agarwala.

Sharma, Sri Ram. 1971. Maharana Raj Singh and His Times. Delhi: Motilal Banarsidas.

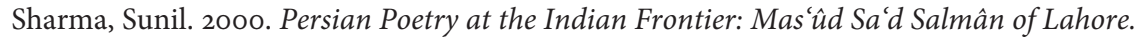
New Delhi: Permanent Black.

- - . 2004. "The City of Beauties in Indo-Persian Poetic Landscape." Comparative Studies of South Asia, Africa and the Middle East 24 (2): 73-81.

- - . 2007. "Novelty, Tradition and Mughal Politics in Nau'î̀s Sùz u Gudāz." In The Necklace of the Pleiades: Studies in Persian Literature Presented to Heshmat Moayyad on His 8oth Birthday, edited by Franklin D. Lewis and Sunil Sharma, 251-65. Amsterdam: Rozenberg; West Lafayette, IN: Purdue University Press.

- - - 2011. "If There Is a Paradise on Earth, It Is Here': Urban Ethnography in IndoPersian Poetic and Historical Texts." In Forms of Knowledge in Early Modern Asia: 
Explorations in the Intellectual History of India and Tibet, edited by Sheldon Pollock, 240-56. Durham, NC: Duke University Press.

Shibli Nu'mani. 2002-4. Shi'r al-'Ajam. 5 vols. Azamgarh: Dar al-Musannifin, Shibli Academy. Siddiqi, Iqtidar Husain. 1993. Majma'ul-Afkār: An Introduction. Patna: Khuda Bakhsh Oriental Public Library.

Siddiqi, Moazzam. 1987. “Ārzū, Major Indo-Muslim Poet, Lexicographer, and Litterateur.” In Encyclopedia Iranica, online ed. Accessed September 28, 2010. www.iranica. com/articles/arzu-seraj-al-din-ali-khan-major-indo-muslim-poet-lexicographer-andlitterateur-b.

- - . 1989. “Bīdel, 'Abd-al-Qāder.” In Encyclopedia Iranica, online ed. Accessed September 28, 2010. www.iranica.com/articles/bidel-bedil-mirza-abd-al-qader-b.

Singh, Abha. 1993. "The Char Bahar [sic] of Balkrishan Brahman: A Hitherto Unknown Source of the Mid-17th Century." Proceedings: Indian History Congress 54:216-22.

Singh, Bhagwan. 2002. "Violence in the Name of Religion." Chandigarh Tribune, March 19. Accessed March 12, 2008. www.tribuneindia.com/2002/20020319/mailbag.htm.

Smart, Ellen. 1999. "The Death of Ināyat Khān by the Mughal Artist Bālchand." Artibus Asiae 58 (3/4): 273-79.

Smith, David. 2003. Hinduism and Modernity. Malden, MA: Blackwell.

Smyth, Adam. 2010. Autobiography in Early Modern England. Cambridge: Cambridge University Press.

Snell, Rupert. 2005. "Confessions of a 17th-Century Jain Merchant: The Ardhakathānak of Banārasīdās." South Asia Research 25 (1): 79-104.

Speziale, Fabrizio. 2003. "The Relation between Galenic Medicine and Sufism in India during the Delhi and Deccan Sultanates." East and West 53 (1/4): 149-78.

- - . 2009a. "The Circulation of Ayurvedic Knowledge in Indo-Persian Medical Literature." Unpublished [?] paper presented at the symposium "Ayurveda in Post-classical and Pre-colonial India," International Institute for Asian Studies, Leiden, July 9, 2009. http://hal-ephe.archives-ouvertes.fr/docs/oo/58/47/49/PDF/Speziale_Paper_2.pdf.

- - . 2009b. "Širāzi, Nur al-Din Mohammad 'Abd Allāh." In Encyclopedia Iranica, online ed. Accessed September 7, 2012. www.iranicaonline.org/articles/sirazi-nur-al-dinmohammad-abd-allah.

- - 2010a. "The Encounter of Medical Traditions in Nūr al-Dīn Šīrāzī's 'Ilājāt-i Dārā Šikōhī." eJournal of Indian Medicine (eJIM) 3 (2): 53-67.

- - 2010b. "Les traités persans sur les sciences indiennes: Médecine, zoologie, alchimie." In Muslim Cultures in the Indo-Iranian World during the Early-Modern and Modern Periods, edited by Denis Hermann and Fabrizio Speziale, 403-47. Tehran: Institut français de recherche en Iran; Berlin: Klaus Schwarz.

- - . 2011. "Indo-Muslim Physicians." In Encyclopedia Iranica, online ed. Accessed September 7, 2012. www.iranicaonline.org/articles/india-xxxiii-indo-muslim-physicians. Steadman, John M. 1990. Redefining a Period Style: "Renaissance," "Mannerist," and "Baroque" in Literature. Pittsburgh, PA: Duquesne University Press.

Stein, Burton. 1998. A History of India. Malden, MA: Blackwell.

Steinfels, Amina M. 2012. Knowledge before Action: Islamic Learning and Sufi Practice in the Life of Sayyid Jalāl al-Dīn Bukhārī Makhdūm-i Jahāniyān. Columbia: University of South Carolina Press. 
Steingass, Francis Joseph. 1892. A Comprehensive Persian-English Dictionary, Including the Arabic Words and Phrases to Be Met with in Persian Literature; Being Johnson and Richardson's Persian, Arabic and English Dictionary Revised, Enlarged, and Entirely Reconstructed. London: Routledge and Kegan Paul.

Storey, C. A. 1953. Persian Literature: A Bio-Bibliographical Survey. Vol. 1. Qur'ānic Literature; History and Biography. Part 2. Biography, Additions and Corrections, Indexes. London: Luzac.

Subrahmanyam, Sanjay. 1992a. "Iranians Abroad: Intra-Asian Elite Migration and Early Modern State Formation." Journal of Asian Studies 51 (2): 340-63.

- - 1992b. "The Mughal State-Structure or Process? Reflections on Recent Western Historiography." Indian Economic and Social History Review 29 (3): 291-321.

- - - 1997. "Connected Histories: Notes towards a Reconfiguration of Early Modern Eurasia." Modern Asian Studies 31 (3): 735-62.

- - 2003. "Turning the Stones Over: Sixteenth-Century Millenarianism from the Tagus to the Ganges." Indian Economic and Social History Review 40 (2): 129-61.

- - - 2006. "A Tale of Three Empires: Mughals, Ottomans, and Habsburgs in a Comparative Context." Common Knowledge 12 (1): 66-92.

- - 2008. "Further Thoughts on an Enigma: The Tortuous Life of Nicolò Manucci, 1638-c. 1720." Indian Economic and Social History Review 45 (1): 35-76.

Sunnami, Bhagawant Rai "Bahar.” N.d. [1930s?]. Gulzār-i Bahār, Ma'rūf ba Bazm-i Nazm-i Brahman. Delhi: n.p.

Suvorova, Anna. 1999. Muslim Saints of South Asia: The Eleventh to Fifteenth Centuries. London: RoutledgeCurzon.

Tagore, Rabindranath. 1987. Selected Poems. Translated by William Radice. London: Penguin Books.

Talatoff, Kamran, and Jerome W. Clinton, eds. 20oo. The Poetry of Nizami Ganjavi: Knowledge, Love, and Rhetoric. New York: Palgrave.

Tavakoli-Targhi, Mohamad. 20o1a. "The Homeless Texts of Persianate Modernity." Cultural Dynamics 13 (3): 263-91.

-—-. 2001b. Refashioning Iran: Orientalism, Occidentalism and Historiography. Hampshire: Palgrave.

- - 2003. "Orientalism's Genesis Amnesia." In Antinomies of Modernity: Essays on Race, Orient, Nation, edited by Vasant Kaiwar and Sucheta Mazumdar, 98-125. Durham, NC: Duke University Press.

Thackston, Wheeler M. 1994. A Millenium of Classical Persian Poetry. Bethesda, MD: Ibex. - - . 1999. The Jahangirnama: Memoirs of Jahangir, Emperor of India. Washington, DC: Freer Gallery of Art and Arthur M. Sackler Gallery; London: Oxford University Press. - - . 2002. "Literature." In The Magnificent Mughals, edited by Zeenut Ziad, 83-111. New Delhi: Oxford University Press.

Tomalin, Claire. 2002. Samuel Pepys: The Unequalled Self. New York: Viking.

Travers, Robert. 2007. Ideology and Empire in Eighteenth-Century India: The British in Bengal. Cambridge: Cambridge University Press.

'Urfi Shirazi, Jamal al-Din. 1620. Dīvān-i 'Urfī, MS, University of Michigan. Hathi Trust Digital Library, http://catalog.hathitrust.org/Record/oo6816035. Accessed May 15, 2015. -_-. 1915. Dìwān-i 'Urfì Shìrāzì. Kanpur: Nawal Kishore Press. 
A Volume of Miscellaneous Extracts. MS, British Library, Or. 1883.

Walih Daghistani. 2001. Riyāz al-Shu'arā. Edited by Sharif Husain Qasimi. Rampur: KitābKhāna-yi Rezā.

Whyman, Susan E. 2009. The Pen and the People: English Letter Writers, 1660-180o. Oxford: Oxford University Press.

Wink, Andre. 2009. Akbar. Makers of the Muslim World Series. Oxford: Oneworld Books. Wolpert, Stanley. 2009. A New History of India. 8th ed. New York; Oxford: Oxford University Press.

Woods, John E. 1987. “The Rise of Tīmūrid Historiography.” Journal of Near Eastern Studies 46 (2): 81-108.

Yarshater, Ehsan. 1988. “The Indian or Safavid Style: Progress or Decline?” In Persian Literature, edited by Ehsan Yarshater, Columbia Lectures on Iranian Studies 3, 249-88. Albany, NY: Bibliotheca Persica and Persian Heritage Foundation.

Yohannan, John D. 1977. Persian Poetry in England and America: A 200 Year History. Delmar, NY: Caravan Books.

Zaman, Taymiya R. 2007. "Inscribing Empire: Sovereignty and Subjectivity in Mughal Memoirs." PhD diss., University of Michigan.

- - 2011. "Instructive Memory: An Analysis of Auto/Biographical Writing in Early Mughal India." Journal of the Economic and Social History of the Orient 54 (5): 677-700.

Zerner, Henri. 1972. "Observations on the Use of the Concept of Mannerism." In The Meaning of Mannerism, edited by Franklin W. Robinson and Stephen G. Nichols Jr., 105-21. Hanover, NH: University Press of New England.

Zilli, Ishtiyaq Ahmed. 200o. "Development of Insha Literature to the End of Akbar's Reign." In The Making of Indo-Persian Culture: Indian and French Studies, edited by Muzaffar Alam, Francoise "Nalini" Delvoye, and Marc Gaborieau, 309-50. New Delhi: Manohar; Centre de sciences humaines.

-_- 2007. The Mughal State and Culture, 1556-1598: Selected Letters and Documents from Munshaat-i Namakin. Delhi: Manohar. 



\section{SOUTH ASIA ACROSS THE DISCIPLINES}

South Asia Across the Disciplines is a series devoted to publishing first books across a wide range of South Asian studies, including art, history, philology or textual studies, philosophy, religion, and the interpretive social sciences. Series authors all share the goal of opening up new archives and suggesting new methods and approaches, while demonstrating that South Asian scholarship can be at once deep in expertise and broad in appeal.

Extreme Poetry: The South Asian Movement of Simultaneous Narration by Yigal Bronner (Columbia)

The Social Space of Language: Vernacular Culture in British Colonial Punjab by Farina Mir (California)

Unifying Hinduism: Philosophy and Identity in Indian Intellectual History by Andrew J. Nicholson (Columbia)

The Powerful Ephemeral: Everyday Healing in an Ambiguously Islamic Place by Carla Bellamy (California)

Secularizing Islamists? Jama'at-e-Islami and Jama'at-ud-Da'wa in Urban Pakistan by Humeira Iqtidar (Chicago)

Islam Translated: Literature, Conversion, and the Arabic Cosmopolis of South and Southeast Asia by Ronit Ricci (Chicago)

Conjugations: Marriage and Form in New Bollywood Cinema by Sangita Gopal (Chicago)

Unfinished Gestures: Devadāsīs, Memory, and Modernity in South India by Davesh Soneji (Chicago)

Document Raj: Writing and Scribes in Early Colonial South India by Bhavani Raman (Chicago)

The Millennial Sovereign: Sacred Kingship and Sainthood in Islam by A. Azfar Moin (Columbia)

Making Sense of Tantric Buddhism: History, Semiology, and Transgression in the Indian Traditions by Christian K. Wedemeyer (Columbia)

The Yogin and the Madman: Reading the Biographical Corpus of Tibet's Great Saint Milarepa by Andrew Quintman (Columbia)

Body of Victim, Body of Warrior: Refugee Families and the Making of Kashmiri Jihadists by Cabeiri deBergh Robinson (California)

Receptacle of the Sacred: Illustrated Manuscripts and the Buddhist Book Cult in South Asia by Jinah Kim (California)

Cut-Pieces: Celluloid Obscenity and Popular Cinema in Bangladesh by Lotte Hoek (Columbia)

Text to Tradition: The Naisadhiyacarita and Literary Community in South Asia by Deven M. Patel (Columbia)

Democracy against Development: Lower Caste Politics and Political Modernity in Postcolonial India by Jeffrey Witsoe (Chicago)

Into the Twilight of Sanskrit Poetry: The Sena Salon of Bengal and Beyond by Jesse Ross Knutson (California) 
Voicing Subjects: Public Intimacy and Mediation in Kathmandu by Laura Kunreuther (California)

Writing Resistance: The Rhetorical Imagination of Hindi Dalit Literature by Laura R. Brueck (Columbia)

Wombs in Labor: Transnational Commercial Surrogacy in India by Amrita Pande (Columbia)

I Too Have Some Dreams: N. M. Rashed and Modernism in Urdu Poetry by A. Sean Pue (California)

The Place of Devotion: Siting and Experiencing Divinity in Bengal-Vaishnavism, by Sukanya Sarbadhikary (California)

We Were Adivasis: Aspiration in an Indian Scheduled Tribe by Megan Moodie (Chicago)

Writing Self, Writing Empire: Chandar Bhan Brahman and the Cultural World of the IndoPersian State Secretary by Rajeev Kinra (California)

Landscapes of Accumulation: Real Estate and the Neoliberal Imagination in Contemporary India by Llerena Searle (Chicago) 


\section{N D E X}

'Abd al-Haqq Shirazi. See Amanat Khan

'Abd al-Karim Ma'muri, Mir (a.k.a. Ma'mur Khan) 27-29, 31, 145, 164, 180-1, 270

'Abd al-Nabi Khan, 48-49

'Abd al-Salam Mashhadi, Mir. See Islam Khan

'Abd al-Rahim Khan-i Khanan, 27, 70, 142, 207,212

'Abd al-Razzaq Fayyaz Lahiji, 206

Abhay Chand (companion of Hakim Sarmad), 253 Abu al-Fath Gilani, Masih al-Din "Hakim"

(d. 1589): as a founder of $t \bar{a} z a-g \bar{u}\urcorner \bar{\imath}$ literary movement, 207-8, 317n 23

Abu al-Fazl ibn Mubarak, 'Allami / Shaikh

(Mughal grandee and intellectual of

Akbar's reign, d. 1602), 17, 34, 69, 86, 208, 258, 291, 298; as the epitome of the learned administrator, 27, 78; as a model for

Chandar Bhan, 52, 157, 270, 275, 325n52

Abu al-Hasan al-Mawardi, 101

Abu al-Hasan Turbati, Khwaja (d. 1633), 69, 30o-1n39

accounting (siyāq, hisāb, istifä): 26, 56, 76-77,

$81,87,120,171,179,292,305 \mathrm{nn} 20,25$; as an essential skill for munshìs and wazìrs, 61-62, $64,65,78,82,94,116$; at the Taj Mahal complex, 56, 58-59; Shah Jahan's expertise in, 116, 120, 124-26, 127

Achal Das Dehlavi, 269-70

adab (culture, courtesy, etiquette, norms; pl. $\bar{a} d \bar{a} b), 70,80,90-91,106,121,237,277$; in epistolary culture, 176-7; Chandar Bhan's alleged lack of, 275-6

$\bar{a} d \bar{a} b$ (literature on political wisdom, morals, statecraft), 17, 64, 258. See also akhlāq

'Adil Khan. See Bijapur

'Adil Shahi court. See Bijapur.

Afghanistan, 3, 26, 100, 112, 152, 186, 309n17. See also Badakhshan, Balkh, Kabul, Qandahar

Africa, Africans: the Swahili Coast, 3; Africans (habshīs) at the Mughal court, 111, 201

Afzal Khan Shirazi, 'Allami, Mirza/Mulla Shukr Allah (wazir of Shah Jahan, d. 1639) 30, 31, 32, 93, 106, 164-70, 171, 178, 180, 181-82, 184, 185, 186, 193, 240, 289, 293, 30on28, 304n14, 313n5; as a mentor to Chandar Bhan and other Hindus, 27, 70-76, 87, 164, 93-94, 164-66, 186; correspondence with Chandar Bhan, 181-82, 189-90; as the epitome of the learned administrator, 6, 26-27, 32, 70-76, 78, 79, 83, $84,161,164,167-68,189-90$; as an exemplar of Mughal civility, 26-27, 32, 70-76, 80, 83, $84,161,167-68,181-82$; as a second Plato or Aristotle, 27, 70, 72, 78, 314n16; as an expert diplomat, 26-27, 93-94; as a literary connoisseur, $165-67,184-85$; as a mystic, 72-73, 165-67; death of, 39, 53, 75-76, 166-69, 293; cultural memory of his relationship with Chandar Bhan, 259-60, 266, 268, 270, 273

Agra (a.k.a. Akbarabad), 1, 7, 28, 33, 82, 91, 131, 242, $243,265,271,275,301 n 60,312 \mathrm{n} 42$; 
as a center of Mughal literary and political culture, 3, 8, 51, 81, 102, 110, 136, 137, 144-7, 276, 293; Mughal administration of, 58-59, 82, 146; Mughal architecture of, 26, 144-46, 147, 313n5; mystical culture of, 146; Chandar Bhan's retirement to, 56-59, 267. See also Taj Mahal Agrarian System of Mughal India, 288

Aḥkām al-Sultanìya, 101

Ahmadabad, 7

Ahmadnagar, 154, 213

Ahmed Shah (Tughlaq prince), 98

'Ain al-Shifā (The fount of healing; medical treatise), 34

A'īn-i Akbarī, 52, 157, 311n31, 325n52; Gladwin's English translation of, 297n10. See also Abu al-Fazl ibn Mubarak

'ajā'ib al-hind ("wonders of India"): as a Persianate literary topos, 216

Ajmer, 7, 91-2, 136, 155

Akbar, Jalal al-Din Muhammad (Mughal emperor, r. 1556-1605), 2, 27, 34, 50, 52, 86, 99, 111, 121-22, 129, 146, 151, 156, 157, 201, 252-4, 292, 309n2o, 315n2; Chandar Bhan's birth and early life under, 21-22; reputation as an exceptional ruler, $2,16-17,25,68,244$, 249, 252-53, 287, 289, 323-24n14, 326n1; narratives of post-Akbar orthodoxy and decline in Mughal historiography, 18-21, $68,106,124,244,249,252-54,277-78$, 292-93, 304n8, 310n3o, 312n42; evidence of continued veneration for his legacy under Shah Jahan, 106, 121-22, 144, 145-46, 154-55, 312n42; Agra renamed "Akbarabad" in honor of, 144, 312n42; connection with Chishti Sufi order, 146, 155; as a literary patron, 206-8; Akbar's tomb at Sikandra (Agra), 26, 145; Dara Shukoh as sole inheritor of his legacy, in modern historiography, 244, 248-49, 252-53, 254, 278, 312n5o, 323-24n14

Akbar Nāma (chronicle of the Mughal emperor Akbar's reign): as favored reading at Shah Jahan's court, 99, 121-22

Aknhbārāt-i Darbār-i Mu'allá (Mughal court records), 56

Akhlāq-i Jalālì (treatise on ethics and statecraft), 61 Akkhlāq-i Muhsinī (treatise on ethics and statecraft), 61

Aḳhlāq-i Nāṣirì (treatise on ethics and statecraft), 61, 64

aḱhlāq / aḱkhlāqì norms (statecraft, civility, ethics), 59, 83, 164, 168, 193, 195, 293; ādāb and $a \underline{k} \underline{h} \bar{a} q$ as genres of political wisdom literature, 17, 61, 63-65, 258; treatises on, as part of the curriculum of Mughal gentlemen, 64-65, 258; "manuals for wazìrs" (dastūr al-wizārat) as a subgenre of, 67

'Ala al-Din Khalji (Sultan of Delhi, r. 1296-1316), 97

'Ala al-Din Sikandar Shah (Sultan of Delhi, d. 1394?), 98

'Alamgir II (Mughal emperor, r. 1754-59), 273

Al-Aqsa (mosque in Jerusalem), 140

al-Razi, Abu Bakr Muhammad ibn Zakariyya, 34 al-Zahrawi, Abu al-Qasim, 34

Alam, Muzaffar 15, 85, 196, 286

Alexander (the Great), 46, 70, 122

Alfaz al-Adwiya, 35

'Ali Mardan Khan (Mughal grandee, d. 1657), $43-44,45,306 \mathrm{n} 49$

'Ali Quli Salim (poet), 206

'Ali Reza (shī'a imam, d. 818), 186

“Aligarh school” (of historical writing), 288

Allah Wardi Khan, 143

Allahabad, 7, 136, 155

'Amal-i Șāliḥ. See Salih Kambuh, Muhammad

Amanabad, 42

Amanat Khan (a.k.a. 'Abd al-Haqq Shirazi, b/o Afzal Khan; d. 1644-45), 26, 168-69, 313n5; as noted calligrapher (e.g. of inscriptions at Taj Mahal), 26

Amar Singh, Rana (ruler of Mewar, d. 1620), 93

Amir Khusrau Dehlawi (d. 1325), 97, 142, 209-11, $216,222,224,261,280$

Anandaghana "Khwash" (Hindu poet of Persian), 250

Anatolia, 106-7, 111, 113, 136

Andhra Pradesh, 153

Andijan, 113

Andrews, Walter, 237

Anìs al-Mu'älijīn (The healers' companion), 35

Anquetil-Duperron, Abraham Hyacinthe (French Orientalist, d. 1805), 245

Anushirwan, Khusrau (celebrated ancient Persian monarch), 29, 46, $300 n 38$

Anwari, Auhad al-Din (poet, d. ca. 1190), 11, 208, 211-12, 235

Aqa Rashid Daylami (Mughal calligrapher), 72, $304 n 16$

'Aqil Khan Shirazi (s/o Amanat Khan, d. 1649), $23,26-28,43,164,168-9$

Ardabil, 113

Ardhakathānaka (Half a tale), 203

'Arif Chela, 35

Aristotle, 27, 34, 70, 73, 78, 85, 164, 177, 198, $314 \mathrm{n} 16$ 
Arjomand Banu Begum. See Mumtaz Mahal Arzu, Siraj al-Din 'Ali Khan (Indo-Persian philologist), 12, 231, 235

Asaf Khan, "Yamin al-Daula" Abu al-Hasan (d. 1641; brother of Empress Nur Jahan), 29-31, $39,49,69-70,144,147,181-82,249$; patronage of Hindu intellectuals, 29-31, 249; correspondence with Chandar Bhan, 29-30, 181-82

Āsafa Vilāsa (Sanskrit work praising Asaf Khan), 31, 301n 45

Asalat Khan, 69, 143

'Ashiqi ‘Azimabadi, Aqa Husain Quli Khan: author of Nishtar-i 'Ishq, 12, 276-7

Asir, Mirza Jalal (poet, d. 1630), 231-32

Assam, 88, 112

Astarabad, 113

Athar Ali, M., 68, 289; his Apparatus of Empire, 289-90

Aurangzeb 'Alamgir (Mughal emperor, r. 1658-1707), 2, 23, 32, 34, 46-47, 48-50, 53-59, $80,82-83,152,154,173,205,231,242-4,246-7$, $248,249-50,252-53,254,256,260,267,269$, 281, 291, 292; reputation for orthodoxy/ bigotry, 19-20, 46-47, 48, 53, 55, 57, 82-83, $173,240,244,249-50,252-53,277-78,282$, 298-99nn11,12, 310-11n3o, 324n16; as the quintessential villain of modern Indian history/historiography, 19-20, 244, 252-53, 277-78, 291, 299n12; correspondence with Chandar Bhan, 54-59, 175, 181, 186, 240, 243-44; Hindu administrators under, 2, 23, $53-59,82-83,231,244,267,314 \mathrm{n} 17$; patronage of mystics, 155, 312n52

autobiography/memoir: as an early modern genre, 8, 203, 315n8; relationship to epistolography and other forms of "life-writing," 8-9, 39, 159-60, 171-72, 173-74, 180-81, 186, 191-200. See also self-fashioning

Avicenna. See Ibn Sina

Awadh, 7, 136, 155, 202-3

Āyat al-Nūr (Qur'an 24:35): mystical interpretations of, 61

Ayurveda, 34. See also medicine Azmi, Shahid Naukhez, 279

Baba Farid. See Farid al-Din Ganj-i Shakar Baba Lal Dayal / Bairagi (Punjabi spiritual divine, $17^{\text {th }} \mathrm{c}$.): Hindi dialogues with Mughal prince Dara Shukoh, 256-58; Chandar Bhan's translation of dialogues into Persian, 256
Babur, Zahir al-Din Muhammad (Mughal emperor, r. 1526-30), 16, 99, 122, 142, 153

Bacon, Francis, 19

Badakhshan, 7, 113, 240; Mughal military campaigns in, 42, 46, 78, 84-85, 88-91, 153, $157,240,306 \mathrm{n} 49$; as a source of rubies (and other precious stones/metals), 38, 128, 139, 157; local Sufi mystics, 157

Baghdad, 113

Baha al-Din Muhammad al-'Amili, Shaikh (a.k.a. Shaikh Baha'i; philosopher, d. 1621), 198. See also Isfahan school

Baha al-Din Zakariya, Shaikh (Suhrawardi Sufi saint, d. 1262), 151

Bahlul Lodi (Delhi Sultan, r. 1451-89), 98

Bahruch, 153

Bairam Khan (Mughal grandee under Akbar, d. 1561): as a model Mughal wazīr, 68

Bakhtar, 113

Balban, Ghiyas al-Din (Sultan of Delhi, r. 1266-87), 97

Balfour, Francis, 28

Bal Krishan (Hindu munshī of Aurangzeb's reign), 83

Balkh, 7, 113, 136; Mughal military campaigns in, $42,46,78,84-85,88-91,92,153,157$, $172,240,306 \mathrm{n} 49$; as a source of melons, 109

Banaras, 54, 155, 267, 275, 313n62, 326n63

Banarasi Das (kāyastha scribe), 24, $299 n 19$

Banarasidas (Jain merchant, author of Ardhakathānaka), 203, 299n19, 315n8

Bangladesh, 5

Baqir Khan, 143

Barbud (medieval Persian musician), 216

Barda', 113

Barzun, Jacques, 239

Basra, 113

Bastam, 113

Bedil, Mirza 'Abd al-Qadir (poet, d. 1720), 51, $238,325 \mathrm{n} 44$; as a paragon of the so-called "Indian style" of Persian poetry, 232, $321 n n 99,100$; his tomb as an early modern tourist destination, 142

Bengal, 3, 7, 76, 87, 136, 149, 156, 163, 175, 226, 242; as an important Mughal commercial hub, 87-88, 156; Indo-Persian scribal communities in, 163

Bernier, Francois, 246

Bhagavad Gita: and Chandar Bhan's notion of "detachment" (bī-ta'alluqī), 161; Faizi's Persian translation of, 214 
Bhakkari, Shaikh Farid (biographer of Mughal notables), 30

Bhäratabhāvadipa (Light on the inner significance of the Mahābhārata): discussion of cosmic illusion (māya), 73

Bhaskara (or Bhaskaracharya; author of Sanskrit mathematical treatise Lìlāvatì), 214

Bhupat Rai “Bi-Gham” Bairagi (poet, d. 1719), 271, 302n69, 325n43

Bhupat Rai (Hindu munshī), 50

Bibi Rasti (female Sufi saint of Multan), 151

Bihar, 7, 149, 156; as a hub of mystical activity center, 156

Bihari Das (Hindu munshī of Shah Jahan's reign), 25

Bijapur, 41, 136; court of the 'Adil Khani/Shahi Sultanate, 30, 85, 113, 154, 213

Birar, 154

bì-ta'alluqī. See detachment

Blake, William, 193

Bombay, 153

Brahmans: in Mughal service, 4-5, 92-93, 185, 292; distinguishing characteristics of, according to Chandar Bhan, 4-5, 9, 21-23, 62-63, 93, 162-63, 189, 191-92; Persian literacy among, 5, 14, 21-25, 51, 81, 170-71; scribal culture among, 21-25, 162-63; as astronomers at the Mughal court, 31, 118, 291-92, 310n24; as Hindi poets, 37; as figures in Persian literature, 47, 50, 182, 217-20, 223, 261-63, 302n67; as mystical figures, 9, 191-92. See also Chandar Bhan Brahman

Brajbhasha, 93, 203

Britain. See colonialism, East India Company Bronner, Yigal, 227

$\mathrm{Bu}$ 'Ali Qalandar. See Sharaf al-Din Bu 'Ali Qalandar Panipati

Bukhara, 113, 224

Burhan al-Din Gharib, Shah (Sufi saint of the Chishti order, d. 1337), 154

Burhan Nizam Shah II (Sultan of Ahmadnagar, r. 1591-95), 213

Burhanpur, 27, 154

Busch, Allison, 31, 93, 203

Bust, 156

Büstān (The fragrant garden; 1247), 61. See also Sa'di Shirazi

Caitanya (bhaktī saint; d. 1534), 202

Calcutta: Asiatick Society of, 6

Calicut, 153 calligraphy: Indo-Persian art of, 65, 77, 117, 213, 304n16, 301n23

Cambay, 153

Candāyan, 202

Cassius (Shakespeare character), 249

caste, 4-5, 9, 21, 22-23, 24, 26-7, 62-63, 162-63, 170, 184-5, 192. See also Brahmans

Cathay, 113

Chahär Chaman (CC) (The four gardens), as an underutilized source for Mughal cultural history, 5-10, 290-92; Guldasta / Qawāiid al-Saltanat as an excerpt of, 7, 100-102, 109, 307-8n10, 308n16; in modern historiography, 6-7, 14-15, 252; as a memoir, $5-6,8-9,21-32,64,85,90,102-4,106-7$, 159-74; as a source for personal letters, letter-writing practices, 8-9, 174, 180-200 (see also Munsha'āt-i Brahman); discussions of medical science in, 32-35; discussions of literary culture in, $36-46,51,210$; discussions of other Hindu administrators in, 49, 53, $76-77,80-82,244$; discussions of secretarial/ administrative culture, $6,21-32,60-84,116$, 124-25, 127, 163-74; discussions of Mughal military and diplomatic policy, 84-94, 255; discussion of daily routines at Shah Jahan's court, 99-135; gazetteer of major Mughal cities and provinces, 135-58; as a work of model inshä', 5-6, 7, 8, 100, 265

Chahār Maqāla ("Four discourses"; treatise on statecraft by Nizami 'Aruzi), 64

Chandar Bhan Brahman: family background, early life, and early career in Mughal administration, 2, 21-32, 159-65, 181-82; career in Shah Jahan's government, 70-83, 164-73, 182-86; personal relationship with Shah Jahan, 5, 31-32, 39-40, 42, 102, 169-71, 172-73, 196, 240, 257, 260-61, 270, 293; military and diplomatic career, 84-94; relationship with Aurangzeb, 52-59; retirement from official service, work as caretaker of Taj Mahal, 54-59; views on secretarial training, conduct, 6o-65 (see also munshiss, secretarial arts); poetry, literary career of, 38-52, 61, 65-66, 67, 71, $79,81,83-84,107-9,122-23,126,138-41,165$, $169-71,175-76,183-85,186-89,192-95,199$, 203-39; mystical inclinations of, 6, 9-10, $22-23,26,47-48,50,52,57-58,59,60-65$, $67-69,71-73,79-80,83-84,105,126,147-57$, $160-62,165-68,175-76,180,182-85,189-200$, 
205, 217-21, 227-28, 256-58, 265, 270, 274; views on Brahmans / Brahmanical identity, $4-5,9,21-23,47,62-63,93-94,160-63$, 189, 191-92, 218-9, 223; views on Indian kingship and Mughal sovereignty, 94, 95-99, 157-58; observations on Shah Jahan and life at Shah Jahan's court, 99-135; gazetteer of major Mughal cities and provinces, 135-58; as a memoirist, 8-9, 159-74; reputation as a gentleman, $83-84$; reputation as an exemplary munsh $\bar{\imath}$ and prose stylist, 5-6, 14-15, 52, 83-84, 100, 259, 270, 325n52; letters, epistolography, 5, 8-9, 10, 23, 24-25, 26, $46-52,54-59,60-64,65,71,76,79,81-82$, 92, 100, 159-60, 172, 174-200, 235, 240-41, 254, 284, 290-94, 313-14n6; correspondence with Shah Jahan, 92, 175, 254, 255; correspondence with Aurangzeb, 54, 57-59, $175,240,254$; correspondence with family members, 6o-64, 179, 189-200, 313-14n6; correspondence with various Mughal nobles and officials, 26, 29-30, 46-50, 52, 79, 175-77, 180-86, 189-90, 240-41; correspondence with poets and literati, 50-51, 179-80, 186-89, 235, 240-41; cultural memory of his (allegedly) close relationship with Dara Shukoh, 241, 251-69, 277-78, 283-85; translation of Dara Shukoh's conversations with Baba Lal 256-58; as the (alleged) author of the first modern Urdu ghazal, 278-82

Chanderi, 154

Chatterjee, Kumkum, 163

Chauragarh, 86-87

China, 3, 113, 316n14

Chingiz Khan: as a Mughal ancestor, 241

Chishti order of Sufi mystics, 32, 146, 150-51, 155, 209, 258, 280, 301n59, 311n37, 312nn52,54

Chittor (fort), 46, 91-92, 94, 136, 255

Chopra, Hira Lall, 14

civility: as a general Mughal cultural and political value, $4,6,17,20,24,27,32,59,61$, $81,82,83-84,86,91,114,201-2,233,249,252$, 260, 270, 293 (see also șulh-i kull); "literary civility" in Mughal cultural and political life, 36-51, 59, 165, 180-91, 194-95, 233; "mystical civility" in Mughal cultural and political life, $59,61-63,65-73,79-80,83-84,161,165-68$, 180-200, 257-58

colonialism, 19-20, 237, 278, 294; effect on modern South Asian historiography, 287-8 cosmopolitanism: at Mughal court, 3, 24, 110, $117-18,127-135,136,138-40,148,153,157-58$,
241, 292, 293; in Indo-Persian literature, 202, 207-9, 211-12, 215-16, 224-27, 234, 236-39, 269

Damghan, 113

Dara Shukoh (Mughal prince, d. 1659): as a patron, 35, 48, 68, 150, 244-45, 256-58, $304 \mathrm{n} 16,312 \mathrm{n} 5 \mathrm{O}$; as commander of failed Qandahar campaign, 46, 242, 256, 258; failure in war of succession to succeed Shah Jahan, 53, 82, 241-44, 310-11n30, 323n10; reputation for liberalism in Mughal historiography (in contrast to Aurangzeb), 244-55, 299n12, 312n5o, 313n62, 323-24n14; as Chandar Bhan's benefactor, supposedly, 241, 251-58, 264-67, 269, 274-75, 278, 281, 283-5; questions about his fitness to rule, $245-51$ 265, 278, 323n10; spiritual dialogues with Baba Lal, 256-58

Dargah Quli Khan (author of Muraqqa'-i Dehlī), 8,142

Darwish Husain, Maulana (Persian calligrapher), 213

dastūr al-wizārat (manuals for wazìrs): as a sub-genre of Indo-Persian advice literature $7,67,82,171$; parts of Chahär Chaman as an example of, 65-84

Dastūr-i Shigarf (treatise on prosody and rhetoric), 50

Data Ganj Bakhsh. See Hujwiri

Da'ud, Maulana (author of Candayan), 202

Daulatabad, 47, 136, 165, 304n14; Mughal conquest of, 85,154

Dayal Das Parasruri (Hindu poet of Persian), 271

Deccan, 3, 7, 106, 113, 129, 136-7, 149, 206, 242, 286; Mughal policy in, 27, 41, 46, 77-78, $80-81,85-86,153-54,172$; as a spiritual center, 154; as a literary center, 206, 213, 280; as a source of good mangoes, 109

Delhi 3, 31, 34, 58-59, 91, 102, 110, 131, 144, 145, $146,147,148,149,243,253,254,256$, 301-2n6o, 309n17; as an ancient seat of power in South Asia, 7, 95-99, 158, 293, 307n5; as a cosmopolitan metropolis, 7-8, 136, 137-39, 293; "old Delhi” (dihli-yi kuhna) in Mughal parlance, 7-8, 141-43; the new city of Shahjahanabad, 45, 137-41; the climate of, 141; law and order in, 123-24; imperial processions through, 129-31; as a spiritual center, 137, 141-42, 253; its tombs and other monuments as tourist attractions, 137 , 142-43; as a literary center, $3,137,139,142$, 209, 216, 222, 224-25, 238, 269-70, 273, 276 
Delhi Sultans / Sultanate (series of north Indian rulers, ca. 1206-1526), 34, 95, 96-98, 155, 222, 286

detachment (bì-ta'alluqī): as a Mughal ethical ideal, 5, 10, 62, 67, 69, 72-3, 79, 161, 191-96, 199; cf. the Bhagawad Gita's notion of niṣkāma karma, 161; cf. the Sanskrit term vairāgya, 161

Dhaka, 156

Dharam Das (f/o Chandar Bhan): in Mughal service, 22; 25-26, 163, 299n15; correspondence with Chandar Bhan, 189-91; Chandar Bhan's admiration for, 189-91; Chandar Bhan's grief, and Shah Jahan's condolences, at the death of, 191, 195-96 dìwānì (Mughal office of fiscal administration), 69, 72, 81, 82, 120, 124-25, 291-92, 305n25; Hindus in charge of, $53,76-77,82,171$; Chandar Bhan's time working in, 3, 32, 70-84, 125, 171-73, 185-86, 255

Diyanat Ray (Hindu munshī of Shah Jahan's reign), 53,76

early modernity: aspects of, in the Mughal Empire, 3-4, 8-9, 11-13, 16-17, 19-21, 22, 28, 51-52, 56, 60-61, 63, 66, 67, 73, 94, 97, 100, $104-5,117-18,130-31,141,142-43,155,162-63$, $176-78,180,198,245,250-51,257,258,259$, 261-63, 267, 272-74, 278, 286-96; and Indo-Persian literary culture, 51-52, 201-39, 302-3n76, 317-18n3o; global context of, 3-4, 8-9, 11-13, 19-21, 73, 100, 141, 178, 198, 201-3, 236-39, 245, 294-95, 298n12, 301n49

East India Company, 6, 7, 28, 100, 163

Egypt, 111, 113, 139, 224, 311n31 epistolary culture. See letter writing

Faiz Allah (brother of 'Aqil Khan Shirazi), 169 "Faizi” Fayyazi, Abu al-Faiz (Mughal poet-laureate under Akbar; d. 1595), 35, 204, 208, 210-17, 220, 224, 234, 235, 237, 316n13, 318-19nn55,62

Farid al-Din Ganj-i Shakar, Shaikh (a.k.a. "Baba Farid”; Chishti Sufi saint, d. 1265), 151, 312n54, 313n55

Faruqi, Shamsur Rahman, 211, 282

Faruqui, Munis D., 242, 247-48, 303n86, 307n1

Farwan, 113

Fazil Khan, Nawab, 271

Fida'i Khan: correspondence with Chandar Bhan Brahman, 49
Fighani Shirazi, “Baba” (poet, d. 1519), 209, 211, 274

Firdausi, Abu al-Qasim (poet, d. 1020; author of Shāhnāma), 11, 210

Fitzgerald, F. Scott, 230

Flood, Finbarr B., 216

"fresh" poetry. See $t \bar{a} z a-g \bar{u} ' \bar{\imath}$

Galen: legacy in Indo-Persian medicine, 34-35, 85

Gang (Braj-Hindi poet; d. ca 1608), 203

Ganges River (a.k.a. Ganga), 31, 143, 281

Ganja (Azerbaijan), 113, 216. See also Nizami Ganjawi

Gascoigne, Bamber, 3

Ghalib, Mirza Asadullah Khan (poet, d. 1869): thought to be the first "modern" letter-writer in Urdu, 176-77

Ghani Kashmiri, Muhammad Tahir (poet, d. 1669), 69

ghazals (lyric poems), 10, 23, 25, 40, 44, 132, 169, 170, 205, 210, 211, 212, 214, 221-25, 239, 258, 261, 299n16; textual circulation of, in Mughal epistolography, 29, 46-51, 175, 182-89, 191, 193-95; as an object of study, 61; as a feature of public performance culture, 121, 139; early modern "fresh" ( $t \bar{z} z a$ ) poetics of, 201-39; Chandar Bhan as author of the first Urdu ghazals, 279-81, 320n75

Ghazali, Abu Hamid Muhammad al- (d.1111), $64,305 n 20$

Ghazali Mashhadi (Persian poet laureate under Akbar, b. 1527), 206

Ghiyas al-Din Mir Miran: early patron of the poet Zuhuri, 212

Gilan, 112, 113, 207

Girdhar Das Kayastha: translator of Ramāyana into Persian, 146-47

Gisu Daraz, Sayyid Muhammad (Chishti saint, d. 1422), 154, 280

Gladwin, Francis (British orientalist), 6-7, 14, 35, 100-101, 290, 297n10, 308nn12,16, $309 n n 17,18,311 n 33$

Goa, 152

Golconda, 85, 153-4, 156; Qutb Shahi Sultanate of, 85-6, 113, 154

Greek / Greco-Hellenic thought in Mughal culture, 4, 34, 35, 85, 122, 301n43. See also Aristotle, Galen, Plato

Guha, Sumit, 163

Gul-i Ra'nā (compendium of literary biographies, 1767-68), 12, 179 
Guldasta / Qawā'id al-Saltanat: as an excerpt of Chahār Chaman, 7, 100-102, 109, 307-8n10, 308n16; Francis Gladwin's translation of, 6 , 7, 14, 100-101, 290, 308nn12,16, 309nn17,18, 311n33. See also Chandar Bhan Brahman

Gulistān (The rose garden; 1258), 61. See also Sa'di Shirazi

Guru Nanak, 202

Habīb al-Siyar (Timurid historical chronicle), 61, 258

Habib, Irfan, 288-89, 327n3

Habsburg Empire, 3

Hafiz Shirazi (poet, d. 1390), 11, 194, 210, 212, 226, 258, $320 n 85$

Hakim 'Abd al-Khaliq (poet), 233

Hakim 'Abd al-Rahim (doctor at the Mughal court), 34

Hakim Fath-Allah (doctor at the Mughal court), 34

Hakim Hamam (brother of Abu al-Fath Gilani), 207, 317 n23

Hakim Haziq (nephew of Abu al-Fath Gilani), 303n8o, 317n23

Hakim Masih al-Zaman (doctor at the Mughal court), 34

Hakim Momina (doctor at the Mughal court), 33

Hakim Muhammad Da'ud (doctor at the Mughal court): as the "Galen of the Times," 34-35

Hakim Nur al-Din (brother of Abu al-Fath Gilani), 207, 317n23

Hakim Salih (doctor at Mughal court), 34

Hali, Altaf Husain (poet, social reformer, d. 1914): as a critic of Mughal prose, 176-78

Hamadan, 113; as the birthplace of various intellectuals, 27, 101, 152, 232, 287, 322n107

Hamadani, Muhammad Sadiq, 27

Hamid al-Din Nagauri, Shaikh (Chishti Sufi saint, d. 1276), 142

Hamisha Bahār (compendium of literary biographies), 12, 269-73. See also Kishan Chand Ikhlas

Harkaran Das Kambuh (Hindu munshī of $17^{\text {th }}$ cent.), 28-29, 292, 300n37; reception of his work among early British colonial intellectuals, 28-9

Hasan Dehlavi (Indo-Persian poet, d. 1338), 210, 234; as the "Sa'di of Hindustan," 224

Hasan Khan Shamlu (Safavid governor of Herat), 186

Hasanāt al-'Ārifīn (Sufi hagiography by Dara Shukoh), 244
Hastings, Warren, 28

Hazin Lahiji, Shaikh 'Ali (poet, critic; d. 1766),

12, 321n10o, 322n121

Hemingway, Ernest, 230

Herat, 61, 113, 139-40, 186, 209, 211, 224, 236, $309 n 17$

Hindi: as Chandar Bhan's native language, 102, 225; literati, musicians, and other intellectuals at the Mughal court, 31, 37, 93, 118, 122, 128; "Hindi books" (kutub-i Hindi) as sources for Persian historiography, 96, 99; "Hindi" swords, 129; early modern literature in, 202-3; so-called sabk-i hindi ("Indian style") of Persian, 204-5, 209, 212-16, 222-6, 229-30, 234, 236-7, 239, 262, 317-18n3o, $321 \mathrm{n} 100,322 \mathrm{nn} 107,121$; as a language for mystical dialogue, 256-7; as the "Hindu" language (contra Persian and "Urdu"), 276, 278-80, 292

Hindus: patronized/employed by the Mughals, $24-25,25-32,49,50,51,53,56,76-77,80-84$, $86-87,93,118-19,122,182,244-45,256-58$, 268-69, 269-72, 301n43, 302n7o, 310n24. See also Chandar Bhan Brahman, munshis, Rajputs

Hindustan, 53, 67, 83, 109, 121, 122, 126, 128, 134, $168,184,246,250,252$; as part of the larger Persianate world, 71, 106, 118-19, 207-8, 224, 226, 277; ancient genealogy of kings in, 95-99; Central Asians and other Muslims as natural residents of, 112; survey of Mughal cities and provinces in, $135-58$

Hotan, 113

Hugli, 87-88

Hujwiri, Pir 'Ali (Sufi saint, d. 1077), 148-49, 182 Humayun, Nasir al-Din Muhammad (Mughal emperor, r. 1530-40, 1555-56), 16-17, 99, $298 \mathrm{n} 2$; his tomb as a tourist attraction, 142-43

Husain Dost Sanbhali, Mir: author of Tazkira-yi Husainī, 12

Husain Sana'i Khurasani (poet), 232

Ibn al-'Arabi, Abu Bakr (philosopher, d. 1148), 198 Ibn Hasan: author of Central Structure of the Mughal Empire, 15

Ibn Sina, Abu 'Ali al-Hussein (a.k.a. "Avicenna”; d. 1037), 34, 198, 208

Ikhlas, Kishan Chand, 12, 269-70, 272

'Ilājāt-i Dārā Shukohī (medical treatise), 35 
imārat (military command/authority): as only one component of good wizārat (governance), 6, 77-81, 168,

'Inayat Khan (Mughal governor of Punjab under Jahangir; d. 1618), 29, 30, 69, 88, 181, 255, 3oon 39, 301-2n59

'Inayat Khan (historian, d. 1670-71), 69, 88, 255, 30on39, 306-7n 49

Indus river, 152

insha' (stylized/creative prose), 28, 36, 50, 67, 82, $100,127,186,188$, 295; as an underutilized source for cultural history, 8, 10-11, 13, 104-5, $178-80,272,290-3,316 \mathrm{n} 11$; as an essential genre in Mughal political and administrative culture, 6o-61, 64-65; Chandar Bhan's works as models of, 5-6, 14-15, 52, 100, 259, 270, 325n52; British colonial interest in, 6, 28-29, 100; Shah Jahan's expertise in, 127; as a medium for self-fashioning, 171-76. See also secretarial arts

Inshä'-yi Harkaran (a.k.a. Irshād al-Tālibìn), 28, 46. See also Harkaran Das Kambuh, Francis Balfour

Iradat Khan Wazih (poet), 232

Iradat Khan (Mughal nobleman), 30, 70

Iraq, 37, 112-3, 118-9, 128, 208

Isfahan, 113, 209, 230, 273

Isfahan School of Persian philosophy, 198 Isfarayin, 113

Islam Khan Mashhadi (Mughal wazir under

Shah Jahan, d. 1647), 25, 32, 88, 171-72, 175, 177; as a literary connoisseur, $40-43,76$, $175-76,182-84$; as a master of secretarial arts, 77; administrative style of, 76-78, 83; correspondence with Chandar Bhan, 175-76, $177,181,182-84,185$

Islamic new millennium, 202

I'tibar Khan, 28-29

I'timad al-Daula, Mirza Ghiyas Beg (Mughal wazir under Jahangir, d. 1622), 69

I'tiqad Khan, 49, 143

Ja'far Khan (Mughal wazìr under Shah Jahan and Aurangzeb, d. 1670), 32, 45, 53, 81-82; correspondence with Chandar Bhan, 53 , $81-82,181,185-86$

Jagannatha Panditaraja (Sanskrit poet and intellectual at Shah Jahan's court), 31

Jahan Ara (Mughal princess, a.k.a. "Begum Sahib"), 26, 144-5, 293; as a beloved figure at court, 32-33; accidental burning and recovery of, $32-33,35-36,38,39,40,293$, 301-2n 59; as a patron, $144-45$

Jahangir, Nur al-Din Muhammad (Mughal emperor, r. 1605-27), 2, 39, 52, 56, 76, $88,145,146-7,252,287,300$ 39, 310n3o; reputation for indolence and mediocrity in modern historiography, 17-18, 252; his reign as witnessing the beginning of Mughal decline, 18-19; his intellectual curiosity, 19; Chandar Bhan's early career under, 25-31, 181; notable administrators under, 69-70; detente with Rana Amar Singh of Mewar, 91, 93; patronage of architecture, 27-28, 154; patronage of mystics, 155; patronage of Sanskrit literature and Persian translations, $31,147,198,218$; patronage of poets, 206, 212-13, 262

Jai Singh I, Raja of Amber (d. 1667), 45, 247 Jai Singh II, Sawai, Raja of Amber (founder of Jaipur, d. 1743): as a patron and astronomical savant 31

Jalal al-Din Bukhari, Shaikh/Sayyid (a.k.a. "Makhdum-i Jahaniyan Jahan Gasht"; Sufi saint, d. 1384), 151, 156, 313n 55

Jalal Hisari, Shaikh (historian, administrator; d. 1660), 83

Jalal Khoka, Shaikh (Sufi saint of Multan), 151 Jam, 113

Jamali, Mulla Hamid bin Fazl Allah (Sufi saint-poet, d. 1535), 142

Jami, Nur al-Din 'Abd al-Rahman (poet, d. 1492), 61, 211, 216, 236; his Yüsuf wa Zulaikha, 227

Janamajeya (legendary king of ancient India), 96 Jats: rebellions under Aurangzeb, 48-49

Jaunpur, 203

Jayasi, Malik Muhammad, 202

Jerusalem, 140

Jigar Barelvi, 279

Jismi Hamadani, Kamal al-Din (poet, d. ca. 1615), 232

Johnson, Samuel, 12, 295

Joyce, James, 230

Jujhar Singh Bundela, 86-87

Jumna River, 58

Jwalamukhi (Hindu temple): as a pilgrimage destination, 149

Kabir (bhakti poet-saint), 202

Kabul, 7, 37, 40, 43-44, 69, 88-89, 134, 136, $149-150,152-3,168,170,230,301,309$ 
Kai Ka'us ibn Iskandar, 64

Kaifi Dihlavi, Brij Mohan Dittatriyah (author of Kaifiyyah, 1942): on Chandar Bhan as the progenitor of Urdu literature, 279

Kalim Kashani, Abu Talib (poet laureate under Shah Jahan, d. 1651), 229, 262, 287

Kalimāt al-Shu'arā (compendium of literary biographies), 12, 229, 259-60, 270, 272-3

Kalinjar, 47

Kalpakh, Mehmet, 237

Kamal al-Din Isfahani (poet, d. 1237), 211, 233

Kangra Fort, 149

Kārnāma (Book of deeds; work of literary criticism by Munir Lahori), 233-36

Kashan, 12, 212, 215, 229, 235; velvets from, as a luxury item at Mughal court, 128, 131

Kashfal-Mahjūb (Revelation of the veiled; treatise on Sufism), 149. See also Hujwiri

Kashghar, 113

Kashmir, 7-8, 37, 42-43, 69, 109, 119, 134, 136, $149,152-3,170,172$

Keshav Rai temple (Mathura), 48

Keshavdas (Braj-Hindi poet), 203

Khalil Allah Khan (Mughal governor of Delhi province under Shah Jahan), 43, 143; rumors of his wife's infidelity with Dara Shukoh, 247

Khan Jahan Lodi (a.k.a. Pir Khan, Pir Afghan), 86

Khan-i Dauran Bahadur Nusrat Jang (d. 1645), 43, 87; murder of, $77-78$

khānazāda / khānazādagì (being a "son of the imperial household"): as an honor conferring duty and privilege among Mughal notables, 42

Khandes, 136, 154

Khaqani Shervani (poet, d. ca. 1190), 11, 208, 210, 211, 235

Khing Suwar, Miran Sayyid Husain, 155

Khizr (prophet), 216

Khujand, 212

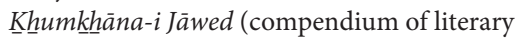
biographies), 279-80

Khurasan, 37, 112-3, 118-9, 128, 208, 212, 225

Khwaf, 113

Khwaja 'Abd al-Razzaq, 150

Khwaja Bhag Mal, 180

Khwaja Qutb al-Din, 142

Khwaja Sagar Mal, 25

Khwushgu, Brindaban Das, 12, 272-3, 325n43

Khusrau Parwez (grandson of Anushirwan, noted hero of Persian romance literature), 228
Khusrau Sultan (Uzbek prince): defection to Mughals, 90-91

kingship: Mughal practice of jharoka darshan as a form of Indian kingship, 309n20; Chandar Bhan's views on, 6-7, 95-158, 293; tension between king's desire for worldly vs. spiritual power, 257-58; questions about Dara Shukoh's fitness to rule, 241-51, 278

Koch, Ebba, 19, 144, 145

Krishna: in early Braj devotional poetry, 203

Kunji Das (Hindu munshi of Shah Jahan's reign), 49

Lahiri (port near Thatta, Sindh), 136, 153

Lahore, 7, 9, 25, 29, 39, 42, 43, 49, 77, 102, 129, 131, 301n56, 316n16; as Chandar Bhan's home town, 4, 22, 25, 56, 70, 163, 169, 181, 182, 205, 256, 270; as a literary center, 3, 71, 147-48, 205, 210, 225, 322n107; as a center of mystical culture, 147-50, 182, 312n48; Mughal architecture of, 27-28, 49, 110, 147-48, 149, $181,182,270$; as a Mughal provincial center, 110, 124, 147-50, 168, 181; as a cosmopolitan metropolis, $8,136,137,147-50,225,293$; as a crossroads between India and Central Asia, 148-49, 225

Lahori, 'Abd al-Hamid (historian of Shah Jahan's reign), 101

Lala, Sri Ram, 279-80

letters, letter writing, 5, 8-9, 10, 23, 24-25, 26, 29-30, 54-59, 60-65, 70, 71, 72-73, 76, 79, 81-82, 92, 100, 159-60, 172, 174-200, 235, 240-41, 254, 255, 284, 290-94, 313-14n6; as a space of social intimacy, 46-52, 174-91, 240-41; as a medium for the circulation of poetry, 46-52, 174-200; as a medium for self-fasioning, 159-6o, 174-200

Lìlāvatì (Sanskrit mathematical treatise): Faizi's Persian translation of, 214

Lisani, Maulana (poet, d. 1534), 232

literary civility. See civility

literary criticism (Indo-Persian): 201-17, 229-39, 287, 317-18nn23,30, 320nn82,85, 321n10o, 322n121, 323n132

Lodi, Sher Khan (literary biographer), 12, 56, 232, 264-69, 270, 272-75, 276, 277, 282, 283, 295, 326n63

Losensky, Paul, 209, 211, 229, 274

Ma'ạsir al-Umarā' (compendium of Mughal political biographies), 26, 76 
Ma'āsirir-i 'Ālamgìrī (chronicle of Mughal Emperor Aurangzeb's reign), 58

Ma'āsir-i Rahìmī (chronicle of Mughal grandee ‘Äbd al-Rahim Khan-i Khanan's court), 207-8, 212-3, 217, 232

Machiavelli, 64

Ma'dan al-Shifá'-yi Sikandar Shāhī (medical treatise), 34

Madhumālatī, 202

Madhya Pradesh, 154

Madrasa Shahi (King's College) mosque in Agra, 26

Mahabat Khan, 142-3, 247

Mahir, Mirza Muhammad Ali (poet, d. 1678), 264

Mahābhārata, 7, 73, 96, 158, 214

Maharashtra, 153, 163

Mahāsin al-Kalām (poetic anthology by Bhupat Rai), 50

Mahmud of Ghazni, 96

Majma' al-Afkār (a miscellany of Mughal prose works), 180

Majma' al-Bahrain (treatise on comparative religion by Mughal prince Dara Shukoh; 1655), 245

Majma' al-Nafä'is (compendium of literary biographies), 12

Majnun, 47, 228, 319n62, 321n88

Makhzan al-Gharä'ib (compendium of literary biographies), 12, 275

Makramat Khan, 143, 168

Maktūbāt-i Muḳhtalifa (a.k.a. Majmū'a-e Khhutūt), 179, 314n12

Malwa, 7, 53, 82, 136, 154, 30on33

Ma'mur Khan. See 'Abd al-Karim Ma'muri

Mandu (fort), 27-28, 154, 30on33

Mangalore, 152

$m a^{i} n \bar{\imath} a \bar{a}$ rīni (poetic meaning creation), 45, 212, 232,238

Manjhan, Mir Sayyid, 202

manșabdār (Mughal "rank-holder"), 22, 87, 163, 169

Manucci, Niccolao (Italian traveler and memoirist), 246, 323nn9-10

ma'rifat (spiritual gnosis), 6, 96, 152, 192, 257; as a crucial component of good wizārat (governance), 6, 65, 67-69, 72-73, 83

Mashhad, 113, 186

Masnawi-yi Kaj-Kulāh, 250

Mas'ud Sa'd Salman (poet, $11^{\text {th }}$ c.), 148, 210

Mathura, 48

Mathura Das (Hindu Persian poet, f/o Harkaran Das munshī), 28 māwarā' al-nahr. See Transoxiana

Mazandaran, 113

maz̧mūn âfrīni (invention of a new literary theme), 212. See also ma'nī äfrīnī

medicine / medical science at the Mughal court, $32-35,118$

memoir. See autobiography

Merv, 113

Mewar, 84-85, 91, 93-94, 175, 240, 255

millenarianism: in Mughal intellectual culture, 202, 307n1, 315n2

Minkowski, Christopher, 163, 305n18, 324n25

Mir Damad. See Muhammad Baqir al-Astarabadi

Mir Dard, Khwaja (poet, d. 1785), 262

Mir Fakhr al-Din (Sufi mystic of Shah Jahan's era), 150

Mir Findarski (Safavid philosopher), 198

Mir Jumla II, Mir Muhammad Sa id Ardastani (a.k.a. "Mu'azzam Khan"; d. 1663), 32, 53, 78, $80-81,83,125$

Mir Jumla I (Shahrastani; d. 1637), 69

Mir Khwand (historian, d.1498), 121, 310nn25,27

Mir Taqi Mir (poet, d.1810), 263

Mirabai (bhaktī poet-saint, d.1557), 202

Mir'àt al-Khayāl (compendium of literary biographies), 12, 42, 56, 232, 265, 267, 295

Mirigāvatī, 202

Mirza Husain (baker in Shiraz), 213

Mirza Muhammad Husain (calligrapher), 24

Mirza Shukr Allah Shirazi. See Afzal Khan

Miyan Bhuwa, 34

Miyan Mir (noted Qadiri Sufi saint, d. 1635), 69, 149-50, 312n5o

Mohiuddin, Momin, 15, 122

Moorcroft, William, 100

Mu'azzam Khan. See Mir Jumla II

Mughal Empire: and global early modernity, $3-4,8-9,11-13,19-21,73,100,141,178$, 198, 201-3, 236-39, 245, 294-95, 298n12, $301 n 49$; in modern historiography and other scholarship, 1-2, 5, 8, 10-15, 16-21, 28, 41, 48, 51-52, 54, 56-57, 59, 94, 95, 97, 99, 100, 104-5, 106, 111, 122, 130, 132, 149-50, 157, $162-63,166,176-78,185,204-5,211-12,213$, 214, 222-23, 229-30, 232, 234-39, 241-58, $272,275-85,286-96,307 \mathrm{n} 1,310-11 \mathrm{n} 30$, $312 \mathrm{n} 42,324 \mathrm{n} 16$; administrative culture, 3-7, $10-11,15,16-17,21-32,34,38-39,43,46-53$, $55-59,60-84,85,89-90,94,99,102,106$, $114-17,119-21,123-27,131-35,143,146-47$, 149, 162-73, 180-86, 199-200, 201, 205, 206, 
207, 242-43, 249, 254, 265, 267, 268, 288-93, 305nn19,20, 307n1, 310-11n30; religious and ethnic pluralism in, 25-32 (see also civility, tolerance, sulh-i kull); patronage of Hindu intellectuals under, $30-31,53,76-77,80-82$, $93,118-19,122,182,244-45,261-63,310 n 24$; scientific culture under, 30-31, 32-35, 118, 301-2n6o, 310n24; literary culture of (see Hindi, Sanskrit, Persian/Indo-Persian literary culture); mystical culture under (see Sufis/Sufism). See also Chandar Bhan Brahman, Akbar, Jahangir, Shah Jahan, Aurangzeb, Dara Shukoh

Muhammad Amin Khan (s/o Mir Jumla II), 8o-81, 306n33

Muhammad Baqir al-Astarabadi (philosopher, a.k.a. "Mir Damad"; d. 1631), 198

Muhammad Shah (Mughal emperor, r. 1719-48), 31,273

Muhtasham Kashani (poet, d.1588), 215

Mu'in al-Din Chishti (Sufi saint, d. 1236), 155, 301-2n59

Mujarrabāt (medical treatise by Hakim Abu al-Fath Gilani), 208

Mukhlis Khan, Qazi Nizama Karhardu'i: correspondence with Chandar Bhan, 49-50; as a literary connoisseur, 50

Mukund Das Kayastha, Ray (Hindu munshi of Jahangir and Shah Jahan's reign): relationship with Asaf Khan, 30, 70

Mulla Sadra (philosopher, d. 1640), 198, 315n37

Mulla Shah (Qadiri Sufi saint in Shah Jahan and Aurangzeb's reign, d. 1661), 149-50, 312n50

Mulla Shaida (poet, d. 1669), 51, 235, 303n8o, 322n117

Multan, 7, 28, 129, 136, 143, 151-53; as a cultural and spiritual center, 151-52, 320n8o

Mumtaz Mahal (Mughal queen, a.k.a. Arjomand Banu Begum, d. 1631), 1, 30, 33, 56, 145, 241

Muni Ram Sahu (Hindu munshī of Shah Jahan's reign), 49

Mun'im Khan (wazìr under Akbar): as a model for later administrators, 68

Munir Lahori, Abu al-Barakat (poet and literary critic, d. 1645): friendship and correspondence with Chandar Bhan, 51, 179, 188-9, 241, 276; as a literary critic, 233-6, 322n117

Munkar and Nakir (Muslim angels of death), 76

Munsha'ät-i Brahman, 5-6, 15, 47-48, 49, 50, $54,57-58,60,80,92,174-76,177,179-80$, $181,186,192,193,206,255,275,277,284,290$, 303n 89,304 n 3 munshīs (secretaries): 46, 62, 290; Hindu munshīs as a "caste," 5; as literati, 36-52; training necessary for the elite, or "true munsh"̈ (munshī-yi haqīqi) , 36, 60-65, 175, 179; and "mystical civility," 65-84; everyday relationships with patrons/employers, 25-32, 65-84; as models of gentlemanly conduct, 65, 67-68, 83-84, 116. See also Chandar Bhan Brahman

Muqarrab Khan (doctor at the Mughal court), 34 Murad Baksh (Mughal prince, s/o Shah Jahan), $46,89,152,154,242-3,310-11 n 30$

Muraqqa'-i Dihlī, 8, 142,

Musa (a.k.a. Musawi) Khan, Mirza Mu'izz (jurist under Shah Jahan), 39, 72-73; as a poet, 271

muta'äkhkhirin ("moderns," in Indo-Persian literary parlance), 11, 148, 203, 208-10, 232, 294

Mu'tamad Khan Bakhshi, Muhammad Sharif (Mughal grandee, d. 1639-40), 40, 168, $301 n_{56}$

mystical civility. See civility

Nahawandi, 'Abd al-Baqi (historian and compiler of literary biographies, d.1637), 208, 210, 232-3

Nand Rai (Hindu munshī of Shah Jahan's reign), 87

Narayana Rao, Velcheru, 283

Nașinhat al-Mulūk: as a genre, 63-64; Ghazali's, 64; Sa'di Shirazi's, 258

Nasir al-Din "Chiragh-i Dehli," Shaikh (Chishti Sufi Saint, d. 1356), 142

Nasir al-Din Tusi, 64

Nasir 'Ali Sirhindi (poet, d. 1696-97), 232

Nau'i Khabushani (poet, d. 1609), 216-7, 223, 319n64

Nazar Muhammad Khan (Uzbek ruler of Balkh and Badakhshan), 88

Naziri Nishapuri, Muhammad Hussain (poet, d. 1614-15), 212, 223

Nik Rai (Hindu munshī of Aurangzeb's reign), 231

Nilakantha Chaturdhara (Sanskrit philosopher), 73, 305n18

Nishapur, 113

Nishtar-i 'Ishq (compendium of literary biographies), 12, 276

Nityananda (Sanskrit intellectual, astronomer), 31, 301n43. See also Asaf Khan

Nizam al-Din Auliya, Shaikh (Chishti Sufi saint, d. 1325), 142, 209 
Nizam al-Mulk, Abu 'Ali Hasan ibn 'Ali Tusi (Saljuq wazir and political theorist, d. 1092), 64, 305n20

Nizami Ganjawi (poet, d. 1209), 210-11, 208, 216, 235; his five epic romances (the "Panj Ganj" or "Khamsa"), as a model for later poets, 211; his Khusrau wa Shìrīn, 216-17, 227-28; his Layla-Majnūn as a model for Faizi's Nal-Daman, 319n62

Nizam Panipati: his translation of Yoga Vasishta, 198

Nizami 'Aruzi Samarqandi (political theorist, d. ca. 116o), 64, 305n19

Nur al-Din Muhammad 'Abd Allah Shirazi (Mughal physician and scientist), 34-35

Nur Jahan, Mihr al-Nissa (Mughal empress, d. 1645), 18, 30, 145

O'Hanlon, Rosalind, 163

Old Delhi (dihlī-yi kuhna). See Delhi

Orientalists: influence of Mughal scholarship on, $6,100,124,178,277,288$

Orissa, $7,136,149,156$

Ottoman Empire, 3, 86, 106, 113; fresh (tāza) poetry in, 236-37; millenarian discourse in, 315n2

\section{Padmāvat, 202}

Pādshāh Nāma, 101

Pakistan, 5, 77, 152, 177, 294, 299n12, 313n55, $326 \mathrm{n} 1$. See also partition

Pandavas, 96

Panipat, 142

Paris, 230

Parker, Charles H., 20

partition of India (1947), 19, 244, 252, 278, 299n12

Patna, 276

Pepys, Samuel, 9

Persian émigrés at Mughal court, 26, 34, 207-8, 233-4, 241, 262

Persian Moonshee, 6-7, 100, 290. See also Francis Gladwin

Persian / Indo-Persian literary culture: cosmopolitanism of, 3, 139-40, 147-49, 153, 201-39, 32onn $8 \mathrm{o}, 82,85,321 \mathrm{n} 10 \mathrm{o}, 322 \mathrm{n} 121$; and mysticism, 3-4, 9-10, 46, 146, 147-49, 160-61, 165-67, 206, 261-2, 264; and civility, $36-46,59,160-61$; in Mughal court culture and politics, $6-7,10-11,17,21,60-66,67$, $69,70,71,73,76,79,81,83-84,85,90-91,111$, $132,165-67,170-71,201-39,240-41,256-85$, 302n73, 304n13, 308n15, 321n88; epistolary circulation of, 8-9, 29, 46-52, 174-200; early modern experimentation in, 11, 170, 201-39, 259, 317-18n3o (see also tāza-gū $\bar{\imath}$ ); Hindu literacy in, 3-5, 21-25, 28-29, 87, 162-64, 170-71, 290-92; biography in (see tazkiras); in modern cultural historiography, 13-15, 201-39, 249, 251-54, 256-85, 287-96

Plato, 27, 46, 70, 72, 74, 85, 127, 208, 314

Podder, Tanushree, 18

political Islam, 4, 17, 20, 151, 287

Portuguese: alleged mischief of in Hugli, 87-88

Pound, Ezra, 204

Pran Nath: correspondent of Chandar Bhan, 25 Pratap Ray Kayastha, 24

Prem Narayan: Gond chieftain murdered by Jujhar Singh Bundela, 86-87

Punjab, 8, 43, 49, 51, 77, 81, 149, 168, 301-2n6o, 306-7n49; as Chandar Bhan's home region, 2, 21, 160, 256; Persian literacy in, 22-24; as part of the larger Persianate world, 225; antelopes from, 118; horses from (Sunujis), 129; ideas about caste in, 163. See also Lahore

Qa'ani Shirazi, Mirza Habib Allah (poet, d. 1854), 212

Qābūs Nāma (Persian "mirror for princes"), 64

Qadiri Sufi order, 32, 69, 149-50, 244, 312nn48,50. See also Miyan Mir, Mulla Shah

Qaiqubad, Mu'izz al-Din (Sultan of Delhi, d. 1290), 97, 307n 3

Qanauji, Sayyid Muhammad, 151, 312n52

Qandahar, 7, 113, 136, 149; Mughal capture of, 44, 156; subsequent loss of, and failed Mughal attempts to recapture, $46,88,156-57,242$, 247-48, 256, 258; spiritual life of, 156-57

Qasemi, S. H., 174

Qasim Khan (Mughal governor of Bengal under Shah Jahan), 87

Qawā'id al-Saltanat-i Shāh Jahān. See Guldasta, Chahār Chaman

Qayin, 113

Qazwin, 113

Qom, 113

Qudsi Mashhadi, Muhammad Jan (poet laureate under Shah Jahan, d. 1646), 37, 51, 186-88, 235, 241, 322n117; correspondence with Chandar Bhan, 51, 180, 186-88

Qureshi, I. H., 19

Qureshi, Wahid, 271-72

Qistās al-Atibbā' (Scales of the physicians), 34

Qutb al-Mulk. See Golconda

Qutb Shahi Sultanate. See Golconda

Qutban Suhrawardi, Shaikh, 202 
Ra‘d Andaz Khan (Mughal official under Aurangzeb): correspondence with Chandar Bhan, 49-50; patronage of Bhupat Rai munshī, 50

Radha: in early Braj devotional poetry, 203

Raghunath Ray Kayastha (a.k.a. "Ray-i Rayan" or "Raja Raghunath"; Hindu munshī under Shah Jahan, wazir under Aurangzeb; d. 1664), 6, 53, 80-82, 94, 125, 244

Raj Mahal (Bengal), 156

Raj Singh, Rana (Rajput ruler of Mewar, r. 1652-80), 85, 91-94, 255-6

Raja Dhokal Singh: correspondent of Chandar Bhan, 24

Raja Jiwan Jit (medieval ruler of northern India), 96

Raja Muhkam Singh: correspondent of Chandar Bhan, 24

Raja Najab Singh: correspondent of Chandar Bhan, 24

Raja Suraj Pal (Tomar ruler of northern India, $10^{\text {th }} \mathrm{c}$.), 96

Rajputs: Mughal political relations with, 17, 86-87, 91-94, 155, 240, 241, 244, 247, 305n22; presence at the Mughal court, 40, 45, 112, 132, 153; literary and intellectual patronage by, 31, 203, 298n17, 301n43; Persian correspondence with Chandar Bhan, 24, 179

Ràmāyana, 147, 203

Rāmcaritmānas, 203

Rasagangādhara (Sanskrit work of literary theory), 31

Rasa'i, Shaikh Muhammad Sharif (Afghan Sufi saint of Shah Jahan's era), 150

Rauzat al-Ṣafā, 61, 121, 310nn25,27

Rauzat al-Salātìn, 61

rawish (mode, manner): as a literary term, 208 , 209-10, 229, 232

Ray Bhan (b/o Chandar Bhan), 23, 164, 191, 194, 304n14

Ray Gobind Das: correspondent of Chandar Bhan, 24

Ray Mohan La'l: correspondent of Chandar Bhan, 24

Ray Thakur Das: correspondent of Chandar Bhan, 24

Razi Danish Mashhadi, Mir (poet, d. 1665), 233

Renaissance, 237

Richards, John F., 5, 18, 19, 41, 312n50

Risāla-i Haqq-numā (mystical treatise by Mughal prince Dara Shukoh, 1646), 245
Riyāz al-Shu'arā (compendium of literary biographies), 12, 273-6

Rizwi Khan, Sayyid 'Ali (s/o Sayyid Jalal, d. 1680 ), 50

Rukn-i 'Alam Suhrawardi, Shaikh (a.k.a. Shaikh Rukn al-Din), 151, 312n53

Rumi, Jalal al-Din (poet, d. 1273), 11, 210, 226, 228,320085

Runi, Abu al-Faraj (poet, 11th c.), 148, 234

Sabab-i Sitta-yi Rashīdī (Mughal medical treatise), 35

Sabha Chand (Hindu munshī of Shah Jahan's reign), 76

sabk-i hindī (so-called "Indian style" of Persian literature), 204-5, 209, 212-5, 222-4, 226, 229-30, 232, 234, 236-7, 239, 262. See also tāza-gù $\bar{\imath}$

Sabzawar, 113

Sa'di Shirazi, Muslih al-Din (Persian poet; d. 1292), 11, 61, 208, 210, 224-5, 235, 258-9, 266, 273, 320n8o

Sadiq Khan, 69

şadr (Mughal judicial position), 39

Sadr al-Din 'Arif, Shaikh (Suhrawardi Sufi saint, d. 1286), 151, 312n 53

Sa'd Allah Khan (wazir of Shah Jahan; d. 1656), $6,32,42,53,125,150,289,292,306 \mathrm{n} 48$; relationship with Chandar Bhan, 43, 78-80, 89-90, 172, 184-85, 186, 255; correspondence with Chandar Bhan, 177, 178, 181, 184-85; as a literary connoisseur, 43, 184-85; mystical inclinations of, $79-80,150,161$; as a military commander, 46, 78, 89-90, 92, 94, 172, 240, 256; reputation as a wise and able administrator, 78-80, 81, 83, 84, 89-90, 106, 172; death, and sadness at the death, of, 53 , $80,173,293$

Safavid Empire, 86, 88, 106, 156, 336

Safina-yi Kh $\underline{h} w u s h g \bar{u}$ (compendium of literary biographies), 12, 273

Safinat al-Auliyā' (Sufi hagiography by Mughal Prince Dara Shukoh), 244

Sa'ib Tabrizi, Mirza Muhammad 'Ali (poet, d. 1676), 69, 207, 229-32, 235; inclusion of Chandar Bhan's poetry in his personal anthology (bayāz), 51, 230-31; as a purveyor of the supposed "Indian style" of Persian poetry, 223, 229-30, 321n93; as a "fresh" (täza) poet, 229, 231-32

Sakinat al-Auliy $\bar{a}$ ' (Sufi hagiography by Mughal Prince Dara Shukoh), 244 
Salih Kambuh, Muhammad (Mughal historian): friendship with Chandar Bhan Brahman, $52-53,179,217-18,220,241$; author of 'Amal-i Șālih, (a chronicle of Shah Jahan's reign, a.k.a. Shāh Jahān Nāma), 12, 229, 255, 270-71, 304n16; author of Bahār-i Sukhan (Springtime of expression), 52, 179; as a source for later writers (e.g. Kishan Chand Ikhlas), 270-72, 274, 276-77, 325n52

Samarqand, 113, 209

Samudrasangama (Sanskrit translation of Majma' al-Bahrain) 245

Samugarh, 247

Sana'i Ghaznawi, Hakim (poet, d. ca. 1140), 210 Sandelvi, Shaikh Ahmad 'Ali Hashimi, 12, 275-76 Sanskrit, 7, 73, 96, 135, 158, 161, 316n11; as the language of Chandar Bhan's ancestors, 4; early modern "new intellectuals" in, 11, 202-3, 298n17; regional traditions in, 227; Mughal patronage/translations of, 17, 31, 35, $245,256,301 n 43$

Sarangpur, 154

Sarkar, Jadunath, 248, 290

Sarkhwush, Muhammad Afzal (poet, noted biographer of poets, d. 1714), 12, 229, 259-61, $263-5,267,269-74,276-9,282-3$

Sarmad, Muhammad Sa'id Hakim (itinerant mystic of Shah Jahan's era, d. 1661), $252-53,254$

Saronj, 154

sati / jauhar: as a trope in Indo-Persian literature, 216-17, 319n64

Sati al-Nisa Khanum, 26 satire: in Indo-Persian literature, 189, 251, 263, 264,282

Savgan, 113

Sayyid 'Alam (darwesh of Manji), 150

Sayyid 'Ali Hamadani, Mir (Kubrawi Sufi saint, d. 1384), 101, 152

Sayyid Jalal Bukhari, Mir (judge under Shah Jahan, d. 1647): literary aspects of correspondence with Chandar Bhan, 50

Sayyid Muhammad Murtazá Qadiri, 190, 290 Sayyid Yusuf Gardezi, 151

Schimmel, Annemarie, 41, 151, 218, 253

Schopenhauer, Arthur, 245

Schofield, Katherine Butler, 31

secretarial arts (funūn-i dabīrī, munshīgirì): and social mobility, 22-25, 64-65, 163-66, 170-71; and Mughal governance, 64-65, 67-84, 116, 127, 293. See also inshä', munshīs

secretaries. See munshīs self-fashioning, 4, 8-9, 159-200, 294, 295, 298n12. See also autobiography/memoir Shafiq, Lachmi Narayan, 12, 179

Shah 'Abbas I (Safavid ruler, r. 1571-1629), 70, 213 Shah Burhan al-Din. See Burhan al-Din Gharib Shāh Jahān Nāma, 69, 88, 99

Shah Jahan, 3, 5-9, 21, 27, 28, 59, 64, 141, 142, $143,165,241,280,287,289,292,300-1 n 39$; as builder of the Taj Mahal, 1-2, 21; imprisonment, death, and burial at Taj Mahal, 56, 82, 173; reputation for severity/ orthodoxy in modern historiography, 1-2, $18-19,41,59,68,105,111,122,124,132,176$, $185,250,252,277-78,281,293,295,310-11 n 30$, $312 \mathrm{n} 42$; mystics and mystical culture under, $7-8,9,141-42,146,147-57,164-67,182,253$, 256-57, 312nn50,52; patronage of Hindu intellectuals under, $30-31,53,76-77,80-82$, $93,118-19,122,182,244-45,261-63,310 n 24$; scientific culture under, 30-31, 32-35, 118, 301-2n6o, 310n24; literary culture under, 31, $36-52,118,142,147-48,153,179-80,183-85$, 186-89, 191-200, 203-6, 210, 217-36, 294, 302n64, 304n16, 308n15; displays of emotion by, 33, 75-76, 80, 166-68; administrative culture under, 65-84, 309n20; as an administrator himself, 110-111, 114-17, 119-21, 123-7, 293; military and diplomatic policy of, 84-94, 152-53, 154, 156-57, 255-56; legitimacy as an Indian sovereign, 95-96, 99-100, 157-58, 293; as a just ruler, 102-6, 110, 119, 132-33, 146, 158, 310n25; charity and public works under, 35, 37, 110, 115, 120-21, 306-7n49; law and order under, 134-35; court culture, style of governance under, 100-58; pluralism/diversity at his court, 109-14, 118, 136, 138-39, 293-94; daily life in his mobile court/camp, 131-35; urban culture under, 135-49; interest in history, 121-22, 310n25; succession crisis at end of his reign, and its historiographical implications, 241-51; evidence of his good personal relationship with Chandar Bhan, 5, 31-32, 39-40, 42, 102, 169-71, 172-73, 196, 240, 257, 260-61, 270, 293; Chandar Bhan's letters to, 175, 181, 254; anecdotes about, and cultural memory of, an alleged angry encounter with Chandar Bhan, 259-69, 273-75, 281-85

Shah Shuja' (Mughal prince, s/o Shah Jahan), 53, $82,156,242-43,310-11 n 30$

Shah Tahmasp I (Safavid ruler, r. 1524-76), 207 Shah Zain al-Din. See Zain al-Din Shirazi 
Shahjahanabad, 7-8, 45, 144, 283; as a cosmopolitan urban metropolis, 8, 136-41. See also Delhi

Shahr-i Safa (fort), 156

Shaikh Baha'i. See Baha al-Din Muhammad al-'Amili

Shaikh Jalal Hisari, 83

Shaikh Jalal Makhdum-i Jahaniyan. See Jalal al-Din Bukhari

Shaista Khan, Mirza Abu Talib (Mughal grandee, s/o Asaf Khan; d. 1694), 247

Shām-i Gharībān (compendium of literary biographies), 12

Shamakhi, 113

Shankar Das: correspondent of Chandar Bhan, 25

Sharaf al-Din Bu 'Ali Qalandar Panipati, Shaikh (Sufi saint, d. 1324), 142

Shearman, John, 237

Sher Shah Suri, Farid Khan (founding ruler of Sur Dynasty of northern India, d. 1545), 16, 99, 292

Shihab al-Din Suhrawardi (Sufi saint, d. 1208), 198

Shirwan, 113

Shiv Ram (Hindu munshī of Aurangzeb's reign; literary apprentice of Chandar Bhan), 271-72

shudras: Persian literacy among, 24, 299n20

Shulman, David, 227, 283

Sialkot, 77

Siddhāntasindhu (Sanskrit translation of Zijj-i Shāhjahānī). See Zīj-i Shāhjahānī.

Siddiqi, W. H., 174

Sikander Lodi (Sultan of Delhi, d. 1517), 34

Sikandra (suburb of Agra, site of Akbar's tomb), 43

Sikhs, 32

Simnan, 113

Sindh, 98, 153, 253. See also Thatta

Sirāj-i Munīr (work of literary criticism), 235, 322nn117,121. See also Arzu

Sirr-i Akbar (Persian translation of Upanishads), 245. See also Dara Shukoh

Sistan, 113

Siyadat Khan, 143

siyāq (accounting). See accounting

Siyāsat Nāma (Treatise on government, $11^{\text {th }}$ c.), 64

sovereignty, 94, 199, 202, 307n1; Mughal

sovereignty as mythical in origin, 95-99;

Shah Jahan as an ideal sovereign, 102-9. See also kingship

Soz-o-Gudāz (Burning and melting), 216-7, 223, $319 n 64$

Speziale, Fabrizio, 35
Subrahmanyam, Sanjay, 15, 85, 196, 286, 319n62

Sufis, Sufism, 5, 9-10, 11, 22, 32, 98, 137, 142,

$147-49,152,154,155,157,175,182,191-200$,

268, 270, 280, 312nn48,50,54, 315nn2,8;

Mughal patronage of, $8,32,111,120,146$,

149-51, 244-45; Sufi mysticism as an element of Mughal political culture, 61-63, 65-84, $105,126-27,160-62,164-67,244-45,257-58$ (see also mystical civility); as an influence on Indo-Persian literary culture, 3, 9-10, 160-61, 202, 209, 215-16, 217-22, 229, 270

șulh-i kull (universal civility): as a general feature of Mughal culture and politics, 4, 25, 28, 86, 91, 92, 114, 201, 233, 270, 315n2; restrictive interpretations of in modern historiography, 17-19, 252, 293. See also civility

Sundar Das (Hindu munshī of Jahangir's reign, d. 1623), 24, 93

Sundar Kaviray (Braj-Hindi poet), 93

Sunnami, Bhagwant Rai "Bahar," 283-84, 316n16

Surat (port in Western India), 72-73, 136, 153, 165, 304n17

Surat Singh: correspondent of Chandar Bhan, 25, 51, 81

Swahili Coast. See Africa

Tabaqāt-i Shāhjahānī (compendium of biographies of Mughal notables), 27

Tabas, 113

Tabriz, 113. See also Sa'ib Tabrizi

Tagore, Rabindranath, 1

Tahir Nasrabadi, Muhammad 12

Taj Bibi Bilqis Makani (third wife of Jahangir, m/o Shah Jahan; d. 1619), 241

Taj Mahal 18, 21, 30, 144, 145-46, 310-11n30; as a symbol of Mughal grandeur, 1-3, 26, 145-46, 286; decorative calligraphy on, 26, 313n5; architecture, financing of, 27; as a site of public gatherings/events, 57-58; Chandar Bhan as manager of, 56-59, 83, 267

Talib Amuli, Sayyid Muhammad (poet laureate under Jahangir, d. 1626-27), 26, 206, 213-14, 229, 233, 235, 262, 287

Talwandi (village near Amanabad), 42

Tanbīh al-Ghäfilìn, 236, 322n121

Taqi Auhadi, 274

Tārīkn-i Adab-i Urdū, 279

Tārīkn-i Guzìda, 61

Tārīkn-i Rājahā-yi Dehli (History of the kings of Delhi), 7, 95-99. See also Chandar Bhan Brahman 
Tārīkh-i Tabarī, 61

Tariqaat al-Haqiqat (mystical treatise by Mughal Prince Dara Shukoh), 245

Tarshiz, 212

tarz (style, manner): as a literary term, 208-9, 210, 213-14, 215, 229, 231-32, 233, 239, 259

tarz-i khayāl ( "imaginative style" of early modern Persian poetry), 231-32, 321n101 tawakkul (acceptance of divine fate), 10, 196 tāza-gū' $\bar{\imath}$ (speaking the fresh; early modern Indo-Persian literary movement), 11, 44-45, 160, 201-39, 259, 265, 294, 302-3n76, $317-18 \mathrm{n} 3 \mathrm{O}, 322 \mathrm{n} 117$; in comparative global context, 11, 236-39, 294

tazkiras (biographical compendia), 179, 231, $258-85,304 \mathrm{n} 16$, 320n 82 ; early modern growth in popularity of as a genre, 11-13, 251, 258-59, 268-69, 294-95; as underutilized sources in modern historiography, 11-13, 272, 274, 277-79, 295

Tazkira-yi Husainī (compendium of literary biographies), 12

Tažkira-yi Nașrābādì (compendium of literary biographies), 12

Tazkkirat al-Mu'ạsirinn (compendium of literary biographies), 12

Tazkirat al-Safar wa Tuhfat al-Zafar (memoir by Nik Rai, munshī of Aurangzeb's reign): discussion of literary culture in, 231

Tej Bhan Brahman (s/o Chandar Bhan): training as a secretary and poet, $23,60-64,66,67$, $196,206,208,210,318 \mathrm{n} 37$; as a revenue official in Aurangzeb's administration, 23, 56-57, 58, 267; correspondence with Chandar Bhan, 23, 38, 60-64, 173, 191, 195-97, 206

Telangana, $153-4$

Thatta (Sindh), 7, 98, 136, 253; as a source of pomegranates, 109; as a commercial entrepôt, 153; as a hub of mystical activity, 153,253

Tibet, 112, 113

Timur, Amir (d. 1405): as a Mughal ancestor, 99, 121-22, 241; Zafar-nāma, as history of his reign, 61,122

Timurid dynasty: 61, 270, 274; influence on Mughal political and intellectual culture, 30-31, 121-22, 202, 242, 250, 307n1, 310n28; astronomy and astrology under, 30-31, 202

Todar Mal, Raja (Hindu wazìr under Akbar, d. 1589), 6, 68-69, 71, 143, 270, 291-92

tolerance: religious pluralism/tolerance as a feature of Mughal culture and society, 4-5,
17-21, 49, 59, 65, 68, 113-14, 195, 201-2; Dara Shukoh as a heroically tolerant figure in modern historiography, 241-58. See also șulh-i kull, civility

Transoxiana, 111, 118, 127, 140, $320 n 82$

Tulsidas (Awadhi-Hindi poet-saint, d. 1623), 203, $315 n 8$

Turan (Central Asia), 71, 111, 127, 148, 224, 277; Mughal diplomacy with, 44, 78, 113

Turkistan, 112, 113, 128, 208

Turko-Mongol: legacy in Mughal political and intellectual culture, 4, 16, 307n1

Tus, 113

Udaipur, 92, 94, 112, 255. See also Mewar, Raj Singh

Uday Bhan Brahman (b/o Chandar Bhan), $23-24,26,164,191$

Ujjain, 154

Ulugh Beg (Timurid ruler, d. 1449): as an astronomer, 30-31

"universal civility." See șulh-i kull

Urdu, 13, 14, 15, 190, 203, 209, 262-63, 276, $278-79,287,313 n 2$; letter writing in, 176-7; Chandar Bhan as first poet of, 278-82, 316-17n16, 319n7o, 320n75. See also Hindi

'Urfi Shirazi, Jamal al-Din Muhammad (poet, d. 1591), 208, 210-11, 212, 214, 221, 223, 231, 233-35, 236, 319n71

Uzbek Khanate: rivalry with Mughals, 88-89, 90,152

vairägya (Sanskrit concept of "dispassion"). See detachment

Vaishnavas: devotional poetry of, 203

Vedanta, 9

Vijayanagara, 286

Vindhya mountains, 153

Wahshi, Kamal al-Din (poet, d. 1583), 213

Wali Deccani, Wali Muhammad (poet,

d. 1707), 280

"Walih" Daghistani, 'Ali Quli Khan, 12, 273-77, 321n10o. See also Riyāz al-Shu'arā

wāqi'a-nawiss (Mughal imperial diarist), 5, 32, 102, 170, 240

Waris, Muhammad (Mughal historian), 288

Wazir Khan, Hakim 'Alim al-Din (governor of Punjab under Shah Jahan, d. 1640-41), 49, 57, 168; as a correspondent of Chandar Bhan, 49; Wazir Khan mosque in Lahore, 49, 148

Wazirabad, 48 
wizārat (governance, administration), 53, 168; as something more than military authority (imārat), 6, 65-84; "manuals for wazirs" (dastūr al-wizārat) as a genre, 7, 67, 74-75, 82, 171. See also literary civility, mystical civility

Yādgār-i Ghālib, 176

Yādgār-i Raftagān, 279

Yahyá Maneri (also pron. "Munyari”), Shaikh Sharaf al-Din Ahmad, 156

Yazd, 113; as a source of pomegranates, 109; the poet Zuhuri's sojourn in, 212-13

Yazdi, Sharaf al-Din (Timurid historian, d. 1454), 122

Yoga-Vasishta: Persian translations and commentaries, 198, 245

Yuddhishtira (legendary king of the Sanskrit epic Mahābhārata): as a model ruler of Delhi, 96, 97, 158

yūnānì (Greek) medicine: in Indo-Persian intellectual culture, 34-35, 118
Zafar Khan “Ahsan,” Mirza Ahsan Allah (governor of Kabul under Shah Jahan, d. 1663), 69, 300-1n39; as a poet and patron of poets, 69

Zafar-nāma (Yazdi's chronicle of Amir Timur's career; 1424-25): influence on Mughal historiography and political culture, 61 , 121-22

Zain al-Din Shirazi, Shah/Shaikh (Sufi saint of the Chishti order, d. 1369), 154

Zakhirrat al-Khawānīn (biographies of Mughal notables) 30

Zakhirirat al-Mulūk (treatise on political theory, $\left.14^{\text {th }} \mathrm{c}.\right), 101$

Zamindawar (fort), 156

Zìj-i Shāhjahānī (Mughal treatise on astronomy), 30-31; Sanskrit translation of, $31,301 n 43$

Zuhuri Tarshizi, Nur al-Din Muhammad (poet, d. 1615), 212-13, 233-34

Zulali Khwansari, Mulla (poet, d. ca. 1615), 233 
Writing Self, Writing Empire examines the life, career, and writings of the Mughal state secretary, or munshi, Chandar Bhan Brahman (d. ca. 1670), one of the great Indo-Persian poets and prose stylists of early modern South Asia. Chandar Bhan's life spanned the reigns of four emperors: Akbar (1556-1605), Jahangir (1605-1627), Shah Jahan (1628-1658), and Aurangzeb "Alamgir (1658-1707), the last of the "Great Mughals" whose courts dominated the culture and politics of the subcontinent at the height of the empire's power, territorial reach, and global influence.

Chandar Bhan was a high-caste Hindu who worked for a series of Muslim monarchs and other officials, forming powerful friendships along the way; his experience bears vivid testimony to the pluralistic atmosphere of the Mughal court, particularly during the reign of Shah Jahan, the celebrated builder of the Taj Mahal. But his widely circulated and emulated works also touch on a range of topics central to our understanding of the court's literary, mystical, administrative, and ethical cultures, while his letters and autobiographical writings provide tantalizing examples of early modern Indo-Persian modes of self-fashioning. Chandar Bhan's oeuvre is a valuable window onto a crucial, though surprisingly neglected, period of Mughal cultural and political history.

"Adds significant depth to our understanding of the intellectual and cultural atmosphere of the Mughal court at its height." RICHARD M. EATON, author of $A$ Social History of the Deccan, 1300-1761

"The fullest study so far of the understudied phenomenon of Hindu writers of Persian. Through the prism of Chandar Bhan's writings, Rajeev Kinra presents a holistic treatment of the cultural concerns of the Mughal empire's Hindu 'men of the pen." NILE GREEN, author of Making Space: Sufis and Settlers in Early Modern India

RAJEeV KINRA is Assistant Professor in the Department of History at Northwestern University.

South Asia Across the Disciplines

\section{UNIVERSITY OF CALIFORNIA PRESS} www.ucpress.edu

Cover illustration: A Prince Visiting His Library, miniature pasted on an album leaf. Attributed to La'l. Northern India, Mughal, ca. 1600, the David Collection.
ISBN 978-0-520-28646-?

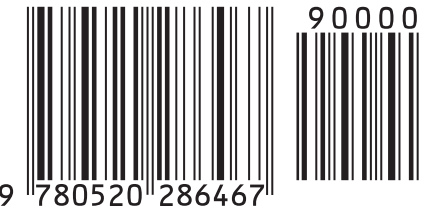

